MARCIO GERALDO BRITTO ARANTES FILHO

\title{
A INTERCEPTAÇÃO DE COMUNICAÇÃO ENTRE PESSOAS PRESENTES COMO MEIO DE INVESTIGAÇÃO DE PROVA NO DIREITO PROCESSUAL PENAL BRASILEIRO
}

\begin{abstract}
Dissertação de Mestrado apresentada à Faculdade de Direito da Universidade de São Paulo como requisito parcial para obtenção do título de Mestre em Direito Processual, sob orientação do Professor Doutor Gustavo Henrique Righi Ivahy Badaró.
\end{abstract}

UNIVERSIDADE DE SÃO PAULO

FACULDADE DE DIREITO

SÃO PAULO

2011 
Dedico este trabalho a Deus, minha fonte de inspiração espiritual, e aos meus queridos pais, Angela e Marcio. 


\section{AGRADECIMENTOS}

Manifestar a minha gratidão àqueles que contribuíram para a concretização do presente trabalho é tarefa aprazível por demais para mim. Nos quatro anos de estudo dedicados à elaboração do trabalho no curso de Pós-Graduação da Faculdade de Direito do Largo de São Francisco, tive a oportunidade de conviver com pessoas que despertam em mim lembranças especiais e saudosas.

O Professor Gustavo Henrique Righi Ivahy Badaró, meu mestre orientador, concedeume a oportunidade de aprender com os seus ensinamentos. Muitas e valiosas foram as lições que aprendi em nosso constante convívio na orientação da elaboração do trabalho e em suas aulas. Além das lições jurídicas, extrai de nosso convívio lições de vida, tendo-o como exemplo de mestre, de advogado e de ser humano.

$\mathrm{Na}$ fase de delimitação do tema e de feitura do projeto de pesquisa, os Professores $A d a$ Pellegrini Grinover e Paulo José da Costa Jr. prestaram-me valorosa colaboração.

Durante as aulas e os exames dos quais participei, o meu aprendizado também foi fruto dos ensinamentos e dos conselhos preciosos de meus mestres: Antonio Magalhães Gomes Filho, Antonio Scarance Fernandes, José Raul Gavião de Almeida, José Rogério Cruz e Tucci, Marcos Alexandre Coelho Zilli, Maria Thereza Rocha de Assis Moura, Marta Cristina Cury Saad Gimenes e Maurício Zanóide de Moraes.

Em atividades de pesquisa e de auxílio acadêmico os funcionários da Faculdade de Direito, aqui representados por Sylvia Regina Ferreira, e do Instituto Brasileiro de Ciências Criminais (IBCCRIM), contribuíram para o desenvolvimento do trabalho.

No período de elaboração do trabalho, estiveram comigo todos os meus amigos, aqui representados por Andréa Akemi Okino Yoshikai, Cristiane Ferreira Gomes Ramos, Dagma 
Paulino dos Reis, Denise Cristina Lima Baptista, Eliana Coimbra Maniglia, Helena Regina Lobo da Costa, Leandra Arantes Consoni Crosta, Mariângela Tomé Lopes e Marianna Moura Gonçalves. Uma menção especial faço à Dagma e à Helena, pelo indispensável auxílio na tradução e na compreensão dos textos escritos, respectivamente, em francês e em alemão.

Com a minha família, neste período, pude compartilhar alguns dos bons momentos da minha vida. Os meus pais, Angela Maria Bellini Arantes e Marcio Geraldo Britto Arantes, as minhas irmãs, Carolina Bellini Arantes de Paula, Larissa Bellini Arantes Guina e Patrícia Bellini Arantes Machado, os meus cunhados, André Renato de Almeida Guina, Marco Augusto Francisco de Paula e Vinícius Goltz de Carvalho Machado, e as pequeninas Chiara Arantes de Paula e Maria Eduarda Arantes Machado, as minhas sobrinhas, sempre estiveram comigo no caminho de elaboração do trabalho.

A todos vocês, obrigado.

Arcadas, 10 de janeiro de 2011. 


\section{RESUMO}

ARANTES FILHO, Marcio Geraldo Britto. A interceptação de comunicação entre pessoas presentes como meio de investigação de prova no direito processual penal brasileiro. Dissertação (Mestrado) - Faculdade de Direito, Universidade de São Paulo, São Paulo, 2011, $326 \mathrm{p}$.

As comunicações entre pessoas presentes são tuteladas na Constituição brasileira, como decorrência da liberdade de manifestação do pensamento, do direito à intimidade e à vida privada, da inviolabilidade do domicílio e do direito a não autoincriminação. Embora sejam constitucionalmente tuteladas, as comunicações entre pessoas presentes podem ser restringidas, desde que sejam observadas as exigências de reserva de lei, de reserva de jurisdição e de proporcionalidade. A interceptação de comunicação entre pessoas presentes é meio de investigação de prova, que, por meio de restrição a direitos e garantias fundamentais, visa a descoberta de fontes de prova para a persecução penal. Trata-se de instrumento processual que consiste em atividade de captação e de registro de comunicação entre pessoas presentes de caráter reservado, por um terceiro, com o emprego de meios técnicos, utilizados em operação oculta e simultânea à comunicação, sem o conhecimento dos interlocutores ou com o conhecimento de um ou de alguns deles. A interceptação domiciliar e a interceptação ambiental são espécies de interceptação de comunicação entre pessoas presentes. O objeto e o caráter insidioso desta modalidade de interceptação impõem a necessidade de uma disciplina jurídica autônoma, sob enfoques da admissibilidade e do procedimento probatório, que devem ser previstos em lei precisa e clara.

Palavras-chave: Meios de investigação de prova. Interceptação de comunicação entre pessoas presentes. Interceptação domiciliar. Interceptação ambiental. 


\section{SUMMARY}

ARANTES FILHO, Marcio Geraldo Britto. The interception of communications between present people as means of investigation of evidence in the Brazilian criminal procedural law. Dissertation (Master) - Law University at the University of São Paulo, São Paulo, 2011, 326 p.

The communications between present people are protected by the Brazilian Constitution, arising out of the freedom of expression of ones thoughts, the right to intimacy and privacy, the dwelling defense and by the right not to produce self-incrimination. Despite being protected constitutionally, the communications between present people can be restricted as long as in accordance with the demands in reserve of law, in reserve of jurisdiction and of proportionality. The communications interception between present people is a means of investigation of evidence, which by means of restriction of rights and fundamental guarantees, objectives uncovering the sources of evidence for accusatory procedure. It is a question of procedural tool which consists in the activity of registering and recording communications between present people with secretive nature, by a third person, with the use of technical means, applied in concealed action and concurrent to the communication without the knowledge of the interlocutors or just the knowledge of one or few of them. Dwelling interception and surrounding-interception are types of interception of communications between present people. The object and deceitful nature of this modality of interception imposes the need of an autonomous juridical regulation, under the perspectives of admissibility and of probatory procedure, which must be foreseen by clear and precise law.

Key terms: Means of investigation of evidence. Interception of communications between present people. Dwelling -interception. Surrounding-interception. 


\section{SUMÁRIO}

INTRODUÇÃO

1. OS MEIOS DE INVESTIGAÇÃO DE PROVA NO DIREITO PROCESSUAL PENAL: ASPECTOS GERAIS

1.1. A investigação na persecução penal: finalidade e atribuição 19

1.2. O direito à prova $\mathrm{e}$ o fenômeno probatório 29

1.2.1. Significados do termo prova 31

1.2.1.1. Definições de fonte de prova, meio de produção de prova, elemento de prova, resultado de prova e meio de investigação de prova

1.2.1.2. Distinções entre meios de produção de prova e meios de investigação de prova 37

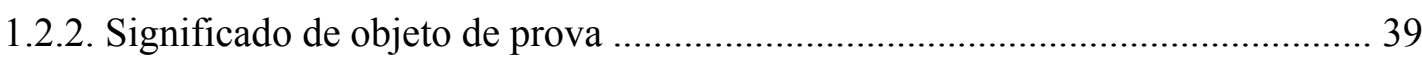

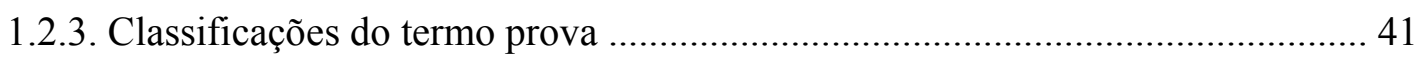

1.2.3.1. Prova ilícita e prova ilegítima ....................................................... 42

1.2.3.2. Prova típica, prova atípica, prova nominada e prova inominada ........ 44

1.2.3.3. Prova irritual e prova anômala ............................................................. 49

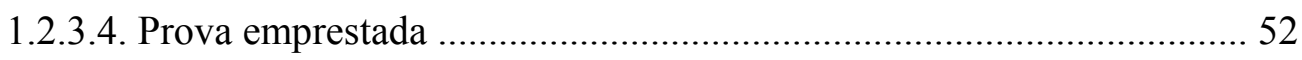

1.2.3.5. Prova cautelar, prova antecipada e prova não-repetível....................... 54

1.3. A cautelaridade dos meios de investigação de prova …..................................................... 58

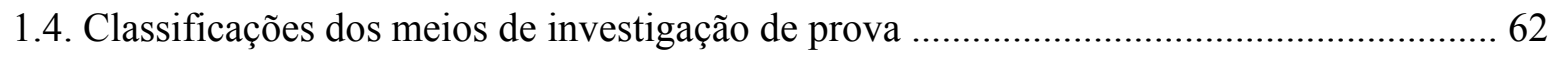

1.4.1. Meios de investigação de prova típicos e atípicos ................................................ 63

1.4.2. Meios de investigação de prova ordinários e extraordinários ............................6 68

1.4.3. Meios de investigação de prova preventivos e repressivos ................................ 71

1.5. A eficácia probatória dos meios de investigação de prova ............................................ 73

1.6. A inadmissibilidade de provas obtidas por meios ilícitos ............................................. 86 
2. FUNDAMENTOS CONSTITUCIONAIS DA TUTELA DAS COMUNICAÇÕES ENTRE PESSOAS PRESENTES

2.1. A abrangência das comunicações entre pessoas presentes 91

2.2. A liberdade de manifestação do pensamento 95

2.2.1. A liberdade de comunicação entre pessoas presentes como espécie da liberdade de manifestação de pensamento 99

2.3. $\mathrm{O}$ direito à intimidade e à vida privada 101

2.3.1. A inviolabilidade do sigilo de comunicação entre pessoas presentes como expressão do direito à intimidade e à vida privada 105

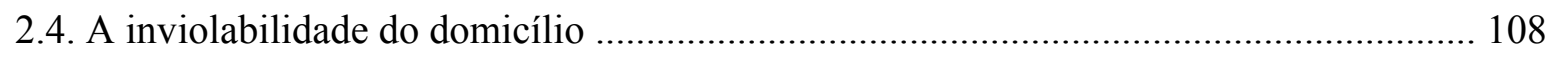

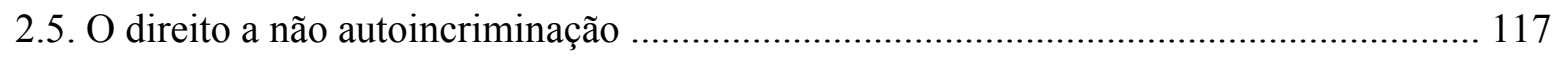

2.6. A restrição às comunicações entre pessoas presentes .................................................. 120

3. A INTERCEPTAÇÃO DE COMUNICAÇÃO ENTRE PESSOAS PRESENTES NO DIREITO PROCESSUAL PENAL: ASPECTOS DOGMÁTICOS E PROPOSTAS DE DISCIPLINA JURÍDICA

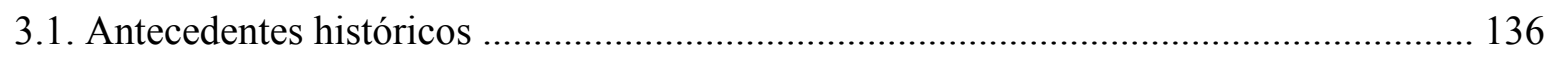

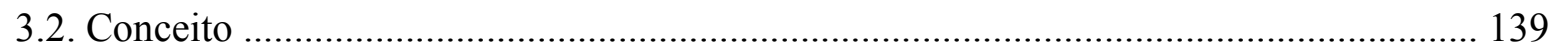

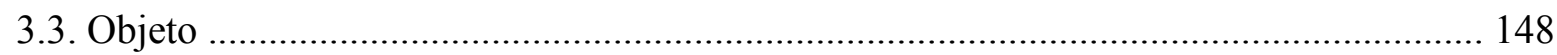

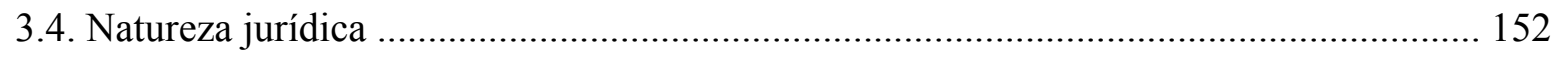

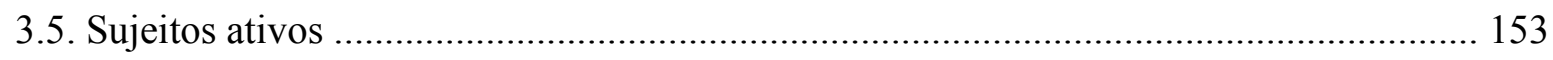

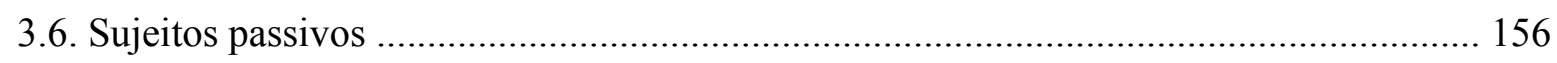

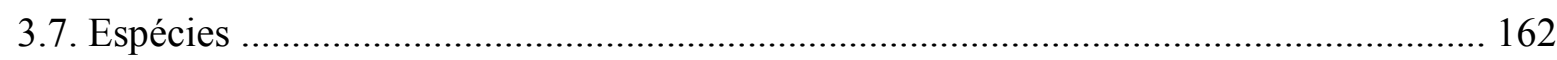

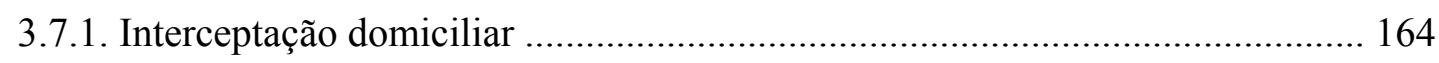

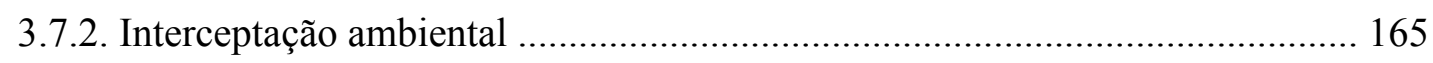

3.8. Distinções entre interceptação de comunicação entre pessoas presentes e figuras

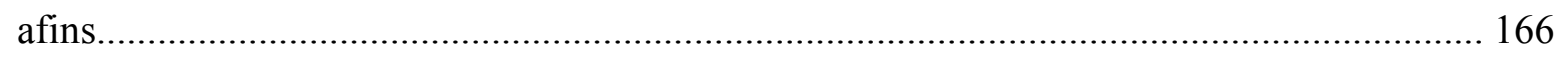

3.8.1. Interceptação de comunicação entre pessoas presentes e interceptação de

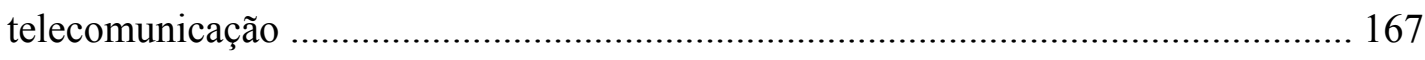

3.8.2. Segue: e gravação clandestina de comunicação entre pessoas presentes ......... 169 
3.8.3. Segue: e revelação do conteúdo de comunicação entre pessoas presentes por um dos interlocutores

3.9. O caráter insidioso 175

3.10. A disciplina jurídica da interceptação de comunicação entre pessoas presentes 179

3.10.1. As propostas sobre o conteúdo 179

3.10.2. As propostas sobre a autonomia: admissibilidade e procedimento 185

\section{ADMISSIBILIDADE E LIMITES DA INTERCEPTAÇÃO DE COMUNICAÇÃO ENTRE} PESSOAS PRESENTES NO DIREITO PROCESSUAL PENAL COMPARADO

4.1. Generalidades sobre o regime jurídico da interceptação de comunicação entre pessoas presentes no direito processual penal comparado ............................................................... 194

4.2. Admissibilidade e limites da interceptação de comunicação entre pessoas presentes .... 196

4.2.1. Na ordem internacional 197

4.2.2. No direito comparado 201

4.2.2.1. Sistema da common law 201

4.2.2.1.1. Direito inglês 201

4.2.2.1.2. Direito norte-americano 204

4.2.2.2. Sistema romano-germânico 208

4.2.2.2.1. Direito alemão 208

4.2.2.2.2. Direito argentino 217

4.2.2.2.3. Direito chileno 220

4.2.2.2.4. Direito espanhol 224

4.2.2.2.5. Direito francês 228

4.2.2.2.6. Direito italiano 230

4.2.2.2.7. Direito português 236

5. A INTERCEPTAÇÃO DE COMUNICAÇÃO ENTRE PESSOAS PRESENTES NO DIREITO PROCESSUAL PENAL BRASILEIRO

5.1. A tutela constitucional das comunicações entre pessoas presentes 241

5.2. A restrição processual penal às comunicações entre pessoas presentes 246 
5.3. A interceptação de comunicação entre pessoas presentes na legislação

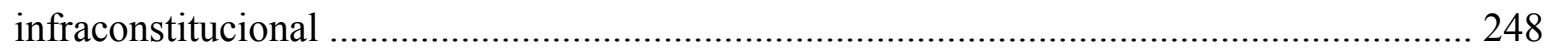

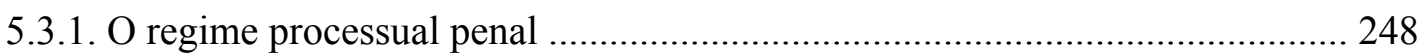

5.3.1.1. O regime previsto na Lei n. 9.034, de 1995 .................................... 249

5.3.1.2. Segue: a proposta de integração com o regime previsto na Lei ${ }^{\circ}$ 9.296,

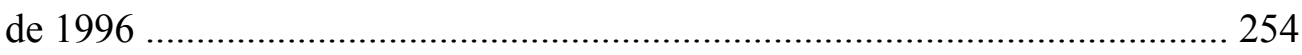

5.3.1.3. Segue: a proposta de integração com o sistema processual penal ..... 261

5.3.1.4. Repercussão processual de interceptação de comunicação entre pessoas

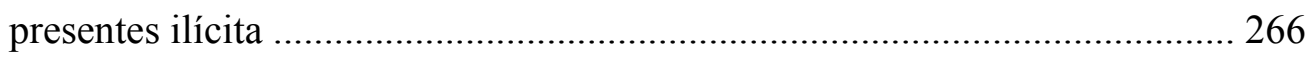

5.3.1.5. Meios de impugnação de interceptação de comunicação entre pessoas presentes ilícita .......................................................................................... 271

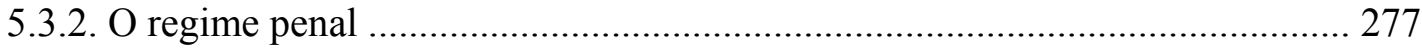

5.4. Projetos de lei sobre a interceptação de comunicação entre pessoas presentes .............. 280

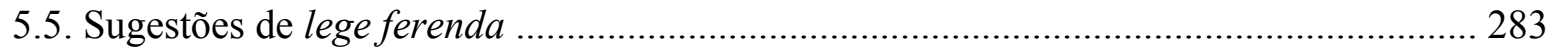

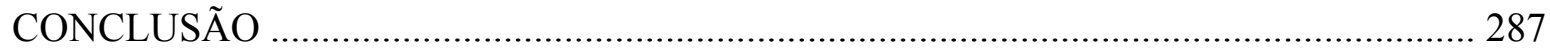

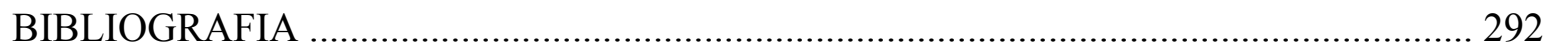




\section{INTRODUÇÃO}

\section{A importância do tema}

Investigar a existência de provas de uma suposta ocorrência de crime: uma tarefa que propicia a elaboração de soluções justas no desenrolar da persecução penal. Muito se evoluiu, na história do processo penal, quanto a admissibilidade de métodos para pesquisa de fontes probatórias, entre os quais se destacam os meios de investigação de prova, também denominados meios de pesquisa de prova ou meios de obtenção de prova.

Reconhece-se a existência de antecedente dos mencionados meios na Antiguidade. A proteção do domicílio já era prevista na Lei das XII Tábuas, servindo de anteparo para busca desmedida de fontes de prova. ${ }^{1}$ Mas não se pode olvidar a errônea consideração, como formas de "obtenção" de prova, de técnicas processuais que com eles em nada se assemelham. Em interrogatório, utilizou-se de meios coercitivos para obrigar o réu a falar, visando a se "obter" como prova a confissão do acusado, então tarifada como prova-mor, regina probationum. ${ }^{2}$

Diante da constatação da equivocada admissão de uma busca desmedida de provas, especialmente em sistemas processuais inquisitivos, firmou-se a moderna concepção da existência de limites para a atividade estatal de investigação, decorrente do resguardo de direitos e garantias fundamentais decorrentes da dignidade da pessoa humana, paulatinamente afirmados em atos normativos nacionais e internacionais. Tais limites se equiparam a

\footnotetext{
1 "Pode-se afirmar que os limites e contornos de legalidade das buscas, especialmente a domiciliar, e da tomadia, através dos tempos guardam estreita relação com a casa do indivíduo" (Cf. PITOMBO, Cleunice A. Valentim Bastos. Da busca e apreensão no processo penal. 2. ed. São Paulo: RT, 2005, p. 23). A ilação da autora se fundamenta no n. XV da Tábua VIII "Dos Delitos", integrante da Lei das XII Tábuas, diploma normativo vigente na Antiguidade.

${ }^{2}$ Os registros bíblicos que retratam a perseguição de Jesus Cristo revelam nitidamente esta perversa concepção. Tal conclusão é extraída dos Livros do Novo Testamento, especialmente do Evangelho de Mateus: Paixão e Ressurreição de Jesus (26-28).
} 
instituição de fronteiras para a procura de provas, sob a perspectiva de consecução de uma verdade processual. ${ }^{3}$

Por outro lado, não se desconheceu que a tutela absoluta de liberdades públicas, traduzida na previsão de direitos e de garantias fundamentais, poderia significar a impossibilidade da necessária repressão penal a prática delitivas. A proteção atribuída a bens jurídicos pode servir como manto para dificultar a descobertas de fontes de prova. É por este motivo que surgiu a necessidade de estruturação dos meios investigação de prova, para propiciar a restrição a algumas das liberdades públicas, ${ }^{4}$ mediante a observância dos demais direitos e garantias nelas inseridas.

Atualmente, pouco se dedica à regulamentação dos aspectos gerais dos meios de investigação de prova. No mais das vezes, os legisladores, nacional e estrangeiro, delineiam a disciplina de suas espécies, o que contribui para a divergência observada em jurisprudência. É da doutrina, nacional e estrangeira, que se podem extrair preciosas considerações para o estudo sistemático do tema. Daí a relevância de se examinarem os seus aspectos gerais.

Em princípio, considerada a restrição de direitos fundamentais, admitem-se os meios de investigação de prova para investigação de delitos graves, entre os quais estão as ações praticadas por por organizações criminosas.

Ademais, os referidos meios são tidos como instrumentos úteis para a investigação pertinente a delitos cuja forma de execução possa ser diferenciada, ainda que não sejam de elevada gravidade. São exemplos desta categoria delitiva: a injúria e a ameaça cometida em

\footnotetext{
${ }^{3}$ Quanto aos limites da persecução penal, FRANCISCO MUNOZ CONDE e MARCELA DE LANGHE compartilham as suas reflexões: "El derecho procesal 'tiene su corazón dividido entre dos grandes amores': por un lado, la misión de investigar os delitos y castigar a los culpables; por outro, la de respetar en esa tarea determinados princicios y garantías que se han convertido en moderno Estado de derecho en derechos e garantías fundamentales del acusado. Esto produce una contradicción difícil de solucionar: el respeto a lãs garantías y derechos fundamentales del acusado puede suponer y, de hecho, supone efectivamente, un límite a la busqueda de la verdad que obviamente ya no puede ser uma verdad a toda costa." (Presentación. In: ROXIN, Claus. La prohibición de autoincriminación y las escuchas domiciliarias. 1. ed. Buenos Aires: Hammurabi, 2008.p. 10)

${ }^{4}$ CLAUS ROXIN salienta que tais meios de pesquisa intervêm, "cada vez mais enérgicamente nos direitos fundamentais" (Derecho procesal penal. 25. ed. Tradução de Gabriela Córdoba y Daniel Pastor. Buenos Aires: Editores Del Puerto, 2003, p. 250).
} 
comunicações. Em hipóteses como tais, o delito se perfaz sob a proteção de direitos e garantias, o que impõe sua restrição. ${ }^{5}$

É o interesse em repressão de conduta delitiva que está a possibilitar uma persecução penal diferenciada, por se valer de meios de obtenção de prova restritivos de liberdades individuais, nas hipóteses mencionadas. À sociedade interessa que sejam repreendidos os responsáveis por prática de infrações penais, independentemente da gravidade atribuída pelo legislador. Por isto, impõe-se a utilização de instrumentos eficazes na investigação de cometimento de delitos.

A compreensão do conceito e da finalidade dos meios de investigação de prova - a possível descoberta de fonte de provas - facilita diferenciá-los dos meios de produção de prova, sobretudo no que se refere a eficácia probatória pertinente a cada um deles. E a distinção é importante, porque o contraditório exige a necessidade de participação das partes na formação de elementos probatórios que possam estribar decisão sobre o meritum causae.

As interceptações de comunicações são espécies de meios de investigação de prova, restritivos da inviolabilidade do sigilo das comunicações.

Multiplicam-se, no desenfreado avanço tecnológico, mecanismos para captação das diferentes espécies de comunicações: telecomunicações (telefônicas, telegráficas, telemáticas, informáticas) e comunicações entre pessoas presentes.

Efetivamente, é impossível ignorar, sob a perspectiva jurídica, a evolução científica, sobretudo porque os citados mecanismos, não raramente, são utilizados, insidiosamente, para

\footnotetext{
5 LEONARDO FILIPPI esclarece, ao examinar as espécies delitivas em cuja investigação se admitem interceptações de comunicações na lei processual penal italiana, os critérios empregados: um, predominantemente quantitativo, concentrado na importância da pena cominada; outro, qualitativo, considerada as particulares características dos delitos, que tornam as interceptações um instrumento útil e, à vezes, o mais idôneo para a investigação (Intercettazione di comunicazioni. In: Enciclopedia Giuridica - Istitvto Enciclopedia Italiana fondata da Giovanni Treccani. Roma: Istituto Poligrafico e Zecca dello Stato, 2001. vol. XVII, p. 3). Em sentido semelhante, cf.: Cf. BALDUCCI, Paola. Le garanzie nelle intercettazioni tra costituzione e legge ordinaria. Milano: Giuffrè, 2002 (Studi di diritto processuale penale, raccolti da Giovanni Conso, n. 95), p. 41.
} 
descoberta de fontes de prova. ${ }^{6}$ Praticam-se, por intermédio deles, verdadeiros atos de devassa da intimidade e da vida privada, por vezes, com perfídia do próprio interlocutor-interessado, que pode ser autoridade pública, ou particular.

Inserido nos espaços mais recônditos da intimidade e da vida privada, a comunicação direta entre duas ou mais pessoas por conversa pode ser captada por instrumentos diversos na investigação de prova. Em geral, os instrumentos empregados são minúsculos, programados para captar o conteúdo de comunicação.

Meio extraordinário de investigação de existência de fontes de prova, a interceptação de comunicação entre pessoas entre presentes, também conhecida por interceptação entre presentes ou por interceptação ambiental, avulta no processo penal, por impor, em elevado grau, lindes a inviolabilidade da intimidade e da vida privada. Não basta dizer que seja um meio de prova. A incompletude da ilação justifica a indagação: Meio de produção de prova ou meio de investigação de prova? A resposta é relevante para delimitação do regime jurídico aplicável ao instituto.

Trata-se de matéria da mais alta relevância, pois, tradicionalmente, utilizam-se meios insidiosos para captação das conversas entre presentes. Diante disso, expõem-se aspectos íntimos do interlocutor, inclusive manifestações imbuídas da mais forte emoção. Além disso, chega-se a divulgar, por vezes, parte das declarações firmadas, que, extraídas das demais e do contexto fático, tem significado distinto, por vezes, deturpado.

Veem-se estimulados, em tal prática, pela frequente admissão de tais declarações, incluídas aí ditas confissões. ${ }^{7}$ As declarações feitas em juízo no sentido de que se os dizeres

\footnotetext{
${ }^{6}$ A doutrina há tempos salienta a relevância do tema: "o problema toma hoje novas dimensões: de um lado existe uma tendência no sentido de se ampliarem os meios de prova, quer sob o ponto de vista jurídico quer sob o ponto de vista técnico; de outro, estas técnicas modernas, facilitando a descoberta dos fatos através da penetração na esfera reservada do homem, colocam em perigo maior um de seus mais invioláveis direitos, o da intimidade" (Cf. GRINOVER, Ada Pellegrini. Liberdades públicas e processo penal: as interceptações telefônicas. 2. ed. São Paulo: RT, 1982, p. 94-96).

${ }^{7}$ Mesmo sabendo que, para ser considerada, a confissão deve ocorrer perante autoridade judiciária, não se pode olvidar evidente influência no espírito do julgador trazida pela confissão dita extrajudicial.
} 
divulgados denotavam outro significado no contexto geral da conversa, por serem dele desacompanhadas, não são acreditadas.

A legislação processual penal brasileira "permite" a interceptação ambiental, como espécie de "procedimentos de investigação e formação de prova", em persecução penal de "ações praticadas por quadrilha ou bando ou organizações ou associações criminosas de qualquer tipo" (artigos $1^{\circ}$ e $2^{\circ}$, caput, inciso IV da Lei n. 9.034, de 1995). A deficiência de requisitos e a não delimitação de um procedimento probatório para sua execução dificulta a exigida "circunstanciada autorização judicial".

Tampouco se reprimem as indevidas captação e divulgação de comunicação entre pessoas presentes, corroborando abuso e utilização indevida de seu conteúdo. Hodiernamente, no Brasil, a tímida tutela penal da intimidade, no campo das conversações, cinge-se às comunicações telefônicas e em sistemas de informática e telemática (art. 10 da Lei $\mathrm{n}^{\circ}$ 9.296, de 1996), o que muito contribui para as indevidas intromissões nas diferentes esferas privadas.

De um lado, a deficiência da disciplina normativa nacional impossibilita a execução regular de meio eficaz para a investigação penal; por outro, propicia abusos com a captação indevida de conteúdo de comunicações, em busca de informações para a persecução penal. Portanto, evidencia-se a necessidade de um exame aprofundado, em que se atente ao conceito, à natureza jurídica e à elaboração de uma proposta de disciplina do instituto.

\section{Limites do tema}

Conforme se observou, no ordenamento jurídico nacional, nota-se a deficiência da regulamentação da interceptação de comunicações entre pessoas presentes, inclusive de normas gerais pertinentes aos meios de investigação de prova. Os seus aspectos gerais são extraídos da doutrina. Sendo assim, a área de trabalho é permeada por pluralidade de 
entendimentos, neles insertos especulações políticas, ${ }^{8}$ desvinculadas do necessário rigor científico.

Sem desprezar a pertinência do debate, a respeito de tema corriqueiro e de interesse da comunidade mundial, o propósito central deste estudo é relevar as considerações doutrinárias que se amoldem ao sistema processual penal brasileiro, considerada a ordem constitucional instaurada em 1988. Parte-se do pressuposto da consagração de um sistema de caráter acusatório e da inarredável observância da constelação de direitos e garantias processuais petrificados na Constituição, que gravitam em torno da dignidade da pessoa humana. Aqui sobressai o contraditório, "condição de eficácia das provas". 9

A tutela constitucional das comunicações entre pessoas presentes - sob as perpectivas de liberdade de comunicação entre pessoas presentes e de inviolabilidade do sigilo das comunicações entre pessoas presentes - é fundamentada nos referidos direitos e garantias fundamentais, em especial na liberdade de manifestação do pensamento, no direito à intimidade e à vida privada, na inviolabilidade do domicílio e no direito a não autoincriminação.

Todavia, a sua restrição é admitida, desde que disciplinada em lei. Entre as formas de restrições reconhecidas, estão a gravação clandestina e a revelação do conteúdo da comunicação por um dos interlocutores. Embora haja referência a tais institutos, o trabalho é elaborado com vistas voltadas à interceptação de comunicações entre pessoas presentes, que é seu objeto.

Além da tutela processual, o tema ainda comportaria divagações sobre a necessidade de criminalização de captação e de divulgação indevidas do conteúdo das comunicações entre presentes. Por isso, será registrada menção a tal questão, em linhas gerais, pela possível

\footnotetext{
${ }^{8}$ PAOLA BALDUCCI lembra que as interceptações constituem um instrumento "poliédrico", o qual, além de ser muito útil nas investigações penais, não é limitado à seara criminal (Le garanzie nelle intercettazioni tra costituzione e legge ordinaria. Milano: Giuffrè, 2002 (Studi di diritto processuale penale, raccolti da Giovanni Conso, n. 95), p. 68).

${ }^{9}$ Cf. GRINOVER, Ada Pellegrini. Prova emprestada. Revista Brasileira de Ciências Criminais, São Paulo, RT, ano 1, n. 4, out-dez. 1993, p. 62).
} 
repercussão processual do tema. É que a ausência de tipificação penal estimula o cometimento de interceptações abusivas, com possível ingresso na persecução penal de informações extraídas do conteúdo da comunicação indevidamente captada.

\section{Plano de trabalho}

Observada a delimitação do tema, a exposição será principiada por um capítulo introdutório, de maior extensão, no qual sistematizaremos os aspectos gerais dos meios de investigação de prova, sob a perspectiva do sentido da investigação no sistema processual penal. Para tanto, serão explicados os diversos significados do termo prova e suas classificações. Além disso, abordaremos a eficácia probatória dos referidos meios e a garantia da inadmissibilidade de provas obtidas por meios ilícitos.

Ingressando nas questões pertinentes à interceptação de comunicação oral, o segundo capítulo será dedicado ao exame dos fundamentos constitucionais da tutela das comunicações entre pessoas presentes. Por primeiro, delinearemos a abrangência desta espécie de comunicação. Depois, invocaremos os direitos e garantias individuais que a fundamentam. A limitação do trabalho não comportaria o esgotamento das diversas considerações que cada um deles pudesse justificar. Objetivaremos pontuá-los, apresentando considerações sobre a relação entre eles e as comunicações entre pessoas presentes, com prévio registro de seus significados.

No terceiro capítulo, trataremos dos aspectos dogmáticos da interceptação de comunicação entre presentes, fixando o conceito, a natureza jurídica, as espécies, as distinções com outros meios de investigação de prova restritivos das comunicações entre presentes e as propostas para sua disciplina jurídica.

Destacada deste capítulo, a disciplina jurídica da interceptação de comunicações entre pessoas presentes será examinada nos dois últimos capítulos: no quarto, abordaremos a admissibilidade e os limites previstos para o instituto no direito processual penal em 
ordenamentos jurídicos estrangeiros; no quinto, apresentaremos normas integrantes do direito processual penal brasileiro, vigentes e esboçadas em projetos de lei.

O encerramento da dissertação se dá com a apresentação de sugestões para a disciplina da interceptação de comunicações entre pessoas presentes no direito processual penal brasileiro, seguida de síntese das principais conclusões resultantes da pesquisa desenvolvida. 


\title{
CAPÍTULO $1^{\circ}$
}

\section{OS MEIOS DE INVESTIGAÇÃO DE PROVA NO DIREITO PROCESSUAL PENAL: ASPECTOS GERAIS}

\begin{abstract}
Sumário: 1.1. A investigação na persecução penal: finalidade e atribuição - 1.2. O direito à prova e o fenômeno probatório: 1.2.1. Significados do termo prova: 1.2.1.1. Definições de fonte de prova, meio de produção de prova, elemento de prova, resultado de prova e de meio de investigação de prova; 1.2.1.2. Distinções entre meios de produção de prova e meios de investigação de prova; 1.2.2. Significado de objeto de prova; 1.2.3. Classificações do termo prova: 1.2.3.1. Prova ilícita e prova ilegítima; 1.2.3.2. Prova típica, prova atípica, prova nominada e prova inominada; 1.2.3.3. Prova irritual e prova anômala; 1.2.3.4. Prova emprestada; 1.2.3.5. Prova cautelar, prova antecipada e prova não-repetível - 1.3. A cautelaridade dos meios de investigação de prova - 1.4. Classificações dos meios de investigação de prova: 1.4.1. Meios de investigação de prova típicos e atípicos; 1.4.2. Meios de investigação de prova ordinários e extraordinários; 1.4.3. Meios de investigação de prova preventivos $\mathrm{e}$ repressivos; 1.5. A eficácia probatória dos meios de investigação de prova; 1.6. A inadmissibilidade de provas obtidas por meios ilícitos.
\end{abstract}

\subsection{A investigação na persecução penal: finalidade e atribuição}

Estabelecer a responsabilidade penal de alguém é tarefa atribuída ao Estado. Afirma-se que o ius puniendi estatal pode ser exercido a partir da prática de um delito no mundo fenomênico. Todavia, a condenação e a sucessiva punição não são concomitantes a infração penal. Somente podem ser operadas em um devido processo legal, cujo desfecho se perfaz em tempo distanciado da prática do crime. Nulla poena sine judicio. ${ }^{1}$

\footnotetext{
${ }^{1}$ Em face do princípio "nulla poena sine judicio", é sempre necessário o processo, pois o Estado não pode autoaplicar a norma penal, mesmo que haja a concordância de quem cometeu o delito (BADARÓ, Gustavo Henrique Righi Ivahy. Correlação entre acusação e sentença. 2. ed. São Paulo: RT, 2009, p. 67-68). Também a doutrina italiana enfatiza a necessidade de processo para aplicação de sanção penal a alguém: "la strumentalità del processo penale è connaturata al vigente ordinamento penale; nel senso che - in ossequio al principio nulla poena sine judicio - non è possibile in nium caso l'applicazione della sanzione penale senza il processo" (LEONE, Giovanni. Trattato di diritto processuale penale. Napoli: Jovene, 1961. v. I, p. 6-7, apud BADARÓ, Gustavo Henrique Righi Ivahy. Correlação entre... op. cit., p. 67-68).
} 
No entanto, a persecução penal não se resume a um processo. A investigação de fatos tidos por delituosos é fase relevante da persecução penal. Concretiza-se num conjunto de atividades desenvolvidas com a finalidade de descobrir e de registrar a existência de fontes de prova pertinentes a materialidade e autoria de um delito tido por ocorrido. ${ }^{2}$

Pudesse o ser humano volver o relógio da vida ao momento em que uma suposta infração penal tenha sido cometida, a necessária reconstrução histórica do fato seria muito facilitada. Mas considerada a limitação humana em interromper a máquina do tempo, é necessário investigar a existência de fontes de prova, das quais se possam extrair elementos de informação esclarecedores do fato propalado.

Embora se reconheça a possibilidade de promoção de uma ação penal sem prévia investigação, ${ }^{3}$ havendo elementos de materialidade e autoria delitivas que perfaçam justa causa, a investigação não perde a sua relevância. É atividade útil não só em situações nas quais não se disponha de quaisquer fontes de prova, como também se as conhecidas não sejam suficientes para a formação da opinio delicti.

Espécie de investigação criminal, o inquérito policial é preconizado no direito brasileiro desde o Império. ${ }^{4}$ Em 1871, definiu-se que "o inquerito policial consiste em todas as diligências necessárias para o descobrimento dos fatos criminosos, de suas circunstâncias e

\footnotetext{
${ }^{2}$ No mesmo sentido estão os ensinamentos de ANTONIO SCARANCE FERNANDES (O equilíbrio na investigação criminal. In: YARSHEL, Flávio Luiz; MORAES, Maurício Zanoide de (Orgs.). Estudos em Homenagem à Professora Ada Pellegrini Grinover. $1^{\text {a }}$ ed. São Paulo: DPJ, 2005, p. 319). E os de AURY LOPES JUNIOR, que insere a investigação na instrumentalidade garantista, porquanto evita acusações infundadas e temerárias. Sob a perspectiva da segurança jurídica, acrescenta o autor, a investigação tem como escopo a pacificação social, por se saber de antemão que condutas possivelmente delitivas serão objeto de investigação (A crise do inquérito policial: breve análise dos sistemas de investigação preliminar no processo penal. Revista Ibero-Americana de Ciências Penais, Porto Alegre, ano 1, n. 0, mai-ago. 2000, p. 59-61).

${ }^{3}$ A dispensabilidade da investigação é afirmada em doutrina, fundamentada nos artigos $12,27,39, \S 5^{\circ}$ e $46, \S 1^{\circ}$ do Código de Processo Penal (Cf. TOURINHO FILHO, Fernando da Costa. Manual de processo penal. 11. ed. São Paulo: Saraiva, 2009, p. 69). Também é corroborada pelo regime dos Juizados Especiais Criminais, elaborado em consonância com as normas constitucionais sobre investigação de crimes de menor potencial ofensivo (art. 98, inciso I da Constituição e art. 77, § $1^{\circ}$ da Lei no 9.099, de 1995).

${ }^{4}$ A doutrina reconhece outras espécies de investigação que ocorrem na primeira fase da persecução penal, antes da acusação formal. Não apenas o inquérito policial, como também investigações outras, das quais eventualmente decorram elementos relacionados à suposta prática de infração penal. Por exemplo, podem-se citar inquéritos parlamentares, inquéritos policiais militares, inquéritos civis e processos administrativo-disciplinares (Cf. SAAD, Marta. O Direito de defesa no inquérito policial. São Paulo: RT, 2004, p. 98-131). Considerada a limitação do presente trabalho, as considerações serão expendidas com vistas ao inquérito policial.
} 
dos seus autores e cúmplices" (art. 42 do Decreto $n^{\circ} 4.824$, de 22 de novembro de 1871). ${ }^{5} \mathrm{O}$ conceito atualmente apresentado em doutrina não destoa da antiga previsão: um conjunto de diligências que visam a apuração da materialidade e autoria de um delito tido por ocorrido. ${ }^{6}$ É regulamentado pelo art. $4^{\circ}$ e seguintes do Código de Processo Penal.

Na ordem jurídica instaurada com a Constituição de 1988, manteve-se a tradição de atribuição da função de investigar as infrações penais à polícia, ${ }^{7}$ Polícia Federal e Polícia Civil dos Estados-Membros da Federação, sob a presidência de autoridade policial, consoante os termos de seu art. $144, \S 1^{\circ}$, inciso I e $\S 4^{\circ} .{ }^{8}$

Ressalte-se que a investigação de infrações penais integra a atividade estatal repressiva, a qual colabora para a consecução de segurança pública. ${ }^{9}$ Concretizada em face de

5 Disponível em: http://www.planalto.gov.br/ccivil_03/decreto/Historicos/DIM/DIM4824.htm. Acesso em: 30/12/2009.

${ }^{6}$ Cf. TOURINHO FILHO, Fernando da Costa. Manual de processo... op. cit., p. 65.

${ }^{7}$ A polícia brasileira, desde o Império, desempenha a função de investigar até o encerramento do inquérito policial (Cf. FERNANDES, Antonio Scarance. O equilíbrio na investigação... op. cit., p. 319). "A tarefa de investigação criminal é realizada de regra por uma organização vinculada ao Poder Executivo, denominada Polícia Judiciária, por meio de um procedimento de caráter inquisitório denominado inquérito policial $\left(\operatorname{art} .4^{\circ} \mathrm{e}\right.$ ss. do CPP). Trata-se, portanto, de atividade administrativa, que se desenvolve sem a participação da acusação e da defesa." (GOMES FILHO, Antonio Magalhães; BADARÓ, Gustavo Henrique Righi Ivahy. Prova e sucedâneos de prova no processo penal brasileiro. Revista Brasileira de Ciências Criminais, São Paulo, RT, n. 65, mar-abr. 2007, p. 193).

${ }^{8}$ Como razões para se atribuir à polícia a função de investigação, apontam-se: a proximidade com o povo, o acesso a meios mais rápidos e eficazes, e o dispêndio de menos recursos financeiros para o custeio da atividade (LOPES JR., Aury. A crise do inquérito... op. cit., p. 62-63). Discute-se, em doutrina, sobre a possibilidade de investigação pelo Ministério Público no direito brasileiro. Na ordem constitucional vigente, no rol de suas funções institucionais (art. 129 da Lei Maior), não se nota a de investigar, como atribuição expressa. De acordo com o disposto no art. art. $144, \S 1^{\circ}$, inciso I e $\S 4^{\circ}$ da Constituição, parece-nos difícil sustentar a transferência da polícia para outrem a integralidade da atividade de investigação. Entende-se ser possível investigação do Ministério Público "em caráter supletivo", desde que regulamentada em lei, com delimitação de condições e limites (Cf. FERNANDES, Antonio Scarance. O equilíbrio na investigação... op. cit., p. 325-326). No mesmo sentido, protesta-se pela regulamentação da atividade ministerial na investigação criminal, extraída da Lei Complementar $\mathrm{n}^{\circ} 75$, de 1993, pelo necessário conhecimento da extensão e dos lindes da atuação dos agentes na persecução (COSTA, Paula Bajer Fernandes Martins da. Inquérito policial e a investigação dos fatos que antecede a ação penal no ordenamento jurídico instaurado pela Constituição de 1988. Revista Brasileira de Ciências Criminais, São Paulo, ano 5, n. 19, p. 171-178, jul-set. 1997, p. 177).

${ }^{9}$ O Poder Constituinte dispôs sobre segurança pública no Capítulo III da Lei Maior, que é composto pelo art. 144, com 5 incisos e 9 parágrafos. Com vistas à consecução da segurança pública, as atividades estatais preventiva e repressiva foram atribuídas a órgãos policiais distintos: Polícia Federal, Polícia Civil e Polícia Militar. Os dois últimos são órgãos que integram a administração pública de cada Estado-Membro da Federação. A atividade preventiva é desenvolvida pela Polícia Federal (art. 144, $\S 1^{\circ}$, inciso II) e pela Polícia Militar (art. $144, \S 5^{\circ}$ ) com vistas a se evitar o cometimento de infrações penais. A atividade repressiva é concretizada pela Polícia Federal (art. 144, § $1^{\circ}$, inciso I) e pela Polícia Civil (art. art. 144, $\S 4^{\circ}$ ) em face de um delito já cometido. Integrada pelas funções de apuração de infração penal e de polícia judiciária, a atividade repressiva se expressa 
um delito cometido, no decorrer da persecução penal, deve ser exercida sob o controle externo do Ministério Público (art. 129, inciso VII) e fisscalização do Poder Judiciário. ${ }^{10}$

O fato de a investigação ser função atribuída à polícia, órgão que realiza as respectivas diligências, não exclui a possibilidade de manifestação de outros entes, desde que circunscrita a esfera de sua atuação institucional. E a manifestação de interessados assume especial importância, ao se considerar a possibilidade de concretização de restrição a direitos e garantias fundamentais.

Por isto, é necessário se atentar para a situação jurídica do investigado e para as atividades desenvolvidas pelas diferentes personagens oficiantes no desenrolar da persecução penal preliminar: Ministério Público, defesa e juiz.

Por primeiro, é de se salientar que o investigado nela não perde sua condição de sujeito de direitos. ${ }^{11}$ Deve-se zelar pelo respeito às garantias e aos direitos processuais, também assegurados na fase de investigação. ${ }^{12}$ É inadmissível, por conseguinte, tratá-lo como objeto da investigação. Significaria odioso retrocesso a sistema inquisitivo.

em diligências realizadas tanto em fase de investigação de infrações, quanto em fase processual. Em atividade preventiva, antevê-se a possibilidade de cometimento de um crime; em atividade repressiva, pressupõe-se o prévio cometimento de um determinado crime. No mesmo sentido, cf.: TOURINHO FILHO, Fernando da Costa. Manual de processo... op. cit., p. 63-64.

${ }^{10}$ A fiscalização da atividade policial pelos representantes ministeriais e pelas autoridades judiciais impõe limites à chamada "discricionariedade de fato". Consoante o exposto por AURY LOPES JR., tal "discricionariedade do fato" é uma realidade confrontante com o ideal de igualdade jurídica. Entre as suas variáveis, estão a gravidade do delito, o comportamento do suspeito e o poderio econômico do infrator. Sem o citado controle, diminui a credibilidade probatória do material recolhido (A crise do inquérito... op. cit., p. 63-65).

${ }^{11}$ Segundo PETRÔNIO CALMON FILHO, "o investigado é aquele sobre quem recai alguma informação que indique ter tido alguma participação no fato ilícito." (A investigação criminal na reforma do Código de Processo Penal: agilidade e transparência. Revista Brasileira de Ciências Criminais, São Paulo, ano 9, n. 34, abr-jun. 2001, p. 67).

${ }^{12}$ A caracterização da imputação desde o principiar da persecução justifica, segundo entendimento doutrinário, imediata reação defensiva, mesmo que operada posteriormente à realização de ato processual, em situações em que o contraditório é diferido (Cf. FERNANDES, Antonio Scarance. A reação defensiva à imputação. São Paulo: RT, 2002, p. 130-133). Tratando-se de meios de investigação de prova, baseados no fator surpresa, deve-se assegurar a informação e a possibilidade de reação, ao término da realização das respectivas diligências. Não apenas autodefesa, como também efetiva assistência de um defensor - aliás, constitucionalmente consagrada (art. $5^{\circ}$, inciso LXIII) - são indispensáveis para o pleno e efetivo respeito aos direitos fundamentais que a Constituição assegura aos investigados, aí se incluindo os princípios e garantias processuais pertinentes aos meios de investigação de prova, mais adiante referidos. A propósito, irresigna-se ENZO ZAPPALÀ com a perigosa tendência de substituir, na fase das investigações, o princípio da presunção de inocência pela regra oposta, segundo a qual a pessoa atingida por indícios é considerada culpada (Le garanzie giurisdizionali in tema di libertà 
Com efeito, para o efetivo exercício dos direitos de que é titular, é indispensável que saiba a posição jurídica por ele ocupada na investigação. Investigados e indiciados devem conhecer o objeto de suspeita contra si formalizada.

A lei processual penal, malgrado se refira, algumas vezes, ao indiciado, não regulamentou o ato de indiciamento. Nem se previu o momento processual em que deva ser realizado. ${ }^{13}$ Segundo lição de FÁBIO KONDER COMPARATO, o indiciamento exerce função de garantia das liberdades individuais. ${ }^{14}$ Por meio dele, dá-se conhecimento oficial da investigação. Além disso, a rigor, é tido por pressuposto para concessão das medidas cautelares, por nele se registrarem os elementos de prova pertinentes à autoria. ${ }^{15}$

No que se refere às atribuições do Ministério Público pertinentes à primeira fase da persecutio criminis, consoante previsto no rol de suas funções institucionais (art. 129, caput e inciso VIII da Constituição Federal), pode "requisitar instauração de inquérito policial e diligências investigatórias, com a necessária indicação dos fundamentos jurídicos de suas manifestações". São atribuições que possibilitam requerimentos de medidas cautelares, com fundamento em elementos de informação constantes nos autos da investigação. Ademais, são indispensáveis para a formação da opinio delicti.

Também é incumbência do órgão ministerial a fiscalização da observância de normas jurídicas no curso da investigação criminal. ${ }^{16}$ Não importa se a persecução do crime se dá por promoção de ação penal de iniciativa pública ou privada. Cumpre ao representante ministerial

personale e di ricerca della prova. Libertà personale e ricerca della prova nell'attuale asseto delle indagini preliminari. Milano: Giuffrè, 1995, p. 64-65).

${ }^{13}$ Como expendido por ANTONIO SCARANCE FERNANDES, em razão da "falha grave" quanto à ausência de regulamentação, fica o ato ao "alvedrio" da autoridade policial, que poderá determinar, livremente, a alteração da situação jurídica do investigado, de suspeito para indiciado (O equilíbrio na investigação... op. cit., p. 328).

${ }^{14}$ Cf. Comissões Parlamentares de Inquérito: limites. Revista Trimestral de Direito Público, São Paulo, ano 2, n. 5, 1994, p. 73.

${ }^{15}$ Cf. Ibidem, p. 73. Não raramente, entretanto, estas medidas são deferidas sem antes ter sido formalizada a alteração da posição jurídica do investigado, de suspeito para indiciado. Nestes casos, em que se determina, por exemplo, quebra de sigilo ou interceptação das comunicações telefônicas, não se pode dizer que seja um simples suspeito, sob pena de não se terem por configurados os pressupostos cautelares.

${ }^{16}$ Retomem-se aqui as observações anteriormente esposadas sobre o controle externo da atividade policial, preconizada no art. 129, inciso VII da Constituição. 
supervisionar o desenrolar das investigações, protestando pelo respeito dos direitos humanos fundamentais, fiel defensor do ordenamento jurídico que é.

Formada opinio delicti no sentido da propositura de uma ação penal, os termos da investigação podem servir não só de elementos de informação para a formulação da acusação, como também para se requerer oportuna produção de prova.

A atuação da defesa nas investigações é imprescindível para a tutela dos direitos do averiguado. ${ }^{17} \mathrm{O}$ efetivo exercício do direito de defesa nesta fase contribui para ser afastado o nefasto e indesejável efeito simbólico da persecução penal.

A garantia da ampla defesa se traduz nos meios de que se dispõe no desenrolar da atividade investigativa para a mencionada tutela de direitos. Entre eles, destacamos requerimentos de realização de diligências em favor do averiguado, observância da disciplina do interrogatório na investigação ${ }^{18}$ e pedidos de revogação de medidas cautelares.

No art. 14 do Código de Processo Penal, prevê-se a possibilidade de o indiciado requerer diligências, cuja realização depende de sua admissibilidade, apreciada por autoridade policial. ${ }^{19}$ Entretanto, a possibilidade de se defender é decorrência inarredável da assegurada garantia da mais ampla defesa, conjugada aos demais direitos e garantias fundamentais.

\footnotetext{
${ }^{17}$ A defesa, que se exibe na contrariedade, pode ser exercida de forma autônoma. No inquérito policial, não há contraditório no sentido técnico, por não haver parte e contraparte. Tal fato não obsta o exercício do direito de defesa. Pelo contrário, por haver imputação em sentido amplo, deve-se possibilitar seja exercido com amplitude. Neste sentido, cf.: MIRANDA, Pontes de. Comentários à Constituição de 1967, com a Emenda n. 1, de 1969. 2. ed. São Paulo: RT, 1971. t. V., p. 234-237. Sobre o momento para o exercício do direito de defesa no inquérito policial, vislumbra-se a atribuição de um fato ao suspeito ou indiciado em diversos atos do inquérito policial: prisão em flagrante, nota de culpa, portaria decorrente de boletim de ocorrência, ato de indiciamento e medidas cautelares (Cf. SAAD, Marta. O direito de defesa ... op. cit., p. 261-265).

${ }^{18}$ Cf. MORAES, Maurício Zanoide de. Perplexidade de Jano: quando o passado é mais presente do que o futuro (nova regulamentação do interrogatório e sua aplicabilidade na fase pré-processual). Estudos em Homenagem à Professora Ada Pellegrini Grinover. 1. ed. São Paulo: DPJ, 2005, p. 373-381.

${ }^{19}$ É de se observar que se a defesa for concretizada por defensor público, aplicam-se as disposições preconizadas na legislação federal e na estadual, respectivamente, Lei Complementar n. 80, de 1994, e Lei Complementar n. 988, de 2006. O art. $8^{\circ}$, inciso XVI da primeira prevê que é atribuição do Defensor Público-Geral da União "requisitar de qualquer autoridade pública e de seus agentes, certidões, exames, perícias, vistorias, diligências, processos, documentos, informações, esclarecimentos e demais providências necessárias à atuação da Defensoria Pública.” O legislador paulista incumbiu a mesma atribuição não só ao Defensor Público-Geral do Estado, como também aos demais membros da Defensoria Pública do Estado (arts. 19, inciso XX e 162, inciso IV). Os citados
} 
Com tais diligências, garante-se ao acusado a possibilidade de descobrir fontes de prova que interessem à demonstração de sua versão sobre os fatos, colaborando para a formação da opinio delicti por parte do órgão ministerial e para a produção de prova em eventual ação penal.

Demais disso, o ofício da defesa evita a adoção indevida de medidas cautelares e acusações destituídas de justa causa, infundadas e temerárias. ${ }^{20}$

Além da atuação defensiva no decorrer da investigação, é inarredável o exercício da função judiciária estatal. O juiz nela oficiante, outrora instrutor, passou a atuar como "juiz de garantia" ou "juiz de liberdades", ${ }^{21}$ que fiscaliza sua adequação ao ordenamento jurídico.

Reservou-se ao Poder Judiciário a deliberação sobre restrição de direitos e garantias fundamentais, ${ }^{22}$ como ocorre na execução dos meios de investigação de prova (por exemplo, interceptação de comunicações, busca e apreensão, quebra de sigilo bancário) e determinação

dispositivos, por reconhecerem a possibilidade de requisição de diligências pela defesa, favorecem a consecução do equilíbrio na investigação criminal.

${ }^{20}$ No mesmo sentido, cf.: SAAD, Marta. $O$ direito de defesa $\ldots$ op. cit., p. 198-204.

${ }^{21} \mathrm{Na}$ Europa, o juiz de instrução deixou de ser instrutor. Passou a atuar como "juiz de garantia" (juiz-garante), ou "juiz de liberdades", durante a fase de investigação, zelando pela legalidade dos atos nela praticados. Sua atuação condiz com o sistema acusatório, mais propício ao respeito dos direitos e garantias processuais. Entre elas estão a da liberdade pessoal, a da liberdade das comunicações e a da duração da investigação em prazo razoável. O mesmo se deu, pode-se dizer, nos países integrantes da América Latina, seguidores do Código de Processo Penal Modelo (Cf. CHOUKR, Fauzi Hassan. Garantias constitucionais na investigação criminal. 2. ed. Rio de Janeiro: Lumen Juris, 2001, p. 43-75). Segundo ENZO ZAPPALÀ, o juiz oficiante nas investigações, com função prevalente de constituir um momento de garantia para as partes, não elimina o risco do desenvolvimento concertado das investigações pelo Ministério Público e o juízo instrutor, em nome de um comum empenho estratégico, de um comum projeto investigativo. Falta, no seu entender, uma real posição de imparcialidade do juízo oficiante nas investigações, vista como equidistância das partes. A ele não seria assegurada a plenitude da função jurisdicional, pois sua cognição não seria embasada no contraditório das partes postas em condições de simétrica paridade, mas sim pelo argumento livremente formulado e ofertado por apenas uma delas: o Ministério Público. Desta maneira, a autoridade judicial, além de não considerar argumentações defensivas que poderiam ser apresentadas, deixa de ter conhecimento de fatos que interessem à defesa, como causas de justificação e de não punibilidade (Le garanzie giurisdizionali... op. cit., p. 56-57). Malgrado se reconheça a pertinência das pesadas críticas à figura do juiz-garante, se comparado com a do juiz instrutor, revela-se condizente com o sistema acusatório. O projeto de novo Código de Processo Penal (Projeto n. 156, de 2009) disciplina a figura do "juiz das garantias", ao qual é atribuída a responsabilidade pelo controle da legalidade das investigações e pela salvaguarda de direitos fundamentais (art. 14) (BRASIL. Projeto de Lei do Senado n. 156, de 2009. Disponível em: http://www.senado.gov.br/atividade/materia/getPDF.asp?t=85509\&tp=1. Acesso em: 10/01/2011).

${ }^{22}$ Cf. infra, item n. 2.6 . 
de prisão cautelar. ${ }^{23}$ É possível a restrição de direitos fundamentais, se por ele for ordenada: questão cuja análise se reserva ao Poder Judiciário.

Por vezes, a investigação de fontes de prova somente é possível por meio de invasão na esfera jurídica de um indivíduo, restringindo-se valores tutelados pelo ordenamento jurídico, para retirada do manto protetor da criminalidade. Nestas situações, há que se requerer à autoridade judicial a execução de um meio de investigação de prova, por meio da observância de sua disciplina legal. ${ }^{24}$

${ }^{23}$ Cf. FERNANDES, Antonio Scarance. O equilíbrio na investigação... op. cit., p. 321. Convém lembrar, também, que o juiz-garante há que resguardar também os direitos assegurados aos investigados presos, porque limitam a atuação estatal na restrição cautelar do direito à liberdade. Exemplificativamente, citamos art. $5^{\circ}$, incisos XLIX (integridade física e moral), LVIII (cumprimento de pena em estabelecimentos distintos), LXII (comunicação a prisão), LXIII (direito ao silêncio), LXIV (identificação dos responsáveis pela prisão) da Constituição Federal. Devem-se resguardar, ainda, os direitos de investigados em desfavor de quem sejam decretadas medidas cautelares reais, como o arresto, o sequestro e a especialização da hipoteca legal (artigo 125 e seguintes do Código de Processo Penal).

${ }^{24}$ Os meios de investigação de prova devem ser eficientes, aptos a proporcionar a descoberta de fontes de prova, sem se descurar da observância de direitos e garantias fundamentais (v., infra, n. 2.1 a 2.6). Reitera-se aqui a utilidade dos meios de investigação de prova para a persecução penal de delitos graves, de delito praticados por organizações criminosas e de delitos cuja execução seja diferenciada, porque se perfaça sob a proteção a direitos e garantias individuais, ainda que a infração não seja de elevada gravidade (v. introdução, n. 1). Sobre a necessidade de se terem meios aptos a possibilitar o conhecimento da realidade fática, é de se ressaltar a lição de ANTONIO SCARANCE FERNANDES: "a eficiência é, em síntese, a capacidade de algo de produzir um determinado efeito. No processo penal, a eficiência é a capacidade de um ato, de um meio de prova, de um meio de investigação, de gerar o efeito que dele se espera. Assim, a eficiência do ato de citação é vista quanto a sua capacidade de ocasionar o efeito consistente na ciência, ao acusado, da acusação que lhe foi imputada. Por outro lado, a eficiência de um meio de investigação que tem como finalidade buscar uma fonte de prova será medida em razão de sua capacidade de propiciar a descoberta da fonte" (Reflexões sobre as noções de eficiência e de garantismo no processo penal. In: FERNANDES, Antonio Scarance; ALMEIDA, José Raul Gavião de; MORAES, Maurício Zanoide de. Sigilo no processo penal. São Paulo: RT, 2008, p. 25). Quanto aos meios de investigação de prova, enfatiza o autor: "um meio de investigação é eficiente se ele se presta ao fim para o qual foi previsto e não afronta norma de garantia. Será eficaz se, em uma investigação produzir o resultado esperado e não ocorrer lesão indevida a garantias do investigado ou a direitos de terceiros. Imagine-se que, na apuração do fato, houve uma infiltração policial. Será eficiente se, em ser vulnerada a garantia, levou à descoberta de membros importantes da organização criminosa e à apreensão de coisas trazidas ou guardadas pelos agentes delituosos ou de produtos provenientes do crime." (FERNANDES, Antonio Scarance. O equilíbrio na repressão ao crime organizado. In: FERNANDES, Antonio Scarance; ALMEIDA, José Raul Gavião de; MORAES, Maurício Zanoide (Coords.). Crime organizado: aspectos processuais. São Paulo: RT, 2009, p. 11). Observe-se que a eficiência dos meios não é exclusiva do direito processual penal. A questão também é analisada em direito processual civil. Preleciona CÂNDIDO RANGEL DINAMARCO: "como o juiz julgará a causa de um modo se certos fatos tiverem ocorrido e de modo oposto se não ocorreram, para julgar é preciso saber se ocorreram ou não. Por isso e dada a institucionalizada ignorância do juiz quanto aos fatos relevantes para julgamento, é indispensável dotar o processo de meios capazes de tirar seu espírito do estado de obscuridade e iluminá-lo com a representação da realidade sobre a qual julgará" (grifou-se) (Instituições de direito processual civil. 2. ed. São Paulo: Malheiros, 2002. v. III, p. 43). No mesmo sentido, JOSÉ ROBERTO DOS SANTOS BEDAQUE conclui que "a grande preocupação da ciência processual contemporânea está relacionada, portanto, à eficiência da Justiça, que se traduz na busca de mecanismos para alcançar a efetividade da tutela jurisdicional. Na medida em que cabe ao direito processual a sistematização do método estatal de solução de controvérsias, devem os 
A propósito, é de se ressaltar que o art. 156 do Código de Processo Penal não atribui poderes de investigação ao juiz penal. Segundo a Constituição, compete aos juízes processar e julgar. Não lhes foi atribuída competência para investigar no âmbito extraprocessual. ${ }^{25} \mathrm{O}$ juiz pode determinar a produção antecipada de $\operatorname{provas}^{26}$ consideradas urgentes e relevantes, atividade distinta da investigação de fontes de prova. ${ }^{27}$

Ainda a propósito da investigação, é salientada a necessidade de consecução de equilíbrio $^{28}$ na atuação dos órgãos públicos e demais interessados no decorrer da persecução preliminar.

estudiosos desta ciência voltar sua atenção para a criação de meios aptos a obtenção do resultado desejado." (Tutela cautelar e tutela antecipada: tutelas sumárias e de urgência (tentativa de sistematização). 5. ed. São Paulo: Malheiros, 2009, p. 15). Não basta, contudo, eficiência. Exige-se observância a direitos e garantias processuais na execução dos mencionados meios. Há que se buscar "o equilíbrio entre a exigência de assegurar ao investigado, ao acusado e ao condenado a aplicação das garantias fundamentais do devido processo legal e a necessidade de proporcionar aos órgãos de Estado encarregados da persecução penal mecanismos para uma atuação positiva.” (FERNANDES, Antonio Scarance. O equilíbrio na repressão... op. cit., p. 10).

${ }^{25}$ Lembrem-se, a propósito, as palavras de ADA PELLEGRINI GRINOVER sobre a previsão da Lei n. 9.034, de 1995, que prevê a possibilidade de o juiz operar diligências de colheita de dados sigilosos em qualquer fase da persecução penal: “o art. $3^{\circ}$ da Lei no 9.034 é, a meu ver, inconstitucional, porque fere a mais importante garantia do 'devido processo legal', que é a imparcialidade do juiz. E é, igualmente, inconstitucional, porque vulnera o modelo acusatório, de processo de partes, instituído pela Constituição de 1988, quando considera os ofícios da acusação e da defesa como funções essenciais ao exercício da jurisdição, atribuindo estas aos juízes, que têm competência para processar e julgar, mas não para investigar no âmbito extra-processual" (Que juiz inquisidor é esse? Boletim IBCCRIM, São Paulo, n.30, p. 1, jun. 1995). Também é de se destacar as considerações de MARCOS ALEXANDRE COELHO ZILLI: "quando o juiz se põe a apurar um fato, não limitado ainda pela descrição formalizada que se subsume a uma previsão típica, ilícita e culpável, acaba por desviar-se do papel a ele originariamente traçado, qual seja, de aplicação do direito e de solução dos conflitos penais, imiscuindo-se na atividade que se esperaria fosse exercida, apenas, pela acusação, o que acaba aproximando o quadro daquele de inspiração inquisitória" (Resquícios inquisitórios na Lei 9.034/1998. Revista Brasileira de Ciências Criminais, São Paulo, n. 46, p. 174-195, jan-fev. 2004). A inconstitucionalidade do dispositivo foi declarada pelo Supremo Tribunal Federal no julgamento da ADIN n. 1570/DF (STF, Pleno, Rel. Min. Maurício Correa, j. em 12/02/2004, DJ 22/10/2004, p. 4).

${ }^{26} \mathrm{Cf}$. infra, item n. 1.2.3.5.

$27 \mathrm{O}$ texto normativo do art. 156 deve se compatibilizar ao modelo de processo acusatório consagrado na Constituição, que tem por primado a imparcialidade. Admitir a investigação pela autoridade judicial significaria transformar o "juiz de garantias” em "juiz inquisidor”. No mesmo sentido, cf: ZILLI, Marcos Alexandre Coelho. Resquícios inquisitórios... op. cit., p. 174-195, jan-fev. 2004; GOMES FILHO, Antonio Magalhães. Provas: Lei 11.690, de 09.06.2008. In: MOURA, Maria Thereza de Assis (Coord.). As reformas no processo penal: as novas Leis de 2008 e os Projetos de Reforma. São Paulo: RT, 2008. p. 260-261. Em doutrina estrangeira, evidencia-se entendimento semelhante: "il ruolo che il nuovo codice di rito assegna al giudice gli impedisce di svolgere, di regola attività di ricerca della prova, essendo cio demandato alle parti" (Cass. 19 dicembre 1991, Principato) (SIRACUSANO, Delfino. Le prove: i mezzi di ricerca della prova. In: SIRACUSANO, Delfino; GALATI, Antonini; TRANCHINA, Giovanni; ZAPPALÀ, Enzo. Diritto Processuale Penale. Milano: Giuffrè, 2006. v. 1. cap. 3. p. 400).

${ }^{28}$ Cf. FERNANDES, Antonio Scarance. O equilíbrio na investigação... op. cit., p. 319-340. 
Concluída a investigação, elementos de informação, extraídos de fontes de prova descobertas, emergem dos termos das diligências nela operadas. Estes elementos propiciam a formação de juízo de admissibilidade de medidas cautelares, de opinio delicti e de juízo de admissibilidade de acusação eventualmente formalizada. ${ }^{29}$ No direito brasileiro, também são úteis para fundamentar absolvição sumária (art. 397 do Código de Processo Penal).

Do exame da investigação penal, sob a perspectiva do cotejo de sua finalidade com a autuação dos entes interessados, evidencia-se a sua relevância para a persecução penal, nela incluída a constatação de sua ligação com o direito à prova. Sendo a finalidade da investigação a colheita de infomações sobre um delito tido por ocorrido, é preciso reconhecer aos entes que nela oficiam a faculdade de procurar as fontes das quais se possam extrair tais informações.

O exercício efetivo do direito a prova na investigação pressupõe a delimitação de meios legais pelo legislador para possibilitar a descoberta de prova, entre os quais sobressaem

\footnotetext{
${ }^{29} \mathrm{O}$ juízo deve verificar a regularidade da prática dos atos de investigação outrora ordenados que a respaldem. Se estiver estribada em elementos de convicção inadmissíveis, porque obtidos com violação de direitos e garantias fundamentais, impõe-se sua rejeição. A respeito da avaliação dos elementos probatórios obtidos no inquérito, confira-se o escólio de SÉRGIO MARCOS DE MORAES PITOMBO: "dizer-se, por isso, que o inquérito policial consiste em mero procedimento administrativo e encerra investigação administrativa, é simplificar, ao extremo, a realidade sensível. Resta-se na necessidade forçada de asseverar, em seguida, que a decisão judicial, que recebe a denúncia ou a queixa, embasada em inquérito, volta no tempo e no espaço, judicializando alguns atos de procedimento. As buscas e as apreensões, bem como todas as perícias (exames, vistorias e avaliações) emergem quais modelos de tal operação. Espécie de banho lustral sobre os meios de prova, encontráveis no inquérito. Preferível reconhecer, com singeleza, que no inquérito policial há atos processuais, praticados por delegação, e nele existe contingente de instrução criminal definitiva" (Inquérito policial: novas tendências. Belém: Cejup, 1987, p. 21). Presentes os requisitos legais e sobressalentes elementos de informação sobre materialidade e autoria regularmente registrados em investigação, a acusação deve ser recebida em decisão, com a devida fundamentação, concisa que seja. Não se espera, a esta altura do desenrolar processual, análise exaustiva do objeto da ação penal: seria o mesmo que admitir decreto condenatório de antemão lavrado, com fulcro em elementos de informação, tornando dispensável a oportuna produção da prova. A motivação expendida na formulação do juízo de admissibilidade da acusação possibilita o controle da regularidade das atividades desenvolvidas na investigação. Dela se extraem elementos para que a decisão possa ser impugnada pelas partes e por terceiros juridicamente interessados (Cf. GOMES FILHO, Antonio Magalhães. A motivação das decisões penais. 1. ed. São Paulo: RT, 2001, p. 205-210). Considere-se, ainda, que, sendo proposta uma ação penal, avulta a função judiciária estatal na fase intermediária da persecução penal, oportunidade em que juízo competente decide se admite ou não a acusação formalizada. Parece-nos que a imparcialidade do órgão jurisdicional resta comprometida, se o mesmo juiz que proferiu provimentos cautelares em investigações venha a formular juízo de admissibilidade da acusação e a julgar a causa. "O juiz prevenido tem sua imparcialidade fulminada pelos prejulgamentos que realizou e não pode ser o que sentencia" (Cf. LOPES JR., Aury. A crise do inquérito... op. cit., p. 79, nota 16). Deixamos, de lege ferenda, sugestão de derrogação da regra que fixa competência por prevenção no processo penal, estabelecendo-se que o juiz sentenciante não seja o mesmo que oficie em investigação.
} 
os meios de investigação de prova, que restringem direitos e garantias processuais. $\mathrm{O}$ significado dos meios de investigação de prova para a persecução penal emerge do fenômeno probatório, por toda sua extensão.

\subsection{O direito à prova e o fenômeno probatório}

A necessidade de colheita de dados esclarecedores de um delito tido por ocorrido, evidenciada já na primeira fase da persecução penal, justificou o reconhecimento da existência de um direito autônono: o direito à prova.

O direito à prova, como lembrado por Antonio Magalhães Gomes Filho se caracteriza em um "verdadeiro direito subjetivo à introdução do material probatório no processo, bem como de participação em todas as fases do procedimento respectivo; direito subjetivo que possui a mesma natureza constitucional e o mesmo fundamento dos direitos de ação e de defesa". ${ }^{30}$ No direito brasileiro, o direito à prova é expressamente previsto no art. $8^{\circ}$, item 2 $2^{\circ}$, alínea "f” da Convenção Americana sobre Direitos Humanos (Pacto de São José da Costa Rica), integrando o sistema de direitos e garantias fundamentais assegurado pela Constituição Federal $\left(\operatorname{art.} 5^{\circ}, \S 2^{\circ}\right) .^{31}$

Assim como os direitos de ação e de defesa, o direito de provar é um direito público. Os seus titulares são os entes titulares da ação - Ministério Público e ofendido -, bem como o assistente de acusação, o acusado e o investigado. E tem como sujeitos passivos: "o Estado, representado pela figura do órgão jurisdicional, que deve tornar efetivas as postulações das partes em relação as atividades probatórias"; "a parte contrária, quando tenha em seu poder

\footnotetext{
${ }^{30}$ Cf. GOMES FILHO, Antonio Magalhães. Direito à prova no processo penal. São Paulo: RT, 1997, p. 84.

${ }^{31}$ FLÁVIA PIOVESAN também se expressa quanto à hierarquia constitucional das normas sobre direitos humanos (A incorporação, a hierarquia, e o impacto dos tratados internacionais de proteção dos direitos humanos no direito brasileiro. In: GOMES, Luiz Flávio; PIOVESAN, Flávia (Coords.). O sistema interamericano de proteção dos direitos humanos e o direito brasileiro. São Paulo: RT, 2000. Cap. V, p. 172-173 e 179). Em sentido contrário, afirmando o "status normativo supralegal" de normas de tratados sobre direitos humanos, cf.: STF, Trib. Pleno, Min. Rel. Carlos Britto, RE 349.703/RS, j. em 03/12/2008, m.v., DJU de 05/06/2009. Disponível em: www.stf.jus.br. Acesso em: 28/10/2010.
} 
alguma prova", ressalvado o direito do acusado e do investigado a não autoincriminação; ou "terceiros, como as testemunhas e os peritos, a cujo dever de veracidade corresponde um direito da parte à obtenção da informação verdadeira". ${ }^{32}$

A propósito do conteúdo do direito à prova, o exercício deste direito "deve permear o fenômeno probatório em toda a sua integralidade". 33 Por esta razão, é assegurado em diferentes momentos da persecução penal: em investigação, como faculdade de "procurar e descobrir provas"; em processo, no qual devem ser garantidas oportunidades para a proposição, a admissão, a produção e a valoração da prova. ${ }^{34}$

Enfatizamos o momento da investigação com o estudo dos meios de investigação de prova. Mas a atividade probatória não se resume em atos de investigação cuja prática visa a descoberta de fontes de prova, pessoas ou coisas, das quais se possam extrair informações relevantes para o desfecho da primeira fase da persecução penal. Constitui um fenômeno ${ }^{35}$ da mais alta complexidade, também integrada por atos realizados em fase processual, se uma acusação for formalizada.

A compreensão do fenômeno probatório é deveras facilitada com o exame do significado do termo prova (rectius: dos diversos significados de prova do termo prova). ${ }^{36}$ Com sua apresentação, não pretendemos esgotar os possíveis usos do termo. O objetivo é salientar a pluralidade de suas denotações, entre as quais destacamos as relevantes para delimitação do conceito de meio de investigação de prova.

\footnotetext{
${ }^{32}$ Neste sentido, cf.: GOMES FILHO, Antonio Magalhães. Direito à prova... op. cit., p.84-86. Às considerações do autor, quanto ao elemento subjetivo do direito à prova, acrescentamos o direito do investigado à prova, considerado a constatação do citado autor de um direito à investigação, como primeiro momento do direito à prova.

${ }^{33}$ Cf.: GOMES FILHO, Antonio Magalhães. Direito à prova... op. cit., p. 87.

${ }^{34}$ Cf.: Ibidem, p. 87-89.

$35 \mathrm{O}$ termo fenômeno é aqui empregado como sinônimo de atividade de interesse científico, suscetível de explicação: no caso, a atividade probatória. O termo também é empregado por GIULIO UBERTIS, ao tratar da dialética probatória (Prova - II) Teoria generale del processo penale. In: Enciclopedia Giuridica - Istitvto Enciclopedia Italiana fondata da Giovanni Treccani. Roma: Istituto Poligrafico e Zecca dello Stato, [2004]. vol. XXV, p. 2) e por MICHELE TARUFFO (La prova dei fatti giuridici: nozioni generali. Milano: Giuffrè, 1992 , p. 413-414).

${ }^{36}$ A dimensão polissêmica do termo prova decorre dos diferentes aspectos do fenômeno probatório (Cf. TARUFFO, Michele. La prova ... op. cit., p. 421).
} 


\subsubsection{Significados do termo prova}

Árdua é a tarefa de conceituar os meios de investigação de prova, abrangendo a diversidade de suas espécies. Todavia, afigura-se imprescindível, para que se possibilite identificar a natureza jurídica de atos praticados na investigação e delimitar o respectivo regime jurídico aplicável. Emerge dos diferentes significados do termo prova.

\subsubsection{Definições de fonte de prova, meio de produção de prova, elemento de prova, resultado de prova e meio de investigação de prova}

O termo prova, em terminologia processual, tem diversos significados: fonte de prova; meio de investigação de prova; meio de produção de prova; elemento de prova e resultado de prova. ${ }^{37}$ As diferentes acepções do termo são correlacionadas, ${ }^{38}$ derivadas da noção de fonte de prova.

Fonte de prova é expressão utilizada para designar pessoa ou coisa, da qual se podem extrair dados objetivos, informações relevantes para investigação ou processo. Daí decorre a classificação entre fontes pessoais (testemunha, vítima, agente do delito, entre outros) e fontes reais (por exemplo, documentos, em sentido amplo). ${ }^{39}$

\footnotetext{
37 Embora não haja, no direito nacional, sistematização legislativa, a doutrina sustenta que os diferentes significados do termo prova são aplicáveis ao direito processual penal brasileiro. A propósito da polissemia do termo prova, cf.: GOMES FILHO, Antonio Magalhães. Notas sobre a terminologia da prova (reflexos no processo penal brasileiro). In: YARSHEL, Flávio Luiz, MORAES, Maurício Zanoide de (Orgs.). Estudos em Homenagem à Professora Ada Pellegrini Grinover. 1. ed. São Paulo: DPJ, 2005, p. 310; GOMES FILHO, Antonio Magalhães; BADARÓ, Gustavo Henrique Righi Ivahy. Prova e sucedâneos... op. cit., p. 177; BADARÓ, Gustavo Henrique Righi Ivahy. Direito processual penal: tomo I. 1. ed. Rio de Janeiro: Elsevier, 2008, p. 197.

${ }^{38}$ Entenda-se que não se trata de preciosismo no emprego de linguagem. A precisão técnica é relevante, porque interfere no regime jurídico aplicável aos institutos pertinentes a prova. "Mede-se o grau de desenvolvimento de uma ciência pelo refinamento maior ou menor de seu vocabulário específico. Onde os conceitos estão mal definidos, os fenômenos ainda confusos e insatisfatoriamente isolados sem inclusão em uma estrutura adequada, onde o método não chegou ainda a tornar-se claro ao estudioso de determinada ciência, é natural que ali também seja pobre a linguagem e as palavras se usem sem grande precisão" (DINAMARCO, Cândido Rangel. Fundamentos do processo civil moderno. 5. ed. São Paulo: Malheiros, 2002. t. I., p. 136-137).

${ }^{39}$ Cf. GOMES FILHO, Antonio Magalhães. Notas sobre a terminologia... op. cit., p. 308; e UBERTIS, Giulio. Prova - II) Teoria... op. cit., p. 2.
} 
Quando um fato delituoso é praticado, o agente do delito não está só. Ele protagoniza um acontecimento. Mas coexiste com outras pessoas e coisas que podem igualmente integrar o palco do mundo fenomênico. É por isso que as fontes de prova, por serem provenientes do fato em si, são anteriores e extraprocessuais: a sua existência - que é concomitante ao fato antecede ao início da persecução penal, e independe da instauração ulterior de um processo.

Em lei processual penal, estruturam-se institutos jurídicos para que se possam extrair informações sobre o fato das fontes de prova.

Os meios de produção prova, também chamados meios de prova, são "os instrumentos ou atividades por intermédio dos quais os dados probatórios (elementos de prova) são introduzidos e fixados no processo (produção de prova). ${ }^{, 40}$ Em outras palavras: com tais meios, uma fonte de prova conhecida, real ou pessoal, e os dados probatórios dela extraídos são criteriosamente selecionados e registrados em termos processuais, tornando-se úteis para apreciação de tema de prova. ${ }^{41}$ A prova testemunhal, a prova documental e a prova pericial os exemplificam.

\footnotetext{
${ }^{40}$ Cf. GOMES FILHO, Antonio Magalhães. Notas sobre a terminologia... op. cit., p. 308.

${ }^{41}$ Cf. GOMES FILHO, Antonio Magalhães. Notas sobre a terminologia... op. cit., p. 309. No mesmo sentido, ANTONIO SCARANCE FERNANDES afirma que "um meio de produção de prova é o mecanismo utilizado para trazer a fonte de prova para o processo. Assim, o depoimento de alguém é um meio de prova, pois transpota para o processo a fonte de prova, ou seja, o fato de conhecimento direto ou indireto da testemunha. Quando se assegura a alguém o direito de não depor e de guardar sigilo sobre o que sabe restringe-se o uso de um meio de prova" (O sigilo e a prova criminal. Revista da Associação de Professores de Ciências Penais, RT, São Paulo, ano 3, n. 4, jan-jun. 2006, p. 158). Segundo LUIGI MONTESANO, "è facile distinguere tra la fonte materiale di prova, che, cercata e trovata fuori del processo, vi entra per iniziativa o indicazione di chi, appunto, l'ha cercata e trovata, e il mezzo istruttorio di quella fonte, cioè il procedimento, tipizzato dalla lege, che, sull'impulso dello stesso soggetto che ha acquisito quella fonte, o di altri, viene svolto per 'assumere' al giudizio la fonte medesima, cioè per valutarne l'utilità o no ai fini della decisione in fatto". Em tradução livre do autor: "é fácil distinguir a fonte material de prova, que, procurada e encontrada fora do processo, nele ingressa por iniciativa ou indicação de quem, justamente, tenha-a procurou e a encontrou, e o meio instrutório daquela fonte, isto é o procedimento, tipificado pela lei, que, sob o impulso do mesmo sujeito que a descobriu, ou de outros, é desenvolvida para 'atribuir' ao juízo a fonte mesma, para que possa apreciar sua utilidade ou não quanto à decisão sobre o fato" (Le prove disponibili d'ufficio e l'imparzialità del giudice civile. Rivista Trimestrale di Diritto e Procedura Civile, Milano, Giuffrè, anno XXXII, 1978, p. 195). No mesmo sentido, CANDIDO RANGEL DINAMARCO os define como "as técnicas destinadas a atuar sobre as fontes e delas efetivamente extrair o conhecimento dos fatos relevantes para a causa" (Instituições de direito... op. cit., p. 47-48).
} 
A produção de prova é atividade endoprocessual, admitida por juízo competente e desenvolvida perante ele, com o conhecimento e a participação das partes, sob o crivo do contraditório. $^{42}$

A relevância da distinção entre meio e fonte de prova diz respeito à distribuição da iniciativa probatória entre partes e o juiz. A este respeito, GuSTAVO HENRIQUE RIGHI IVAHY BADARÓ enfatiza: "as partes têm disponibilidade plena sobre as fontes de prova, visto que são elas, e não o juiz, quem melhor conhece como provar os fatos alegados. Contudo, no momento que a existência de uma fonte de prova chega ao conhecimento do juiz, poderá ele determinar que seja produzido o meio de prova a ela relativo". ${ }^{43}$

Elemento de prova constitui dado objetivo extraído de fonte de prova que confirma ou nega uma asserção sobre fato relevante para a decisão da causa (objeto de prova). ${ }^{44}$ Deve ser

\footnotetext{
${ }^{42}$ Cf. GOMES FILHO, Antonio Magalhães. Notas sobre a terminologia... op. cit., p. 309. A prova produzida possibilita a feitura de considerações sobre os temas de prova: visa-se a atingir o mais alto grau de denotação na reconstrução histórica dos fatos.

${ }^{43}$ Cf. Onus da prova no processo penal. 1. ed. São Paulo: RT, 2003, p. 167. Como ressaltado pelo autor, os meios de prova têm por destinatário o juiz, pois, por inserirem as fontes de prova no processo, possibilitam o convencimento da veracidade ou falsidade das alegações fáticas. Já as fontes de prova destinam-se, em princípio, às partes. Cabe a elas buscar e levá-las ao processo, se for lhes for interessante. O juiz, por seu turno, recebe-as na forma estabelecida para sua produção - o que o permite conhecer os fatos e valorá-los. Enfatiza, porém, merecer reparos a conclusão de que as fontes de prova destinam-se exclusivamente às partes, porque podem ser utilizadas por quem as conheça, partes ou juiz, o qual, no exercício de seu poder instrutório, determina, ex officio, a produção de prova diante de fonte levada ao seu conhecimento pelas partes ou na produção de outra prova. Lembra, ainda, que a determinação de produção de prova pelo juiz pode ocorrer sem prévia referência a fonte nos autos, como, por exemplo, na ordenação de juntada de certidão de antecedentes criminais. Não admite, entretanto, falar que cabe ao juiz "averiguar ou buscar fontes de prova, sob pena de perder a sua imparcialidade $\mathrm{e}$ desnaturar a sua verdadeira função", por se tornar, concomitantemente, juiz instrutor e julgador da causa.

Frise-se, também, que a distinção entre meio de prova e fonte de prova interessa aos acusados em geral. Certo que não são obrigados a produzir prova ("nemo tenetur se detegere"), sobretudo contra si mesmo, constituem, eventualmente, fonte de prova. Suas declarações, espontaneamente prestadas em interrogatório - que não é meio de prova, mas meio de defesa - podem configurar elementos úteis para decisão da causa. No mesmo sentido do ora afirmado, repisando a natureza do interrogatório como meio de defesa, cf.: GRINOVER, Ada Pellegrini. Interrogatório do réu e direito ao silêncio. Ciência Penal, São Paulo, v. 3, n. 1, 1976, p. 20-21; MORAES, Maurício Zanoide. Interrogatório: uma leitura constitucional. In: MORAES, Maurício Zanoide de et al. Escritos em homenagem a Alberto Silva Franco. São Paulo: RT, 2003, p. 336; MORAES, Maurício Zanoide de. Perplexidade de Jano... op. cit., p. 367-368; GRINOVER, Ada Pellegrini. O interrogatório como meio de defesa. Revista do Instituto Brasileiro de Ciências Criminais, São Paulo, n. 53, p. 185-200, mar-abr. 2005; GRINOVER, Ada Pellegrini. O processo: estudos e pareceres. São Paulo: Perfil, 2005, p. 307; GOMES FILHO, Antonio Magalhães. Notas sobre a terminologia... op. cit., p. 309; GRINOVER, Ada Pellegrini; GOMES FILHO, Antonio Magalhães; FERNANDES, Antonio Scarance. As nulidades no processo penal. 11. ed. São Paulo: RT, 2009, p. 75; BADARÓ, Gustavo Henrique Righi Ivahy. Direito processual penal: tomo I... op. cit., p. 199.

${ }^{44}$ Cf. UBERTIS, Giulio. Prova - II) Teoria... op. cit., p. 2; e GOMES FILHO, Antonio Magalhães. Notas sobre a terminologia... op. cit., p. 307.
} 
empregado no plural (elementos de prova ou elementos probatórios), pois o convencimento judicial, em princípio, resulta de mais de um, isto é, de uma pluralidade de informações. ${ }^{45}$ Podem-se citar, como exemplo, o conteúdo de um documento e as declarações de uma testemunha.

A conclusão sobre o conjunto de elementos probatórios extraídos de fontes de prova pertinentes ao fato investigado insertos nos autos do processo é o resultado da prova, obtido numa valoração judicial destes elementos. ${ }^{46} \mathrm{O}$ elemento de prova, antes da apreciação judicial, é "o dado bruto que se extrai da fonte de prova". 47

Note-se que de uma fonte de prova ao respectivo resultado probatório, há uma longa caminhada. Entretanto, a fonte de prova pode ser desconhecida antes de se iniciar o percurso, o que torna necessária a investigação de sua existência ou inexistência. ${ }^{48} \mathrm{~A}$ tarefa de pesquisa pode ser obstada por direitos e garantias que integram a esfera do indivíduo. Por isso, com vistas a possibilitar a restrição de tais direitos e garantias para a descoberta de fontes de prova, o legislador delineia outros institutos: os meios de investigação de prova.

\footnotetext{
${ }^{45}$ Cf. GOMES FILHO, Antonio Magalhães. Notas sobre a terminologia... op. cit., p. 307.

${ }^{46}$ No mesmo sentido, ANTONIO MAGALHÃES GOMES FIHO conceitua resultado de prova, "que é obtido não apenas pela soma daqueles elementos, mas sobretudo por meio de um procedimento intelectual feito pelo juiz, que permite estabelecer se a afirmação de um fato é verdadeira ou não" (Notas sobre a terminologia.. op. cit., p. 308). Nesta linha de pensamento, MICHELE TARUFFO conclui que prova também "indica il risultato che deriva dall'acquisizione dei mezzi di prova nel processo e dalla loro valutazione da parte del giudice" (La prova... op. cit., p. 422). Importa salientar que a conclusão do processo não resulta de uma consequência de uma análise passiva dos resultados probatórios pelo juízo. "La conclusione del processo, insomma, non è la conseguenza della passiva recezione delle risultanze probatorie da parte del giudice, ma dell'attiva partecipazione di tutti i soggetti processuali che, da diverse prospettive, intervengono in ogni fase dello svolgersi procedimentale, indirizzandone il corso anche in dipendenza della differente incidenza delle loro personalità". Em tradução livre do autor: "a conclusão do processo, em suma, não é a consequência da passiva recepção dos resultados probatórios por parte do juiz, mas da ativa paricipação de todos os sujeitos processuais que, por diversas perspectivas, intervêm em qualquer fase do desenvolvimento procedimental, interferindo em seu curso de acordo com a diferente incidência de sua personalidade" (UBERTIS, Giulio. Prova - II) Teoria... op. cit., p. 2).

${ }^{47}$ Cf. BADARÓ, Gustavo Henrique Righi Ivahy. Direito processual penal: tomo I... op. cit., p. 198. No mesmo sentido, MICHELE TARUFFO afirma que "qui si ha dunque un procedimento nel senso processuale del termine, mediante il quale la prova 'si forma' o 'viene ad esistenza' come dato giuridico, ossia come elemento del processo e come base leggitima della decisione sul fatto. È attraverso questo procedimento, in altri termini, che dati conoscitivi 'bruti' preesistenti diventano 'prove' nel senso giuridico del vocabolo, o che si creano 'prove' ad hoc, ossia specificamente destinate alla conoscenza dei fatti di quella causa". Em tradução livre do autor: "há, portanto, um procedimento no sentido processual do termo, mediante o qual a prova 'se forma' ou 'vem à existência' como dado jurídico, ou seja, como elemento do processo e como base legítima da decisão sobre o fato. É através deste procedimento, em outros termos, que os dados cognoscitivos 'brutos' pré-existentes se tornam 'provas' no senso jurídico do vocábulo, ou que se criam 'provas' ad hoc, ou seja, especificamente destinadas ao conhecimento dos fatos daquela causa" (La prova... op. cit., p. 424).

${ }^{48}$ Cf. supra, item n. 1.1 .
} 
Meios de investigação de prova ${ }^{49}$ são reconhecidos pela doutrina como os instrumentos usados "para descobrir ou recolher a fonte de prova". ${ }^{50}$

Em Itália, são definidos como "instrumentos de que se serve a autoridade judiciária para descobrir e assegurar ao processo coisas, traços, documentos ou qualquer outro elemento útil para provar os fatos que se referem à imputação, à punibilidade e à determinação da pena. São instrumentos indispensáveis para a pesquisa probatória. Mas não são, por si só, instrumentos de convencimento. Servem à prova, mas não ao juízo". ${ }^{51}$

\footnotetext{
${ }^{49}$ Meios de investigação de prova parece ser a nomenclatura adequada. Nominá-los meios de obtenção de prova pode induzir a equivocada conclusão de que tais instrumentos conduzem, necessariamente, à descoberta de uma fonte de prova. E pressupor a descoberta de fonte de prova pertinente a um fato ilícito pode ser entendido como consideração prévia de culpabilidade. Preferimos denominá-los, portanto, meios de investigação de prova: sua utilização não acarreta, necessariamente, em descoberta de fonte de prova. Em verdade, tem-se atividade de pesquisa, de investigação de prova, da qual pode decorrer obtenção de fontes de prova. Antever o resultado de diligências investigativas, presumindo a obtenção de fontes, significaria inaceitável afronta à presunção de inocência. A título de exemplo, no atual Código de Processo Penal italiano, foram intitulados mezzi di ricerca della prova (meios de pesquisa da prova), regulamentados nos artigos 244 a 271. O legislador português o fez sob a denominação meios de obtenção de prova, nos artigos 171 a 190 da lei processual penal. A doutrina nacional utiliza as seguintes denominações: meios de investigação de prova, meios de pesquisa de prova, meios de obtenção de prova e meios de busca de prova. A propósito das duas primeiras denominações, cf.: GOMES FILHO, Antonio Magalhães. Notas sobre a terminologia... op. cit., p. 308-309; GOMES FILHO, Antonio Magalhães; BADARÓ, Gustavo Henrique Righi Ivahy. Prova e sucedâneos... op. cit., p. 178. Quanto ao emprego de meios de obtenção de prova, cf.: FERNANDES, Antonio Scarance. Prova e sucedâneos de prova no processo penal. Revista Brasileira de Ciências Criminais, São Paulo, RT, n. 66, mai-jun. 2007, p. 209-210; MACHADO, André Augusto Mendes; KEHDI, André Pires de Andrade. Sigilo das comunicações e de dados. In: FERNANDES, Antonio Scarance; ALMEIDA, José Raul Gavião de; MORAES, Maurício Zanoide de (Coord.) Sigilo no processo penal: eficiência e garantismo. São paulo: Editora Revista dos Tribunais, 2008. p. 251. No que se refere à nomenclatura meios de busca de prova, cf.: ZILLI, Marcos Alexandre Coelho. A iniciativa instrutória do juiz no processo penal. São Paulo: RT, 2003, p. 199; SILVA, Eduardo Araujo da. Crime organizado: procedimento probatório. São Paulo: Atlas, 2003, p. 64. No Anteprojeto de reforma do Código de Processo Penal brasileiro, atualmente em trâmite como Projeto de Lei do Senado n. 156, empregou-se a nominação meios de obtenção de prova (BRASIL. Senado. Projeto de Lei do Senado n. 156, de 2009. Disponível $\mathrm{em}$ : http://www.senado.gov.br/atividade/materia/getPDF.asp?t=85509\&tp=1. Acesso em: 10/01/2011).

${ }^{50}$ Cf. FERNANDES, Antonio Scarance. O sigilo... op. cit., p. 158. No mesmo sentido: GOMES FILHO, Antonio Magalhães. Notas sobre a terminologia... op. cit., p. 308-309.

${ }^{51}$ Tradução livre do autor de: "i mezzi di ricerca della prova sono gli strumenti di cui si serve l'autorità giudiziaria per individuare ed assicurare al processo cose, tracce, documenti ed ogni altro elemento utile per provare $\mathrm{i}$ fatti che si refferiscono all'imputazione, alla punibilità e alla determinazione della pena. Sono instrumenti indispensabili per la ricerca probatoria, ma non sono di per sé strumenti di convincimento. Serveno alla prova ma non al giudizio" (SIRACUSANO, Delfino. Le prove: i mezzi... op. cit., p. 399). MARIO MERCONE, em comentários sobre os meios de investigação de prova, salienta que consistem em atividades voltadas à descoberta de fontes de prova (Manuale di Procedura Penale. 4. ed. Napoli: Esselibri - Simone, 1997, p. 371).
} 
Os meios de investigação de prova, a nosso ver, são instrumentos ${ }^{52}$ jurídicoprocessuais por intermédio dos quais é possível a descoberta e o sucessivo registro da existência de fontes de prova. Tais fontes, cuja existência passa a ser conhecida pelas partes, se pertinentes ao thema probandi, podem ser oportunamente introduzidas no processo, pelo meio de produção correspondente. As buscas, as interceptações de comunicações e a infiltração de agentes, por exemplo, são espécies destes meios. ${ }^{53}$

A investigação de prova, operada com a utilização dos referidos meios, perfaz-se em procedimentos regulados pela lei (em geral, extraprocessuais), ${ }^{54}$ que se desenrolam, em regra, sob autorização e fiscalização judicial. ${ }^{55}$ Tais meios são caracterizados pela "surpresa", sem a qual pode ser dificultada a descoberta de fontes de prova. ${ }^{56} \mathrm{E}$ os atos do respectivo procedimento podem ser praticados por policiais. ${ }^{57}$

\footnotetext{
${ }^{52}$ Parece-nos que possam ser definidos tanto como instrumento, quanto como atividade. Ao se empregar o termo instrumento, enfatiza-se o meio em si, um instituto jurídico determinado, tipificado em lei para possibilitar a descoberta de fontes de prova (a interceptação de comunicações entre pessoas presentes, por exemplo). Também nos afigura correto o emprego do segundo termo, porquanto a execução do meio é composta por diversos atos, conformando verdadeira atividade. Como a referência a instrumento em si antecede a execução dos atos que o compõe, preferimos utilizar tal termo na definição.

53 "O campo dos meios de pesquisa ou de obtenção de prova é amplo, podendo-se, a grosso modo, englobá-los em quatro grupos: a) os exames, as vistorias, as revistas; b) as buscas, apreensões, os seqüestros; c) as interceptações, as escutas; as quebras de sigilo; c) as ações encobertas, a infiltração policial." (FERNANDES, Antonio Scarance. Prova e sucedâneos... op. cit., p. 209).

${ }^{54}$ Cf. GOMES FILHO, Antonio Magalhães. Notas sobre a terminologia... op. cit., p. 309.

${ }^{55}$ A respeito da necessidade de autorização e fiscalização judiciais, verifiquem-se os comentários expendidos no capítulo segundo sobre a reserva de jurisdição (v. infra, n. 2.6).

56 Tais características são salientadas pela doutrina, nacional e estrangeira (TONINI, Paolo. A prova no processo penal italiano. Tradução de Alexandra Martins e Daniela Mróz. São Paulo: RT, 2002, p. 242-243; PERCHINUNNO, Vincenzo. I mezzi di recerca della prova. In: PISANI, Mario; MOLARI, Alfredo; PERCHINUNNO, Vincenzo; CORSO, Piermaria. Manuale di Procedura Penale. Bologna: Monduzzi Ed, 1994. cap. XVII. p. 251; SANGUINETI, Luigi Maria. Lezioni di Procedura Penale. Milano: Giuffrè, 1996, p. 129; FELICIONI, Paola. Le ispezioni e le perquisizioni. Milano: Giuffrè, 2004, p. 22; GOMES FILHO, Antonio Magalhães. Notas sobre a terminologia... op. cit., p. 309). DELFINO SIRACUSANO, para salientar tais caracteres, transcreve trecho da Relazione al progetto preliminare del codice di procedura penale 1988: "dal punto di vista tecnico processuale, i mezzi di ricerca della prova, mirando a far penetrare nel processo elementi che preesistono all'indagine giudiziaria, si basano sul fattore sorpresa". Em tradução livre do autor: "do ponto de vista técnico-processual, os meios de investigação de prova, objetivando a fazer penetrar no processo elementos que pré-existem à investigação judiciárias, baseiam-se sob o fator surpresa" (Prova - III) Nel nuovo Codice di Procedura Penale. In: Enciclopedia Giuridica - Istitvto Enciclopedia Italiana fondata da Giovanni Treccani. Roma: Istituto Poligrafico e Zecca dello Stato, 2003. vol. XXV, p. 4). Quanto à surpresa, parece-nos arma legítima de que podem se valer as partes. Não só a acusação pode surpreender, visando à descoberta de prova. Também a defesa pode fazê-lo. Ambas são titulares do direito à prova, em momento de investigação (v. supra, n. 1.2). Daí porque se sustenta, já adiantando uma conclusão sobre a disciplina da interceptação de comunicações entre presentes, a necessidade de atribuição de legitimidade à acusação, ao assintente de acução e à defesa.

${ }^{57}$ Cf. GOMES FILHO, Antonio Magalhães. Notas sobre a terminologia... op. cit., p. 309.
} 


\subsubsection{Distinções entre meios de produção de prova e meios de investigação de prova}

É fundamental compreender a diferença entre os meios de produção de prova e os meios de investigação de prova, por meio da análise de suas características gerais, para identificação da natureza e do regime jurídico aplicável - aqui inserida a eficácia probatória ${ }^{58}$ a uma de suas espécies. Das definições anteriormente expostas, podem-se extrair relevantes distinções, pontuadas a serguir: ${ }^{59}$

1. Os meios de produção de prova, em regra, são realizados na fase processual da persecução penal; excepcionalmente, na fase de investigação, observado o contraditório. Os meios de investigação de prova, em geral, são realizados na fase das investigações $^{60}$ - o que não exclui a possibilidade de execução na fase processual, para possibilitar descoberta de fontes de prova diversas das que serviram para formação da opinio delicti. ${ }^{61}$

\footnotetext{
${ }^{58}$ Cf. infra, item n. 1.5 .

${ }^{59}$ Cuida-se aqui de contraposição de características gerais - que temos por relevantes -, as quais possibilitam a identificação de um instituto como meio de investigação de prova ou meio de produção de prova. Isto não significa que não possa haver uma de suas espécies que destoe de um dos caracteres, em razão de uma particularidade.

${ }^{60}$ Em Itália, onde a lei processual penal disciplina de forma sistemática os meios de investigação de prova, DELFINO SIRACUSANO enfatiza que são destinados a fase de investigações preliminares. Por este motivo, ele sustenta que a disciplina do Código de Processo Penal italiano sobre os meios de investigação de prova (arts. 244-271) devem ser integrada pelas disposições específicas sobre as investigações preliminares. "Insomma: se nello studio dei mezzi di prova occorre rifarsi alle regole dettate per l'struzione dibattimentale, nello studio dei mezzi di ricerca dell aprova bisogna tener conto delle prescrizioni fissate per le indagini preliminari". Em tradução livre do autor: "em suma, se no estudo dos meios de prova se deve atentar para as regras estabelecidas para a instrução em debates das partes, no estudo dos meios de investigação de prova se necessita considerar as prescrições fixadas para as investigações preliminares" (Le prove: i mezzi... op. cit., p. 400).

${ }^{61}$ É de se ressaltar que, embora consideremos que os meios de investigação de prova sejam concebidos para propiciar a descoberta de fontes de prova, finalidade que se confunde com a primeira fase da persecução penal, não se exclui a possibilidade de sua execução em outra fase da persecução penal, como, por exemplo, a fase processual. Se já instaurada a ação penal, tais meios servem não só para propiciar a descoberta de prova relevante para avaliação da veracidade das alegações constantes na imputação, como também para decretação de outras medidas cautelares com lastro nos respectivos elementos de informação. Imagine-se, por exemplo, a necessidade de comprovação de requisitos que justifiquem a decretação de uma prisão cautelar. Todavia, o fato de poder ser autorizado no curso de ação penal não altera o regime jurídico do meio. ERCOLE APRILE e FILLIPO SPEZIA, ao tratarem de interceptação, ressaltam que o instrumento pode ter não apenas a função de meio de investigação de prova, como também a de instrumento de atuação do poder punitivo do Estado, que se concretiza na execução de provimentos cautelares e nas sentenças de condenação - esta última função é relacionada pelos autores à procura do foragido (Le intercettazioni telefoniche ed ambientali: innovazioni tecnologiche e nuove questioni giuridiche. Milano: Giuffrè, 2004, p. 9 e 96 (Teoria e Pratica del Diritto, sez. III, n. 133. Diritto e Procedura Penale)). Sobre a procura de foragidos por meio de interceptação, cf. item n. 4.2.2.2.6, infra, nota n. 108.
} 
2. Os meios de produção de prova são atividades endoprocessuais; os meios de investigação de prova, atividades extraprocessuais.

3. Os meios de produção de prova consistem em atividades desenvolvidas perante juiz competente; os meios de investigação de prova são operados, em regra, por policiais, aos quais sejam atribuídas investigações de infrações penais, com prévia autorização e concomitante fiscalização judiciais.

4. Os atos integrantes dos meios de produção de prova são praticados sob o crivo do contraditório, com prévio conhecimento e participação das partes; os atos dos meios de investigação de prova são praticados, em regra, com fundamento na surpresa, com desconhecimento de interessados. ${ }^{62}$

5. As informações obtidas na execução de um meio de produção de prova (elementos de prova) são úteis para o exame de objeto de prova e, a fortiori, podem fundamentar, sob a forma de resultados de prova, decisão proferida por juiz sobre o mérito da causa; elementos de informações obtidos na execução de um meio de investigação de prova, juntamente com a descoberta de fontes de prova, em regra, não são úteis para o exame de objeto de prova, nem servem para fundamentar decisão judicial sobre o mérito da causa. Estas informações, em regra, são úteis para a formação do juízo de admissibilidade de medidas cautelares, de opinio delicti e de juízo de admissibilidade de acusação formalizada, e para a instrução - aqui considerados não só o possível ingresso no processo da fonte de prova descoberta cuja produção seja requerida pelas

\footnotetext{
${ }^{62}$ A propósito, CLAUDIO MARINELLI observa que, fundados sob a clandestinidade, os atos praticados na execução dos meios de investigação de prova dispensam o prévio aviso do defensor e a sua participação na execução das operações (Intercettazioni processuali e nuovi mezzi di ricerca della prova. Torino: Giappichelli, 2007, p. 94 (Procedura Penale: studi, n. 24. Collana diretta da M. Bargis, G. Giostra, V. Grevi, G. Illuminati, R.E. Kostoris, R. Orlandi, E. Zappalà)). ROGÉRIO LAURIA TUCCI, em observações sobre a interceptação de comunicação telefônica, explica que se trata de medida "inaudita altera parte" (Direitos e garantias individuais no processo penal brasileiro. 2. ed. São Paulo: RT, 2004, p. 408). Embora, sejam fundados no dito fator "surpresa", não significam que os interessados não devam ser informados, concluídas as diligências, sobre os termos da documentação dos atos praticados na execução do meio, com a sucessiva possibilidade de impugnação. Tal consideração assume especial relevância no direito brasileiro, considerado o disposto no art. 155 do Código de Processo Penal e o fato de os referidos termos integrarem os autos de eventual ação penal. Por isso, o contraditório deve se operar, de forma diferida.
} 
partes ou ordenada de ofício pelo juízo, bem como a condução da instrução pelas partes. $^{63}$

6. Os atos integrantes dos meios de produção de prova, se praticados em desconformidade com o modelo legal previsto para sua execução, são sancionados, em regra, com nulidade; os atos integrantes dos meios de investigação de prova, com inadmissibilidade. $^{64}$

Considerada a complexidade do fenômeno probatório, antes de ingressarmos na análise das classificações do termo de prova, é necessária a delimitação do objeto da prova, que se liga aos diversos significados do termo prova.

\subsubsection{Significado de objeto da prova}

A pretensão punitiva estatal, formulada em juízo no exercício do direito de ação, fundamenta-se em certo fato delituoso tido por ocorrido. Demonstrar, por meio de referência a elementos probatórios, a veracidade das alegações apresentadas no processo é indispensável para o juiz estabelecer a adequada qualificação jurídica do fato, os efeitos dela decorrentes e o julgamento do pedido de tutela jurisdicional.

Questões de direito, independente de comprovação do que se afirma, hão que ser necessariamente solucionadas pela autoridade judicial (iura novit curia), ${ }^{65}$ competente para

\footnotetext{
${ }^{63}$ Adianta-se aqui, de forma sintetizada, algumas das conclusões a que chegamos no desenvolvimento do tema do item intitulado "eficácia probatória" (v., infra, n. 1.5).

${ }^{64}$ "Na prática, essa diversidade terminológica também serve para identificar possíveis repercussões das irregularidades verificadas em relação aos meios de prova e aos meios de investigação. No primeiro caso, a conseqüência do vício será a nulidade da prova produzida (rectius: dos elementos de prova), enquanto no segundo caso tratar-se-á de prova inadmissível no processo, diante da violação de regras relacionadas à sua obtenção (art. 5, LVI, da CF)." (Cf. GOMES FILHO, Antonio Magalhães. Notas sobre a terminologia... op. cit., p. 310). A afirmação constante do item, com fundamento na doutrina citada, é feita em caráter geral. Não se desconhece, contudo, a possibilidade de a ilicitude ocorrer na produção da prova, como, por exemplo, um testemuho de médico ou de advogado que se amolde à conduta prevista no art. 154 do Código Penal (Violação de segredo profissional).

${ }^{65}$ Refere-se aqui às questões ditas "exclusivamente" de direito, cujas soluções se pautam, abstratamente, no exame das diversas normas jurídicas, princípios e regras, integrantes do arcabouço jurídico. O fato de serem decididas pelo juiz não exclui a possibilidade de discussão das partes sobre os respectivos termos (Cf. BADARÓ, Gustavo Henrique Righi Ivahy. Correlação entre... op. cit., p. 31-36).
} 
determinação do direito aplicável. Não importa o grau de sua complexidade. De outro lado, "as dúvidas sobre a veracidade das afirmações feitas pelas partes no processo constituem as questões de fato que devem ser resolvidas pelo juiz, à vista da prova de acontecimentos pretéritos relevantes. A prova constitui, assim, numa primeira aproximação, o instrumento por meio do qual se forma a convicção do juiz a respeito da ocorrência de certos fatos". ${ }^{6}$

O objeto da prova, sobre o qual recai a pesquisa probatória, não são simples fatos externos, mas a interpretação a eles conferida, sob a perspectiva de quem os afirma no processo (fatos interpretados).

Segundo a doutrina, o thema probandum (objeto de prova) "é determinado pelas proposições representativas do fato juridicamente relevantes, e colocadas pelas partes como base da acusação e da defesa, ou mesmo como fundamento de eventual pesquisa judicial". ${ }^{67}$ Provar, em sentido amplo, significa demonstrar a veracidade de um enunciado sobre o fato tido por ocorrido no mundo real. ${ }^{68}$

${ }^{66}$ Cf. GRINOVER, Ada Pellegrini, GOMES FILHO, Antonio Magalhães; FERNANDES, Antonio Scarance. As nulidades... op. cit., p. 112.

${ }^{67}$ Cf. GOMES FILHO, Antonio Magalhães. Notas sobre a terminologia... op. cit., p. 317. No mesmo sentido, GUSTAVO HENRIQUE RIGHI IVAHY BADARÓ ressalta que: "embora seja comum a afirmação de que o objeto de prova são os fatos, o que se provam não são os fatos, mas sim as 'alegações dos fatos"'. Lembrando a sistemática do Código de Processo Civil (art. 334), o autor enfatiza, ainda, que, "no processo penal, embora não haja regra semelhante, os fatos impertinentes, irrelevantes e notórios não são objeto de prova. Porém, mesmo os fatos incontroversos devem ser objeto de prova (p. ex.: não é porque o réu confessou que ele deve ser condenado)" (Direito processual penal: tomo I... op. cit., p. 203-204). De forma mais abrangente, JOSÉ FREDERICO MARQUES define objeto da prova como "a coisa, fato, acontencimento ou circunstância que deva ser demonstrrado no processo" (Elementos de direito processual penal. Atualização de Eduardo Reale Ferrari e Guilherme Madeira Dezem. Campinas: Millennium, 2009. v. 2, p. 268). Não destoa o conceito firmado em doutrina estrangeira. GIULIO UBERTIS afirma que o thema probandum "è dato dall'insieme delle proposizioni rappresentative del 'fatto' giuridichamente rilevante". Em tradução livre do autor: "é expressado pelas proposições representativas do 'fato' juridicamente relevante" (Prova - II) Teoria... op. cit., p. 2). E MICHELE TARUFFO conclui que "si ha la prova di un fatto quando si hanno elementi di conoscenza idonei a fondare la veridicità dell'enunciazione di quel fatto". Em tradução livre do autor: "se tem prova de um fato quando existam elementos de conhecimento idôneos a fundar a veracidade da enunciação sobre aquele fato" (La prova .. op. cit., p. 415). Com fundamento em tais lições, afirmamos que não se têm, em processo, os fatos ocorridos como fenômeno social, por impossibilidade física de serem transportados. Há, em verdade, apenas uma parcela da realidade, que se traduz em afirmações expendidas sobre os fatos, conforme a interpretação de quem as faz. $\mathrm{O}$ brocardo latino "da mihi factum, dabo tibi ius", que expressa a atividade jurisdicional, deve ser entendido com a seguinte ressalva: o que se apresenta em juízo não é o fato... são alegações fáticas.

${ }_{68}$ Bem salienta GIULIO UBERTIS que "cio su cui verte ciascuna prova è quindi la verità o meno di una affermazione. È quest'ultima il vero e proprio oggeto di prova, cosi come è sempre tale affermazione probatoria a trovarsi in corrispondenza com ogni singola prova." "Non esistono 'fatti veri' o 'fatti falsi': un fatto 'è' o 'non è'; soltanto la sua enunciazione può essere "vera' o "falsa". Em tradução livre do autor: "isto a que se refere cada prova é, portanto, a verdade ou menos de uma afirmação. É esta última o vero e próprio objeto de prova, assim 
Nota-se, portanto, a estreita relação entre o objeto da prova e os resultados probatórios: são os elementos probatórios valorados criticamente, que propiciam a autoridade judicial a verificação da veracidade das alegações firmadas pelas partes.

\subsubsection{Classificações do termo prova}

Não decorre apenas dos diversos significados do substantivo prova e do objeto da prova a complexidade do fenônemo probatório. Também se estende pelas diferentes classificações do termo, que o qualificam e possibilitam a conclusão sobre o sentido em que o termo é empregado. Ora destacamos, por meio da apresentação de suas principais características, as reputadas relevantes para compreensão dos meios de investigação de prova.

As classificações operadas pela doutrina servem para enfatizar a inarredável observância dos princípios e das regras integrantes da disciplina probatória. Delas sobressaem os princípios da legalidade ${ }^{69}$ e do contraditório. ${ }^{70}$

como é sempre tal afirmação probatória a se encontrar em correspondência com qualquer prova singular." "Não existe 'fatos verdadeiros' e 'fatos falsos': um fato 'é' ou 'não é'; somente a sua enunciação pode ser 'verdadeira' ou "falsa"” (Prova - II) Teoria... op. cit., p. 2). Em processo, busca-se um "conhecimento processualmente verdadeiro", estribado em elementos obtidos por meio de procedimentos racionais (Cf. GOMES FILHO, Antonio Magalhães. Notas sobre a terminologia... op. cit., p. 306). Cuida-se, portanto, de verdade processualmente atingível. Neste sentido, cf. ainda: COMOGLIO, Luigi Paolo. Prove ed accertamento dei fatti nel nuovo c.p.p. Rivista Italiana di Diritto e Procedura Penale, Milão, Giuffrè, anno XXXIII, fasc. 1, gen-mar. 1990, p. 130-132; TARUFFO, Michele. Modelli di prova e di procedimento probatorio. Rivista di Diritto Processuale, Padova, v. 45, n. 2, apr-giug. 1990, p. 442; PITOMBO, Sérgio Marcos de Moraes. O juiz penal e a pesquisa da verdade material. In: PORTO, Hermínio Alberto Marques; SILVA, Marco Antonio Marques da. Processo penal e Constituição Federal. São Paulo: Acadêmica, 1993, p. 74; e BADARÓ, Gustavo Henrique Righi Ivahy. Provas atípicas e provas anômalas: inadmissibilidade da substituição da prova testemunhal pela juntada de declarações escritas de quem poderia ser testemunha. Estudos em Homenagem à Professora Ada Pellegrini Grinover. 1. ed. São Paulo: DPJ, 2005, p. 342-344.

${ }^{69}$ A busca da verdade, nela incluída a investigação da existência de fontes de prova, deve ser concretizada sob a observância do princípio da legalidade. Afirma-se a existência de um princípio de legalidade probatória, com fundamento no qual uma prova só pode ser adquirida por meio da observância de uma série de limites. Quanto à afirmação da legalidade probatória, ANTONIO MAGALHÃES GOMES FILHO observa que a legalidade probatória "representa a mais valiosa garantia do acusado contra decisões arbitrárias" (Notas sobre a terminologia... op, cit., p. 315). Em doutrina estrangeira, no mesmo sentido, afirmando a legalidade probatória, cf.: LARONGA, Antonio. Le prove atipiche nel processo penale. Padova: Cedam, 2002, p. 7; AMODIO, Ennio. 


\subsubsection{Prova ilícita e prova ilegítima}

A questão das denominadas "prova ilícita" e "prova ilegítima" se relaciona com a inobservância de direitos e de garantias fundamentais em procedimentos probatórios. ${ }^{71} \mathrm{~A}$ ilicitude ou a ilegitimidade de uma prova decorrem da ilegalidade operada na obtenção ou na produção prova.

A mencionada ilegalidade, que caracteriza a "prova ilegal" (prova contra legem), perfaz-se com a violação de normas ou de princípios gerais do ordenamento, de natureza processual ou material. ${ }^{72}$ Do gênero "prova ilegal", consente a doutrina na identificação de duas espécies: "prova ilícita", se a violação for de normas de direito material; "prova ilegítima", se a violação for de natureza processual. ${ }^{73}$ Tenha-se, como exemplo de prova

Libero convincimento e tassatività dei mezzi di prova: un approccio comparativo. Rivista Italiana di Diritto e Procedura Penale, Milano, Giuffrè, anno XLII, gen-mar. 1999, p. 5.

${ }^{70} \mathrm{O}$ "contraditório como condição de eficácia das provas" é ressaltado por ADA PELLEGRINI GRINOVER: "de extrema relevância é o problema do contraditório, entendido como participação das partes e do juiz no momento da produção das provas. Trata-se, agora, das atividades dirigidas à constituição do material probatório que vai ser utilizado pelo órgão jurisdicional na formação de seu convencimento. E a relevância de tais atividades, necessariamente banhadas pelo contraditório, tem sido posta em destaque pela doutrina universal, encontrando ressonância nas legislações mais avançadas" (Prova emprestada... op.cit., p. 62). Também o faz ANTONIO MAGALHÃES GOMES FILHO, em comentários ao texto normativo do art. 155 do Código de Processo Penal: “A Lei 11.690/2008, ao tornar explícita essa diferença essencial entre prova e elemento informativo trazido pela investigação, ressalta que a observância do contraditório é verdadeira condição de existência da prova. De fato, só podem ser considerados provas, no sentido jurídico-processual, os dados de conhecimento introduzidos no processo na presença do juiz e com participação das partes, em contraditório." (GOMES FILHO, Antonio Magalhães. Provas: Lei 11.690... op. cit.. p. 250). Representando a doutrina estrangeira, DELFINO SIRACUSANO: “il giusto processo eleva il contraddittorio tra le parti a 'metodo' di conoscenza dei fatti oggetto di giudizio" (Prefazione. In: SIRACUSANO, Delfino; GALATI, Antonini; TRANCHINA, Giovanni; ZAPPALÀ, Enzo. Diritto Processuale Penale. 2. ed. Milano: Giuffrè, 2006. v. 1. p. $\mathrm{V})$.

71 “'A questão da denominada 'prova ilícita' ubica-se, juridicamente, na investigação a respeito da relação entre o ilícito e o inadmissível no procedimento probatório e, sob o ponto de vista da política legislativa, na encruzilhada entre a busca da verdade em defesa da sociedade e o respeito a direitos fundamentais que podem ver-se afetados por esta investigação" (GRINOVER, Ada Pellegrini. Liberdades públicas... op. cit., p. 93). No mesmo sentido, cf.: Cf. GRINOVER, Ada Pellegrini, GOMES FILHO, Antonio Magalhães; FERNANDES, Antonio Scarance. As nulidades... op. cit., p. 124.

72 ADA PELLEGRINI GRINOVER, ao tratar das provas ilegais, adota a terminologia empregada pela doutrina italiana (Liberdades públicas... op. cit., p. 93. No mesmo sentido, cf: Cf. GRINOVER, Ada Pellegrini; GOMES FILHO, Antonio Magalhães; FERNANDES, Antonio Scarance. As nulidades... op. cit., p. 125.

73 "No campo das proibições de prova, a tônica é dada pela natureza processual ou substancial da vedação: a proibição tem natureza exclusivamente processual quando for colocada em função de interesses atinentes à lógica e a finalidade do processo; tem, pelo contrário, natureza substancial quando, embora servindo imediatamente também a interesses processuais, é colocada essencialmente em função dos direitos que o ordenamento reconhece 
ilícita, a obtida com violação dos direitos e garantias individuais que fundamentam a tutela das comunicações entre pessoas presentes; e, de ilegítima, um tetemunho prestado sem observância do procedimento previsto na lei processual penal.

Volvendo aos significados do termo prova, concluímos que ilegais não são os meios em si - de investigação ou de produção da prova -; mas, sim, atos concretamente praticados na investigação ou na produção da prova, que tornam, a fortiori, ineficazes a descoberta de uma fonte de prova (ilicitude na colheita) ou o registro de elementos de prova (ilegitimidade na produção). ${ }^{74}$

Importante ressaltar, quanto à violação de norma de direito material, que a ilicitude da prova decorre não só de uma ofensa direta a um bem jurídico, como também de inobservância de garantias asseguradas como meio de tutela de direitos fundamentais. É por isso que se adjetiva ilícita a prova colhida infringindo-se normas, princípios e regras, previstos pela Constituição ou pelas leis, para proteção de liberdades públicas, entre as quais se destaca o direito a intimidade. ${ }^{75}$

aos indivíduos, independentemente do processso" (GRINOVER, Ada Pellegrini; GOMES FILHO, Antonio Magalhães; FERNANDES, Antonio Scarance. As nulidades... op. cit., p. 124).

${ }^{74}$ ADA PELLEGRINI GRINOVER esclarece o sentido do termo prova empregado: "quando a proibição for colocada por uma lei processual, a prova (rectius, o meio de prova) será ilegítima (ou ilegitimamente produzida); quando, pelo contrário, a proibição for de natureza material, a prova será ilícita (rectius à fonte de prova será ilicitamente colhida)." (Liberdades públicas... op. cit., p. 98). De outro lado, ao interpretar o art. $5^{\circ}$, inciso LVI da Constituição Federal, que assegura a inadmissibilidade de prova obtida por meios ilícitos, ANTONIO MAGALHÃES GOMES FILHO, diferenciando os meios de produção de prova dos meios de investigação de prova, afirma: "devem entender-se inadmissíveis os elementos de prova resultantes de atos de obtenção praticados com violação de direitos". Mais adiante pondera: "essa diversidade terminológica também serve para identificar as possíveis repercussões das irregularidades verificadas em relação aos meios de prova e aos meios de investigação. No primeiro caso, a conseqüência do vício será a nulidade da prova produzida (rectius: dos elementos de prova), enquanto no segundo tratar-se-á de prova inadmissível no processo, diante da violação de regras relacionadas à sua obtenção" (Notas sobre a terminologia... op. cit., p. 307 e 310). Discordamos do primeiro entendimento, quanto a identificação de ilegítimo o meio de prova, pois a ilegalidade se perfaz na execução do meio de produção de prova, já que o meio, em si, como instrumento previsto em lei é legítimo. Também discordamos do segundo entendimento, quanto à afirmação da inadmissibilidade de "elementos de prova", porque os atos praticados com vistas a obtenção de prova tem por finalidade a descoberta de fonte, não a formação de elementos de prova. Dos ensinamentos transcritos, concluímos que, em "prova ilegítima", o termo se refere a elementos probatórios (ilegítimos) e, em "prova ilícita", a fonte de prova (ilicitamente colhida).

${ }^{75}$ Cf. GRINOVER, Ada Pellegrini; GOMES FILHO, Antonio Magalhães; FERNANDES, Antonio Scarance. As nulidades... op. cit., p. 125. No mesmo sentido, cf.: BADARÓ, Gustavo Henrique Righi Ivahy. Direito Processual Penal: tomo I... op. cit., p. 206. 
O art. 157 do Código de Processo Penal define como provas ilícitas "as obtidas em violação a normas constitucionais ou legais.” Embora não preconizada em lei, parece-nos que ainda persiste a dicotomia entre prova ilícita e prova ilegítima, que é relevante para compreensão do regime jurídico de cada uma delas. ${ }^{76}$

Distinguir as modalidades de prova ilegal é relevante para delimitação da sanção processual a elas aplicável: nulidade à "prova ilegítima"; inadmissibilidade à "prova ilícita". A nulidade implica ineficácia do ato de produção, que poderá ser renovado; a inadmissibilidade impede o ingresso em processo, considerada a ineficácia do ato de descoberta da fonte. Todavia, se uma prova inadmissível vier a ingressar nos autos de um processo, impõe-se o desentranhamento. ${ }^{77}$

É de se salientar que a inadmissibilidade das provas obtidas por meios ilícitos é erigida a garantia constitucional (art. 5\%, caput e inciso LVI da Constituição Federal). Em regra, tal modalidade de sanção processual também é aplicável às provas derivadas da ilícita (art. $157, \S$ $1^{\circ}$ da lei processual penal). ${ }^{78}$

\subsubsection{Prova típica, prova atípica, prova nominada e prova inominada}

Também relacionada ao princípio da legalidade, a qualificação da prova como típica ou atípica decorre da noção de tipo processual, ${ }^{79}$ que, em matéria de provas, traduz-se na

\footnotetext{
${ }^{76}$ ANTONIO MAGALHÃES GOMES FILHO após salientar a persistência da distinção, afirma que "não parece ter sido a melhor, assim, a opção do legislador nacional por uma definição legal de prova ilícita, que, longe de esclarecer o sentido da previsão constitucional, pode levar a equívocos e confusões, fazendo crer, por exemplo, que a violação de regras processuais implica ilicitude da prova e, em conseqüência, o seu desentranhamento do processo. O descumprimento da lei processual leva à nulidade do ato de formação da prova e impõe a necessidade de sua renovação, nos termos do que determina o art. 573, caput, do CPP." (Provas: Lei 11.690... op. cit., p. 266)

77 Neste sentido, cf.: GRINOVER, Ada Pellegrini; GOMES FILHO, Antonio Magalhães; FERNANDES, Antonio Scarance. As nulidades... op. cit., p. 125-137; GOMES FILHO, Antonio Magalhães. Provas: Lei $11.690 \ldots$ op. cit., p. 265-266.

${ }^{78}$ Outras considerações sobre a inadmissibilidade das provas obtidas por meios ilícitos, juntamente com o tema das provas derivadas da ilícita - igualmente, inadmissíveis - estão expostas no item n. 1.6.

${ }^{79}$ Vê-se o desenvolvimento da ideia de tipicidade processual e sua relação com a prova penal em doutrina. Entre os autores que se dedicaram ao tema, estão os seguintes: GIAN FRANCO RICCI (Le prove atipiche. Milano: Giuffrè, 1999, p. 1-71); ANTONIO LAROGA (Le prove atipiche... op. cit., p. 1-32), ANTONIO MAGALHÃES
} 
necessidade de delimitação legal das espécies de prova (tipicidade probatória). A diferença entre ambas consiste na existência de disciplina legal da modalidade probatória. Em sentido amplo, uma prova é atípica se não é regulamentada em lei.

Não se desconhece que os frutos da incessante criatividade humana podem aflorar fora dos modelos delineados pelo legislador. É por isso que a estruturação de um sistema processual deve possibilitar a utilização de novos instrumentos desenvolvidos na evolução tecnológica, observados os direitos e garantias processuais.

A doutrina debate o significado do termo prova na expressão prova atípica. E a discussão é sempre reavivada quando uma imaginada nova espécie de prova é cotejada com os modelos pré-existentes. ${ }^{80}$

Em Itália, onde o tema é versado em lei processual penal (art. 189 do Código Processual Penal italiano), em linhas gerais, destacam-se duas posições assumidas pela doutrina: a posição restritiva e a posição ampliativa. ${ }^{81}$

Adeptos da primeira apregoam que a atipicidade probatória se refere à ausência de previsão legal de fonte de prova. ${ }^{82}$

De acordo com a segunda corrente doutrinária, a atipicidade cinge-se ao procedimento probatório. ${ }^{83}$ A prova é tida por atípica em duas situações: se é legalmente nominada, sem a

GOMES FILHO e GUSTAVO HENRIQUE RIGHI IVAHY BADARÓ (Prova e sucedâneos... op. cit., p. 175208); ANTONIO SCARANCE FERNANDES (Prova e sucedâneos... op. cit., p. 198); GUSTAVO HENRIQUE RIGHI IVAHY BADARÓ (Direito processual penal: tomo I... op. cit., p. 200-201) e GUILHERME MADEIRA DEZEM (Da prova penal: tipo processual, provas típicas e atípicas: (Atualizado de acordo com as Leis 11.689/08, 11.690/08 e 11.719/08). Campinas: Millenium, 2008, p. 31 e ss., e 79 e ss).

${ }^{80}$ ANTONIO LARONGA examina algumas hipóteses de prova atípica no sistema italiano, entre as quais está o registro de conversa por um dos interlocutores (Le prove... op. cit., p. 196 e s.).

${ }_{81}$ Ressalta GUILHERME MADEIRA DEZEM as duas posições identificadas na doutrina italiana (Da prova penal... op. cit., p. 144-147).

${ }^{82}$ Representante da primeira corrente, FRANCESCA FERRARI afirma que "in realtà sembra che la nozione di atipicità debba essere utilizzata com referimento alla fonte di prova non al modo di acquisizione del materiale probatorio" (La "prova migliore": una ricerca di diritto comparato. Milão: Giuffrè, 2004, p. 338, nota de rodapé $\mathrm{n}^{\mathrm{o}} 145$, gn, apud DEZEM, Guilherme Madeira. Da prova penal... op. cit., p. 145).

${ }^{83}$ Sustenta GIAN FRANCO RICCI: "ne deriva che la soluzione dovrebbe essere quella per cui il concetto di atipicittà può tendenzialmente essere riferito anche al procedimento" (negrito nosso) (Atipicità della prova, 
previsão do respectivo procedimento probatório; e se sequer é nominada, o que também implica a ausência de delimitação de procedimento probatório. ${ }^{84}$

A doutrina brasileira, referindo-se à italiana, também sustenta a inclusão do procedimento na noção de tipicidade probatória. A este respeito, ANTONIO SCARANCE FERNANDES esclarece que "prova típica é aquela prevista e dotada de procedimento próprio para sua efetivação; a prova atípica é aquela que, prevista ou não, é destituída de procedimento para sua realização." 85

Com base nesta consideração, identificam-se cinco situações possíveis a respeito da tipicidade e atipicidade da prova: “a) o meio de prova está previsto e é regulado mediante procedimento próprio; b) o meio de prova está previsto, não está regulado, mas há remissão ao procedimento a ser seguido; c) o meio de prova é previsto, não está regulado e não há remissão a nenhum procedimento a ser seguido; d) o meio de prova é apenas referido nominalmente, sem qualquer regulamentação ou remissão sobre o procedimento a ser seguido; e) o meio de prova não é sequer referido". ${ }^{86}$

processo ordinário e rito camerale. Rivista Trimestrale di Diritto e Procedura Civile, Milano, Giuffrè, anno LVI, n. 2, giugno 2002, p. 415).

${ }^{84}$ No mesmo sentido, está o ensinamento de GIAN FRANCO RICCI: “in senso meramente letterale, prova atipica significa prova 'diversa' dai tipi dei modelli legali previsti dal codice. Tale definizione è però ovviamente genérica e vale solo per un primo approccio al problema. Se infatti si approfondisce l'indagine cominciano ad emergere i primi dubbi, poichè appare subito chiaro come il significato del termine 'prova atípica si possa prestare a definire due realtà abbastanza diverse. Esso há infatti un significato che non sarebbe errato chiamare ibrido. Per un verso la parola è infatti sinonimo di prova innominata, cioè di una prova non prevista dalla legge. Per altro verso peró, essa può prestarsi ad indicare anche deviazioni da uno schema probatorio già esistente, quando non è riferita al mezzo di prova, ma al meccanismo di assuzione (e nessuno potrebbe negare che l'uso del termine 'atipico' rifferito alla prova, possa prestarsi ad indicare anche deviazioni dal procedimento acquisitivo di prove previste dalla legge)". Adiante, afirma que: "Il termine di prova atipica si trova usato anche per contrassegnare il modo attraverso il quale la prova viene assunta" (negritos nossos) (Le prove... op. cit., p. 41-43). Semelhante conclusão sobre a posição ampliativa da doutrina italiana é expendida por GUILHERME MADEIRA DEZEM: "para posição ampliativa, tem-se que uma prova é atípica em duas situações: 1) quando ela seja prevista no ordenamento, mas não o seja o seu procedimento probatório; 2) quando nem ela nem seu procedimento probatório sejam previstos em lei” (negrito do autor) (Da prova penal... op. cit., p. 147).

${ }^{85}$ Prova e sucedâneos de prova no processo penal. Revista Brasileira de Ciências Criminais, São Paulo, RT, n. 66, mai-jun. 2007, p. 199. O autor se pauta no conceito de prova atípica de GIAN FRANCO RICCI (Le prove... op. cit., p. 41-42), citado por ANTONIO LARONGA (Le prove... op. cit., p. 6). No mesmo sentido, GUSTAVO HENRIQUE RIGHI IVAHY BADARÓ afirma que: "não se pode confundir tipicidade probatória, entendida com a previsão de um procedimento probatório típico para produção de um determinado meio de prova, com a simples nominação de uma prova" (Direito processual penal: tomo I... op. cit., p. 200).

${ }^{86} \mathrm{O}$ autor, analisando ordenamentos jurídicos estrangeiros, afirma que é comum a remissão a um meio de prova similar para a produção de prova sem procedimento próprio. Nesta hipótese, não haveria propriamente atipicidade, considerada a regulamentação por remissão. Inexistindo remissão, sustenta o emprego de analogia, 
Salienta Gustavo Henrique Righi IVAhy BADARÓ que a observância do procedimento probatório previsto em lei "assegura a genuinidade e a capacidade demonstrativa" do meio de prova. ${ }^{87}$

Dos conceitos citados, extrai-se o sentido do termo prova empregado em prova atípica: meio de prova. ${ }^{88}$ Parece-nos que se refere tanto aos meios de produção de prova, quanto aos meios de investigação de prova. É difícil pensar em fontes de prova atípicas, porque são reconduzíveis a categoria de pessoas ou coisas.

Verifica-se, ainda, que a tipicidade probatória de um determinado meio de prova é integrada pela admissibilidade e pelo procedimento probatório, também denominado rito probatório ou método probatório. ${ }^{89}$ A referida admissibilidade engloba, a nosso ver, não só a nominação do meio, como também os seus requisitos, ${ }^{90}$ os quais, somados ao procedimento probatório, devem conformar a disciplina legal do meio de prova, da qual se extrai o tipo probatório.

Portanto, em sentido estrito, prova típica é a prevista em lei, com o respectivo procedimento probatório (próprio ou por remissão); prova atípica, a prevista em lei, sem o

\footnotetext{
observando-se o procedimento de um meio de prova similar previsto em lei: "incumbe ao juiz decidir sobre a admissibilidade de prova atípica e a forma de sua produção, que deve seguir um determinado rito: o do meio de prova indicado por uma norma remissiva ou um similar aplicado por analogia. Indicado ou escolhido o procedimento, a desobediência às suas regras ocasiona irritualidade da prova" (Cf. FERNANDES, Antonio Scarance. Prova e sucedâneos... op. cit., p. 199-200, 214 e 227).

${ }^{87}$ Cf. Provas atípicas... op. cit., p. 200.

${ }^{88}$ No mesmo sentido, cf. TARUFFO, Michele. La prova... op. cit., p. 422.

${ }^{89}$ A propósito do procedimento probatório, GIULIO UBERTIS identifica duas fases que o integram: inicialmente, a de formação do juízo de admissibilidade da prova; sucessivamente, se admitida, a de execução do procedimento previsto na disciplina do respectivo meio. Ressalta também a finalidade do procedimento: "sia quella di offrire all'attenzione del giudice gli elementi temporalmente iniziali della complessa struttura probatoria. Non può pertanto riguardare l'introduzione processuale della prova tout court, dato che quest'ultima non può nemmeno venire ad esistenza senza la presenza di tutte le componenti della sequenzia probatoria." Em tradução livre do autor: "seja aquela de oferecer à atenção do juiz os elementos temporalmente iniciais da complexa estrutura probatória. Não se pode, portanto, considerar a introdução processual da prova tout court, dado que esta última não pode nem mesmo vir a existência sem a presença de todos os componentes da sequência probatória" (Prova - II) Teoria... op. cit., p. 5).

${ }_{90}$ É da disciplina legal de determinado meio de prova que se podem extrair a nominação, os requisitos e o procedimento probatório, como, por exemplo, a prova testemunhal (art. 202 e ss. do Código de Processo Penal) e a interceptação de comunicações telefônicas (Lei n. 9.296, de 1996).
} 
respectivo procedimento probatório (próprio ou por remissão), a referida nominalmente em lei e a não referida em lei. Para que se perfaça o tipo probatório não basta, portanto, previsão legal - nominação e fixação de requisitos. É necessária delimitação de procedimento.

E prova nominada é a prevista em lei, com ou sem delimitação de procedimento probatório. Inexistindo procedimento, mesmo sendo nominada, reputamo-la espécie de prova atípica. Também o é a prova inominada, na hipótese por último referida, se sequer o meio de prova é referido em lei. ${ }^{91}$

Compreendido o conceito de prova atípica e de prova inominada, debate-se sobre a admissibilidade de meios de prova atípicos (meios de investigação e de produção de prova). ${ }^{92}$

Adiantamos o nosso entendimento de que são admissíveis, com fundamento no art. 332 do Código de Processo Civil, apenas os meios de produção de prova atípicos, observado um procedimento probatório de meio típico, por analogia. Além disso, deve-se observar o contraditório, antes da formação do juízo de admissibilidade da prova cuja produção se requer.

Um exemplo de meio de prova atípico é a "reprodução simulada dos fatos" (art. $7^{\circ}$ do Código de Processo Penal), ${ }^{93}$ também conhecida por "reconstituição do crime". Embora nominada em lei, não se prevê procedimento probatório.

Admitida e produzida a prova atípica sob os cânones legais, reflete-se sobre sua eficácia probatória. ${ }^{94}$

\footnotetext{
${ }^{91}$ Em sentido contrário, diz-se que prova atípica e prova inominada são sinônimos: cf. APRILE, Ercole. La prova penale (artt. 187-271 cod. proc. pen.). Milano: Giuffrè, 2002. (Pratica giuridica: dottrina e giurisprudenza nella casistica. Senconda serie diretta de O. Fanelli, n. 12), p. 60. Parece-nos que não só a prova inominada é atípica, como também o é a prova nominada, desprovida de procedimento.

${ }^{9} \mathrm{O}$ mencionado tema é exposto adiante, no tratamento dos meios de investigação de prova típicos e atípicos (v. infra, n. 1.4.1).

${ }^{93}$ A propósito, cf.: GOMES FILHO, Antonio Magalhães; BADARÓ, Gustavo Henrique Righi Ivahy. Prova e sucedâneos... op. cit., p. 182.

${ }^{94}$ Neste sentido, DELFINO SIRACUSANO salienta que a aptidão dos elementos extraídos das fontes de prova descobertas por meios típicos, regularmente introduzidas no processo, à apuração dos fatos (thema probandi) é pressuposta. Constitui, em seu dizer, a ratio essendi da previsão normativa. Acrescenta também que o mesmo não se pode dizer quanto às provas atípicas, pois a abstrata idoneidade à representação dos fatos deve ser apurada antes da verificação da concreta adequação ao pontual tema de prova, posto pelas partes ou proposto pelo juiz.
} 
A atribuição de um valor menor se fundamentaria no fato de que as provas atípicas, por não serem regulamentadas, têm margens de incertezas superiores, que lhe confeririam uma menor eficácia. ${ }^{95}$ No entanto, não nos parece correto afirmar, em termos absolutos, que da prova atípica se extraiam elementos menos confiáveis, se comparados com os das provas típicas. $^{96}$

De modo semelhante ao que se procede com a prova típica, deve-se verificar se a prova atípica foi produzida com observância de direitos e de garantias processuais, e se os seus resultados são úteis. ${ }^{97}$ Em caso afirmativo, os respectivos elementos probatórios hão que ser valorados no caso concreto, com critérios racionais. ${ }^{98}$

\subsubsection{Prova irritual e prova anômala}

O exame da tipicidade probatória não se esgota com a prova atípica e a prova inominada. Em regra, os procedimentos probatórios previstos na regulamentação dos meios de prova devem ser observados; excepcionalmente, admitem-se, com restrições, procedimentos não previstos em lei. ${ }^{99}$ Aqui a interpretação restritiva impera. ${ }^{100}$

Entretanto, se previsto um procedimento, sua observância, para execução de determinado meio de prova, é inarredável. É inadmissível a instituição de outro procedimento,

\footnotetext{
Afirma, ainda, o autor: "per le prove 'atipiche', la astratta idoneità alla rappresentazione dei fatti è, invece, tutta da appurare e va, perciò, delibata 'nel' processo, prima ancora di postularne la concreta adeguatezza in relazione al puntuale thema, posto dalle parti o proposto dal giudice". Em tradução livre do autor: "Para as provas atípicas, a função relacionada à verificação dos fatos é, por assim dizer, ao contrário, toda por apurar e deve, por isto, ser analisada no processo, primeiro ainda de se postular a concreta adequação em relação ao pontual thema, posto pelas partes ou proposto pelo juiz" (Prova - III)... op. cit., p. 5).

${ }_{95}$ Cf. RICCI, Gian Franco. Le prove... op. cit., p. 643.

${ }^{96}$ Cf. Ibidem, p. 645.

${ }^{97}$ Cf. Ibidem, p. 650-651.

${ }^{98}$ No mesmo sentido estão os ensinamentos de GIAN FRANCO RICCI, que protesta pela análise da eficácia da prova atípica na motivação, sob o livre convencimento do juiz (Le prove... op. cit., p. 650-651).

${ }^{99}$ ANTONIO SCARANCE FERNANDES lembra que "a admissibilidade de uma prova atípica deve estar sujeita a critérios mais rígidos e deve ser marcada pela excepcionalidade" (Prova e sucedâneos... op. cit., p. 214).

${ }^{100}$ Cf.: RICCI, Gian Franco. Le prove... op. cit., p. 529.
} 
distinto do legalmente preconizado, com fulcro em pretensa atipicidade probatória. ${ }^{101}$ Semelhante prática fulminaria o princípio da legalidade probatória. ${ }^{102}$

Com efeito, a prova contra legem não pode ser admitida. Nem valorada como atípica pelo "cômodo expediente" do livre convencimento. ${ }^{103}$

Diante da impossibilidade de convalidação da prova ilegal ou da prova ilegítima com a afirmação de atipicidade, a doutrina adjetiva de irritual ou de anômala provas cujas disciplinas não sejam observadas.

Note-se que ambas, a prova irritual e a prova anômala, são provas, em tese, típicas, disciplinadas em lei, a qual estabelece o respectivo procedimento probatório, também denominado rito probatório. Todavia, tanto na investigação, quanto na produção da prova, o rito não é observado na execução do meio, perfazendo irritualidade ou anomalia. Um outro procedimento é seguido, do que decorre ilegalidade.

A diferença entre as duas reside na forma de inovação - reitere-se, ilegal - do procedimento: a prova irritual decorre da inobservância de normas que disciplinam o procedimento do meio típico, ${ }^{104}$ sem utilização de procedimento previsto para outro meio; a

\footnotetext{
${ }^{101}$ GIAN FRANCO RICCI bem enfatiza a impossibilidade de se pretender transformar em atípica a prova ilícita ou a prova ilegítima: "a tale impostazione restrittiva la dottrina è rimasta aderente anche nell'interpretazione dell'ambito di operatività dell'art. 189 c.p.p., tanto che si è incisivamente affermato non possano assolutamente 'registrarsi come atipiche prove illegittimamente acquisite o illegittimamente convertite'. In sostanza la dottrina processual penalistica ha sempre posto una netta demarcazione fra la prova atipica, cioè il mezzo di prova nuovo e la prova illecita o illegittimamente acquisita, cioè la prova, tipica o atipica che sia, acquisita in deroga alle regole che presiedono alla sua acquisizione". Em tradução livre do autor: "a tal impostação restritiva a doutrina permaneceu aderente também na interpretação do âmbito de incidência do art. 189 c.p.p., tanto que se afirmou, incisivamente, que não se pode 'registrar como atípica provas ilegitimamente obtidas ou ilegitimamente convertidas'. Em substância, a doutrina processual penalística sempre pôs uma precisa demarcação entre a prova atípica, isto é o meio de prova novo e a prova ilícita ou ilegitimamente obtida, isto é, a prova, típica ou atípica que seja, obtida sem a observância das regras que regem a sua obtenção" (Le prove... op. cit., p. 530-531).

${ }^{102}$ Cf., infra, item n. 2.6.

${ }^{103}$ Cf. SIRACUSANO, Delfino. Prova - III)... op. cit., p. 5. ANTONIO SCARANCE FERNANDES ressalta: “a prova, seja típica ou atípica, deve ser lícita, ou seja, obtida ou produzida com respeito às garantias e liberdades fundamentais". Acrescenta ainda: "o exame da atipicidade da produção da prova pressupõe a prévia constatação da licitude da prova” (Prova e sucedâneos... op. cit., p. 213 e 227).

${ }^{104}$ Nota-se a referência a prova irritual em doutrina nacional e estrangeira: cf. LARONGA, Antonio. Le prove... op. cit., p. 13. Em Brasil, cf.: BADARÓ, Gustavo Henrique Righi Ivahy. Provas atípicas... op. cit., p. 344; GOMES FILHO, Antonio Magalhães; BADARÓ, Gustavo Henrique Righi Ivahy. Prova e sucedâneos... op. cit., p. 190; BADARÓ, Gustavo Henrique Righi Ivahy. Direito processual penal: tomo I... op. cit., p. 200.
} 
prova anômala advém da observância de normas que disciplinam um procedimento de outro meio típico, ${ }^{105}$ distinto do meio previsto para investigação ou produção da prova. Na primeira, o raciocínio se pauta em apenas um meio de prova, ao passo que, na segunda, dois são os meios de prova imaginados.

Tornando aos significados do termo prova, parece-nos que o sentido empregado em prova irritual e em prova anômala é o de meio, de investigação ou de produção de prova.

Considerada a abstração do tema, imagine-se, v.g., a inobservância da regra que possibilita às partes a formulação de perguntas diretas à testemunha (art. 212 do Código de Processo Penal) por juízo que indague por meio de reperguntas (prova irritual); e a tentativa de produção de prova testemunhal por meio de juntada de declarações prestadas perante uma das partes, quem a documenta e requer a juntada em autos de processo, como se prova documental fosse ${ }^{106}$ (prova anômala).

Outra ilustração que pode contribuir para a compreensão: a realização de busca e apreensão em que não se lavre o exigido auto circunstanciado (art. $245, \S 7^{\circ}$ do Código de

\footnotetext{
${ }^{105}$ Em doutrina estrangeira, nota-se a referência à prova anômala. ANTONIO LARONGA adverte, sob o título "il divieto di fungibilità delle forme dei mezzi di prova" "a proibição de fungibilidade das formas dos meios de prova" - negrito do autor): "più precisamente, la dottrina ha costantemente criticato quella tendenza della prassi a ricondurre nell'ambito di operatività dell'articolo 189 c.p.p., le prove dirette a conseguire um risultato probatorio típico, assunte con le modalità corrispondenti a quelle di un altro mezzo di prova”. Em tradução livre do autor: "mais precisamente, a doutrina constantemente criticou aquela tendência da práxis de reconduzir ao âmbito de incidência do artigo 189 c.p.p. as provas diretas direcionadas a obter um resultado probatório típico, realizadas com as modalidades correspondentes àquelas de um outro meio de prova" (Le prove atipiche nel processo penale. Padova: Cedam, 2002, p. 8-9). Em Brasil, cf.: BADARÓ, Gustavo Henrique Righi Ivahy. Provas atípicas... op. cit., p. 344-345; BADARÓ, Gustavo Henrique Righi Ivahy. Direito Processual Penal: tomo $I \ldots$ op. cit., p. 201.

${ }^{106}$ ANTONIO MAGALHÃES GOMES FIHO, comentando o exemplo, enfatiza: "trata-se aqui de um verdadeiro jogo de palavras que levaria a se admitir a introdução, no processo, de elementos obtidos com violação da própria natureza da prova testemunhal, cujo valor está, justamente, na sua produção na presença do juiz em contraditório, de forma a permitir que o magistrado e as partes possam acompanhar o depoimento, observando o comportamento e as reações do depoente, e formulando perguntas necessárias ao esclarecimento completo dos fatos relatados" (Notas sobre a terminologia... op. cit., p. 315). No mesmo sentido, GUSTAVO HENRIQUE RIGHI IVAHY BADARÓ, conclui que “o 'documento-declaração' sobre fatos do conhecimento de quem poderia ou deveria ser testemunha não pode ser aceito como meio de prova, por ferir frontalmente as garantias do contraditório e do devido processo legal (art. $5^{\circ}$, LV e LIV, da CF), respectivamente. Alude também ao art. 14, 3, alínea $e$, do Pacto Internacional de Direitos Civis e Políticos e o art. $8^{\circ}, 2$, alínea $f$, da Convenção Americana sobre Direitos Humanos, que preconizam o direito a inquirir as testemunhas presentes no tribunal (Provas atípicas... op. cit., p. 347). Na mesma esteira: MALAN, Diogo Rudge. Direito ao confronto no processo penal. Rio de Janeiro: Lumen Iuris, 2009, p. 204.
} 
Processo Penal) (prova irritual); a execução de interceptação de comunicações telefônicas, que é disciplinada pela Lei n. 9.296/96, observando-se o procedimento previsto para busca e apreensão (art. 240 a 250 da lei processual penal) (prova anômala).

Compreenda-se que a adjetivação, de irritual ou de anômala, da prova não implica possibilidade de admissão. Pelo contrário, a distinção é operada para enfatizar a ilegalidade da prova, com a sucessiva aplicação de sanção processual, conforme o caso, de nulidade ou de inadmissibilidade.

\subsubsection{Prova emprestada}

A sistematização da disciplina de prova em legislação processual penal pressupõe as diferentes fases do desenrolar da persecução penal. O legislador delineia institutos considerando o estágio processual em que se possam operar os meios de prova. ${ }^{107}$ No entanto, pode ocorrer a necessidade de utilização de uma prova em momento distinto. Para tanto, é necessário amoldá-la aos direitos e garantias processuais, entre os quais sobressaem a legalidade e o contraditório.

Exemplo desta constatação empírica é a prova emprestada, definida como a "prova produzida em num determinado processo e que depois é trasladada, na forma documental, para outro processo". ${ }^{108}$ A dicotomia aqui se dá entre a prova original (que provém do processo no qual foi produzida, originária do processo no qual se operou sua produção) e a prova emprestada (documentação de um meio de prova levada a outro processo com objeto distinto, para ser utilizada em empréstimo). ${ }^{109}$

\footnotetext{
${ }^{107}$ Registramos aqui nossa conclusão sobre a análise dos meios de prova em cotejo com a fase processual, que decorreu do exame dos diversos significados de prova (v, supra, n. 1.2.1.1). O processo é atividade que demanda tempo... poderíamos dizer o "tempo do processo", para evidenciar o dispêndio temporal necessário para a realização de todos os atos que integram a atividade processual. Analisando a disciplina dos diferentes meios de prova, nota-se sintonia com a finalidade da respectiva fase processual.

${ }^{108}$ Cf. BADARÓ, Gustavo Henrique Righi Ivahy. Direito Processual Penal: tomo I... op. cit., p. 201.

${ }^{109}$ Extraímos esta dicotomia do conceito proposto pela doutrina, justificando-se a inserção entre as classificações do termo prova. Como o tema é tradicionalmente conhecido por prova emprestada, sem o contraponto da prova original, inserimos no título do item apenas prova emprestada.
} 
A doutrina aponta os requisitos de admissibilidade da prova emprestada: a observância da garantia do juiz natural e a observância do princípio do contraditório. ${ }^{110}$

No que se refere ao primeiro requisito, diz-se possível o empréstimo se a prova foi produzida perante o juízo natural, competente para processar e julgar a segunda causa. A presença concomitante das partes e do juiz confere validade à prova. ${ }^{11}$

Também se exige a observância do princípio do contraditório. Contudo, não basta que se perfaça o contraditório das partes no segundo processo. É necessário que a produção do meio de prova tenha ocorrido, em processo originário, sob o crivo do contraditório entre as mesmas partes do segundo processo, ou "ao menos, em processo em que tenha figurado como parte aquele contra quem se pretenda fazer valer a prova". ${ }^{112}$

Outros requisitos são indicados: a observância da disciplina do meio de prova; ${ }^{113}$ a identidade de objeto de prova; e identidade de âmbito de cognição. ${ }^{114}$

Conhecidos os requisitos de admissibilidade da prova emprestada, indagamos: Em que sentido é empregado o termo prova, ao se perquirir a possibilidade de empréstimo? A nosso ver, a resposta depende da natureza do meio de prova utilizado no primeiro processo. Em se tratando de meio de investigação de prova, reputamos serem emprestados a fonte de prova ou

\footnotetext{
${ }^{110}$ Cf. GRINOVER, Ada Pellegrini. Prova emprestada... op. cit., p. 66; e BADARÓ, Gustavo Henrique Righi Ivahy. Direito processual penal: tomo I... op. cit., p. 201.

${ }^{111}$ A exigência se refere à identidade do órgão jurisdicional constitucionalmente competente, cf.: GRINOVER, Ada Pellegrini; GOMES FILHO, Antonio Magalhães; FERNANDES, Antonio Scarance. As nulidades... op. cit., p. 117-118; BADARÓ, Gustavo Henrique Righi Ivahy. Direito processual penal: tomo I... op. cit., p. 201.

112 "Isso porque o princípio constitucional do contraditório exige que a prova emprestada somente possa ter valia se produzida, no primeiro processo, perante quem suportará os seus efeitos no segundo, com a possibilidade de ter contado naquele, com todos os meios possíveis de contrariá-la" (GRINOVER, Ada Pellegrini; GOMES FILHO, Antonio Magalhães; FERNANDES, Antonio Scarance. As nulidades... op. cit., p. 117). No mesmo sentido, cf.: BADARÓ, Gustavo Henrique Righi Ivahy. Direito processual penal: tomo I... op. cit., p. 201; e GRINOVER, Ada Pellegrini. Prova emprestada... op. cit., p. 66.

${ }^{113}$ Cf. GRINOVER, Ada Pellegrini. Prova emprestada... op. cit., p. 66.

114 Quanto aos dois requisitos por últimos citados, cf. BADARÓ, Gustavo Henrique Righi Ivahy. Direito processual penal: tomo I... op. cit., 2008, p. 203.
} 
os elementos de informação dela extraídos; ${ }^{115}$ sendo meio de produção de prova, entendemos serem emprestados os elementos de prova.

Quanto à eficácia da prova emprestada, afirma-se a identidade de valor em ambos os processos, no primitivo e no segundo. A documentação do meio de prova é operada no primeiro e transportada para o segundo. Entretanto, o valor probante é o mesmo do processo originário. $^{116}$

Se a prova emprestada for transportada sem a observância de seus requisitos, efeito algum poderá lhe ser atribuído.

\subsubsection{Prova cautelar, prova antecipada e prova não-repetível}

Ainda sob a perspectiva de compatibilizar a utilização de prova em estágio processual diverso daquele em que é inserida, importa assinalar a prova cautelar, a prova antecipada e a prova não-repetível, ressalvadas no art. 155 do Código de Processo Penal como possíveis fontes de formação do convencimento judicial. As ressalvadas provas devem ser lidas com reservas.

Como salientado por ANTÔNIO MAGAlHãEs Gomes FILHO, o processo, por sua natureza, é atividade que demanda tempo. Em razão do possível comprometimento do desenvolvimento da atividade processual, delineiam-se mecanismos para antecipar algumas providências, visando a "evitar que a demora possa comprometer a eficácia ou a correção da função judiciária". ${ }^{117}$

\footnotetext{
${ }^{115}$ A possibilidade de empréstimo em se tratando de meio de investigação de prova é admitida em doutrina, ao se sustentar a admissibilidade de utilização, em processo civil, da prova (fonte de prova) descoberta em interceptação de comunicação telefônica operada em processo penal, desde que seja lícita (GRINOVER, Ada Pellegrini; GOMES FILHO, Antonio Magalhães; FERNANDES, Antonio Scarance. As nulidades... op. cit., p. 183-184).

${ }^{116}$ ADA PELLEGRINI GRINOVER enfatiza que o "valor é o de sua essência, consoante foi produzida no processo primitivo" (Prova emprestada... op. cit., p. 66). Na mesma esteira, cf.: BADARÓ, Gustavo Henrique Righi Ivahy. Direito processual penal: tomo I... op. cit., p. 201.

${ }^{117}$ Cf. Provas: Lei $11.690 \ldots$ op. cit., p. 252. PIERO CALAMANDREI observa que, nos provimentos cautelares, "lo scopo immediato di assicurare la efficacia pratica del provvedimento definitivo che servirà a sua volta ad attuare il diritto". Em tradução livre do autor: "o escopo imediato de assegurar a eficácia prática do provimento definitivo, que servirá, por sua vez, para a atuação do direito" (Introduzione allo studio sistematico dei
} 
Entre tais mecanismos, destacam-se providências cautelares ${ }^{118}$ destinadas "a assegurar a eficiência da atividade probatória, diante do risco de que a ação do tempo impeça ou dificulte que pessoas ou coisas possam servir como fonte de prova". ${ }^{119}$

Parece-nos que tanto a prova cautelar, quanto a prova antecipada, são medidas cautelares.

Entendemos que ao ressalvar a prova cautelar pretendeu o legislador se referir aos meios de investigação de prova, previstos no Código de Processo Penal e em leis especiais. Reiteramos aqui a observação de que tais meios se caracterizam pela surpresa que lhe é inerente. Por isso, o contraditório é diferido, operado após a execução do meio.

Embora ressalvados no art. 155, caput, o contraditório se perfaz, de forma postergada. Além disso, deles podem resultar elementos de informação, que somente podem ser utilizados como fonte de convencimento judicial para avaliação de objetos de prova se confirmados por elementos probatórios produzidos em contraditório. A finalidade de tais meios é a descoberta de fontes de prova; e não a produção de elementos probatórios. ${ }^{120}$

Exemplo de prova cautelar, em sentido estrito, é a interceptação de comunicações telefônicas, cujo regime jurídico, no Brasil, é previsto na Lei n. 9.296, de 1996.

Igualmente providência cautelar, a também excepcionada prova antecipada, em nosso entender, se refere a meios de produção de prova. A produção antecipada de prova diz respeito à produção de prova antes do momento procedimental oportuno, em razão de antevista impossibilidade, ou dificuldade, de ulterior extração de elementos da fonte de prova

provedimenti cautelari. In: CAPPELLETTI, Mauro (Org.). Opere Giuridiche. Napoli: Moriano, 1983. v. IX,, p. 176).

${ }^{118}$ Cf. infra, item n. 1.3.

${ }^{119}$ Cf. GOMES FILHO, Antonio Magalhães. Provas: Lei 11.690... op. cit., p. 252.

${ }^{120}$ Cf. supra, item n. 1.2.1.1, e infra, item n. 1.5. 
(pessoa ou coisa). ${ }^{121}$ Trata-se de medida cautelar prevista pela lei processual (artigos 846 a 851 e 861 a 866 do Código de Processo Civil, c.c. art. $3^{\circ}$ a art. 225 do Código de Processo Penal), em regra, concretizada sob o crivo do contraditório.

Cuida-se de produção de prova, de forma excepcional, e cercada de limitações, antes da instauração da relação jurídico-processual (por exemplo, na fase de investigação) ou, na fase processual, mas em tempo anterior ao que ocorreria a sua produção. ${ }^{122}$ A disciplina do meio de produção de prova é observada, juntamente com as disposições normativas por último referidas. ${ }^{123}$ Não se desconhece a possibilidade da persecução se encerrar em investigação. Mas se visa a assegurar a atividade probatória.

Imagine-se, como ilustração, a descoberta de uma fonte de prova pessoal, uma testemunha idosa e muito enferma, durante a investigação. É possível a antecipação da produção da prova, em que é assegurada a participação de todos os interessados (art. 225 do Código de Processo Penal e art. 848, parágrafo único do Código de Processo Civil).

\footnotetext{
${ }^{121}$ Lembre-se de que o art. 156 do Código de Processo Penal possibilita ao juiz, de ofício, ordenar a produção antecipada de provas consideradas urgentes e relevantes, observando a necessidade, a adequação e a proporcionalidade da medida. Observamos, a propósito, que não se trata de instituição de poderes investigatórios ao juiz (v. supra, n. 1.1). A respeito da previsão normativa, é oportuna a invocação da lição de MARCOS ALEXANDRE COELHO ZILLI, ao explicar que a iniciativa instrutória do julgador deve obedecer a uma figura e forma apropriadas, sob pena de violação do devido processo legal e, em última análise, do próprio Estado democrático de Direito. "Há, pois, que se observar a necessidade de respeito ao juiz natural e de sua imparcialidade, da obediência ao princípio da presunção de inocência, do dever de motivar os atos decisórios, da duração razoável do processo, da obrigatoriedade de publicidade dos atos processuais, da licitude e da legitimidade das provas, e do respeito à ampla defesa e do contraditório." (A iniciativa instrutória... op. cit., p. 133-134).

${ }^{122}$ Em Itália, há previsão de instituto semelhante: o incidente probatório. Em havendo prova cuja realização seja urgente, por risco de desaparecimento ou de deterioração até a fase judicial, é prevista a possibilidade de antecipação de sua produção em incidente probatório. Pode ser requerida nos casos previstos no art. 392 do Código de Processo Penal italiano, observado o procedimento do meio de produção pertinente (art. 401.5). Ocorre em audiência, sob o crivo do contraditório (art. 398). MARIO CHIAVARIO se refere aos incidentes probatórios como " "parênteses jurisdicionais” introduzidos na fase de investigação" (O processo penal na Itália. In: DELMAS-MARTY, Mireille (Org.). Processo Penal e direitos do homem: rumo à consciência européia. Trad. Fernando de Freitas Franco. Barueri: Manole, 2004, p. 43-57).

${ }^{123}$ No mesmo sentido, AURY LOPES JR. enfatiza que "a prova antecipada deve ser produzida: a) em audiência pública, salvo o segredo justificado pelo controle ordinário da publicidade dos atos processuais; b) o ato será presidido por um órgão jurisdicional (nos sistemas policial e a cargo do MP, presidirá o juiz garante; c) na presença dos sujeitos (futuras partes) e seus respectivos defensores; d) sujeitando-se ao disposto para a produção da prova em juízo, ou seja, com os mesmos requisitos formais que deveria obedecer o ato se realizado na fase processual" (Sistemas de Investigação Preliminar no Processo Penal. 1. ed. Rio de Janeiro: Lumen Juris, 2001, p. 125).
} 
A última ressalva versa sobre a prova "não repetivel", também denominada prova irrepetível, inserida no direito brasileiro sob inspiração do direito italiano, no qual se permite a "leitura de atos por superveniente impossibilidade de repetição" (lettura di atti per sopravvenuta impossibilità di ripetizione) (art. 512 do Código de Processo Penal italiano). ${ }^{124}$

A impossibilidade de repetição (reprodução, reapresentação) se relaciona a fonte de prova. $^{125}$ A fonte, reputamo-la não-repetível. Em razão da superveniência de fatos ou circunstâncias imprevisíveis, não se pode tornar a apresentar uma fonte de prova conhecida, pessoa ou coisa, em juízo. A oportuna produção da prova, ocasião em que se extrairiam elementos de prova, é obstada. Por isso, é possível a utilização do registro da existência da fonte e dos respectivos elementos de informação, desde que sejam submetidos a contraditório diferido, do qual não se pode prescindir.

Tornando ao exemplo da testemunha, imaginemos, agora, que se tratasse de pessoa jovem e saudável que tenha deposto perante autoridade policial no curso de inquérito policial. Em razão de um trágico acidente viesse a falecer, impossibilitando a sua apresentação em juízo. No exemplo, a testemunha é fonte cuja repetição não mais é possível.

Também se costuma exemplificar com a prova pericial. Contudo, nem sempre uma fonte periciada é não-repetível. ${ }^{126}$

Enfatize-se que se for previsivel o fato apto a impedir a oportuna produção da prova na fase de debates, deve-se proceder à antecipação de sua produção (prova antecipada). Somente

\footnotetext{
${ }^{124} \mathrm{Na}$ fase de debates, em que provas podem ser produzidas sob o crivo do contraditório, o artigo 512 autoriza a leitura de declarações prestadas anteriormente perante a Polícia Judiciária ou o Ministério Público, na investigação, ou na presença de juiz, no curso da audiência preliminar, se, por fatos ou circunstâncias imprevisíveis, tornou-se impossível a sua repetição. A norma é respaldada por expressa ressalva constitucional ao contraditório: impossibilidade de natureza objetiva (art. 111 da Constituição italiana).

${ }^{125}$ No mesmo sentido, sobre a impossibilidade de repetição da fonte de prova, DENILSON FEITOZA afirma: “A prova não repetível, não-repetível ou irrepetível é aquela que não tem como ser novamente coletada ou produzida, em virtude do desaparecimento, destruição ou perecimento da fonte probatória" (itálico nosso) (Direito processual penal: teoria, crítica e práxis. 6. ed. Niterói: Impetus, 2009, p. 691).

126 “Se não há urgência na prova, não deve ser aceita a perícia produzida na fase de investigação, sem o prévio contraditório e sem mesmo a participação judicial. Em tal caso, a perícia deve ser realizada somente em juízo e não na fase de investigação preliminar." (Cf. GOMES FILHO, Antonio Magalhães; BADARÓ, Gustavo Henrique Righi Ivahy. Prova e sucedâneos... op. cit., p. 195).
} 
na restrita hipótese de o fato ser imprevisível, reputa-se a fonte de prova não-repetível, e se admite a utilização do registro da existência da fonte e dos respectivos elementos de informação, desde que sejam submetidos a contraditório diferido.

Volvendo aos termos do art. 155, caput, concluímos que o juiz formará sua convicção, em regra, pela livre apreciação de elementos probatórios (dados de conhecimento formados em contraditório) produzidos em juízo. Excepcionalmente, poderá considerar elementos probatórios cuja produção seja antecipada, ${ }^{127}$ elementos de informação extraídos de fonte de prova "não repetível" e elementos de informação obtidos em investigação - em meios de investigação de prova ou em outros atos de investigação. Os dois últimos deverão ser confirmados por elementos de prova produzidos em contraditório. ${ }^{128}$

A utilização dos elementos de prova resultantes da prova cautelar, da prova antecipada e da prova não-repetível depende da observância do contraditório, ainda que posterior ao ato de produção. ${ }^{129}$

\subsection{A cautelaridade dos meios de investigação de prova}

A técnica da cautelaridade, cujo fundamento foi esboçado nas considerações sobre a prova cautelar, ${ }^{130}$ é aplicável ao processo penal. ${ }^{131}$ Embora inexistente uma disciplina

\footnotetext{
${ }^{127}$ Pressupõe-se aqui que tais elementos de prova foram produzidos sob a forma e com as garantias da produção antecipada da prova, entre as quais se insere o contraditório.

${ }^{128}$ Cf. infra, item n. 1.5 .

${ }^{129}$ No mesmo sentido, cf.: GOMES FILHO, Antonio Magalhães. Provas: Lei 11.690... op. cit., p. 254-255.

${ }^{130}$ Cf. supra, item n. 1.2.3.5.

131 Cf. GOMES FILHO, Antonio Magalhães. Presunção de inocência e prisão cautelar. 1. ed. São Paulo: Saraiva, 1991, p. 56-57; GOMES FILHO, Antonio Magalhães. Provas: Lei 11.690... op. cit., p. 252-254; SAAD GIMENES, Marta Cristina Cury. As medidas assecuratórias do Código de Processo Penal como forma de tutela cautelar destinada à reparação do dano causado pelo delito. 2007. Tese (Doutorado) - Faculdade de Direito, Universidade de São Paulo (USP), São Paulo, 2007, p. 35-39; CINTRA, Antonio Carlos de Araújo Cintra; GRINOVER, Ada Pellegrini; DINAMARCO, Cândido Rangel. Teoria Geral do Processo. 21. ed. São Paulo: Malheiros, 2005, p. 327-328; GRINOVER, Ada Pellegrini; GOMES FILHO, Antonio Magalhães; FERNANDES, Antonio Scarance. As nulidades... op. cit., p. 261-262.
} 
normativa sistematizada, a doutrina reconhece como cautelas $^{132}$ providências instituídas pelo legislador na tentativa de solucionar possíveis problemas decorrentes da demora inerente à atividade processual.

Os meios de investigação de prova integram a tutela cautelar no processo penal: ${ }^{133}$ são medidas ${ }^{134}$ urgentes destinadas a assegurar a investigação do fato criminoso e a eficiência da atividade probatória, "diante do risco de que a ação do tempo impeça ou dificulte que pessoas ou coisas possam servir como fonte de prova". ${ }^{135}$

É possível extrair da tutela normativa processual comum e da doutrina aspectos gerais da cautelaridade no processo penal.

Os requisitos ${ }^{136}$ gerais das medidas cautelares são: o fumus commissi delicti e o periculum in mora. ${ }^{137}$ Quem pretende descobrir prova com a utilização dos meios de

132 "A cautela é espécie de um gênero mais amplo: a tutela jurídica" (BARROS, Romeu Pires de Campos. Processo penal cautelar. Rio de Janeiro: Forense, 1982, p. 1).

133 "Esses meios de obtenção de prova distinguem-se dos meios de produção de prova e constituem normalmente providências de natureza cautelar" (Cf. FERNANDES, Antonio Scarance. Prova e sucedâneos... op. cit., p. 209). No mesmo sentido, ROGÉRIO LAURIA TUCCI, comentando a interceptação de comunicação telefônica, salienta: "bem é de ver, a propósito, que não afronta regra do contraditório o fato de ser determinada a medida inaudita altera parte, dada a sua natureza manifestamente cautelar" (Direitos e garantias... op.cit., p. 408). Na mesma esteira, cf.: GOMES FILHO, Antonio Magalhães; FERNANDES, Antonio Scarance. Os resultados da interceptação telefônica como prova penal. Revista de Processo, São Paulo, RT, ano 11, n. 44, out-dez. 1986, p. 97; GRINOVER, Ada Pellegrini. Interceptações telefônicas e gravações clandestinas no processo penal. Revista Universitaria de Derecho Procesal, Madrid, n. 4, 1990, p. 424; GRINOVER, Ada Pellegrini; FERNANDES, Antonio Scarance; GOMES FILHO, Antonio Magalhães. As nulidades... op. cit., p. 165 e 174; GRECO FILHO, Vicente. Interceptação telefônica: considerações sobre a Lei n. 9.296, de 24 de julho de 1996. 2. ed. São Paulo: Saraiva, 2005, p. 45; AVOLIO, Luiz Francisco Torquato. Provas ilícitas - interceptações telefônicas, ambientais e gravações clandestinas. 3. ed. São Paulo: RT, 2003, p. 94.

${ }^{134} \mathrm{Em}$ doutrina, identificamos referência a tutela cautelar tanto no plano normativo, quanto no plano jurisdicional. Emprega-se o termo medidas ou providências para expressar a disciplina legal de institutos que se amoldam à técnica da cautelaridade (Cf. GRINOVER, Ada Pellegrini; GOMES FILHO, Antonio Magalhães; FERNANDES, Antonio Scarance. As nulidades... op. cit., p. 261-262). Também se utiliza provimento cautelar, para expressar a natureza do provimento jurisdicional que determina sua realização (Cf. GRINOVER, Ada Pellegrini; GOMES FILHO, Antonio Magalhães; FERNANDES, Antonio Scarance. As nulidades... op. cit., p. 174; CALAMANDREI, Piero. Introduzione allo studio... op. cit., p. 164). Ao se tratar, por exemplo, de requisitos de uma medida cautelar, parece-nos que seja enfatizado o plano normativo; ao se tratar da cognição, evidencia-se enfoque no plano jurisdicional. Preferimos o emprego do termo medidas que, em nosso entender, abarcaria as cautelas sob os dois enfoques. No mesmo sentido, cf.: SAAD GIMENES, Marta Cristina Cury. As medidas assecuratórias... op. cit., p. 36, especialmente nota 123.

${ }^{135}$ Cf. GOMES FILHO, Antonio Magalhães. Provas: Lei $11.690 \ldots$ op. cit., p. 252.

${ }^{136}$ Em razão dos objetivos deste trabalho, preferimos a referência a requisitos, sem discutir detidamente a sua inserção na teoria geral do processo. Convém registrar, todavia, o desencontro doutrinário quanto à sistematização das exigências das medidas cautelares, que são classificadas de diferentes formas, entre as quais 
investigação de prova deve demonstrar ambos os requisitos. O primeiro se traduz na existência de elementos de materialidade e autoria delitivas. E o outro consiste em perigo concreto, ínsito à necessidade de preservação de prova e de correta apuração do fato investigado. ${ }^{138}$

Além dos referidos requisitos gerais, é necessária a configuração dos requisitos específicos, previstos na disciplina legal de cada uma das medidas cautelares.

Em processo penal, em que avulta a liberdade do cidadão, recomenda-se um rigor mais acurado na avaliação de seus requisitos. ${ }^{139}$

destacamos: pressupostos (TUCCI, Rogério. Teoria do direito processual penal: jurisdição, ação e processo penal (estudo sistemático). São Paulo: RT, 2002, p. 107); requisitos (GOMES FILHO, Antonio Magalhães. Presunção de inocência... op. cit., p. 54); condições da ação cautelar (CALAMANDREI, Piero. Introduzione allo studio... op. cit., p. 201). Por vezes, o binômio fumus boni iuris e periculum in mora é referido, indistintamente, como pressuposto ou requisito (BARROS, Romeu Pires de Campos. Processo penal... op. cit., p. 191).

${ }^{137}$ Cf. GRINOVER, Ada Pellegrini; GOMES FILHO, Antonio Magalhães; FERNANDES, Antonio Scarance. As nulidades... op. cit., p. 261-262.

${ }^{138}$ É preciso demonstrar o risco de que, ao tempo da instrução, a fonte de prova não mais exista ou se tenha dificultado a sua descoberta.

${ }^{139}$ Cf. GOMES FILHO, Antonio Magalhães. Presunção de inocência... op. cit., p. 57. FLÁVIO LUIZ YARSHELL, no direito processual civil brasileiro, sustenta a possibilidade de antecipação da prova sem o requisito de urgência. Sob a perspectiva da ligação entre a pesquisa de fatos e a pré-constituição da prova e a ideia de investigação na área civil, o autor enfatiza a existência de um direito à investigação, que está abrangido pelo direito à prova (Antecipação de prova sem o requisito da urgência e direito autônomo à prova. São Paulo: Malheiros, 2009, p. 212). A este respeito, o autor afirma: "identificou-se na prerrogativa de buscar e de obter a prova a semente de um verdadeiro e autônomo direito à prova, concebido de forma não diretamente vinculada a proceso cujo objeto é a declaração do direito, mero desdobramento da ação e da defesa exercitadas neste contexto. Por outras palavras, vislumbrou-se o direito de invocar a intervenção estatal tão-somente para a produção de certa prova; ou, considerando aquela relativa desvinculação, um direito à pré-constituição da prova. Trata-se de posição jurídica de vantagem que autoriza a produção de prova de forma antecipada mesmo fora das hipóteses de urgência ou daquelas nas quais o acesso a certa pessoa ou coisa é prerrogativa contida no direito material. A esse autônomo direito propôs-se atribuir a denominação 'direito à prova', deixando-se a locução 'direito de provar' para designar a prerrogativa de produzir prova como desdobramento da ação e da defesa exercitadas no bojo de um processo cujo objeto é a declaração do direito." (Antecipação de prova ... op. cit., p. 303-304). Estas premissas o permitiram diferenciar as situações de produção antecipada da prova "com fundamento no requisito do periculum in mora e mediante estreita vinculação com o processo dito 'principal"', e de produção antecipada da prova sem vinculação "a uma concreta pretensão de declaração do direito ('ação principal')." (Antecipação de prova... op. cit., p. 244-245). Não reputamos que o raciocínio possa ser estendido ao direito processual penal, em especial quanto aos meios de investigação de prova, que reputamos medidas cautelares, as quais pressupõem a configuração de fumus commissi delicti e periculum in mora. No mesmo sentido, o autor reconhece a impossibilidade de semelhança de raciocínio quanto a tais institutos, cuja concretização é fundada na surpresa: "sem embargo do reconhecimento de que a distinção entre ilícito civil e ilícito penal é relativa, é de se duvidar, por outro lado, que a atividade de investigação no campo penal encontre exata correspondência no campo civil. Ainda que se possa aceitar que o objeto da investigação possa eventualmente revelar alguma sobreposição entre os dois planos do direito material, parece lícito reconhecer que as técnicas empregadas são diversas e que, como conseqüência disso, os agentes responsáveis pela respectiva implementação também são diversos". Mais ainda: "não parece possível tratar igualmente, sem qualquer ressalva, as técnicas - e os respectivos resultados - empregadas para o combate ao crime, de um lado, e para apuração de fatos com relevância na esfera civil, de outro. Exemplo bastante significativo disso é a aceitação da surpresa na 
E a observância da regulamentação legal da medida cautelar abrange não só os seus requisitos, como também o procedimento para sua execução. Os atos do procedimento devem ser praticados sob a fiscalização do juízo competente que vier a autorizar sua realização. Em geral, são medidas incidentais, porque se inserem em outro procedimento em curso. ${ }^{140}$

As características das medidas cautelares apontadas pela doutrina justificam sua urgência e excepcionalidade. ${ }^{141}$

As medidas cautelares são caracterizadas por sua instrumentalidade ao processo principal, ${ }^{142}$ que se caracteriza por ser eventual e de segundo grau. É eventual, por se efetivar se for necessário o processo principal. ${ }^{143}$ É de segundo grau porque servem como "instrumento a serviço do instrumento: elas servem à eficiência do provimento jurisdicional principal e este, por sua vez, serve ao direito material e à própria sociedade". ${ }^{144}$

Um provimento cautelar encerra um juízo de cognição sumária, ${ }^{145}$ que tem como “contrapeso" a sua provisoriedade, ${ }^{146}$ i.e., a limitação temporal de seus efeitos.

\footnotetext{
investigação criminal, que não parece ser aceitável com tanta complacência na esfera civil." (Antecipação de prova... op. cit., p. 37).

${ }^{140}$ Cf. SAAD GIMENES, Marta Cristina Cury. As medidas assecuratórias ... op. cit., p. 36.

${ }^{141}$ A urgência e excepcionalidade das medidas cautelares são enfatizadas em doutrina. A propósito, cf. : GOMES FILHO, Antonio Magalhães. Provas: Lei 11.690... op. cit., p. 253; GRINOVER, Ada Pellegrini; GOMES FILHO, Antonio Magalhães; FERNANDES, Antonio Scarance. As nulidades... op. cit., p. 261-262.

${ }^{142}$ Quanto ao caráter instrumental das medidas cautalares no direito processual penal, cf. BARROS, Romeu Pires de Campos. Processo penal... op. cit., p. 45. E, no direito processual civil, cf. BEDAQUE, José Roberto dos Santos. Tutela cautelar... op. cit., p. 143-145.

${ }^{143}$ Cf. DINAMARCO, Cândido Rangel. A instrumentalidade do processo. 13. ed. São Paulo: Malheiros, 2008, p. 308.

${ }^{144}$ Cf. Ibidem, p. 308. No mesmo sentido, cf.: CINTRA, Antonio Carlos de Araújo Cintra; GRINOVER, Ada Pellegrini; DINAMARCO, Cândido Rangel. Teoria Geral... op. cit., p. 326. PIERO CALAMANDREI, salientando a relação de instrumentalidade, também referida como relação de subsidiariedade (Introduzione allo studio... op. cit., p. 175-176. Em relação a instrumentalidade, MARTA CRISTINA CURY SAAD GIMENES salienta a acessoriedade das medidas cautelares em relação ao processo (As medidas assecuratórias ... op. cit., p. 37).

${ }^{145}$ Cf. CALAMANDREI, Piero. Introduzione allo studio... op. cit., p. 170.

${ }^{146}$ A provisoriedade, caráter distintivo dos provimentos cautelares, significa um "temperamento" da sumariedade de cognição (Cf. CALAMANDREI, Piero. Introduzione allo studio... op. cit., p. 168-170).
} 
Diferentemente do direito processual comum, não se deve cogitar de Poder Geral de Cautela em direito criminal. Em se tratando de processo penal, exige-se legalidade em todo o desenrolar da atividade de repressão. ${ }^{147}$ As medidas cautelares devem ser taxativas. ${ }^{148}$ Por isso, é vedado o emprego de analogia.

Com efeito, impõe-se, como decorrência inarredável da legalidade, a tipicidade das medidas cautelares. A atipicidade subverte princípio fundamental do Estado Democrático de Direito, "consagrando algo próximo a idéia de justiça sumária". ${ }^{149} \mathrm{Um}$ dos argumentos que sustenta a inadmissibilidade dos meios de investigação de prova atípicos é a sua natureza cautelar, ao qual se somam os apresentados a seguir. ${ }^{150}$

\subsection{Classificações dos meios de investigação de prova}

As classificações dos meios de investigação de prova não são matéria sistematizada em doutrina. Entretanto, identificamos em considerações expendidas sobre os aspectos gerais de tais meios, algumas dicotomias. Pontuamos aquelas que nos pareceram importantes para a análise do tema.

\footnotetext{
${ }^{147}$ Cf. GOMES FILHO, Antonio Magalhães. Presunção de inocência... op. cit., p. 57; LOPES JR., Aury. A (in)existência de poder geral de cautela no processo penal. Boletim IBCCRIM, São Paulo, ano 17, n. 203, out. 2009, p. 08-09; MORAES, Maurício Zanoide de. Presunção de Inocência no processo penal brasileiro: análise da estrutura normativa para a elaboração legislativa e para a decisão judicial. Rio de Janeiro: Lumen Juris, 2010 , p. 296.

${ }^{148}$ Cf. infra, item n. 2.6.

${ }^{149}$ Cf. GOMES FILHO, Antonio Magalhães. Presunção de inocência... op. cit., p. 57."No processo penal, as medidas cautelares são sempre típicas" (Cf. SAAD GIMENES, Marta Cristina Cury. As medidas assecuratórias... op. cit., p. 36.

${ }^{150}$ Cf. infra, item n. 1.4.1. Ressalvamos há posicionamento doutrinário em sentido contrário, admitindo medidas cautelares atípicas e emprego de analogia em se tratando de meios de prova. A este respeito, cf.: LIMA, Marcellus Polastri. A tutela cautelar no processo penal. Rio de Janeiro: Lumen Juris, 2005, p. 119; GOMES FILHO, Antonio Magalhães; BADARÓ, Gustavo Henrique Righi Ivahy. Prova e sucedâneos... op. cit., p. 183; DEZEM, Guilherme Madeira. Da prova penal... op. cit., p. 301-302.
} 


\subsubsection{Meios de investigação de prova típicos e atípicos}

Considera-se a previsão ou não no ordenamento jurídico a divisão entre meios de investigação de prova típicos e atípicos, sob a perspectiva da noção de tipo probatório. Com fundamento na noção de prova típica e de prova atípica já expostas, ${ }^{151}$ a tipicidade de um meio de investigação de prova decorre não só de sua previsão legal, como também de procedimento probatório preconizado pelo legislador.

Um meio de investigação de prova é típico se é prevista em lei sua regulamentação, que engloba não só nominação e requisitos, como também o procedimento para sua execução, específico ou comum a outro meio, a cuja disciplina o legislador nos remete. Em contraposição, é atípico o previsto em lei, sem o respectivo procedimento (próprio ou por remissão), o referido nominalmente em lei e o não referido em lei.

A atipicidade dos meios de investigação de prova é questão debatida em diversos ordenamentos jurídicos. ${ }^{152} \mathrm{O}$ avanço tecnológico propicia o desenvolvimento, diuturnamente, de novas formas de obtenção de prova.

No direito brasileiro, um exemplo de meio de investigação de prova atípico é a interceptação de comunicação entre pessoas presentes, a qual é prevista em lei (art. $2^{\circ}$, caput e inciso IV da Lei n. 9.034/95), sem procedimento probatório.

O Código de Processo Penal não disciplinou a admissibilidade ou não de provas atípicas. Os fundamentos normativos para sustentar a admissibilidade de execução de meios atípicos, são as disposições de seu art. $3^{\circ}$ e do art. 332 da lei processual civil: "todos os meios legais, bem como os moralmente legítimos, ainda que não especificados neste Código, são

\footnotetext{
${ }^{151}$ Cf. supra, item n. 1.2.3.2.

${ }^{152} \mathrm{O}$ tema é analisado, em diferentes países, por ANTONIO SCARANCE FERNANDES, em relatório geral das XX Jornadas Ibero-americanas de Direito Processual (Málaga, 2006), com fundamento em relatórios nacionais dos seguintes países: Argentina, Brasil, Chile, Colômbia, Costa Rica, Espanha, Paraguai, Portugal e Uruguai. O autor apresenta disposições normativas de ordenamentos estrangeiros que preconizam a liberdade probatória e a invocação doutrinária de princípio da verdade material (Prova e sucedâneos... op. cit., p. 193-236, especialmente em p. 209-213 e 233-234)
} 
hábeis para provar a verdade dos fatos, em que se funda a ação ou a defesa." O catálogo das espécies de meios de prova não é tido por taxativo.

Evidenciam-se duas correntes doutrinárias. Ambas admitem a prova atípica, desde que se observe, por analogia, a disciplina normativa de uma prova típica. Diverge-se na extensão da admissibilidade da atipicidade: tanto meios de produção de prova, quanto meios de investigação de prova; ${ }^{153}$ somente nos meios de produção de prova. ${ }^{154}$

Merece destaque, no direito estrangeiro, a disciplina italiana, na qual se regulamentou a prova atípica. Inserto em disposições gerais sobre as provas, o art. 189 do Código de Processo Penal italiano ("prove non disciplinate dalla legge") estabelece que uma prova não disciplinada pela lei pode ser admitida se for idônea à verificação dos fatos e não prejudicar a liberdade moral da pessoa, requisitos avaliados pelo juiz, ouvidas as partes sobre a modalidade probatória. Previu-se, portanto, que o juízo de admissibilidade da prova requerida se perfaça em contraditório.

Interpretando os termos legais, reconhece-se a pertinência do dispositivo legal aos meios de produção de prova, facilmente conciliáveis com os seus termos. Porém, muito se discute sobre a admissibilidade de meios de investigação de prova atípicos.

Atento ao elevado grau de restrição a direitos constitucionalmente tutelados, DELFINO SIRACUSANO reconhece que deveria estar previsto um melhor grau de garantia nas previsões legislativas sobre o modo de ser e a forma dos meios de investigação de prova. Tal constatação se expresssa em dúvida por ele extraída da interpretação da norma sobre "provas

\footnotetext{
${ }^{153}$ Neste sentido, cf.: GOMES FILHO, Antonio Magalhães; BADARÓ, Gustavo Henrique Righi Ivahy. Prova e sucedâneos... op. cit., p. 180-183; FERNANDES, Antonio Scarance. Prova e sucedâneos... op. cit., p. 198-199 e 209-211; DEZEM, Guilherme Madeira. Da prova penal... op. cit., p. 275-290 e 299-308.

${ }^{154}$ GUSTAVO HENRIQUE RIGHI IVAHY BADARÓ, afirma que "embora não haja um dispositivo semelhante do Código de Processo Penal, há consenso de que não vigora no campo penal um sistema rígido de taxatividade dos meios de prova, sendo admitida a produção de prova não disciplinadas em lei, desde que obedecidos a determinadas restrições" (negrito nosso) (Provas atípicas... op. cit., p. 200)
} 
não disciplinadas pela lei” (art. 189): a normativa é aplicável aos meios de investigação de prova ${ }^{155}$

Em resposta à indagação, CLAUDIO MARINELli identifica uma verdadeira "aporia", porque a citada disciplina, perfeitamente coerente com as características próprias dos meios de prova, parece-lhe dificilmente conciliável com os meios de investigação de prova, que operados inaudita altera parte, não raramente de modo oculto ou insidioso. ${ }^{156}$ A aplicação literal da disposição frustraria a finalidade dos meios de investigação de prova. ${ }^{157}$

Em tentativa de solução da referida aporia, a doutrina italiana propõe soluções de duas ordens, sintetizadas pelo autor na forma de correntes doutrinárias.

De um lado, admitem-se os meios de investigação de prova atípicos, com a necessária observância do princípio do contraditório. ${ }^{158}$ Com vistas a adaptar o texto normativo à

\footnotetext{
155 "Nelle pontuali previsioni legislative cerca il loro modo d'essere e la loro forma il migliore e più adeguato tasso di garanzia. Sorge, però, un problema. Ad evocarlo è la normativa sulle 'prove non disciplinate dalla legge'. Può comprendere questa normativa i mezzi di ricerca della prova?". Confiram-se também as sucessivas indagações do autor: "sono, insomma, ipotizzabili mezzi 'atipici' di ricerca della prova, fuori dagli schemi predisposti dal legislatore per le ispezioni, le perquizioni, i sequestri e le intercettazioni telefoniche? O l'avvertita esigenza di dotare la ricerca della prova di insopprimibili garantizie esclude in partenza le aperture sperimentabili in base all'art. 189 c.p.p.?". Mais adiante, afirma o autor que os meios de investigação de prova típicos podem ser considerados sob a seguinte perspectiva: "reunindo as diferentes disciplinas no sentido de uma comum experiência e delimitando a esfera subjetiva da ação do meio de investigação". Ele cita, exemplificativamente, as proibições de utilização dos citados meios, como a pertinente à captação de conversa entre defensor e investigado (SIRACUSANO, Delfino. Le prove: i mezzi... op. cit., p. 399-400).

156 "La citata disciplina, a dispetto de tale equivocità, è perfettamente coerente con le caratteristiche proprie dei mezzi di prova, ma apare dificilmente conciliabile con i mezzi di ricerca della stessa. L'osservazione, se vale in generale per tali strumenti, ordinariamente disposti inaudita altera parte, assume um particolare rilievo per quelli che operino in modo occulto o insidioso, come ad es. la video-osservazione, il pedinamento o il tele-rilevamento satellitare. Rispetto a questi ultimi, infatti, l'applicazione letterale della disposizone finirebbe per frustrarne la stessa operatività." Em tradução livre do autor: "a citada disciplina, a despeito de tal equivocidade, é perfeitamente coerente com as características próprias dos meios de prova, mas parece dificilmente conciliávelcom os meios de investigação de prova. A observação - válida em geral para tais instrumentos, ordinariamente dispostos inaudita altera parte - assume um particular realce para aqueles que se operam de modo oculto ou insidioso, como, por exemplo, a vídeo-observação, o monitoramente ou a tele-observação por satélite. Com relação a estes últimos, de fato, a aplicação literal da disposição implicaria frustrar a respectiva operatividade." (Intercettazioni processuali... op. cit., p. 123-124.).

${ }^{157}$ Cf. Intercettazioni processuali... op. cit., p. 123-124.

${ }^{158}$ Salienta-se o respeito às condições previstas no ao art. 189 do Código de Processo Penal italiano compensa, adequadamente, o defeito de tipicidade do meio de investigação de prova. As referidas condições: "a) puntano sulla idonietà del "mezzo" as assicurare l'accertamento dei fatti; b) escludono iniziative in punto di prova, comunque pregiudizievoli alla libertà morale della persona; c) implicano l'intervento delle parti per organizzare le 'modalità di assunzione delle prove"' (SIRACUSANO, Delfino. Le prove: i mezzi... op.cit., p. 400). Ainda quanto ao reconhecimento da admissibilidade de meios de investigação de prova atípicos, afirma ERCOLE
} 
"surpresa" que os caracteriza, diverge-se quanto ao momento em que se deva conceder às partes oportunidade de se manifestarem sobre a prova requerida: antes ou depois da execução do procedimento probatório.

Tanto para os meios de produção de prova, quanto para os meios de investigação de prova, sustenta-se, numa primeira corrente de pensamento, a formação de um juízo de admissibilidade prévio a execução do procedimento probatório, formado após a oitiva das partes, em contraditório ex ante. ${ }^{159}$

Afirma-se, também, em outra corrrente doutrinária, a instauração de um contraditório ex post para os meios de investigação de prova, que exigiria a formulação de juízo de admissibilidade depois da execução do respectivo procedimento: operado o contraditório diferido e demonstrada a inidoneidade do meio, protesta-se pela prolação de decisão de inadmissibilidade da fonte de prova. ${ }^{160}$

Entenda-se: a corrente que admite a possibilidade de execução dos meios de investigação de prova atípicos, fá-lo com a necessária adequação aos limites impostos pelo legislador, entre os quais sobressai a observância do contraditório (ex ante ou ex post).

Uma terceira corrente doutrinária propugna pelo reconhecimento da aplicabilidade do dispositivo que regulamentou a prova atípica apenas aos meios de produção de prova. A previsão inserta na disciplina geral da prova seria especial, referente apenas a estes. Segundo esta corrente, os meios de investigação de prova atípicos são tidos por inadmissíveis. ${ }^{161}$

\footnotetext{
APRILE que o elenco dos meios de investigação de prova e dos meios de produção de prova não constitui um "numerus clausus", asseverando a necessária observância do contraditório (La prova... op. cit., p. 60-61). ANTONIO LARONGA também conclui no sentido da admissibilidade de meios de investigação de prova atípicos (Le prove... op. cit., p. 29-32).

${ }^{159}$ DELFINO SIRACUSANO afirma: "eis um ponto certo: a relevância destas provas não deve ser apurada somente posteriormente (ex post), no momento em que o juízo procede à valoração do conjunto de aquisições probatórias. Mas deve ser avaliada sua admissibilidade anteriormente (ex ante): no momento da requisição (richiesta) do meio de prova ou do meio de investigação da prova. A prova, como prova atípica, deve ser, antes de tudo, admitida (e não revogada)" (tradução livre do autor) (Prova - III)... op. cit., p. 5).

${ }^{160}$ Cf. MARINELLI, Claudio. Intercettazioni processuali... op. cit., p. 123-124.

${ }^{161}$ Cf. BORRELLI G. Riprese filmate nel bagno di um pubblico esercizio e garanzie costituzionali, in Cass. pen., 2001, p. 2446, apud MARINELLI, Claudio. Intercettazioni processuali... op. cit., p. 123-124. No mesmo sentido, GIAN FRANCO RICCI afirma que: 'l' interpretazione che è prevalsa presso questi studiosi è stata dunque quella
} 
Volvendo ao direito nacional, parece-nos inadmissível a execução de um meio de investigação de prova atípico. ${ }^{162}$

O art. 332 do Código de Processo Civil, invocado pela doutrina pátria, deve ser interpretado restritivamente. ${ }^{163}$ É aplicável apenas aos meios de produção de prova. A única limitação nele inserta é a prevista legitimidade moral, que deve avaliada sob o crivo do contraditório das partes (art. $5^{\circ}$, inciso LV, da Constituição Federal).

Veja-se que o dispositivo se refere a meios "hábeis para provar a verdade dos fatos, em que se funda a ação ou a defesa". Em regra, elementos probatórios para verificação da veracidade das alegações fáticas expendidas pela acusação e pela defesa podem ser extraídos das fontes de prova apenas pelos meios de produção de prova. ${ }^{164}$

Demais disso, é inerente aos atos de produção de prova a observância do princípio do contraditório, que viabiliza o emprego da analogia: sob o crivo do debate das partes, aplica-se procedimento previsto em lei para outro meio. Aqui a legalidade é observada não só pela expressa previsão do citado art. 332 da lei processual civil e do art. $3^{\circ}$ do Código de Processo Penal, como também pela disciplina de um meio típico, utilizada por analogia.

restritiva, nel senso che il catalogo delle prove possa essere superato solo ed esclusivamente per cio che riguarda eventuali mezzi istruttori non previsti dal diritto e non anche con riferimento alla possibilità d'introdure nuove forme di acquisizione probatoria o deroghe a quelle già esistenti” (Le prove... op. cit., p. 530).

${ }^{162}$ No mesmo sentido, examinando a restrição de direitos fundamentais, MAURÍCIO ZANOIDE DE MORAES afirma: "se não se discute mais a impositividade da parêmia 'nulla poena nullun crimen sine lege', o mesmo se dá com sua correspondente projeção processual ('nulla coactio sine lege') e pela qual devem ser 'tipificadas' tanto as condições de aplicação, com o conteúdo das intervenções processuais no âmbito dos direitos fundamentais dos cidadãos. Nessa transposição de áreas jurídico-criminais, os atributos inerentes a toda lei penal material serão também ínsitos às normas processuais infraconstitucionais, de finalidade restritiva, pois elas deverão ser prévias, escritas e estritas. Dessas características ressurte a anterioridade e especificidade normativa. Tal qual no âmbito penal, não se pode restringir direito fundamental sem lei processual anterior que determine o modo, a intensidade e a finalidade da restrição." (Presunção de Inocência... op. cit., p. 315-316). Ressalvamos, contudo, que há entendimento em sentido contrário, admitindo medidas cautelares não taxativas em matéria probatória (cf., supra, item n. 1.3, nota n. 150).

${ }^{163}$ No mesmo sentido, quanto à necessidade de interpretação restritiva no direito italiano, cf.: RICCI, Gian Franco. Le prove... op. cit., p. 529.

${ }^{164}$ Cf. supra, item n. 1.2.1.1. 
Entretanto, temos por inadmissível a execução de meio de investigação de prova atípico, excluindo a aplicabilidade do mencionado art. 332 do Código de Processo Civil, porque restrições de liberdades públicas devem atender à exigência de reserva de lei. ${ }^{165}$ É necessária uma regulamentação específica, da qual se possam extrair requisitos, limites e procedimento probatório.

A execução de um meio de investigação de prova atípico, por analogia, presentes os pressupostos exigidos para concessão das medidas cautelares e considerados os requisitos e o procedimento legais previstos para efetivação de outro meio típico, assemelhado, violaria o princípio da legalidade, por ser manifesta sua incompatibilidade com o disposto no art. 332 da lei processual civil. Aliás, árdua seria a pretensa tarefa de identificar um meio análogo, pois o grau de restrição a liberdades públicas varia em cada um deles. ${ }^{166}$

Ademais, exigir a observância ex ante do princípio do contraditório, na tentativa de delimitar um procedimento entre os preconizados em lei, antes da formação do juízo de admissibilidade de meio de investigação de prova, inviabilizaria a utilização do instituto - que é fundada no fator surpresa - e a possível descoberta de fontes de prova úteis.

Reitere-se que a observância do princípio do contraditório é diferida (ex post) na execução destes meios. ${ }^{167}$ Mas isto não sana a ilicitude resultante da execução de um meio de investigação de prova atípico, porque já operada a restrição ilegal de direito ou de garantia fundamental.

\subsubsection{Meios de investigação de prova ordinários e extraordinários}

Fala-se ainda em meios de investigação de prova extraordinários e de meios de investigação de prova ordinários. ${ }^{168}$ A distinção se pauta no elevado grau de restrição a bens

\footnotetext{
${ }^{165}$ Cf. infra, item n. 2.6.

${ }^{166}$ Cf. infra, item n. 1.4.2.

${ }^{167}$ Cf.. supra, item n. 1.2.1.2.

${ }^{168}$ A doutrina argentina, como aponta ANTONIO SCARANCE FERNANCES, emprega a terminologia meios de provas ordinários e meios de prova extraordinários. Os segundos se caracterizariam pela maior dificuldade para
} 
jurídicos operada pelos primeiros. Neles, a observância de garantias fundamentais é de difícil concretização, o que torna tormentosa sua efetivação. ${ }^{169}$

Os meios de investigação de prova ditos extraordinários são previstos, em geral, para investigação de atividade concretizada por organizações criminosas. ${ }^{170}$ Os agentes encobertos e infiltrados os exemplificam. ${ }^{171}$

De outro lado, restariam como ordinários os previstos não só para investigação de delitos graves, neles insertos os cometidos por organização criminosa, como também infrações de menor gravidade, cuja forma de execução é diferenciada, por ser escondida sob o manto protetor da inviolabilidade de bens jurídicos individuais.

Discordamos dos fundamentos desta classificação. Dela se poderia chegar à equivocada conclusão de que existem meios de investigação de prova "ordinários", cuja utilização seria usual. ${ }^{172}$

efetivação e para observância de direitos e garantias processuais. Mas o faz com exemplos tanto de meios de produção quanto de investigação (Prova e sucedâneos... p. 199).

${ }^{169}$ Comentando meios em que se tem elevado grau de restrição de direitos fundamentais, MANUEL DA COSTA ANDRADE os critica: "a verdade é que as novações legislativas a que nos vimos reportando convergem todas no mesmo sentido final: redução de neutralização de garantias de defesa; multiplicação, em número e em potencial de lesividade e devassa, dos meios institucionalizados de intromissão nos direitos fundamentais; deslocação das linhas de equilíbrio normativo do lado da liberdade, da autonomia e da dignidade, para o lado da segurança" (ANDRADE, Manuel da Costa. Métodos ocultos de investigação (Plädoyer para uma teoria geral). In: COLÓQUIO EM HOMENAGEM AO INSTITUTO BRASILEIRO DE CIÊNCIAS CRIMINAIS, 2007, Coimbra. Justiça Penal Portuguesa e brasileira: tendências e reforma. $1^{\text {a }}$ ed. São Paulo: IBCCRIM, 2008. p. 101).

${ }^{170}$ Quanto aos meios de prova ditos "extraordinários", vale ressaltar o alarde de FRANCISCO MUNOZ CONDE e de MARCELA DE LANGHE: "igualmente importantes son los llamados 'medios de prueba extraordinarios' que, justificados originariamente por la necessidad de reforzar la investigación de hechos delictivos también extraordinários, no solo por su inusitada gravedad sino además por los serios problemas que presentan para su investigación, conllevan el grave riesgo o proposito de legitimar la ilegalidad em la averiguación penal, so pretexto de dotarla de una mayor eficácia para la averiguación y, en su caso, represión de tales ilícitos." Os autores exemplifica com o agente encoberto. E complementam: "una cosa nos parece segura: quien quiera negar la operatividad de lãs garantías costitucionales en la investigación de ciertos hechos, en función de ser más eficiente, tendrá un concepto torpe de eficiencia y a la larga deberá asumir que el pago que debe hacer por esta pretendida eficacia será la perdida de identidad del Estado de derecho." (Presentación. In: ROXIN, Claus. La prohibición de autoincriminación y las escuchas domiciliarias. 1. ed. Buenos Aires: Hammurabi, 2008, p. 11).

${ }^{171}$ Cf. LOPES NEISTEIN, Mariangela. $O$ agente infiltrado como meio de investigação. Dissertação de Mestrado - Faculdade de Direito, Universidade de São Paulo (USP), São Paulo, 2006, p. 40-62.

172 Atenta ao perigo de se considerar comum restrição de direitos e garantias fundamentais, CLAUDIA CARMONA afirma: "allora l'interrogativo più pressante in tema di garanzie per l'acusato sembra essere non come salvaguardale, ma fino a che punto sia consentito restringerle". Em tradução livre do autor: "então o questionamento mais premente em tema de garantias para o acusado parece ser não como salvaguardá-las, mas 
Todavia, reitere-se, por diversas vezes, que os meios de investigação de prova, pela ínsita restrição a direitos e a garantias fundamentais operadas, são extraordinários. ${ }^{173}$ Cuida-se de medidas excepcionais, em razão de seu caráter insidioso. ${ }^{174}$

É oportuno registrar que é de elevado grau a restrição operada por interceptação de comunicações. $^{175}$

As interceptações são gravosas, quanto a restrições a direitos e a garantias fundamentais, porque, além de serem deferidas inaudita altera parte (lembre-se do fator surpresa), a prática dos atos integrantes do procedimento probatório também se perfaz sem o conhecimento da parte interessada. É diferente, por exemplo, da busca e da apreensão, em que a execução é conhecida e pode ser acompanhada pelo interessado. ${ }^{176}$

até que ponto seja consentido restringi-las" (itálico nosso) (Le intercettazioni ambientali in relazione alla normativa del 1991 sui reati di criminalità organizzata. Rivista Italiana di Diritto e Procedura Penale, Milano, Giuffrè, anno XLII, fasc. 1, gen-mar. 1999, p. 358).

${ }^{173}$ A este respeito, ANTÓNIO HENRIQUES GASPAR assevera: "tendo o Estado o direito - e o fundamental dever - de utilizar no máximo limite todo o seu arsenal de instrumentos e meios legais para prevenir e reprimir as actividades terroristas e a grande e complexa criminalidade, não podem, todavia, usar indiscriminadamente meios e realizar acções que afectem ou desconsiderem os valores fundamentais que devem também garantir" (Os novos desafios do processo penal no século XXI e os direitos fundamentais (um difícil equilíbrio). Revista Portuguesa de Ciência Criminal, Coimbra, ano 15, n. 2, abr-jun. 2005, p. 260).

${ }^{174} \mathrm{O}$ caráter insidioso dos meios de investigação de provas é ressaltado por MARIA LUCIA KARAM (Meios invasivos de busca de provas: incompatibilidade com a democracia. Boletim IBCCRIM, São Paulo, ano 17, n. 200, julho 2009, p. 17-18).

175 "As escutas telefônicas são o meio de prova mais invasivo dos direitos e liberdades fundamentais das pessoas. Os estragos têm uma dimensão subjectiva (apanhamos sempre mais pessoas do que queríamos apanhar) e lesam sempre muitos mais bens jurídicos, muitos mais interesses do que aqueles que se queria lesar. Através de uma escuta, sabe-se da vida da pessoa escutada, sabe-se da vida das pessoas de quem ela fala, a vida das pessoas que falam para ela. Põem-se em causa todas as esferas de segredo que a lei protege: o segredo do advogado, do médico, do confessor, a confidencialidade das relações familiares, tudo isto é devassado pelas escutas" (ANDRADE, Manuel da Costa. Das escutas telefônicas. In: COSTA, José de Faria; SILVA, Marco Antonio Marques da. Direito penal especial, processo penal e direitos fundamentais: visão luso-brasileira. São Paulo: Quartier Latin, 2006. p. 206).

176 "Diversamente dagli altri mezzi di ricerca della prova (ispezione, perquisizioni, sequestri), l'intercettazione si qualifica non per il suo carattere 'coattivo', bensì per le sue modalità 'insidiose'. Come la perquisizione, è un atto 'a sorpresa'; ne differisce perchè 'occulto'. Se la perquisizione ammette un contestuale controllo sullo svolgimento delle operazioni, mediante evenutale assistenza o rappresentanza da parte di persona di fiducia, l'intercettazione, invece, si svolge ad insaputa dei dialoganti". Em tradução livre do autor: "diversamente dos outros meios de investigaçã de prova (inspeções, buscas e sequestros), a interceptação se qualifica não pelo seu caráter 'coativo', mas sim por sua modalidade 'insidiosa'. Como a busca, é um ato 'a surpresa'; dela se diferencia porque é oculto. Se a busca admite um contextual controle sob o desenvolvimento das operações, mediante eventual assistência ou representação de uma pessoa de confiança, a interceptação, ao contrário, desenvolve-se sem o conhecimento dos dialogantes" (Cf. BALDUCCI, Paola. Le garanzie... op. cit., p. 1). Bem salienta 


\subsubsection{Meios de investigação de prova preventivos e repressivos}

Outra dicotomia dos meios de obtenção de prova é a que os divide em preventivos e repressivos. A doutrina adjetiva apenas de "preventivos" os meios cuja execução se admite em atividade de prevenção. De outro lado, supõem-se repressivos - como necessário contraponto lógico - os que se inserem em atividade de repressão a prática de fatos delituosos. Enquanto nesta se pressupõe a perpetração de conduta criminosa, naquela se pretende evitá-la.

No principiar do milênio, diante de devastadores ataques concretizados por grupos extremistas, ${ }^{177}$ declarou-se verdadeira guerra ao terrorismo, tido por inimigo oculto. Alardeouse a necessidade de repreensão a grupos terroristas nos mais diversos países. Por transcender as dimensões nacionais, reputamos que a questão é de difícil solução. Deve ser discutida na ordem internacional, com os percalços e vicissitudes que lhe são inerentes.

Foi neste contexto histórico que se tentou equacionar o problema em âmbito nacional. Para tanto, elaboraram-se diplomas normativos que evidenciam uma política de segurança caracterizada por relativização dos direitos e garantias individuais. A corroborar odiosa tendência processual estão os ditos meios de investigação de prova intitulados preventivos, instituídos por legislações de diferentes países. ${ }^{178}$

CLAUDIO MARINELLI o caráter insidioso das interceptações: "le intercettazioni sono essenzialmente clandestine, avendo lo scopo di raccogliere elementi utili per le investigazioni mediante un'operazione occulta". Em tradução livre do autor: "as interceptações são essencialmente clandestinas, tendo o escopo de recolher elementos úteis para as investigações, mediante uma operção oculta" (Intercettazioni processuali... op. cit., p. 17).

${ }^{177}$ Rememorem-se, a propósito, os ataques terroristas concretizados em 11 de setembro de 2001, uma série de ataques suicidas contra alvos civis nos Estados Unidos atribuídos à organização fundamentalista islâmica AlQaeda. Na ocasião, foram atingidos dois edifícios em território norte-americano, conhecidos por torres do "World Trade Center", causando a morte de milhares de pessoas. LEONARDO FILIPPI e MARIA FRANCESCA CORTESI lembram que um dos efeitos do morticínio nova-iorquino foi a contemporânea intensificação em todo o mundo de sistemas de prevenção do delito. O resultado de tal "globalização", o autor observa, foi a produção de uma série de legislações tendentes a prevenir a prática de delitos (Intercettazione preventiva di comunicazioni. In: Enciclopedia Giuridica - Istitvto Enciclopedia Italiana fondata da Giovanni Treccani. Roma: Istituto Poligrafico e Zecca dello Stato, 2003. vol. XVII, p. 1).

178 Exemplo disso é a instituição de interceptação preventiva de telecomunicações e de comunicações entre pessoas presentes no direito italiano, operada pelo art. $5^{\circ}$ do "Decreto Legge 18 ottobre 2001, n. 374", convertido pela "Legge 15 Dicembre 2001, n. 438". Trata-se de norma que versa sobre "disposizioni urgenti per contrastare il terrorismo internazionale", estabelecendo regras especiais sobre interceptações, que alteraram, para os fins nela 
Muito se discute na doutrina sobre a possibilidade de investigação de prova preventivamente. Em seu favor, invocam-se os princípios de prevenção e de segurança social, que seriam pressupostos nos diferentes ordenamentos jurídicos. ${ }^{179}$ Por outro lado, considere-se que, com a execução de meio de investigação de prova, almeja-se descobrir fontes de prova. Pressupõe-se prévio cometimento de crime, a justificar o desenvolvimento da atividade repressiva estatal.

Aqui a reflexão é imperiosa: admitir meios de investigação de prova em atividade preventiva transformaria "l'attività di ricerca della prova" em "attività di ricerca in genere della notitia criminis". ${ }^{180}$

Além disso, permitir-se-ia a inadmissível dispensa de comprovação de elementos suficientes para a saída em busca de prova, por meio de restrição dos direitos inerentes à personalidade humana, em pelo divórcio com a natureza cautelar da medida. ${ }^{181}$ Corretamente, identifica-se o risco de que com o "ardil das etiquetas" se conceda espaço para atividades que são absolutamente estranhas ao processo penal. ${ }^{182}$

previstos, a disciplina geral prevista no Codice di Procedura Penale (art. 266 e ss.). Cf., a propósito, infra, item n. 4.2.2.6, nota n. 109 .

${ }^{179}$ A este respeito, CLAUDIO MARINELLI recorda o fundamento que motivou a elaboração da citada legislação em Itália: "l'elemento unificante risiede nella preordinazione funzionale all'acquisizione di notizie concernenti la prevenzione di gravi fattispecie criminose" (Intercettazioni processuali... op. cit., p. 59).

${ }^{180}$ Cf. BALDUCCI, Paola. Le garanzie... op. cit., p. 83. No mesmo sentido, CLAUDIO MARINELLI conclui: "ocorre dunque prendere atto del fatto che l'inoperatività delle citate garanzie in tema di intercettazioni preventive, non rimediabile per via esegetica né attraverso mezzi di autointegrazione del sistema, depone per la persistente antinomia dell'istituto com le previsioni cosituzionali, che condurrà probabilmente alla proposizione di ulteriori questioni di legittimità". Em tradução livre do autor: "ocorre, portanto, tomar conta de que a incidência das citadas garantias em tema de interceptações preventivas, não remediável por via esegética, nem através de meios de integração do sistema, contribui para a persistente antinomia do instituto com as previsões constitucionais, que conduzirão provavelmente à proposição de posteriores questões de legitimidade" (Intercettazioni processuali... op. cit., p. 60).

${ }^{181}$ Cf. supra, item n. 1.3.

${ }^{182}$ Cf. BALDUCCI, Paola. Le garanzie... op. cit., p. 87. 
A excepcional ingerência em direitos fundamentais tornar-se-ia regra, o que nos afigura inadmissível em Estado Democrático de Direito que preze pelo respeito à dignidade da pessoa humana e dos valores que dela decorrem. ${ }^{183}$

O inconformismo registrado pela comunidade global com a dilaceração de bens jurídicos a que assiste, perplexa e estarrecida, em ataques terroristas é o mesmo decorrente da investigação preventiva, desmedida e desproporcional. Em ambas as situações, são demasiadamente reduzidos, ou suprimidos, valores imprescindíveis ao regular desenvolvimento do ser humano.

Destarte, consideramos correta é a orientação que contraria a adoção de meios de investigação de prova preventivos. ${ }^{184}$ A execução de meios de investigação de prova se insere na atividade repressiva estatal, desenvolvida em face de fato ilícito concreto tido por previamente cometido. ${ }^{185}$ É necessária a demonstração de elementos concretos que nela justifiquem a restrição (não supressão) temporária de direitos e garantias individuais. Os meios de investigação de prova, reputamo-los repressivos.

\subsection{A eficácia probatória dos meios de investigação de prova}

Delimitados o conceito e as classificações dos meios de investigação de prova, impõese o exame de sua eficácia probatória, ${ }^{186}$ objeto das mais acirradas discussões.

\footnotetext{
${ }^{183}$ Quanto aos meios de prova preventivos, critica CLEUNICE A. VALENTIM BASTOS PITOMBO o sistema de vigilância urbana. Salienta que "a paz pública não se obtém com a violação de direito individual”. Ainda: "a sociedade só se encontra protegida à medida que se preserva a individualidade de cada um". Considerações sobre a tutela da intimidade e vida privada no processo penal. Revista Brasileira de Ciências Criminais, São Paulo, ano 7, n. 26, p. 59-79, abr-jun. 1999.

${ }^{184}$ Cf. BADARÓ, Gustavo Henrique Righi Ivahy. Interceptações de comunicações telefônicas e telemáticas: limites ante o avanço da tecnologia. In: LIMA, José Corrêa de; CASARA, Rubens R. R. (Coords.). Temas para uma perspectiva crítica do Direito: homenagem ao Professor Geraldo Prado. Rio de Janeiro: Lumen Juris, 2010. p.496; FILIPPI, Leonardo; CORTESI, Maria Francesca. Intercettazione preventiva... op. cit., p. 4-11.

${ }^{185}$ Cf. supra, itens n. 1.1 e 1.3 .

186 A expressão "eficácia probatória" significa os efeitos que os atos processuais integrantes dos meios de investigação de prova produzem na persecução penal, considerada a sua finalidade, $i$. e., o efeito dele esperado para fins probatórios. A expressão é utilizada pela doutrina nacional e estrangeira, cf.: GOMES FILHO, Antonio
} 
A eficácia probatória dos atos processuais praticados na execução de um meio de investigação de prova deve ser examinada juntamente com sua finalidade: a descoberta de fontes de prova. A consecução da finalidade de um meio de investigação de prova redunda em encontro de uma fonte de prova.

Reconhece-se aptidão probatória à fonte de prova descoberta em meio de investigação. ${ }^{187}$ Aliás, trata-se de característica inerente a qualquer fonte de prova, independentemente do meio que propiciou o conhecimento de sua existência. Uma fonte, cuja existência é revelada na execução de um meio de investigação de prova, e as informações dela extraídas podem ingressar em autos de um processo, observada a disciplina do meio de produção de prova pertinente.

Diferentemente dos meios de produção de prova, os meios de investigação de prova não geram fontes de convencimento, mas tornam possível a descoberta e o recolhimento de fontes de prova. Para as fontes de prova descobertas constituírem fonte de convencimento e propiciarem o exame de objetos de prova, as informações delas extraídas devem ser regular e oportunamente introduzidos no processo, pelo respectivo meio de produção. Daí se falar em aptidão probatória. Reitere-se: da fonte.

Magalhães. Notas sobre a terminologia... op. cit., p. 311; LOPES JR., Aury. Sistemas de investigação... op. cit., p. 119; RICCI, Gian Franco. Le prove... op. cit., p. 642. Sobre o emprego do termo eficácia no processo penal, cf.: FERNANDES, Antonio Scarance. Reflexões sobre as noções... op. cit., p. 9-28.

${ }^{187}$ DELFINO SIRACUSANO, para salientar a apontada aptidão, transcreve trecho da Relazione al progetto preliminare del codice di procedura penale 1988: "I mezzi di ricerca della prova non sono di per sé fonte di convincimento, ma rendono possibilie acquisire cose materiali, tracce o dichiarazioni, dotate di attitudine probatoria" (grifou-se) (Prova - III)... op. cit., p. 4). E LUIGI PAOLO COMOGLIO complementa: "senza mai assurgere da sé soli alla dignità di prove stricto sensu" (Prove ed accertamento... op. cit., p. 122). Na doutrina brasileira, o mesmo é sustentado por ANTONIO SCARANCE FERNANDES, ao salientar a descoberta de uma fonte de prova (o sangue do suspeito, o teor de uma conversa, um registro bancário) pela utilização de algum meio de obtenção de prova (busca e apreensão, interceptação telefônica, quebra do sigilo bancário). A materialização da descoberta e o subsequente registro do recolhimento da fonte são documentados em instrumentos físicos, que são juntados nos autos da investigação: auto, termo, degravação, extrato bancário. Acrescenta o autor que, conforme a natureza da fonte descoberta, exige-se a utilização de um meio de produção de prova, para que dela se possam extrair elementos a serem considerados na decisão da causa. Cita, como exemplo, a perícia que se deve realizar para demonstrar que o sangue é do suspeito; e a perícia e o reconhecimento para identificação de um cadáver (Prova e sucedâneos... op. cit., p. 207-208). 
Os meios de produção de prova servem, por sua essência, à verificação dos temas de prova, pois oferecem a juízo elementos probatórios diretamente utilizáveis em sede de decisão. ${ }^{188}$ Os meios de investigação de prova têm funções e estrutura mais complexas, porque se prestam indiretamente ao exame dos temas de prova, considerada a mencionada aptidão probatória da fonte de prova cuja descoberta propiciam.

Isto ocorre de forma indireta porque, se forem descobertas fontes de prova, é necessário o sucessivo ingresso nos autos do processo, pelo respectivo meio de produção de prova, para que sejam, então, diretamente consideradas. ${ }^{189}$ Não importa se a aquisição da fonte de prova ocorreu em fase investigativa, ou quando já instaurada a ação penal: a prova deve ser produzida, para que dela se extraiam informações (elementos de prova), úteis para a análise dos temas de prova. ${ }^{190}$

Em síntese, concluímos que a eficácia dos atos praticados na investigação de prova, entre os quais estão os praticados em execução de meio de investigação de prova, em regra, restringe-se à descoberta de fontes de provas, aptas a surgirem como prova produzida. ${ }^{191}$

\footnotetext{
${ }^{188}$ Cf. SIRACUSANO, Delfino. Prova - III)... op. cit., p. 4. No mesmo sentido, LUIGI PAOLO COMOGLIO salienta que os meios de produção de prova se caracterizam por "un comune denominatore, che ne esprime 'l'idoneità ad offrire al giudice risultanze probatorie direttamente utilizzabili in sede di decisione' (quali prove, aggiungerei, in senso proprio, dottate appunto di autosufficienza)" (Prove ed accertamento... op. cit., p. 121-122). 189 "Só são provas, assim, no sentido processual, os dados objetivos de informação introduzidos em procedimento em que se assegure a participação daqueles em cuja esfera jurídica a decisão final produzirá efeitos" (GOMES FILHO, Antonio Magalhães. O livre convencimento do juiz no projeto de Código de Processo Penal: primeiras anotações. Boletim IBCCRIM, São Paulo, ano 17, n. 200, julho 2009, p. 8).

${ }^{190}$ Não importa em que fase sejam obtidas as fontes de prova. Quer na fase investigativa, quer no decorrer da ação penal: para se tornarem utilizáveis para o exame do tema de prova, e, por conseguinte, para a decisão da causa, é imprescindível que sejam registradas no processo regular e oportunamente, por meio da observância da disciplina legal de produção de prova. Parece-nos importante salientar que a referida utilização de fontes de prova descobertas como fonte de convencimento exige prévia observância do meio de produção de prova. Reitere-se, a propósito, que a existência das fontes de prova e das informações que dela se podem extrair antecede à instauração da ação penal. Obviamente, pré-existem à obtenção ou produção da prova. É irrelevante, portanto, se a fonte foi descoberta na investigação, se foi referida pela parte interessada em sua produção, ou se na produção de outra prova. O seu ingresso no processo, com vistas ao exame do tema de prova, deve ocorrer pelo meio previsto em lei.

${ }^{191}$ AURY LOPES JR. salienta a importância da oportuna produção da prova. A produção da prova, em regra, ocorre no decorrer da ação, no exercício da jurisdição, cercada pelas garantias processuais. Dela se extraem elementos para o convencimento. Na fase investigativa, buscam-se elementos úteis para verificação da ocorrência provável do fato, a justificar, ou não, o exercício do direito de ação (A crise do inquérito... op. cit., p. 57-86).
} 
O problema decorre do fato de que, por vezes, com a fonte descoberta, algumas informações (elementos de informação) ${ }^{192}$ são registradas na documentação dos atos praticados na realização do meio de investigação de prova.

Também sob a perspectiva da formação destes elementos de informação, é reconhecida eficácia probatória aos meios de investigação de prova. Estes elementos podem ser utilizados em momentos da persecução penal, da fase pré-processual e da fase processual.

A doutrina, em geral, afirma a utilidade dos elementos de informação: para fundar juízo de admissibilidade de medidas cautelares; para formação da opinio delicti; para formação de juízo de admissibilidade de acusação formalizada. ${ }^{193}$

Além disso, os elementos de informação podem ser utilizados em decisão que declare a absolvição sumária do acusado. No Brasil, os fundamentos da absolvição sumária são previstos no Código de Processo Penal: o juiz deverá absolver sumariamente o acusado quando verificar": a) "a existência manifesta de causa excludente da ilicitude do fato;" b) "a existência manifesta de causa excludente da culpabilidade do agente, salvo inimputabilidade;"

${ }^{192}$ Cf. GOMES FILHO, Antonio Magalhães; BADARÓ, Gustavo Henrique Righi Ivahy. Prova e sucedâneos... op. cit., p. 193-196.

${ }^{193}$ Neste sentido, ANTONIO MAGALHÃES GOMES FILHO, salienta a diferença entre prova e elemento informativo da investigação, em comentários ao disposto no art. 155 do Código de Processo Penal: "o legislador consagrou e sublinhou a nítida e apropriada distinção entre o que é prova e aquilo que constitui elemento informativo de investigação. São, com efeito, conceitos que não se confundem, até porque constituem resultado de atividades que têm finalidades diversas: os atos de prova objetivam a introdução de dados probatórios no processo - necessariamente em contraditório -, que servem a formação de um juízo de certeza próprio da sentença; os atos de investigação visam à obtenção de informações que levam a um mero juizo de probabilidade idôneo a sustentar a opinio delicti do órgão da acusação ou fundamentar a adoção de medidas cautelares pelo juiz" (Provas: Lei $11.690 \ldots$ op. cit., p. 260-250; O livre convencimento... op. cit., p. 9). A mesma linha de pensamento é perfilhada pelo citado autor e por GUSTAVO HENRIQUE RIGHI IVAHY BADARÓ: "os elementos trazidos pela investigação não constituem, a rigor, provas no sentido técnico-processual do termo, mais informações de caráter provisório, aptas somente a subsidiar a formulação de uma acusação perante o Juiz ou, ainda, servir de fundamento para a admissão dessa acusação, e, eventualmente, para a decretação de alguma medida de natureza cautelar" (Prova e sucedâneos... op. cit., p. 193). Também AURY LOPES JUNIOR, na mesma esteira, aponta a finalidade dos atos de investigação: "e) servem para a formação da opinio delicti do acusador; f) não estão destinados à sentença, mas a demonstrar a probabilidade do fumus commissi delicti para justificar o processo (recebimento da ação penal) ou o não-processo (arquivamento); g) também servem de fundamento para decisões interlocutórias de imputação (indiciamento) e adoção de medidas cautelares pessoais, reais ou outras restrições de caráter provisional". "Os elementos recolhidos em fase pré-processual são considerados como meros atos de investigação e, como tal, destinados a ter uma eficácia restrita às decisõos interlocutórias que se produzem no curso da instrução preliminar e na fase intermediária" (Sistemas de investigação... op. cit., p. 120-121). 
c) "que o fato narrado evidentemente não constitui crime;" ou d) "extinta a punibilidade do agente" (art. 397, caput, incisos I a IV). ${ }^{194}$

Acrescente-se, ainda, a utilidade dos elementos de informação para a atuação das partes em instrução - aqui considerados não só o possível ingresso no processo da fonte de prova descoberta cuja produção seja requerida pelas partes ou ordenada de ofício pelo juízo, bem como a participação das partes, sabedoras das informações, na instrução. ${ }^{195}$

Nos referidos momentos, não são apenas as informações extraídas de fontes existentes, descobertas na execução de meio de investigação de prova que podem ser utilizadas. Igualmente, a informação sobre a inexistência de fontes de provas, retratada em execução de um meio de investigação de prova, repercute no fenômeno probatório. Tal informação - a inexistência de fontes de prova - é relevante para persecução penal. ${ }^{196}$

Ao contrário do que ocorre nos mencionados momentos da persecução penal, os elementos de informação eventualmente conhecidos na descoberta da fonte de prova, em regra, são inidôneos para serem valorados em decisão sobre o mérito da causa, pela sua inerente inaptidão para formação de resultados probatórios. ${ }^{197}$ Necessária se faz a produção

\footnotetext{
${ }^{194}$ E o $§ 4^{\circ}$ do art. 394 estabelece: “as disposições dos arts. 395 a 398 deste Código aplicam-se a todos os procedimentos penais de primeiro grau, ainda que não regulados neste Código."

${ }^{195}$ Eventuais informações registradas juntamente com o encontro da fonte podem ser utilizadas pelas partes no exercício de suas faculdades processuais. No mesmo sentido, GUSTAVO HENRIQUE RIGHI IVAHY BADARÓ conclui que é possível às partes, ao exercerem o direito a prova, na sub-espécie do direito à investigação, objetivarem a descoberta de fontes de prova e a obtenção de informações, para que, posteriormente, sejam introduzidas no processo pelo respectivo meio de produção de provas, observado o contraditório. Examina a substituição de prova testemunhal pela juntada de declarações escritas de quem poderia ser testemunha, concluindo por se tratar de prova anômala. Mas não exclui a possibilidade de as partes utilizarem as informações em oportuna produção de prova (Provas atípicas... op. cit., p. 351).

${ }^{196}$ Imangine-se que alguém seja investigado por suposta participação em organização criminosa que se dedique a tráfico de drogas, tendo a função de custodiante de droga. Feita uma busca na casa do referido acusado, nada é encontrado. Esta informação é relevante, do ponto de vista probatório, para se inferir que e o investigado ou acusado não é participante da organização criminosa. Embora não se desconheça a impossibilidade de consideração prévia de culpabilidade do investigado, a informação sobre a inexistência de prova é relevante para a formação do juízo de admissibilidade de eventual acusação contra ele formulada. Também o é, em fase processual, para prolação de sentença, inserindo-se a mencionada informação na produção da prova.

${ }_{197}$ É neste sentido do termo prova (resultado de prova) que se discute o valor ou a eficácia da prova (TARUFFO, Michele. La prova... op. cit., p. 423). A inaptidão é reconhecida em doutrina: “em última análise, tanto será viciada a prova que for colhida sem a presença do juiz, como o será a prova colhida pelo juiz, sem a presença das partes (...) Dessa afirmação básica decorre a inarredável conseqüência de que não são provas, que o juiz possa utilizar pra a formação do seu convencimento, as que forem produzidas em procedimentos administrativos
} 
da prova em juízo, para que dela se possam extrair dados (elementos de prova) úteis para solução da demanda processual. Os meios de investigação de prova são úteis para produção oportuna de prova, tout court. ${ }^{198}$

Convém observar que um exame desatento dos meios de investigação de prova poderia levar à equivocada conclusão de que são aptos a fundamentar a avaliação do mérito da causa. Semelhante raciocínio decorreria do fato de serem documentados os diferentes atos que os integram. Todavia, embora sejam registrados em uma base material, perceptível pela visão, não se trata de prova documental. Cuida-se de documentação de atos processuais. ${ }^{199}$

prévios ou mesmo em outros processos juridicionais.” (Cf. GRINOVER, Ada Pellegrini. O conteúdo da garantia do contraditório. In: Novas tendências do direito processual. Rio de Janeiro: Forense Universitária, 1990, p. 22). "A única verdade admissível é a processual, produzida no âmago da estrutura dialética do processo penal e com plena observância das garantias de contradição e defesa" (Cf. LOPES JR., Aury. Sistemas de investigação... op. cit., p. 121).

${ }^{198} \mathrm{Na}$ doutrina italiana, considera-se que os meios de investigação de prova "servono alla prova ma non al giudizio." Além disso, diz-se que sua eficácia se restringe às investigações preliminares (SIRACUSANO, Delfino. Le prove: i mezzi... op. cit., p. 415-417).

${ }^{199}$ Como bem salientado por GUSTAVO HENRIQUE RIGHI IVAHY BADARÓ, são inconfundíveis o documento e a documentação de atos processuais: "documento é meio de prova pré-constituído, no qual se materializa a representação de um fato estranho e, normalmente, anterior ao processo. Outra coisa bem distinta é a documentação dos atos processuais, isto é, o seu registro por meio de símbolos. Enquanto o documento representa algo que está fora do procedimento, sendo extraprocessual, a documentação representa um ato do próprio procedimento, sendo, portanto, endoprocessual" (Provas atípicas... op. cit., p. 350). No mesmo sentido, cf. TONINI, Paolo. A prova... op. cit., p. 192-194. O fato de se registrar, por meio de símbolos, um ato processual de investigação em mesmo instrumento físico da prova documental não significa alteração da natureza jurídica da produção de prova relacionada às fontes descobertas. Deve ser produzida em estrita observância do rito legal, sob o crivo do contraditório. Entendimento similar é identificado a doutrina italiana, que diferencia documentação e documento. Um documento representa um ato que se perfaz "fora" do processo, motivo por que é também denominado documento extraprocessual. Documentação se refere a atividades que operam representação de atos processuais, por meio de registro dos seus termos. Por isso, tais documentos (rectius: documentações) são conhecidos por documentos endoprocessuais. O próprio Código de Processo Penal não deixa dúvidas sobre a distinção: a documentação dos atos se procede mediante termos (art. 134.1). E a ideia é estendida para a fase préprocessual: "la disciplina é basata su uma impostazione concettuale chiara, che distingue i documenti extraprocessuali, o semplicemente documenti, in quanto formati al di fuori del processo, dai documenti endoprocessuale, o più precisamente atti, costituiti dai verbali di atti formati nelle fasi anteriori del medisimo processo" (Cf. D'ISA, R. L'aplicazione del cumulo giuridico ai sensi dell'articolo 81 C.P. quando le pene previste per i reati della fattispecie complessa siano eterogenee. Rivista Italiana di Diritto e Procedura Penale, Milão, Giuffrè, Anno XXXV, outubro-dezembro 1992, p. 1.405). Em igual sentido, estão as observações de RAFFAELE CANTONE, quem ressalta a razão da distinção: "la ragione della distinzione netta tra atti e documenti appare fuzionale ad un obiettivo: si deve evitare - in ossequio al principio dell'oralità che informa il rito processuale - che attraverso la qualificazione come documenti possano filtrare nel dibattimento attività probatorie procedimentali che devono tradursi in prova soltanto attraverso il metodo del contraddittorio" (Cf. $\mathrm{La}$ prova documentale - Quaderni di Cassazione Penale 4. Milano: Giuffrè, 2004, p. 12). A propósito, CLAUDIO MARINELLI salienta que tanto documento, quanto documentação, têm, como elemento comum, a aptidão de representação, que é expressada em termos processuais. Mas a diferença, segundo o autor, consiste na representação, respectivamente, de atividades extraprocessuais e endoprocessuais: "tale collocazione, interna alla seqüela degli atti che compongono l'accertamento penale, non si deve ad un dato puramente cronológico, legato, dunque, alla circostanza che la formazione intervenga dopo l'avvio di um procedimento penale. L'atto del 
A propósito, não só os institutos de que ora se trata são documentados nos autos do processo. Os atos processuais são documentados em autos, em que se registra uma investigação ou um processo. Tem-se documentação de atos que integram um instituto abstrato (meios de prova, por exemplo). É que as ficções jurídicas, ao se amoldarem a uma situação concreta, em regra, necessitam de um registro perceptível pelos órgãos sensoriais humanos, para possibilitar seu conhecimento e a segurança jurídica das relações sociais delas decorrentes.

Conforme já observado, a documentação dos atos integrantes do meio de investigação de prova não os transformam em prova documental. Se fosse assim, os atos de investigação documentados em autos se transformariam em "documento". E todos os demais meios de produção de prova seriam despiciendos. ${ }^{200}$

A mera documentação não elide a necessidade de produção da prova em juízo, de acordo com as normas que regulamentam cada um dos meios de produção de prova. ${ }^{201}$ É pela observância destas normas que fontes de provas ingressam legitimamente em processo. Delas se podem extrair dados que, conjugados em elementos de prova, são necessários para fundamentar ou rechaçar a veracidade dos enunciados fáticos formulados pelas partes. Os

procedimento se segnala per provenire dai soggetti legitimatti a porlo in essere e reisponde alle finalità proprie dell'attività di accertamento dell'illecito penale" (Intercettazioni processuali... op. cit, p. 153).

200 Atribuir eficácia probatória atos documentados na fase investigativa significaria negar o princípio da legalidade, do contraditório e do juiz natural. A comprovação legal da culpabilidade decorre de prova produzida sob o crivo do contraditório, perante juiz natural e imparcial, observados os ritos dos meios de prova.

${ }^{201}$ Afirmar que se trata de prova documental em todas as situações significaria admitir produção de prova anômala, com o objetivo de burlar regras sobre admissão ou produção de prova. A definição do rito probatório a ser observado, previsto na disciplina do meio, depende da natureza da fonte de prova. "No tocante à prova documental (meio de prova), a distinção entre fonte de prova e meio de prova pode levar a alguma confusão. $O$ documento em si é o meio de prova, enquanto o seu conteúdo, na parte em que interessa para a demonstração de um fato, é fonte de prova. Quando, por meio da quebra de um sigilo financeiro, obtém-se um documento, como o extrato bancário, este constitui meio de prova e, nele, encontra-se a fonte de prova, ou seja, o informe sigiloso e que serve para evidenciar determinado fato, como, por exemplo, um depósito. Se há dificuldade em conhecer a fonte de prova (informe sigiloso) constante do documento, tendo-se em vista que isso depende de esclarecimento feitos por um expert, mister se faz a utilização de outro meio de prova, a perícia" (Cf. FERNANDES, Antonio Scarance. O sigilo... op. cit., p. 158). 
elementos de prova valorados geram resultados probatórios, dos quais se serve o juízo para proferir decisão sobre meritum causae. ${ }^{202}$

A evidenciada inaptidão das informações (elementos de informação) que acompanham a descoberta de fonte de prova para formação de resultados probatórios não significa sua desprezibilidade para a persecução penal. Lembre-se de que os elementos de informação podem ser utilizados em outros momentos da persecução penal, anteriormente mencionados.

No Brasil, segundo a antiga redação do art. 157 do Código de Processo Penal, o juiz formaria sua convicção pela prevista "livre apreciação da prova".

Sob a égide da citada disposição normativa, discutiu-se sobre a possibilidade de utilização pelo juiz, como razão para decidir, de elementos colhidos no inquérito em sentença. De um lado, criticava-se semelhante atitude por não constituírem prova em sentido técnicoprocessual. ${ }^{203}$ Por outro, segundo entendimento jurisprudencial, poderiam ser considerados, se confirmados, ainda em que parcialmente, por outros elementos colhidos na fase processual. ${ }^{204}$

A questão era imediatamente relacionada à eficácia probatória dos meios de investigação de prova, que, no mais das vezes, concretizam-se na primeira fase da persecução penal. E são registrados nos autos que a ela se referem.

Progrediu o legislador ao alterar a redação do art. 155, caput, da lei processual penal, o qual prevê que "o juiz formará sua convicção pela livre apreciação da prova produzida em contraditório judicial, não podendo fundamentar sua decisão exclusivamente nos elementos

\footnotetext{
${ }^{202}$ Em Itália, não basta a indicação dos resultados probatórios que fundamentaram a decisão. A lei impõe, ao delimitar os requisitos da sentença, a enunciação das razões que estribaram a desconsideração de provas tidas por contrárias (art. 546.1, alínea "e" do Código de Processo Penal italiano). Embora não haja dispositivo semelhante na lei processual penal brasileira, não identificamos obstáculo que impeça o juízo de assim agir. Deixamos, contudo, a sugestão, de lege ferenda.

${ }^{203}$ Cf. GOMES FILHO, Antonio Magalhães; BADARÓ, Gustavo Henrique Righi Ivahy. Prova e sucedâneos... op. cit., p. 193-196.

${ }^{204}$ ANTONIO MAGALHÃES GOMES FILHO e GUSTAVO HENRIQUE RIGHI IVAHY BADARÓ criticam este entendimento jurisprudencial, em prol da observância do contraditório (Prova e sucedâneos... op. cit., p. 194).
} 
informativos colhidos na investigação, ressalvadas as provas cautelares, não repetíveis e antecipadas."

O propalado progresso decorre da prevista obrigatoriedade de contraditório judicial na formação dos elementos de prova - a qual, aliás já decorria do art. $5^{\circ}$, caput e inciso LV da Constituição Federal -, com a consequente exclusão de eficácia probatória dos atos de investigação, entre os quais se inserem os meios de investigação de prova. Logo, a norma evidencia a conclusão a que chegamos, quanto à ineficácia probatória das informações captadas na execução dos referidos meios para fundamentação de sentença.

Em regra, tem-se a inaptidão de tais elementos informações para lastrearem o convencimento judicial sobre uma imputação em decisão sobre o mérito da causa. Excepcionalmente, é reconhecida a eficácia probatória para fundamentação de sentença dos atos que geraram os elementos de informação, desde que sejam confirmadas por elementos probatórios produzidos em contraditório perante o juiz competente. ${ }^{205}$

Equivale a dizer: de acordo com o art. 155, caput, eventuais elementos de informação colhidos em investigação poderão demonstrar a veracidade ou falsidade de uma afirmação fática em decisão sobre o mérito da causa, excepcionalmente, desde que sejam ratificados em fase processual, sob o crivo do contraditório.

Portanto, os elementos de informações neles registrados podem ser utilizados em decisão final sobre o mérito da causa - excepcionalmente - desde que sejam convergentes com os elementos probatórios produzidos em juízo, sob o crivo do contraditório. A convergência dos diversos elementos - os da investigação e os produzidos em contraditório - relaciona-se a tendência de ambos a produzir, quanto à mesma hipótese, o mesmo resultado. ${ }^{206}$ Afirmar a possibilidade de valoração irrestrita de elementos de informação em julgamento de mérito é

205 ANTONIO MAGALHÃES GOMES FILHO lembra que "é possível utilizar informações obtidas na investigação, mas sob a condição de que existam também - para confirmá-las - provas (elementos de prova), produzidas em contraditório judicial.” (Provas: Lei 11.690... op. cit., p. 251).

${ }^{206}$ Cf. Ibidem, p. 252. 
reconhecer a possibilidade de conversão dos meios de investigação de prova em meios de produção de prova, sem a observância da disciplina da prova: uma anomalia probatória.

De lege ferenda, melhor se se eliminasse o desnecessário "exclusivamente", do caput do art. 155 do Código de Processo Penal. ${ }^{207}$ A possibilidade de consideração dos elementos de informação, de forma excepcional, se convergentes com os elementos probatórios, já defluiria do sistema processual.

Recorde-se, neste ponto, que os meios de investigação de prova são espécie de provas cautelares. $^{208}$ Isto não autoriza que a documentação de atos que o integrem possam lastrear uma sentença. Excepcionalmente, a lei admite valoração dos "elementos de informação" insertos na documentação dos atos praticados na execução do meio em decisão final sobre o mérito, se forem confirmados em juízo.

Também deve ser lembrado que, de acordo com o já afirmado anteriormente, não são apenas as informações extraídas de fontes existentes, descobertas na execução de meio de investigação de prova que podem ser utilizadas. A informação sobre a inexistência de fontes de provas, retratada em execução de um meio de investigação de prova é, por igual, relevante.

\footnotetext{
${ }^{207}$ No art. 165 do Anteprojeto de reforma do Código de Processo Penal, autuado no Senado Federal, previa-se que "o juiz formará livremente o seu convencimento com base nas provas submetidas ao contraditório judicial, indicando na fundamentação os elementos utilizados e os critérios adotados." Evidente a melhora na redação do texto normativo, se comparado com a redação do atual art. 155, considerada a eliminação das ressalvas. Todavia, na tramitação do agora Projeto de Lei n. 156, de 2009, a redação do dispositivo foi alterada: "o juiz formará livremente o seu convencimento com base nas provas submetidas ao contraditório judicial, indicando na fundamentação todos os elementos utilizados e os critérios adotados, resguardadas as provas cautelares, as não repetíveis e as antecipadas." (art. 168). Embora esta redação seja melhor do que a do art. 155 do Código de Processo Penal vigente, parece-nos que a proposta constante no Anteprojeto melhor atenderia a exigência da observância do contraditório na formação da prova. A distinção entre prova e elemento informativo é evidenciada em seu art. 33: "os elementos informativos da investigação deverão ser colhidos na medida necessária à formação do convencimento do Ministério Público sobre a viabilidade da acusação, bem como à efetivação de medidas cautelares, pessoais ou reais, a serem decretadas pelo juiz das garantias.” Tais dispositivos podem ser verificados nas seguintes referências: BRASIL. Senado. Comissão de Juristas responsável pela elaboração de anteprojeto de reforma do Código de Processo Penal. Anteprojeto. Brasília: Senado Federal, 2009. p. 62. Disponível em: http://legis.senado.gov.br/mate-pdf/58503.pdf. Acesso em: 29/12/2009; BRASIL. Senado. Projeto de Lei do Senado n. 156, de 2009. Disponível em: http://www.senado.gov.br/atividade/materia/getPDF.asp?t=85509\&tp=1. Acesso em: 10/01/2011).

${ }^{208}$ Cf. supra, item n. 1.3 .
} 
Uma derradeira observação: Quid iuris se uma sentença condenatória for alicerçada em informações obtidas "exclusivamente" em meios de investigação de prova, atribuindo eficácia probatória aos elementos de informação registrados na documentação dos atos que o integram?

A nosso ver, o art. 155, caput do Código de Processo Penal, ainda que indiretamente, preconiza uma regra de julgamento no processo penal: a presunção de inocência só pode ser elidida com elementos probatórios extraídos da prova produzida em contraditório que justifiquem uma condenação. ${ }^{209}$ Por esta razão, com fundamentação calcada "exclusivamente" em elementos de informação, tem-se vício no juízo de valoração da prova em sentença.

O evidente erro operado em sentença (error in judicando) decorreria da errônea aplicação da apontada regra de valoração das provas. A decisão, a fortiori, deve ser reformada e o acusado absolvido, por não haver prova suficiente para a condenação.

De outro lado, a sentença absolutória pode ser fundamentada exclusivamente em elementos de informações indicativos da ausência de reponsabilidade penal do acusado. A já apontada absolvição sumária é fulcrada em tais elementos (art. 397 do Código de Processo Penal). A propósito, a absolvição já deveria ter sido decretada neste momento procedimental. Mas se o feito prosseguir, consideramos possível a avaliação de elementos de informação em sentença absolutória. Isto não exclui a possibilidade de reforma da sentença, pretendida pela acusação, com base em elementos probatórios indicativos da responsabilidade do acusado, produzidos sob o crivo do contraditório.

Como exemplo ilustrativo dos conceitos acima expostos e para compreensão da sua eficácia probatória, imagine-se que o conteúdo de uma conversa seja captado em interceptação de comunicação entre pessoas presentes.

\footnotetext{
${ }^{209}$ A presunção de inocência somente pode ser afastada pela comprovação legal da culpabilidade, que se perfaz em contraditório. Em não havendo elementos suficientes extraídos da prova produzida, a absolvição se impõe (in dubio pro reo). Sob esta perspectiva, a presunção de inocência significa regra de julgamento no processo penal. $\mathrm{O}$ ônus da prova é da acusação, a qual só dele se desincumbe, se produzir prova em contraditório. Em outras palavras: não são suficiente para afastar o in dubio pro reo, exclusivamente, elementos de informação obtidos em investigação. Neste sentido, cf. BADARÓ, Gustavo Henrique Righi Ivahy. Ônus da prova... op. cit., p. 225-229, 293-300 e 433-439.
} 
Realizada a interceptação (meio de investigação de prova) no curso das investigações, descobrem-se fontes de prova sobre os fatos investigados pelo conteúdo das declarações firmadas por membros de uma organização criminosa. Os respectivos termos são documentados e juntados em autos de investigação.

Ulteriormente, determinam-se busca, que propicia sucessiva apreensão de objetos materiais do crime, atos também documentados (meio de investigação da prova).

Demais disso, inquirem-se testemunhas referidas no diálogo dos investigados (meio de produção de prova), arroladas em acusação formal, extraindo-se delas dados objetivos (elementos de prova), que, conjugados a outros, possibilitem conclusão por juízo competente (resultado da prova) firmada em decisão condenatória.

Poder-se-ia indagar: é dispensável a oportuna inquirição de uma testemunha (meio de produção de prova) que fora interlocutora na conversa interceptada? Sob outra perspectiva: a documentação da conversa em que se registrem a existência de testemunha (fonte de prova) e suas declarações (elementos de informação), juntada nos autos da ação penal, substitui a sua inquirição em juízo?

A pergunta deve ser respondida negativamente, por retratar evidente tentativa de burla às regras de produção de prova previstas na lei processual penal. A eficácia do meio de investigação de prova que culminou na descoberta da testemunha se restringe à possibilidade de registrar a existência da fonte de prova descoberta (a testemunha, no exemplo), a qual deve ingressar no processo pelo meio de produção correspondente. Os elementos de informação captados na interceptação só poderiam ser considerados na mencionada decisão se convergentes com elementos probatórios que se perfizerem na produção da prova testemunhal em contraditório.

Em outro exemplo, se houver interceptação de conversa entre acusados ou investigados, parece-nos que a eficácia probatória também se restinge a descoberta de fontes 
de prova referidas na conversa (por exemplo, uma testemunha ou um documento). Tais fontes devem ingressar no processo pelo meio de produção de prova correspondente (no exemplo, prova testemunhal e prova documental).

Se além da menção a fontes de prova, os acusados trocarem informações relevantes para a persecução penal (elementos de informação), podem ser utilizadas, como dito anteriormente, em formação de juízo de admissibilidade de medidas cautelares, em formação da opinio delicti, em formação de juízo de admissibilidade da acusação, em decisão de absolvição sumária e em instrução.

Todavia, em regra, não se pode atribuir eficácia probatória às declarações de investigados ou de acusados para fundamentar decisão final sobre o mérito da causa. Dizer o contrário significaria dispensar a oportuna observância das normas que regulamentam o interrogatório, entre as quais sobressai a obrigatoridade de concessão de oportunidade para exercício do direito ao silêncio, que atribui a natureza de meio de defesa ao interrogatório e torna o acusado fonte de prova eventual. ${ }^{210}$ Afirmar eficácia probatória às declarações é considerar o acusado não como fonte de prova eventual (se, espontaneamente, prestar declarações), mas fonte de prova necessária. O direito a não autoincriminação, do qual decorre o direito ao silêncio, é restringindo apenas para descoberta de fontes de prova. ${ }^{211}$

Excepcionalmente, os elementos de informação emergentes na interceptação de conversa entre investigados ou entre acusados podem ser valorados em sentença sobre o mérito da causa, se forem convergentes com os elementos probatórios produzidos sob o crivo do contraditório entre as partes no decorrer da instrução.

Se eles afirmarem a responsabilidade na prática da conduta delitiva, tal informação, para ser utilizada, deve ser confirmada perante o juízo competente, por meio de declarações

\footnotetext{
${ }^{210}$ Cf. supra, itens n. 1.1 e n. 1.2.1.1, nota n. 43.

${ }^{211}$ Cf. infra, item n. 2.5.
} 
espontaneamente prestadas em interrogatório, ${ }^{212}$ observada a disciplina da confissão, ou, caso não haja a confissão, há que convergir com outros elementos probatórios. De forma semelhante, se negarem a responsabilidade penal, esta informação deve convergir com outros elementos probatórios, como, por exemplo, a confirmação espontânea da negação de responsabilidade em interrogatório.

As questões analisadas sobre a eficácia probatória dos meios de investigação de prova, obviamente, pressupõe a descoberta de uma prova, sob a observância do princípio da legalidade, nos limites previtos na disciplina legal do meio e nos direitos e garantias fundamentais previstos na Lei Maior. Sendo ilícitos os atos praticados na execução do meio, a eventual prova descoberta é desprovida de qualquer eficácia probatória, porque é inadmissível.

\subsection{A inadmissibilidade de provas obtidas por meios ilícitos}

O debate sobre a admissibilidade processual da prova ilícita muito evoluiu no direito processual. "Da posição inicial que admitia a prova relevante e pertinente, preconizando apenas a punição do responsável pelo ato ilícito (penal, civil ou administrativo) praticado na colheita ilegal da prova, chegou-se à convicção de que a prova obtida por meios ilícitos deve ser banida do processo, uma vez que se subsume ela ao conceito de inconstitucionalidade, por vulnerar normas ou princípio constitucionais - como, por exemplo, a intimidade, o sigilo das comunicações, a inviolabilidade do domicílio, a própria integridade e dignidade da pessoa humana". 213

\footnotetext{
${ }^{212}$ Conforme já salientado, o interrogatório não constitui meio de prova. Mas, eventualmente, o acusado pode constituir fonte de prova, se espontaneamente prestar declarações, das quais se extraiam elementos úteis para avaliação do mérito da causa (v. supra, 1.2.1.1, nota n. 43).

${ }^{213}$ Cf. GRINOVER, Ada Pellegrini; FERNANDES, Antonio Scarance; GOMES FILHO, Antonio Magalhães. As nulidades... op.cit., p. 127. GUSTAVO HENRIQUE RIGHI IVAHY BADARÓ recorda a posição inicial quanto à admissibilidade das provas ilícitas, conforme a teoria do male captum, bene retentum: "como não havia sanção processual para a violação da regra de direito material, o autor da lesão seria punido no plano do direito material, mas a prova ilícita introduzida no processo era licitamente valorada." (Direito Processual Penal: tomo I... op.cit., p. 206).
} 
A prova ilícita implica, portanto, aspectos distintos: um de direito material, consistente na identificação do ato ilícito; outro, de direito processual, concernente à aplicação de sanção processual à prova obtida por meio do ato ilícito. Como observado anteriormente, ${ }^{214}$ o tema é ligado aos meios de investigação de prova, porque é ilícita a prova obtida com violação à disciplina destes meios, nela incluídos os direitos e garantias constitucionais.

No direito brasileiro, a inadmissibilidade da prova ilícita, assegurada na Constituição e no Código de Processo Penal (art. 5 , caput e inciso LVI da Constituição Federal e art. 157, caput do Código de Processo Penal), liga os dois planos, do direito material e do direito processual. A inadmissibilidade é sanção processual cominada às provas ilícitas, isto é, às provas colhidas com infringência a normas, princípios e regras, previstos em Constituição ou em leis ${ }^{215}$.

As provas ilícitas, por serem inadmissíveis, inexistem juridicamente. Como observam Ada Pellegrini Grinover, Antonio Scarance Fernandes e Antonio Magalhães GOMES FILHO, “as provas ilícitas, sendo consideradas pela Constituição inadmissíveis, não são por esta tida como provas. Trata-se de não-ato, de não-prova, que as reconduz à categoria de inexistência jurídica. Elas simplesmente não existem como provas: não têm aptidão para surgirem como provas. Daí a sua total ineficácia”. 216

E a inadmissilidade é extensível às provas derivadas da prova ilícita (art. 157, § $1^{\circ}$, primeira parte, da lei processual penal). Trata-se de aplicação da teoria dos frutos da árvore envenenada ("fruit of the poisonous tree doctrine" ou "taint doctrine"), segundo a qual o vício da planta se propaga por seus frutos. Esta teoria, propugnada pela jurisprudência norteamerica, é acolhida pela doutrina nacional, com o propósito de proteção dos direitos e garantias fundamentais. ${ }^{217}$ Como exemplo, imagine-se uma interceptação de comunicações

\footnotetext{
${ }^{214}$ Confira-se a ligação entre os meios de investigação de prova e a prova ilícita no item n. 1.2.3.1, supra.

${ }^{215}$ Quanto a noção de prova ilícita, cf. supra, item n. 1.2.3.1.

${ }^{216}$ Cf. GRINOVER, Ada Pellegrini; FERNANDES, Antonio Scarance; GOMES FILHO, Antonio Magalhães. As nulidades... op.cit., p. 136.

217 "Essa questão foi colocada à Suprema Corte norte-americana no julgamento do caso Silverthone Lumber Co. v. U.S., em 1920, que a partir de então formulou a chamada fruit of the poisonous tree doctrine ou taint doctrine, segundo a qual a regra de exclusão é aplicável a toda prova maculada por uma investigação inconstitucional." (GOMES FILHO, Antonio Magalhães. Provas: Lei $11.690 \ldots$ op. cit., p. 266). No mesmo sentido, cf.:
} 
entre pessoas presentes ilícita, na qual se obtenham informações que propiciaram busca e apreensão de instrumentos utilizados para a prática de crime. A apreensão, neste caso, seria ilícita, por derivação.

As provas ilícitas por derivação, consideradas em si mesmas, seriam lícitas. São ilícitas porque a sua descoberta decorreu de informação decorrente da colheita ilícita de outra prova. ${ }^{218}$ É necessário haver relação de causalidade entre a ilicitude da prova por primeiro descoberta e a sucessiva obtenção da prova dela derivada, para se afirmar a ilicitude. ${ }^{219}$

Entrentanto, a proibição de utilização de provas derivadas da ilícita não é absoluta. Há exceções à inadmissibilidade das provas derivadas da ilícita, extraídas, uma vez mais, da jurisprudência norte-americana. São apontadas três exceções: attenuation of the taint, independent source, e inevitable discovery.

Os elementos que possibilitam a avaliação da ocorrência da attenuation of the taint: the time period between the illegality and the acquisition of the secondary evidence (o período temporal entre a ilegalidade e a aquisição da segunda prova); the occurrence of intervening events (a ocorrência de eventos intervenientes) e the flagrancy of the inicial illegality (a flagrância da ilegalidade inicial). ${ }^{220}$

A fonte é independente (independent source) se "a conexão entre as provas forem tênues, de modo a não se colocarem a primária e as secundárias como causa e efeito". ${ }^{221} \mathrm{~A}$ afirmação da existência de uma fonte independente pressupõe a derivação da prova, concretamente, de duas origens - uma ilícita e outra lícita (fonte independente), "de tal modo que, ainda que suprimida a fonte ilegal, o dado probatório trazido ao processo subsiste e, por

GRINOVER, Ada Pellegrini; FERNANDES, Antonio Scarance; GOMES FILHO, Antonio Magalhães. As nulidades... op. cit., p. 128. A doutrina também é conhecida por derivative evidence doctrine (BADARÓ, Gustavo Henrique Righi Ivahy. Direito Processual Penal: tomo I... op. cit., p. 207).

${ }^{218}$ Cf. GRINOVER, Ada Pellegrini; FERNANDES, Antonio Scarance; GOMES FILHO, Antonio Magalhães. As nulidades... op.cit., p. 128.

${ }^{219}$ Cf. Ibidem, p. 133.

${ }^{220}$ Cf. BADARÓ, Gustavo Henrique Righi Ivahy. Direito Processual Penal: tomo I... op. cit., p. 208.

${ }^{221}$ Cf. GRINOVER, Ada Pellegrini; FERNANDES, Antonio Scarance; GOMES FILHO, Antonio Magalhães. As nulidades... op. cit., p. 128-129. 
isso, pode ser validamente utilizado."222 Note-se que tal "exceção" descaracteriza a própria relação de causalidade, que é inerente à noção de prova derivada. ${ }^{223}$

É inevitável a descoberta (inevitable discovery) se "as provas derivadas da ilícita poderiam de qualquer modo ser descobertas por outra maneira". ${ }^{224}$ A descoberta, neste caso, é inevitável, pois "a prova tem efetivamente uma origem ilícita, mas as circunstâncias do caso permitem considerar, por hipótese, que seria inevitavelmente obtida, mesmo se suprimida a fonte ilícita." 225

A necessidade de relação de causalidade entre a prova ilícita e a prova que dela deriva é prevista no art. $157, \S 1^{\circ}$ do Código de Processo Penal. Malgrado a lei se refira à exceção da fonte independente (art. 157, $\S 1^{\circ}$, segunda parte, e $\S 2^{\circ}$ ), afasta-se de sua noção original.

$\mathrm{O} \S 1^{\circ}$ do art. 157 ressalva a inadmissibilidade da prova derivada da ilícita, "quando as derivadas puderem ser obtidas por uma fonte independente da primeira". O emprego do verbo no condicional pode levar à conclusão de que a mera possibilidade de descoberta por um meio lícito afasta a contaminação pela ilegalidade inicial. ${ }^{226}$

E, no $\S 2^{\circ}$ do art. 157 , o legislador pretendeu definir a fonte independente: "considerase fonte independente aquela que por si só, seguindos os trâmites típicos e de praxe, próprios da investigação ou instrução criminal, seria capaz de conduzir ao fato objeto da prova". Os termos normativos revelam uma confusão etnre as exceções da fonte independente e da descoberta inevitável. E a amplitude dos termos pode conduzir a uma interpretação errônea de que a prova derivada da ilícita pode ser convalidada. ${ }^{227}$ Por tal razão, é afirmada a inconstitucionalidade do art. $157, \S 2^{\circ}{ }^{2} 28$

\footnotetext{
${ }^{222}$ Cf. GOMES FILHO, Antonio Magalhães. Provas: Lei 11.690... op. cit., p. 268.

${ }^{223}$ Cf. Ibidem, p. 268.

${ }^{224}$ Cf. GRINOVER, Ada Pellegrini; FERNANDES, Antonio Scarance; GOMES FILHO, Antonio Magalhães. As nulidades... op. cit., p. 128-129.

${ }^{225}$ Cf. GOMES FILHO, Antonio Magalhães. Provas: Lei 11.690... op. cit., p. 268.

${ }^{226}$ Cf. GOMES FILHO, Antonio Magalhães. Provas: Lei 11.690... op. cit., p. 269; GRINOVER, Ada Pellegrini; FERNANDES, Antonio Scarance; GOMES FILHO, Antonio Magalhães. As nulidades... op. cit., p. 133.

${ }^{227}$ Cf. GRINOVER, Ada Pellegrini; FERNANDES, Antonio Scarance; GOMES FILHO, Antonio Magalhães. As nulidades... op. cit., p. 133.

${ }^{228}$ Cf. Ibidem, p. 134.
} 
Por serem inadmissíveis, as provas ilícitas e as provas que dela derivam não podem ingressar em autos de um processo. No entanto, se vierem a ser introduzidas, devem ser desentranhadas (art. 157, caput e $\S 3^{\circ}$ do CPP). ${ }^{229}$

Delimitada a abrangência da garantia da inadmissibilidade de provas ilícitas, cumpre reconhecê-la inserida em um sistema coordenado de direitos e garantais fundamentais. Vista no contexto de outros valores igualmente relevantes, é admitida a atenuação da inadmissibilidade, observada a proporcionalidade. ${ }^{230}$ A atenuação é pautada no necessário "equilíbrio entre valores fundamentais contrastantes." 231 Um exemplo desta atenuação é a possibilidade de utilização, no processo penal, de prova favorável ao acusado, obtida por meio de infringência de direitos e garantias fundamentais, seus ou de terceiros. ${ }^{232}$

Consideramos que a garantia da inadmissibilidade de provas obtidas por meios ilícitos, considerada a sua ligação com a exigência de legalidade da prova, limita a restrição das comunicações entre presentes. A restrição processual penal de direitos fundamentais, entre os quais destacamos o sigilo das comunicações entre pessoas presentes, somente pode se operar se observados os limites da disciplina legal do respectivo meio de investigação de prova e dos direitos e garantias fundamentais a ela pertinentes. Do contrário, eventual prova descoberta é ilícita e inadmissível. Cuida-se de garantia pertinente à proteção de direitos fundamentais em geral. Vejamos, a seguir, os fundamentos específicos da tutela da comunicação entre pessoas presentes.

\footnotetext{
${ }^{229}$ Vejam-se considerações sobre o desentranhamento e o incidente de inutilização da prova ilícita, previsto no $\S$ $3^{\circ}$ do art. 157 no item n. 5.3.1.4, infra, que versa sobre a repercussão processual da interceptação de comunicação entre pessoas presentes ilícita.

${ }^{230}$ Com relação à norma da proporcionalide, cf., infra, item n. 2.6.

${ }^{231}$ Cf. GRINOVER, Ada Pellegrini; FERNANDES, Antonio Scarance; GOMES FILHO, Antonio Magalhães. As nulidades... op. cit., p. 127. ANTONIO SCARANCE FERNANDES salienta que "a norma constitucional que veda a utilização de provas obtidas por meio ilícito deve ser analisada à luz do princípio da proporcionalidade, devendo o juiz, em cada caso, sopesar se outra norma, também constitucional, não supera em valor aquela que estaria sendo violada".

${ }^{232}$ Cf. GRINOVER, Ada Pellegrini; FERNANDES, Antonio Scarance; GOMES FILHO, Antonio Magalhães. As nulidades... op. cit., p. 127.
} 


\title{
CAPÍTULO 20
}

\section{FUNDAMENTOS CONSTITUCIONAIS DA TUTELA DAS COMUNICAÇÕES ENTRE PESSOAS PRESENTES}

\begin{abstract}
Sumário: 2.1. A abrangência das comunicações entre pessoas presentes - 2.2. A liberdade de manifestação do pensamento: 2.2.1. A liberdade de comunicação entre pessoas presentes como espécie da liberdade de manifestação de pensamento - 2.3. O direito à intimidade e à vida privada: 2.3.1 A inviolabilidade do sigilo de comunicação entre pessoas presentes como expressão do direito à intimidade e à vida privada - 2.4. A inviolabilidade do domicílio - 2.5. O direito a não autoincriminação - 2.6. A restrição às comunicações entre pessoas presentes.
\end{abstract}

\subsection{A abrangência das comunicações entre pessoas presentes}

A comunicação é inerente a natureza do homem. Por ser racional e pensante, ele necessita contatar outras pessoas para o pleno desenvolvimento de suas faculdades. Tanto na esfera privada, quanto na esfera pública, o ser humano expressa o seu pensamento por meios de comunicação em diferentes relações que brotam na vida em sociedade. ${ }^{1}$ As comunicações humanas se inserem no âmbito de proteção da sociabilidade do indivíduo, que é assegurada pela liberdade de se relacionar espiritualmente com os semelhantes, com eles se comunicando. $^{2}$

Já dizia ARISTÓTEles que o ser humano necessita de coisas e de outras pessoas para alcançar a sua plenitude. Com a sua memorável afirmação de que "o homem é um ser social",

\footnotetext{
${ }^{1}$ Considerem-se desde as mais simples comunicações, como algumas da ocorridas em âmbito familiar, até as mais complexas e sofisticadas, como, por exemplo, no cumprimento de ofícios nos quais a comunicação configura ingrediente fundamental para o artífice.

${ }^{2}$ Cf. BALDUCCI, Paola. Le garanzie nelle intercettazioni... op. cit., p. 38.
} 
a quem foi atribuído o "dom da palavra", expressa a importância que a comunicação assume para o desenvolvimento da personalidade humana. ${ }^{3}$

Sob o plano ontológico, comunicação significa um ato de transmissão do pensamento de um sujeito a um ou mais destinatários, mediante meios naturais (a voz, por exemplo) ou artificiais (o telefone, por exemplo), idôneos a propiciar o ato de transmissão. ${ }^{4}$ Com a comunicação, opera-se troca de mensagem, de informação entre sujeitos. ${ }^{5}$

Os referidos meios de comunicação se multiplicam diuturnamente, consideradas as constantes inovações tecnológicas. Conforme o meio empregado pelos sujeitos interlocutores, altera-se a denominação das comunicações concretizadas pelos indivíduos, entre as quais destacamos: a comunicação entre pessoas presentes; a comunicação epistolar; a comunicação telefônica; a comunicação telemática; a comunicação telegráfica.

Apesar das especificidades de cada meio de comunicação, é possível identificar duas categorias de comunicações: comunicações entre pessoas presentes; e comunicações inter absentes $^{6}$ (entre ausentes), também conhecida como telecomunicações (comunicações à distância), nas quais os interlocutores, distantes um do outro, utilizam um meio idôneo para transmissão do pensamento.

É a primeira das categorias que nos interessa, para compreensão do instituto da interceptação de comunicações entre pessoas presentes.

\footnotetext{
3 “Claramente se compreende a razão de ser o homem um animal sociável em grau mais elevado que as abelhas e todos os outros animais que vivem reunidos. A natureza, dizemos, nada fez em vão. O homem só, entre todos os animais, tem o dom da palavra; a voz é o sinal da dor e do prazer, e é por isso que ela foi também concedida aos outros animais. Estes chegam a experimentar sensações de dor e de prazer, e a fazer compreender que é útil ou prejudicial, e, em conseqüência, o que é justo ou injusto. O que distingue o homem de um modo específico é que ele sabe discernir o bem, o justo do injusto, e assim todos os sentimentos da mesma ordem cuja comunicação constitui precisamente a família do Estado" (A Política (Livro I, Capítulo I). Tradução de Nestor Silveira Chaves. São Paulo: Editora Escala, [2010]. (Coleção Grandes Obras do Pensamento Universal, n. 16), p. 15.

${ }^{4}$ Cf. MARINELLI, Claudio. Intercettazioni processuali... op. cit, p. 21.

${ }^{5}$ Cf. MARTINO, Corrada di. Le intercettazioni ambientali. L'Indice Penale, Verona, Cedam, anno VI, $\mathrm{n}^{\mathrm{o}} 3$, setdic. 2003, p. 1.151; MARTINO, Corrada di; PROCACCIANTI, Teresa. Le intercettazioni telefoniche. Padova: Cedam, 2001, p. 67; APRILE, Ercole. La prova... op. cit., p. 357.

${ }^{6}$ Cf. MARINELLI, Claudio. Intercettazioni processuali... op. cit, p. 20.
} 
As comunicações entre pessoas presentes se concretizam por meio da reprodução da voz, com a inerente emissão de sinais sonoros. Cuida-se de conversações, ${ }^{7}$ que se propagam no "fluído aéreo", isto é, em um âmbito estruturalmente livre. ${ }^{8}$

Tal forma de comunicação se diferencia das telecomunicações por voz, pois não se emprega um meio de difusão de sinal sonoro. A percepção do sinal que conduz uma informação se dá pela percepção sensorial dos interlocutores que se encontram em um mesmo ambiente. ${ }^{9}$ Por meio da comunicação entre pessoas presentes, é transmitida, de forma presencial, uma informação.

Embora sejam inúmeros os meios de telecomunicação criados no desenvolvimento da tecnologia, as comunicações entre pessoas presentes persistem, porque é imprescindível para convivência entre os seres humanos, tanto na vida privada, quanto na vida social.

O valor das comunicações para o ser humano é reconhecido e protegido juridicamente.

A Declaração dos Direitos do Homem e do Cidadão, de 1789, em seu art. 11, já assegurava que "a livre comunicação das ideias e das opiniões é um dos mais preciosos direitos do homem." O dispositivo preconiza tanto a liberdade de expressão do pensamento, como as formas em que possa se operar, entre as quais está a comunicação oral: "todo cidadão pode, portanto, falar, escrever, imprimir livremente, respondendo, todavia, pelos abusos desta liberdade nos termos previstos na lei.",10

\footnotetext{
${ }^{7} \mathrm{O}$ presente trabalho é voltado para a análise da interceptação de comunicações entre presentes orais, por meio da propagação da voz. Há outras modalidades de comunicação entre pessoas presentes, como, por exemplo, a comunicação por meio de sinais, como no caso de duas pessoas surdas-mudas. Estas outras modalidades escapam ao objeto do presente trabalho.

${ }^{8}$ Cf. BRUNO, Pierfrancesco. Intercettazioni di comunicazioni o conversazioni. In: Digesto delle Discipline Penalistiche. 4. ed. Torino: UTET, [2001]. v. VII, p. 179.

${ }^{9}$ Cf. BALDUCCI, Paola. Le garanzie nelle intercettazioni... op. cit., p. 18.

${ }^{10}$ A respeito da tutela das comunicações entre pessoas presentes na ordem internacional, cf., infra, n. 4.2.1.
} 
Igualmente, as Constituições modernas resguardam as comunicações entre pessoas presentes, expressa ou implicitamente. ${ }^{11}$ Neste caso, a sua proteção pode ser extraída de outros direitos e garantias fundamentais.

$\mathrm{Na}$ ordem constitucional brasileira, as comunicações entre pessoas presentes não está tutelada expressamente. Isto poderia levar à equivocada conclusão de que não é juridicamente protegida. Muito ao contrário, adiantamos a conclusão de que se cuida de valor protegido pela Constituição da República Federativa do Brasil de 1988, ainda que implicitamente. ${ }^{12}$

A tutela das comunicações entre pessoas presentes ${ }^{13}$ é extraída de direitos e garantias ${ }^{14}$ fundamentais expressos na Constituição, sob diferentes perspectivas: ora de liberdade de comunicação, isto é, de se comunicar, do poder de se comunicar ou não se comunicar; ora de

${ }^{11}$ Cf. infra, itens n. 4.2.2.1.1, n. 4.2.2.1.2, e n. 4.2.2.2.1 a n. 4.2.2.2.7.

${ }^{12}$ Quanto à proteção das comunicações entre pessoas presentes, cf., também, infra, item n. 5.1.

13 PIERFRANCESCO BRUNO prefere falar em "tutela delle comunicazioni orali" (tutela das comunicações orais) (Intercettazioni di comunicazioni... op. cit., p. 181).

${ }^{14} \mathrm{O}$ termo garantias tem variados sentidos. Na doutrina processual penal, ANTONIO MAGALHÃES GOMES FILHO, em obra sobre a garantia da motivação das decisões penais, observa que, "na sua acepção mais valiosa e difundida, garantia indica a sustentação, a proteção, a tutela das posições do indivíduo na sociedade política, as chamadas liberdades individuais; sugere, assim, a existência de mecanismos presentes no ordenamento cujo objetivo é tornar seguros os direitos dos cidadãos, diante do poder estatal e também dos outros cidadãos." Salientando que as garantias processuais constituem valores compartilhados pelo grupo social, o autor afirma a correlação entre as diversas garantias processuais: "trata-se do enfoque de conjunto que proporciona, possibilitando falar então em um modelo ou sistema de garantias processuais, pois, como observou Comoglio, o direito fundamental ao processo justo não se cristaliza, nem se exaure, em garantias particulares, mas, ao contrário, está fundamentado na coordenação de várias garantias concorrentes" (A motivação... op. cit., p. 25, 3033). ROGÉRIO LAURIA TUCCI enfatiza que de nada valeria "a projeção do ideal de definir os direitos do homem, notoriamente uma das mais importantes conquistas do século XVIII, se a respectiva declaração não se fizesse prover de meios hábeis à sua realização por um dos poderes do Estado, autônomo e independente dos demais, vale dizer, se não se vissem eles garantidos por instrumentos aptos à sua asseguração, ao seu reconhecimento ou à sua satisfação por órgãos estatais aos quais conferidos poderes para sua precaução, determinação ou efetivação." (Direitos e garantias individuais no processo penal brasileiro. 2. ed. São Paulo: RT, 2004, p. 53-54). Na doutrina constitucional, MANOEL GONÇALVES FERREIRA FILHO destaca, também, o emprego do termo em sentido restrito, as "garantias-limite" e as "garantias-instrumentais". "A primeira são as defesas postas a direitos especiais. Constituem proibições que visam a prevenir a violação do direito. São, por exemplo, a proibição à censura, para proteger a liberdade de expressão do pensamento, a proibição das prisões (salvo em flagrante delito ou por ordem de autoridade), para garantir a liberdade pessoal e de locomoção, a proibição do confisco, para salvaguardar a propriedade etc. Pode-se dizê-las garantias-limite, visto que servem de limite para o poder." "As garantias-instrumentais - garantias em sentido restritíssimo - são, ao mesmo tempo, meios de defender direitos específicos e de provocar a atuação do sistema de proteção desses referidos direitos específicos. Servem, assim, para mobilizar a garantia institucional, em prol das garantias-limite, servindo de instrumento de defesa dos direitos fundamentais." Observa, ainda, que "as próprias garantias em sentido estrito são de determinado ângulo direitos fundamentais. Sim, porque há um direito a não sofrer censura, a não ter confiscados os bens, a recorrer ao Judiciário, a impetrar mandado de segurança ou a requerer habeas corpus. São direitos subjetivos à garantia: direitos-garantia, portanto" (Direitos humanos fundamentais. 4. ed. São Paulo: Saraiva, 2000, p. 32-33). 
inviolabilidade do sigilo de comunicações, que assegura o segredo do conteúdo da comunicação. ${ }^{15}$

Os direitos e garantias fundamentais que fundamentam a tutela das comunicações entre pessoas presentes são os seguintes: a liberdade de manifestação do pensamento, o direito à intimidade e à vida privada, a inviolabilidade do domicílio e o direito à não autoincriminação. ${ }^{16}$ Vejamos, então, a conexão ${ }^{17}$ existente entre as comunicações entre pessoas presentes e estes direitos e garantias fundamentais, após apresentação de generalidades ${ }^{18}$ sobre cada um deles.

\subsection{A liberdade de manifestação do pensamento}

A liberdade de manifestação do pensamento, também denominada liberdade de expressão do pensamento, ${ }^{19}$ tem por pressuposto o reconhecimento prévio de outra liberdade: a liberdade de pensar. Pensar significa raciocinar, combinar ideias no espírito. ${ }^{20} \mathrm{E}$

\footnotetext{
${ }^{15}$ Cf. infra, itens n. 2.2 a 2.5 .

${ }^{16}$ Trata-se dos direitos e garantias processuais que, para fundamentar a tutela das comunicações entre pessoas presentes, são invocados pela doutrina. Tais direitos e garantias fundamentais, identificamo-los em pesquisa elaborada para a feitura da presente dissertação, consoante obras cujos dados estão registrados em notas de rodapé e em bibliografia. Para intitularmos os mencionados direitos e garantias, empregamos a terminologia comumente usada em doutrina. Interessante notar que, em Itália, mesmo havendo explícita previsão da garantia do sigilo de qualquer forma de comunicação, a doutrina invoca outros fundamentos constitucionais para amparar a tutela: a liberdade, a privacidade dentro do domicílio e o sigilo de qualquer forma de comunicação privada (APRILE, Ercole; SPIEZIA, Filippo. Le intercettazioni telefoniche ed ambientali: innovazioni tecnologiche e nuove questioni giuridiche. Milano: Giuffrè, 2004. (Teoria e Pratica del Diritto, sez. III, n. 133. Diritto e Procedura Penale), p. XVII).

${ }^{17}$ O termo "conexão" é também empregado pela doutrina italiana, que identifica, por exemplo, conexão entre liberdades, especialmente entre à liberdade pessoal, domiciliar e de comunicação (MARINELLI, Claudio. Intercettazioni processuali... op. cit, p. 64.).

${ }^{18}$ Os temas comportam diversos aspectos, sobretudo pela variedade institutos jurídicos que se ligam a tais direitos e garantias fundamentais. Entre os diversos aspectos que os temas comportam, salientaremos apenas aqueles que nos pareceram mais relevantes para traçar a ligação com a proteção das comunicações entre pessoas presentes.

${ }^{19}$ A liberdade de manifestação do pensamento é assegurada no art. $5^{\circ}$, caput e inciso IV da Constituição da República Federativa do Brasil.

${ }^{20}$ Entre os significados do verbo "pensar" propostos por AURÉLIO BUARQUE DE HOLANDA FERREIRA estão os seguintes: "formar ou combinar no espírito pensamentos ou idéias; raciocinar" (Novo Dicionário Aurélio. 3. ed. Curitiba: Editora Positivo, 2004. Versão eletrônica).
} 
"pensamento manifestado ou transitivado é o que se projeta da mente do sujeito para o mundo dos homens." 21

O ser humano, como ser racional, não se contenta apenas com a possibilidade de pensar. "Ele é escravo de um certo princípio de coerência. Se crê em certas idéias, é levado a desejar o seu implemento, a conformar o mundo segundo sua visão, necessitando destarte de liberdade para exprimir as suas crenças e opiniões."22 Daí a constatação de que, com a manifestação do pensamento, o homem, em regra, visa a compartilhar a informação pensada como outra pessoa, quem, como seu destinatário, passa a conhecê-la.

Em atenção à relevância de se assegurar ao indivíduo a possibilidade de externar os seus pensamentos, reconhece-se que se trata de liberdade individual: "a manifestação do pensamento pela palavra oral ou escrita é uma das liberdades públicas supremas do ser humano." ${ }^{23}$ Desta liberdade se extrai o direito à manifestação do pensamento.

Em Brasil, a liberdade de manifestação do pensamento é assegurada no art. $5^{\circ}$, caput, inciso IV da Constituição Federal: "é livre a manifestação do pensamento, sendo vedado o anonimato".

O direito à manifestação do pensamento, espécie de liberdade jurídica, ${ }^{24}$ tem como sujeito ativo as pessoas, físicas e jurídicas; e, como sujeito passivo, os entes privados e os entes públicos. O sujeito passivo tem, em princípio, um dever de abstenção. Quanto ao Estado,

\footnotetext{
${ }^{21}$ Cf. CRETELLA JR, José. Comentários à Constituição de 1988. Rio de Janeiro: Forense Universal, 1997. v. 1. (art. $1^{\circ}$ a $5^{\circ}$, incisos I a LXVII), p. 205.

${ }^{22}$ Cf. BASTOS, Celso Ribeiro; MARTINS, Ives Gandra. Comentários à Constituição do Brasil: promulgada em 5 de outubro de 1988. São Paulo: Saraiva, 1988. v. 2, p. 40.

${ }^{23}$ Cf. CRETELLA JR, José. Comentários à Constituição de 1988. Rio de Janeiro: Forense Universal, 1997. v. 1. (art. $1^{\circ}$ a $5^{\circ}$, incisos I a LXVII), p. 205.

${ }^{24}$ MANOEL GONÇALVES FERREIRA FILHO ensina que, em termos técnico-jurídicos, as liberdades "são direitos subjetivos. São poderes de agir reconhecidos e protegidos pela ordem jurídica a todos os seres humanos. E, eventualmente, a entes a eles assimilados." Acrescenta que tais liberdades têm como sujeito ativo a pessoa, física ou jurídica, como sujeitos passivos são os entes públicos - entre os quais destaca o Estado - e os entes privados. Ademais, o autor esclarece o objeto das liberdades, que é uma conduta: agir ou não agir, fazer ou não fazer; usar ou não usar; ir, vir ou ficar. São "direitos-liberdades" que se traduzem em "poderes de agir, ou não agir, independentemente da ingerência do Estado" (Direitos humanos... op. cit., p. 23-31). No mesmo sentido, ADA PELLEGRINI GRINOVER lembra que liberdade jurídica é "o poder de autodeterminação, por força do qual o homem faz o que lhe apraz, ressalvado o que é defeso por lei” (Liberdades públicas... op. cit., p. 6-7).
} 
reconhece-se não só um dever de abstenção, como também a tarefa de, preventivamente, evitar que seja ele desrespeitado, e de, repressivamente, restaurá-los, se forem violados, inclusive com a punição de responsáveis pela violação. ${ }^{25}$

As liberdades de pensar e de manifestar um pensamento, por serem liberdades individuais, têm por objeto o poder agir (pensar, manifestar o pensamento) ou de não agir (não pensar, não manifestar o pensamento). Compreendem, por conseguinte, dois aspectos: um ativo; outro negativo. ${ }^{26}$

A propósito de ambos os aspectos, PONTES De MiRAnda lembra os respectivos desdobramentos: "liberdade de pensar, liberdade de não pensar; liberdade de emitir o pensamento, liberdade de não emitir o pensamento; liberdade de emitir o pensamento para todos, liberdade de só o emitir para alguns ou para alguém, ou para si mesmo.,27

Interessante questão se refere à inserção da delimitação de eventual destinatário do pensamento manifestado pelo emitente nos aspectos da liberdade.

Pressupondo que a liberdade de expressão de pensamento se traduz em um poder de agir, é possível inserir a escolha do destinatário, como manifestação positiva. Ter-se-ia, assim, um exercício sucessivo de liberdades, em termos positivos: pensar, escolher o destinatário e emitir o pensamento.

A inserção da escolha do destinatário no aspecto positivo da liberdade de manifestação do pensamento pode ser extraída do reconhecimento do direito de escolha do meio para manifestação do pensamento, que é reconhecido como consequência da liberdade de

\footnotetext{
${ }^{25}$ Cf. FERREIRA FILHO, Manoel Gonçalves. Direitos humanos... op. cit., p. 30.

${ }^{26}$ Cf. MIRANDA, Pontes de. Comentários à Constituição de 1967, com a Emenda n. 1, de 1969. 2. ed. São Paulo: RT, 1971. t. V, p. 170. Recorde-se de que, na mesma esteira, o reconhecimento do exercício negativo de uma liberdade - do poder de não agir -, é desenvolvido quanto a liberdade de locomoção: o direito de ir, de vir e de ficar (Cf. FERREIRA FILHO, Manoel Gonçalves. Direitos humanos... op. cit., p. 142).

${ }^{27}$ Cf. Comentários à Constituição... op. cit., p. 170.
} 
manifestação do pensamento. ${ }^{28}$ Além disso, tal inserção pode ser identificada na ligação existente entre a liberdade de manifestação do pensamento e a liberdade de comunicação. ${ }^{29}$

De outro lado, a escolha do destinatário também é vista como integrante do aspecto negativo da liberdade: "de não pensar, de não emitir o pensado e o de emiti-lo secretamente". 30

A liberdade de não emitir o pensamento, como observa PONTES DE MiRANDA, abrange as seguintes liberdades: “a) liberdade de não emitir o pensamento, cuja espécie mais radical é a de pensar e não emitir o pensamento de maneira alguma"; "b) liberdade de não emitir o pensamento, exceto para reduzido número"; "c) liberdade de não emitir o pensamento, exceto para um"; "d) liberdade de não emitir o pensamento, exceto para si mesmo"; e "e) liberdade de não emitir o pensamento, exceto a certa data".31

Note-se que a inserção da escolha de eventual destinatário no aspecto negativo da liberdade pressupõe a compreensão de que as demais pessoas (distintas do destinatário) são excluídas da manifestação do pensamento. O pensamento, portanto, não é manifestado às pessoas distintas do destinatário, do que decorre a afirmação do aspecto negativo (poder de não manifestar).

Sem embargo da pertinência do debate, cremos que a inserção da delimitação do destinatário da manifestação do pensamento - seja no aspecto positivo da liberdade, seja no

\footnotetext{
${ }^{28}$ Determinadas consequências são extraídas do direito de manifestação do pensamento: "o direito de escolha do meio de manifestação do pensamento pela palavra escrita, rádio, televisão, imprensa, livro etc; b) o direito correspondente de receber publicações estrangeiras e ouvir emissões e ver televisões em outros países" (Cf.

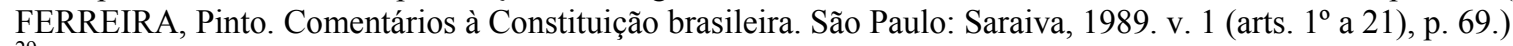

${ }^{29}$ Cf., infra, item n. 2.2 .

${ }^{30}$ Cf. MIRANDA, Pontes de. Comentários à Constituição... op. cit., p. 169.

31 PONTES DE MIRANDA registra exemplos dos citados desdobramentos da liberdade de não emitir o pensamento, respectivamente: a) "pensar, porém não emitir; saber, porém não dizer" (itálico nosso); b) "segredo da correspondência circular, dos avisos reservados a empregados, ou a amigos, habitantes de prédio ou de povoação"; c) "cartas particulares"; d) "originais de cartas não enviadas, de livros, de diários íntimos, de notas de família"; e) hipóteses semelhantes às anteriores, nas quais o segredo dure até certo termo. A última hipótese, o autor ressalta, é combinada com as retratada em "b", "c" e "d", porque cessado o segredo, as informações são exibidas à publicidade, a alguns ou a um (Comentários à Constituição... op. cit., p. 169-171).
} 
aspecto negativo da liberdade - evidencia que o exercício da liberdade de forma reservada, para si ou para o conhecimento de um ou de alguns destinatários, também é assegurado.

\subsubsection{A liberdade de comunicação entre pessoas presentes como espécie da} liberdade de manifestação de pensamento

Uma comunicação é representada por atos de transmissão do pensamento, caracterizados por atualidade e intersubjetividade, praticados por um emitente a um ou mais destinatários individuais. ${ }^{32}$ Correlata à liberdade de manifestação do pensamento, ${ }^{33}$ a liberdade de comunicação é igualmente indispensável para vida em comunidade.

A liberdade de manifestação do pensamento, conforme evidenciado anteriormente, ${ }^{34}$ pressupõe a liberdade de pensar, inerente ao ser humano, como ser racional que é.

Entretanto, não basta assegurar apenas a liberdade de pensamento, como antecedente de sua expressão. É preciso que a ordem jurídica garanta a liberdade de manifestação do pensamento, e "regule os meios para que se viabilize esta transmissão". ${ }^{35}$ Desta constatação decorre que a liberdade de expressão do pensamento está intimamente ligada com a liberdade de comunicação, em os seus meios e respectivos estatutos jurídicos. ${ }^{36}$

A liberdade de comunicação é espécie de liberdade de manifestação do pensamento. ${ }^{37}$

\footnotetext{
${ }^{32}$ Cf. MARINELLI, Claudio. Intercettazioni processuali... op. cit, p. 64.

${ }^{33}$ No mesmo sentido, reconhecendo a ligação entre liberdade de manifestação do pensamento e a liberdade de comunicação, cf. BALDUCCI, Paola. Le garanzie nelle intercettazioni... op. cit., p. 38.

${ }^{34}$ Cf., supra, item n. 2.2.

${ }^{35}$ Cf. BASTOS, Celso Ribeiro; MARTINS, Ives Gandra. Comentários à Constituição... op. cit., p. 40.

${ }^{36}$ Cf. Ibidem, p. 40.

${ }^{37}$ Cf. GRINOVER, Ada Pellegrini. Liberdades públicas... op. cit., p. 192-193. Relembrem-se aqui os aspectos positivo e negativo da liberdade de manifestação do pensamento. A liberdade de comunicação pode ser tida como espécie da liberdade de manifestação do pensamento em seu aspecto positivo ou negativo, dependendo da inserção da delimitação do destinatário pelo emitente em um destes aspectos da liberdade.
} 
Distinguem-se tais liberdades - a liberdade de manifestação do pensamento e a liberdade de comunicação - pelo destinatário do pensamento difundido: "a primeira concerne a uma difusão do pensamento que pode não ter destinatário certo, enquanto a segunda diz respeito a uma transmissão de pensamento com relação a determinado destinatário."38 A diferença entre elas advém do interesse de que se mantenha em segredo o conteúdo das comunicações, que é protegido pelo sigilo. ${ }^{39}$

Como liberdade jurídica, constitui um direito subjetivo, o direito a se comunicar. ${ }^{40} \mathrm{Da}$ mesma forma como observado quanto à liberdade de manifestação do pensamento, a liberdade de comunicação é integrada por um aspecto positivo (poder de se comunicar) e por um aspecto negativo (poder de não se comunicar).

A distinção interna entre os aspectos positivo e negativo da liberdade é ressaltada por Claudio Marinelli: a liberdade de comunicação implica o reconhecimento do direito à autodeterminação, quanto à possibilidade de contatar terceiros ou de se abster, e a não sofrer uma limitação em seu exercício sob a forma de inibição, de interrupção ou de qualquer outra interferência. $^{41}$

Interessa-nos, em especial, o aspecto positivo da liberdade, traduzido no exercício da liberdade de comunicação por meio de emissão de sons no fluído aéreo. Sendo espécie da liberdade de manifestação do pensamento, está tutelada no art. $5^{\circ}$, caput e inciso IV da Constituição da República.

\footnotetext{
${ }^{38}$ Cf. GRINOVER, Ada Pellegrini. Liberdades públicas... op. cit., p. 192-193.

${ }^{39}$ Cf. Ibidem, p. 193.

${ }^{40}$ Quanto a noção de liberdade, seus sujeitos ativos, passivos e objeto, cf., supra, item n. 2.2, nota n. 24.

41 "Libero é o ato comunicativo che non subisca indebite coercizioni o restrizioni, da parte di privati o dei publici poteri. È dunque riconosciuto il diritto di autodeterminazione in ordine alla possibilità di entrare in contatto con terzi o di astenersene, in ossequio alla distinzione interna tra il profilo positivo e quelo negativo di tale posizione soggetiva, e di non subire una limitazione nel suo esercizio sotto forma di inibizione, interruzione o di qualquiasi altra interferenza". Em tradução livre do autor: "livre é o ato comunicativo que não sobre indevidas coerções ou restrições, por parte de privados ou dos poderes públicos. É, portanto, reconhecido o direito a autodeterminação, em ordem à possibilidade de entrar em contato com terceiros ou de se abster, em observância à distinção interna entre o aspecto positivo e aquele negativo de tal posição subjetiva, e de não sofrer uma limitação no seu exercício sob a forma de inibição, interrupção ou qualquer outra interferência.” (Intercettazioni processuali... op. cit, p. 66).
} 


\subsection{O direito à intimidade e à vida privada}

A liberdade de comunicação - espécie da liberdade de comunicação do pensamento, como já observado - já assegura ao indivíduo a possibilidade de se contatar pessoas determinadas, escolhidas entre os concidadãos. Mas esta liberdade é insuficiente para a proteção dos diversos interesses que podem emanar de uma comunicação entre pessoas presentes. Não basta ao indivíduo poder contatar pessoas de forma presencial. Também pode ser de seu interesse que o conteúdo da comunicação ocorrida seja reservado às pessoas que dela participem, excluindo-o do conhecimento de terceiros.

É do interesse individual no resguardo do conteúdo ${ }^{42}$ da comunicação que se invoca o direito à intimidade e à vida privada. ${ }^{43}$ Este interesse se evidencia em situações nas quais as informações mencionadas pelos interlocutores sejam confidenciais, o que atribui um caráter reservado ${ }^{44}$ à comunicação.

Antes, porém, de ressaltar a relação existente entre o direito à intimidade e à vida privada e a proteção das comunicações, cumpre-nos apresentar considerações gerais sobre o tema.

A Constituição brasileira assegura, de forma conjunta, a intimidade e a vida privada: "são invioláveis a intimidade, a vida privada, a honra e a imagem das pessoas, assegurado o direito a indenização pelo dano material ou moral decorrente de sua violação" (art. $5^{\circ}$, caput e inciso $\mathrm{X})$.

\footnotetext{
${ }^{42}$ No mesmo sentido, cf. GRINOVER, Ada Pellegrini. Liberdades públicas... op. cit., p. 193.

${ }^{43} \mathrm{Na}$ doutrina nacional, são variadas as formas de referência a estes bens jurídicos. Embora se identifique a diferenciação entre a intimidade e a vida privada, alguns se referem intitular às respectivas considerações apenas com o emprego do termo intimidade (GRINOVER, Ada Pellegrini. Liberdades públicas... op. cit., p. 69 e ss.); outros, com o emprego dos termos intimidade e vida privada (COSTA JUNIOR, Paulo José da. O direito de estar só: tutela penal da intimidade. 4. ed. São Paulo: RT, 2007, p. 9-70; BELLOQUE, Juliana Garcia. Sigilo Bancário: análise crítica da LC 105/2001. São Paulo: RT, 2003, p. 21 e ss.). Considerada a tutela de ambos os aspectos da esfera privada na ordem constitucional (art. $5^{\circ}$, caput e inciso X da Constituição brasileira), preferimos a referência à intimidade e à vida privada.

${ }^{44}$ A propósito do caráter reservado do conteúdo da comunicação, verifiquem-se as observações sobre o conceito e objeto da interceptação de comunicação entre pessoas presentes: infra, itens n. 3.2 e 3.3.
} 
A intimidade e a vida privada de uma pessoa são valores indispensáveis para o desenvolvimento de suas faculdades. Mas tais valores não são incompatíveis com a vida em sociedade. O ser humano guarda espaços reservados para si e para relações que não deseja compartilhar com pessoas distintas de seus integrantes. Portanto, são valores inseridos no convívio coletivo.

É por esta razão que se protege uma esfera privada ao indivíduo, sob a afirmação da existência do direito à intimidade e à vida privada. Cuida-se de direito subjetivo público. ${ }^{45} \mathrm{O}$ sujeito ativo é pessoa física ou jurídica, e o sujeito passivo, entes privados ou entes públicos, entre os quais está o Estado. ${ }^{46}$

A doutrina costuma diferenciar vida privada e intimidade, a despeito de reconhecer a dificuldade. ${ }^{47}$

Segundo Manoel GonçAlves Ferreira Filho, vida privada, definida em oposição à vida pública, é a que se desenvolve "fora das vistas da comunidade, perante, eventualmente, um grupo de íntimos. Compreende, portanto, a intimidade, isto é, a vida em ambiente de convívio, no interior de um grupo fechado e reduzido, normalmente, ao grupo familiar."48

Conforme PAUlo José DA COSTA JUNIOR, a vida privada e a intimidade devem ser examinadas em conjunto. Ou melhor: vê-las sob a perspectiva das várias esferas da vida

\footnotetext{
${ }^{45}$ Neste sentido, cf.: GRINOVER, Ada Pellegrini. Liberdades públicas... op. cit., p. 72-77; BELLOQUE, Juliana Garcia. Sigilo Bancário: análise crítica da LC 105/2001. São Paulo: RT, 2003, p. 32.

${ }^{46}$ Neste sentido, cf.: BELLOQUE, Juliana Garcia. Sigilo Bancário... op. cit., p. 31-33; PISANI, Mario. La tutela giuridica della vita privata. L'indice penale, Padova, Cedam, anno I, n. 3, set-dic. 1967, p. 432. Sobre os sujeitos e o objeto das liberdades jurídicas, cf., também, supra, nota n. 24, do item n. 2.2.

${ }^{47}$ Cf. FERREIRA FILHO, Manoel Gonçalves. Comentários à Constituição brasileira de 1988. São Paulo: Saraiva, 1990. v. 1., p. 35.

${ }^{48}$ Cf. FERREIRA FILHO, Manoel Gonçalves. Comentários à Constituição... op. cit., p. 35-36. No mesmo sentido, CLEUNICE PITOMBO observa: "ao menos entre nós, a rigor, 'vida privada' é mais ampla, ou abrangente, do que 'intimidade' e a sinonímia aparece remota" (Da busca... op. cit., p. 75; Idem. Considerações sobre a tutela da intimidade e vida privada no processo penal. Revista Brasileira de Ciências Criminais, São Paulo, ano 7, n. 26, abr-jun. 1999, p. 63).
} 
privada, que se subdivide em esferas outras, de dimensões progressivamente menores, na medida em que a intimidade for restringindo. ${ }^{49}$

O âmbito maior da intimidade é abrangido pela esfera privada stricto sensu. ${ }^{50}$ Nela estão insertos todos os comportamentos e acontecimentos que o indivíduo não quer que sejam de domínio público. ${ }^{51}$

Contida na esfera precedente está a esfera da intimidade (ou esfera confidencial), da qual participam as pessoas nas quais o indivíduo deposita certa confiança e com as quais mantém certa intimidade. ${ }^{52}$

A derradeira esfera, inserta no âmago da intimidade, é a nuclear: a do segredo. "Ela compreende aquela parcela da vida particular que é conservada em segredo pelo indivíduo, do qual compartilham uns poucos amigos, muito chegados. Dessa esfera não participa sequer pessoas da intimidade do sujeito. Conseqüentemente, a necessidade de proteção legal contra a indiscrição, nessa esfera, faz-se sentir mais intensa". ${ }^{3}$

Portanto, da corrente de pensamento citada, extrai-se que três são as esferas da vida privada, com dimensões distintas pelo tamanho dos seus sobrepostos diâmetros, ordenadas da

\footnotetext{
${ }^{49}$ Cf. COSTA JUNIOR, Paulo José da. O direito de estar só... op. cit., p. 23-31. No mesmo sentido, na doutrina norte-americana, reconhecendo o caráter composto da privacidade, SAMUEL D. WARREN e LOUIS D BRANDEIS afirmam que o direito de ser deixado só ("the right to be let alone") é integrado por um feixe de interesses, que decorrem do reconhecimento do aspecto espiritual, do intelecto e dos sentimentos do ser humano (The right to privacy. Harvard Law Review, V. IV, n. 5, dec.1890. Disponível em: http://faculty.uml.edu/sgallagher/Brandeisprivacy.htm. Acesso em: 07/09/2010). Em Itália, CLAUDIO MARINELLI, seguindo a mesma linha de pensamento, salienta que se deve reconhecer uma noção ampla de privacidade, idônea a compreender um feixe de posições subjetivas conotadas por um elevado grau de heterogeneidade, as quais, sendo expressão da vida privada, mantêm aspectos autônomos quanto ao objeto de tutela e a tipologia de interferências potencialmente lesivas. Exemplifica o autor com a inviolabilidade do domicílio e a inviolabilidade do sigilo das comunicações, para as quais há específica proclamação e tutela por meio de uma previsão expressa. Cuida-se de "direitos de personalidade tipificados" (Intercettazioni processuali... op. cit, p. 88).

${ }^{50}$ Cf. COSTA JUNIOR, Paulo José da. O direito de estar só... op. cit., p. 29. No mesmo sentido, cf.: MARINELLI, Claudio. Intercettazioni processuali... op. cit, p. 83.

${ }^{51}$ Cf. COSTA JUNIOR, Paulo José da. O direito de estar só... op. cit., p. 29.

${ }^{52}$ Dela são excluídas não só o público em geral, como também as pessoas que convivem com o indivíduo num ambiente mais amplo (COSTA JUNIOR, Paulo José da. O direito de estar só... op. cit., p. 30).

${ }^{53}$ Cf. Ibidem, p. 30.
} 
maior a menor: esfera privada stricto sensu (vida privada, na outra definição apresentada), esfera da intimidade (ou esfera confidencial) e esfera do segredo.

Também ANTONIO SCARANCE FERNANDES analisa a vida privada e a intimidade sob a perspectiva de esferas: a esfera da intimidade, a esfera da vida privada e a esfera social. ${ }^{54}$

Na primeira, esfera da intimidade o indivíduo deposita os seus segredos. Alguns deles não são compartilhados; outros são revelados a pessoas muito próximas. ${ }^{55}$

A esfera da vida privada, com diâmetro mais extenso, compreende segredos que são conhecidos por um grupo reduzido de pessoas com quem o indivíduo se relaciona, especialmente familiares, amigos e profissionais. ${ }^{56}$ Ao compartilhar segredos com tais pessoas, ele pretende que não sejam divulgados a outros, sem o seu prévio consentimento. ${ }^{57}$

Reduz-se a preocupação com a tutela dos segredos na esfera da vida social, que tem maior amplitude, porque abrange as relações estabelecidas com maior número de pessoas. ${ }^{58}$ Não se pode olvidar, contudo, fatos íntimos nela insertos, que merecem ser resguardados. ${ }^{59}$

Delimitados o objeto de tutela do direito à intimidade e à vida privada, identificamos, em doutrina, os interesses delas extraídos. O elemento objetivo do direito é, pois, complexo, por envolver mais de um interesse.

Salientando a pluralidade de interesses, PAULO José DA COSTA JUNIOR observa que, “na expressão 'direito à intimidade', são tutelados dois interesses, que se somam: o interesse

\footnotetext{
${ }^{54}$ Cf. FERNANDES, Antonio Scarance. O sigilo... op. cit., p. 154-155.

${ }^{55}$ Cf. Ibidem, p. 154.

${ }^{56}$ Cf. Ibidem, p. 155.

${ }^{57}$ ANTONIO SCARANCE FERNANDES insere nesta esfera se inserem diversas espécies de sigilo: o sigilo bancário, o sigilo profissional, o sigilo dos parentes e o sigilo das comunicações privadas (O sigilo... op. cit., p. 155). Parece-nos que o sigilo das comunicações privadas deve ser inserido tanto na esfera da vida privada, quanto na esfera da intimidade.

${ }^{58}$ Cf. Ibidem, p. 155.

${ }^{59}$ Lembra ANTONIO SCARANCE FERNANDES que "haveria aqui uma esfera especial, a de determinados grupos de pessoas: aquelas que, em virtude de sua atuação, como políticos, artistas, precisam tonar-se mais conhecidas da comunidade e, por isso, permitem seja sua vida particular mais desvendada. Mesmo essas pessoas, contudo, não perdem o direito à preservação do segredo". (O sigilo... op. cit., p. 155).
} 
de que a intimidade não venha a sofrer agressões (diritto alla segretezza ou diritto al rispetto della vita privata) e o de que não venha a ser divulgada (diritto alla riservatezza)" ${ }^{60}$

Por igual, ADA PELlegrini GRINOver afirma: "por direito à intimidade, genericamente, entendemos quer o direito ao segredo, quer o direito à reserva". ${ }^{61}$ Mais ainda: "as infrações a este único direito [à intimidade] é que podem tomar contornos diversos, consoante se trate de atos de devassa, clandestina ou abusiva, ou de atos de divulgação de dados obtidos lícita ou ilicitamente. Violada, nesse caso, será sempre a intimidade, ainda que se prefira falar, em sentido estrito, em segredo, no primeiro caso, e em reserva, no segundo.” 62

Os referidos interesses são protegidos também sob a inviolabilidade do sigilo das comunicações, que é expressão do direito à intimidade e à vida privada.

\subsubsection{A inviolabilidade do sigilo de comunicação entre pessoas presentes} como expressão do direito à intimidade e à vida privada

A intimidade e a vida privada constituem fenômenos poliédricos, dos quais a doutrina extrai um feixe de interesses: além dos já mencionados - de segredo e de reserva - outros delas derivam.

Em minuciosa análise da interceptação de comunicações telefônicas, ADA PELLEGRINI GRINOVER já observava que o direito à intimidade se insere entre os direitos de personalidade, e que dele decorrem manifestações múltiplas, entre as quais destaca: “o direito à imagem, à

\footnotetext{
${ }^{60}$ De acordo com o autor, a diferenciação entre os dois interesses decorrentes do direito à intimidade importa para distinguir as formas de sua agressão, que podem ser duas: aquisição de notícias íntimas ilegítimas (violação da intimidade sob a perspectiva do interesse de não ser agredida); e revelação ilícita de notícias adquiridas legitimamente (violação da intimidade sob o enfoque do interesse de não ser divulgada). No último caso, "o extraneus foi trazido para a esfera da vida privada pelo seu legítimo titular, que dela podia livremente dispor. Não houve, pois, invasão. Adquiriu o terceiro legitimamente os segredos que lhe foram confiados. Sem fraude, sem captação irregular. No momento ulterior, abusou da confiança depositada, divulgando as intimidades reveladas" (O direito de estar só... op. cit., p. 25-27). De forma semelhante, CELSO RIBEIRO BASTOS e IVES GANDRA MARTINS afirmam que o direito a intimidade e à vida privada "consiste na faculdade que tem cada indivíduo de obstar a intromissão de estranhos na sua vida privada e familiar, assim como de impedir-lhes o acesso a informações sobre a privacidade de cada um, e também impedir que sejam divulgadas informações sobre esta área da manifestação existencial do ser humano.” (Comentários à Constituição... op. cit., p. 63).

${ }^{61}$ Cf. GRINOVER, Ada Pellegrini. Liberdades públicas... op. cit., p. 77.

${ }^{62}$ Cf. Ibidem, p. 194.
} 
defesa do nome, à tutela de obra intelectual, à inviolabilidade do domicílio, o direito ao segredo (epistolar, documental, profissional).",63

Ademais, de forma pontual, a autora ressaltou que o sigilo das comunicações "é uma expressão do direito à intimidade, genericamente entendido" ${ }^{64}$ A sua tutela se dá quer com a proteção do segredo, ${ }^{65}$ quer com a proteção da reserva. ${ }^{66}$ Note-se que o entendimento esposado se refere ao sigilo das comunicações, genericamente considerado.

Acrescentamos nós, agora sob a perspectiva do exame de comunicações de forma presencial, que também o sigilo de comunicações entre pessoas presentes é expressão do direito à intimidade e à vida privada. ${ }^{67}$ Dependendo da esfera em que esteja inserida a comunicação dos interlocutores, o respectivo sigilo é protegido por ser expressão quer do direito à intimidade, quer do direito à vida privada.

Interessa aos interlocutores de comunicações presenciais que o seu conteúdo - as informações mencionadas pelos interlocutores - não seja conhecido por terceiro, e, se conhecido lícita ou ilicitamente, não seja divulgado. Tais interesses - por segredo e por

\footnotetext{
${ }^{63}$ Ressalva a autora que "são apenas algumas de suas expressões, não se tratando de um rol taxativo, uma vez que a tutela da intimidade poderá ser estendida a novos atributos da personalidade" (Liberdades públicas... op. cit., p. 75). No mesmo sentido, DANILO DONEDA ressalta "a conotação contemporânea da proteção da privacidade, que se manifesta sobretudo (porém não somente) através da proteção de dados pessoais; e que deixa de dar vazão somente a um imperativo de ordem individualista, mas passa a ser a frente onde irão atuar vários interesses ligados à personalidade e às liberdades fundamentais da pessoa humana, fazendo com que na disciplina da privacidade passe a se definir todo um estatuto que acaba por compreender as relações da própria personalidade com o mundo exterior." (Da privacidade à proteção dos dados pessoais. Rio de Janeiro: Renovar, 2006, p. 30).

${ }^{64}$ Cf. GRINOVER, Ada Pellegrini. Liberdades públicas... op. cit., p. 194. Na mesma esteira, em direito estrangeiro, ANTONIO PABLO RIVES SEVA salienta a ligação entre as tutela do sigilo das comunicações e da intimidade e vida privada. Ressalta o autor, contudo, que a liberdade de comunicação deve ser protegida, independentemente de estar ligada ao âmbito privado (La intervención de las comunicaciones en la jurisprudencia penal. Elcano [Navarra]: Aranzadi, 2000, p. 24).

${ }_{65}$ Cf. GRINOVER, Ada Pellegrini. Liberdades públicas... op. cit., p. 194. No mesmo sentido, ANTONIO SCARANCE FERNANDES diferencia, em termos técnicos, o segredo do sigilo: "em suma, o segredo é o que não pode ser revelado, ou seja, o conteúdo da informação; o sigilo é o meio de proteção do segredo a fim de não ser revelado; a violação do sigilo consiste na divulgação do segredo quando não autorizados" (Processo penal constitucional. 6. ed. São Paulo: RT, 2010, p. 91). Além disso, o autor explica que a diferença entre o segredo e o sigilo decorre da etimologia: "são conceitos extraídos a partir do sentido etimológico dos vocábulos "segredo" e "sigilo". O primeiro provém de secretum, ou seja, aquilo que está oculto e o segundo de sigilum, diminutivo de signum, cujo significado é o de pequeno sinal ou, ainda, de selo, isto é, daquilo que serve para ocultar ou guardar" (O sigilo... op. cit., p. 155).

${ }^{66}$ Cf. GRINOVER, Ada Pellegrini. Liberdades públicas... op. cit., p. 194.

${ }^{67}$ Adiantamos aqui uma de nossas conclusões, que também é exposta no Capítulo $5^{\circ}$, infra, item n. 5.1.
} 
reserva da comunicação ${ }^{68}$ - são protegidos pelo sigilo das comunicações entre pessoas presentes.

A doutrina reconhece a existência de direito ao sigilo. ${ }^{69}$ Tratando-se de comunicação presencial, identificamos o direito ao sigilo das comunicações entre pessoas presentes. $\mathrm{O}$ remetente e o destinatário são tidos como sujeitos ativos. ${ }^{70}$ Os sujeitos passivos são os demais entes privados e os entes púbicos, inclusive o Estado. ${ }^{71}$

Parece-nos que a sigilo das comunicações também possa ser entendido como garantia, ${ }^{72}$ sob a perspectiva de que assegura a liberdade de comunicação, a intimidade e a vida privada.

\footnotetext{
${ }^{68}$ Interesse por segredo da comunicação, para que não seja conhecida por outros, sem o consentimento dos interlocutores; e interesse por reserva da comunicação, para que, conhecida lícita ou ilicitamente, a comunicação não seja divulgada.

${ }^{69}$ Cf. GRINOVER, Ada Pellegrini. Liberdades públicas... op. cit., p. 184; FERNANDES, Antonio Scarance. O sigilo... op. cit., p. 156. Segundo TERCIO SAMPAIO FERRAZ JUNIOR, o direito ao sigilo se expressa na "faculdade de agir (manter o sigilo, resistir ao devassamento". Sigilo de dados: o direito à privacidade e os limites à função fiscalizadora do Estado. In: PIZOLIO, Rinaldo; GAVALDÃO JUNIOR, Jayr Viégas. Sigilo Fiscal e Bancário. São Paulo: Quartier Latin, 2005, p. 22).

70 Cf. GRINOVER, Ada Pellegrini. Liberdades públicas... op. cit., p. 191. ANTONIO SCARANCE FERNANDES observa que o sujeito ativo é "o detentor do segredo, próprio ou alheio" (O sigilo... op. cit., p. 156). VICENTE GRECO FILHO, em comentários sobre a interceptação de comunicação telefônica, afirma: "os titulares do sigilo das telecomunicações são os interlocutores e estes é que estão protegidos pela garantia constitucional, não o dono do direito de uso da linha telefônica" (Interceptação telefônica... op. cit., p. 10). No mesmo sentido, em exame do direito ao segredo das comunicações ("derecho al secreto de las comunicaciones") no direito espanhol, VICENTE GIMENO SENDRA afirma que "la titularidad de este derecho fundamental corresponde a todos los sujetos de derecho, incluidas las personas jurídicas". Em tradução livre do autor: "a titularidade deste direito fundamental corresponde a todos os sujeitos de direito, incluídas as pessoas jurídicas" (Derecho Procesal Penal. 2. ed. Madrid: Colex, 2007, p. 418). O mesmo entendimento é sustentado por José Francisco Valls GOMBAU e por JOSÉ MARIA RIFÁ SOLER, ao afirmarem o direito ao segredo das comunicações "frente a terceiros alheios à comunicação" (Derecho procesal penal. Madrid: Iurgium, 2000, p. 213).

${ }^{71}$ Neste sentido, cf. GRINOVER, Ada Pellegrini. Liberdades públicas... op. cit., p. 191. Na mesma esteira, JOSÉ MARTÍNEZ DE PISÓN CAVERO, em comentários sobre o art. 18.3 da Constituição espanhola, que garante o segredo das comunicações, esclarece que "la norma constitucional sólo garantiza a impenetrabilidad del proceso de comunicación frente a terceros". Em tradução livre do autor: "a norma constitucional somente garante a impenetrabilidade no proceso de comunicação frente a terceiros" (La configuración constitucional del derecho a la intimidad. Derechos y Libertades: Revista del Instituto Bartolome de Las Casas, Madrid, año II, n. 3, may-dic. 1994, p. 335-336).

${ }^{72}$ Sobre a abrangência do termo garantia, cf. supra, nota n. 14, item n. 2.1. No sentido da possibilidade de consideração da inviolabilidade do sigilo como garantia, cf.: FERRAZ JUNIOR, Tercio Sampaio. Sigilo de dados... op. cit., p. 23.
} 
O fato de ser protegido o interesse de que as informações transmitidas em comunicações entre presentes não sejam conhecidas ou reveladas não exclui a possibilidade de ambos os interlocutores as divulguem a outras pessoas, diretamente ou por meio de autorização concedida por um a outro interlocutor, ou por ambos a terceiros. A inviolabilidade do sigilo de uma comunicação não exclui a possibilidade de os seus interlocutores compartilharem as informações nela mencionadas com outros entes, incluindo-as fora da esfera privada. ${ }^{73}$

Especial atenção deve ser dispensada às situações em que as comunicações presenciais são mantidas na esfera da vida privada ou na esfera da intimidade, porque são protegidas pela inviolabilidade do sigilo das comunicações entre pessoas presentes, que é tutelada no o art. $5^{\circ}$, caput e inciso $\mathrm{X}$ da Constituição da República, por ser expressão do direito à intimidade e à vida privada. ${ }^{74}$

\subsection{A inviolabilidade do domicílio}

O conteúdo de uma comunicação, que é protegido pela inviolabilidade do sigilo das comunicações entre pessoas presentes, tem o seu caráter reservado evidenciado em grau mais elevado se os interlocutores compartilharem informações confidenciais em locais em que as relações insertas na esfera da intimidade e na esfera da vida privada se intensificam. $O$

\footnotetext{
${ }^{73}$ Em sentido semelhante, ANTONIO SCARANCE FERNANDES se manifesta: "o conteúdo secreto da informação transmitida poderá constituir fonte de prova se interessar à investigação criminal. $O$ conhecimento dessa fonte pela autoridade encarregada da investigação pode decorrer de revelação feita pela própria pessoa protegida pelo sigilo; não há obviamente violação. Quando o conhecimento do segredo decorre de atividades ilegais de autoridades, de policiais ou advém de revelação feita pelo destinatário da comunicação ou por terceira pessoa sem permissão do titular do segredo e sem amparo na lei, haverá ilicitude na obtenção da prova”. (Processo penal... op.cit., p. 91).

${ }^{74}$ Quanto à proteção das comunicações entre presentes pela tutela da intimidade e da vida privada, ADA PELLEGRINI GRINOVER, ANTONIO MAGALHÃES GOMES FILHO e ANTONIO SCARANCE FERNANDES observam: "as gravações sub-reptícias de conversas entre presentes, efetuadas por terceiro, com o desconhecimento de todos os interlocutores ou de um deles, embora sejam interceptações em sentido técnico (v. supra, n. 1), no Brasil não se enquadram na disciplina do art. $5^{\circ}, \mathrm{XII}$, da CF, que cuida exclusivamente da quebra de sigilo das comunicações telefônicas. Mas, desde que se trate de conversas confidenciais, as interceptações entre presentes infringem, induvidosamente, o disposto no inc. X do mesmo artigo da Constituição, que protege a intimidade" (As nulidades... op. cit., p. 184).
} 
domicílio simboliza os mencionados locais. Por isso, a inviolabilidade do domicílio também fundamenta a proteção do conteúdo da comunicação que nele ocorrer.

A Constituição brasileira preconiza a inviolabilidade do domicílio, em seu art. $5^{\circ}$, caput e inciso XI: “a casa é asilo inviolável do indivíduo, ninguém nela podendo penetrar sem consentimento do morador, salvo em caso de flagrante delito ou desastre, ou para prestar socorro, ou, durante o dia, por determinação judicial”.

A prevista inviolabilidade do domicílio é um direito fundamental arraigado na tradição britânica. É frequentemente recordado o dito inglês "my house is my castle", para expressar o intuito de, com o reconhecimento desta inviolabilidade, assegurar-se "proteção ao indivíduo, à família e à tranquilidade e segurança individuais." 75

Além de direito, a inviolabilidade do domicílio é também garantia, ${ }^{76}$ porque assegura o exercício de liberdades, ${ }^{77}$ entre as quais, pela relevância com a tutela das comunicações entre pessoas presentes, destacamos: a liberdade física, a liberdade de manifestação do pensamento, a intimidade e a vida privada. A determinação do local em que se operam tais liberdades fundamenta a proteção de uma pessoa sob outra forma: a da inviolabilidade do espaço de exercício da liberdade, conhecida como inviolabilidade do domicílio.

A proteção à liberdade física é reconhecida independentemente do local onde se esteja: em local público ou particular, o indivíduo é livre para ir, vir e ficar. Entretanto, a liberdade

\footnotetext{
${ }^{75}$ Cf. MIRANDA, Pontes de. Comentários... op. cit., p. 186. A propósito, MANOEL GONÇALVES FERREIRA FILHO lembra que "é este direito um dos que profundamente estão arraigados na tradição britânica, de onde provém. Conhecida é a afirmação (que Colliard acoima de romântica Les libertés publiques, 6. ed., Paris, Dalloz, 1982, p. 368) de Lord Chatham, em discurso proferido no Parlamento: 'O homem mais pobre desafia na sua casa todas as forças da Coroa; sua cabana pode ser muito frágil, seu teto pode tremer, o vento pode soprar por entre as portas mal ajustadas, a tormenta pode nela penetrar, mas o rei da Inglaterra não pode nela entrar'" (Comentários à Constituição... op. cit., p. 36-37).

${ }^{76}$ Sobre a noção de garantia, cf. supra, item n. 2.1, nota n. 14.

77 Segundo PONTES DE MIRANDA, a imprescindibilidade da proteção da habitação para o pleno desenvolvimento das faculdades do ser humano é decorrência de sua condição biológica na natureza. "O homem precisa de espaço que o proteja, como todos os outros animais. Porém o homem mais do que os outros. É ente sem defesas de casco, ou de pêlos espessos, ou de epiderme resistente. Nasce frágil, e frágil continua meses e anos, à diferença de outros vertebrados." "A casa foi, desde cedo, como se fora o casco, ou a couraça do homem. Conceber a liberdade física e segurança, constituiu, para êle, defender-se a si na sua habitação." (Comentários... op. cit., p. 183-184).
} 
física pode estar agregada a um espaço determinado, no qual se exerçam as faculdades que dela decorrem. PONTES DE MIRANDA enfatiza que a inviolabilidade do domicílio é a "liberdade física espacializada". ${ }^{78}$ Trata-se de uma "espacialização do direito de ficar - parte, por sua vez, da liberdade física". 79

A inviolabilidade do domicílio também propicia o exercício da liberdade de comunicação, ${ }^{80}$ que, como vimos, é espécie da liberdade de manifestação do pensamento. ${ }^{81}$ Locais reservados, como são os domicílios, permitem ao remetente a escolha de seu destinatário, possibilitando que somente eles conheçam o conteúdo da comunicação.

Relaciona-se a ligação entre o domicílio e a liberdade de manifestação do pensamento, a afirmação da doutrina italiana sobre a existência de um ius excludenti alios, ${ }^{82}$ do qual é titular a pessoa que esteja em domicílio.

\footnotetext{
${ }^{78}$ Fundamenta o autor o seu entendimento: "eliminemos assim a opinião que liga a inviolabilidade da casa à propriedade dessa. Primeiro, porque na história não se esboçou, como princípio de independência fundado nas coisas, e sim como princípio fundado na pessoa, à guisa da liberdade de ir, ficar e vir. Segundo, porque sempre protegeu a porção espacial - portas dentro - sem qualquer distinção quanto ao título de uso da casa." (Cf. MIRANDA, Pontes de. Comentários... op. cit., p. 177 e 183).

${ }^{79}$ Cf. MIRANDA, Pontes de. Comentários... op. cit., p. 182.

${ }^{80}$ ALFREDO BARGI ressalta que, no sistema de direitos fundamentais, a liberdade domiciliar e a liberdade de comunicação são diretamente ligadas à liberdade pessoal (Intercettazioni di comunicazioni o conversazioni. In: Digesto delle Discipline Penalistiche: aggiornamento. 4. ed. Torino: UTET, 2005. Tomo I: A-M, p. 789).

${ }^{81}$ Quanto ao reconhecimento da relação entre liberdade de manifestação do pensamento, especialmente quanto ao aspecto negativo, cf. MIRANDA, Pontes de. Comentários ... op. cit., p. 171.

82 "A inviolabilidade do domić́lio implica o direito de o morador excluir da sua casa aqueles que nela se encontrem indevidamente" (BASTOS, Celso Ribeiro; MARTINS, Ives Gandra. Comentários à Constituição... op. cit., p. 69). Tal direito é tutelado penalmente pela incriminação da violação do domicílio prevista no art. 614 do Código Penal italiano: "chiunque s'introduce nell'abitazione altrui, o in un altro luogo di privata dimora, o nelle appartenenze di essi, contro la volontà espressa o tacita di chi ha il diritto di escluderlo, ovvero vi s'introduce clandestinamente o con inganno, è punito con la reclusione fino a tre anni". Em tradução livre do autor: "aquele que se introduz na habitação alheia, ou em outro lugar de domicílio privado, ou em suas dependências, contra a vontade expressa ou tácita de quem tem o direito de o excluir, ou nele se introduz clandestinamente ou com ardil, é punido com reclusão de até três anos" (grifou-se). Trata-se de um dos critérios utilizados pela doutrina para definição dos locais que configuram domicílio privado (Cf. APRILE, Ercole; SPIEZIA, Filippo. Le intercettazioni... op. cit., p. 65). Note-se que se liga o ius excludenti alios à liberdade de manifestação do pensamento, diferente da clássica concepção de que a exclusão de terceiros se dá para a proteção do direito de propriedade. Neste sentido, MARIA CECILIA RAMÍREZ G. afirma que a faculdade individual de excluir terceiros é o denominador comum dos locais onde um sujeito desenvolva a vida familiar, o trabalho, o descanso e outros assuntos reservados (Protección de las comunicaciones telefónicas en Chile. In: MARTíN, Adán Nieto (coord.). Homenaje ao Dr. Marino Barbero Santos - in memoriam. V. II. Cuenca: Ediciones de la Universidad de Castilla-La Mancha, 2001. p. 541).
} 
Demais disso, a inviolabilidade do domicílio assegura, ainda, a intimidade e a vida privada. ${ }^{83}$ Esta estreita relação é afirmada em doutrina de forma enfática, que considera o domicílio: "o âmbito mais sagrado e inviolável da intimidade", ${ }^{84}$ um dos pressupostos para o exercício da vida privada. ${ }^{85}$

Expressão do direito à intimidade e do direito a vida privada, o sigilo das comunicações entre pessoas presentes é, por igual, assegurado pela inviolabilidade do domicílio. ${ }^{86}$ CORRADA DI MARTINO e TERESA PROCACCIANTI justificam a ligação entre a tutela do sigilo das comunicações entre presentes e a tutela do domicílio na concepção de domicílio como noção jurídica autônoma, com a consequente salvaguarda de interesses que transcendem a proteção conferida ao direito de propriedade. ${ }^{87}$

Evidencia-se, portanto, que a relação entre a proteção das comunicações entre pessoas presentes e a inviolabilidade do domicílio pode ser vista, a nosso ver, quer sob o enfoque do nexo entre a última e a liberdade de comunicação - considerada a destinação do espaço para o exercício, em concreto, da liberdade -, quer sob o enfoque de inviolabilidade do sigilo das comunicações entre pessoas presentes, pela ligação umbilical do domicílio com a vida privada e a intimidade.

\footnotetext{
${ }^{83}$ Sobre o direito nacional, cf.: TUCCI, Rogério Lauria. Direitos e garantias... op.cit., p. 398. Em direito estrangeiro, cf.: APRILE, Ercole; SPIEZIA, Filippo. Le intercettazioni... op. cit., p. 68; RUIZ, Jesús Martínez. Limites jurídicos de las grabaciones de la imagen y el sonido. Barcelona: Bosch, 2004, p. 74-75.

${ }^{84}$ Cf. CONDE, Francisco Munoz; LANGHE, Marcela de. Presentación... op. cit., p. 29. A propósito do domicílio como aspecto essencial para a proteção da esfera privada do ser humano, o Tribunal Constitucional alemão, em sentença BVerfGE 109, de 2004, reconheceu a existência de um "âmbito essencial da vida privada", tido por indispensável para o desenvolvimento da personalidade. No mencionado âmbito, no entender do tribunal, estariam inseridas a possibilidade de expressar sucessos, reflexões opiniões e experiências íntimas estritamente pessoais, sem medo de ser observado por instituições públicas. Para o exercício de tais faculdades, reconheceu a necessidade do domicílio privado, local tido como refúgio último, meio para preservar a dignidade humana, do qual devem ser excluídas outras pessoas. Consta ainda da sentença que não se exige uma proteção absoluta de espaços de domicílio privado, mas uma proteção das condutas das pessoas nestes espaços, as quais são consideradas inseridas no âmbito essencial da vida privada (Cf. ROXIN, Claus. La prohibición... op. cit., p. 91).

${ }^{85}$ Cf. MARINELLI, Claudio. Intercettazioni processuali... op. cit, p. 74.

${ }^{86}$ Cf. CORRADA DI MARTINO enfatiza a existência da ligação entre a tutela do sigilo das comunicações e a tutela do domicílio (Le intercettazioni ambientali... op. cit., p. 1.155). Em sentido semelhante, cf. BALDUCCI, Paola. Le garanzie... op. cit., p. 38 e 93. Outras formas de comunicação são protegidas com a inviolabilidade do domicílio, como a comunicação epistolar. ROGÉRIO LAURIA TUCCI ressalta o "seu íntimo relacionamento 'com outros direitos que protegem a individualidade', como, por exemplo, o sigilo da correspondência" (Direitos e garantias... op.cit., p. 398).

${ }^{87}$ Cf. Le intercettazioni... op. cit., p. 60.
} 
Uma observação da mais alta relevância: a garantia da inviolabilidade do domicílio fundamenta a proteção das comunicações entre presentes se o fluído aéreo em que se propagam as ondas sonoras estiver circunscrito em um domicílio. ${ }^{88}$

Muito se discute sobre a extensão do conceito de domicílio. A definição dos locais que constituam domicílio é dificultada não só pela pluralidade de liberdades nele exercidas, como também pelas especificidades de institutos jurídicos a elas se relacionadas, não raramente decorrentes da diversidade de ramos do Direito em que estão inseridos.

E a tarefa de delimitação da abrangência dos locais que constituam domicílio é dificultada, porque o legislador nacional emprega os termos "casa" e "domicílio" de forma aleatória. ${ }^{89} \mathrm{O}$ primeiro é previsto na Constituição. ${ }^{90} \mathrm{O}$ segundo, no Código Civil. ${ }^{91}$ Identifiquese o emprego, juntamente, de "casa" e de "domicílio" no Código Penal, ${ }^{92}$ no Código de Processo Penal ${ }^{93}$ e no Código de Processo Penal Militar. ${ }^{94}$

\footnotetext{
${ }^{88} \mathrm{Em}$ outras palavras: o fundamento é invocado em se tratando se interceptação domiciliar, que é espécie de interceptação de comunicações entre pessoas presentes. A respeito das espécies desta interceptação, cf., infra, itens n. 3.7, n. 3.7.1 e 3.7.2. Neste sentido, CLAUDIO MARINELLI salienta que as interceptações incidem, de modo insidioso, sobre o sigilo das comunicações e, por vezes, sobre a inviolabilidade domiciliar (Intercettazioni processuali... op. cit, p. 79 ).

${ }^{89}$ Cf. PITOMBO, Cleunice A. Valentim Bastos. Da busca... op. cit., p. 65.

90 "A casa é asilo inviolável" (art. $5^{\circ}$, inciso XI).

${ }^{91}$ No Código Civil, o domicílio é assim definido: "o domicílio da pessoa natural é o lugar onde ela estabelece a sua residência com ânimo definitivo" (art. 70); "se, porém, a pessoa natural tiver diversas residências, onde, alternadamente, viva, considerar-se-á domicílio seu qualquer delas" (art. 71); "é também domicílio da pessoa natural, quanto às relações concernentes à profissão, o lugar onde esta é exercida" (art. 72, caput); "se a pessoa exercitar profissão em lugares diversos, cada um deles constituirá domicílio para as relações que lhe corresponderem" (art. 72, parágrafo único); "ter-se-á por domicílio da pessoa natural, que não tenha residência habitual, o lugar onde for encontrada" (art. 73).

${ }^{92}$ Ao disciplinar o tipo "Violação de domicílio", no art. 150 do Código Penal, o legislador estabelece: "§ $4^{\circ}$ - A expressão 'casa' compreende: I - qualquer compartimento habitado; II - aposento ocupado de habitação coletiva; III - compartimento não aberto ao público, onde alguém exerce profissão ou atividade." (§ $\left.4^{\circ}\right)$; "não se compreendem na expressão 'casa': I - hospedaria, estalagem ou qualquer outra habitação coletiva, enquanto aberta, salvo a restrição do n. ${ }^{\circ}$ II do parágrafo anterior; II - taverna, casa de jogo e outras do mesmo gênero." (§ $5^{\circ}$.

${ }^{93} \mathrm{Na}$ disciplina das buscas e das apreensões do Código de Processo Penal, nota-se a referência à busca domiciliar (art. 240 e 245) e a casa (art. 243, 245 e 248). O art. 246 se refere a "compartimento habitado ou em aposento ocupado de habitação coletiva ou em compartimento não aberto ao público, onde alguém exercer profissão ou atividade".

${ }^{94}$ Integram a disciplina da "Busca domiciliar" as seguintes disposições: "o têrmo 'casa' compreende: a) qualquer compartimento habitado; b) aposento ocupado de habitação coletiva; c) compartimento não aberto ao público, onde alguém exerce profissão ou atividade." (art. 173); "não se compreende no têrmo 'casa': a) hotel, hospedaria ou qualquer outra habitação coletiva, enquanto abertas, salvo a restrição da alínea $b$ do artigo anterior; b) taverna, boate, casa de jôgo e outras do mesmo gênero; c) a habitação usada como local para a prática de infrações penais." (art. 174).
} 
Embora o termo "casa" seja previsto na Lei Maior, não significa que apenas esteja assegurada a inviolabilidade do local destinado à habitação do indivíduo. A inviolabilidade não se refere, exclusivamente, à "casa de residência". 95

Sob a égide da ordem constitucional anterior, PONTES DE MiRANDA já sustentava um alargamento da noção de domicílio: "no direito constitucional, domicílio é onde se habita e onde se ocupa espaço, próprio, para uso pessoal, ou para negócios, oficina, escritório, e abrange o pátio, o quintal, as estribarias, a garagem, os quartos, de empregados etc.: o 'todo da habitação ou do prédio ocupado para uso exclusivo dos ocupantes'. O simples quarto de hotel ou de pensão é domicílio. O apartamento onde o advogado tem o seu escritório é domicílio. A parte em que está a família de um gerente de casa de diversões, com exclusão das outras pessoas, é domicílio."96

Em relação à atual Constituição, MANOEL GonÇALVES FERREIRA FILHO considera que "o termo domicílio tem amplitude maior do que no direito privado e até na linguagem coloquial. O domicílio, constitucionalmente falando, não é a residência apenas nem reclama estabelecimento com intenção definitiva. É todo local, delimitado e separado, que alguém ocupa com direito exclusivo e próprio, a qualquer título. O ponto essencial da caracterização está na exclusividade em relação ao público em geral." ${ }^{97}$ Mais ainda: "é inviolável como domicílio tanto a moradia quanto o estabelecimento de trabalho, desde que este não seja aberto a qualquer um do povo, como um bar ou restaurante". 98

\footnotetext{
${ }^{95}$ Neste sentido, posiciona-se PONTES DE MIRANDA (Comentários... op. cit., p. 187), ao examinar julgado em que se entendeu não ser asilo inviolável a oficina de impressão de um jornal. Segundo o autor, o entendimento esposado no julgamento é equivocado, considerado o caráter de uma oficina: "quem monta oficina de impressão de jornal não a franqueia ao público; exclui a entrada de outras pessoas, sem o consentimento do proprietário da oficina, ou dêle e do proprietário do próprio jornal. O princípio da inviolabilidade do domicílio não se refere só à casa de residência. A lei pode permitir a penetração na oficina de que se trata, porém só nas espécies em que seriam penetráveis as casas puramente residenciais, ou se a lei mesma prevê o caso das oficinas de jornal, em geral." Também no direito estrangeiro, afirma-se que o conceito de domić́lio é mais amplo do que o de habitação (APRILE, Ercole; SPIEZIA, Filippo. Le intercettazioni... op. cit., p. 68).

${ }^{96}$ Cf. Comentários... op. cit., p. 185-187.

${ }^{97}$ Cf. Comentários à Constituição... op. cit., p. 37.

${ }^{98}$ Cf. FERREIRA FILHO, Manoel Gonçalves. Comentários à Constituição... op. cit., p. 37. Outrossim, PONTES DE MIRANDA acentua: "os teatros, os cafés, restaurantes, bares, cabarés, mercados, lojas, enquanto permanecem abertos, isto é, não destinados à inviolabilidade, não podem invocá-lo. Desde que se cerrem as portas, e nêles haja domicílio, estabelece-se a inviolabilidade por destinação e protege-os o princípio da
} 
A salientar a extensão do conceito de domicílio, também se dedicou PINTO FERREIRA: “o conceito de casa é amplo no direito constitucional pátrio, pois abrange: a) qualquer compartimento habitado; b) aposento ocupado de habitação coletiva, em pensões, hotéis, casas de pousada; c) dependências de casas, sendo cercadas, gradeadas, muradas".99 Também estende o conceito para escritório de advocacia e para "casas flutuantes, que constituem espaços fechados e de habitação". ${ }^{100}$

Adepta de uma ampla abrangência do termo domicílio, CLEUNICE VALENTIM BASTOS PIтомво propõe que a expressão "casa", prevista na Constituição, "deve abranger: (a) a habitação definitiva, ou morada transitória; (b) casa própria, alugada, ou cedida; (c) dependências da casa, sendo cercadas, gradeadas ou muradas; (d) qualquer compartimento habitado; (e) aposento ocupado de habitação coletiva, em pensões, hotéis e em casas de pousada; (f) estabelecimentos comerciais e industriais, fechados ao público; (g) local onde se exerce a atividade profissional, não aberto ao público; (h) barco, trailer, cabine de trem ou navio e barraca de acampamento; (i) áreas comum de condomínio, vertical e horizontal."

Reputamos que deve ser reconhecida a amplitude do termo "casa". Com o resguardo da casa, evidencia-se o propósito do Poder Constituinte em proteger o "domicílio", que abrange não apenas a "casa de residência", como também outros espaços em que o indivíduo exerce as suas liberdades.

É neste sentido que a doutrina citada reconhece como domicílio tanto os mais diversos locais destinados à habitação, permanente ou provisória - neles incluídas as suas dependências,

inviolabilidade do domicílio". Reconhece o autor a existência de "zona cinza entre o domicílio e o não-domicílio, como a pousada de caça, a casa de rendez-vous, os recantos de casa de diversões" (Comentários... op. cit., p. 185-187). No mesmo sentido, em doutrina estrangeira, cf.: APRILE, Ercole; SPIEZIA, Filippo. Le intercettazioni... op. cit., p. 68.

${ }^{99}$ Cf. FERREIRA, Pinto. Comentários à Constituição... op. cit., p. 82.

${ }^{100}$ Cf. Ibidem, p. 82.

${ }^{101}$ Cf. Da busca... op. cit., p. 74. 
de uso exclusivo ou compartilhado -, quanto os espaços em que se desenvolvem as atividades profissionais. $^{102}$

Entendemos que, para além da definição abstrata dos locais que configuram domicílio, há elementos que possibilitam uma avaliação em concreto de espaços que não se amoldem às apontadas categorias. ${ }^{103} \mathrm{~A}$ avaliação da configuração concreta de domicílio privado complementa a definição abstrata. Semelhante raciocínio, útil para a análise de locais que não se amoldem às categorias abstratas, decorre da constatação de que a proteção do domicílio se fundamenta na pessoa, e propicia o exercício das várias liberdades de que é titular.

Um primeiro elemento é o tempo de permanência da pessoa em determinado espaço, ${ }^{104}$ que evidencia o constante exercício de suas liberdades.

Outro elemento é o ius excludenti alios, que se traduz na possibilidade de exclusão de terceiros do espaço em que se esteja. Este elemento não propicia somente o exercício das faculdades inerentes à liberdade de propriedade. Uma pessoa, em seu domicílio, pode excluir

\footnotetext{
${ }^{102}$ Quanto à caracterização de domicílio em espaços destinados ao desenvolvimento de atividades profissionais, interessante destacar de voto proferido pelo Ministro Celso de Mello, do Supremo Tribunal Federal, sobre monitoramento ambiental em escritório de advocacia as seguintes considerações: "entendo assistir razão, por isso mesmo, ao Advogado que ora figura como denunciado, no ponto em que sustenta, corretamente, a ilicitude da referida diligência policial, pois a atividade probatória do Poder Público, no caso, decorreu de procedimento de agentes estatais que infringiram, não obstante investidos de mandado judicial, a protecão

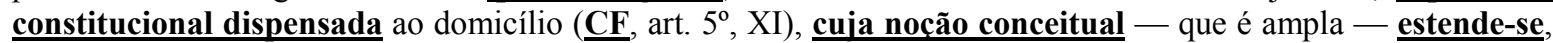
dentre outros espaços privados, a "compartimento não aberto ao público onde alguém exerce profissão ou atividade" (como um escritório de Advocacia, p. ex.)". Mais ainda: "a Polícia Federal não podia, ainda que munida de autorização judicial dada por esta Suprema Corte, ingressar, durante a noite, em espaço privado protegido pela cláusula constitucional da inviolabilidade domiciliar (um escritório de Advocacia), pois a Constituição, tratando-se de determinação judicial, somente permite o seu cumprimento "durante o dia", como resulta claro, inequívoco, do que se acha previsto na parte final do inciso XI do art. $5^{\circ}$ de nossa Lei Fundamental." (BRASIL. Supremo Tribunal Federal. Informativo n. 584 (Voto vencido do Min. Celso de Mello no Inq 2424/RJ). Disponível em: http://www.stf.jus.br//arquivo/informativo/documento/informativo584.htm. Acesso em: 20/12/2010).

${ }^{103}$ A respeito da avaliação, em concreto, da abrangência de domicílio, cf.: Cf. MARTINO, Corrada di. Le intercettazioni ambientali... op. cit., p. 1.160 e 1.168; MARTINO, Corrada di; PROCACCIANTI, Teresa. Le intercettazioni... op. cit., p. 61-62.

${ }^{104}$ Afirma-se, no que se refere ao tempo de permanência de um sujeito em determinado lugar, que deve apresentar um mínimo grau de estabilidade (MARTINO, Corrada di. Le intercettazioni ambientali... op. cit., p. 1.168; MARTINO, Corrada di; PROCACCIANTI, Teresa. Le intercettazioni... op. cit., p. 61-62.).
} 
terceiros do exercício de todas as liberdades de que é titular, ${ }^{105}$ entre as quais destacamos: a liberdade física, a liberdade de manifestação do pensamento, a intimidade e a vida privada. ${ }^{106}$

Alguns exemplos, extraídos da doutrina estrangeira, esclarecem o reconhecimento, com fulcro em tais elementos, de locais que constituíram domicílio em avaliação concreta: espaços de meios de transporte (automóvel ${ }^{107}$ e caravana ${ }^{108}$ ); a casa de lazer ${ }^{109}$; local destinado ao exercício de atividade profissional ${ }^{110}$; estabelecimento aberto ao público, em que o respectivo titular pode obstar o acesso ou a permanência daqueles com quem não deseja manter alguma relação. ${ }^{111}$

Assim, podemos afirmar que são domicílio: os mais diversos locais destinados à habitação, permanente ou provisória - neles incluídas as suas dependências, de uso exclusivo ou compartilhado -; o espaço em que se desenvolva atividade profissional, não aberto ao público; outros locais em que o tempo de permanência de uma pessoa que nele esteja e a possibilidade de ela excluir terceiros, para do exercício das liberdades de que é titular, evidencie tratar-se de domicílio.

\footnotetext{
${ }^{105}$ Considera-se domicílio o local onde a pessoa física ou jurídica tenha legitimamente a disponibilidade, para o desenvolvimento de atividades conexas à vida privada ou de relações e da qual possa excluir terceiros (MARINELLI, Claudio. Intercettazioni processuali... op. cit, p. 75). No que se refere ao ius excludenti alios, verifiquem-se, também, as observações registradas neste item.

${ }^{106}$ A função que o local cumpre é de domicílio privado se concretamente serve para proteger a vida privada (repouso, alimentação, administração, ocupações funcionais ou recreação) (MARTINO, Corrada di. Le intercettazioni ambientali... op. cit., p. 1.160 e 1.168; MARTINO, Corrada di; PROCACCIANTI, Teresa. Le intercettazioni ... op. cit., p. 61-62). No mesmo sentido, quanto ao reconhecimento de locais que concretamente cumpram a função de proteção da vida privada (repouso, alimentação, administração, ocupações profissionais ou de lazer): cf. APRILE, Ercole; SPIEZIA, Filippo. Le intercettazioni... op. cit., p. 64-66; ALMA, Marco Maria. Intercettazioni telefoniche e ambientali: questioni giurisprudenciali. Brescia: Consiglio Superiore della Magistratura, 2007, p. 12.

${ }^{107}$ No que tange ao espaço de automóvel: de um lado, entende-se não ser domicílio porque não cumpre a função de habitação, mas de transporte; por outro, afastando-se do requisito de habitação, é afirmado domicílio privado, pela possibilidade de exercício do ius excludenti alios. Tratando-se de automóvel de recreação, o direito a vida privada é invocado como fundamento para tê-lo como domicílio privado (APRILE, Ercole; SPIEZIA, Filippo. Le intercettazioni... op. cit., p. 65-66).

${ }^{108}$ Caravana destinada a habitação permanente do nômade, ou precariamente do turista, é local de domicílio privado (MARTINO, Corrada di. Le intercettazioni ambientali ... op. cit., p. 1.159).

109 Cf. MARTINO, Corrada di. Le intercettazioni ambientali... op. cit., p. 1.168; MARTINO, Corrada di; PROCACCIANTI, Teresa. Le intercettazioni... op. cit., p. 62.

${ }^{110}$ Cf. APRILE, Ercole; SPIEZIA, Filippo. Le intercettazioni... op. cit., p. 68-69; MARTINO, Corrada di. Le intercettazioni ambientali ... op. cit., p. 1.161.

${ }^{111}$ Cf. MARTINO, Corrada di. Le intercettazioni ambientali ... op. cit., p. 1.160 e 1.168; MARTINO, Corrada di; PROCACCIANTI, Teresa. Le intercettazioni... op. cit., p. 62.
} 
Estando os interlocutores de comunicações presenciais em um dos locais acima referidos, a inviolabilidade do domicílio, preconizada no art. $5^{\circ}$, caput e inciso XI da Constituição também fundamenta a proteção das comunicações presenciais por eles concretizadas, porque assegura tanto o exercício da liberdade de comunicação, quanto a inviolabilidade do sigilo das comunicações entre pessoas presentes.

\subsection{O direito a não autoincriminação}

Outra questão atinente às comunicações entre pessoas presentes diz respeito a sua íntima relação com o direito a não autoincriminação. É mais um fundamento que pode ser invocado para a afirmação de sua proteção no ordenamento jurídico nacional.

O direito a não autoincriminação é extraído do princípio “"nemo tenetur prodere seipsum, quia nemo tenetur detegere turpitudinem suam' (em vernáculo: ninguém pode ser compelido a depor contra si próprio, porque ninguém é obrigado a auto-incriminar-se), já conhecido na Antiguidade, no ius commune e no processo penal canônico."112

Igualmente, reconhecendo que o direito a não autoincriminação deriva deste princípio, em sua fórmula sintetizada - nemo tenetur se detegere - MARIA ELIZABETH QUEIJO afirma: "como direito fundamental, objetiva proteger o indivíduo contra excessos cometidos pelo Estado, na persecução penal, incluindo-se nele o resguardo contra violências físicas ou morais, empregadas para compelir o indivíduo a cooperar na investigação e apuração de delitos, bem como contra métodos proibidos de interrogatório, sugestões e dissimulações". ${ }^{113}$ Mais ainda: "como direito fundamental, o nemo tenetur se detegere insere-se entre os direito de primeira geração, ou seja, entre os direitos de liberdade. O titular de tais direitos é o indivíduo diante do Estado." 114

\footnotetext{
${ }^{112}$ Cf. TUCCI, Rogério Lauria. Direitos e garantias... op.cit., p. 363.

${ }^{113}$ Cf. $O$ direito de não produzir prova contra si mesmo (o princípio nemo tenetur se detegere $e$ suas decorrências no processo penal). São Paulo: Saraiva, 2003, p. 55.

${ }^{114}$ Cf. Ibidem, p. 55.
} 
Sob outra perspectiva, a autora considera o direito à não autoincriminação como garantia: "trata-se de garantia da liberdade, em especial da liberdade de autodeterminação do acusado". 115

No ordenamento jurídico brasileiro, o direito à não autoincriminação é previsto no art. $8^{\circ}$, item $2^{\circ}$, alínea "g" da Convenção Americana sobre Direitos Humanos, que assegura à pessoa o "direito de não ser obrigado a depor contra si mesma, nem a declarar-se culpada". Esta Convenção, também conhecida por Pacto de São José da Costa Rica foi incorporada no direito brasileiro pelo Decreto $n^{\circ} 678$, de 1992. O direito ao silêncio, consagrado no art. $5^{\circ}$, caput e inciso LXII da Constituição é considerado decorrência do direito a não autoincriminação. ${ }^{116}$

Reputamos que, por sua natureza materialmente constitucional, o direito a não autoincriminação está consagrado na Constituição, considerado o disposto em seu art. $5^{\circ}, \S$ $2^{\text {o }}{ }^{117}$

A relação entre a tutela das comunicações entre pessoas presentes e o direito a não autoincriminação é ressaltada pela doutrina.

\footnotetext{
${ }^{115}$ Cf. QUEIJO, Maria Elizabeth. O direito de não produzir... op. cit., p. 56.

${ }^{116}$ Cf. FERNANDES, Antonio Scarance. Processo penal... op. cit., p. 263. No mesmo sentido, cf.: FEITOZA, Denilson. Direito processual... op. cit., p. 145. MARIA ELIZABETH QUEIJO ressalta que o direito a não autoincriminação "não se resume ao direito ao silêncio" ( $O$ direito de não produzir... op. cit., p. 55). A ligação entre direito ao silêncio e o direito a não autoincriminação também pode ser extraída das considerações de MARIA THEREZA ROCHA DE ASSIS MOURA e de MAURÍCIO ZANOIDE DE MORAES (Direito ao silêncio no interrogatório. Revista Brasileira de Ciências Criminais, São Paulo, v. 2, n. 6, abr-jun. 1994, p. 133147).

${ }^{117}$ Evidenciando o status constitucional, estão as considerações de ANTONIO SCARANCE FERNANDES sobre o tema em obra sobre o Processo Penal Constitucional, na qual discorre sobre "o direito a não se autoincriminar" (Processo penal... op. cit., p. 262-263). A este respeito, DENILSON FEITOZA salienta: "o direito ao silêncio, a rigor, é um corolário do princípio da não auto-incriminação. Mas, no Brasil, houve uma inversão, tendo em vista a previsão constitucional do direito ao silêncio. Então, busca-se afirmar que o princípio da não-auto-incriminação tem natureza constitucional e se encontra implicitamente na previsão do direito ao silêncio." (Direito processual... op. cit., p. 145.). Também MARIA ELIZABETH QUEIJO salienta que se trata de norma de hierarquia constitucional, pois, além do disposto no art. $5^{\circ}, \S 2^{\circ}$ da Constituição, considera o direito a não autoincriminação é intimamente ligado a tutela da dignidade da pessoa humana, expressamente prevista no art. $1^{\circ}$, inciso III da Lei Maior ( $O$ direito de não produzir... op. cit., p. 80). JULIANA GARCIA BELLOQUE também afirma o status constitucional da garantia ( $O$ recrudescimento da repressão ao crime e as garantias da prova oral. 2007. Tese (Doutorado) - Faculdade de Direito, Universidade de São Paulo (USP), São Paulo, 2007, p. 45-46). Quanto ao status constitucional de normas sobre direitos humanos, cf., supra, item n. 1.2, nota n. 31.
} 
A propósito, EnRIQUE BACIGALUPO, lembrando a importância das possibilidades técnicas de gravação de conversas diretas entre pessoas situadas em um domicílio e a sua ingerência de "singular transcendência" no âmbito da vida privada, assevera: "se trata de una medida que solo puede ser eficaz si se dispone sin conocimiento del sospechoso. De allí que este sufra también una restricción de su derecho a no declararse culpable". ${ }^{118}$

Outrossim, MARCELA De LANGHE, ao tratar de interceptação de comunicação telefônica, salienta a ligação entre a liberdade de comunicação e o direito a não autoincriminação: “en el contexto de la garantía que prohíbe la autoincriminación, la injerencia que conlleva la intervención telefónica frente a la inmunidad del secreto cobra inmensa trascendencia, pues no puede obviarse que la vigilancia estatal permite captar manifestaciones vertidas por el imputado, sin su conocimiento, que constituyen aporte de prueba em su proprio perjuicio." 119

Parece-nos que a ligação entre o direito-garantia a não autoincriminação e a tutela das comunicações presenciais pode ser entendida tanto sob a forma de liberdade de comunicação, notavelmente quanto ao poder de não se comunicar, ${ }^{120}$ quanto sob a forma de inviolabilidade

\footnotetext{
${ }^{118}$ Em tradução livre: "trata-se de uma medida que somente pode ser eficaz se for disposta sem o conhecimento do suspeito. Disto se extrai que ele sofra também uma restrição de seu direito a não se declarar culpado". (Derecho Penal y El Estado de Derecho. 1. ed. Santiago: Editorial Juridica de Chile, 2005, p. 235-236). No mesmo sentido, cf.: AVOLIO, Luiz Francisco Torquato. Provas ilícitas... op. cit., p. 101; CONDE, Francisco Muñoz. Valoración de las grabaciones audiovisuales en el proceso penal. $2^{\mathrm{a}}$ ed. Buenos Aires: Hammurabi, 2007, p. 61; MALAN, Diogo Rudge. Gravações Ambientais Domiciliares no Processo Penal. In: LIMA, José Corrêa de; CASARA, Rubens R. R. (Coords.). Temas para uma perspectiva crítica do Direito: homenagem ao Professor Geraldo Prado. Rio de Janeiro: Lumen Juris, 2010, p. 349. Por seu turno, MANUEL DA COSTA ANDRADE, ao examinar as escutas telefônicas, reconhece que a ligação existente entre a proteção das comunicações e "o direito que o arguido tem de não ter de contribuir positivamente para a sua condenação" (Das escutas telefônicas. In: COSTA, José de Faria; SILVA, Marco Antonio Marques da. Direito penal especial, processo penal e direitos fundamentais: visão luso-brasileira. São Paulo: Quartier Latin, 2006, p. 206).Confiramse, ainda, as ponderações de CLAUS ROXIN, analisando gravação de comunicação telefônica, assevera que o princípio nemo tenetur proíbe não só a coação para declarar, como também protege o imputado de uma autoinciminação induzida pelo Estado por meio de erro, de uma manipulação de sua decisão de declarar por meio do engano estatal (La prohibición de autoincriminación... op. cit., p. 61-62).

${ }^{119}$ Em tradução livre do autor: "no contexto da garantia que proíbe a autoincriminação, a ingerência que se opera com a intervenção telefônica quanto à imunidade do segredo significa imensa transcendência, pois pode se evidenciar que a vigilância estatal permite captar manifestações concretizadas pelo investigado, sem seu conhecimento, que constituem prova em seu prejuízo" (Escuchas telefónicas. 1. ed. Buenos Aires: Hammurabi, 2009, p. 35)

${ }^{120}$ Cf. supra, item n. 2.2.1.
} 
do sigilo das comunicações, em hipóteses em que a comunicação ocorra. ${ }^{121}$ Nas duas perspectivas, a proteção das comunicações entre pessoas presentes pode ser extraída do art. $8^{\circ}$, item $2^{\circ}$, alínea "g" da Convenção Americana sobre Direitos Humanos, e do art. $5^{\circ}, \S 2^{\circ}$ da Constituição Federal.

\subsection{A restrição às comunicações entre pessoas presentes}

Vistos a abrangência das comunicações entre pessoas presentes e os fundamentos constitucionais de sua tutela - todos correlacionados e convergentes para a proteção da dignidade da pessoa humana -, cumpre-nos apontar os limites para que, excepcionalmente, sejam restringidas tais comunicações, para conhecimento de eventuais fontes de prova.

Considere-se, por primeiro, que os valores reconhecidos sob a forma de direitos fundamentais da pessoa humana coexistem em harmonia. Em atenção à coordenação entre os valores, ADA PELLEgRINI GRINOver adverte que “o ordenamento jurídico não pode ser concebido senão como um sistema de limitações recíprocas dos diversos direitos subjetivos nele existentes, a fim de que possam coexistir em plena harmonia". ${ }^{12}$

É preciso manter o equilíbrio entre os direitos e as garantias constitucionais asseguradas à pessoa e as contrapostas exigências de tutela da coletividade. ${ }^{123}$ Eventual restrição ${ }^{124}$ de um deles somente é possível se identificado um valor concorrente, também constitucionalmente tutelado. ${ }^{125}$

\footnotetext{
${ }^{121}$ Em sentido contrário, tratando da interceptação de comunicação telefônica, cf.: GRINOVER, Ada Pellegrini. Liberdades públicas... op. cit.,p. 199-200.

${ }^{122}$ Cf. GRINOVER, Ada Pellegrini. Liberdades públicas... op. cit., p. 88.

${ }^{123}$ Cf. BALDUCCI, Paola. Le garanzie... op. cit., p. 8. CLAUDIA CARMONA frisa que a questão não se cinge a verificar até que ponto se permite restringir os direitos e garantias processuais: deve-se, pelo contrário, protestar pela salvaguarda das garantias do acusado, com os limites impostos pela vida em sociedade (Le intercettazioni ambientali... op. cit., p. 357-358). Também reputamos ser necessária a busca da consecução de equilíbrio: de um lado, o Estado, titular do ius puniendi, deve dispor de meios aptos ao combate da criminalidade, cada vez mais violenta e organizada; por outro, ancora-se a dignidade da pessoa humana e toda constelação dos direitos fundamentais do cidadão que giram em torno dela.

${ }^{124}$ Neste item, com o emprego do termo restrição, queremos expressar a intervenção estatal legítima em direitos e garantias fundamentais. Considerada a ausência de explícita disposição que verse sobre a proteção das
} 
Em tema de interceptação de comunicações, é, com frequência, ressaltada a tensão entre interesses opostos: de um lado, as liberdades individuais; de outro, a tutela da segurança pública e a repressão a condutas criminosas. ${ }^{126}$ Ambos interessam aos membros da sociedade. Mas, por vezes, a segurança pública e a repressão a delitos justificam a restrição dos primeiros, para que se busquem fontes de prova. ${ }^{127}$

Da proteção absoluta dos direitos fundamentais decorreriam barreiras intransponíveis à busca da verdade, com a consequente desfiguração da função jurisdicional estatal. ${ }^{128}$ Veja-se que a própria vida, bem relacionado ao exercício de direitos inerentes à personalidade humana, é relativizada em nosso ordenamento jurídico (art. 50, inciso XLVII, alínea "a" da Constituição). ${ }^{129}$

comunicações entre pessoas presentes, com a locução "restrição às comunicações entre pessoas presentes", que integra o título do presente item, expressamos a restrição de seus fundamentos constitucionais, com os quais tais comunicações estão umbilicalmente ligadas, ora sob a perspectiva de liberdade, ora sob o enfoque de inviolabilidade do sigilo de seu conteúdo (v. supra, itens n. 2.2 a 2.5). No mesmo sentido, quanto ao emprego do termo restrição, MAURÍCIO ZANOIDE DE MORAES extrai do gênero "intervenção estatal", as seguintes espécies: "a intervenção legítima ou permitida" (restrição); "a intervenção ilegítima ou não permitida" (violação) (Presunção de Inocência... op. cit., p. 284). Também ROBERT ALEXY utiliza o termo restrição a direitos fundamentais (ALEXY, Robert. Teoria dos Direitos Fundamentais. Tradução de Virgílio Afonso da Silva. São Paulo: Malheiros, 2008, p. 277).

${ }^{125}$ Em sentido semelhante, no direito nacional, cf.: MORAES, Maurício Zanoide de. Presunção de Inocência... op. cit., p. 288, 317. E, no direito estrangeiro: cf. BALDUCCI, Paola. Le garanzie... op. cit., p. 39.

${ }^{126}$ No mesmo sentido, cf.: APRILE, Ercole; SPIEZIA, Filippo. Le intercettazioni telefoniche... op. cit., p. XVII; GREVI, Vittorio. Un caso di registrazione di colloqui fra persone presenti. L'Indice Penale, Padova, Cedam, Anno X, n. 3, set-dic. 1976, p. 493; MARTINO, Corrada di. Le intercettazioni ambientali... op. cit., p. 1.149; MARINELLI, Claudio. Intercettazioni processuali... op. cit, p. 71. Com relação ao choque de interesses quanto aos meios de investigação de prova em geral, em comentários sobre o direito português, JOÃO CONDE CORREIA observa: "a máxima protecção dos direitos fundamentais colocaria barreiras intransponíveis à descoberta da verdade e, em consequência, à realização da justiça e a busca da verdade a todo custo eliminaria os mais elementares direitos, conduzindo a uma mistificação da justiça. Este conflito revela-se, em toda a sua amplitude, de forma exponencial, no domínio dos meios de prova e de obtenção da prova" (Qual o significado de abusiva intromissão na vida privada, no domicílio, na correspondência e nas telecomunicações (art. 32, n. 8, 2. parte, da C.R.P.)? Revista do Ministério Público, Lisboa, ano 20, n. 79, jul-set. 1999, p. 46).

127 A propósito, CLAUS ROXIN se refere aos meios de pesquisa, como a espionagem acústica, como medidas coercitivas, nas quais se tem ingerências (intromissões) em direito fundamental, que são cada vez mais enérgicas (Derecho procesal penal. 1. ed. Tradução de Gabriela Córdoba y Daniel Pastor. Buenos Aires: Editores del Puerto, 2003, p. 250-251).

${ }^{128}$ ALFREDO BARGI nos traz a lembrança de que o complexo sistema das liberdades fundamentais não é composto por liberdades absolutas (Intercettazioni di comunicazioni... op. cit., p. 789 e 795).

${ }^{129}$ Não se diga, todavia, que todos os direitos individuais possam ser restringidos em busca por fontes de prova. A referência à relativização da vida serve apenas para ilustrar que as normas constitucionais devem ser interpretadas sistematicamente. Certos "meios" de prova, como a coação física (maus tratos, sevícias, intervenção médica, uso de substâncias, entre outros) ou psíquica (engano, hipnose, drogas, promessa de vantagem, expressões vexatórias) são inadmissíveis, por restringirem a integridade física e psíquica. Nestes casos, ter-se-ia 
A existência da restrição aos fundamentos constitucionais da tutela de comunicações entre pessoas presentes em sua interceptação é afirmada em doutrina. ${ }^{130}$ Varia a forma de invocação dos fundamentos: por vezes, a consideração versa sobre todos os fundamentos; noutras oportunidades, apenas sobre um ou alguns deles.

Reconhecendo a restrição da liberdade de manifestação do pensamento, na forma específica da liberdade de comunicação, CORRADA DI MARTINO lembra a posição extremada de se considerar que as interceptações de comunicações implicam um problema não de limitação da liberdade de se comunicar, mas de compressão total, de expropriação de tal liberdade, porque envolvem a inteira via comunicativa do indivíduo, especialmente se operadas em domicílio. ${ }^{131}$

Uma interceptação de comunicação também restringe a intimidade e a vida privada. ${ }^{132}$ O direito à intimidade não constitui "um direito ilimitado". ${ }^{133}$

Ainda no âmbito da tutela da intimidade e da vida privada, ANTONIO SCARANCE FERNANDES identifica um "conflito entre dois relevantes interesses: o da proteção ao sigilo e o da necessidade de se produzir prova no processo criminal". ${ }^{134}$ E ressalta que o sigilo "não é,

instituição antecipada de pena cruel, esdrúxulo expediente atentatório aos mandamentos constitucionais. No mesmo sentido, cf.: GASPAR, António Henriques. Os novos desafios... op. cit., p. 267.

${ }^{130}$ No direito brasileiro, há entendimento que contraria a possibilidade de restrição a comunicação entre pessoas presentes, considerada a previsão no art. $5^{\circ}$, caput e inciso XII da possibilidade de restrição apenas de comunicação telefônica (SILVA, Eduardo Araujo da. Crime organizado... op. cit., p. 104).

${ }^{131}$ Cf. Le intercettazioni ambientali ... op. cit., p. 1.168.

${ }^{132}$ No sentido da restrição da intimidade e da vida privada, cf.: LENNON, Maria Inês Horvitz, MASLE, Julian Lopez. Derecho procesal penal chileno. Tomo II. 1. ed. Santiago: Editorial Juridica de Chile, 2004., p. 95-97, 123-125. MARIA LUCIA KARAM enfatiza o risco de uma restrição desmedida: "o indivíduo permanentemente vigiado acaba por reprimir suas opiniões, por mudar seus hábitos, por ter medo de ser diferente, de questionar, acaba por se conformar aos padrões dominantes, acaba por aderir a submissão." (Meios invasivos de busca de provas: incompatibilidade com a democracia. Boletim IBCCRIM, São Paulo, ano 17, n. 200, jul. 2009, p. 17-18).

${ }^{133}$ Cf. GRINOVER, Ada Pellegrini. Liberdades públicas... op. cit., p. 88.

134 Ademais, o autor complementa: "não é tarefa fácil realizar a justa ponderação entre o interesse público na revelação do sigilo para a consecução de prova e o interesse privado de que quem tem desvendado o seu segredo, normalmente o investigado ou acusado. Encontram-se normalmente vozes extremadas. De um lado, a dos que sustentam ardorosamente a necessidade de ampla permissividade de acesso aos sigilos pessoais para coibir as práticas criminosas, e, de outro, a daqueles que, em defesa da privacidade, apregoam a necessidade de serem os indivíduos intensamente protegidos contra as invasões em suas esferas íntima e particulares. Necessário buscar o ponto de equilíbrio, de modo que se garanta a eficiência do sistema persecutório, mas, ao mesmo tempo, se preservem os direitos do investigado ou acusado" (Cf. O sigilo... op. cit., p. 154). 
normalmente, considerado direito absoluto. Pode ser restringido quando prevalecem outros direitos, de maior ou de igual valor social."135

Sendo a interceptação de comunicação entre pessoas presentes operada em um domicílio, também é restringida a inviolabilidade do domicílio. ${ }^{136}$ No Brasil, a possibilidade de restrição à inviolabilidade do domicílio é expressamente prevista na Constituição Federal: “a casa é asilo inviolável do indivíduo, ninguém nela podendo penetrar sem consentimento do morador, salvo em caso de flagrante delito ou desastre, ou para prestar socorro, ou, durante o dia, por determinação judicial." 137

Igualmente, há restrição ao direito a não autoincriminação em interceptação de comunicação presencial. ${ }^{138}$ Admitindo que não se trata de direito absoluto, MARIA ELIZABETH QUEIJO salienta a existência de limites implícitos, que decorrem da necessidade de coexistência com outros valores. ${ }^{139}$

\footnotetext{
${ }^{135}$ Cf. FERNANDES, Antonio Scarance. O sigilo... op. cit., p. 156.

${ }^{136}$ Já afirmava PONTES DE MIRANDA que "a própria liberdade física, com a qual nascera, e de que faz parte a inviolabilidade de domicílio, pode ser limitada nos casos da lei" (Comentários... op. cit., p. 182.). ENZO MARIA DELL'ANDRO frisa a necessidade de sopesar os interesses constitucionalmente garantidos, a inviolabilidade do domicílio e outros (Intercettazioni ambientali e Costituizione. In: IANNONE, Leonardo (Org.). Percorsi di Procedura Penale: dal garantismo inquisitório a un accusatorio non garantito. Milano: Giuffrè, 1996, p. 157). No mesmo sentido, KARL HEINZ GÖSSEL refere-se a ponderação de interesses (El derecho procesal penal en el estado de derecho. Dirigido por Edgarde Alberto Donna. 1. ed. Santa Fe: Runbinzal-Culzoni, 2007, p. 210).

${ }^{137}$ Interessante notar que há ordenamentos jurídicos nos quais a Constituição disciplina as hipóteses em que é possível a restrição à inviolabilidade do domicílio. É o caso, por exemplo, da Constituição italiana que prevê a restrição apenas para determinados meios de investigação de prova: admite-se a execução de inspeções, buscas e sequestros (art. 14 da Constituição Italiana). Desta previsão decorre a discussão sobre a viabilidade de restrição, tratando-se de meios não preconizados na norma constitucional, como é o caso das interceptações de comunicações. A propósito, cf.: MARINELLI, Claudio. Intercettazioni processuali... op. cit, p. 75-77; MARTINO, Corrada di. Le intercettazioni ambientali... op. cit., p. 1.170. Esta questão culminou na formação de corrente doutrinária em que se sustenta a necessidade de fixação, em Constituição, das hipóteses de restrição a garantias constitucionais, especialmente quanto à inviolabilidade do domić́lio (DELL'ANDRO, Enzo Maria. Intercettazioni ambientali... op. cit., p. 161).

${ }^{138}$ Neste sentido, MANUEL DA COSTA ANDRADE, ressaltando o caráter invasivo da interceptação de comunicação, aponta para a restrição ao "direito que o arguido tem de não ter de contribuir positivamente para a sua condenação" (Das escutas telefônicas... op. cit., p. 206).

${ }_{139}$ Além disso, a autora observa que eventuais restrições devem ser reguladas por lei, observando-se o princípio da proporcionalidade - traduzido na adequação, na necessidade e na razoabilidade da medida adotada- e a necessidade de controle judicial. É interessante notar, ainda, que a autora reconhece, sob estas ressalvas, a possibilidade de restrição do direito a não autoincriminação, em concretização de ação controlada, instituto previsto no art. $2^{\circ}$, caput, inciso II da Lei $\mathrm{n}^{\circ}$ 9.034, de 1995 (QUEIJO, Maria Elizabeth. $O$ direito de não produzir... op. cit., p. 56, 355-357, 366-369). Consideramos que a ação controlada, bem como a interceptação de comunicações de pessoas presentes, são espécies de meios de investigação de prova. No sentido da restrição do direito a não-autoincriminação, cf.: KARAM, Maria Lucia. Meios invasivos... op. cit., p. 17-18.
} 
Entretanto, a possibilidade de restrição aos direitos e garantias fundamentais que embasam a tutela das comunicações entre pessoas presentes não significa o reconhecimento de que ocorra de forma arbitrária e desmedida. Há limites intransponíveis à restrição das comunicações entre pessoas presentes, que pode ser operada pelo Estado para repressão a delito. ${ }^{140}$ Estes limites são exigências que não podem ser desprezadas, pois, do contrário, a eventual obtenção de fonte de prova será ilícita - inadmissível, por consequência. ${ }^{141}$

As exigências-limites para a restrição de comunicações entre presentes serem concretizadas são, em síntese, as seguintes: a reserva de lei, a reserva de jurisdição e a proporcionalidade. ${ }^{142}$

\footnotetext{
${ }^{140}$ Sobre tais limites, MAURÍCIO ZANOIDE DE MORAES observa que "da mesma forma como o âmbito de proteção não pode permanecer ilimitado e absoluto, sob pena do direito prima facie atingir um nível expansivo tão elevado que chegue à sua 'absolutização', também as restrições não podem ser ilimitadas sob pena de levarem à supressão da norma fundamental. Para isso, a doutrina constitucional identifica formas de limitação para as restrições" (Presunção de Inocência... op. cit., p. 310).

${ }^{141}$ Sobre a garantia da inadmissibilidade de provas obtidas por meios ilícitos (art. $5^{\circ}$, caput, inciso LVI da Constituição Federal), cf., supra, item n. 1.6.

${ }^{142}$ Mais adiante, discorreremos sobre as garantias da motivação e da duração razoável da restrição. Parece-nos que a necessidade de motivação pode ser entendida como decorrência da reserva de jurisdição, e a observância de prazo razoável, como aspecto da proporcionalidade. Essas exigências também são invocadas em direito estrangeiro. Em Espanha, SARA ARAGONESES MARTÍNEZ salienta, para as diligências de averiguação e comprovação restritivas de direitos fundamentais ("diligencias de averiguación y comprovación restrictivas de derechos fundamentales"), a existência de requisitos gerais: " $1.0^{\circ}$ Fin constitucionalmente legítimo"; " 2. " Necesidad de previsión legal concreta y detallada"; "3. Jurisdicionalidad"; " $4 .^{\circ}$ Motivación de la resolución judicial"; e "5. Proporcionalidad". Em tradução livre do autor: "1. ${ }^{\circ}$ Fim constitucionalmente legítimo"; " $2 .{ }^{\circ}$ Necessidade de previsão legal concreta e detalhada"; "3. Jurisdicionalidade"; "4. " Motivação da decisão judicial"; e "5. Proporcionalidade" (Capítulo primero: procesos ordinarios: sección primera: el proceso por delitos graves: § 12. El sumario. In: SANTOS, Andrés de La Oliva; MARTÍNEZ, Sara Aragoneses; SEGOVIA, Rafael Hinojosa; ESPARZA, Julio Muerza; GARCÍA, José Antonio Tomé. Derecho procesal penal. 8. ed. Ramón Areces, Madrid, 2007, p. 366-367). Também no que tange ao direito espanhol, RICARDO RODRÍGUEZ FERNÁNDEZ ressalta as exigencias de legalidade, de judicialidade e de proporcionalidade das restrições a direitos fundamentais (La intervención telefónica como restricción al derecho fundamental a la intimidad. Revista Penal, Barcelona, n. 5, 2000, p. 65-67).Ademais, CLAUDIO MARINELLI, em exame sobre o direito italiano, refere-se à tríplice previsão para a limitação do sigilo da comunicação: a reserva de lei, a atribuição exclusiva à autoridade judicial do poder de dispor sobre a limitação e a obrigação de motivar o respectivo provimento, às quais acrescenta a necessidade de um balanceamento entre os interesses contrapostos do sigilo das comunicações e da repressão penal, para evitar que o primeiro seja desproporcionalmente sacrificado (Intercettazioni processuali... op. cit, p. 69-71). No direito português, BENJAMIM SILVA RODRIGUES, repisando a necessidade de observância das mencionadas exigências, ao tratar de interceptação de comunicação telefônica, afirma: "o 'paradigma da ponderação constitucional e legalmente codificado' da intervenção nas comunicações electrónicas, nomeadamente, em matéria de comunicações telefónicas, tal como identificado, quer a nível penal, quer a nível processual penal e constitucional, está gizado sob três princípios essenciais: i) o princípio da legalidade ou reserva de lei; ii) o princípio da jurisdicionalidade; iii) o princípio da proporcinalidade" (Das escutas telefónicas: I: a monitorização dos fluxos informacionais e comunicacionais. 2. ed. Coimbra: Coimbra Ed., 2008, p. 204). Em direito francês, DIMITRI GIANNALOPOULOS e RAPHAÊLLE PARIZOT também
} 


\section{Expressão do princípio da legalidade (art. $5^{\circ}$, caput e incisos II e LIV da Constituição}

Federal), a reserva de lei é exigida para que a restrição a direito fundamental seja legítima. A lei processual penal que a discipline deve ser prévia, escrita e estrita. Destes atributos decorrem a anterioridade e especificidade da norma processual penal restritiva de direito fundamental. ${ }^{143}$ Também deve ser qualificada por precisão e por clareza. ${ }^{144}$

enfatizam a necessidade de observância do princípio da legalidade (La preuve technologique des interceptions et surveillances. In: GIUDICELLI-DELAGE, Geneviève (Dir.). Les transformations de l'administration de la preuve pénale. Paris: Société de Législation Comparé, 2006. p. 278).

${ }^{143}$ Tais atributos são afirmados por MAURÍCIO ZANOIDE DE MORAES, para quem se deve operar uma transposição das áreas jurídico-criminais, especialmente, reconhecendo-se, também às normas processuais penais restritivas, os atributos inerentes a toda lei penal material, pois elas deverão ser prévias, escritas e estritas. O autor extrai destes atributos a anterioridade e a especificidade (Presunção de Inocência... op. cit., p. 315-317). A propósito, cf., supra, nota n. 162 do item n. 1.4.1, em que citamos trecho desta obra, em que, além da referida ligação, o autor sustenta a necessidade de tipicidade das intervenções em direitos fundamentais. Em Espanha, VICENTE GIMENO SENDRA, VÍCTOR MORENO CATENA e VALENTÍN CORTÉS DOMÍNGUEZ também salientam a necessidade de legalidade de restrições a direitos fundamentais, nelas incluídos os atos probatórios limitativos de direitos fundamentais (Lecciones de Derecho Procesal Penal. 2. ed. Madrid: Colex, 2007, p. 367-368). Também no direito espanhol, ALEXANDRE H. CATALÀ BAS, em detida análise da jurisprudência da Corte Européia de Direitos Humanos e dos órgãos jurisdicionais espanhóis, salienta a necessidade de "calidad" (qualidade) da lei que restrinja direitos humanos, que deve ser acessível e previsível: "el requisito de accesibilidad requiere que la ley pueda conocerse. El ciudadano debe disponer de suficiente información sobre las normas jurídicas aplicables al caso. Para ello, la ley aplicable ha de estar publicada en los cauces normales de difusión del Derecho en el Estado concreto o, como mínimo, tenerla a disposición de los ciudadanos. Además, ha de ser previsible: sólo se puede considerar como ley, la norma que se expresa con la suficiente precisión para permitir al ciudadano ajustar su conducta, y que pueda prever razonablemente las consecuencias que pueda ocasionar una acción determinada. La previsibilidad supone: a) claridad en los términos; b) razonable certeza sobre los casos en que un órgano público puede llevar a cabo una injerencia en el ejercicio de alguno de los derechos objeto de protección". Em tradução livre do autor: "o requisito de acessibilidade exige que a lei possa ser conhecida. O cidadão deve dispor de suficiente informação sobre as normas jurídicas aplicáveis ao caso. Para tanto, a lei aplicável deve estar publicada nos meios normais de difusão do Direito no Estado concreto ou, no mínimo, estar à disposição dos cidadãos. Ademais, deve ser previsível: somente se pode considerar como lei a norma que se expressa com a suficiente precisão para permitir ao cidadão ajustar sua conduta, e que preveja razoavelmente as consequências que possa ocasionar uma ação determinada. A previsibilidade supõe: a) a clareza nos termos; b) razoável certeza sobre os casos em que um órgão público pode concretizar uma injerência no exercício de algum dos direitos fundamentais objeto de proteção." (La problemática adecuación de la legislación española sobre escuchas telefónicas a las exigencias del Convenio europeo de derechos humanos y sus consecuencias. Revista del Poder Judicial, Madrid, ano II, n. 66, 2002, p. 39). Ademais disso, enfatiza o autor que, em matéria de direitos fundamentais, rege a mais absoluta reserva de lei (La problemática adecuación... op. cit., p. 65). Em comentários sobre o direito português, também se afirma a indispensabilidade da reserva de lei para restrição a direitos e garantias fundamentais: "a ideia de reserva de lei, para a concretização dos direitos fundamentais e liberdades públicas, bem como para a sua restrição, não se basta com a existência de uma lei prévia, devendo a mesma ser suficiente para com isso permitir que o lesado, alvo da ingerência nas comunicações, goze de um mínimo de protecção legal no seu direito" (RODRIGUES, Benjamim Silva. Das escutas... op. cit., p. 204). No mesmo sentido, cf.: CORREIA, João Conde. Qual o significado... op. cit., p. 62.

${ }^{144}$ Cf. MORAES, Maurício Zanoide de. Presunção de Inocência... op. cit., p. 316-317. 
De forma específica, quanto à restrição aos direitos e garantias fundamentais que estribam a tutela das comunicações entre pessoas presentes, também deve ser reconhecida a necessidade de disciplina legal. ${ }^{145}$

Entre os institutos que restringem as comunicações entre pessoas presentes, destacamos a interceptação processual, que deve ser disciplinada em lei, ${ }^{146}$ escrita e estrita, e com os demais atributos antes referidos: anterioridade, especificidade, precisão e clareza. ${ }^{147}$

Sob a perspectiva da finalidade probatória da interceptação processual de comunicações presenciais, note-se que a exigência de legalidade pode ser invocada sob duas perspectivas: a da legalidade da prova, com a correlata inadmissibilidade de provas obtidas por meios ilícitos, ${ }^{148}$ e a da legalidade da restrição das comunicações entre presentes.

\footnotetext{
${ }^{145}$ VITTORIO GREVI afirma que os atos de "limitação" da liberdade de comunicações devem ser previstos em lei (Un caso di registrazione... op. cit., p. 493). MANUEL DA COSTA ANDRADE enfatiza, em comentários sobre restrição de telecomunicações, que "os juízes e a polícia podem se intrometer se for nos limites da lei." (Das escutas telefônicas.... op. cit., p. 208). Em sentido semelhante, cf.: ANDRADE, Manuel da Costa. Métodos ocultos... op. cit., p. 104, 111, 114.

${ }^{146}$ A restrição das comunicações entre presentes por meio de interceptação deve ocorrer em preceito que contenha uma "brecha" nas margens mais restritas possíveis (CAMON, Alberto. Le intercettazioni... op. cit., p. 183 apud MARTINO, Corrada di; PROCACCIANTI, Teresa. Le intercettazioni... op. cit., p. 60). No que se refere à exigência de reserva de lei para as interceptações, cf: SCHLÜCHTER, Ellen. Derecho Procesal Penal. Colaboración de Jörg Knupger y Mathias Terbach. Traduccion de Iñaki Esparza Leibar y Andrea Planchadell Gargallo. 2. Ed. Valencia: Tirant lo Blanc, 1999, p. 66; BRUNO, Pierfrancesco. Intercettazioni di comunicazioni... op. cit., p. 182; BALDUCCI, Paola. Le garanzie nelle intercettazioni... op. cit., p. 37; GASPAR, António Henriques. Os novos desafios... op. cit., p. 265.

${ }_{147}$ A Corte Europeia de Direitos Humanos, reconhecendo a necessidade de reserva de lei (in accordance with the law) para concretização de interceptações de comunicações, também afirma a necessidade de clareza das disposições legais: "the law must be sufficiently clear in its terms to give citizens an adequate indication as to the circumstances in which and the conditions on which public authorities are empowered to resort to this secret and potentially dangerous interference with the right to respect for private life and correspondence". Em tradução livre do autor: "a lei deve ser suficientemente clara em seus termos para que os cidadãos conheçam as circunstâncias e as condições em que as autoridades públicas podem utilizar esta [interceptação de comunicações] secreta e potencialmente perigosa interferência no direito ao respeito da vida privada e da comunicação" (Case of Malone v. The United Kingdom (Judgmentes [Merits], n. 8691/79). Disponível em: http://cmiskp.echr.coe.int/tkp197/view.asp?action=html\&documentId=695410\&portal=hbkm\&source=externalby docnumber\&table=F69A27FD8FB86142BF01C1166DEA398649. Acesso em: 26/09/2010.).

${ }^{148}$ Cf. supra, itens n. 1.2.3.1 e n. 1.6.
} 
Uma vez disciplinada em lei a medida restritiva de direito fundamental, é necessária autorização judicial para sua efetivação. ${ }^{149}$ Tal exigência, conhecida por reserva de jurisdição, é corolário do princípio da judicialidade. ${ }^{150}$

Desta forma, assegura-se que restrição de direitos e garantias fundamentais seja autorizada por decisão de órgão judiciário, imparcial e independente. Apenas um sujeito com atribuição distinta da de investigar pode conduzir as investigações em seus momentos críticos, sobretudo naquele em que se perfaça o conflito entre inviolabilidades e exigências investigativas. ${ }^{151}$ A função exercida pelo juízo, neste caso, é predominantemente de controle da investigação. ${ }^{152}$

Os fundamentos da reserva de jurisdição, no Brasil, devem ser extraídos da Constituição Federal: a consagração do sistema acusatório - inerente às normas constitucionais que delimitam de atribuições institucionais, nelas incluída as do Poder Judiciário; da garantia do devido processo legal (art. $5^{\circ}$, caput, inciso LIV); ${ }^{153}$ da garantia

\footnotetext{
${ }^{149}$ A determinação judicial pressupõe lei que determine os casos em que ela caiba (FERREIRA FILHO, Manoel Gonçalves. Comentários à Constituição... op. cit., p. 37). A exigência também é atestada em direito estrangeiro. Em comentários sobre a primeira fase da persecução penal, ENZO ZAPPALÀ frisa: "se, durante questa fase indicate dalla legge, peró, esigenze processuali, tassativamente indicate dalla legge, richiedono sacrifici per le situazioni giuridiche soggettive dell'indagato è necessario l'intervento del giudice" (ZAPPALÀ, Enzo. Le garanzie... op. cit., p. 68). Em tradução livre: "se, durante esta fase preconizada pela lei, porém, exigências processuais, taxativamente indicadas pela lei, implicarem sacrifícios para as situações jurídicas subjetivas do investigado, é necessária a intervenção do juiz". No mesmo sentido, quanto ao direito português, cf.: ANDRADE, Manuel da Costa. Métodos ocultos... op. cit., p. 115; RODRIGUES, Benjamim Silva. Das escutas... op. cit., p. 205.

${ }^{150}$ A judicialidade, como um dos princípios do Estado de Direito, é identificado por MANOEL GONÇALVES FERREIRA FILHO na Magna Carta, de 21 de junho de 1215: “está em seu item 39: 'sem julgamento leal dos seus pares, de conformidade com a lei da terra (law of the land)', nenhum homem livre será detido ou despojado de seus bens, exilado ou prejudicado de qualquer maneira que seja." (Direitos humanos... op. cit., p. 32-33).

${ }^{151}$ Cf. BALDUCCI, Paola. Le garanzie... op. cit., p. 100.

152 Retomamos aqui as considerações expendidas sobre a investigação criminal e a natureza jurídica do provimento jurisdicional que autoriza a execução do meio de investigação: cf. supra, itens n. 1.1 e n. 1.3.

${ }^{153}$ Quanto aos dois primeiros fundamentos, ANTONIO SCARANCE FERNANDES, lembrando a diversidade de tratamento atribuída às inviolabilidades no texto constitucional, afirma a necessidade de reserva de jurisdição: "não se pode, dessa diversidade, extrair a conclusão de que, para a quebra de inviolabilidade com vista à consecução de prova para uso em investigação ou processo criminal, a regra da reserva de jurisdição somente existiria nos casos de expressa determinação de autorização judicial." Conclui o autor: "ora, para a equilibrada e correta atuação de um sistema acusatório em consonância com os ditames do devido processo penal, conforme atualmente se propugna em quase todos os cantos, é essencial que um juiz, conhecido como juiz de garantias, e somente ele, seja dotado de poderes para restringir direitos do acusado e de terceiros com a finalidade de produzir prova. Assim, se é possível visualizar na Constituição a estruturação de um sistema acusatório, fundado nas garantias do devido processo penal, não se pode aceitar que uma das partes seja dotada de poderes para restringir direitos da outra, considerados invioláveis. Esses poderes só podem ser exercidos pelo órgão que, na relação
} 
genérica do acesso à Justiça (art. $5^{\circ}$, inciso XXX); da garantia do juiz natural (art. $5^{\circ}$, inciso LIII); de previsões expressas para a restrição de direitos fundamentais; e da previsão das ações impugnativas do habeas corpus e do mandado de segurança. ${ }^{154}$

No tange às comunicações entre pessoas presentes, embora não assegurada expressamente na Lei Maior, vimos que nela se preconizam direitos e garantias individuais que fundamentam a sua tutela. Sendo assim, é necessária prévia autorização judicial para sua restrição. $^{155}$

É de se ressaltar que a autorização judicial para interceptação de comunicações entre pessoas presentes não pode ultrapassar os limites delineados pela Constituição Federal: a decisão judicial dever ser motivada (art. 93, inciso IX); e, tratando-se de interceptação domiciliar, ${ }^{156}$ pode ocorrer somente durante o dia (art. $5^{\mathrm{o}}$, caput e inciso XI). ${ }^{157}$

jurídica processual, atua com imparcialidade e, assim, pode avaliar com equilíbrio e ponderação, a necessidade da restrição ao direito individual para a produção de prova. Extraída a regra de reserva de jurisdição para a quebra do sigilo do sistema acusatório e das regras do devido processo, inscritos na Constituição, conclui-se que não pode a lei ordinária dar tal atribuição ao Ministério Público ou à autoridade policial." (O sigilo... op. cit., p. 160161).

${ }^{154}$ Os fundamentos por último citados são afirmados por MAURÍCIO ZANOIDE DE MORAES, quem extrai a reserva de jurisdição das seguintes garantias constitucionais: acesso à Justiça (art. $5^{\circ}$, inciso XXX), juiz natural (art. $5^{\circ}$, inciso LIII). O autor complementa os fundamentos, afirmando que: "de forma específica, para as prisões provisórias, a Constituição determina que 'a prisão ilegal será imediatamente relaxada pela autoridade judiciária (art. $5^{\circ}$, inciso LXV), e de forma mais abrangente ao direito de locomoção por decisão judicial alcançada por meio de habeas corpus (art. $5^{\circ}$, inciso LXVIII). Como outro meio de tutela constitucional de direitos fundamentais diversos do direito de locomoção, há o mandado de segurança (art. $5^{\circ}$, inciso LXIX), também este instrumento constitucional somente decidido por autoridade judiciária." (Presunção de Inocência... op. cit., p. 320). Lembramos, ademais, a previsão expressa de necessidade de intervenção judicial para ingresso em domicílio (art. $5^{\circ}$, caput e inciso XI) e para autorização de comunicações telefônicas (art. $5^{\circ}$, caput e inciso XII).

${ }^{155}$ Também em direito estrangeiro, identificamos a exigência de manifestação judicial para restrição das comunicações entre pessoas presentes. Em Itália, por exemplo, a exigência é explícita, no art. 15 da Constituição. Daí a afirmação da doutrina de que, em matéria de interceptações, sejam telefônicas, sejam ambientais, o pressuposto de sua licitude é a existência de um ato de autoridade judiciária (CARMONA, Claudia. Le intercettazioni ambientali... op. cit., p. 351-352). No mesmo sentido, cf.: Cf. BRUNO, Pierfrancesco. Intercettazioni di comunicazioni... op. cit., p. 181. FAUZI HASSAN CHOUKR, ao tratar, no direito brasileiro, de desdobramentos da tutela da intimidade na persecução penal, afirma a sua possibilidade de restrição apenas por manifestação judicial (Garantias constitucionais... op. cit., p. 36).

156 Com relação à interceptação domiciliar, que é espécie de interceptação de comunicação entre pessoas presentes, cf. infra, itens n. 3.7 e 3.7.1.

157 "Para fins judiciais, o dia se estende de 6 às 18 horas" (SILVA, José Afonso da. Comentário Contextual à Constituição. 3. ed. São Paulo: Malheiros, 2006, p. 103). 
Não basta, portanto, a mera existência de uma decisão judicial que autorize a interceptação de comunicação entre pessoas presentes. A decisão há que ser motivada. ${ }^{158}$

Algumas particularidades quanto à exigência de motivação para as interceptações de comunicação entre pessoas presentes devem ser salientadas.

Como meio de investigação de prova que é, fundado no fator surpresa, ${ }^{159}$ a motivação do provimento em que seja autorizada a restrição de comunicações entre pessoas presentes é exigida com um maior rigor da autoridade judicial, porque a possibilidade de controle da defesa sobre o provimento restritivo sucede a sua expedição e a restrição da comunicação. ${ }^{160}$

Sendo assim, como é exigível para as decisões em geral, a motivação da decisão que a autorize a interceptação deve conter a explicitação das razões fáticas e jurídicas, ${ }^{161}$ apreciadas com "parâmetros racionais"" 162 e legais. ${ }^{163}$

\footnotetext{
${ }^{158}$ Em considerações sobre a proteção dos direitos fundamentais, ANTONIO MAGALHÃES GOMES FILHO ressalta a motivação das decisões judiciais como uma limitação imposta ao Poder Judiciário, como garantia dos direitos fundamentais: "de um lado, serve para verificar - pelo acompanhamento do raciocínio desenvolvido pelo juiz para chegar a um eventual provimento restritivo daqueles direitos - se foram efetivamente obedecidas as regras do devido processo; por outro, será igualmente por intermédio da fundamentação que será viável constatar se a decisão aplicou validamente as normas que permitiam a restrição e se apreciou de maneira correta o contexto fático que a autorizava". O autor explica, também, as funções da garantia. As funções da motivação são as seguintes: função política, pois significa um instrumento de controle popular do exercício da função jurisdicional, por meio da avaliação da legalidade e da justiça da decisão; e funções processuais: assegura a efetividade da cognição judicial, a independência e a imparcialidade do juiz, o contraditório, o duplo grau de jurisdição e a publicidade judicial (A motivação... op. cit., p. 93, p. 79-81, 95-105). Na mesma esteira, PAOLA BALDUCCI aponta para a necessidade de explicação do percurso seguido na elaboração da decisão, e ressalta que a "jurisdição de garantia" em matéria de interceptações se perfaz na motivação do provimento que as autoriza (Le garanzie nelle intercettazioni... op. cit., p. 120-128). No direito estrangeiro, quanto à exigência de motivação, cf.: CERVETTI, Fernanda. Captazione indebita di dialoghi tra imputati detenuti. Rivista Italiana di Diritto e Procedura Penale, Milano, Giuffrè, Anno XIX, fasc. 3, lug-set. 1976, p. 1.103; MARINELLI, Claudio. Intercettazioni processuali... op. cit, p. 43; BRUNO, Pierfrancesco. Intercettazioni di comunicazioni... op. cit., p. 186; BALDUCCI, Paola. Le garanzie... op. cit., p. 37-38, 48; ANDRADE, Manuel da Costa. Métodos ocultos... op. cit., p. 116; RODRIGUES, Benjamim Silva. Das escutas... op. cit., p. 231-235.

${ }^{159}$ V. supra, itens n. 1.2.1.1 e n. 1.2.1.2.

160 Cuida-se de "controle sucessivo", porque a defesa não participa da fase de formação do juízo de admissibilidade da interceptação (BALDUCCI, Paola. Le garanzie... op. cit., p. 135-136).

${ }^{161}$.Cf. GOMES FILHO, Antonio Magalhães. A motivação ... op. cit., p. 127-130.

${ }^{162}$ Cf. AMODIO, Ennio. Libero convincimento... op. cit., p. 5.

${ }^{163}$ É este o modo de motivar que possibilita a observância de uma garantia de Jurisdição que, ao contrário de formal, seja substancial (BALDUCCI, Paola. Le garanzie... op. cit., p. 135).
} 
Mais ainda: na motivação deve constar a apresentação todos os requisitos da disciplina legal que propicie a restrição das comunicações, ${ }^{164}$ com a necessária referência a dados concretos que a eles se amoldem, para demonstração de que a medida é admissível. ${ }^{165}$

Também deve ser indicado o procedimento a ser observado em sua execução, aí incluído a quem se atribui a prática dos atos materiais de investigação de prova, que precisa observar fielmente as balizas traçadas.

Além do modo de realização da interceptação, a autoridade judicial deve motivar a duração da interceptação. ${ }^{166}$ A exigência de motivação se estende também para a definição do prazo para execução das operações de interceptação. Eventual prorrogação também deve ser motivada, ${ }^{167}$ com a demonstração não só a persistência dos requisitos legais da medida restritiva, como também a necessidade de prorrogação. ${ }^{168}$

A respeito da motivação, observamos, por último, a inadmissibilidade de se proceder a motivação per relationem, ${ }^{169}$ situação em que a decisão omissa é completada por justificação

\footnotetext{
${ }^{164}$ Cf. BALDUCCI, Paola. Le garanzie... op. cit., p. 126.

${ }^{165}$ A este respeito, lembra-se a possibilidade de controle (BALDUCCI, Paola. Le garanzie... op. cit., p. 127) e de impugnação (MARINELLI, Claudio. Intercettazioni processuali... op. cit., p. 70) pelos interessados.

${ }^{166}$ Cf. DELL'ANDRO, Enzo Maria. Intercettazioni ambientali... op. cit., p. 157.

167 Cf. CAPRARO, Laura. Intercettazioni in autoventtura, eccezionali ragioni di urgenza e motivazione per relationem. Rivista Italiana di Diritto e Procedura Penale, Milano, Giuffrè, anno XLV, 2002, p. 1.461.

${ }^{168}$ Também em prorrogação a motivação não pode ser per relationem (BALDUCCI, Paola. Le garanzie... op. cit., p. 139).

169 Trata-se de consideração muito ressaltada em doutrina. Considerada a finalidade extraprocessual da motivação, pertinente a função política da motivação, é inaceitável a motivação per relationem, porque não se apresentam os elementos para o necessário controle dos concidadãos (GOMES FILHO, Antonio Magalhães. $A$ motivação ... op. cit., p. 199-200; .BADARÓ, Gustavo Henrique Righi Ivahy. Vícios de Motivação da sentença penal: ausência de motivação, motivação contraditória, motivação implícita e motivação per relationem. Revista Brasileira de Ciências Criminais, São Paulo, Ano 9, n. 38, abr-jun. de 2002, p. 137). Ademais, decisão assim motivada não perfaz adequada cognição judicial. Ao considerar como suas as razões apresentadas para justificar outra decisão ou uma pretensão, mesmo que se admita a integração por "razões fáticas e jurídicas" constantes de outros atos processuais, o juiz omite a inarredável valoração crítica da argumentação e deixa de considerar elementos supervenientes, de cuja apreciação não pode prescindir (GOMES FILHO, Antonio Magalhães. $A$ motivação ... op. cit., p. 200). No direito estrangeiro, cf.: BARGI, Alfredo. Intercettazioni di comunicazioni... op. cit., p. 801; CAPRARO, Laura. Intercettazioni in autoventtura ... op. cit., 1.457; BRUNO, Pierfrancesco. Intercettazioni di comunicazioni... op. cit., p. 193. De acordo com ALBERTO CAMON, "questo modo di motivare diminuisce il livello d'attenzione ed il coinvolgimento del giudice nell'operazione decisoria”. Em tradução livre do autor: "este modo de motivar diminui o nível de atenção e de envolvimento do juiz na operação decisória” (Le intercettazioni nel processo penale. : Giuffrè, Milano, 1996, p. 114, apud CAPRARO, Laura. Intercettazioni in autoventtura... op. cit., 1.457). Segundo PAOLA BALDUCCI, é inidônea uma motivação na qual se faça referência ao requerimento de autorização de interceptação não pode substituir a valoração do juiz
} 
constante em outros atos processuais, praticados pelas partes ou pelo juízo. ${ }^{170}$ Os fundamentos do decisum devem ser apresentados de forma explícita e clara. ${ }^{171}$

A terceira das exigências que limitam a restrição estatal a direitos fundamentais é a proporcionalidade. ${ }^{172}$

A propósito da proporcionalidade, são sempre lembradas as observações de NICOLAS GONZALEZ-Cuellar SERRANO, que identifica os seus pressupostos (legalidade e justificação teleológica), requisitos extrínsecos (judicialidade e motivação) e requisitos intrínsecos (adequação, necessidade e proporcionalidade em sentido estrito). ${ }^{173}$

acerca da subsistência de seus requisitos. A autora ressalva, contudo, que não se identifica vício em motivação se a autoridade judicial considerar argumentos expendidos na requisição, desde que a referência seja acompanhada de valoração crítica (Le garanzie... op. cit., p. 130).

${ }^{170}$ A motivação per relationem é a "repousante em fundamentação outra, porém constante do mesmo processo, sendo mais freqüente a hipótese em que o órgão recursal se reporta aos argumentos decisórios expendidos pelo inferior, no julgamento recorrido" (TUCCI, Rogério Lauria. Direitos e garantias ... op. cit., p. 236-237).

${ }^{171}$ Havendo vício na motivação, a restrição às comunicações entre presentes é ilícita. No mesmo sentido, PAOLA BALDUCCI salienta que pouco importa a qualificação dada à motivação (defeituosa, carente, lacunosa, insuficiente), porque, se não cumprir a sua função, é uma motivação ausente (Le garanzie... op. cit., p. 195).

${ }^{172}$ Cuida-se de tema que, pela complexidade, é deveras controvertido em doutrina. Pretendemos apenas pontuálo, como uma norma que constitui um limite reconhecido pela doutrina para a restrição de direitos fundamentais. O esgotamento dos diversos aspectos que podem ser extraídos do tema escapa do objeto da presente dissertação. Note-se, por exemplo, que há divergências quanto a sua natureza normativa. A proporcionalidade é tida como: "princípio" (GOMES FILHO, Antonio Magalhães. Direito à prova... op. cit., p. 125; FERNANDES, Antonio Scarance. Processo penal... op.cit., p. 49-56), "regra" (SILVA, Luís Virgílio Afonso da. O proporcional e o razoável. Revista dos Tribunais, São Paulo, ano 91, volume 798, abr. 2002, p. 23-50), "postulado" (ÁVILA, Humberto. Teoria dos princípios: da definição à aplicação dos princípios jurídicos. 7. ed. São Paulo: Malheiros, 2007, p. 160-162; GRAU, Eros Roberto. Ensaio e discurso sobre a interpretação/aplicação do direito. 4.ed. São Paulo: Malheiros, 2006, p. 191), "critério" (MARTINS, Leonardo. Proporcionalidade como critério do controle de constitucionalidade (problemas de sua recepção pelo direito e jurisdição constitucional brasileiros). Revista da AJURIS (Associação dos Juízes do Rio Grande do Sul), ano XXXIII, n. 101, mar. 2006, p. 203-208).

${ }^{173}$ Cf. Proporcionalidad y derechos fundamentales en el processo penal. 2. ed. Madrid: Colex, 1990, p. 69. REOBET ALEXY se refere à "máxima da proporcionalidade", da qual extrai as máximas parciais "da adequação, da necessidade (mandamento do meio menos gravoso) e da proporcionalidade em sentido estrito (mandamento do sopesamento propriamente dito)" (Teoria dos Direitos... op.cit., p. 117). Em sentido semelhante, VICENTE GIMENO SENDRA extrai da análise da jurisprudência da Corte Européia de Direitos Humanos e do Tribunal Constitucional espanhol notas essenciais da proporcionalidade, a saber: "a) todo acto limitativo de un derecho fundamental ha de fundarse y estar previsto (principio da legalidad) en una ley"; "b) toda resolución que limite o restrinja el ejercicio de un derecho fundamental ha de estar motivada"; c) "ha de observarse el cumplimiento del subprincipio de necesidad"; "d) ha de existir una adecuación o "congruencia entre la medida prevista o aplicada y la procuración de dicho bien constitucionalmente relevante",; "e) la finalidad perseguida por el acto instructorio y lesivo del derecho fundamental no ha de poder alcanzarse, sino mediante dicho acto y no con otro igualmente eficaz, pero no restrictivo del derecho fundamental (subprincipio de la 'alternativa menos gravosa' para el derecho fundamental) o no debe poderse comprobar 'ex post' que el mismo objetivo hubiera podido alcanzarse con un medio no o menos restrictivo del derecho fundamental". Em tradução livre do autor: "a) todo ato limitativo de um direito fundamental há de se fundar e estar previsto (principio da legalidade) em uma lei"; "b) toda decisão que limite ou restrinja o exercício de um direito fundamental deve estar motivada"; "c) há de se 
No direito brasileiro, a proporcionalidade é extraída do princípio da igualdade ( $\operatorname{art} .5^{\circ}$, caput e inciso I da Constituição Federal). ${ }^{174}$ Da igualdade decorrem tanto a necessidade de tratamento igualitário, para situações semelhantes, quanto a exigência de tratamento distinto, para situações diferentes. É com fulcro neste último aspecto que se liga a proporcionalidade à igualdade. $^{175}$

Examinando a relação entre a proporcionalidade e a restrição de direitos individuais, MAURÍCIO ZANOIDE DE MORAES enfatiza que a garantia da proporcionalidade se opera em dois níveis distintos: "o primeiro, destinado ao campo legislativo-abstrato, pelo qual o Judiciário verifica se a elaboração normativa apresentou justificação constitucional; e o segundo nível, relacionado com o campo concreto da aplicação e execução das leis pelo Judiciário e pelo Executivo, no caso específico."176

Tratando-se de comunicações entre pessoas presentes, é necessária a observância da proporcionalidade na restrição dos fundamentos constitucionais das comunicações entre pessoas presentes: tanto no nível legislativo-abstrato; quanto no nível de aplicação concreta das normas que a prevejam. ${ }^{177}$

observar o cumprimento do subprincípio de necessidade"; “d) há de existir uma adequação ou "congruência entre a medida prevista ou aplicada e a tutela do dito bem constitucionalmente relevante"”; "e) a finalidade perseguida pelo ato instrutório e lesivo do direito fundamental não se pode alcançar, senão mediante dito ato e não com outro igualmente eficaz, porém não restritivo do direito fundamental (subprincípio da 'alternativa menos gravosa' para o direito fundamental) ou não se deve poder comprovar 'expost' que o mesmo objetivo se poderia alcançar comum meio não ou menos restritivo do direito fundamental” (Derecho Procesal... op. cit., p. 61-62).

${ }^{174}$ Cf. FERREIRA FILHO, Manoel Gonçalves. Direitos humanos... op. cit., p. 112-113.

${ }^{175}$ Cf. FERNANDES, Antonio Scarance. Processo penal... op.cit., p. 91.

${ }^{176}$ Cf. Presunção de Inocência... op. cit., p. 311. ADA PELLEGRINI GRINOVER, enfatizando a necessidade de observância da proporcionalidade no plano normativo, refere-se ao princípio da reserva legal proporcional (O regime brasileiro das interceptações telefônicas. Revista Forense, Rio de Janeiro, v. 338, ano 93, abr-jun. 1997, p. 8; A marcha do processo. Rio de Janeiro: Forense Universitária, 2000, p. 107). Conforme MANUEL DA COSTA ANDRADE, "o regime legal corresponde a uma ponderação de interesses desejada pelo legislador" (Das escutas telefônicas... op. cit., p. 206). Embora o legislador tenha feito uma ponderação de interesses, não significa que esteja correta. Daí a pertinência de se exigir a apreciação judicial.

177 Neste sentido, manifesta-se ANTONIO SCARANCE FERNANDES, quem invoca do princípio da proporcionalidade para solução do conflito entre o direito ao sigilo e o direito à produção de prova, cuja aplicação pressupõe a prévia observância do princípio da legalidade, mediante a delimitação da disciplina do meio de acesso a dados sigilosos. $\mathrm{O}$ autor salienta, ainda, a necessidade de interpretação restritiva da disciplina do meio e examina os requisitos intrínsecos (adequação, necessidade e proporcionalidade em sentido estrito) e os requisitos extrínsecos (judicialidade e motivação) do princípio da proporcionalidade (O sigilo... op. cit., p. 159-161). 
Já vistos o nível legislativo-abstrato (legalidade e justificação) e os requisitos extrínsecos (judicialidade e motivação), nas considerações anteriores sobre as restrições aos direitos e garantias que fundamentam a tutela das comunicações entre pessoas presentes e acerca das exigências de reserva de lei e de jurisdição, resta a análise dos requisitos intrínsecos da proporcionalidade.

No nível da aplicação concreta, a autoridade judicial, avaliando a solicitada medida restritiva dos direitos e garantais que fundamentam a proteção das comunicações entre pessoas presentes, deve examinar, sucessivamente, a adequação, a necessidade e a proporcionalidade em sentido estrito. ${ }^{178}$

A adequação significa a aptidão do meio para possível descoberta de fontes de prova. $^{179}$

Além de apto, o meio deve ser necessário. ${ }^{180}$ Com a exigência de necessidade ${ }^{181}$ expressa-se que o meio deva ser residual, ${ }^{182}$ indispensável, ${ }^{183}$ subsidiário, isto é, entre os

${ }^{178}$ Cf. FERNANDES, Antonio Scarance. Processo penal... op. cit., p. 53-54; MORAES, Maurício Zanoide de. Presunção de Inocência... op. cit., p. 323-329. No mesmo sentido, em avaliação sobre as exigências para diligências restritivas de direitos fundamentais no direito espanhol, SARA ARAGONESES MARTÍNEZ nelas insere a proporcionalidade: "para comprobar si una medida restrictiva de un derecho fundamental supera el juicio de proporcionalidad, es necesario constatar si cumple estas tres condiciones: si la medida es susceptibile de conseguir el objetivo propuesto (idoneidad); si, además, no existe outra medida más moderada para la consecución del propósito con igual eficacia (necesidad); $y$, finalmente, si la medida es ponderada o equilibrada, por derivarse de ella más beneficios o ventajas para el interés general que perjuicio sobre otros bienes (proporcionalidad em sentido estricto)." Em tradução livre do autor: "para comprovar se uma medida restritiva de um direito fundamental supera o juízo de proporcionalidade, é necessário constatar se cumpre estas três condições: se a medida é suscetível de obter o objetivo proposto (idoneidade); se, ademais, não existe outra medida mais moderada para a consecução do propósito com igual eficácia (necessidade); e, finalmente, se a medida é ponderada ou equilibrada, por decorrerem dela mais benefícios ou vantagens para o interesse geral do que prejuízo sobre outros bens (proporcionalidade em sentido estrito)" (Capítulo primero: procesos ordinarios: sección primera: el proceso por delitos graves: § 12. El sumario... op.cit., p. 366-367). Verifiquem-se, também, sobre o direito português, as considerações de MANUEL MONTEIRO GUEDES VALENTE, para quem a exigencia de proporcionalidade "deve-se repartir nos seus corolários directos - adequação, exigilidade e necessidade, proporcionalidade stricto sensu - e um corolário indirecto - subsidiariedade" (Escutas telefónicas: da excepcionalidade à vulgaridade. 2. ed. Coimbra: Almedina, 2008, p. 61-67).

179 "Consiste em um exame empírico realizado sobre a aptidão do meio contribuir para a consecução do fim almejado" (MORAES, Maurício Zanoide de. Presunção de Inocência... op. cit., p. 323). Segundo ELLEN SCHLÜCHTER, adequação, ou idoneidade, diz respeito à aptidão da medida para consecução do fim por ela visado (Derecho Procesal... op. cit., p. 66).

180 "Diante dos meios declarados idôneos procede-se a um exame comparativo entre eles para se determinar qual é o necessário" (MORAES, Maurício Zanoide de. Presunção de Inocência... op. cit., p. 326). 
meios possíveis para a descoberta de fontes de prova, há que se utilizar o menos restritivo, ${ }^{184}$ considera o caráter excepcional da restrição a direitos fundamentais.

Já a proporcionalidade em sentido estrito se traduz em um juízo de ponderação sobre valores em conflito em cada caso concreto, com vistas à afirmação da prevalência de um deles. ${ }^{185}$ Em restrição às comunicações entre pessoas presentes, identificamos um conflito entre os direitos e garantias que fundamentam a sua tutela e o interesse em repressão a delitos, a ser solucionado em caso concreto.

Por derradeiro, frisamos que a proporcionalidade da medida restritiva - nos planos abstrato e concreto - também se estende pelo período de sua duração. A medida deve ser cumprida em prazo razoável (art. 5º , caput e inciso LXXVIII da Constituição Federal), ${ }^{186}$ que, em matéria de interceptação de comunicações, traduz-se na delimitação de um prazo para a

\footnotetext{
${ }^{181}$ A necessidade da interferência (the necessity of interference) é reconhecida pela Corte Europeia de Direitos Humanos (Case of Lambert v. France (Judgment [Merits and Just Satisfaction], n. 23618/94). Disponível em: http://cmiskp.echr.coe.int/tkp 197/view.asp?item=1\&portal=hbkm\&action=html\&highlight=Lambert\&sessionid= 59715152\&skin=hudoc-en. Acesso em: 26/09/2010).

${ }^{182} \mathrm{O}$ caráter residual do meio interceptante é ressaltado por PAOLA BALDUCCI (Le garanzie... op. cit., p. 113).

${ }^{183} \mathrm{~A}$ indispensabilidade do meio, que somente possa ser executado se não houver outro meio menos insidioso (BRUNO, Pierfrancesco. Intercettazioni di comunicazioni... op. cit., p. 189).

${ }^{184}$ Lembra ANTONIO SCARANCE FERNANDES o requisito da necessidade, que também denomina "de intervenção mínima", "de alternativa menos gravosa" ou de "subsidiariedade" (O sigilo... op. cit., p. 160). Em semelhante sentido, ELLEN SCHLÜCHTER recorda a necessidade do meio, salientando que se deve restringir o mínimo possível na busca do fim almejado (Derecho Procesal ... op. cit., p. 66).

185 "É um juízo valorativo e é nesse âmbito que se realiza a ponderação indispensável entre todos os direitos fundamentais afetados ou afetáveis pela medida processual penal, já definida como idônea e necessária, para se determinar se ela será ou não realizada." (MORAES, Maurício Zanoide de. Presunção de Inocência... op. cit., p. 329). Trata-se de uma análise do "justo equilíbrio" em cada caso (FERNANDES, Antonio Scarance. O sigilo... op. cit., p. 160). ELLEN SCHLÜCHTER protesta pela supremacia do valor protegido em confronto com aquele a ser restringido (Derecho Procesal... op. cit., p. 66)

${ }^{186}$ GUSTAVO HENRIQUE RIGHI IVAHY BADARÓ e AURY LOPES JR. reconhecem a aplicabilidade do direito ao prazo razoável desde a fase de investigações da persecução penal e afirmam: "o art. $5^{\circ}$, LXXVIII, da Constituição, prevê que 'a todos, no âmbito judicial e administrativo' é assegurada a garantia do prazo razoável". Além disso, ressaltam que "esta garantia nasce na investigação preliminar, na fase administrativa pré-processual" (Direito ao processo penal no prazo razoável. 2 ed. Rio de Janeiro: Lumen Juris, 2009, p. 82-83). Em sentido semelhante, cf.: LOPES JR., Aury. Direito ao processo penal no prazo razoável. Revista Brasileira de Ciências Criminais, São Paulo, n. 65, mar-abr. 2007, p. 219-224. Demais disso, MARCOS ALEXANDRE COELHO ZILLI, em comentários sobre a exigência de prazo razoável, observa: "a garantia em foco é ambivalente. Com efeito, se por um lado objetiva resguardar a esfera da liberdade jurídica do cidadão contra persecuções penais demasiadamente prolongadas, assegura, por outro, uma efetividade ao processo penal que certamente estaria comprometida acaso a solução do conflito viesse a ser proferida tardiamente" (A iniciativa instrutória... op.cit., p. 153). Em direito estrangeiro, também se exige prazo razoável de duração da medida restritiva: cf. BALDUCCI, Paola. Le garanzie... op. cit., p. 42.
} 
execução da medida. Todavia, o fato de estar delimitado em lei o prazo máximo para ser menor a sua duração.

Destarte, a tutela das comunicações entre pessoas presentes se fundamenta em direitos e garantias fundamentais previstos na ordem constitucional brasileira (a liberdade de manifestação do pensamento, o direito à intimidade e à vida privada, a inviolabilidade do domicílio - sendo a interceptação domiciliar -, e o direito a não autoincriminação). Também as protegem as exigências constitucionais que propiciam as suas restrições, decorrentes da vida em sociedade. A interceptação de comunicações entre pessoas presentes é uma das formas destas restrições se operarem. 


\title{
CAPÍTULO $3^{\circ}$
}

\section{A INTERCEPTAÇÃO DE COMUNICAÇÃO ENTRE PESSOAS PRESENTES NO DIREITO PROCESSUAL PENAL: ASPECTOS DOGMÁTICOS E PROPOSTAS DE DISCIPLINA JURÍDICA}

\begin{abstract}
Sumário: 3.1. Antecedentes históricos - 3.2. Conceito - 3.3. Objeto - 3.4. Natureza jurídica - 3.5. Sujeitos ativos - 3.6. Sujeitos passivos - 3.7. Espécies: 3.7.1. Interceptação domiciliar; 3.7.2. Interceptação ambiental - 3.8. Distinções entre interceptação de comunicação entre pessoas presentes e figuras afins: 3.8.1. Interceptação de comunicação entre pessoas presentes e interceptação de telecomunicação; 3.8.2. Segue: e gravação clandestina de comunicação entre pessoas presentes; 3.8.3. Segue: e revelação do conteúdo de comunicação entre pessoas presentes por um dos interlocutores - 3.9. O caráter insidioso - 3.10. A disciplina jurídica da interceptação de comunicação entre pessoas presentes: 3.10.1. As propostas sobre o conteúdo; 3.10.2. As propostas sobre a autonomia: admissibilidade e procedimento.
\end{abstract}

\subsection{Antecedentes históricos}

A constatação de que a liberdade de comunicação é essencial ao ser humano decorre do reconhecimento de sua sociabilidade. O Homem, como ser racional, pensante e social, necessita de meios para se comunicar com os seus semelhantes. É da natureza humana a faculdade de compartilhamento de pensamentos, por meio da qual ele defende interesses pessoais e alheios. ${ }^{1}$

Na evolução histórica, patenteia-se a preocupação da comunidade global em assegurar a liberdade de manifestação do pensamento, da qual provém a liberdade de comunicação.

\footnotetext{
${ }^{1}$ Confiram-se outras considerações sobre as comunicações entre os seres humanos no item n. 2.1, supra.
} 
Igual empenho pode ser notado quanto à proteção do conteúdo das comunicações concretizadas em relações que o indivíduo deposita em sua esfera privada. ${ }^{2}$

De forma concomitante, foram admitidas restrições a comunicações, em situações nas quais um valor social prepondera sobre um valor individual. Entre os valores sociais que podem justificar restrições a comunicações, sobressaem a segurança jurídica e a repressão estatal a prática de delitos.

De acordo com as possibilidades técnicas de cada época, variaram as formas de restrições às comunicações pessoais de supostos autores de delito. Por primeiro, foram estabelecidas limitações às comunicações por correspondência privada. Em seguida, autorizaram-se interceptações de comunicações telefônicas, e, depois, de comunicações privadas dentro de domicílio. ${ }^{3}$

Desde a Antiguidade, identifica-se a tutela das comunicações por correspondência. Ada Pelligrini Grinover nota, no direito romano, a possibilidade de sua restrição, pela preconizada possibilidade de supressão e de divulgação de notícias contidas em cartas ou em testamentos, por meio da actio furti e da actio iniuriarum. ${ }^{4}$

Lembra ROGÉRIO LAURIA TUCCI que da preocupação quanto à proteção do sigilo da correspondência, que remonta aos trabalhos da Assembléia Constituinte francesa de 1791, à dos demais meios modernos de comunicação são passados séculos. ${ }^{5}$

E com os meios modernos, multiplicaram-se, no desenfreado avanço tecnológico, mecanismos para captação das diferentes espécies de comunicações: telecomunicações (telegráficas, telefônicas, por sistema de telemática, por sistema de informática); e

\footnotetext{
${ }^{2}$ A respeito da evolução histórica da proteção das comunicações - em especial, das comunicações entre pessoas presentes-, cf., infra, item n. 4.2.1.

${ }^{3}$ ENRIQUE BACIGALUPO salienta a particular importância de que as possibilidades técnicas de interceptação de conversas diretas entre pessoas, especialmente dentro do domicílio, assumiram na atualidade na persecução de delitos praticados por associações criminosas (Derecho Penal... op. cit, p. 235).

${ }^{4}$ Cf. Liberdades públicas... op. cit., p. 186.

${ }^{5}$ Cf. Direitos e garantias... op. cit., p. 404.
} 
comunicações entre pessoas presentes. ${ }^{6}$ Em geral, são instrumentos minúsculos, que são programados para captar e gravar o conteúdo das comunicações. ${ }^{7}$

A estruturação da interceptação de comunicação telefônica sucedeu aos meios de quebra da inviolabilidade do sigilo da correspondência. No atual estágio da ciência jurídica, muitos são os Estados em que a interceptação de comunicação telefônica é disciplinada, ${ }^{8}$ e executada com os aparatos cada vez mais evoluídos, em razão dos anos de utilização do instituto. No Brasil, por exemplo, este meio de investigação de prova é disciplinado na Lei ${ }^{o}$ 9.296, de 1996.

É neste contexto que a desconfiança de agentes de delito quanto à utilização do meio telefônico para comunicação, sabedores que são da possibilidade de interceptação, implicou a alteração da forma de comunicação. ${ }^{9}$ Daí decorreu a necessidade de utilização de outros meios para a investigação de crimes e de seus autores, como a interceptação de comunicação entre pessoas presentes.

\footnotetext{
${ }^{6}$ No mesmo sentido, ADA PELLEGRINI GRINOVER ressalta que "a evolução da vida moderna, através da intensificação das relações sociais e do progresso dos meios tecnológicos, tende a uma limitação cada vez maior da esfera em que se pode viver ao abrigo de interferências alheias." E adverte quanto a consequência deste progresso: "se cada um de nós tivesse que viver sempre sob as luzes da publicidade, acabaríamos todos perdendo as mais genuínas características de nossa personalidade, para nos dissolver no anônimo e no coletivo, como qualquer produto de massa" (Liberdades públicas... op. cit., p. 69).

${ }^{7}$ Com relação à multiplicação de mecanismos de captação das comunicações, ROGÉRIO LAURIA TUCCI assevera: "em que pesem, no decorrer deste tempo, as abusivas violações, que se multiplicaram, sobretudo no declarado interesse de investigações criminais, verdade é que a tutela constitucional tem evoluído e se aperfeiçoado, ajustando-se, como é natural, ao progresso das instituições e dos meios de comunicação." (Cf. TUCCI, Rogério Lauria. Direitos e garantias... op. cit., p. 404).

${ }^{8}$ Entre os países que regulamentaram a interceptação de comunicação telefônica, destacamos os expostos no capítulo $4^{\circ}$ (itens n. 4.2.1 e 4.2.2, infra).

${ }^{9}$ Cf. DELL'ANDRO, Enzo Maria. Intercettazioni ambientali... op. cit., p. 160. No mesmo sentido, ALBERTO CAMON observa que as interceptações de comunicações telefônicas se tornaram uma prática difundida, e, por isso, conservam um caráter "oficial" (Le intercettazioni nel processo penale. Milano: Giuffrè, 1996, p. 176, apud MARTINO, Corrada di. Le intercettazioni ambientali ... op. cit., p. 1.155). A este respeito, DIMITRI GIANNALOPOULOS e RAPHAÊLLE PARIZOT observam: "a evolução impressionante da tecnologia audiovisual conduziu, por consequência, ao nascimento de uma tecnologia revolucionária de vigilância. Além disso, os criminosos já ficaram conscientes da possibilidade das interceptações telefônicas; eles estão progressivamente se dedicando mais a meios eficazes. As escutas telefônicas não representam mais, nos dias de hoje, o interesse que apresentavam antes". Tradução livre do autor de: "l'evolution impressionnante de la technologie audiovisuelle a conduit subsquentemment à la naissance d'une technologie revolutionnaire de surveillance. Em outre, les criminels étant devenus conscients de la possibilité toutjours plus importante d'interceptions téléphoniques, celles-ci sont progressivement devenues beaucoup moins eficaces. Les écoutes téléphoniques ne présentent plus, de nos jours, l'intérêt qu'elles présentaint auparavant" (La preuve technologique... op. cit., p. 269).
} 
Conquanto a comunicação entre pessoas presentes seja a mais genuína do ser humano, em geral, a primeira conhecida, os meios de investigação de prova que a restringem são recentes. $\mathrm{O}$ conteúdo da comunicação entre duas ou mais pessoas por conversa direta poderá ser captado de maneiras diversas na investigação de prova, entre os quais está a intercepção de comunicações entre presentes.

Vejamos, então, os aspectos dogmáticos deste instituto, com especial ênfase no direito brasileiro.

Antes, porém, de analisarmos os aspectos dogmáticos deste instituto, registramos que é deveras criticado o "mito" de que a interceptação de comunicações entre presentes fornece algo próximo a "fotografia sonora do crime". ${ }^{10}$ Esta espécie de interceptação apresenta margens de ambiguidades, especialmente quanto à atribuição de vozes e a interpretação de conversas gravadas, se comparadas com a interceptação de comunicações telefônicas. ${ }^{11}$ Estes aspectos devem ser considerados pelo legislador na elaboração da respectiva disciplina jurídica. $^{12}$

\subsection{Conceito}

$\mathrm{O}$ conceito da interceptação de comunicação entre pessoas presentes se liga ao conceito de interceptação de comunicação, da qual é espécie. Apesar dos esforços envidados pela doutrina para a delimitação de conceito ou de noção de interceptação de comunicação, ${ }^{13}$

\footnotetext{
${ }^{10}$ Cf. MARTINO, Corrada di; PROCACCIANTI, Teresa. Le intercettazioni ... op. cit., p. 58.

${ }^{11}$ Cf. Ibidem, p. 58.

${ }^{12}$ A propósito da disciplina jurídica da interceptação de comunicações entre pessoas presentes, cf., infra, itens n. 3.10 , n. 3.10 .1$, n. 3.10 .2 , n. 4.1 a n. 4.2 , e n. 5.1 a 5.5 .

${ }^{13}$ A doutrina diverge quanto à necessidade de delimitação de um conceito ou de noção de interceptação: alguns protestam pela fixação de um conceito (MARINELLI, Claudio. Intercettazioni processuali... op. cit, p. 3-6); outros preferem falar em noção (APRILE, Ercole; SPIEZIA, Filippo. Le intercettazioni... op. cit., p. 1).
} 
que a diferencie de outras operações técnicas que não se sujeitem ao mesmo regime jurídico, não há consenso sobre o tema. ${ }^{14}$

Em uma primeira aproximação, lembre-se de que interceptar deriva do termo latino intercipio, que significa "tomar ou apanhar o que vai para outro ou de repente ou à traição". 15 Assim, a interceptação de comunicação é uma atividade tendente à captação de conteúdo de comunicação, isto é, de informações verbalizadas pelos respectivos interlocutores. Se a atividade é desenvolvida para captação de comunicação entre pessoas presentes, tem-se interceptação de comunicação entre pessoas presentes, ${ }^{16}$ também conhecida por interceptação entre pessoas presentes,${ }^{17}$ interceptação entre presentes,${ }^{18}$ ou pela denominação de suas espécies (interceptação ambiental e interceptação domiciliar). ${ }^{19}$

Preferimos denominá-la interceptação de comunicação entre pessoas presentes ${ }^{20}$ por duas razões: primeiro, pela precisão da delimitação de seu objeto, a comunicação entre pessoas presentes, que é protegida sob fundamentos distintos das demais formas de comunicação; ${ }^{21}$ ademais, pela expressão de um gênero, que tem como espécies a interceptação ambiental e a interceptação domiciliar. ${ }^{22}$

\footnotetext{
${ }^{14}$ Cf. APRILE, Ercole; SPIEZIA, Filippo. Le intercettazioni... op. cit., p. 3. Sem embargo dos protestos pela definição de um conceito claro de interceptação - por meio de uma "adjetivação diacrítica" ("aggetivazione diacrítica"), que a separe de outros meios de investigação de prova - a doutrina reconhece a inexistência de uma noção unitária de interceptação de comunicações (MARINELLI, Claudio. Intercettazioni processuali... op. cit, p. 4-6).

${ }^{15}$ Cf. CRETELLA JÚNIOR, José; CINTRA, Geraldo de Ulhôa. Dicionário Latino-Português. 7. ed. São Paulo: Companhia Editora Nacional, 1956, p. 620.

${ }^{16}$ Cf. MARTINO, Corrada di; PROCACCIANTI, Teresa. Le intercettazioni ... op. cit., p. 57.

${ }^{17}$ Cf. FILIPPI, Leonardo. Intercettazione di comunicazioni..., p. 1; BALDUCCI, Paola. Le garanzie... op. cit, p. 18.

${ }^{18}$ Cf. GRINOVER, Ada Pellegrini; GOMES FIHO, Antonio Magalhães; FERNANDES, Antonio Scarance. As nulidades... op. cit., p. 164 e 184

${ }^{19}$ Sobre as espécies de interceptação de comunicação entre pessoas presentes, cf., infra, n. 3.10.

${ }^{20}$ No mesmo sentido, CORRADA DI MARTINO e TERESA PROCACCIANTE também salientam a ausência de identidade entre interceptação ambiental e interceptação de comunicação entre presentes: "intercettazione ambientale, rectius: di conversazioni tra presenti" (Le intercettazioni... op. cit., p. 57). Manifestam-se na mesma esteira, referindo-se a interceptações entre pessoas presentes: FILIPPI, Leonardo. Intercettazione di comunicazioni..., p. 1; BALDUCCI, Paola. Le garanzie... op. cit, p. 18. Confiram-se, ainda, os termos normativos do Código de Processo Penal chileno: "la grabación de comunicaciones entre personas presentes" (art. 226) (cf., infra, item n. 4.2.2.2.3).

${ }^{21}$ Cf., supra, itens n. 2.1 a n. 2.6 .

${ }^{22}$ Verifiquem-se considerações sobre as espécies da interceptação de comunicação entre pessoas presentes no item n. 3.10, infra.
} 
Sob as denominações ora mencionadas, muito se discute quanto aos elementos que integram o seu conceito. A doutrina, nacional e estrangeira, identifica alguns de seus elementos que conformam sua "estrutura mínima". ${ }^{23}$ Mas não há um conceito uniforme.

Em Brasil, Ada Pellegrini Grinover, Antonio Magalhães Gomes Filho e ANTONIO SCARANCE FERNANDES definem interceptação como "a captação da conversa por um terceiro, sem o conhecimento dos interlocutores ou com o conhecimento de só um deles. Se o meio utilizado for o 'grampeamento' do telefone, tem-se a interceptação telefônica; se se tratar de captação de conversa por um gravador, colocado por um terceiro, tem-se interceptação entre presentes, também chamada de interceptação ambiental." ${ }^{24} \mathrm{E}$ distinguem a "interceptação da conversa entre presentes, por terceiro, sem o conhecimento de nenhum dos interlocutores" (interceptação "stricto sensu") da "interceptação da conversa entre presentes por terceiro, com conhecimento de um ou de alguns dos interlocutores" (escuta). ${ }^{25}$

Por igual, em doutrina italiana, pode ser identificada a conceituação da interceptação de comunicação entre presentes. Da mesma forma, o conceito formulado é de interceptação de comunicação, abrangendo tanto a interceptação de telecomunicações, quanto a interceptação de comunicação entre pessoas presentes.

A interceptação de comunicação é definida por ERCOLE APRILE e FILIPPO SPIEZIA como uma "atividade de escuta (ou leitura) e captação de comunicações, que se operam de forma diversa da escrita, entre duas ou mais pessoas, que se encontram distantes, e que transmitem as suas mensagens por meio do telefone ou de outro instrumento técnico idôneo a garantir a reserva do sinal enviado e recebido, ou entre pessoas presentes no mesmo lugar, caso em que se fala de interceptação ambiental". ${ }^{26}$

\footnotetext{
${ }^{23}$ Cf. BARGI, Alfredo. Intercettazioni di comunicazioni... op. cit., p. 791.

${ }^{24}$ Os citados autores a nominam, ainda, de "gravações sub-reptícias de conversas entre presentes" (As nulidades... op. cit., p. 164 e 184).

${ }^{25}$ Cf. As nulidades... op. cit., p. 164-165. No mesmo sentido, cf.: FERNANDES, Antonio Scarance. Processo penal... op. cit., p. 92-93; GRECO FILHO, Vicente. Interceptação telefônica... op. cit., p. 6.

${ }^{26}$ Tradução livre do autor de: "un'attività di ascolto (o lettura) e captazione di comunicazioni, che avvengono in forma diversa da quella scritta, tra due o più persone, che si trovano a distanza tra loro, e che trasmettono i loro messaggi a mezzo del telefono o di altro strumento técnico idoneo a garantire la riservatezza del segnale inviato e ricevuto, ovvero tra persone presenti nello stesso luogo, nel qual caso si parla di intercettazione ambientale." (Le intercettazioni... op. cit., p. 2-3).
} 
Segundo Corrada Di MARTino e Teresa Procaccianti, a interceptação de comunicação é definida como "a atividade de um terceiro, que, valendo-se de instrumentos mecânicos, toma conhecimentos, de uma comunicação reservada, sob o desconhecimento de ao menos um dos interlocutores". ${ }^{27}$ Diferenciam, ainda, a interceptação de comunicação entre presentes da interceptação telefônica "pelo fato de que a conversa não se perfaz utilizando-se um particular meio de difusão do sinal, como, por exemplo, o telefone, mas entre pessoas que se encontram em um mesmo ambiente, geralmente uma na presença de outra". ${ }^{28}$

Outros elementos são inseridos no conceito de interceptação de comunicação por ClAUdio MARINELli, quem, de forma mais abrangente, denomina-a interceptação processual. Do conceito proposto pelo autor, extraímos que a interceptação de comunicação é operação oculta de conhecimento do conteúdo de uma comunicação entre presentes ou de uma comunicação inter absentes, com caráter reservado e não realizada por escrito, efetuada com o escopo investigativo, sob controle judicial, e executada mediante instrumentos técnicos idôneos à captação e ao registro em tempo real do dado comunicativo. ${ }^{29}$

Das propostas de conceito apresentadas, evidencia-se que não há consenso, quanto aos elementos que integram o conceito de interceptação. Lembra ALFREDO BARGI, a propósito,

\footnotetext{
${ }^{27}$ Tradução livre do autor de: "l'attività di un terzo, che, avvalendosi di strumenti meccanici, prende conoscenza di una comunicazione riservata, all'insaputa di almeno uno degli interlocutori" (MARTINO, Corrada di; PROCACCIANTI, Teresa. Le intercettazioni... op. cit., p. 21).

${ }^{28}$ Tradução livre do autor de: "il fato che la conversazione non avviene servendosi di um particolare mezzo di diffusione del segnale, quale, ad. es., il telefono, ma tra persone che si trovano in uno stesso ambiente, generalmente l'uma al cospetto dell'altra" (MARTINO, Corrada di; PROCACCIANTI, Teresa. Le intercettazioni... op. cit., p. 57-58).

${ }^{29}$ O conceito proposto pelo autor tem os seguintes termos: "a operação oculta de conhecimento do conteúdo de uma comunicação entre presentes ou de uma comunicação inter absentes, também informática ou telemática, com caráter reservado e não realizada por escrito, efetuada com o escopo investigativo dos órgãos investigativos, sob o controle judicial, preventivo ou sucessivo, e executada mediante instrumentos técnicos idôneos à captação e ao registro em tempo real do dado comunicativo". Tradução livre de: "operazione di occulta presa di conoscenza del contenuto di uma conversazione tra presenti o di uma comunicazione inter absentes, anche informatica o telematica, purché a carattere riservato e non realizzata per iscritto, effettuata a scopo investigativo dagli organi inquirenti sotto il controllo giurisdizionale, preventivo o sucessivo, ed eseguita mediante strumenti tecnici idonei alla captazione e alla registrazione in tempo reale del dato comunicativo" (Intercettazioni processuali... op. cit, $\mathrm{p}$. 6). Nos termos citados no corpo do texto, com vistas voltadas à formulação de um conceito aplicável ao direito brasileiro, não mencionamos a comunicação informática ou telemática, porque escapa ao objeto do presente trabalho. Com o mesmo propósito, suprimimos a referência do autor a controle judicial, preventivo ou sucessivo, porque diferente da Itália (cf. item n. 4.2.2.2.6, infra), reputamos que, no Brasil, deve haver autorização judicial prévia e controle judicial no desenvolvimento da atividade de interceptação (cf. item n. 2.6, supra).
} 
que a interceptação de comunicação é um instituto em constante evolução, para que haja integração entre o desenvolvimento de instrumentos de comunicação e a relativa disciplina jurídica. $^{30}$

Consideramos necessária a formulação de definição autônoma da interceptação de comunicação entre pessoas presentes, consideradas as especificidades do objeto do instituto: a comunicação entre pessoas presentes. ${ }^{31}$

A interceptação de comunicação entre pessoas presentes, em nosso entender, consiste em atividade de captação e de registro de comunicação entre pessoas presentes de caráter reservado, por um terceiro, com o emprego de meios técnicos, utilizados em operação oculta e simultânea à comunicação, sem o conhecimento dos interlocutores ou com o conhecimento de um ou de alguns deles.

Analisemos, separadamente, os elementos constantes da proposta de conceito para a intercepção de comunicação entre pessoas presentes: a atividade de captação e de registro, a comunicação presencial de caráter reservado, a realização por terceiro, o emprego de meios técnicos, a ocultação da operação, a simultaneidade da operação, o desconhecimento de interlocutor.

Como espécie que é dos meios de investigação de prova, a interceptação de comunicação entre presentes é um instrumento processual cuja concretização se revela em uma atividade, ${ }^{32}$ isto é, uma série ordenada de atos, tendentes à captação e ao registro do conteúdo de comunicação presencial.

Esta atividade é voltada à captação e ao registro de uma comunicação presencial reservada $^{33}$ que é intencionalmente subtraída pelos participantes do conhecimento de

\footnotetext{
${ }^{30} \mathrm{Cf}$. Intercettazioni di comunicazioni... op. cit., p. 791.

${ }^{31}$ Cf. supra, itens n. 2.1 a n. 2.6.

${ }^{32}$ Quanto à concepção de meio de investigação de prova como instrumento e como atividade, cf. supra, item n. 1.2.1.1 e nota $\mathrm{n} .52$.

${ }^{33}$ No que se refere à reserva da comunicação, como elemento integrante do gênero interceptação de comunicação, cf.: CAMON, Alberto. Le intercettazioni nel processo penale. Milano: Giuffrè, 1996, p. 16, apud
} 
terceiros. O caráter reservado da comunicação é evidenciado pelo local escolhido pelos interlocutores e pela forma de exteriorização, que revelam o desejo de manter o seu conteúdo alheio ao conhecimento de terceiros. A comunicação reservada constitui o objeto da interceptação de comunicação entre pessoas presentes. ${ }^{34}$

Ademais, a interceptação de comunicação presencial pressupõe que o sujeito captador seja um terceiro, isto é, pessoa distinta dos interlocutores. ${ }^{35}$ A terzietà, como se diz em Itália, é elemento que integra o conceito da interceptação de comunicação entre pessoas presentes. ${ }^{36}$

No que se refere ao meio empregado na atividade de interceptação de comunicação entre pessoas presentes, há divergência em doutrina. Duas categorias de meios de captação do conteúdo da comunicação são invocadas: meios naturais (captação fisiológica das comunicações orais, com os próprios sentidos) e meios artificiais (técnicos, também denominados mecânicos, eletrônicos ou tecnológicos). ${ }^{37}$

Identificamos, em doutrina, três correntes de pensamento sobre os meios que podem ser empregados para captação do conteúdo de uma comunicação em atividade de interceptação: apenas meios técnicos; ${ }^{38}$ meios técnicos e meios naturais; ${ }^{39}$ meios técnicos e

MARTINO, Corrada di; PROCACCIANTI, Teresa. Le intercettazioni... op. cit., p. 16; MARTINO, Corrada di. Le intercettazioni ambientali ... op. cit., p. 1.149-1.150; TONINI. A prova... op. cit., p. 248-249.

${ }^{34}$ Mais detidamente, analisamos o objeto da interceptação de comunicação entre pessoas presentes no item n. 3.3, infra.

${ }^{35}$ Cf. GRINOVER, Ada Pellegrini; GOMES FIHO, Antonio Magalhães; FERNANDES, Antonio Scarance. As nulidades... op. cit., p. 164-165; FERNANDES, Antonio Scarance. Processo penal... op. cit., p. 92-93; AVOLIO, Luiz Francisco Torquato. Provas ilícitas... op. cit., p. 92. O terceiro aqui referido é ainda apresentado no item sobre os sujeitos ativos (infra, n. 3.5) e no item acerca da distinção entre interceptação de comunicação entre pessoas presentes e gravação clandestina de comunicação entre pessoas presentes (infra, n. 3.8.2).

36 Tal elemento é intitulado pela doutrina italiana como "terzietà dell'operatore" (BRUNO, Pierfrancesco. Intercettazioni di comunicazioni... op. cit., p. 179). Em sentido semelhante, cf.: BARGI, Alfredo. Intercettazioni di comunicazioni... op. cit., p. 791; MARTINO, Corrada di; PROCACCIANTI, Teresa. Le intercettazioni... op. cit., p. 20; BALDUCCI, Paola. Le garanzie... op. cit., p. 12; FILIPPI, Leonardo. Intercettazione di comunicazioni... op. cit., p. 1; MARTINO, Corrada di. Le intercettazioni ambientali ... op. cit., p. 1.149-1.150; TONINI. A prova... op. cit., p. 248-249.

${ }^{37}$ CLAUDIO MARINELLI, para expressar a artificialidade do meio empregado em interceptação, adjetiva-o de técnico, mecânico, eletrônico ou tecnológico (Intercettazioni processuali... op. cit, p. 6, 13-16). Quanto ao emprego dos adjetivos mecânico e eletrônico, cf: MARTINO, Corrada di; PROCACCIANTI, Teresa. Le intercettazioni... op. cit., p. 18-19. Utiliza o adjetivo mecânico: CAPRIOLI, Francesco. Intercettazione e registrazione... op. cit., p. 152-160.

${ }^{38}$ Neste sentido, cf.: CAPRIOLI, Francesco. Intercettazione e registrazione... op. cit., p. 152-160; MARTINO, Corrada di; PROCACCIANTI, Teresa. Le intercettazioni... op. cit., p. 18-19; MARTINO, Corrada di. Le 
meios naturais, desde que o emprego destes seja acompanhado da utilização de um instrumento de registro. ${ }^{40}$

A distinção entre o emprego de meio natural ou de meio técnico em interceptação consiste no fato de que os dispositivos tecnológicos geram reprodução do conteúdo da comunicação com um alto grau imitativo e permitem uma indefinida repetição da escuta do conteúdo gravado. ${ }^{41}$ De outro lado, os órgãos sensoriais conduzem a um conhecimento direto do ato comunicativo, que pode ser conhecido por meio de uma "prova declarativa". ${ }^{4}$

O emprego de meios mecânicos ou eletrônicos propiciam a superação dos limites do que é naturalmente perceptível para o registro de dado comunicativo, ${ }^{43}$ ou seja, são idôneos a superar as normais aptidões dos sentidos humanos. ${ }^{44}$

Sem embargo da pertinência do debate, a delimitação do instituto da interceptação, nele incluído o respectivo procedimento probatório, parece-nos voltada ao emprego de meios técnicos para captação de conteúdo de comunicação. ${ }^{45}$ As informações registradas por meios

intercettazioni ambientali ... op. cit., p. 1.149-1.150; MARINELLI, Claudio. Intercettazioni processuali... op. cit, p. 13-14; BARGI, Alfredo. Intercettazioni di comunicazioni... op. cit., p. 791; BALDUCCI, Paola. Le garanzie... op. cit., p. 12; GIANNALOPOULOS, Dimitri; PARIZOT, Raphaêlle. La preuve technologique... op. cit., p. 246. No Brasil, ADA PELLEGRINI GRINOVER afirma que a interceptação configura "operação técnica" (Interceptações telefônicas... op. cit., p. 423).

39 Os seguidores desta corrente doutrinária ressaltam a necessidade de observância da regulamentação da interceptação, independentemente do meio empregado (Cf. BRUNO, Pierfrancesco. Intercettazioni di comunicazioni... op. cit., p. 179; FILIPPI, Leonardo. Intercettazione di comunicazioni... op. cit., p. 1).

${ }^{40}$ Neste sentido, cf: FILIPPI, Leonardo. L'intercettazioni di comunicazioni. Milano: Giuffrè, p. 8, apud MARINELLI, Claudio. Intercettazioni processuali... op. cit, p. 15.

${ }^{41}$ Cf. MARINELLI, Claudio. Intercettazioni processuali... op. cit, p. 14.

${ }^{42}$ Cf. Ibidem, p. 14.

${ }^{43} \mathrm{O}$ meio artificial não deve ser necessariamente sofisticado. O importante não é o grau de complexidade do aparato tecnológico, mas a idoneidade para superar as precauções que os interlocutores adotam para manter em reserva o conteúdo da comunicação entre eles travada (Cf. MARINELLI, Claudio. Intercettazioni processuali... op. cit, p. 13-14). Em sentido semelhante, ADA PELLEGRINI GRINOVER, em estudo sobre interceptação telefônica, enfatiza que a interceptação constitui “operação técnica” (Liberdades públicas... op. cit., p. 203).

${ }^{44}$ Justifica-se tal elemento, como integrante da noção de interceptação, com a observação de que se cuida de meios de investigação insidiosos que se inserem onde a percepção dos sentidos humanos não pode chegar. Este elemento justifica a instituição de uma disciplina específica, distinta dos demais meios de prova (MARTINO, Corrada di; PROCACCIANTI, Teresa. Le intercettazioni... op. cit., p. 18-19).

${ }^{45}$ Com fundamento neste elemento integrante do conceito de interceptação, FRANCESCO CAPRIOLI, embora reconheça a existência de violação ao sigilo das comunicações, exclui do regime de interceptação as seguintes hipóteses: o sigilo é violado sem o emprego de instrumentos mecânicos; o destinatário da comunicação efetua a captação; e a comunicação é captada pelos próprios sentidos (Intercettazione e registrazione... op. cit., p. 152 160). Também com esteio neste elemento, CLAUDIO MARINELLI assevera que não constitui interceptação a 
naturais - isto é, com os sentidos humanos - podem ser conhecidas por outros meios de prova, como, por exemplo, na hipótese de prova testemunhal. ${ }^{46}$

A operação de interceptação de comunicação entre pessoas presentes, mediante os referidos meios técnicos, há que ser oculta e simultânea ao processo comunicativo.

Por ser espécie de meio de investigação de prova, a interceptação é fundada no fator surpresa, ${ }^{47}$ que acompanha sua realização. É com base em sua natureza ${ }^{48}$ que a doutrina afirma que se trata de operação oculta, ${ }^{49}$ clandestina $^{50}$ ou sigilosa. ${ }^{51}$

oculta apreensão propria aure (com o próprio ouvido), de uma comunicação alheia. Acrescenta o autor, ainda, que parece pouco convincente considerar como interceptação a mera "captação fisiológica" de diálogos entre presentes (Cf. Intercettazioni processuali... op. cit, p. 13 e 16). O emprego de meio técnico como integrante do conceito de interceptação de comunicação entre pessoas presentes também é preconizado em doutrina nacional. ADA PELLEGRINI GRINOVER, ANTONIO MAGALHÃES GOMES FIHO e ANTONIO SCARANCE FERNANDES afirmam: "se o meio utilizado for o 'grampeamento' do telefone, tem-se a interceptação telefônica; se se tratar de captação de conversa por um gravador, colocado por um terceiro, tem-se interceptação entre presentes, também chamada de interceptação ambiental" (As nulidades... op. cit., p. 164-165). No mesmo sentido, FERNANDES, Antonio Scarance. Processo penal... op. cit., p. 92-93). O mencionado "gravador" é meio técnico.

${ }^{46}$ Para as hipóteses de conhecimento direto, sem o emprego de instrumentos mecânicos, FRANCESCO CAPRIOLI sugere a aplicação da disciplina do testemunho indireto (testimonianza indiretta), com as limitações que lhe são inerentes (Intercettazione e registrazione... op. cit., p. 152-160). O testemunho dito indireto ("testimonianza indiretta"), é regulamentado no art. 195 do Código de Processo Penal italiano. Nesta modalidade de testemunho, a testemunha "de referência" ou "por ouvir dizer", fonte de prova secundária, conhece um fato indiretamente, colhendo informações de fonte primária (testemunha direta), sem os mecanismos estabelecidos pela legislação para a sua colheita. A lei italiana estabelece a necessidade de a testemunha indireta indicar a pessoa ou a fonte da qual apreendeu a notícia acerca do fato objeto do depoimento. Desta forma, possibilita-se a sucessiva produção da prova testemunhal direta, requerida pelas partes, ou ordenada de ofício pelo juiz (arts. 195.1 e 195.2), observadas as balizas do exame cruzado. Embora não regulamentada na lei processual penal brasileira, a doutrina reconhece a pertinência do debate sobre o testemunho indireto. GUSTAVO HENRIQUE RIGHI IVAHY BADARÓ observa que os elementos de informações prestados pela testemunha indireta são válidos para que se descubra a fonte de prova originária, isto é, a testemunha presencial, a qual deverá ingressar em processo pelo respectivo meio de produção de prova. O autor acrescenta: "é necessário que a testemunha reproduza uma percepção originária e direta do fato a ser provado, isto é, por ela imediatamente recebido. No testemunho indireto há uma cognição reflexa, que não fornece elementos seguros de informação, até mesmo porque a testemunha direta não terá qualquer responsabilidade pelo que a testemunha indireta tenha dito" (Direito processual penal: tomo I... op. cit., p. 247, e nota 83 desta página).

${ }^{47}$ Cf. supra, item n. 1.2.1.1.

${ }^{48} \mathrm{Cf}$., infra, item n. 3.4.

${ }^{49}$ A "Corte di Cassazione" italiana decidiu que a interceptação consiste na captação oculta e contextual de uma comunicação entre dois ou mais sujeitos, operada por um sujeito estranho à mesma (ud. 28 maggio $2003 \mathrm{n}$. 36747, Torcasio, rv. 225465) Disponível em: http://www.cortedicassazione.it/Documenti/RelSezUnPenali_2004.pdf. Acesso em: 15/07/2010. p. 85. Cf. Comentários sobre o aresto em: APRILE, Ercole; SPIEZIA, Filippo. Le intercettazioni... op. cit., p. 2, nota 1).

${ }^{50}$ Cf. TONINI. A prova... op. cit., p. 248-249.

${ }^{51}$ Cf. CAPRIOLI, Francesco. Intercettazione e registrazione... op. cit., p. 152-160. 
Também integra o conceito de interceptação a simultaneidade entre a ocorrência da comunicação presencial e a captação do respectivo conteúdo ${ }^{52}$ Os operadores da interceptação devem, concomitantemente, escutar e registrar o conteúdo da comunicação. ${ }^{53}$

Como se trata de atividade oculta, sigilosa, a interceptação é concretizada sem o conhecimento dos interlocutores. ${ }^{54}$ Não desfigura a natureza da interceptação o fato de um dos interlocutores saber que ela esteja a ocorrer, ${ }^{55}$ hipótese em que é denominada escuta $^{56}$ de comunicação entre pessoas presentes. ${ }^{57}$

${ }^{52}$ CLAUDIO MARINELLI, afirmando a simultaneidade, afirma que a captação deve ocorrer em tempo real, de
forma contextual (Intercettazioni processuali... op. cit, p. 16).
${ }^{53}$ Cf. MARTINO, Corrada di; PROCACCIANTI, Teresa. Le intercettazioni... op. cit., 2001, p. 124. A Corte di ${ }^{53}$ Cf. MARTINO, Corrada di; PROCACCIANTI, Teresa. Le intercettazioni... op. cit., 2001, p. 124. A Corte di
Cassazione italiana decidiu que a interceptação consiste na captação oculta e contextual de uma comunicação entre dois ou mais sujeitos, operada por um sujeito estranho à mesma (ud. 28 maggio 2003 n. 36747, Torcasio, rv. 225465) Disponível em: http://www.cortedicassazione.it/Documenti/RelSezUnPenali_2004.pdf. Acesso em:

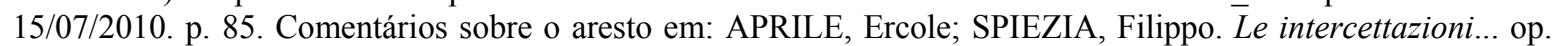
cit., p. 2, nota 1).

${ }^{54}$ Cf. CAPRIOLI, Francesco. Intercettazione e registrazione... op. cit., p. 159.

${ }^{55} \mathrm{O}$ terceiro deve ser ignorado por pelo menos um dos interlocutores (BRUNO, Pierfrancesco. Intercettazioni di comunicazioni... op. cit., p. 184).

${ }^{56}$ Cf. GRINOVER, Ada Pellegrini; GOMES FIHO, Antonio Magalhães; FERNANDES, Antonio Scarance. As nulidades... op. cit., p. 164-165; AVOLIO, Luiz Francisco Torquato. Provas ilícitas... op. cit., p. 99.

${ }^{57}$ A propósito, a doutrina italiana debate acerca do grau de clandestinidade necessário para o reconhecimento de uma interceptação, isto é, se todos os interlocutores devem desconhecer a atividade de captação do conteúdo da comunicação, ou se basta que seja ignorada por apenas um deles (MARINELLI, Claudio. Intercettazioni processuali... op. cit, p. 18-20). E o sucessivo questionamento versa sobre a aplicabilidade de um mesmo regime para ambos os institutos, sobre o qual identificamos correntes de pensamento distintas. Segundo alguns, não se trata de interceptação, porque a situação se assemelharia àquela em que um dos interlocutores capta o conteúdo da comunicação de que participa (MARTINO, Corrada di; PROCACCIANTI, Teresa. Le intercettazioni... op. cit., p. 20). Outros a consideram como interceptação, sob o argumento de que a negativa do regime da interceptação significaria a possibilidade de a operação se realizar com o consentimento de um dos interlocutores, com dispensa de autorização judicial, o que violaria a exigência de reserva de jurisdição para interferência em esfera jurídica alheia. Invoca-se, também, o âmbito de admissibilidade da interceptação (cf., infra, item n. 4.2.2.2.6), no qual se insere a persecução de ameaça por meio de telefone, que é costumeiramente noticiada pela vítima (art. 266.1 do Código de Processo Penal italiano) (MARTINO, Corrada di; PROCACCIANTI, Teresa. Le intercettazioni... op. cit., p. 21; BALDUCCI, Paola. Le garanzie... op. cit., p. 13-14; CAMON, Alberto. Le intercettazioni nel processo penale. Milano: Giuffrè, 1996, p. 21, apud MARTINO, Corrada di; PROCACCIANTI, Teresa. Le intercettazioni... op. cit., p. 21). O conhecimento da escuta por parte de alguns dos interlocutores não exclui a natureza de interceptação. Mas tal fato influi sobre a genuinidade e espontaneidade da conversa, do que se extrai a questão sobre a valoração por autoridade judicial dos elementos de informação captados (BALDUCCI, Paola. Le garanzie... op. cit., p. 14). No direito brasileiro, o legislador apenas se referiu nominalmente à interceptação de comunicação entre presentes (art. $2^{\circ}$, caput e inciso IV da Lei ${ }^{\circ}$ 9.034, de 1995), sem diferenciar interceptação e escuta (cf., infra, item n. 5.3.1.1). No que se refere à atual regulamentação da interceptação de comunicações telefônicas no direito brasileiro, prevista na Lei no 9.296, de 1996, também não se identifica distinção no tratamento legislativo. Nas Emendas ao Projeto de novo Código de Processo Penal Instituto Brasileiro de Direito Processual (IBDP), também se propõe, como hipótese de cabimento, assim como previsto no ordenamento italiano, a ameaça e os crimes contra a honra cometidos por meio de telefone (art. 241, inciso XIII), evidenciando a manutenção da semelhança de tratamento legislativo a ambos os institutos, interceptação e escuta (Cf. INSTITUTO BRASILEIRO DE DIREITO PROCESSUAL. Propostas de emendas ao 
Considerado o caráter clandestino das interceptações, afirma-se que nenhuma eficácia se pode atribuir a uma captação de comunicação com o consentimento de todos aqueles que dela participam. ${ }^{58}$

Vistos os elementos do conceito de interceptação de comunicação entre pessoas presentes, deles destacamos, no item seguinte, a comunicação entre pessoas presentes, que é seu objeto, para o aprofundamento da análise que o tema exige.

\subsection{Objeto}

O objeto da interceptação de comunicação entre pessoas presentes é uma conversação por meio de reprodução de emissão de sinais sonoros da voz humana, ${ }^{59}$ que se propagam no espaço aéreo em que estejam presentes as pessoas interlocutoras. De forma sintetizada, trata-se de comunicação oral entre pessoas de forma presencial. ${ }^{60}$

Três aspectos da comunicação entre pessoas presentes objeto de interceptação processual devem ser salientados: a voluntariedade do ato comunicativo, o número de participantes e o caráter reservado.

$\mathrm{O}$ ato comunicativo é essencialmente voluntário. A liberdade de comunicação, que é espécie da liberdade de manifestação do pensamento, pode ser exercida ou não pelo seu titular, de acordo com sua vontade. ${ }^{61}$

projeto de lei de código de processo penal. Substitutivo CCJ do Senado. Disponível em: http://novo.direitoprocessual.org.br/content/blocos/96/1. Acesso em: 06/01/2011, p. 23).

${ }^{58}$ Cf. MARINELLI, Claudio. Intercettazioni processuali... op. cit, p. 17.

59 ADA PELLEGRINI GRINOVER, em estudo sobre a interceptação de comunicação telefônica, refere-se a "elementos fonéticos" (Liberdades públicas... op. cit., p. 203).

${ }^{60}$ A respeito da abrangência da comunicação entre pessoas presentes, verifiquem-se, também, as considerações expendidas no item n. 2.1, supra.

${ }^{61}$ Sobre a liberdade de comunicação entre pessoas presentes, cf., supra, itens n. 2.2 e n. 2.2.1. 
Sendo necessariamente voluntário o ato comunicativo, havendo coação física em desfavor da pessoa interlocutora, a vontade não será do sujeito coagido, mas do sujeito coator (autor mediato), quem se serve do primeiro como instrumento. ${ }^{62}$ De outro lado, o erro, a violência moral e o dolo, empregados para indução de alguém a concretizar uma comunicação não descaracterizam a voluntariedade do ato, apesar de alterá-lo em seu processo formativo. ${ }^{63}$

No que tange ao número de participantes, em geral, diz-se que a noção de comunicação pressupõe a pluralidade de participantes. ${ }^{64}$ Tratando-se de diálogo ou colóquio, ${ }^{65}$ da percepção empírica da comunicação se extrai o seu caráter intersubjetivo.

Todavia, a doutrina diverge quanto à natureza do monólogo, ${ }^{66}$ isto é, se há ou não comunicação na hipótese de uma pessoa externar o seu pensamento a si mesmo. Em outras palavras, a discussão se expressa em reconhecer ou não a possibilidade de comunicação do "eu exterior" com o "eu interior". ${ }^{67}$ Esta questão surge do fato de que, embora não haja comunicação em sentido estrito, o conteúdo da reflexão exteriorizada pode interessar à persecução penal.

Em Itália, notam-se duas correntes doutrinárias sobre o monólogo, que podem ser assim sintetizadas: o monólogo não constitui comunicação, pela ausência do caráter de intersubjetividade ${ }^{68}$ o monólogo é tido como comunicação do sujeito consigo mesmo. ${ }^{69}$

\footnotetext{
${ }^{62}$ Cf. MARINELLI, Claudio. Intercettazioni processuali... op. cit, p. 22.

${ }^{63}$ Cf. Ibidem, p. 22.

${ }^{64}$ Cf. Ibidem, p. 22.

${ }^{65}$ Diálogo e colóquio são aqui empregados como termos sinônimos, para expressarmos a "fala entre duas ou mais pessoas" (FERREIRA, Aurélio Buarque de Holanda. Novo Dicionário Aurélio. 3. ed. Curitiba: Editora Positivo, 2004. Versão eletrônica).

${ }^{66}$ Sinônimo de solilóquio, monólogo significa a fala de alguém consigo mesmo em voz alta (ROXIN, Claus. $L a$ prohibición... op. cit., p. 99).

${ }^{67}$ Em doutrina, o monólogo também é apontado como o ato de "pensar em alta voz" (MARINELLI, Claudio. Intercettazioni processuali... op. cit, p. 23).

${ }^{68}$ Cf. MARINELLI, Claudio. Intercettazioni processuali... op. cit, p. 23; CAMON, Alberto. Le riprese visive come mezzo d'indagine: spunti per una riflessione sulle prove incostituzionali. In: Cassazione penale, 1999 apud MARTINO, Corrada di; PROCACCIANTI, Teresa. Le intercettazioni... op. cit., p. 68.

${ }^{69}$ Cf. CAPRIOLI, Francesco. Colloqui riservatti e prova penale. Torino: Giappichelli, 2000, p. 176, apud MARINELLI, Claudio. Intercettazioni processuali... op. cit, p. 23.
} 
Sem embargo da pertinência do debate sobre a consideração do monólogo como comunicação ou não, ${ }^{70}$ consideramos necessária a sua proteção.

No direito brasileiro, reputamos que eventual interceptação de monólogo restringiria os direitos e garantias individuais que fundamentam a tutela da comunicação entre pessoas presentes: a liberdade de manifestação do pensamento, o direito à intimidade e à vida privada, a inviolabilidade do domicílio (estando a pessoa em domicílio) e o direito a não autoincriminação. ${ }^{71}$ Não se considerando o monólogo comunicação, obviamente, não se pode invocar a liberdade de comunicação. No entanto, a liberdade de manifestação do pensamento, da qual é espécie a liberdade de comunicação, é também restringida com a interceptação do monólogo.

A diferença consiste na intensidade de restrição a estes direitos e garantias fundamentais, maior em captação de conteúdo de monólogo. ${ }^{72}$ Trata-se de manifestação em âmbito recôndito do indivíduo, cuja proteção é indispensável para o exercício de suas liberdades. É por isso que entendemos que deva ser excluída da admissibilidade de interceptação processual o monólogo. ${ }^{73}$

O último aspecto aqui salientado da comunicação entre pessoas presentes que seja objeto de interceptação processual diz respeito ao seu caráter reservado.

\footnotetext{
70 Escapa aos limites do presente trabalho o aprofundamento da questão sobre a identidade ou não entre monólogo e comunicação. Avaliamos que a reflexão sobre este tema deva abarcar também outras áreas do conhecimento humano, entre as quais destacamos a psicologia. A despeito disso, deixamos, nos parágrafos seguintes, uma proposta de tratamento jurídico do tema, sob a perspectiva da interceptação processual, independentemente de prévia definição sobre a identidade ou não entre o monólogo e a comunicação.

${ }^{71}$ Cf. supra, itens n. 2.1 a 2.6 .

72 Chegamos a semelhante conclusão ao examinarmos, no tema dos sujeitos passivos da interceptação de comunicação entre pessoas presentes, as conversas mantidas no âmbito profissional e no âmbito familiar. Em razão da maior intensidade de restrição de direitos e garantias fundamentais, sustentamos que, em regra, não deve ser admitida interceptação de comunicação nestes âmbitos (cf., infra, item n. 3.6).

${ }^{73}$ Neste sentido, o Tribunal Supremo alemão, em sentença proferida em 10 de agosto de 2005 (BHGHst 50, p. 206 e ss.) - interpretando a sentença BVerfGE 109 (p. 179 e ss.) proferida pelo Tribunal Constitucional Alemão e a nova regulamentação legal da vigilância acústica - considerou que não poderia valorar como prova a gravação de um monólogo de investigado, ocorrido em uma habitação de hospital, por se inserir no "âmbito essencial da vida privada". Tal entendimento, acolhido pela doutrina, impossibilita a realização de interceptação (ROXIN, Claus. La prohibición... op. cit., p. 87, 99-113). No que se refere à disciplina alemã da interceptação de comunicação entre pessoas presentes, cf., infra, item n. 4.2.2.2.1.
} 
A comunicação entre pessoas presentes captada em interceptação deve ser reservada. ${ }^{74}$ A verificação da configuração ou não do caráter reservado da comunicação deve ser extraído, de forma objetiva, de suas características, especialmente da forma de exteriorização, que visa a resguardar o seu conteúdo. ${ }^{75}$

Para tanto, é necessário examinar o contexto concreto em que estejam os interlocutores. Deve-se observar se eles observaram as precauções necessárias para criação de uma "zona franca" (região isolada e delimitada), dentro da qual seria desarrazoado cogitar a possibilidade de intrusões alheias. ${ }^{76}$

A comunicação é reservada se a sua percepção é restrita a determinados sujeitos presentes no espaço onde seja concretizada, com exclusão de qualquer terceiro que não seja destinatário direto ou indireto. ${ }^{77} \mathrm{O}$ destinatário direto é a pessoa a quem a informação comunicada é dirigida; o destinatário indireto é qualquer pessoa que o emitente - não ignorando a sua presença e identidade - consinta que esteja em condições de escutar, como a pessoa estranha a conversa, presente de modo manifesto no local em que se desenvolva a comunicação. ${ }^{78}$ Note-se que o destinatário indireto da comunicação é quem esteja em situação

\footnotetext{
${ }^{74}$ Cf. BRUNO, Pierfrancesco. Intercettazioni di comunicazioni... op. cit., p. 178 e 180; BARGI, Alfredo. Intercettazioni di comunicazioni... op. cit., p. 791.

${ }^{75}$ Cf. FILIPPI, Leonardo. Intercettazione di comunicazioni... op. cit., p. 1.

${ }^{76}$ Cf. BRUNO, Pierfrancesco. Intercettazioni di comunicazioni... op. cit., p. 179 e 184.

${ }^{77}$ Cf. CAPRIOLI, Francesco. Intercettazione e registrazione... op. cit., p. 146. A doutrina italiana afirma que se uma comunicação reservada percebida por um sujeito que não seja aqueles aos quais é endereçada, direta ou indiretamente, é violado o diritto alla segretezza das comunicações. De outro lado, se o conteúdo de uma comunicação reservada for revelado a terceiros por quem a escutou de forma legítima, tem-se lesão ao diritto alla riservatezza (CAPRIOLI, Francesco. Intercettazione e registrazione... op. cit., p. 146-148). Demais disso, reconhece-se a possibilidade de lesão ao diritto alla segretezza sem violação ao diritto alla riservatezza (por exemplo, se a notícia irregularmente captada não for divulgada, ou não tiver caráter privado), e de lesão ao diritto alla riservatezza sem violação do diritto alla segretezza (como no caso de a notícia privada divulgada ser regularmente captada), e de lesão a ambos os aspectos da intimidade (a comunicação é captada irregularmente e o seu conteúdo, de caráter privado, é divulgado) (CAPRIOLI, Francesco. Intercettazione e registrazione... op. cit., p. 149). Tal raciocínio pode ser estendido ao direito brasileiro, considerando que a doutrina também extrai da intimidade os mencionados interesses, de segredo e de reserva (cf. supra, item n. 2.3).

${ }^{78}$ A doutrina observa que o ânimo do autor da comunicação, quanto à delimitação de seus destinatários, emerge de suas características objetivas, nelas compreendidas o seu conteúdo e a forma pela qual é realizada. Por exemplo, não são tidos por reservados: as comunicações entre pessoas que discutem em voz alta em lugar com aglomeração de pessoas; o apelo lançado por pessoa a outra por meio da televisão; a comunicação que tenha por destinatário um número indeterminado de sujeitos, como a conferência e o programa televisivo (CAPRIOLI, Francesco. Intercettazione e registrazione... op. cit., p. 146). Ao contrário, também como ilustração, é reconhecido o caráter reservado a palavras pronunciadas por uma pessoa no próprio domicílio em presença
} 
que o permita conhecer o conteúdo da comunicação, por vontade de todos os comunicantes. Sendo assim, o destinatário indireto não é terceiro e não desenvolve atividade de interceptação.

Certos locais, considerada a função que exercem para o exercício das liberdades humanas, são permeados pela intimidade. É o caso do domicílio privado ou do domicílio profissional. ${ }^{79}$ Nestes locais, há que se considerar o caráter reservado da comunicação, mesmo se os dialogantes falarem sem cautelas, com tom e forma que, se empregados em local público, podem significar exclusão do caráter reservado. ${ }^{80}$

Com efeito, reputamos que o caráter reservado de uma comunicação é evidenciado pelo local escolhido pelas pessoas interlocutoras e pela forma de sua exteriorização. Se estiverem em domicílio, é nítido o caráter reservado da comunicação; mas se o local não for domicílio, é necessária a avaliação das características do local, da forma de exteriorização da comunicação e das cautelas observadas pelos interlocutores, para excluir de terceiros o conhecimento de seu conteúdo.

\subsection{Natureza jurídica}

Delimitado o conceito e o objeto da interceptação de comunicação entre pessoas presentes, inserimo-la entre os meios de investigação de prova. ${ }^{81}$

\footnotetext{
somente de interlocutor, ou de interlocutor e de terceiras pessoas por ele notadas (CAPRIOLI, Francesco. Intercettazione e registrazione... op. cit., p. 146).

${ }^{79}$ Cf. BRUNO, Pierfrancesco. Intercettazioni di comunicazioni... op. cit., p. 179. CLAUDIO MARINELLI salienta que, em se tratando de comunicação operada em domicílio, em regra, é presumido o caráter reservado (Intercettazioni processuali... op. cit, p. 24-25).

${ }^{80}$ Cf. BRUNO, Pierfrancesco. Intercettazioni di comunicazioni... op. cit., p. 179; CAPRIOLI, Francesco. Intercettazione e registrazione... op. cit., p. 146. Em sentido contrário, entende-se que o comportamento dos interlocutores pode retratar intenção de divulgação, como no caso em que se converse em alta voz com as janelas abertas (MARINELLI, Claudio. Intercettazioni processuali... op. cit, p. 24-25).

${ }^{81}$ Reiteramos aqui todas as observações sobre os aspectos gerais dos meios de investigação de prova, aos quais dedicamos o primeiro capítulo: cf. supra, itens n. 1.1. a n. 1.6. No mesmo sentido, quanto a interceptação de comunicação telefônica, ADA PELLEGRINI GRINOVER a insere entre os "meios de busca da prova", afirmando que se trata de coação processual in re: "poder de coação que se exerce sobre as comunicações
} 
A interceptação de comunicação entre pessoas presentes deve ver vista como meio de investigação de prova típico, extraordinário e repressivo.

A admissibilidade e o procedimento probatório deste meio devem constar de sua disciplina legal - considerada a exigência de reserva legal para a restrição de comunicação entre pessoas presentes - e integram a sua tipicidade probatória. ${ }^{82}$

É extraordinário, porque restringe, em demasia, direitos e garantias fundamentais assegurados pela Constituição ao indivíduo. ${ }^{83}$

E a sua utilização se insere, na persecução penal, em atividade repressiva, desenvolvida após o cometimento de um delito.

É também com fulcro na noção de tipo processual, que apresentamos os sujeitos ativos, os sujeitos passivos e o objeto deste instituto. ${ }^{84}$

\subsection{Sujeitos ativos}

Os sujeitos ativos ${ }^{85}$ de interceptação de comunicação se referem tanto a legitimados ativos, para formulação de requerimento de autorização da medida, como também a órgãos

telefônicas alheias, por intermédio de formas de ingerência feitas por terceiro" (Liberdades públicas... op. cit., p. 202).

${ }^{82}$ Sobre a exigência de reserva legal e dos aspectos que devem integrar a disciplina do instituto, cf. supra, item $\mathrm{n}$. 2.6, e, infra, item n. 3.10.

${ }^{83}$ Retomamos aqui a crítica expendida quanto à classificação entre meios de investigação de prova ordinários e extraordinários. Considerada a sua inerente restrição a direitos fundamentais, os meios de investigação de prova constituem são, em sua essência, meios extraordinários (v., supra, item n. 1.4.2).

${ }^{84}$ No que se refere à noção de tipicidade processual, de forma especial quanto aos meios de investigação de prova, cf. supra, itens n. 1.2.3.2 e n. 1.4.1.

${ }^{85}$ Cf. MARINELLI, Claudio. Intercettazioni processuali... op. cit, p. 43; BRUNO, Pierfrancesco. Intercettazioni di comunicazioni... op. cit., p. 26; BALDUCCI, Paola. Le garanzie... op. cit., p. 13. 
executivos, ${ }^{86}$ também chamados pessoas operantes,${ }^{87}$ que desenvolvem a atividade de captação e de registro do conteúdo da comunicação.

No direito brasileiro, parece-nos que a legitimidade ativa para requerimento de execução de interceptação de comunicação entre pessoas presentes deva ser atribuída aos entes titulares do direito à prova ${ }^{88} \mathrm{e}$ ao órgão incumbido da investigação criminal.

A justificativa da legitimidade ativa da autoridade policial decorre de sua atribuição constitucional de concretização da investigação criminal. ${ }^{89}$

Além disso, a legitimidade ativa deve ser reconhecida aos entes que formulam a acusação. Não deve ser atribuída apenas ao Ministério Público. ${ }^{90} \mathrm{O}$ mesmo interesse que tem a acusação em descoberta de fontes de prova, para fundamentar o exercício do direito de ação, justifica a atribuição de legitimidade à vítima. ${ }^{91}$

Igualmente recomendável é a atribuição de legitimidade a acusado, para propiciar a descoberta de fontes de prova em seu favor e para efetivação da garantia da ampla defesa. ${ }^{92}$

\footnotetext{
${ }^{86}$ Cf. BRUNO, Pierfrancesco. Intercettazioni di comunicazioni... op. cit., p. 190.

${ }^{87}$ Cf. Ibidem, p. 190.

${ }^{88}$ A respeito da atribuição da investigação no direito nacional e do exercício do direito a prova na fase de investigação, cf. supra, itens n. 1.1 e n. 1.2.

${ }^{89}$ A Lei $\mathrm{n}^{\circ}$ 9.296, de 1996, por exemplo, atribui legitimidade à autoridade policial para requerimento de interceptação de comunicação telefônica. Reputamos semelhante previsão compatível com a interceptação de comunicação entre pessoas presentes.

${ }^{90}$ Neste sentido, confiram-se as críticas da doutrina estrangeira sobre a atribuição de legitimidade exclusiva ao Ministério Público (infra, item n. 4.2.2.2.6). É preciso observar o princípio da igualdade, na atividade probatória, na concessão de oportunidades processuais aos interessados na persecução penal.

${ }^{91}$ Em sentido semelhante, referindo-se a interceptação de comunicação telefônica, cf.: MACHADO, André Augusto Mendes; KEHDI, André Pires de Andrade. Sigilo das comunicações... op. cit., p. 254.

${ }^{92}$ Em sentido semelhante, referindo-se a interceptação de comunicação telefônica, cf.: DELMANTO, Roberto; DELMANTO JUNIOR, Roberto. A permissão constitucional e a nova lei de interceptação telefônica. Boletim IBCCRIM, São Paulo, n.47, out. 1996, p. 2; STRECK, Lenio Luiz. As interceptações telefônicas e os direitos fundamentais: Constituição, Cidadania, Violência: a Lei 9.296/96 e seus reflexos penais e processuais. Porto Alegre: Livraria do Advogado, 2001, p. 81-82; MACHADO, André Augusto Mendes; KEHDI, André Pires de Andrade. Sigilo das comunicações... op. cit., p. 254. Sobre a relação entre o direito de defesa e a atividade probatória: cf. GRINOVER, Ada Pellegrini. A defesa penal e sua relação com a atividade probatória. Revista Brasileira de Ciências Criminais, São Paulo, RT, ano 10, n. 40, out-dez. 2002, p. 95-98.
} 
A interceptação de comunicação entre presentes há que ser requerida por legitimado ativo a autoridade competente, que, no direito nacional, é a autoridade judicial, ${ }^{93}$ porque a restrição a direitos fundamentais é matéria reservada à análise do Poder Judiciário. ${ }^{94}$

Debate-se sobre a possibilidade de autorização judicial ex officio para realização de interceptações de comunicações. ${ }^{95}$ Reputamos que, no sistema acusatório estruturado pela Constituição brasileira, à autoridade judicial é atribuída a função de processar e de julgar, motivo pelo não pode exercer a função de investigação, ${ }^{96}$ por exemplo, com o decreto, de ofício, de interceptação de comunicação presencial.

Autorizada a interceptação de comunicação entre pessoas presentes requerida por um legitimado à autoridade competente, a captação e o registro do conteúdo da comunicação são operados por um terceiro - distinto dos interlocutores - integrante do órgão incumbido da investigação criminal. $^{97}$ No Brasil, a atividade de investigação é atribuída à polícia repressiva. $^{98}$

\footnotetext{
${ }^{93}$ Em outros ordenamentos, a autorização de interceptação de comunicações é atribuída a outros entes, como, por exemplo, o Ministério Público. Isto ocorre, por exemplo, em situações excepcionais e com limitações, no direito italiano (v., infra, item n. 4.2.2.2.6), o que é criticado em doutrina, pois os atos que implicam restrições a direitos fundamentais de pessoa devem ser atribuídos a um sujeito diverso daquele que possa exercer a ação penal (BALDUCCI, Paola. Le garanzie... op. cit., p. 120). No direito brasileiro, entende-se que, em razão da consagração do sistema acusatório e da reserva de jurisdição, o legislador não pode atribuir a mencionada autorização ao Ministério Público: "extraída a regra de reserva de jurisdição para a quebra do sigilo do sistema acusatório e das regras do devido processo, inscritos na Constituição, conclui-se que não pode a lei ordinária dar tal atribuição ao Ministério Público ou à autoridade policial.” (FERNANDES, Antonio Scarance. O sigilo... op. cit., p. 160-161).

${ }^{94}$ Cf. supra, item n. 2.6.

${ }^{95}$ No Brasil, a discussão versa sobre a possibilidade de determinação de realização de interceptação de comunicação telefônica, de ofício, considerada o disposto no art. $3^{\circ}$, caput da Lei $\mathrm{n}^{\circ}$ 9.296, de 1996. Reputamos que o debate também é válido para a interceptação de comunicação entre pessoas presentes. Quanto à impossibilidade de decreto de interceptação de comunicação de ofício, cf:: STRECK, Lenio Luiz. As interceptações telefônicas... op. cit., p. 81-82; GOMES, Luiz Flávio. Interceptação telefônica "de ofício": inconstitucionalidade. Revista IOB de Direito Penal e Processo Penal, IOB, ano VIII, n. 45, ago-set. 2007, p. 1516. De outro lado, MARCOS ALEXANDRE COELHO ZILLI sustenta a possibilidade de determinação de ofício de interceptação telefônica na fase processual, lembrando o exemplo de o réu estar subornando testemunhas arroladas pela acusação (A iniciativa instrutória... op. cit., p. 204).

${ }^{96}$ A este respeito, cf., supra, item n. 1.1, nota n. 25.

${ }^{97}$ Convém recordar que é elemento do conceito de interceptação a efetivação das operações de captação e de registro por um terceiro (v., supra, item n. 3.2).

${ }^{98}$ Cf., supra, item n. 1.1.
} 
Destarte, é com base nestas observações que aconselhamos, em disciplina sobre a interceptação de comunicações entre pessoas presentes no direito brasileiro, a atribuição de legitimidade ativa ao Ministério Público, à Defesa, ao ofendido e à autoridade policial. ${ }^{99}$ No que tange aos terceiros, operadores da interceptação, consideramos que a já assentada atribuição dos atos de investigação à polícia repressiva ${ }^{100}$ na Constituição deve ser retratada na mencionada disciplina. ${ }^{101}$

Ademais disso, sugerimos a previsão de necessidade de autorização judicial, por meio de decisão motivada. ${ }^{102}$ Embora também se possa extrair a autorização judicial da ordem constitucional, em razão da ausência de tutela explícita das comunicações presenciais, a previsão as evidenciariam como valor protegido na sociedade brasileira.

\subsection{Sujeitos passivos}

Com a denominação sujeitos passivos, a doutrina processual trata de pessoas cujas comunicações podem ser interceptadas. Tal denominação abarca não só os legitimados passivos - os investigados, por exemplo -, como também terceiros que com eles se comunicam.

\footnotetext{
${ }^{99}$ Em sentido semelhante, quanto a interceptação de comunicação telefônica, cf.: BADARÓ, Gustavo Henrique Righi Ivahy. Direito processual penal: tomo I... op. cit., p. 290.

${ }^{100}$ Cf., supra, item n. 1.1 .

${ }^{101}$ Como se trata de providência de natureza coercitiva, a interceptação de comunicação entre pessoas presentes deve ser concretizada pelas autoridades públicas incumbidas da investigação e da persecução penal. Assim se manifesta ADA PELLEGRINI GRINOVER quanto à busca e preensão, também providência coercitiva. Enfatiza a autora - salientando a reserva jurisdicional prevista no art. $5^{\circ}$, caput e inciso XI da Constituição da República que o particular não pode efetivar tal medida: "a autorização excepcional, conferida ao cidadão para prender quem esteja em situação de flagrante delito, não implica a extensão ao particular de outros poderes, senão aqueles essencialmente necessários para realizar o ato permitido pelo art. 301, CPP, o que não inclui, evidentemente, o direito de acesso ao domicílio alheio para investigar a possível ocorrência de crime." (A marcha do processo. Rio de Janeiro: Forense Universitária, 2000, p. 480-484. O trecho citado consta na p. 483).

${ }^{102}$ A respeito da reserva de jurisdição e da exigência de motivação, cf., supra, item n. 2.6.
} 
Em regra, a legitimação passiva é reconhecida a investigado ou a acusado por suposta prática de infração penal prevista entre as hipóteses de admissibilidade do instituto. ${ }^{103}$

Mas a interceptação também pode ter como objeto o conteúdo de comunicação de terceiros, entendidos como sujeitos não submetidos a uma investigação, como o ofendido, a pessoa informada sobre o fato investigado, ${ }^{104}$ ou a pessoa que tenha ligação com o fato ou com o sujeito investigado. ${ }^{105}$ Os parentes próximos e os conviventes exemplificam a categoria dos terceiros. $^{106}$

Ainda sob o tema dos sujeitos passivos, a doutrina reconhece a existência de limites subjetivos às interceptações, no plano da legitimação passiva.

Merecem destaque, entre estes limites os reconhecidos se as comunicações entre pessoas presentes forem mantidas em âmbito profissional e em âmbito familiar. ${ }^{107}$ São dois aspectos do direito à intimidade e à vida privada ${ }^{108}$ que repercutem mais intensamente no fenômeno probatório.

\footnotetext{
${ }^{103}$ Cf. MARINELLI, Claudio. Intercettazioni processuali.. op. cit, p. 44; BRUNO, Pierfrancesco. Intercettazioni di comunicazioni... op. cit., p. 186. Na mesma esteira, PAOLA BALDUCCI enfatiza a necessidade de uma precisa delimitação subjetiva, com a previsão de que possa ter interceptada a sua comunicação a pessoa em desfavor de quem haja elementos concretos de prática de um delito, retratados em persecução penal já iniciada. Desta forma, conclui a autora que se evita a interceptação de comunicação de pessoas estranhas à investigação, ou de pessoas cuja suspeita de cometimento de delito seja vaga e genérica (Le garanzie... op. cit., p. 44). MANUEL DA COSTA ANDRADE ressalta a legitimidade passiva do investigado e de pessoas que passem notícias ao investigado, por ele chamados de "mediadores de noticias" (Das escutas telefônicas... op. cit., p. 209). ${ }^{104}$ Cf. MARINELLI, Claudio. Intercettazioni processuali... op. cit, p. 43.

${ }^{105}$ Cf. BRUNO, Pierfrancesco. Intercettazioni di comunicazioni... op. cit., p. 186.

${ }^{106}$ Cf. CLAUDIO MARINELLI salienta que, na decisão motivada, que autoriza a interceptação de comunicação, deve ser registrada a específica ligação do terceiro com o investigado ou com o fato investigado (Intercettazioni processuali... op. cit, p. 43-44).

${ }^{107}$ Estes limites também se ligam à prova testemunhal. A propósito disto, FRANCISCO MUNOZ CONDE e MARCELA DE LANGHE salientam que um procedimento próprio do Estado de Direito preconiza restrições à averiguação da verdade, entre as quais destaca: "el derecho a no testificar por razones de parentesco, proximidad social o secreto profesional". "Estas prohibiciones en el proceso penal van, sin duda, en contra del interés de conocimiento en una forma típicamente intensa, pues se refieren a las fuentes de información que en general resultan más ricas e accesibles; pero son derechos de defensa frente a los intereses de la investigación en un procedimiento penal adecuado a un Estado de derecho que debe lograr una relación bien equilibrada entre el interés en la verdad, por un lado, y la dignidad de los afectados, por el otro.” (Presentación... op. cit., p. 15).

${ }^{108}$ Com relação ao direito à intimidade e à vida privada, v., supra, item n. 2.3.
} 
A proteção atribuída ao âmbito profissional, nele inserido o sigilo profissional, decorre não apenas no interesse individual por resguardo da vida privada e da intimidade ${ }^{109}$ - em especial, do interesse individual de cliente e de profissional no segredo e na reserva das informações entre eles trocadas -, como também do valor atribuído pela sociedade à própria relação bilateral entre profissional e cliente, ${ }^{110}$ pela confiança que lhe é inerente.

Outrossim, para efetivação da mencionada proteção à relação profissional, são reconhecidas proibições probatórias que visam a tutelar não só não apenas o exercício da liberdade de profissão, como também direitos e garantias individuais de investigado ou de acusado, entre os quais estão os já apontados direito à intimidade e à vida privada.

A este respeito, Antonio Magalhães Gomes Filho identifica a preponderância de um interesse social, mais elevado do que o interesse na obtenção da prova no âmbito profissional, no qual se incluem não apenas o sigilo profissional, como também o sigilo pertinente a práticas religiosas. ${ }^{111}$ Cuida-se de uma "ponderação de valores: entre o direito à prova e, em contrapartida, a proteção de certas atividades reconhecidamente úteis e necessárias à vida social, o ordenamento privilegia estas últimas, reconhecendo que a possível exposição de fatos ocorridos nas relações profissionais, ou de crença religiosa, colocaria em risco a própria normalidade de atuação dos envolvidos."

No Brasil, o legislador, em atenção à necessidade de proteção das relações profissionais, no art. 207 do Código de Processo Penal, norma integrante da disciplina da prova testemunhal, proíbe o depoimento de pessoas que, em razão de função, ministério,

\footnotetext{
${ }^{109}$ Quanto aos interesses inerentes à intimidade e à vida privada, cf., supra, item n. 2.3.

${ }^{110}$ Em semelhante sentido, cf.: GOMES FILHO, Antonio Magalhães. Direito à prova... op. cit., p. 130.

111 Cf. Direito à prova... op. cit., p. 129. ANTONIO SCARANCE FERNANDES salienta que o sigilo profissional constitui um direito absoluto, exemplificando com o sigilo do advogado, do médico e do jornalista. "Há nestes casos todos relações de confidência, essenciais para as atividades referidas. Também se inclui, nesse grupo, o sigilo do religioso." (O sigilo... op. cit., p. 157). A este respeito, PONTES DE MIRANDA já enfatizava que: "no segrêdo profissional, o portador dele tem o dever, em muitos casos, e, de regra, o direito, de não no revelar, isto é, a que só o saibam êle e o seu cliente ou declarante, ou o círculo de pessoas que dêle podem ter conhecimento ou devem ter" (MIRANDA, Pontes de. Comentários à Constituição... op.cit., p. 171). No direito estrangeiro, quanto à proibição de interceptação de comunicação de profissionais, cf.: ANDRADE, Manuel da Costa. Sobre as Proibições de Prova em Processo Penal. Coimbra: Coimbra Ed., 1992, p. 300-301.
} 
ofício ou profissão, devam guardar segredo, salvo se, desobrigadas pela parte interessada, quiserem prestar depoimento. ${ }^{112}$

O outro aspecto do direito à intimidade e à vida privada cuja proteção é ressaltada pela doutrina é o da vida familiar. ANTONIO MAGALHÃES GOMES FILHO observa que "nas relações entre cônjuges, ou entre pais e filhos, caracterizadas por uma maior liberdade e emotividade, há certos fatos íntimos cujo conhecimento só a eles interessa e sua divulgação, fora do âmbito doméstico, deve ser vedada." 113

Demais disso, o autor ressalta a importância da questão sobre "a intromissão de terceiros no círculo da intimidade conjugal ou familiar, especialmente em face dos modernos processos tecnológicos." ${ }^{\text {114 }}$ Em resposta à indagação sobre a possibilidade de utilização, como prova penal, de informações colhidas, fortuita ou propositadamente, na área mais restrita da convivência pessoal, ele afirma: "as intromissões na vida familiar não se justificam pelo interesse na obtenção da prova, pois, da mesma forma do que sucede em relação aos segredos profissionais, deve ser igualmente reconhecida a função social a uma vivência conjugal $e$ familiar à margem de restrições e intromissões". 115

\footnotetext{
${ }^{112}$ As proibições de testemunho de pessoas que devem guardar segredos, em relação a fatos conhecidos em exercício de determinadas profissões tem o objetivo de assegurar ao cidadão a efetividade de direitos considerados essenciais (GOMES FILHO, Antonio Magalhães. Direito à prova... op. cit., p. 100). Lembre-se, ainda, que o art. 154 do Código Penal tipifica a conduta de violação do segredo profissional: "revelar alguém, sem justa causa, segredo, de que tem ciência em razão de função, ministério, ofício ou profissão, e cuja revelação possa produzir dano a outrem". A respeito da vedação do testemunho de profissional, em especial de advogado, ADA PELLEGRINI GRINOVER observa: "o testemunho do advogado não apenas é inviável logicamente, pela posição que este ocupa na relação processual, mas constitui, rigorosamente, uma prova proibida e criminosa, que incide na sanção de inadmissibilidade inscrita no art. $5^{\circ}$, inc. LVI, da Constituição" ( $A$ marcha... op. cit., p. 459).

${ }^{113}$ Cf. Direito à prova... op. cit., p. 126. No mesmo sentido, LUCRECIO REBOLLO DELGADO, enfatizando o caráter privado da vida familiar, individualiza-o sob a denominação de "vida privada familiar": "la vida privada familiar lo que protege es un ámbito de relaciones, ya sean de carácter jurídico o sentimental, un conjunto de pretensiones y de opciones personales. También conviene reseñar ahora, que la vida privada familiar no se delimita por un espacio físico concreto (casa, hogar, etc) sino por la suma de varias vidas privadas personales, tantas como los miembros que integran la familia." Em tradução livre do autor: "a vida privada familiar, o que protege é um âmbito de relações, que sejam de caráter jurídico ou sentimental, um conjunto de pretensões e de opções pessoais. Também convém assinalar agora, que a vida privada familiar não se delimita por um espaço físico concreto (casa, lar, etc), mas por a soma das varias vidas privadas pessoais, tantas como os membros que integram a família." (Vida privada y protección de datos en la Unión Europea. Dykinson, S. L: Madrid, 2008, p. $60)$.

${ }_{114}^{114}$ Cf. GOMES FILHO, Antonio Magalhães. Direito à prova... op. cit., p. 128.

${ }^{115}$ Cf. Ibidem, p. 128.
} 
O art. 206 do Código de Processo Penal brasileiro, também integrante da disciplina da prova testemunhal, reconhece ao ascendente ou descendente, ao afim em linha reta, ao cônjuge, ainda que desquitado, ao irmão e ao pai, à mãe, ou ao filho adotivo do acusado a faculdade de se recusar a depor. Todavia, no mesmo dispositivo legal há uma ressalva, em sua parte final, a impor o testemunho: salvo se não for possível, por outro modo, obter-se ou integrar-se a prova do fato e de suas circunstâncias, hipótese em que não se exige compromisso destas pessoas (art. 208). Nas situações para as quais há a ressalva acima mencionada, o interesse na apuração da verdade processual prepondera sobre a tutela da intimidade familiar, o que evidencia a menor proteção atribuída ao âmbito familiar, que não pode ser extraída da ordem constitucional. É por isso que a doutrina critica tal norma, em prol da tutela da função social da vida familiar e do direito à intimidade e à vida privada. ${ }^{116}$

No direito brasileiro, não há norma que expressamente disponha sobre a admissibilidade de interceptação de comunicações entre pessoas presentes ocorridas no âmbito profissional e no âmbito familiar.

Entretanto, identificamos a proteção destas comunicações na consagração constitucional dos direitos e garantias individuais que fundamentam a tutela das comunicações entre presentes. ${ }^{117}$ Salientamos que eventual restrição a estes direitos e garantias individuais implicariam um maior grau de exposição da intimidade e da vida privada, considerada a interseção entre o sigilo das comunicações entre presentes e o sigilo inerente a relações profissionais e a relações familiares.

Sendo assim, parece-nos que, em regra, não possam ser restringidas as comunicações entre pessoas presentes ocorridas no âmbito de relações profissionais e de relações familiares.

\footnotetext{
116 A respeito disso, ANTONIO SCARANCE FERNANDES, critica o disposto no art. 206 do Código de Processo Penal, porque embora a lei preveja a possibilidade de recusa a depor, consagra uma exceção: "salvo quando não for possível, por outro modo, obter-se ou integrar-se a prova do fato e de suas circunstâncias." Salienta o autor: "trata-se de norma que merece ser contestada, pois poderá, por exemplo, o filho ser constrangido a depor contra o pai." (O sigilo... op. cit., p. 157.). No mesmo sentido, cf.: GOMES FILHO, Antonio Magalhães. Direito à prova... op. cit., p. 126.

${ }^{117}$ Cf., supra, itens n. 2.1 a n. 2.6.
} 
A função social das relações profissionais ${ }^{118}$ e das relações familiares ${ }^{119}$ e os mencionados direitos e garantias individuais que fundamentam a sua proteção preponderam sobre interesse em obtenção de prova pertinente a fato tido por delituoso.

Demais disso, é necessária uma interpretação das normas do sistema processual penal em conjunto. Se, em regra, tem-se proibição de depoimento por profissional (art. 207), não se pode possibilitar o conhecimento de informações por ele conhecidas por outros meios. Semelhante raciocínio pode ser aplicável a depoimento de familiares, pois, como visto, apesar de a lei facultar a recusa (parte final do art. 206), a doutrina acrescenta considerações sobre a impropriedade da norma.

Excepcionalmente, consideramos admissível a restrição se houver elementos concretos de que os profissionais ou os familiares estejam a cometer delitos em conjunto com o investigado ou acusado. Nesta hipótese, sob o manto de relações profissionais ou de relações

\footnotetext{
${ }^{118}$ No mesmo sentido, em comentários sobre a interceptação de comunicação telefônica, MARIA THEREZA ROCHA DE ASSIS MOURA observa: “a interceptação de comunicação telefônica entre o indiciado, ou acusado, e seu defensor, relativamente aos fatos objeto de investigação criminal ou de instrução processual, está, a nosso ver, vedada" (Interceptação telefônica: breves reflexões. Revista Brasileira de Ciências Criminais, São Paulo, RT, ano 6, n. 21, jan-mar. 1998, p. 411). Igual entendimento é sustentado por LUIZ VICENTE CERNICCHIARO, ao afirmar que: "a interceptação não pode colher a conversa do indiciado ou do réu com seu advogado. Vou além. De qualquer pessoa que procure o profissional a fim de aconselhar-se porque praticara uma infração penal. Será contraditório o Estado obrigar o advogado a guardar segredo profissional e imiscuir-se na conversa e dela valer-se para punir o cliente. O Direito não admite contradição lógica!" (Lei 9296/96: interceptação telefônica. Boletim IBCCRIM, São Paulo, n. 47, out. 1996, p. 3). Também em direito estrangeiro, em específico quanto à questão sobre as interceptações de comunicações e a relação profissional no direito italiano, CLAUDIO MARINELLI afirma a existência de limites "ratione personae sive officii" (Intercettazioni processuali... op. cit, p. 44). Em propostas de aspectos para uma regulamentação homogênea da interceptação de comunicação telefônica em âmbito europeu, ENRIQUE BACIGALUPO assevera: "a) no se debe autorizar la interceptación de comunicaciones telefónicas de abogados, de profesionales o ministros de culto que tengan deber de secreto profesional; b) esta regla no es de aplicación cuando existan hechos que permitan suponer que el abogado, el profesional o el ministro de culto presta alguna clase de cooperación para la comisión de un delito." Em tradução livre do autor: "a) não se deve autorizar a interceptação de comunicações telefônicas de advogados, de profissionais ou ministros de culto que tenham dever de segredo profissional; b) esta regra não é aplicável quando existam fatos que permitam supor que o advogado, o profissional ou o ministro de culto presta alguma classe de cooperação para o cometimento do delito" (Derecho Penal... op. cit., p. 250).

119 MANUEL DA COSTA ANDRADE, em comentários sobre o direito português, manifesta semelhante entendimento, ressaltando que "o particular potencial de devassa e danosidade social" de interceptação de comunicações familiares, "por via de regra marcadas pela densidade da emotividade e intimidade", sugerindo um tratamento distinto (Sobre as Proibições... op. cit., p. 303).
} 
familiares, cometem-se delitos, motivo por que a ratio da proteção não se opera, e nos parece de todo recomendável a interceptação, para repressão a prática de infrações penais. ${ }^{120}$

Em direito estrangeiro, na disciplina da interceptação de comunicação entre pessoas presentes, por vezes, a proibição probatória se opera sob o plano da admissibilidade da interceptação, cuja execução é vedada. Noutras hipóteses, embora admitida a interceptação, os respectivos resultados não podem ser utilizados. ${ }^{121}$

Recomendamos que, para o efetivo resguardo das relações profissionais e das relações familiares, em disciplina sobre a interceptação de comunicação entre pessoas presentes no direito nacional, a proibição probatória deve se operar no plano da admissibilidade da interceptação, com a previsão de vedação de sua execução. Esta proibição deve ser acompanhada de exceção de que a interceptação é admitida, em havendo elementos da colaboração de profissionais e de familiares para a prática de delito.

A instituição de vedação quanto à utilização dos respectivos resultados significaria permitir restrição às comunicações entre presentes, porque as informações mencionadas por interlocutores seriam conhecidas, ainda que se vedasse a divulgação.

\subsection{Espécies}

Apresentados o conceito, o objeto, a natureza jurídica e os sujeitos da interceptação de comunicação entre pessoas presentes, cumpre-nos assinalar as suas espécies.

\footnotetext{
${ }^{120}$ A possibilidade de interceptação de comunicação entre profissionais e clientes, na hipótese em que haja elementos de cometimento de delitos em conjunto com o investigado é prevista, por exemplo, no $\S 100 . c, 6$ da StPO (cf., infra, item n. 4.2.2.2.1) e nos artigos 222 e 226 do Código de Processo Penal chileno (cf., infra, item n. 4.2.2.2.3).

${ }^{121}$ A regulamentação de proibições probatórias relacionadas às relações profissionais pode ser identificada, por exemplo, no direito italiano. Sobre este ordenamento jurídico, adiantamos aqui que a proibição de execução de interceptação é prevista para as comunicações mantidas entre cliente e defensor; com relação às demais profissões, a vedação é de utilização dos resultados da interceptação, a qual, em princípio, pode ser realizada (cf., infra, item n. 4.2.2.2.6). A regulamentação de proibição probatória pertinente às relações familiares é identificada no direito alemão, em que se veda a utilização dos respectivos resultados (cf., infra, item n. 4.2.2.2.1).
} 
Antes, porém, convém lembrar que as interceptações de comunicações, em geral, são diferenciadas pela doutrina pela modalidade de comunicação captada. Reconhece-se a existência de duas categorias: a interceptação de telecomunicação, isto é, comunicação à distância (telefônica, telemática, informática, entre outras); e interceptação de comunicação entre pessoas presentes, de pessoas que se encontrem em um mesmo ambiente, domiciliar ou não. $^{122}$

A segunda categoria, a da interceptação de comunicação entre pessoas presentes, deve ser bipartida em: interceptação domiciliar, operada em locais que caracterizam domicílio; e interceptação ambiental, concretizadas locais que não sejam considerados domicílio. ${ }^{123}$ Portanto, interceptação de comunicação entre pessoas presentes é gênero, do qual se pode extrair, como espécies, a interceptação domiciliar e a interceptação ambiental. O que as distingue é o local onde são operadas: respectivamente, em domicílio e em local diverso de domicílio. A diferença é relevante, porque a restrição a direitos e garantias fundamentais é mais intensa na primeira espécie: a interceptação domiciliar.

\footnotetext{
122 Cf. FILIPPI, Leonardo. Intercettazione di comunicazioni..., p. 1. No que tange a abrangência das telecomunicações e das comunicações entre pessoas presentes, cf., supra, item n. 2.1.

123 Cf. FILIPPI, Leonardo. Intercettazione di comunicazioni..., p. 1. No mesmo sentido, referindo-se a interceptação ambiental extradomiciliar e a interceptação domiciliar, cf: BALDUCCI, Paola. Le garanzie... op. cit., p. 42. Na mesma esteira, distinguindo captação de comunicação em domicílio e fora do domicílio, cf.: CORDERO, Franco. Procedura Penale. 3. ed. Milano: Giuffrè, 1995, p. 734-737. ERCOLE APRILE enfatiza que "in tema de intercettazini tra presenti, la collocazione di microspie all'interno di un luogo di privata dimora" constitui uma modalidade de atuação de tal meio de investigação de prova (La prova..., p. 361). Em sentido contrário, criticando a diferenciação entre da interceptação ambiental e da interceptação domiciliar, cf.: CAPRIOLI, Francesco. Intercettazione e registrazione... op. cit., p. 170-172. Em Alemanha, fala-se em "grande espionagem acústica" ("grober Lauschangriff") para expressar a escuta em âmbito domiciliar; e em "pequena espionagem acústica" (kleiner Lauschangriff") para significar a escuta fora de domicílios privados (ROXIN, Claus. La prohibición... op. cit., p. 75). No mesmo sentido, JESÚS MARTÍNEZ RUIZ esclarece que, em Alemanha, as interceptações domiciliares, considerada a maior restrição a direitos fundamentais, são conhecidas por "grandes escutas" ("grober lauschangriff”); e as interceptações ambientais, por "pequenas escuchas ("kleiner lauschangriff") (Límites jurídicos... op. cit., p. 85). Embora se diferencie entre "pequena" e "grande" espionagem, ambas as modalidades são consideradas "escutas intensivas" ("Lauschangriff") (AMBOS, Kai; BELING, Ernest; GUERRERO, Julián Óscar. Las prohibiciones probatorias. Bogotá: Editorial Temis, 2009, p. 89).
} 


\subsubsection{Interceptação domiciliar}

A interceptação domiciliar é espécie de interceptação de comunicação entre pessoas presentes que se pretenda realizar em local considerado domicílio. ${ }^{124}$ É mais invasiva, ${ }^{125}$ porque, além da liberdade de comunicação entre pessoas presentes, da inviolabilidade do sigilo da comunicação entre pessoas presentes, e do direito a não autoincriminação, restringe a inviolabilidade do domicílio. ${ }^{126}$

Ademais, como já dito no exame do objeto da interceptação, ${ }^{127}$ a escolha do local (no caso, um domicílio) pelos interlocutores evidencia o caráter reservado da comunicação, elemento integrante do conceito de interceptação de comunicação entre pessoas presentes. ${ }^{128}$

Tais peculiaridades justificam a instituição de um tratamento legislativo diferente à interceptação domiciliar na disciplina jurídica da interceptação de comunicação entre presentes, por meio da instituição de requisitos específicos. ${ }^{129}$

É importante ressaltar que, a nosso ver, a interceptação domiciliar não está necessariamente relacionada ao ingresso físico em domicílio, para instalação de um meio técnico que propicie a captação do conteúdo da comunicação. ${ }^{130}$ Além de a humanidade já

\footnotetext{
${ }^{124}$ Retomamos aqui as considerações expendidas sobre a concepção jurídica de domicílio (v., supra, item n. 2.4). ${ }^{125}$ Quanto ao caráter insidioso da interceptação de comunicação entre pessoas presentes, cf., infra, item n. 3.9.

126 No mesmo sentido, cf.: BALDUCCI, Paola. Le garanzie... op. cit, p. 95. Acerca dos fundamentos constitucionais da tutela da comunicação entre pessoas presentes, cf., supra, itens n. 2.1 a n. 2.6.

${ }^{127}$ Cf., supra, item n. 3.3.

${ }^{128}$ Cf., supra, item n. 3.2.

129 Exemplos de tratamento diferenciado atribuído à interceptação domiciliar podem ser notados no direito italiano e no direito alemão. O art. 266.2 do Codice di Procedura Penale estabelece que, se a interceptação de comunicação entre pessoas presentes for operada em domicílio, exige-se, também, fundado motivo para reconhecer que nele se esteja desenvolvendo a atividade criminosa (cf., infra, item n. 4.2.2.2.6). Os $\S 100 . c$ a $\S$ 100.e da StPO disciplinam a interceptação domiciliar, prevendo admissibilidade mais restrita e procedimento específico (cf., infra, item n. 4.2.2.2.1). No direito brasileiro, não há distinção entre os institutos em plano normativo. $\mathrm{O}$ art. $2^{\circ}$, inciso IV da Lei $\mathrm{n}^{\circ}$ 9.034, de 1995, previu apenas a interceptação ambiental (cf., infra, item n. 5.3.1.1). Deixaremos a proposta de tratamento diferenciado, em sugestões de lege ferenda (cf., infra, item n. 5.5).

${ }^{130}$ Sobre a necessidade de ingresso físico em domicílio, JESÚS MARTÍNEZ RUIZ diferencia as seguintes hipóteses: "de una parte, aquellas que entrañan una entrada física en el espacio domiciliario a los efectos de colocar subrepticiamente los aparatos o instrumentos técnicos de escucha, transmisión, grabación o reproducción del sonido o de la imagen y, de otra, aquellas que por las características técnicas de los instrumentos, habilitan la indiscreción en el ámbito domiciliario desde el exterior, esto es, sin necesidad de una previa entrada, toda vez que no podemos soslayar la existencia en el mercado de micrófonos direccionales capaces de captar el sonido en un
} 
conhecer meios técnicos de captação de ondas sonoras vocálicas sem a necessidade de ingresso em domicílio, a captação pode se operar por um instrumento que esteja instalado no domicílio por pessoa distinta do terceiro que realiza a interceptação. ${ }^{131}$

\subsubsection{Interceptação ambiental}

A interceptação ambiental é espécie de interceptação de comunicação entre pessoas presentes que se efetive em local distinto de domicílio. Por este motivo, não restringe a inviolabilidade do domicílio. Mas restringe os demais direitos e garantias individuais que amparam a comunicação entre pessoas presentes: a liberdade de comunicação entre pessoas presentes, a inviolabilidade do sigilo de comunicação entre pessoas presentes e o direito a não autoincriminação. $^{132}$

radio de doscientos metros, o de aparatos láser que apuntando a una ventana son capaces de soslayar las barreras de los muros de nuestros domicilios, por medio de la emisión de un rayo invisible que una vez alcanza el objetivo, es capaz de transformar a kilómetros de distancia las micro vibraciones que produce una conversación en los cristales de la vivienda." Em tradução livre do autor: "de uma parte, aquelas que significam uma entrada física no espaço domiciliário com vistas a colocar de forma sub-repitícea os aparatos ou instrumentos técnicos de escuta, transmissão, gravação ou reprodução do som ou da imagem; e, de outra, aquelas que, pelas características técnicas dos instrumentos, habilitam a indiscrição no âmbito domiciliar desde o exterior, isto é, sem necessidade de uma prévia entrada, já que não podemos desconsiderar a existência no mercado microfones direcionados capazes de captar o som em um raio de duzentos metros, ou de aparatos laser que, apontados a uma janela, são capazes de superar as barreiras dos muros de nossos domicílios, por meio da emissão de um raio invisível que, uma vez alcançada a mira, é capaz de transformar, a quilômetros de distancia, as micro vibrações que produz uma conversa nos cristais do domicílio." (Límites jurídicos... op. cit., 76). Delimitadas tais hipóteses, o autor manifesta o seu entendimento de que a inviolabilidade do domicílio só é restringida se houver ingresso físico no domicílio (RUIZ, Jesús Martínez. Límites jurídicos... op. cit., p; 80-81). Em sentido contrário, sustentando a restrição, mesmo sem ingresso físico em domicílio, cf.: SANCHES DOMINGO, M. B. Análisis del delito contra la inviolabilidad del domicilio del artículo 534 del Codigo Penal. Granada: Comares, 1998, p. 41 e ss., apud RUIZ, Jesús Martínez. Límites jurídicos... op. cit., p. 76). Por igual, MAXIMILIANO HAIRABEDIÁN afirma: "toda captación de sonidos, principalmente conversaciones, que se realice desde cualquier sitio hacia el interior de un recinto privado sin el conocimiento de los que se encuentran adentro, ya sea por particulares o por los órganos estatales de investigación, significa el ingreso- aunque no sea físico - al ámbito de privacidad, puesto que ésta se ve vulnerada". Em tradução livre do autor: "toda captação de sons, principalmente conversas, que se realize desde qualquer lugar ao interior de um recinto privado sem o conhecimento dos que se nele se encontram, seja por particulares ou por órgãos estatais de investigação, significa ingresso - ainda que não seja físico - ao âmbito de privacidade, considerando que esta se vê vulnerada" (La grabación como prueba en el proceso penal. Pensamiento penal y criminológico: revista de derecho penal integrado, Córdoba, Editorial Mediterrânea, ano 3, n. 4, 2002, p. 121-122). Preferimos o segundo entendimento, porque, mesmo à distância, concretiza-se interferência no domicílio e nas liberdades subjetivas que nele se desenvolvem.

${ }^{131}$ A este respeito, confiram-se as considerações sobre a interceptação "a cornetta solevata", modalidade de interceptação ressaltada no direito italiano (cf., infra, item n. 3.8.1).

${ }^{132}$ Sobre os fundamentos constitucionais da tutela da comunicação entre pessoas presentes, cf., supra, itens n. 2.1 a n. 2.6 . 
Estando os interlocutores em local distinto de domicílio, ao critério da escolha do local, soma-se a forma de exteriorização da comunicação, ${ }^{133}$ para a avaliação de seu caráter reservado, que integra o conceito de interceptação de comunicação entre pessoas presentes, ${ }^{134}$ como objeto.

Embora reputemos um instituto menos invasivo, se comparado com a interceptação domiciliar, não significa que se possa descurar da reserva de lei exigida para a restrição de direitos fundamentais. Por igual, a interceptação ambiental deve ser disciplinada em lei, da qual se possa extrair a admissibilidade e o procedimento probatório a ela aplicáveis. Entendemos que o objeto da interceptação ambiental, a comunicação entre pessoas presentes, justifica um tratamento diferenciado da interceptação de telecomunicação, pela maior exposição da intimidade. ${ }^{135}$

\subsection{Distinções entre interceptação de comunicação entre pessoas presentes e} figuras afins:

Os aspectos dogmáticos da interceptação de comunicação entre pessoas presentes possibilitam diferenciar a interceptação de comunicação entre presentes de outros institutos jurídicos assemelhados.

Para proceder à diferenciação, elencamos três institutos jurídicos que são confrontados com a interceptação de comunicação entre pessoas presentes pela doutrina: a interceptação de telecomunicação, a gravação clandestina e a revelação do conteúdo da comunicação por um dos interlocutores.

\footnotetext{
${ }^{133}$ Cf. ,supra, item n. 3.3.

${ }^{134}$ Cf. ,supra, item n. 3.2.

135 Neste sentido, verifique-se o tratamento legislativo operado pelo legislador alemão (cf., infra, item $\mathrm{n}$. 4.2.2.2.1). O legislador estruturou a disciplina da interceptação ambiental com normas integrantes da disciplina da interceptação domiciliar e da interceptação de telecomunicação (§ 100.f da StPO).
} 


\subsubsection{Interceptação de comunicação entre pessoas presentes e interceptação de telecomunicação}

A distinção entre interceptação de comunicação entre pessoas presentes e interceptação de telecomunicação decorre de seus objetos. Enquanto a telecomunicação se desenvolve por um meio de um instrumento de difusão do sinal - por exemplo, o telefone -, a comunicação entre pessoas presentes ocorre entre pessoas que se encontram em um mesmo ambiente, ${ }^{136}$ domiciliar ou não. É a diversidade de objeto, de espécie de comunicação, que as diferencia, justificando a necessidade de disciplinas jurídicas diferentes. ${ }^{137}$

Entre as interceptações de telecomunicação, destacamos a interceptação de comunicação telefônica, que consiste na captação da comunicação telefônica por um terceiro, sem o conhecimento dos interlocutores ou com o conhecimento de só um deles. O meio técnico utilizado em interceptação de comunicação telefônica é o "grampeamento" do telefone. Subdivide-se em: interceptação da conversa telefônica por terceiro, sem o conhecimento dos dois interlocutores (interceptação stricto sensu); e interceptação da conversa telefônica por terceiro, com o conhecimento de um dos interlocutores (escuta). ${ }^{138}$

Do conceito apresentado, poder-se-ia concluir que a distinção entre a interceptação de comunicação telefônica e a interceptação de comunicação entre pessoas presentes também é extraída do meio técnico empregado na realização da interceptação.

Todavia, não nos parece acertado distingui-las pelo meio técnico empregado, pois o que as diferencia são os seus objetos, as espécies de comunicações interceptadas: comunicação telefônica e comunicação entre pessoas presentes. O dito grampeamento do telefone pode ser operado em execução de interceptação de comunicações entre presentes.

\footnotetext{
${ }^{136}$ Cf. MARTINO, Corrada di; PROCACCIANTI, Teresa. Le intercettazioni... op. cit., p. 58; BALDUCCI, Paola. Le garanzie... op. cit, p. 20.

${ }^{137}$ Sobre a questão da autonomia da disciplina jurídica da interceptação de comunicação entre pessoas presentes, cf., infra, item n. 3.10. Verifiquem-se, também, as considerações expendidas acerca dos fundamentos constitucionais da tutela da comunicação entre presentes (v., supra, itens n. 2.1 a 2.6) e do caráter insidioso da interceptação de comunicação entre pessoas presentes (v., infra, item n. 3.9).

${ }^{138}$ Cf. GRINOVER, Ada Pellegrini, GOMES FILHO, Antonio Magalhães, FERNANDES, Antonio Scarance. As nulidades... op. cit., p. 164-165. No mesmo sentido, cf.: FERNANDES, Antonio Scarance. Processo penal... op. cit., p. 92-93.
} 
A este respeito, a doutrina italiana analisa a questão das interceptações casuais de comunicações entre presentes ("intercettazioni casuali di conversazioni tra presenti”), também conhecida por interceptação telefônica 'de acústica erguida' ("intercettazione telefonica 'a cornetta sollevata"”). ${ }^{139}$ Trata-se de situação em que, em interceptação de comunicação telefônica, concretiza-se a captação de comunicação entre pessoas presentes ocorrida em ambiente onde esteja um aparelho telefônico com a acústica acionada. ${ }^{140}$

A legitimidade desta "modalidade" de interceptação é discutida em doutrina, porque o conteúdo de uma comunicação entre presentes seria interceptado de modo dito anômalo e fortuito. ${ }^{141}$ Diz-se que a interceptação de comunicação telefônica não pode se traduzir em interceptação de comunicação entre presentes, sem que estejam configurados os requisitos previstos em lei para a interceptação de comunicações entre presentes. ${ }^{142}$

Embora a questão surgida na doutrina italiana tenha pressuposto distinto - consistente em concretização de interceptação de comunicação telefônica autorizada, no curso da qual se intercepta uma comunicação entre pessoas presentes -, não nos parece desarrazoado pensar na possibilidade de que, em interceptação de comunicação entre pessoas presentes autorizada em face da presença de seus requisitos legais, seja estabelecida a utilização, como meio técnico, o grampeamento do telefone, fixo ou móvel. ${ }^{143}$

\footnotetext{
${ }^{139}$ Cf. APRILE, Ercole. La prova..., p. 377; APRILE, Ercole; SPIEZIA, Filippo. Le intercettazioni... op. cit., p. 126-128.

${ }^{140}$ Os interlocutores acabam por deixar que a sua conversa "viaje" livremente ao longo da rede telefônica, por meio da qual é conhecida por terceiros (Cf. APRILE, Ercole. La prova ..., p. 377). Em linguagem coloquial, podese dizer que a comunicação entre pessoas presentes é captada pelo telefone com a acústica "fora do gancho".

${ }^{141}$ Cf. APRILE, Ercole; SPIEZIA, Filippo. Le intercettazioni... op. cit., p. 127; ALMA, Marco Maria. Intercettazioni telefoniche... op. cit., p. 16.

${ }^{142}$ Cf. APRILE, Ercole; SPIEZIA, Filippo. Le intercettazioni... op. cit., p. 126-128. No mesmo sentido, cf. MARTINO, Corrada di. Le intercettazioni ambientali... op. cit., p. 1.153. A afirmação decorre do fato de que a lei processual penal italiana prevê requisitos específicos para a interceptação domiciliar, a qual é admitida se houver fundados motivos de que a atividade criminosa esteja se desenvolvendo em domićlio (art. 266.2 do Código de Processo Penal italiano) (cf., infra, item n. 4.2.2.2.6).

${ }^{143}$ A este respeito, RUBENS VALENTE relata a possibilidade técnica de emprego de telefone celular para gravação de comunicação entre pessoas presentes: “A CPI dos Grampos, no Congresso Nacional, preocupa-se há meses com maletas e interceptações supostamente feitas pelas companhias telefônicas sem amparo judicial, mas os últimos saltos tecnológicos empurraram esses métodos para trás, no submundo das escutas clandestinas. A última onda são programas do tipo 'cavalo-de-tróia', vendidos livremente na internet por preços que variam de 100 a 250 por ano. Inseridos num telefone celular, os programas simulam teleconferências, abrindo o áudio de conversas para o invasor. 'Cavalo-de-tróia' é um programa que, instalado, derruba as proteções do aparelho e
} 
Neste caso, não nos parece que se trataria de interceptação de comunicação telefônica, mas de interceptação de comunicação entre pessoas presentes, com a acústica do telefone servindo como meio técnico para captação de comunicação entre pessoas presentes. Frisamos, contudo, que os requisitos da interceptação de comunicação entre pessoas presentes devem estar presentes, conforme demonstrado em autorização judicial, que estabeleça a utilização deste meio técnico. ${ }^{144}$

\subsubsection{Segue: e gravação clandestina de comunicação entre pessoas}

\section{presentes}

O elemento subjetivo do conceito de interceptação de comunicação entre pessoas presentes a distingue da gravação clandestina de comunicação entre pessoas presentes. A interceptação é realizada por terceiro, pessoa distinta dos interlocutores; a gravação clandestina é feita por um dos interlocutores.

A gravação clandestina de comunicação entre pessoas presentes consiste, pois, em captação de própria conversa pessoal e direta, por um dos interlocutores, sem o conhecimento $\operatorname{do}(\mathrm{s})$ outro(s). ${ }^{145}$

abre espaço para o invasor. O novo patamar do grampo de alta tecnologia foi debatido em seminário promovido no auditório JK, da Procuradoria Geral da República, em Brasília, pela organização não governamental Cipae (Comunidade de Inteligência Policial e Análise Evidencial), formada por investigadores do Ministério Público Federal, peritos da Polícia Federal, auditores da Caixa e do Banco Central e funcionários da Agência Brasileira de Inteligência, entre outros. Um site na internet, supostamente sediado em Taiwan (o endereço não será divulgado para não ajudar a propagar o arquivo), oferece programas do gênero em quatro versões. Pode ser comprado com cartão de crédito e baixado pelo site. Segundo a empresa, o programa ajuda a revelar 'traição de mulheres e maridos', 'impedir espionagem de empregados', além de 'proteger crianças', já que os pais poderiam passar a ouvir as conversas dos filhos. Na versão 'bug', diz o site, o programa possibilita o acionamento remoto do celular, que passaria a funcionar como um gravador do ambiente." (grifos nossos) (Internet dissemina novos métodos de grampo ilegal. Folha de São Paulo, São Paulo, 22 de dezembro de 2008. Disponível em: http:/www1.folha.uol.com.br/fsp/brasil/fc2212200804.htm. Acesso em: 22/12/2008). Acerca da possibilidade técnica de um telefone celular ser utilizado como gravado, cf.: BOSCO, Dario; ZAPPALÀ, Angelo; MARCHETTI, Daniela. Intercettazioni telefoniche e ambientali: metodi, limiti e sviluppi nella trascrizione e verbalizzazione. Torino: Centro Scientifico Editore, 2007, p. 91.

${ }^{144}$ Quanto à necessidade de a autorização judicial estabelecer o procedimento a ser observado em execução de interceptação de comunicação entre pessoas presentes, cf., infra, item n. 3.10.2.

${ }^{145}$ Cf. GRINOVER, Ada Pellegrini; GOMES FIHO, Antonio Magalhães; FERNANDES, Antonio Scarance. As nulidades... op. cit., p. 164-165. No mesmo sentido, cf.: FERNANDES, Antonio Scarance. Processo penal... op. cit., p. 92-93. Em Itália, também a jurisprudência distingue os institutos ora citados. A "Corte di Cassazione" italiana decidiu que a interceptação consiste na captação oculta e contextual de uma comunicação entre dois ou 
Tratando-se de gravação do conteúdo da comunicação efetuada por um dos interlocutores, a quem é endereçada a informação compartilhada pelo emitente, não se tem captação indevida do segredo. Mas, ainda que não se vislumbre interesse do emitente da informação em manter a informação em segredo, pode haver interesse na reserva da informação compartilhada, igualmente integrante do direito à intimidade de que é titular. ${ }^{146}$ Por este motivo, a divulgação da informação captada em gravação clandestina pode ser ilegal.

Em Itália, a doutrina ressalta que os aspectos da intimidade relacionados aos institutos são distintos: enquanto a interceptação é relacionada ao "diritto alla segretezza" (interesse no segredo), a qual é circunscrita à esfera do que é inacessível pelo conhecimento alheio; o registro por um dos interlocutores se liga ao "diritto alla riservatezza" (interesse na reserva), a qual se estende por aquilo que, embora sendo de conhecimento alheio, não deve ser indiscretamente propalado. $^{147}$

No que tange ao direito brasileiro, AdA Pellegrini Grinover, Antonio Magalhães Gomes Filho e Antonio SCARAnce Fernandes lembram que "a gravação em si, quando realizada por um dos interlocutores que queira documentar a conversa tida com terceiro, não configura nenhum ilícito, ainda que o interlocutor não tenha conhecimento de sua ocorrência. Mas a divulgação da conversa pode significar afronta à intimidade, qual seja a violação de segredo."148

mais sujeitos, operada por um sujeito estranho à mesma. Desta noção, exclui o registro de uma conversa, de modo clandestino, por um sujeito que participe da conversa, ou, de qualquer forma, seja admitido a assisti-la (Cf. ud. 28 maggio 2003 n. 36747, Torcasio, rv. 225465) Disponível em: http://www.cortedicassazione.it/Documenti/RelSezUnPenali_2004.pdf. Acesso em: 15/07/2010. p. 85. Cf. Comentários sobre o aresto em: APRILE, Ercole; SPIEZIA, Filippo. Le intercettazioni... op. cit., p. 2, nota 1).

${ }^{146}$ Quanto aos interesses abrangidos pelo direito à intimidade, cf., supra, item n. 2.3.

147 Salientando a diferença entre os institutos, a doutrina nega natureza de interceptação ao registro da comunicação por um dos interlocutores, com o desconhecimento do outro, cf.: APRILE, Ercole; SPIEZIA, Filippo. Le intercettazioni... op. cit., p. 129-131; LARONGA, Antonio. Le prove atipiche... op. cit., p. 196-198). No mesmo sentido, cf.: MARTINO, Corrada di; PROCACCIANTI, Teresa. Le intercettazioni... op. cit., p. 24; FILIPPI, Leonardo. Intercettazione di comunicazioni..., p. 1; BRUNO, Pierfrancesco. Intercettazioni di comunicazioni... op. cit., p. 178.

${ }^{148}$ Cf. GRINOVER, Ada Pellegrini, GOMES FILHO, Antonio Magalhães, FERNANDES, Antonio Scarance. As nulidades... op. cit., p. 186. 
O Código Penal brasileiro tipifica a conduta de violação de segredo, em seu art. 153, que consiste em divulgar, sem justa causa, conteúdo de documento particular ou de correspondência confidencial, de que é destinatário ou detentor, e cuja divulgação possa produzir dano a outrem. Considerados os elementos da tipificação penal, é ressalvada a descaracterização da ilicitude, se a prova for usada em defesa de direitos violados ou ameaçados de quem gravou e divulgou a conversa. ${ }^{149}$

Parece-nos que, em tese, o crime que poderia ocorrer na situação acima retratada, não seria o delito de violação de segredo (art. 153) que tem como elemento normativo - conteúdo de documento particular ou de correspondência confidencial - mas, sim, violação do sigilo profissional (art. 154), desde que a informação tenha natureza de segredo, de que se tenha ciência em razão de função, ministério, ofício ou profissão.

Demais disso, a questão da gravação clandestina de conversa entre pessoas presentes é apontada como deveras polêmica se a captação e o registro do conteúdo da comunicação são realizados por uma pessoa que dela participa, agindo sob encargo da polícia, condição desconhecida pelos demais interlocutores. Nesta hipótese, o sujeito executor da interceptação utiliza instrumentos escondidos no próprio corpo. A situação é conhecida como "registro por parte de agente secreto equipado para o som" ("registrazione da parte dell'agente segreto 'attrezzato per il suono"'). ${ }^{150}$

O debate acerca do tema se refere a considerar ou não, na situação apontada, a caracterização da existência de um terceiro, que justificaria o reconhecimento de interceptação, submetendo-a ao regime previsto em lei.

Identificamos duas correntes doutrinárias no direito italiano: de um lado, entende-se que o agente não é terceiro, razão pela qual não se aplica o regime das interceptações; ${ }^{151}$ por

\footnotetext{
${ }^{149}$ Cf. GRINOVER, Ada Pellegrini, GOMES FILHO, Antonio Magalhães, FERNANDES, Antonio Scarance. As nulidades... op. cit., p. 186.

${ }^{150}$ Cf. APRILE, Ercole; SPIEZIA, Filippo. Le intercettazioni... op. cit., p. 133. Em sentido semelhante, cf.: MARINELLI, Claudio. Intercettazioni processuali... op. cit, p. 37; FILIPPI, Leonardo. Intercettazione di comunicazioni..., p. 1.

${ }^{151}$ Em sentido semelhante, cf.: CAPRIOLI, Francesco. Intercettazione e registrazione... op. cit., p. 152, 155-156.
} 
outro, diz-se que o agente se traduz em uma "longa manus" da polícia, atuando como um "mero instrumento material" para execução da interceptação. ${ }^{152}$

Em se tratando de agente ligado à polícia que se aproxima com o propósito de captar e de registrar o conteúdo de comunicação entre pessoas presentes, reputamos oportuno a referência à advertência de ERCOLE APRILE e de FILIPPO SPIEZIA quanto à aplicabilidade da regulamentação da interceptação: "é manifesto, de fato, a diferente posição de quem se aproxima de outras pessoas para captar e registrar o colóquio, sem dele tomar parte, de quem, ao contrário, participa diretamente e pessoalmente da conversa: não se pode colocar em dúvida que, no primeiro caso, a operação é igualável a uma normal interceptação executada 'à distância' mediante apropriado instrumento técnico". ${ }^{153}$ Complementam os citados autores: "quando, em substância, tolhe-se do confidente qualquer autonomia e espontaneidade, a polícia está, em realidade, servindo de um meio de captação das conversas entre terceiros, fazendo-o, posteriormente, aparecer como registro de conversações entre presentes". ${ }^{154}$

\footnotetext{
${ }^{152}$ As duas correntes de pensamento são sintetizadas por CLAUDIO MARINELLI, que observa a necessidade da configuração dos elementos da definição de interceptação, para considerar a atividade como tal (Intercettazioni processuali... op. cit, p. 37-40). Quanto a reconhecimento de natureza de interceptação, cf., ainda: Cf. FILIPPI, Leonardo. Intercettazione di comunicazioni..., p. 1; CAMON, Alberto. Le intercettazioni nel processo penale. Milano: Giuffrè, 1996, p. 23, apud MARINELLI, Claudio. Intercettazioni processuali... op. cit, p. 38; BRUNO, Pierfrancesco. Intercettazioni di comunicazioni... op. cit., p. 184. Parece-nos que o tema retratado na discussão possa comportar análise entre as possíveis questões que possam ser suscitadas sobre o instituto do agente infiltrado. MARIÂNGELA LOPES NEISTEIN enfatiza as características do agente infiltrado: "1. ser policial; 2. agir de forma disfarçada ocultando a identidade; 3 . atuar com autorização judicial; 4. inserir-se de forma estável, e não esporádica, nas organizações criminosas; 5. fazer-se passar de criminoso para ganhar a confiança dos membros das organizações; 6 . visar a descoberta de provas de crimes graves." ( $O$ agente infiltrado como meio de investigação. Dissertação de Mestrado - Faculdade de Direito, Universidade de São Paulo (USP), São Paulo, 2006, p. 44). Contudo, as limitações do presente trabalho não nos permitem discorrer sobre as mencionadas questões.

${ }^{153}$ É a tradução livre do autor de: "è palese, infatti, la differente posizione di chi si avvicini ad altre persone per captarne e registrarne il colloquio, senza ad esso prendere parte, da chi invece partecipa direttamente e personalmente alla conversazione: non potendosi revocare in dubbio che, nel primo caso, l' operazione è parificabile ad uma normale intercettazione eseguita 'a distancia' mediante apposita strumentazione técnica" (Cf. APRILE, Ercole; SPIEZIA, Filippo. Le intercettazioni... op. cit., p. 134; APRILE, Ercole. La prova..., p. 367368).

${ }^{154}$ Cuida-se de tradução livre do autor de: "quando, in sostanza, si toglie al confidente qualsiasi autonomia e spontaneità d'azione, la polizia si sta in realtà servendo di un mezzo di captazione delle conversazioni tra terzi facendolo a posteriori apparire como registrazione di conversazioni tra presenti" (Cf. APRILE, Ercole; SPIEZIA, Filippo. Le intercettazioni... op. cit., p. 136). Também a doutrina alemã reconhece a natureza de interceptação de semelhante atividade. O exemplo alemão versa sobre a possibilidade de a polícia se valer de pessoas de confiança do investigado, como companheiros, para secretamente captar e registrar o conteúdo de comunicação ocorrida entre eles. Embora seja reconhecida a natureza de interceptação, a mencionada doutrina alemã protesta pelo reconhecimento de uma vedação probatória que impediria a sua execução, por identificar violação do "âmbito essencial" da vida privada (ROXIN, Claus. La prohibición... op. cit., p. 109).
} 
E a discussão vai além da figura de um encarregado da polícia, a quem se tenha incumbido a tarefa de gravar o conteúdo de uma comunicação presencial. Também se reflete sobre a figura de pessoa que, sob orientação de um mandante (sem a ligação com a polícia), portando um meio de captação da comunicação entre presentes, aproxima-se de alguém para se comunicar e registrar a conversa. Nesta hipótese, ALBERTO CAMON reconhece a natureza de interceptação: "todas as vezes em que atrás do interlocutor esteja um mandante e o registro suceda sob encargo deste último, se está em presença de um verdadeiro e próprio registro; o instrumento mecânico cumpre, desde o momento em que é acionado, a típica função que caracteriza o instituto: permite a um terceiro superar as normais capacidades perceptivas e reproduzir comunicações de outra forma não cognoscível" (grifo do autor). ${ }^{155}$

Consideramos, no mesmo sentido da corrente de pensamento ora referida, que, havendo um terceiro que incumba uma pessoa de proceder, por meio de emprego de meios técnicos, a captação de comunicação entre pessoas presentes - mesmo sendo ela interlocutora -, caracteriza-se interceptação de comunicação entre pessoas presentes. O elemento subjetivo (terceiro) que diferencia a interceptação da gravação clandestina não mais subsiste, porque há um terceiro, que incumbe uma pessoa de ser interlocutor com o objetivo de gravação da conversa. Nesta situação, como um dos interlocutores conhece o fato de que está sendo gravada a conversa - pois esconde em seu corpo o meio técnico de captação do seu conteúdo , trata-se de escuta de comunicação entre pessoas presentes. ${ }^{156}$

\footnotetext{
${ }^{155}$ Tradução livre do autor de: "tutte le volte in cui dietro all'interlocutore vi sia un mandante e la registrazione avvenga su incarico di quest'ultimo, si è in presenza di uma vera e propria registrazione; il congegno menccanico assove, sin dal momento in cui viene azionato, la tipica funzione che carratteriza l'istituto: permette ad un terzo di superare le normali capacità percettive e di riprodurre comunicazioni altrimenti inconoscibili" (CAMON, Alberto. Le intercettazioni nel processo penale. Milano: Giuffrè, 1996, p. 48, apud APRILE, Ercole; SPIEZIA, Filippo. Le intercettazioni... op. cit., p. 138). Se, atrás da atividade do sujeito, que efetua a captação, houver um mandante, é difícil sustentar que não haja interceptação, porque se tem uma terceira pessoa, quem, em razão de um instrumento mecânico, conhece sons e palavras, que não poderiam ser percebidos de outra forma (MARTINO, Corrada di; PROCACCIANTI, Teresa. Le intercettazioni... op. cit., p. 27). No mesmo sentido, cf.: LARONGA, Antonio. Le prove atipiche... op. cit., p. 200. Em sentido contrário, refutando-se a natureza de interceptação, cf.: CAPRIOLI, Francesco. Intercettazione e registrazione... op. cit., p. 152, 155-156.

${ }^{156}$ Sobre a distinção entre escuta e interceptação, cf., supra, item n. 3.2.
} 


\subsubsection{Segue: e revelação do conteúdo de comunicação entre pessoas presentes por um dos interlocutores}

A interceptação de comunicação entre pessoas presentes e a revelação do conteúdo de comunicação entre pessoas presentes por um dos interlocutores ${ }^{157}$ se diferenciam pelo elemento subjetivo e pelo meio empregado.

Quanto ao elemento subjetivo, em revelação do conteúdo da comunicação, não se identifica a figura de terceiro. É o próprio interlocutor quem revela o conteúdo da comunicação de que participou.

Além disso, em interceptação de comunicação, tem-se o emprego de meio técnico. Diferentemente, a revelação do conteúdo da informação pressupõe o conhecimento da informação por meios naturais, com os próprios sentidos, para posterior divulgação.

Como se trata de interlocutor da comunicação, não se identifica violação da intimidade, sob a perspectiva de interesse em manutenção do segredo das informações comunicadas, pois o emissor voluntariamente as compartilhou com o destinatário. ${ }^{158}$ Entende-se que o interlocutor pode revelar a terceiros a informação, transformando-se em "testigo de la información". ${ }^{159}$ Assim, é sugerido que o tema da revelação seja tratado sob a disciplina da prova testemunhal. $^{160}$

Ainda com relação ao tema, duas questões são ressaltadas: a da proibição de determinados testemunhos e a do agente encoberto.

\footnotetext{
${ }^{157}$ A doutrina chilena identifica "la revelación de la comunicación por el interlocutor" como uma das possíveis formas de restrição à garantia da inviolabilidade das comunicações, em especial, em se tratando de comunicação profissional (LENNON, Maria Inês Horvitz, MASLE, Julian Lopez. Derecho procesal penal chileno. Tomo II. 1. ed. Santiago: Editorial Juridica de Chile, 2004, p. 125-128).

${ }^{158}$ Neste sentido, cf.: LENNON, Maria Inês Horvitz, MASLE, Julian Lopez. Derecho procesal... op. cit., p. 125.

${ }^{159}$ Considera-se que "esta conducta podría, en algunos casos, considerarse como social o éticamente incorrecta, pero, en ningún caso, como conducta ilegal". Mas se reconhece a existência de debate doutrinário sobre a possibilidade de o Estado se valer da inexigibilidade de resguardo do segredo pelo interlocutor para obter, sem autorização judicial prévia, informação relevante para a investigação criminal (LENNON, Maria Inês Horvitz, MASLE, Julian Lopez. Derecho procesal... op. cit., p. 125).

${ }^{160}$ Lembramos, neste ponto, as ponderações sobre o testemunho indireto (cf., supra, item n. 3.2, nota n. 46), as quais podem se relacionar à revelação do conteúdo da conversa por um dos interlocutores.
} 
Embora não se tenha violação da intimidade sob a perspectiva do interesse no segredo do conteúdo da comunicação, o seu resguardo pode ser exigido. O interlocutor pode ser proibido pela lei de revelar a terceiros o conteúdo da comunicação. É o que ocorre, por exemplo, em relação a informações trocadas em relação profissional. ${ }^{161}$

A segunda questão versa sobre a possibilidade de o Estado inserir pessoas no círculo de relacionamento de investigados, para, como interlocutores, procederem à colheita de informação relevante para a persecução penal. Para esta questão, é proposta a solução sob o tema do agente encoberto. ${ }^{162}$

\subsection{O caráter insidioso}

A atividade de interceptação de comunicações se traduz em uma operação caracterizada pelo emprego de artifícios insidiosos. ${ }^{163}$ É por isso que sobressai o seu caráter insidioso. $^{164}$

${ }^{161}$ Cf. LENNON, Maria Inês Horvitz, MASLE, Julian Lopez. Derecho procesal... op. cit., p. 125. O art. 207 do Códigode Processo Penal brasileiro proíbe, em regra, o depoimento sobre informações conhecidas no exercício da profissão. Sobre este tema, cf., supra, item n. 3.6.

${ }^{162}$ Cf. LENNON, Maria Inês Horvitz, MASLE, Julian Lopez. Derecho procesal... op. cit., p. 126-128. A respeito do agente encoberto, MARIÂNGELA LOPES NEISTEN observa: "o agente encoberto seria aquela figura específica trazida pelas legislações com a finalidade de combate ao crime organizado, ou seja, aquele policial expressamente nomeado por um Juiz para ingressar nas organizações criminosas, fazendo-se passar por um de seus membros, com vistas à obtenção de provas de determinado crime, já identificado, que inclusive já é objeto de investigação ou processo criminal" ( $O$ agente infiltrado... op. cit., p. 51). Os diversos aspectos do tema do agente encoberto escapam ao objeto do presente trabalho. A referência ao instituto serve apenas de registro da proposta doutrinária para solução do tema da revelação do conteúdo de comunicação entre pessoas presentes por um dos interlocutores.

163 Cf. BRUNO, Pierfrancesco. Intercettazioni di comunicazioni... op. cit., p. 180. ADA PELLEGRINI GRINOVER se refere a interceptação como um "poderoso meio posto à disposição do Estado para fins de obtenção da prova, mas também instrumento insidioso de quebra da intimidade, não só do investigado, como também de terceiros." (Novo anteprojeto de lei disciplina a quebra de sigilo das comunicações telefônicas. Revista Literária de Direito, São Paulo, ano 9, n. 47, jun-jul. 2003, p. 19).

${ }_{164}$ A doutrina ressalta que "le intercettazioni di cui si trata non sono soltanto l'importante mezzo di ricerca di cui si é detto, ma sono anche strumento assai insidioso non solo sul piano pratico, a ragione delle manipolazioni e delle difficoltà interpretative cui possono dar luogo, ma soprattutto perché si scontrano com l'esigenza di tutela della liberta di comunicazione". Em tradução livre do autor: "as interceptações de que se trata não são somente o importante meio de investigação a que se referiu, mas são também instrumento bastante insidioso não apenas sob 
Diversamente de outros meios de investigação de prova (a busca, por exemplo), a interceptação se opera por atos insidiosos. Tanto a busca, quanto a interceptação, são fundadas em "surpresa", porque são autorizadas sem o conhecimento de investigado. A busca dela difere, porque possibilita um controle contextual sobre o desenvolvimento das operações; a interceptação, ao contrário, por ser oculta, desenvolve-se sem o conhecimento dos interlocutores. $^{165}$

Em razão de seu caráter insidioso, a interceptação de comunicações é meio de investigação de prova que opera uma significativa restrição em direitos fundamentais da pessoa humana. ${ }^{166}$

o plano prático, por razões das manipulações e das dificuldades interpretativas que podem delas decorrer, mas, sobretudo, porque colidem com a exigência de tutela da liberdade de comunicação" (TAORMINA, Carlo. Il regime della prova nel processo penale. Torino: G. Giappichelli, 2007, p. 105). Por igual, cf. CAPRIOLI, Francesco. Intercettazione e registrazione... op. cit., p. 144; BARGI, Alfredo. Intercettazioni di comunicazioni... op. cit., p. 791.

${ }^{165}$ Vejam-se, a este respeito, as observações de PAOLA BALDUCCI: "diversamente dagli altri mezzi di ricerca della prova (ispezione, perquisizioni, sequestri), l'intercettazione si qualifica no per il suo carattere 'coattivo', bensì per le sue modalità 'insidiose'. Come la perquisizione, è un atto 'a sorpresa'; ne differisce perchè 'occulto'. Se la perquisizione ammette un contestuale controllo sullo svolgimento delle operazioni, mediante eventuale assistenza o rappresentanza da parte di persona di fiducia, l' intercettazione, invece, si svolge ad insaputa dei dialoganti". Em tradução livre do autor: "diversamente dos outros meios de investigação de prova (inspeções, buscas, sequestros), a interceptação se qualifica não pelo seu caráter 'coativo', mas sim pelas suas modalidades 'insidiosas'. Como a busca, é um ato 'sob surpresa'; dela difere porque é oculta. Se a busca admite um controle contextual sobre o desenvolvimento das operações, mediante eventual assistência ou representação por parte de uma pessoa de confiança, a interceptação, ao contrário, desenvolve-se sem o conhecimento dos interlocutores" (Le garanzie... op. cit, p. 1). Em sentido semelhante, PAOLO CARNUCCIO enfatiza que a técnica operativa da interceptação, por meio de invasão na esfera pessoal, impossibilita a intervenção do interessado (Strategie e tecniche difensive in tema di intercettazioni. Torino: Giappichelli, 2007, p. 1-2).

${ }^{166}$ PAOLA BALDUCCI salienta que "questo mezzo di ricerca della prova, infatti, da un lato, è munito di una elevatissima efficacia investigativa, dall'altro esprime uma significativa invasività a danno dei diritti fondamentali della persona" (Le garanzie... op. cit, p. 1). Em tradução livre do autor: "este meio de investigação da prova, de fato, por um lado, é munido de uma elevadíssima eficácia investigativa; de outro, exprime uma significativa restrição em prejuízo dos direitos fundamentais da pessoa". No mesmo sentido MANUEL DA COSTA ANDRADE, analisando a interceptação de comunicação telefônica, afirma que se trata de meio invasivo, e salienta: "os estragos, têm uma dimensão subjectiva (apanhamos sempre mais pessoas do que queríamos apanhar) e lesam sempre muitos mais bens jurídicos, muitos mais interesses do que aqueles que se queria lesar. Através de uma escuta, sabe-se da vida da pessoa escutada, sabe-se da vida das pessoas de quem ela fala, a vida das pessoas que falam para ela. Põem-se em causa todas as esferas de segredo que a lei protege: o segredo do advogado, do médico, do confessor, a confidencialidade das relações familiares, tudo isto é devassado pelas escutas" (Das escutas telefônicas... op. cit., p. 206). PAULA BAJER FERNANDES MARTINS DA COSTA se refere a interceptação de comunicação telefônica como medida "drástica" (Igualdade no direito processual penal brasileiro. São Paulo: RT, 2001, p. 98). 
O caráter insidioso, reconhecido nas interceptações de comunicações em geral, potencializa-se em interceptação de comunicação entre pessoas presentes. Nesta, o caráter insidioso é "mortal". 167

Como consequência, em interceptação de comunicação entre pessoas presentes, com a qual, não raramente, pretende-se registrar uma "fotografia sonora" do crime, ${ }^{168}$ é intensificada a restrição a direitos fundamentais. ${ }^{169}$ Trata-se de medida dita intrusiva ${ }^{170}$ ou invasiva, ${ }^{171} \mathrm{da}$ qual decorre uma ingerência de "singular transcendência". ${ }^{172}$

Se comparada com as interceptações de comunicações em geral - nelas incluídas a interceptação de comunicação telefônica -, a interceptação de comunicação entre pessoas presentes, restringe, em maior grau, direitos fundamentais. ${ }^{173}$

A propósito da referida restrição a direitos fundamentais, VITTORIO GREVI ressalta o maior grau do caráter insidioso das interferências relativas às comunicações entre presentes. ${ }^{174}$ Lembra ainda a restrição mais grave da intimidade, porque incidem no âmbito de conversações reservadas, desenvolvidas sem intermediação de instrumentos de transmissão por cabo ou ondas eletromagnéticas. ${ }^{175}$

Acrescenta MANUEl DA COSTA ANDRADE que "as gravações de conversas entre presentes são mais gravosas e mais invasivas do que as escutas telefónicas. Já porque frustam

\footnotetext{
${ }^{167}$ Cf. DELL'ANDRO, Enzo Maria. Intercettazioni ambientali... op. cit., p. 160. No Brasil, DIOGO RUDGE MALAN, ao tratar de instituto também restritivo das comunicações presenciais, por ele intitulado "gravação ambiental domiciliar", acentua o caráter mais invasivo e restritivo de direitos fundamentais (Gravações Ambientais... op. cit., p. 349).

168 Cf. MARTINO, Corrada di. Le intercettazioni ambientali... op. cit., p. 1.168; MARTINO, Corrada di; PROCACCIANTI, Teresa. Le intercettazioni... op. cit., p. 58.

${ }^{169}$ CORRADA DI MARTINO se refere ao "potente caráter instrusivo" do meio (Le intercettazioni ambientali... op. cit., p. 1.155 e p. 1.168$)$.

${ }^{170}$ Cf. MARTINO, Corrada di. Le intercettazioni ambientali ... op. cit., p. 1.155.

${ }^{171}$ Cf. BALDUCCI, Paola. Le garanzie... op. cit, p. 91.

${ }^{172}$ Cf. BACIGALUPO, Enrique. Derecho Penal... op. cit, p. 236.

${ }^{173}$ Neste sentido, cf. MARTINO, Corrada di. Le intercettazioni ambientali ... op. cit., p. 1.155.

${ }^{174}$ Cf. Un caso di registrazione... op. cit., p. 495-496.

${ }^{175}$ Cf. Ibidem, p. 495-496. Volvendo aqui a teoria das esferas (cf., supra, item n. 2.2), já se sustentou que as conversações estão insertas na esfera da intimidade, ou esfera confidencial (COSTA JUNIOR, Paulo José. $O$ direito de estar só... op. cit., p. 30.). Parece-nos que, em se tratando de comunicações entre presentes, aproximase da esfera do segredo. Disto decorre a maior restrição da intimidade.
} 
uma expectativa mais consistente de confidencialidade e segredo; já porque não oferecem as mesmas possibilidades e os mesmos estímulos de auto-tutela. Quem confia as suas mensagens aos serviços de telecomunicações sabe que perde o domínio e o controlo das coisas, partindo com expectativas de reserva mais baixas do que quem fala cara-a-cara, num ambiente que fundadamente se presume asséptico e imune a intromissões."176

O indivíduo cuja comunicação presencial seja interceptada é surpreendido em momento em de exercício da liberdade de se comunicar no qual é maior a exposição de sua intimidade. ${ }^{177}$ Reputamos que fatores da comunicação entre presentes como a escolha do local e a proximidade física, por propiciarem um contato pessoal com o emprego de toda a dimensão física humana ${ }^{178}$ - não se restringindo a um contato de voz como ocorre na comunicação telefônica -, contribuem para maior exposição de informações pertinentes a intimidade dos interlocutores.

Apesar de mais intensa, a restrição às comunicações presenciais é legitimada por interesses constitucionalmente assegurados, entre os quais está a repressão a delitos, desde que sejam observadas determinadas exigências: reserva de lei, reserva de jurisdição e proporcionalidade. $^{179}$ Passamos a apresentar, então, propostas de disciplina para a interceptação de comunicações entre pessoas presentes, que atenda a tais exigências.

\footnotetext{
${ }^{176}$ Cf. ANDRADE, Manuel da Costa. Métodos ocultos... op. cit., p. 108-109. Outras considerações são expostas por MANUEL DA COSTA ANDRADE: "Uma coisa é escuta; outra é a escuta de pessoas cara a cara. Como é que se metem microfones ocultos legitimamente na casa das pessoas a título escutas? É que há uma diferença fundamental: quando falamos ao telefone atiramos com a palavra, não sabemos para onde. Corremos um pouco por risco próprio, isto é, temos que ter cuidado. A palavra que proferimos ao telefone é como a pedra que atiramos, sabe-se lá onde vai cair, temos que ter cuidado." (Das escutas telefônicas... op. cit., p. 207). Verifiquem-se, ainda, as ponderações de BERNSMANN/JANSEN: "a palavra dita ao telefone deve, em princípio, ser proferida com uma consciência da possibilidade de sua audição por terceiros maior do que as conversas que têm lugar num espaço público mas sob quatro olhos, em que, por via de regra, há muito mais possibilidades de protecção contra a eventual audição ou devassa. Esta ultima agressão revela-se, por isso e em princípio, mais grave" (Heimliche Ermittlungsmethode und ihre Kontrolle. Ein Systematische Überblick, Stv, 1998, p. 109, apud ANDRADE, Manuel da Costa. Métodos ocultos... op. cit., p. 108-109).

${ }^{177}$ Neste sentido: Cf. CAMON, Alberto. Le intercettazioni nel processo penale. Milano: Giuffrè, 1996, p. 176, apud MARTINO, Corrada di. Le intercettazioni ambientali ... op. cit., p. 1.155.

${ }^{178}$ É difundido, no conhecimento popular, repetidas vezes, que determinados assuntos se deve conversar "olho no olho", "cara a cara", ou, ainda, em "conversa particular", o que evidencia a maior exposição da intimidade.

${ }^{179} \mathrm{Com}$ relação ao fundamento e às exigências para restrição a comunicações entre pessoas presentes, cf., supra, item n. 2.6.
} 


\subsection{A disciplina da interceptação de comunicação entre pessoas presentes}

No atual estágio de desenvolvimento do direito processual penal, muito diverge a doutrina sobre a disciplina jurídica ${ }^{180}$ da interceptação de comunicação entre pessoas presentes. A divergência se estende não apenas pela discussão sobre seu conteúdo, como também acerca de sua autonomia.

\subsubsection{As propostas sobre o conteúdo}

A restrição à comunicação entre pessoas presentes, como já pudemos observar, tem como exigência a observância da reserva de lei, conjugada à reserva de jurisdição e a proporcionalidade. ${ }^{181}$ Sendo a interceptação um meio restritivo de comunicação entre pessoas presentes, a doutrina propõe aspectos que devem constar da respectiva disciplina jurídica. ${ }^{182}$

Com relação às interceptações de comunicações, PAOLA BALDUCCI ressalta que a reserva de lei não pode ser entendida em sentido meramente formal. ${ }^{183}$ É necessária a instituição de uma série de garantias, para assegurar o equilíbrio entre os interesses conflitantes em tema de interceptação: a repressão de delito e direitos e garantias individuais. $^{184}$

\footnotetext{
${ }^{180}$ Com a locução "disciplina jurídica”, expressamos um conjunto de normas jurídicas, autônomo e organizado, que regulamente os aspectos do instituto em análise.

${ }^{181}$ Cf., supra, itens n. 2.1 a 2.6.

182 As observações aqui apresentadas são extraídas, em geral, da doutrina estrangeira, considerados os estudos dispensados ao tema, propulsionados ora pela inércia do legislador, ora por uma disciplina que, embora existente, seja deficiente. Entre os resultados da pesquisa realizada, selecionamos, para apresentação de forma destacada, os autores que apontaram, de forma sistematizada, os aspectos tidos por essenciais para a disciplina da interceptação de comunicações.

${ }^{183}$ Cf. Le garanzie... op. cit., p. 39.

184 Cf. BALDUCCI, Paola. Le garanzie... op. cit., p. 39. Em sentido semelhante, ADA PELLEGRINI GRINOVER, ANTONIO MAGALHÃES GOMES FILHO e ANTONIO SCARANCE FERNANDES, comentando a regulamentação da interceptação de comunicação telefônica em Brasil, que "o princípio da reserva legal converte-se em princípio da reserva legal proporcional", segundo o qual "uma lei restritiva, mesmo quando adequada e necessária, pode ser inconstitucional quando adote cargas coativas desmedidas, desajustadas, excessivas ou desproporcionais em relação ao resultado." (As nulidades... op. cit., p. 173).
} 
É sob estas premissas que a citada autora propõe aspectos que devem ser versados na regulamentação de interceptação de comunicações, ${ }^{185}$ entre os quais destacamos os seguintes: a) a observância do princípio da proporcionalidade na avaliação de interesses constitucionalmente consagrados; b) subsistência de concretas e graves exigências de Justiça; c) subsistência de fundados motivos para reconhecer que o meio probatório possibilita a formação de resultados positivos para a investigação; d) predeterminação da duração em que seja possível a limitação do sigilo; e) controle sobre a legitimidade do provimento que autoriza a limitação do sigilo; f) sigilo dos resultados do ato; g) utilização limitada ao material relevante para a infração cuja prática se investiga; h) garantias relacionadas à identificação dos sujeitos da conversa, bem como do momento e do lugar em que ocorra. ${ }^{186}$

Também em comentários sobre as intercepções de comunicações, ANTÓNIO HENRIQUES GASPAR afirma que a previsão legal "não pode significar apenas que a lei enuncie a medida e preveja a possibilidade de utilização". ${ }^{187}$ Segundo o autor, a lei deve prever: "as categorias de pessoas susceptíveis de ser sujeitas às medidas de intercepção de conversas ou ao registro de imagens e som; a natureza das infracções que podem permitir o uso de tais meios de investigação; as condições em que devem ser fixadas as transcrições das conversas interceptadas; o procedimento de transmissão ao juiz dos registros para controlo judicial e para confrontação com a defesa; as circunstâncias em que se deve proceder à destruição dos elementos recolhidos". 188

Com relação à interceptação de comunicação telefônica, ENRIQUE BACIGALUPO propõe, para respectiva regulamentação, os seguintes aspectos: "pressupostos para ordenar a interceptação de comunicações telefônicas"; "competência para ordenar a medida"; "formalidades da decisão que ordena a interceptação"; "duração da medida"; "pessoas que podem ser afetadas"; "utilização em outros processos do material probatório obtido";

\footnotetext{
${ }^{185}$ Cf. BALDUCCI, Paola. Le garanzie... op. cit., p 39-40.

${ }^{186}$ PAOLA BALDUCCI critica, ainda, a disposição do Código de Processo Penal italiano que dispõe sobre a possibilidade de utilização dos resultados da interceptação em procedimentos diversos (art. 270) (Le garanzie... op. cit., p. 40). A este respeito, verifiquem-se, também, as observações constantes da análise do direito italiano (cf., infra, item n. 4.2.2.2.6).

${ }^{187}$ Cf. GASPAR, António Henriques. Os novos desafios... op. cit., p. 269.

${ }^{188}$ Cf. Ibidem, p. 269.
} 
"encontros fortuitos"; "destruição dos suportes das informações obtidas"; "proibição de interceptação"; "proibição de utilização". ${ }^{189}$

Referindo-se ao tema da interceptação de comunicações em geral, a doutrina, menciona, ainda, a necessidade de previsão legal de um meio de impugnação. ${ }^{190}$

Em especial quanto à interceptação de comunicação presencial, CLAUDIA CARMONA protesta pela fixação de requisitos rigorosos, para observância do princípio da taxatividade, que é corolário da reserva de lei. ${ }^{191}$

Considerados os entendimentos doutrinários mencionados, e retomando as exigências para restrição da comunicação entre pessoas presentes ${ }^{192}$ e os aspectos dogmáticos já

\footnotetext{
${ }^{189}$ Tradução livre do autor de: "presupuestos para ordenar la interceptación de comunicaciones telefónicas; competência para ordenar la medida"; "formalidades de la resolución que ordena la interceptación"; "duración de la medida"; "personas que pueden ser afectadas"; "utilización en otros procesos del material probatorio obtenido"; hallazgos casuales"; "destruición de los soportes de las informaciones obtenidas"; "prohibición de interceptación"; "prohibición de utilización" Derecho Penal... op. cit., p. 248-250). Quanto ao conteúdo da previsão normativa da interceptação de comunicação telefônica, é oportuno ressaltar a crítica da doutrina espanhola no que se refere à insuficiência da disciplina prevista na "Ley de Enjuiciamiento Criminal". Neste sentido, TERESA ARMENTA DEU, lembrando a jurisprudência da Corte Européia de Direitos Humanos, dela destacando os seguintes aspectos a serem versados pela disciplina legal: a definição de categorias de pessoas suscetíveis de poder ensejar a medida; a fixação de um limite a duração da execução da medida; o procedimento de transcrição das conversas interceptadas; as precauções a observar para comunicar intactas e completas as gravações realizadas, para fins de controle eventual pelo juiz e pela defesa; as circunstâncias nas quais se pode ou se deve apagar ou destruir os registros da gravação (Lecciones de Derecho Procesal Penal. 3. ed. Madrid: Marcial Pons, 2007, p. 154). Tal proposta de conteúdo normativo é extraída de julgamento proferido pela Corte Européia de Direitos Humanos cujos dados são os seguintes: CORTE EUROPEIA DE DIREITOS HUMANOS. Case of Valenzuela Contreras v. Spain (Merits and Just Satisfaction, n. 27671/95). Disponível em: http://cmiskp.echr.coe.int/tkp197/portal.asp?sessionId=63635425\&skin=hudoc-en\&action=request. Acesso em: 16/12/2010. Sobre o direito argentino, MARCELA DE LANGHE, também em considerações sobre a interceptação de comunicações telefônicas, sugere que a respectiva regulamentação seja integrada pelas seguintes "precisões": "1 - catálogo de delitos"; "2 - preexistencia de un proceso penal en trámite"; "3 - motivación suficiente": "I - existencia de un determinado grado de sospecha"; "II - ponderación, proporcionalidad y subsidiariedad"; "4 - sujetos afectados"; "5 - duración de la interceptación, mantenimiento, cese, prórrogas"; "6 - registros e transcripciones"; "7 - control del juez y de los afectados, selección, facultades de la defensa". Em tradução livre do autor: "1 - catálogo de delitos"; "2 - pré-existência de uma persecução penal em trâmite"; "3 motivação suficiente": "I - existência de um determinado grado de suspeita"; "II - ponderação, proporcionalidade e subsidiariedade"; "4 - sujeitos afetados"; "5 - duração da interceptação, manutenção, cessação, prorrogações"; "6 - registros e transcrições"; "7 - controle do juiz e dos afetados, seleção, faculdades da defesa" (Escuchas telefónicas... op. cit., p. 215).

${ }^{190}$ Cf. BALDUCCI, Paola. Le garanzie... op. cit., p. 43; Cf. AVOLIO, Luiz Francisco Torquato. Provas ilícitas... op. cit., p. 106.

${ }_{191}$ Cf. Le intercettazioni ambientali... op. cit., p. 357-358.

${ }^{192}$ Cf., supra, item n. 2.6.
} 
apresentados, ${ }^{193}$ exporemos, a seguir, por dever de síntese, os aspectos constantes de propostas de disciplina jurídica para a interceptação de comunicações em geral, os quais consideramos extensíveis para a interceptação de comunicação entre pessoas presentes. ${ }^{194}$

Por primeiro, deve estar prevista em lei a admissibilidade do instituto, ${ }^{195}$ com precisa delimitação de seus requisitos. ${ }^{196}$ Deve-se exigir a existência de elementos de materialidade e de autoria ${ }^{197}$ pertinentes a prática de espécies de delitos graves - considerando a relevância do bem jurídico -, ${ }^{198}$ previstas expressamente na lei, ${ }^{199}$ com a respectiva indicação do dispositivo

${ }^{193}$ Cf., supra, itens n. 3.1 a n. 3.9 .
${ }^{194}$ Não desconhecemos que as particularidades de cada ordenamento jurídico possam alterar a compreensão da formulação das propostas. Procuramos salientar, contudo, as que consideramos relevantes para a análise do instituto em âmbito nacional.

${ }^{195}$ Sobre a admissibilidade dos meios de investigação de prova, cf., supra, n. 1.2.3.2 e 1.4.1.

${ }^{196}$ Cf. ELLEN SCHLÜCHTER enfatiza a necessidade de delimitação de requisitos para o instituto (Derecho Procesal... op. cit., p. 65). Em razão da restrição de direitos fundamentais, deve-se operar interpretação restritiva destes requisitos. Neste sentido, cf.: SCA O autor salienta, ainda, a necessidade de interpretação restritiva da disciplina do meio (FERNANDES, Antonio Scarance. O sigilo... op. cit., p. 159-161; ANDRADE, Manuel da Costa. Das escutas telefônicas... op. cit., p. 206).

197 Neste sentido, manifesta-se ENRIQUE BACIGALUPO, ao formular propostas para regulamentação homogênea da interceptação de comunicação telefônica em âmbito europeu (Derecho Penal... op. cit., p. 246).

198 Quanto aos critérios para fixação de espécies delitivas, em considerações sobre a interceptação de comunicação telefônica, a doutrina sugere, em observância à proporcionalidade no plano normativo, a excepcional gravidade e a forma particular de execução do delito. ANTONIO MAGALHÃES GOMES FILHO, neste sentido, observa que: "em se tratando de interceptações, somente a excepcional gravidade de certos delitos ou a forma particular de execução de outros (como v.g., ameaça ou injúria cometidas por telefone) é que poderia justificar a intromissão do aparato repressivo nas conversações telefônicas, com o fim de recolher informações." (Direito à prova... op. cit., p. 125). No mesmo sentido, cf.: GOMES FILHO, Antonio Magalhães. A violação do princípio da proporcionalidade pela Lei 9.296/96. Boletim IBCCRIM, São Paulo, n. 45, ago. 1996, p. 14; BELLOQUE, Juliana Garcia. Nova disciplina jurídica da quebra do sigilo das comunicações telefônicas. Boletim IBCCRIM, São Paulo, Ano 11, n. 127, jun. 2003, p. 12. Na mesma esteira, GUSTAVO HENRIQUE RIGHI IVAHY BADARÓ, para a interceptação de comunicação telefônica, ressalta a gravidade do delito e as particularidades da forma de seu conhecimento como critérios para a especificação dos delitos (Direito processual penal: tomo I... op. cit., p. 288).

${ }^{199}$ Em relação aos requisitos, a melhor técnica é a de expressá-los, em ordem direta. A doutrina nacional assim se manifesta, em crítica à técnica empregada na Lei n. 9.296, de 1996, na qual se previram hipóteses em que a interceptação de comunicação telefônica não é admitida, do que decorre a necessidade de operar interpretação contrario sensu. Neste sentido, cf.: GRINOVER, Ada Pellegrini; GOMES FIHO, Antonio Magalhães; FERNANDES, Antonio Scarance. As nulidades... op. cit., p. 172 e 173; GRINOVER, Ada Pellegrini. O regime brasileiro... op. cit., p. 7; GRINOVER, Ada Pellegrini. A marcha... op. cit., p. 106; FERNANDES, Antonio Scarance. Processo penal... op. cit., p. 96-97; FERNANDES, Antonio Scarance. Interceptações telefônicas: aspectos processuais da nova lei. Boletim IBCCRIM. São Paulo: n. 45, ago. 1996, p. 15; FERNANDES, Antonio Scarance. A lei de interceptação telefônica. In: PENTEADO, Jaques de Camargo (Coord.). Justiça penal - 4: críticas e sugestões: provas ilícitas e reforma pontual. São Paulo: RT, 1997, p. 55-56; BADARÓ, Gustavo Henrique Righi Ivahy. Direito processual penal: tomo I... op. cit., p. 247; MACHADO, André Augusto Mendes; KEHDI, André Pires de Andrade. Sigilo das comunicações... op. cit., p. 254. Em direito estrangeiro, a doutrina se refere à necessidade de a lei prever o "catálogo" de delitos em cuja persecução penal se admite interceptação de comunicação (ANDRADE, Manuel da Costa. Das escutas telefônicas... op. cit., p. 207). 
normativo em que são previstas. ${ }^{200}$ Em outras palavras: os delitos em cuja persecução se admita a interceptação devem ser especificados, relacionados, catalogados em lei.

Além da previsão de requisitos, há que se exigir a demonstração da necessidade da interceptação, porque se trata de meio subsidiário. ${ }^{201}$ A interceptação não deve ser admitida se, para a investigação de fontes de prova pertinentes a um delito em cuja persecução seja cabível, houver outros meios menos invasivos.

Uma precisa delimitação legal do aspecto subjetivo que legitime o emprego de interceptação também é necessária. ${ }^{202}$ Assim, tantos os sujeitos ativos (legitimados ativos e órgãos executivos), ${ }^{203}$ quanto os sujeitos passivos (legitimados passivos e terceiros), ${ }^{204}$ devem ser extraídos da regulamentação do instituto. Neste ponto, lembramos a inadmissibilidade de interceptação de conversas mantidas em âmbito profissional e em âmbito familiar, com exceção à hipótese em que haja elementos concretos de que os profissionais ou os familiares também contribuam para a prática de delito investigado. ${ }^{205}$

Igualmente, a disciplina legal há que versar sobre a autoridade competente para autorizar a realização da interceptação, ${ }^{206}$ estabelecendo os requisitos dos respectivos requerimento e deliberação. ${ }^{207}$

${ }^{200}$ Note-se, a propósito, a técnica utilizada pelo legislador alemão para delimitação da admissibilidade da interceptação de comunicação entre presentes: previsão das espécies delitivas, com a respectiva indicação do dispositivo normativo em que são previstas (cf., infra, item n. 4.2.2.2.1).

${ }^{201}$ Neste sentido, prevê o legislador italiano a necessidade de demonstração da indispensabilidade da medida para o prosseguimento da investigação (art. 267 do Código de Processo Penal italiano) (cf., infra, item n. 4.2.2.2.6). Em sentido semelhante, é previsto na lei processual penal alemã a necessidade de demonstração da existência de fundados motivos de que, com a execução da interceptação, obter-se-ão informações relevantes para a investigação (§100.c, 1.1 a 1.4) (cf., infra, item n. 4.2.2.2.1). A este respeito, ENRIQUE BACIGALUPO, ao formular propostas para regulamentação homogênea da interceptação de comunicação telefônica em âmbito europeu, afirma a necessidade de "comprobación de que la investigación no sería posible o que resultaría desproporcionadamente dificultosa por otros medios" (Derecho Penal... op. cit., p. 248). Lembre-se, ainda, que a análise da proporcionalidade do meio impõe a verificação de sua adequação, necessidade e proporcionalidade em sentido estrito (cf., supra, item n. 2.6).

${ }^{202}$ Cf. BALDUCCI, Paola. Le garanzie nelle intercettazioni... op. cit., p. 44.

${ }^{203}$ Cf., supra, item n. 3.5.

${ }^{204} \mathrm{Cf}$., supra, item n. 3.6.

${ }^{205}$ Cf., supra, item n. 3.6.

${ }^{206}$ ANTONIO SCARANCE FERNANDES também se refere à necessidade da explícita previsão da autoridade competente para a autorização da realização de um meio de investigação de prova, ao tratar de acesso aos registros sigilosos: "A autorização legislativa para acesso aos registros sigilosos para obtenção da prova criminal deve: a) explicitar as hipóteses possíveis de acesso, b) arrolar as pessoas ou entidades que têm direito ao acesso, 
O prazo de duração é mais um aspecto do instituto a ser tratado em lei. ${ }^{208} \mathrm{~A}$ proporcionalidade da medida restritiva, como visto, estende-se pelo período de sua duração. ${ }^{209}$

Outro aspecto a ser delimitado em lei é o procedimento probatório, ${ }^{210}$ que seja integrado por fases de autorização, de execução e de documentação da interceptação.

A interceptação de comunicação entre presentes, sendo um meio de investigação de prova, como já pudemos observar, ${ }^{211}$ é fundada no fator surpresa. Isto implica a sua autorização e execução sem o conhecimento de seus sujeitos passivos. Todavia, na fase de documentação dos atos nela praticados devem ser asseguradas em lei aos seus sujeitos ativos e passivos oportunidades para a efetiva defesa de seus interesses.

É recomendada, demais disso, a previsão da preservação dos suportes técnicos de registro do conteúdo da comunicação sob sigilo, até o trânsito em julgado da sentença. ${ }^{212}$

O legislador deve estabelecer, ainda, a necessidade de tramitação sob sigilo de investigações e de processos em que constem registros da interceptação de comunicação entre presentes, ${ }^{213}$ assegurando a reserva dos resultados da interceptação. ${ }^{214}$

c) prever os órgãos competentes para autorizar o acesso." (O sigilo... op. cit., p. 159). Também o faz ENRIQUE BACIGALUPO, em propostas para regulamentação da interceptação de comunicação telefônica em âmbito europeu (Derecho Penal... op. cit., p. 248).

${ }^{207}$ Tenha-se, como exemplo, os requisitos previstos no $\S 100 . d, 3$ da StPO (cf., infra, item n. 4.2.2.2.1). No mesmo sentido, ENRIQUE BACIGALUPO sustenta a necessidade de previsão legal dos requisitos da ordenação de interceptação de comunicação (Derecho Penal... op. cit., p. 249).

${ }^{208}$ Cf. BALDUCCI, Paola. Le garanzie... op. cit., p. 40. É interessante notar a íntima ligação entre a natureza cautelar da medida e o seu caráter provisório (PRADO, Geraldo. Limite às interceptações telefônicas e a jurisprudência do Superior Tribunal de Justiça. Rio de Janeiro: Lumen Iuris, 2005, p. 32).

${ }^{209}$ Cf., supra, item n. 2.6.

${ }^{210}$ Cf. GASPAR, António Henriques. Os novos desafios... op. cit., p. 269.

${ }^{211}$ Cf., supra, itens n. 3.3, e itens n. 1.1 a n. 1.6.

212 É o que também se propôs para nova regulamentação de interceptação de comunicação telefônica (GRINOVER, Ada Pellegrini. Novo anteprojeto... op. cit., p. 21).

${ }^{213}$ Por igual, é o que se sugere para nova regulamentação de interceptação de comunicação telefônica (GRINOVER, Ada Pellegrini. Novo anteprojeto... op. cit., p. 21).

${ }^{214}$ Neste sentido, cf.: BALDUCCI, Paola. Le garanzie... op. cit., p. 40. 
Também temos por necessário o tratamento da utilização dos resultados da interceptação em outras investigações ou outros processos e dos encontros fortuitos.

Além disso, apesar de assegurada constitucionalmente a garantia da inadmissibilidade de provas obtidas por meios ilícitos, parece-nos recomendável a previsão de impossibilidade de utilização dos resultados de interceptação que contrarie as normas da respectiva disciplina jurídica.

Por último, entendemos que deva ser assegurado em lei um meio de impugnação à interceptação de comunicações, que deve ser extraído do sistema processual penal, ou ser previsto na disciplina da interceptação.

Entre os aspectos apontados, cumpre-nos enfatizar a admissibilidade e o procedimento probatório da interceptação de comunicação entre pessoas presentes, sobre os quais versa a discussão sobre a autonomia do instituto.

\subsubsection{As propostas sobre a autonomia: admissibilidade e procedimento}

Analisadas as propostas sobre o conteúdo de disciplina sobre a interceptação de comunicação entre pessoas presentes, pode-se notar que, no mais das vezes, são formuladas para as interceptações de comunicações em geral; estendidas, portanto, às interceptações de comunicações presenciais.

Entretanto, conquanto integre um mesmo gênero (interceptações de comunicações), a interceptação de comunicação entre pessoas presentes se diferencia das interceptações de telecomunicações (comunicação telefônica, por exemplo) pelo seu objeto. ${ }^{215}$ A maior restrição a direitos e garantias fundamentais ${ }^{216}$ embasa considerações sobre a necessidade de instituição uma disciplina específica para a interceptação de comunicação entre pessoas presentes, na qual a admissibilidade e o procedimento probatório se amoldem ao seu objeto.

\footnotetext{
${ }^{215}$ Cf., supra, item n. 3.3.

${ }^{216}$ Cf., supra, itens n. 2.1 a n. 2.6.
} 
O tratamento legislativo específico de intromissões em comunicação entre pessoas presentes, como lembrado por VITTORIO GREVI, visa a assegurar maior proteção de "espaço vital" para o desenvolvimento da personalidade do ser humano. ${ }^{217}$ A intensificação do caráter insidioso $^{218}$ e, por conseguinte, da restrição a direitos fundamentais justifica a diversidade de tratamento legislativo que a elas deve ser dispensada.

No mesmo sentido, CORRADA DI MARTINO, cotejando a interceptação de comunicação telefônica e a interceptação de comunicações entre presentes, ressalta a maior restrição a liberdades públicas nas segundas como justificativa para a elaboração de uma disciplina específica, com admissibilidade mais restrita. ${ }^{219}$

Igualmente, MANUEL DA COSTA ANDRADE sustenta a autonomia da disciplina da interceptação de comunicação entre pessoas presentes, e assevera que sua admissibilidade

\footnotetext{
${ }^{217} \mathrm{O}$ autor sustenta a necessidade de diversidade de tratamento legislativo, apresenta a seguinte justificativa: "in definitiva è bene che sia cosí vi sia un'area di rapporti umani protetta da qualunque intromissione - sia del magistrato, sia a maggior ragione, della polizia - trattandosi del minimo spazio vitale per la tutela della personalità di ciascuno. In caso contrario, qualora si legitimasse l'uso di tavole d'ascolto o di microfoni nascosti per registrare conversazioni confidenziali, ancorché a fini di giustizia, si aprirebbe una breccia estremamente pericolosa per l'intimità delle case e per la sicurezza degli altri ambienti di comune frequentazione, che invece non si vorrebbero in alcun modo contaminati dalla civiltà delle microscopie. Si obietterà che il prezzo di una simile scelta è rappresentato da un minor grado di efficienza delle indagini, ma è questo un prezzo che forse conviene pagare per garantire all'individuo un sia por esiguo margine di assoluta inviolabilità nella sfera di riservatezza delle sue relazioni con gli altri individui". Em tradução livre do autor: "em definitivo, é bom que assim seja, isto é, que seja uma área das relações humanas protegida de qualquer intromissão - seja do magistrado, seja, por maior razão, da polícia, tratando-se do mínimo espaço vital para a tutela da personalidade de cada um. Em caso contrário, acaso se legitimasse o uso de mesas de escuta ou de microfones escondidos para registrar conversações confidenciais, mesmo que para fins de Justiça, se abriria uma brecha extremamente perigosa para a intimidade das casas e para a segurança dos outros ambientes de comum frequentação, que, ao contrário, não se queria, de algum modo, contaminados pela civilização das microscopias. Objetar-se-á que o preço de uma similar escolha é representado um menor grau de eficiência das investigações, mas é este um preço que talvez convém pagar para garantir ao indivíduo uma também exígua margem de absoluta inviolabilidade na esfera de reserva das suas relações com outros indivíduos" (Un caso di registrazione... op. cit., p. 495) (grifou-se). ${ }^{218}$ VITTORIO GREVI se refere ao maior grau de "insidiosità" da interceptação de comunicação entre pessoas presentes (Un caso di registrazione... op. cit., p. 495-496). No mesmo sentido: cf. CAPRARO, Laura. Intercettazioni ... op. c, p. 1.453-1.455.

${ }^{219}$ A autora ressalta a desproporcionalidade entre a gravidade dos delitos em cuja persecução se admitem as interceptações e o caráter insidioso do meio, o que sobressai em captações de comunicações entre presentes (Le intercettazioni ambientali... op. cit., p. 1.155).
} 
deve se restringir a um "catálogo" mais reduzido de crimes graves, se comparado com o "catálogo" da interceptação de comunicação telefônica. ${ }^{220}$

E a afirmação da autonomia de tratamento legislativo também é feita para as espécies da interceptação de comunicação entre pessoas presentes. ${ }^{221}$ A este respeito, PAOLA BALDUCCI ressalta a necessidade de distinção entre a disciplina das espécies de interceptações de comunicações entre pessoas presentes: a interceptação ambiental e a interceptação domiciliar. ${ }^{222}$ Em análise do ordenamento jurídico italiano, a autora, criticando a ausência de uma graduação do poder limitativo da inviolabilidade do sigilo das comunicações em relação à gravidade do caso e a correlata necessidade de sua averiguação, protesta pela observância da proporcionalidade, de modo a se distinguirem os requisitos de interceptações telefônicas e de interceptações ambientais extradomiciliares das interceptações em domicílio. ${ }^{223}$

Mas a autonomia da disciplina da interceptação de comunicação entre presentes se refere não só à admissibilidade, como também ao procedimento probatório. Comentando a disciplina instituída para a interceptação de comunicação entre presentes pelo Código de Processo Penal italiano, FrANCESCO CAPRIOLI observa a inadequação da equiparação às interceptações telefônicas, tanto sob o aspecto da admissibilidade, quanto sob o aspecto do procedimento probatório. $^{224}$

\footnotetext{
${ }^{220}$ Cf. ANDRADE, Manuel da Costa. Métodos ocultos... op. cit., p. 114. Ainda sobre a necessidade de restrição do catálogo de crimes, MANUEL DA COSTA ANDRADE, em outra obra, assevera: "quando falamos cara a cara com os nossos amigos, isto pode ser escutado em termos iguais? De que forma fica a sociedade se todos passarmos a andar com medo que tenhamos por perto microfones? Onde está a coesão social? A tranquilidade das pessoas? Isto é uma solução orweliana de Big Brother em toda a parte e em todo o canto. Do meu ponto de vista, este alargamento não se justificava. Talvez, naturalmente, seja possível identificar casos em que seja legítimo recorrer a este tipo de intercepção, mas tinha que se limitar o catálogo de crimes; tinha que se prescrever, por exemplo, a proibição absoluta de microfones nas casas de habitação, o que a lei não faz. Esta é uma equiparação, do meu ponto de vista, indesejável” (Das escutas... op. cit., p. 207).

${ }^{221}$ Quanto às espécies da interceptação de comunicação entre pessoas presentes, cf., supra, item n. 3.10.

${ }^{222}$ Cf. BALDUCCI, Paola. Le garanzie... op. cit., p. 42.

${ }^{223}$ Para as interceptações domiciliares, a autora afirma a necessidade de instituição de exigências "excepcionais" (Le garanzie nelle intercettazioni... op. cit., p. 41-42).

${ }^{224} \mathrm{O}$ autor lembra, por exemplo, a previsão de cabimento, em persecução dos delitos de moléstia e distúrbio em desfavor de pessoas se cometidos por meio de telefone, de ambas as espécies de interceptação, além de criticar, quanto ao procedimento previsto (Intercettazione e registrazione... op. cit., p. 171-172, 176). Neste sentido, PIERFRANCESCO BRUNO considera que a interceptação de comunicação entre pessoas presentes diverge tanto do ponto de vista das modalidades operativas, como de sua maior potencialidade intrusiva. E observa que a possibilidade de restrição da liberdade de comunicação, para atender a exigida reserva de lei, depende de uma objetiva predeterminação de instrumentos jurídicos e de técnicas mediante as quais possa ser concretizada (Intercettazioni di comunicazioni... op. cit., p. 206-207). PAOLA BALDUCCI também critica a falta de
} 
O procedimento probatório deve ser diferenciado, porque as operações de interceptação de comunicação entre pessoas presentes, ao contrário das interceptações de comunicações telefônicas, envolvem o emprego de diferentes técnicas.

Tratando-se de interceptação de comunicação telefônica, que se realiza com "grampeamento" do telefone, basta a comunicação do número de telefone ao ente gestor do serviço telefônico, para que se possibilite a captação do conteúdo da comunicação. ${ }^{225} \mathrm{~A}$ inexistência de previsão da necessidade de expressão do modo de execução desta modalidade de interceptação não é considerado um problema. ${ }^{226}$

De outro lado, as interceptações de comunicações entre pessoas presentes podem ser realizadas de diferentes modos. ${ }^{227}$ Assim, em observância da reserva de lei e de jurisdição, CORRADA Di MARTINO e TERESA PROCACCIANTI frisam a necessária previsão da exigência de constar da autorização judicial a expressa determinação do modo a ser empregado na execução desta modalidade de interceptação. ${ }^{228}$

O modo a ser empregado engloba a necessidade de indicação do local (domicílio ou não) onde se pretenda captar o conteúdo de uma conversa presencial, do meio técnico, da forma de utilização do meio técnico e da maneira de sua inserção no referido local. Se for preciso o ingresso, de qualquer forma, ${ }^{229} \mathrm{em}$ domicílio, a determinação judicial do modo de

regulamentação das modalidades executivas das interceptações entre pessoas presentes (Le garanzie... op. cit, p. $18)$.

${ }^{225}$ Neste sentido, cf.: MARTINO, Corrada di; PROCACCIANTI, Teresa. Le intercettazioni... op. cit., p. 71.

${ }^{226}$ Cf. MARTINO, Corrada di. Le intercettazioni ambientali... op. cit., p. 1.168; MARTINO, Corrada di; PROCACCIANTI, Teresa. Le intercettazioni... op. cit., p. 71. No mesmo sentido, cf.: CAMON, Alberto. Le intercettazioni... op. cit., p. 189-190, apud CAPRARO, Laura. Intercettazioni in autoventtura... op. cit., p. 1.459; ${ }^{227}$ Lembra LAURA CAPRARO que as interceptações de comunicações entre presentes são, no mais das vezes, tecnicamente incompatíveis com estruturas fixas e centralizadas de escuta (Intercettazioni in autoventtura... op. cit., p. 1.453). PAOLA BALDUCCI também salienta a pluralidade de formas pelas quais possa se desenvolver uma comunicação entre pessoas presentes (Le garanzie... op. cit., p. 18).

${ }^{228}$ No mesmo sentido, Cf. MARTINO, Corrada di. Le intercettazioni ambientali... op. cit., p. 1.171; MARTINO, Corrada di; PROCACCIANTI, Teresa. Le intercettazioni... op. cit., p. 71-72.

${ }^{229}$ Ainda que o meio técnico empregado propicie a captação do conteúdo de comunicação presencial à distância, por exemplo, por meio de emissão de ondas sonoras tendentes à captação, pela oscilação, da frequência das ondas integrantes de som vocálico, consideramos que há ingresso em domicílio, das ondas emitidas que seja. 
inserção do meio técnico é fundamental, considerada a proteção constitucionalmente atribuída a esta categoria de espaço físico. ${ }^{230}$

Muito se enfatiza a necessidade de indicação do modo de inserção no local onde se pretenda interceptar a comunicação presencial. Afirma-se que, diferentemente de interceptação de comunicação telefônica - em que se tem uma linha telefônica na qual se liga fisicamente o meio de captação e de registro -, em interceptação de comunicação entre pessoas presentes, o meio a ser utilizado deve ser oportunamente inserido, de forma oculta e sem o conhecimento dos interlocutores em um determinado local. ${ }^{231}$ Se a comunicação que se pretenda captar se desenvolver em domicílio, é necessário que nele se ingresse, com o escopo de inserir o meio de captação. ${ }^{232}$

Ainda no que se refere à inserção do meio de captação do conteúdo da comunicação, PAOLA BALDUCCI observa que a forma pode variar: o ingresso e a permanência em domicílio de operadores que, portando instrumentos apropriados para a captação da comunicação, escondem a própria presença dos interlocutores; a participação direta em conversa por operadores que portam consigo instrumentos apropriados para a captação da comunicação, oportunamente escondidos; a ocultação no ambiente de dispositivos chamados microscópicos que estejam ligados a aparelhos de captação e registros externos, instalados próximo ao local onde a interceptação seja realizada. ${ }^{233}$

Demais disso, GiACOMO FUMU salienta que, em interceptação de comunicação entre pessoas presentes, a descrição da modalidade de captação e registro é relevante para o

\footnotetext{
${ }^{230}$ Cf., supra, item n. 2.4 .

${ }^{231}$ Cf. MARTINO, Corrada di; PROCACCIANTI, Teresa. Le intercettazioni ... op. cit., p. 58.

${ }^{232}$ A propósito, CORRADA DI MARTINO e TERESA PROCACCIANTI, referindo-se à necessidade de ingresso em locais fechados, sugerem que a introdução do instrumento de captação possa ocorrer por meio da observância dos institutos da inspeção ou da busca (Le intercettazioni... op. cit., p. 58). Tais institutos são previstos, respectivamente, nos arts. 244 a 246, e 247 a 252 do Código de Processo Penal italiano.

${ }^{233}$ A autora indica tais formas, salientando a variedade de modalidade de execução da interceptação de comunicação entre pessoas presentes (Le garanzie... op. cit., p. 18). Note-se que autora, nesta oportunidade, expressa seu entendimento quanto à natureza de interceptação do "agente equipado para o som" (v., supra, item 3.8.2), hipótese em que o sujeito interceptor se aproxima do investigado, com aparelhos ocultos, para com ele se comunicar e gravar o conteúdo da respectiva conversa (Le garanzie... op. cit., p. 18).
} 
exercício do direito de defesa e o controle sobre a genuinidade dos elementos registrados. ${ }^{234}$ Isto porque a individuação dos interlocutores e a correta atribuição das várias frases pronunciadas representam uma incumbência bem mais delicada na interceptação de comunicações entre pessoas presentes, se comparada com a interceptação de comunicações telefônicas. $^{235}$

É por estas razões, ligadas a admissibilidade e ao procedimento probatório da interceptação de comunicação entre pessoas presentes, que se critica a aplicação, por analogia, da disciplina da interceptação de comunicação telefônica. A este respeito, ENZO MARIA DELL'ANDRO recorda que a ausência de normas precisas sobre as modalidades de interceptação viola a reserva de lei exigida para a restrição da comunicação presencial. ${ }^{236}$

Com relação ao direito brasileiro, adiantamos, doravante, algumas de nossas conclusões, que repercutirão na formulação de sugestões para a disciplina jurídica da interceptação de comunicação entre pessoas presentes. ${ }^{237}$

Afirmar a identidade de disciplina jurídica entre as interceptações de comunicações (de telecomunicação e de comunicação presencial) é examiná-las com vistas voltadas somente para a técnica processual empregada (a interceptação).

Além da técnica processual, é preciso se atentar para o objeto da interceptação, que é por demais relevante para a delimitação da respectiva disciplina jurídica. De acordo com o objeto, como pudemos verificar, varia a intensidade da restrição a direitos e garantias individuais. ${ }^{238} \mathrm{~A}$ interceptação de comunicação entre pessoas presentes, sobretudo se ocorrida

\footnotetext{
${ }^{234}$ Cf. FUMU, Giacomo. Sub artt. 266-271, in Commento al nuovo codice di procedura penale, coord. Da M. Chiavario, vol. II. Torino: UTET, p. 331, apud MARTINO, Corrada di; PROCACCIANTI, Teresa. Le intercettazioni... op. cit., p. 58.

${ }^{235}$ Cf. MARTINO, Corrada di. Le intercettazioni ambientali... op. cit., p. 1.168; MARTINO, Corrada di; PROCACCIANTI, Teresa. Le intercettazioni... op. cit., p. 58.

${ }^{236} \mathrm{O}$ autor salienta a violação da reserva de lei, e protesta pela instituição de uma disciplina minuciosa (Intercettazioni ambientali... op. cit., p. 160-161).

${ }^{237}$ Cf., infra, item n. 5.5.

${ }^{238}$ Cf., supra, item n. 3.9.
} 
em domicílio, é mais restritiva, se comparada com a interceptação de telecomunicação, por exemplo, de comunicação telefônica. ${ }^{239}$

A necessária diversidade de tratamento legislativo da interceptação de comunicação entre pessoas presentes decorre, portanto, de seu objeto. ${ }^{240}$ As exigências para a restrição dos direitos e garantias individuais que fundamentam a comunicação entre pessoas presentes (a reserva de lei, a reserva de jurisdição e a proporcionalidade) justificam a disciplina jurídica específica de sua interceptação.

Reputamos que deve haver uma disciplina específica para a interceptação de comunicação entre pessoas presentes, sob a perspectiva tanto de sua admissibilidade, como de seu procedimento probatório.

Em disciplina legal, a interceptação de comunicação entre pessoas presentes deve ser admitida em persecução penal de delitos especificados de forma expressa a indicação dos respectivos dispositivos legais que os tipificam, de forma mais restrita do que a da interceptação de comunicação telefônica.

Além disso, há que se diferenciarem as espécies de interceptação de comunicação entre pessoas presentes, restringindo a admissibilidade da interceptação domiciliar, com a instituição de requisitos mais rigorosos, se comparados com os da interceptação ambiental. Entre estes requisitos destacamos o período em que possam ser realizadas. ${ }^{241}$ a interceptação domiciliar, durante o dia; a interceptação ambiental, durante o dia ou a noite. ${ }^{242}$

Frisamos, por oportuno, que o fato de ser menos restrita a admissibilidade da interceptação ambiental, não deve significar, a nosso ver, a possibilidade de equiparação com a admissibilidade da interceptação de comunicação telefônica. O objeto da interceptação ambiental (a comunicação entre pessoas presentes) é, uma vez mais, o fundamento para

\footnotetext{
${ }^{239}$ A propósito, cf., supra, itens n. 2.1 a 2.6.

${ }^{240}$ Quanto ao objeto da interceptação de comunicação entre pessoas presentes, cf., supra, item n. 3.3.

${ }^{241}$ Sobre as espécies de interceptação de comunicação entre pessoas presentes, cf., supra, item n. 3.10.

${ }^{242}$ Lembre-se de que o art. $5^{\circ}$, inciso XI da Constituição da República (cf., supra, item n. 2.4) possibilita interferência em domicílio por autorização judicial apenas durante o dia.
} 
restrição da admissibilidade, que deve ser distinta da prevista para interceptação de telecomunicações.

Quanto ao procedimento probatório, devem ser previstos em lei os requisitos legais da autorização judicial da interceptação de comunicação entre presentes. É necessária a previsão, como requisito legal, de indicação do modo pelo qual a interceptação será realizada, por meio da exigência de indicação do local (domicílio ou não) onde se pretenda captar o conteúdo de uma conversa presencial, do meio técnico, da forma de utilização do meio técnico e da maneira de sua inserção no referido local.

A indicação do modo, nos termos acima mencionados, de realização da interceptação repercute nas diferentes fases do procedimento: de autorização, de execução e de documentação da interceptação.

$\mathrm{Na}$ fase de autorização, não se pretende exigir do juiz conhecimento técnico sobre a pluralidade de aparatos que propiciem a captação e o registro de som vocálico. Mas a indicação é necessária, para resguardar os interesses dos sujeitos passivos da interceptação. ${ }^{243}$ Por isto, é recomendável que o legitimado a requerer a interceptação se refira ao meio a ser utilizado. Além disso, nada obsta que a autoridade requisite esclarecimentos a requerente ou a profissional técnico sobre as implicações da utilização do meio.

Em execução da interceptação, a indicação do modo de sua realização serve como limite, que não pode ser ultrapassado em prática de atos concretos de captação do conteúdo de comunicação presencial.

A imprescindibilidade de delimitação do modo de realização da interceptação repercute, ainda, na fase de documentação.

Concluída a interceptação, deve-se exigir a realização de auto circunstanciado dos atos praticados e a juntada dos registros do conteúdo da comunicação, o qual possibilita verificar se

\footnotetext{
${ }^{243}$ Quanto aos sujeitos passivos da interceptação, cf., supra, item n. 3.6.
} 
não foram ultrapassados os limites da autorização judicial, neles incluído o modo de realização da interceptação. ${ }^{244}$ Nesta fase, sobressai a necessidade de assegurar a participação de sujeitos passivos, para verificação, por exemplo, da legalidade de sua autorização e execução e da autenticidade de voz e dos diálogos. ${ }^{245}$

Note-se que, na fase de documentação, a indicação do modo de execução propicia a proteção não só dos interesses do investigado, como também dos interesses de terceiros. Conforme o instrumento empregado em execução de interceptação de comunicação entre presentes, pela proximidade física do investigado, também o conteúdo da comunicação de terceiros pode ser captado. Considerada a possibilidade de proximidade física do investigado em determinado local, ainda que terceiros não tenha relação com ele ou com o fato tido por criminoso, os conteúdos de suas comunicações podem ser captados.

Verificadas as propostas sobre a disciplina da interceptação de comunicação entre pessoas presentes, vejamos como o legislador, estrangeiro e nacional, tratou do tema. É o que faremos nos dois próximos capítulos.

\footnotetext{
${ }^{244}$ Sobre a necessidade de exigência de lavratura de auto circunstanciado, ADA PELLEGRINI GRINOVER lembra, comentando outro meio de investigação de prova, a busca e apreensão, afirma que "constitui a maior garantia de atendimento das prescrições legais" ( $A$ marcha... op. cit., p. 482).

${ }^{245}$ Recordamos a advertência da doutrina, anteriormente exposta, quanto à relevância da descrição da modalidade de captação e registro é para o exercício do direito de defesa e o controle sobre a genuinidade dos elementos registrados. Ademais, como também já ressaltado, a individuação dos interlocutores e a correta atribuição das várias frases pronunciadas representam uma incumbência mais delicada na interceptação de comunicações entre pessoas presentes, o que também é justificativa para assegurar a participação dos sujeitos passivos.
} 


\title{
CAPÍTULO $4^{\circ}$
}

\section{ADMISSIBILIDADE E LIMITES DA INTERCEPTAÇÃO DE COMUNICAÇÃO ENTRE PESSOAS PRESENTES NO DIREITO PROCESSUAL PENAL COMPARADO}

\begin{abstract}
Sumário: 4.1. Generalidades sobre o regime jurídico da interceptação de comunicação entre pessoas presentes no direito processual penal comparado - 4.2. Admissibilidade e limites da interceptação de comunicação entre pessoas presentes: 4.2.1. Na ordem internacional; 4.2.2. No direito comparado: 4.2.2.1. Sistema da common law: 4.2.2.1.1. Direito inglês; 4.2.2.1.2. Direito norte-americano; 4.2.2.2. Sistema romano-germânico: 4.2.2.2.1. Direito alemão; 4.2.2.2.2. Direito argentino; 4.2.2.2.3. Direito chileno; 4.2.2.2.4. Direito espanhol; 4.2.2.2.5. Direito francês; 4.2.2.2.6. Direito italiano; 4.2.2.2.7. Direito português.
\end{abstract}

\subsection{Generalidades sobre o regime jurídico da interceptação de comunicação entre pessoas presentes no direito processual penal comparado}

Examinados os aspectos dogmáticos e as propostas de disciplina jurídica para a interceptação de comunicação entre pessoas presentes, a análise de seu regime jurídico ${ }^{1}$ em ordenamentos jurídicos estrangeiros possibilita avaliar se há acolhimento pelo legislador das tendências firmadas em doutrina.

Antes do início da análise, algumas observações devem ser feitas.

Por primeiro, uma observação é necessária quanto ao critério que nos orientou na escolha de ordenamentos jurídicos apresentados. A principal baliza da seleção foram os

\footnotetext{
${ }^{1}$ Empregamos a locução "regime jurídico" para expressar o conjunto de normas extraídas do ordenamento jurídico que, mesmo de forma não autônoma e organizada, são aplicáveis ao instituto. A locução "regime jurídico" tem, portanto, maior amplitude do que a locução "disciplina jurídica", com a qual expressamos um conjunto de normas jurídicas, autônomo e organizado, que regulamenta aspectos da interceptação de comunicação entre pessoas presentes (cf., supra, item n. 3.10, nota n. 180, e, infra, item n. 5.3.1.1, nota n. 23).
} 
resultados da pesquisa efetuada. De cada ordenamento, procuramos ressaltar os aspectos do regime jurídico do instituto que tivemos por mais relevantes para nosso propósito de formulação de sugestões, de lege ferenda, ${ }^{2}$ para a delimitação de uma disciplina jurídica ${ }^{3}$ processual da interceptação de comunicação entre pessoas presentes no direito brasileiro. ${ }^{4}$

Ademais, como bem observa ADA PELlegrini GRINOver, "todos aqueles que se aprestam a uma obra de síntese, na base de alguns ordenamentos ou grupos de ordenamentos jurídicos, devem conhecer os perigos que se corre em qualquer tentativa de comparação jurídica. À dificuldade da colheita de dados, e do idioma, acrescenta-se aquela dos problemas, dos conceitos, das idéias. Questões ainda vivas e atuais para os juristas de um determinado ordenamento podem representar problemas já superados para os estudiosos de outros; conceitos que têm, para alguns, um sentido preciso podem tomar outro, incerto ou inteiramente diverso, para os demais; idéias operantes no plano da interpretação e da evolução do direito, em alguns países, podem configurar lugares-comuns para outros etc."5

Dito isto, em uma primeira aproximação, podemos dizer que o regime jurídico da interceptação de comunicação entre pessoas presentes é distinto em ordenamentos jurídicos estrangeiros.

O regime jurídico do instituto se inicia na ordem internacional, nas previsões de declarações e de tratados internacionais que preconizam os fundamentos da tutela das comunicações entre pessoas presentes, ${ }^{6}$ como a liberdade de manifestação do pensamento, a vida privada, a intimidade, a inviolabilidade do domicílio e o direito a não autoincriminação.

\footnotetext{
${ }^{2}$ Cf., infra, item n. 5.5 .

${ }^{3}$ Como já observamos, com a locução "disciplina jurídica" (cf., supra, item n. 3.10, nota n. 180, e, infra, item n. 5.3.1.1, nota n. 23), expressamos um conjunto de normas jurídicas, autônomo e organizado, que regulamenta aspectos da interceptação de comunicação entre pessoas presentes.

${ }^{4}$ Considerada a limitação do presente trabalho, voltado à análise do instituto sob a perspectiva processual, não avaliaremos, no âmbito penal de cada ordenamento estrangeiro, a gravidade do delito ou a relevância do bem jurídico penalmente tutelado, pertinentes a infrações em cuja persecução penal se admita a restrição de comunicações entre presentes nos ordenamentos jurídicos analisados.

${ }^{5}$ Cf. Liberdades públicas... op. cit., p. 113.

${ }^{6}$ No que se refere às mencionadas declarações e tratados internacionais, cf., infra, n. 4.2.1.
} 
Estas previsões normativas vigentes na ordem internacional, em geral, integram as constituições dos Estados cujos ordenamentos jurídicos apresentamos, de forma expressa, por integração com os mencionados atos internacionais, ou por consolidação de entendimento doutrinário em interpretação de dispositivos constitucionais. Em alguns países, as comunicações entre pessoas presentes são expressamente tuteladas em Constituição.

No plano infraconstitucional, são distintos os tratamentos normativos da interceptação de comunicação entre pessoas presentes em ordenamentos estrangeiros, mesmo em países integrantes de uma mesma origem jurídica.

Destas primeiras notas, evidencia-se a dificuldade em se extrair um denominador comum na análise de cada ordenamento.

É sob tais ressalvas que passamos a uma breve análise das tendências no direito comparado no tocante à admissibilidade da interceptação entre pessoas presentes, sem pretensão de esgotamento do tema.

\subsection{Admissibilidade e limites das interceptações de comunicações entre pessoas} presentes

A interceptação processual, como forma de restrição às comunicações entre pessoas presentes, é tratada de forma distinta nos ordenamentos jurídicos estrangeiros selecionados.

A distinção existente entre os ordenamentos que a admitem decorre da delimitação do respectivo tipo probatório. Em alguns deles, é um meio de investigação de prova típico; noutros, um meio de investigação de prova atípico, seja em razão de não ser admitido, seja porque, embora admitido, não se preveja procedimento probatório. 
Além disso, varia a nomenclatura do instituto e a forma de tratamento de suas espécies, a interceptação domiciliar e a interceptação ambiental. ${ }^{7}$

Antes, porém, de verificarmos esses regimes jurídicos, é preciso examinar a tutela das comunicações entre pessoas presentes na ordem internacional, porque, como pudemos verificar, cuida-se de valor inerente ao ser humano. ${ }^{8}$

\subsubsection{Na ordem internacional}

Em âmbito internacional, as comunicações entre pessoas presentes estão tuteladas em sistemas de direitos humanos, ${ }^{9}$ que preconizam os seus fundamentos. ${ }^{10}$

No sistema global, ${ }^{11}$ no art. 11 da Declaração dos Direitos do Homem e do Cidadão, de 1789, assegura-se que "a livre comunicação das ideias e das opiniões é um dos mais preciosos direitos do homem. Todo cidadão pode, portanto, falar, escrever, imprimir livremente, respondendo, todavia, pelos abusos desta liberdade nos termos previstos na lei." O dispositivo preconiza tanto a liberdade de expressão do pensamento, como as formas em que possa se operar, entre as quais está a comunicação oral.

Ainda no sistema universal, é preconizada nos artigos 18 e 19 da Declaração Universal dos Direitos Humanos, de 1948, a liberdade de manifestação do pensamento.

\footnotetext{
${ }^{7}$ Sobre a nomenclatura, o conceito e as espécies do instituto, cf., supra, itens n. 3.2 e n. 3.7 .

${ }^{8}$ Cf., supra, item n. 2.1 .

${ }^{9}$ Adotamos aqui a terminologia empregada por FLÁVIA PIOVESAN, quem, para fins didáticos, divide o sistema de proteção de direitos humanos em sistema global e sistemas regionais, sem descurar da observância do princípio da norma mais favorável, que implica a prevalência da norma que confira maior proteção aos direitos humanos (Introdução ao sistema interamericano de proteção dos direitos humanos: a Convenção Americana de Direitos Humanos. In: GOMES, Luiz Flávio; PIOVESAN, Flávia (Coords.). O sistema interamericano de proteção dos direitos humanos e o direito brasileiro. São Paulo: RT, 2000. Cap. I, p. 20-22; A incorporação... op. cit., p. 176-179). No mesmo sentido, CARLOS WEIS analisa os sistemas, nominando-os sistema universal e sistema regional (Os Direitos Humanos Contemporâneos. 1. ed. São Paulo: Malheiros, 2006, p. 31, 66, 95). Considerada não só a limitação da presente dissertação, como também os ordenamentos jurídicos estrangeiros apresentados no presente capítulo, referir-nos-emos apenas ao sistema universal e aos sistemas regionais americano e europeu.

${ }^{10}$ No que se refere aos fundamentos da tutela das comunicações entre pessoas presentes, cf., supra, itens n. 2.2 a n. 2.5 .

${ }^{11}$ Quanto à nomenclatura "sistema global”, cf.: PIOVESAN, Flávia. Introdução ao sistema... op. cit., p. 20-22.
} 
É previsto no artigo 12.2, também da Declaração de 1948, que "ninguém será sujeito a interferências na sua vida privada, na sua família, no seu lar ou na sua correspondência, nem a ataques à sua honra e reputação. Mais ainda: "toda pessoa tem direito à proteção da lei contra tais interferências ou ataques." Tanto a vida privada, quanto a inviolabilidade do domicílio são protegidas nesta norma.

Semelhante disposição, igualmente protetora da inviolabilidade do domicílio e da vida privada, consta no artigo 17.3 do Pacto Internacional de Direitos Civis e Políticos, de 1966: “ninguém será objeto de intervenções arbitrárias ou ilegais na sua vida privada, na sua família, no seu domicílio ou na sua correspondência, nem de atentados ilegais à sua honra e à sua reputação."

O Pacto assegura, ademais, a liberdade de manifestação do pensamento (art. 18) e o direito a não autoincriminação (art. 14.4, alínea "g”), o qual também é garantido no Estatuto de Roma, de 1998 (art. 55.1, alínea "a").

A tutela das comunicações entre pessoas presentes também pode ser extraída do sistema regional americano ${ }^{12}$ de proteção dos direitos humanos.

$\mathrm{Na}$ sistemática americana, nota-se, por primeiro, a previsão dos fundamentos nas disposições da Declaração Americana dos Direitos e Deveres do Homem, de 1948: liberdade de manifestação do pensamento (art. $4^{\circ}$ ); vida privada (art. $5^{\circ}$ ); inviolabilidade do domicílio $\left(\operatorname{art.} 9^{\circ}\right)$.

A liberdade de manifestação do pensamento, por qualquer meio, é garantida no art. 13.1 da Convenção Americana de Direitos Humanos, de 1969. O item $6^{\circ}$ da Declaração de Princípios sobre a Liberdade de Expressão, de 2000, assegura a liberdade de comunicação pelos mais diversos meios: "toda pessoa tem o direito a comunicar suas opiniões por qualquer meio e forma."

\footnotetext{
${ }^{12}$ Identifique-se a nomenclatura sistema regional em: PIOVESAN, Flávia. Introdução ao sistema... op. cit., p. 20 22; WEIS, Carlos. Os Direitos Humanos... op. cit., p. 66.
} 
No artigo 11.2 da referida Convenção, sob o título "Proteção da honra e da dignidade", protege-se a vida privada e a inviolabilidade do domicílio: "ninguém pode ser objeto de ingerências arbitrárias ou abusivas em sua vida privada, em sua família, em seu domicílio ou em sua correspondência, nem de ofensas ilegais à sua honra ou reputação.”

Além disso, em seu art. $8^{\circ}$, item $2^{\circ}$, alínea "g", a Convenção assegura a toda pessoa acusada de prática de delito o "direito de não ser obrigado a depor contra si mesma, nem a declarar-se culpada", também conhecido como direito a não autoincriminação

Por fim, verificando o sistema regional europeu, o art. $9^{\circ}$ da Convenção Europeia sobre Direitos Humanos preconiza a liberdade de manifestação do pensamento.

O direito ao respeito da vida privada e do domicílio da pessoa também são nela assegurados, conforme previsão de seu art. $8^{\circ}$. Neste dispositivo, estabelece-se que "não pode haver ingerência da autoridade pública no exercício deste direito senão quando esta ingerência estiver prevista na lei e constituir uma providência que, numa sociedade democrática, seja necessária para a segurança nacional, para a segurança pública, para o bem-estar econômico do país, a defesa da ordem e a prevenção das infrações penais, a proteção da saúde ou da moral, ou a protecção dos direitos e das liberdades de terceiros.”

Embora a Convenção Européia não preveja expressamente a garantia do direito a não autoincriminação, a Corte Européia de Direitos Humanos o extrai das disposições do art. $6^{\circ}$ da Convenção, que tutela o processo equitativo. ${ }^{13}$

Sem embargo da consagração dos fundamentos da tutela das comunicações em atos internacionais, reconhece-se, quanto a interceptações de comunicações telefônicas, a

\footnotetext{
${ }^{13}$ Cf. CORTE EUROPEIA DE DIREITOS HUMANOS. Case of Funke v. France (Merits and Just Satisfaction, n. 10828/84). Disponível em: http://cmiskp.echr.coe.int/tkp197/portal.asp?sessionId=60604352\&skin=hudocen\&action=request. Acesso em: 14/10/2010.
} 
desatenção quanto à elaboração de uma regulamentação expressa. ${ }^{14}$ Em razão disso, com a propagação de inovações tecnológicas, as restrições às comunicações tendem a ser mais frequentes. $^{15}$

Tratando-se de interceptação de comunicações entre presentes, à primeira vista, poderse-ia pensar que uma disciplina em âmbito internacional seria despicienda, pois, em regra, ocorre em território de um determinado Estado.

No entanto, não se pode olvidar que o progresso tecnológico também é voltado à captação de comunicações entre pessoas presentes. O terceiro-interceptador, como já pudemos observar, pode se encontrar distante dos interlocutores. Lembre-se da hipótese em que o telefone (fixo ou celular) pode ser utilizado como instrumento para execução de interceptação de comunicações entre pessoas presentes. ${ }^{16}$

Sendo assim, parece-nos que a discussão sobre a regulamentação de interceptações entre pessoas presentes também deve ser inserida entre os itens da pauta da agenda internacional.

\footnotetext{
${ }^{14}$ É o que observa PAOLA BALDUCCI (Le garanzie... op. cit., p. 224-225). ADA PELLEGRINI GRINOVER, por seu turno, já salientava os esforços envidados nos trabalhos desenvolvidos pela Conferência Internacional dos Direitos do Homem em Teerã, em 1968, do qual resultaram um relatório preliminar (Resolução ${ }^{\circ}{ }^{10}$ ) e um relatório definitivo (Doc. $\mathrm{n}^{\circ}$ E Cm. 4/1.116, de 23-01-1973). A autora salienta, demais disso, as recomendações constantes no documento, como a de os países e regulamentarem os institutos da gravação e da interceptação, restringindo-os aos delitos mais graves, e tipificarem criminalmente condutas que signifiquem interceptação ou gravação ilícita (Liberdades públicas... op. cit., p. 211-212). Em âmbito europeu, atenção especial deve ser dispensada à "Recomendación 2/99 sobre la protección de 1 aintimidad en el contexto de al interceptación de las telecomunicaciones, de 3 de mayo de 1999". Trata-se de recomendações elaboradas pelo "Grupo de Protección de las personas por lo que respecta al tratamiento de datos personales", criada pela Diretiva 95/46/CE do Parlamento Europeu e do Conselho de 24 de outubro de 1995. Entre as recomendações feitas aos membros da União Europeia, destacamos as seguintes: a previsão das autoridades competentes para concessão de interceptação de telecomunicações; a observância da proporcionalidade; a delimitação dos requisitos e do prazo de duração da medida; a definição de um procedimento probatório, com possibilidade de manifestação de interessados; a preservação das informações registradas na interceptação; a previsão de meios de impugnação por parte do investigado; a publicidade da política de interceptação de telecomunicações; os requisitos para envio de informações captadas a terceiros em acordos bilaterais ou multilaterais (Recomendación 2/99 sobre la protección de 1 aintimidad en el contexto de al interceptación de las telecomunicaciones, de 3 de mayo de 1999. Disponível em:http://www.agpd.es/portalwebAGPD/canaldocumentacion/docu_grupo_trabajo/wp29/1999/common/pdfs/Rec omendaci-oo-n-2-99-sobre-la-protecci-oo-n-de-la-intimidad-en-el-contexto-de-la-interceptaci-oo-n-de-las.pdf. Acesso em: 14/10/2010).

${ }^{15}$ Cf. BALDUCCI, Paola. Le garanzie... op. cit., p. 224-225.

${ }^{16} \mathrm{Cf}$., a propósito, supra, item n. 3.8.1.
} 


\subsubsection{No direito comparado}

No direito comparado, como já pudemos observar, ${ }^{17}$ não há uniformidade de regime jurídico para a interceptação de comunicação entre pessoas presentes. Na maioria dos países examinados, o instituto é atípico, ora por não ser admitido, ora por inexistir procedimento probatório. Há Estados, contudo, que o disciplinam de forma autônoma, tanto sob a perspectiva da admissibilidade, quanto sob a perspectiva do procedimento probatório.

Observamos, como critérios para a apresentação dos ordenamentos jurídicos selecionados: a divisão entre as duas famílias jurídicas: sistema da "common law" e sistema romano germânico; a ordem alfabética, quanto à nomenclatura dos sistemas jurídicos e dos ordenamentos.

\subsubsection{Sistema da common law.}

Iniciando pelo sistema da "common law", passamos a apresentar o ordenamento jurídicos inglês e o norte-americano.

\subsection{Direito inglês}

Em Inglaterra, a interceptação de comunicações é regulamentada no Capítulo I da Parte I do "Regulation of Investigatory Powers Act 2000 (RIPA)" ("Part I Communications: Chapter I Interception”). ${ }^{18}$

Apesar da referida regulamentação se referir a "comunicações", a interceptação prevista tem por objeto comunicações postais e telecomunicações. ${ }^{19}$ É admitida a

\footnotetext{
${ }_{17}^{17}$ Cf., supra, item n. 4.1.

${ }^{18}$ O texto normativo do "Regulation of Investigatory Powers Act 2000 (RIPA)" consultado é o disponível em: http://www.legislation.gov.uk/ukpga/2000/23/part/I/chapter/I. Acesso em: 02/01/2011.
} 
interceptação de telecomunicação operada tanto em "sistema de telecomunicação privado", quanto em "sistema de telecomunicação público" (seção 2.1).

A interceptação é admita no curso da transmissão da comunicação, por meio da captação de seu conteúdo. É o previsto na seção 2.7 , que preconiza a possibilidade de interceptação de "enquanto esteja sendo transmitida".

Exige-se autorização do Secretário de Estado para a realização de interceptação (seção 5.2), desde que estejam presentes os seguintes requisitos: necessidade de atendimento de interesses de segurança nacional, de propósito de prevenir ou descobrir crimes graves, de assegurar o bem-estar econômico ou de efetivar as previsões de qualquer acordo de mútua assistência internacional; a proporcionalidade entre a interceptação e o objetivo que se almeja alcançar com a sua prática; a informação que se procura obter com a interceptação não possa ser, de forma razoável, por outros meios (seções 5.2.a e 5.2.b, 5.3.a a 5.3.d, e 5.4). ${ }^{20}$

\footnotetext{
${ }^{19}$ A este respeito, COLIN TURPIN e ADAM TOMKINS observam que a interceptação de comunicações postais e de telecomunicações foi por muitos anos efetivada sem regulamentação. Salientam os autores que, depois de julgamento proferido pela Corte Européia de Direitos Humanos contra a Inglaterrra (Malone v. United Kingdom), a admissibilidade da interceptação passou a ser prevista em regulamentação intitulada "Interception of Communicatons Act 1985", substituída pela atual regulamentação, que é denominada "Regulation of Investigatory Powers Act 2000" (British Government and the Constitution. 6. ed. Cambridge: Cambridge University Press, 2007. Disponível em: http://books.google.com.br/books?id=QYuF6jmoem8C\&pg=PA475\&dq=interception+rules\&hl=ptBR\&ei=6Qqa TMGLCIT48AaHpJFJ\&sa $=$ X\&oi=book_result\&ct=bookthumbnail\&resnum $=10 \& v e d=0 C F 0 Q 6 w E w C T g K \# v=0$ nepage $\& \mathrm{q}=$ interception $\% 20$ rules $\& \mathrm{f}=$ false. Acesso em: 02/01/2011. p. 475). THOMAS WONG lembra que o "Interception of Communicatons Act 1985" (IOCA) previa a interceptação de telecomunicações, postais e operadas por sistemas públicos de telecomunicações. Acrescenta, ainda, que, em razão de mudanças enormes na tecnologia de telecomunicação e de serviços de telecomunicação, entre os quais destacas os populares telefones móveis e as comunicações por meio da internet, expandiram-se as telecomunicações "não-públicas", e surgiram empresas privadas prestadoras de tais serviços. Estas mudanças, segundo o autor, justificaram, para melhor proteção de direitos humanos, a elaboração de uma nova legislação, a atual "Regulation of Investigatory Powers Act 2000 (RIPA)" (Regulation of Interception of Communications in Selected Jurisdictions. 2005. Disponível em: http://www.legco.gov.hk/yr04-05/english/sec/library/0405rp02e.pdf. Acesso em: 03/01/2011, p. 4). No mesmo sentido, cf.: OXFORD PRO BONO PUBLICO. Legal opinion in interception communication. Oxford: 2006. Disponível em: http:/www2.law.ox.ac.uk/opbp/OPBP\%20Intercept\%20Evidence\%20Report.pdf. Acesso em: 03/01/2011, p. 5 e 7.

${ }^{20}$ No mesmo sentido, cf.: WONG, Thomas. Regulation of Interception... op. cit., p. 8; COLIN TURPIN e ADAM TOMKINS exemplificam "interesses de segurança nacional” com a prática de terrorismo, de espionagem ou de grave atividade de subversão (British Government... op. cit., p. 475).
} 
Além da "interceptação de comunicações", o "Regulation of Investigatory Powers Act 2000 (RIPA)" regulamenta, em sua Parte II, os institutos da vigilância e do agente encoberto ("surveillance and covert human intelligence sources").

Constitui espécie de vigilância a denominada "vigilância intrusiva" ("surveillance intrusive"), definida como a "vigilância oculta que é executada em relação a algo ocorrido em quaisquer propriedades residenciais ou em qualquer veículo privado, e que envolva a presença de uma pessoa nas propriedades ou em veículo, ou é executada por meios de vigilância artificiosa" (seções 26.3.a e 26.3.b). ${ }^{21}$

A "vigilância intrusiva" inclui: "a) monitorar, observar ou ouvir pessoas, seus movimentos suas conversas ou suas atividades ou comunicações; b) gravar algo monitorado, observado ou ouvido no curso de vigilância; e c) vigilância por ou com a assistência de artifício de vigilância." (seções 48.2.a a 48.2.c). ${ }^{22}$

Também é exigida a autorização do Secretário de Estado para a execução de "vigilância intrusiva", desde que estejam presentes requisitos semelhantes aos previstos para a interceptação de comunicações: necessidade de atendimento de interesses de segurança nacional, de propósito de prevenir ou descobrir crimes graves, de assegurar o bem-estar econômico ou de efetivar as previsões de qualquer acordo de mútua assistência internacional; a proporcionalidade entre a vigilância e o objetivo que se almeja alcançar com a sua prática; a informação que se procura obter com a interceptação não possa ser, de forma razoável, por outros meios (seções 32.2.a e 32.2.b, 32.3.a a 32.3.d, e 32.4). ${ }^{23}$

\footnotetext{
${ }^{21}$ Tradução livre do autor de termos normativos das seções 26.3.a e 26.3.b: "it is covert surveillance that — (a) is carried out in relation to anything taking place on any residential premises or in any private vehicle; and (b) involves the presence of an individual on the premises or in the vehicle or is carried out by means of a surveillance device."

${ }^{22}$ Tradução livre de termos normativos das seções 48.2.a a 48.2.c: "surveillance includes- (a) monitoring, observing or listening to persons, their movements, their conversations or their other activities or communications; (b) recording anything monitored, observed or listened to in the course of surveillance; and (c)surveillance by or with the assistance of a surveillance device."

${ }^{23}$ Os requisitos foram extraídos dos termos normativos previsto nas seções 32.2.a e 32.2.b, 32.3.a a 32.3.d, e 32.4 , os quais foram traduzidos, de forma livre pelo autor, considerando a técnica de remissão normativa nelas disposta. Originalmente, os termos normativos das subseções da seção 32 são dispostos da seguinte maneira: "(2) Neither the Secretary of State nor any senior authorising officer shall grant an authorisation for the carrying out of intrusive surveillance unless he believes - (a) that the authorisation is necessary on grounds falling within
} 
Quanto ao procedimento previsto para a execução da vigilância intrusiva, é de se ressaltar a prevista necessidade de observância da descrição e da especificação da forma da vigilância e do respectivo local (seções 32.5.a. a 32.5.c).

No ordenamento jurídico inglês, resta evidenciada, portanto, que, apesar de não regulamentada de forma conjunta com a interceptação de comunicações na Parte I do "Regulation of Investigatory Powers Act 2000 (RIPA)", prevê-se a restrição às comunicações presenciais, por meio do instituto da "vigilância intrusiva" previsto em sua Parte II. ${ }^{24}$ Trata-se de instituto que, a nosso ver, assemelha-se com a interceptação de comunicação entre pessoas presentes, pois, como observado acima, a "vigilância intrusiva" propicia a captação e o registro de comunicações presencias.

\subsection{Direito norte-americano}

No direito norte-americano, a interceptação de telecomunicações e de comunicações eletrônicas e a interceptação de comunicações orais ("wire and electronic communications interception and interception of oral communications"), são regulamentadas no "U.S Code"

subsection (3); and (b)that the authorised surveillance is proportionate to what is sought to be achieved by carrying it out. (3)Subject to the following provisions of this section, an authorisation is necessary on grounds falling within this subsection if it is necessary - (a)in the interests of national security;(b)for the purpose of preventing or detecting serious crime; or(c)in the interests of the economic well-being of the United Kingdom. (4)The matters to be taken into account in considering whether the requirements of subsection (2) are satisfied in the case of any authorisation shall include whether the information which it is thought necessary to obtain by the authorised conduct could reasonably be obtained by other means."

${ }^{24}$ A Corte Européia de Direitos Humanos examinou a restrição às comunicações presenciais no direito inglês no "Case P.G. and J.H. v. The United Kingdom", em que foi analisada a questão de autorização para instalação de artifício de escuta oculto em flat onde estava um investigado. A Corte considerou que a medida efetivada não atendia às exigências previstas no art. $8^{\circ}$ da Convenção Europeia sobre Direitos Humanos - que prevê a restrição do direito a vida privada e familiar de acordo com a lei -, no ano em que foi efetivada (1995). Entendeu-se, conforme estampado no julgamento, que apenas a partir de 25 de setembro de 2000 , data em que passou a vigorar o "Regulation of Investigatory Powers Act 2000" (RIPA), a questão passou a ser regulamentada no direito inglês em sua seção 26 (the Regulation of Investigatory Powers Act 2000 (RIPA)). A respeito deste julgamento, ERCOLE APRILE e FILIPPO SPIEZIA salientam que a Corte reconheceu que a legislação inglesa, embora previsse o meio na época em que foi realizada a gravação, carecia de "clareza, generalidade e abstração", motivo por que teve por violado o art. $8^{\circ}$ da Convenção Europeia sobre Direitos Humanos (Le intercettazioni... op. cit., p. 70-71). 
(Título 18 - “Crimes and Criminal Procedure”, Parte I, Capítulo 119, seções 2.510 a 2.522), de forma conjunta. ${ }^{25}$

O instituto da interceptação de comunicações se liga ao âmbito de proteção da $4^{\mathrm{a}}$ Emenda Constituição norte-americana, que versa sobre a busca e apreensão. ${ }^{26}$ Os termos normativos da $4^{\mathrm{a}}$ Emenda $^{27}$ são interpretados pela Suprema Corte norte-americana com vistas à tutela da vida privada contra restrições ilegais. ${ }^{28}$ Em tema de interceptação de comunicação, sob este âmbito de proteção da vida privada, avalia-se a razoável expectativa de privacidade ("reasonable expectation of privacy") de um interlocutor. ${ }^{29}$

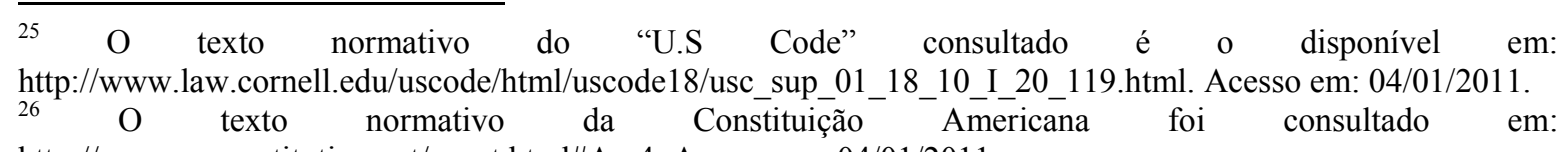
http://www.usconstitution.net/const.html\#Am4. Acesso em: 04/01/2011.

${ }^{27}$ Os termos normativos da $4^{\mathrm{a}}$ Emenda à Constituição norte-americana são os seguintes: "the right of the people to be secure in their persons, houses, papers, and effects, against unreasonable searches and seizures, shall not be violated, and no Warrants shall issue, but upon probable cause, supported by oath or affirmation, and particularly describing the place to be searched, and the persons or things to be seized." Em tradução livre do autor: "O direito do povo de estar seguro em suas pessoas, casas, papéis, e demais pertences, contra desarrazoadas buscas e apreensões, não poderá ser violado, nem mandados poderão ser expedidos, senão baseados em causa provável, suportada por juramento ou afirmação, e particular descrição do local a ser buscado e das pessoas e coisas a serem apreendidas."

${ }^{28}$ A Suprema Corte norte-americana, no caso "Katz v. United States, 389 U.S. 347 (1967)", avaliou a questão sobre a proteção da privacidade em comunicações orais. O exame versou sobre a gravação, por meio de instrumentos eletrônicos de comunicação ocorrida no interior de uma cabine telefônica, sem observância das garantias legais. A Corte asseverou que, embora fosse a cabine em parte integrada por vidros - que permitiam ver o interlocutor como se ele estivesse fora dela -, o interlocutor, ao ingressar na cabine, procurou excluir não o "olho intrometido", mas o "ouvido não convidado". Alem disso, afirmou-se que, ao ocupar a cabine, com porta fechada, o usuário espera que as palavras pronunciadas no aparelho telefônico não sejam difundidas para "o mundo". Neste julgamento, a Corte evidencia o seu entendimento de que o âmbito de proteção da vida privada assegurada na $4^{\mathrm{a}}$ Emenda transcende os interesses inerentes ao direito de propriedade, estendendo-se, também, para restrição de comunicações, inclusive em área acessível ao público, mas constitucionalmente protegida. Assim, a Corte evolui da doutrina do "trespass" (violação do direito de propriedade), para a extensão de proteção do âmbito da vida privada, avaliada sob a perspectiva da razoabilidade. Disponível em: $\mathrm{http}: / /$ caselaw.lp.findlaw.com/scripts/getcase.pl?court=US\&vol=389\&invol=347. Acesso em: 05/01/2011.

${ }^{29}$ A respeito do assunto, DANIEL J. SOLOVE e PAUL M. SCHWARTZ observam: "The Katz decision established a widely cited test for whether the Fourth Amendment is applicable in a given situation. That test was articulated not in the majority opinion but in the concurring opinion by Justice Harlan. The rule as articulated in Justice Harlan's concurrence has become known as the 'reasonable expectation of privacy test'. Under the test, (1) a person must exhibit an 'actual (subjective) expectation of privacy' and (2) 'the expectation [must] be one that society is prepared to recognize as "reasonable". Em tradução livre do autor: "A decisão proferida no caso Katz estabeleceu o teste, bastante citado, sobre se a Quarta Emenda é aplicável em uma determinada situação. Este teste foi articulado não em opinião da maioria, mas em opinião predominante do Juiz Harlan. Sob o teste, (1) a pessoa deve exibir uma 'atual (subjetiva) expectativa de privacidade' e (2) 'a expectativa [deve] ser aquela que a sociedade está preparada para reconhecer como razoável" (Privacy, information and technolgy. 2. ed. New York: Aspen Publishers, 2009, p. 99). Neste sentido, cf.: SIMONS, Christian Sthefan. A prova ilícita no directo processual penal norte-americano e alemão e as influências no processo penal brasileiro. 2007. Dissertação (mestrado) - Faculdade de Direito, Universidade de São Paulo (USP), 2007, p. 61 e 65. 
Interessa-nos quanto à mencionada regulamentação legal da interceptação de comunicações, normas pertinentes à interceptação de comunicações orais.

A regulamentação é iniciada pela delimitação de "definições". Segundo disposto na seção n. 2.510, “'interceptar’ significa a captação aural ou outra forma de captação dos conteúdos de qualquer telecomunicação, comunicação eletrônica ou comunicação oral por meio do uso de qualquer instrumento eletrônico, mecânico ou outro instrumento". ${ }^{30} \mathrm{E}$ ““comunicação oral' significa qualquer comunicação oral emitida por uma pessoa que exiba uma expectativa de que esta comunicação não seja sujeita a interceptação sob as circunstâncias que justificam a sua expectativa; a comunicação oral não inclui qualquer comunicação eletrônica."31

Admite-se a interceptação de comunicação, em persecução das infrações relacionados na seção n. 2.516 (1), alíneas "a" a "s", desde que estejam presentes os requisitos preconizados nas alíneas da seção 2.518 (3), que podem ser assim resumidos: a) a existência de causa que aponte para a probabilidade de cometimento de infração relacionada na seção 2.516 pelo investigado; ${ }^{32}$ b) a existência de causa que aponte para a probabilidade de que serão obtidas comunicações pertinentes à infração; c) os meios de investigação normais não possibilitem a obtenção de informações sobre a infração; d) a existência de causa que aponte para a probabilidade de que o uso de instrumentos ou o local onde se pretenda realizar a interceptação, considerada a ligação com o investigado, relacione-se a comunicações acerca da infração.

\footnotetext{
${ }^{30}$ Tradução livre do autor de: “'intercept' means the aural or other acquisition of the contents of any wire, electronic, or oral communication through the use of any electronic, mechanical, or other device" (seção 2.510 $(4))$.

${ }^{31}$ Tradução livre do autor de: “'oral communication' means any oral communication uttered by a person exhibiting an expectation that such communication is not subject to interception under circumstances justifying such expectation, but such term does not include any electronic communication" (seção 2.510 (4)). DANIEL J. SOLOVE e PAUL M. SCHWARTZ lembram que comunicações orais são interceptadas por meio de instrumento de transmissão ou de gravação (Privacy, information... op. cit., p. 99)

${ }^{32}$ Neste dispositivo, integra os termos normativos a locução "probable cause", igualmente exigida para busca. Todavia, em interceptação se exige um grau mais elevado de probabilidade (SIMONS, Christian Sthefan. A prova ilicita ... op. cit., p. 70).
} 
A legitimidade ativa para requerimento da medida é atribuída a autoridades federais designadas pelo Procurador Geral de Estado (seção n. 2.516 (1)). O requerimento deve ser endereçado a juiz, que é a autoridade competente para autorizar a interceptação (seções n. 2.516 (1) e $2.518(1)) .^{33}$

Os requisitos do requerimento, previstos nas alíneas da seção 2.518 (1), podem ser sintetizados da seguinte forma: a) a identidade do solicitante e do executor da medida; b) a completa descrição dos fatos e de suas circunstâncias, incluindo: detalhes da infração cometida ou a ser cometida; descrição particularizada do local onde se pretende realizar a interceptação e dos respectivos instrumentos; a particular descrição da espécie de comunicação que se pretende interceptar; a identidade da pessoa, se conhecida, que terá sua comunicação interceptada; c) a justificativa da utilização da interceptação; d) a duração da medida; e) referência a requerimentos de interceptação anteriores; e f) resultados obtidos em interceptações anteriores, se o requerimento for de extensão da interceptação.

Requerida a interceptação de comunicação oral, a autoridade judicial, se deferir a sua execução, deve proferir autorização com os requisitos estabelecidos nas alíneas da seção 2.518 (4): a) a identidade da pessoa, se conhecida, que terá sua comunicação interceptada; b) o local onde se pretende realizar a interceptar a comunicação; c) a particular descrição da espécie de comunicação que se pretende interceptar e da infração que se esteja a investigar; d) a identidade do solicitante e do executor da medida; e e) a duração da interceptação. O prazo de duração da interceptação é de não mais do que trinta dias, prorrogável por igual período, desde que demonstrada a necessidade de postergação da medida (seção 2.518 (5)).

Documentados os resultados das diligências, às pessoas cuja comunicação foi captada é assegurada a possibilidade de manifestação sobre a licitude da interceptação, inclusive sobre a observância das formalidades da autorização e acerca da conformidade do cumprimento das diligências pelos operadores com a autorização (seção n. 2.518 (10), alínea “a”).

\footnotetext{
${ }^{33}$ A seção n. 2.518 (7) prevê a possibilidade de, em situações emergenciais, investigador ou de funcionário designado pelo Procurador Geral de Estado executar interceptação, desde que seja convalidada pela autoridade judicial no prazo de quarenta e oito horas.
} 


\subsubsection{Sistema romano-germânico}

Examinados os ordenamentos jurídicos do sistema da "common law", vejamos, nos Estados selecionados do sistema romano-germânico, como se estrutura o regime jurídico da interceptação de comunicações entre pessoas presentes.

O critério de apresentação dos ordenamentos é, uma vez mais, a ordem alfabética quanto à nomenclatura: direito alemão, direito argentino, direito chileno, direito espanhol, direito francês, direito italiano e direito português.

\subsubsection{Direito alemão}

No ordenamento jurídico alemão, a interceptação de comunicação entre pessoas presentes é regulamentada de forma autônoma na lei processual penal (§ 100.c a $\S 100 . f$, e $\S$ 101, todos da StPO). ${ }^{34}$

O art. 13 da Lei Fundamental (Constituição alemã) regulamenta a inviolabilidade do domicílio. No art. 13.1, tal garantia é assegurada em termos gerais. E, nos itens seguintes (13.2 a 13.7), são previstas hipóteses de restrição.

Entre as hipóteses constitucionais de restrição da inviolabilidade do domicílio, cumpre destacar o disposto no art. 13.3, que preconiza, no curso da persecução penal, a possibilidade de instalação de meios técnicos que propiciem a vigilância acústica dos domicílios nos quais se presume estar o investigado, por determinado período. ${ }^{35}$

\footnotetext{
${ }^{34}$ Para compreensão da disciplina que se passa a apresentar, contamos com a tradução constante das seguintes obras jurídicas: ROXIN, Claus. La prohibición... op. cit., p. 173 e ss.; ALMEIDA, Carlos Alberto Simões de. Medidas cautelares e de polícia do processo penal em direito comparado. Coimbra: Almedina, 2006, p. 180 e ss.; BACIGALUPO, Enrique. Derecho Penal... op. cit, p. 245 e ss. Em espanhol, costuma-se referir ao instituto por "escucha", considerada a tradução de alguns dos termos de sua regulamentação (§ 100.c da StPO), que expressam atos praticados em sua execução: "escuchar e grabar" (ROXIN, Claus. La prohibición de autoincriminación... op. cit., p. 173 e ss.). ENRIQUE BACIGALUPO, comentando a citada regulamentação, refere-se a "interceptar e gravar" (Derecho Penal... op. cit., p. 246). Parece-nos que, considerada a completude da regulamentação, a tradução deva ser por "interceptar e gravar".

${ }^{35}$ Esta norma foi inserida na Constituição pela por uma lei de 28 de março de 1998 (ROXIN, Claus. La prohibición de autoincriminación... op. cit., p. 86).
} 
As exigências constitucionais para concretização da diligência prevista no mencionado artigo são as seguintes: existência de circunstâncias fáticas determinadas que fundamentem a suspeita de que alguém cometeu um delito especialmente grave, em cuja persecução a lei admita a instalação dos referidos meios; a investigação do fato, por outro modo, seja dificultada ou inviável; ${ }^{36}$ e autorização judicial.

Em observância aos termos da norma constitucional, o legislador alemão disciplinou a interceptação de comunicações entre pessoas presentes, de forma autônoma, na StPO (lei processual penal): ${ }^{37}$ nos $\$ 100 . c$ a $§ 100 . e$, a interceptação domiciliar; no $\S 100 . f$, a interceptação ambiental. $^{38}$

Por primeiro, considerada a técnica legislativa adotada pelo legislador, convém apresentar a disciplina da interceptação domiciliar.

$\mathrm{O} \S 100 . c$ estabelece que, sem o conhecimento dos interlocutores, admite-se captar e gravar, com meios técnicos, o conteúdo de comunicação privada realizada em domicílio. A medida pode ser autorizada se estiverem configurados os requisitos preconizados no $§ 100 . c$,

\footnotetext{
${ }^{36}$ Da previsão se extrai o caráter subsidiário da medida (BACIGALUPO, Enrique. Derecho Penal... op. cit, p. 246).

${ }^{37}$ Em Alemanha, a regulamentação do assunto constitui um tema político-jurídico. A atual disciplina foi inserida pela "Lei sobre a Vigilância Acústica do Domicílio, de 24 de maio de 2005". Antes dela, esta modalidade de vigilância acústica era prevista no $\S 100 . c, 1.3$, instituída - após a reforma constitucional ocorrida em 28 de março de 1998, quando se alterou o já mencionado art. 13 da Constituição Alemã - por lei de 4 de maio de 1998. Levada a julgamento a constitucionalidade da norma, o Tribunal Constitucional Federal alemão, em sua sentença de 3 de março de 2004 (BverfGE 109, p. 279-391), declarou inconstitucional esta reforma da StPO. Consideradas as novas disposições do art. 13 da Constituição, tidas por constitucionais, o referido tribunal reputou necessário, que, em regulamentação legal da medida, deveria haver uma redução substancial de delitos em cuja persecução se admitiria a medida e o reconhecimento da proteção absoluta de um "âmbito essencial de configuração da vida privada". As orientações insertas no aresto foram observadas pela atual regulamentação, inserida pela referida "Lei sobre a Vigilância Acústica do Domicílio, de 24 de maio de 2005" (ROXIN, Claus. La prohibición... op. cit., p. 85-87).

${ }^{38}$ KAI AMBOS, ERNEST BELING e JULIÁN ÓSCAR GUERRERO afirmam a maior intensidade de restrição a direitos fundamentais em interceptações domiciliares (Las prohibiciones... op. cit., p. 89-90). Note-se, como já observado anteriormente (v., supra, item n. 3.7, nota n. 123), que, no direito alemão, a doutrina, atenta à diferença de tratamento legal, distingue a "grande espionagem acústica" ("grober Lauschangriff"), que expressa a escuta em âmbito domiciliar da "pequena espionagem acústica" (kleiner Lauschangriff"), que significa a escuta fora de domicílios privados (ROXIN, Claus. La prohibición... op. cit., p. 75). Embora se diferencie entre "pequena" e "grande" espionagem, ambas as modalidades são consideradas "escutas intensivas" ("Lauschangriff”) (AMBOS, Kai; BELING, Ernest; GUERRERO, Julián Óscar. Las prohibiciones... op. cit., p. 89).
} 
1.1 a $\S$ 100.c, 1.4: circunstâncias de fatos determinados fundamentem a suspeita de que alguém tenha praticado, como autor ou partícipe, um dos delitos especialmente graves, previstos no $\S 100 . c, 2$, ou os tenha tentado praticar, nos casos em que a tentativa seja possível; o fato, concretamente considerado, seja especialmente grave; existam fundadas razões para crer que, por meio de vigilância, registrar-se-ão expressões do investigado, das quais se possam obter informações para investigação dos fatos ou para a descoberta do paradeiro de outro investigado; a investigação do fato ou a averiguação do paradeiro de outros investigados seja, de outro modo, dificultada ou malograda de forma desproporcional.

A admissibilidade da interceptação domiciliar é restrita à persecução penal de determinados delitos ( $\S 100 . c, 2.1$ a $\S 100 . c, 2.7),{ }^{39}$ tidos pelo legislador por delitos especialmente graves $(\S 100 . \mathrm{c}, 1.1, \S 100 . \mathrm{c}, 1.2){ }^{40}$ A técnica empregada pelo legislador alemão para delimitação da admissibilidade da interceptação domiciliar é a seguinte: indicação das espécies delitivas, com a respectiva indicação do dispositivo normativo em que são previstas. $^{41}$

Do cotejo entre as disposições da lei processual tedesca que preveem os delitos em cuja persecução é cabível a interceptação domiciliar (§ 100.c, 2.1 a § 100.c, 2.7) e a interceptação ambiental e a interceptação de telecomunicações (§ 100.f, § 100.a, 2.1 a $\S 100$ a, 2.11), evidencia-se que não há identidade entre os delitos previstos nas duas disciplinas. A admissibilidade é mais restrita na interceptação domiciliar. ${ }^{42}$

O local em que a interceptação domiciliar pode ser realizada é, em regra, o domicílio do investigado. Em domicílios de outras pessoas, a medida só é admissível, excepcionalmente:

\footnotetext{
39 São exemplos de delitos em cuja persecução se admite a interceptação domiciliar: crimes contra a autodeterminação sexual (§ 100.c, 2.1, alínea “d”); homicídio (§ 100.c, 2.1, alínea “f”); crimes contra a liberdade pessoal (§ 100.c, 2.1, alínea “g”).

${ }^{40}$ É de se observar que, na disciplina das interceptações ambientais e das interceptações de telecomunicações (v., infra, neste item, nota 57), o legislador não se refere a delitos especialmente graves, mas a delitos graves ( $\S$ 100.f, § 100.a, 1 e $\S 100$. a, 2) (ROXIN, Claus. La prohibición... op. cit., p. 168, 173 e 180).

${ }^{41}$ A adequação da técnica, também empregada na regulamentação das comunicações telefônicas, é reconhecida em doutrina. A este respeito, cf.: BACIGALUPO, Enrique. Derecho Penal... op. cit, p. 239.

${ }^{42}$ Releva notar, a título meramente explicativo, que não constam no rol do $\S 100 . c, 2.1$ a $\S 100 . c, 2.7$, os delitos previstos nos seguintes dispositivos da regulamentação da interceptação ambiental e da interceptação de telecomunicações: $\S 100 . \mathrm{a}, 2.2$; § 100.a, 2.3; §100.a, 2.6; § 100.a, 2.8; § 100.a, 2.10.
} 
havendo suspeita, fundada em circunstâncias fáticas determinadas, de que o acusado se encontre em tais locais (§ 100.c, 3.1); a medida em domicílio do investigado não propicie, por si só, a investigação do fato ou a averiguação do paradeiro de outro investigado (§ 100.c, 3.2);

Quanto ao objeto da interceptação, a medida só pode ser ordenada se, com base em elementos objetivos, especialmente no que se refere à espécie do local onde será realizada e às relações entre as pessoas que serão vigiadas, seja possível identificar que não serão registradas expressões pertinentes ao âmbito essencial de configuração da vida privada (§ 100.c, 4). ${ }^{43}$ Tanto comunicações tidas em ambientes empresariais ou comerciais, quanto "comunicações sobre delitos cometidos ou expressões mediante as quais se cometem delitos", não se inserem no âmbito essencial da vida privada. ${ }^{44}$

Complementado a vedação probatória, o $\S$ 100.c, 5 estabelece que a captação e a gravação devem ser interrompidas, imediatamente, se houver elementos de que tenham sido registradas expressões pertinentes ao âmbito essencial da vida privada. ${ }^{45}$ Além disso, o

\footnotetext{
${ }^{43}$ Esta norma reflete o entendimento do Tribunal Constitucional, externado na já mencionada sentença BVerfGE 109, de 2004. O Tribunal Constitucional alemão, em tal sentença, asseverou que os conhecimentos que sejam realizados com intervenção ilegítima não podem ser utilizados em qualquer fase da persecução penal. Também consta do julgamento que as informações obtidas mediante a violação do âmbito essencial da vida privada estão submetidas à violação constitucional de valoração de provas obtidas ilegalmente (ROXIN, Claus. La prohibición... op. cit., p. 94).

${ }^{44}$ Tais conteúdos de comunicações, também previstas no §100.c, 4, são excluídos do âmbito essencial da vida privada. CLAUS ROXIN avalia as normas integrantes da disciplina, e adverte para o perigo que a captação de conversa domiciliária significa para o direito à intimidade e à inviolabilidade do domicílio. Ele se insurge quanto a interpretação de que comunicações integrantes do "âmbito essencial da vida privada", possam ser conhecidas. A crítica é formulada sob duas perspectivas. Sob uma primeira perspectiva, ele critica a consideração categórica de que são excluídas do âmbito essencial da vida privada comunicações sobre delitos já cometidos. Tal interpretação poderia ser extraída da previsão de que são excluídas do referido âmbito comunicações sobre delitos cometidos ( $§ 100 . c, 4)$. Isto porque, considerada esta exclusão legal, poder-se-ia pensar em conhecimento do conteúdo de comunicações integrantes do âmbito essencial da vida privada, no curso das quais houvesse menção a delitos cometidos (La prohibición... op. cit., p. 96-97). Considerada a necessidade de maior proteção, pela maior intensidade a restrição de direitos e garantias fundamentais, a crítica de ROXIN versa sobre a impossibilidade, de antemão, de saber se a conversa do investigado ou do acusado com a pessoa próxima deve versar sobre um delito grave já cometido, ou sobre acontecimentos pertinentes a vida privada (CONDE, Francisco Munoz; LANGHE, Marcela de. Presentación... op. cit., p. 29-30).

${ }^{45}$ Sob uma segunda perspectiva, interpretando a norma prevista no $\S 100 . c, 5$, CLAUS ROXIN continua a sua crítica à disciplina. Afirma que o "âmbito essencial de configuração da vida privada" é afetado não apenas no período compreendido entre o início das diligências e o momento em que é interrompida, como também pela restrição imposta aos cidadãos, os quais, por desconhecerem se suas comunicações estão sendo gravadas, são submetidos a um clima de "medo de ser vigiado", o que prejudica, de forma relevante, a configuração da vida privada. Ele adverte que tal tarefa ficaria confiada a funcionário incumbido da gravação, questionando a capacitação de policiais encarregados de interceptação para distinguir, por meio de pontos de referência, comunicações pertinentes ao âmbito essencial da vida privada em que possa haver menção a delitos cometidos e
} 
referido dispositivo prevê a necessidade de inutilização das gravações e a impossibilidade de consideração do seu conteúdo. ${ }^{46}$

Não se admite a execução da interceptação de comunicações das quais participem pessoas que sejam proibidas de depor como testemunha, como os profissionais (§ 100.c, 6). ${ }^{47}$

Tratando-se de comunicações que tenham como interlocutores pessoas que participem do desenvolvimento de atividade profissional, como os assistentes, a interceptação é admitida, e seus resultados somente podem ser utilizados se o interesse da investigação ou a averiguação do paradeiro de um investigado prevalecer à importância do vínculo de confiança identificado

comunicações em que semelhante menção não seja possível (La prohibición... op. cit., p. 103-104). LEPSIUS também questiona a legitimidade da norma, afirmando que a determinação do âmbito essencial é deixada nas mãos do interceptador (Der grobe Lauschangriff vor dem Brundesverfassungsgericht, Segunda Parte, Jura, 2005, apud ROXIN, Claus. La prohibición... op. cit., p. 96-97, p. 105).

Após criticar a disciplina, CLAUS ROXIN propõe, para compatibilizar a previsão normativa com os direitos e garantias constitucionais e com a jurisprudência alemã, uma "interpretação restritiva materialmente adequada" do dispositivo, ressaltando que o domicílio privado, onde o investigado se encontra com familiares e pessoas de sua confiança, é o lugar por ele utilizado para as comunicações mais pessoais. Sendo assim, ele sustenta que uma limitação, com fundamento no $\S 100 . c$, 4 da StPO, somente pode ser concretizada se a pessoa de confiança do investigado for suspeita da prática de um delito. Tal interpretação se pauta no que ele denomina "prognose negativa do âmbito essencial". Com base na ideia de prognose negativa, afirma que deve haver um "ponto de conexão" ou um motivo concreto para se entender que a comunicação não verse sobre o âmbito essencial. De acordo com a interpretação por ele sugerida, pontos de conexão existem se o investigado se encontra em seu domicílio com pessoas suspeitas de serem partícipes na prática de um delito (por exemplo, em tráfico de drogas ou terrorismo), ou se pessoas de confiança - especialmente familiares e companheiros sentimentais - forem suspeitas de prática de delito apurado junto com o investigado, do que se é extraída a possibilidade de estarem conversando no domicílio sobre o delito que cometeram juntos. De outro lado, segundo sua interpretação, não seria possível a realização de uma interceptação se as pessoas de confiança do investigado que estejam em seu domicílio não estejam relacionadas à prática de delito tido por cometido (La prohibición... op. cit., p. 106-107 e p. 112-113). Em resumo, extraímos da interpretação proposta doutrinária que a interceptação de comunicação entre presentes é considerada admissível, em âmbito domiciliar, se houver elementos concretos de que as pessoas que lá estejam em companhia do investigado sejam suspeitas de terem praticado delitos cometidos previamente (CONDE, Francisco Munoz; LANGHE, Marcela de. Presentación... op. cit., p. 29-30).

${ }^{46} \mathrm{O}$ Ministério Público pode requerer a autoridade judicial a descaracterização da proibição prevista no $\S 100$.c, 5. Se a autoridade judicial indeferir o pleito, a proibição se estende para eventual processo (§ 100.c, 6).

${ }^{47} \mathrm{O} \S 100 . \mathrm{c}, 6$ ao prever tal norma, refere-se ao $\S 53$ da StPO que integra a disciplina da prova testemunhal, e preconiza as hipóteses de proibição de depor a profissionais, entre os quais estão, entre outros, os advogados, os contadores, os psicólogos e os médicos. Caso seja operada interceptação de suas comunicações, aplica-se a norma do $\S 100 . c, 5$. Assim, a interceptação deve ser interrompida tão logo se identifique que um profissional esteja a se comunicar, e os respectivos registros devem ser inutilizados. 
na relação mantida entre os auxiliares e os profissionais. ${ }^{48} \mathrm{O}$ mesmo ocorre quanto a pessoas dispensadas de depor, como familiares $(\S 100 . c, 6) .{ }^{49}$

Não se aplicam as hipóteses de proibição probatória apontadas - de inadmissibilidade de execução da interceptação e de impossibilidade de utilização dos resultados da interceptação - se houver elementos de que as mencionadas pessoas tenham colaborado para a prática do fato delituoso investigado $(\S 100 . c, 6){ }^{50}$

O Ministério Público é o órgão legitimado para requerimento de interceptação a autoridade judicial competente (§ 100.d).

A execução da medida somente pode ser concedida em desfavor do investigado ( $\S$ 100.c, 3). ${ }^{51}$

Requerida a interceptação, a autoridade judicial ${ }^{52}$ deve proferir decisão fundamentada, por escrito, na qual, conforme estabelece o $§ 100 . d, 2$, devem constar: no que seja possível, o nome e o domicílio do acusado contra quem se dirige a medida; a qualificação do fato em razão do qual se ordena a medida; o domicílio ou os recintos a vigiar; espécie, alcance e duração da medida; e a espécie de informação que pode ser captada na execução da medida, acompanhada da indicação de sua importância para a persecução penal.

Ademais, ainda com relação ao conteúdo da ordem judicial, o $\S 100 . d$, 3 estabelece a necessidade de registro de referências a circunstâncias do caso concreto: demonstração dos requisitos da medida no caso; indicação de elementos fáticos que fundamentem a suspeita em relação ao investigado; indicação de elementos objetivos que revelem a ligação entre a pessoa

\footnotetext{
${ }^{48} \mathrm{O} \S 100 . c, 6$ ao prever tal normas, refere-se ao $\S$ 53.a da StPO que também integra a disciplina da prova testemunhal, e trata da dispensa de depor como testemunha de auxiliares de profissionais.

${ }^{49} \mathrm{O} \S 100 . \mathrm{c}, 6$ ao prever tais normas, refere-se ao $\S 52$ da StPO, que cuida da dispensa de depor como testemunha, por exemplo, a cônjuge e a parentes.

${ }_{50}$ É o previsto também no $§ 100$.c, 6, ao se remeter ao $\S 160,4$ da StPO.

${ }^{51}$ Todavia, o $\S 100 . c, 3.2$ prevê que a medida pode ser operada, mesmo que outras pessoas sejam afetadas. Além disso, o dispositivo veda a utilização da medida com a finalidade exclusiva de investigação de circunstâncias fáticas que a autorizem ou de descoberta do paradeiro de outro acusado.

${ }^{52}$ Conforme disposto no $\S 100 . d, 1$, o órgão jurisdicional é a Câmara de tribunal estadual. Em caso de perigo na demora, a ordem pode ser expedida pelo respectivo presidente.
} 
investigada e o local onde devam ser realizadas as diligências; e considerações essenciais sobre a necessidade e a proporcionalidade da medida (§ 100.d, 3).

O prazo máximo de duração da interceptação é de um mês, prorrogável por períodos de igual duração, desde que subsistam os requisitos para autorização da medida. Por igual, a decisão que prorroga a interceptação deve ser motivada, nos termos anteriormente referidos. ${ }^{53}$

Por todo o período em que a interceptação seja autorizada, a autoridade judicial deve controlar a execução da medida. É necessária a informação à autoridade judicial das diligências nela concretizadas. Deixando de existir os respectivos requisitos, o juízo deve ordenar a interrupção da medida. ${ }^{54}$

A utilização dos resultados da interceptação para outros fins é prevista no $§ 100$ d, 5 , do qual sobressai a possibilidade das informações nela obtidas serem consideradas em outros feitos criminais ( $\$ 100 . d, 5.1)$. Para tanto, é dispensado o consentimento do interceptado, e o empréstimo há que esclarecer a suposta prática de um delito para o qual, nos termos do já apontado $\S 100$.c, a medida poderia ter sido ordenada. ${ }^{55}$

Concluída a regulamentação da interceptação domiciliar, a lei processual penal alemã disciplina a interceptação ambiental.

O $\S 100 . f$ estabelece que, sem o conhecimento dos interlocutores, admite-se captar e gravar, com meios técnicos, o conteúdo de comunicação privada fora do domicílio. A medida pode ser autorizada se estiverem configurados os requisitos preconizados no $\$ 100 . f$ : circunstâncias de fatos fundamentem a suspeita de que alguém tenha praticado, como autor ou

\footnotetext{
${ }^{53}$ É o que prevê o § 100.d, 3. Interessante notar, ainda, que o§ 100.d, 1 estabelece a necessidade de a autorização para prorrogação do prazo de duração da interceptação ser proferida por autoridade judicial superior à que proferiu as decisões anteriores, se a medida já tenha durado, consideradas as somas de períodos sucessivos, seis meses $(\S 100 . d, 1)$.

${ }^{54} \mathrm{O}$ controle judicial, disposto no $\S 100 . \mathrm{d}$, 4, deve ser exercido ex officio. Conforme previsto no referido dispositivo, mesmo que não haja requisição ministerial, a autoridade judicial deve avaliar a manutenção dos requisitos.

55 Outras hipóteses são previstas, como, por exemplo, a possibilidade de utilização dos resultados da interceptação para evitar perigo de vida evidenciado em caso concreto, perigo urgente para o corpo ou a liberdade de uma pessoa, ou, ainda, perigo a objetos valiosos para o abastecimento da população (§ 100.d, 5.2).
} 
partícipe, um dos delitos graves, previstos no $§ 100 . c, 2$, ou os tenha tentado praticar, nos casos em que a tentativa seja possível; o fato, concretamente considerado, seja grave; a investigação do fato ou a averiguação do paradeiro de outros investigados seja, de outro modo, malograda ou dificultada.

A admissibilidade da interceptação ambiental, que é equiparada à interceptação de telecomunicações, é restrita à persecução penal de determinados delitos (§ 100.f e $§ 100$ a, $2),{ }^{56}$ tidos pelo legislador por delitos graves $(\$ 100 . c, 1.1, \S 100 . c, 1.2) .{ }^{57}$ A técnica empregada pelo legislador alemão para delimitação da admissibilidade da interceptação domiciliar é, uma vez mais, a seguinte: indicação das espécies delitivas, com a respectiva indicação do dispositivo normativo em que são previstas. ${ }^{58}$

A legitimidade para requerimento da medida é atribuída ao Ministério Público. ${ }^{59}$

Em regra, a interceptação ambiental só pode ocorrer em desfavor de um investigado ( $§$ 100.f, 2). Mas é possível ser interceptado o conteúdo da comunicação de outras pessoas, desde que existam circunstâncias de fatos determinados no sentido de que elas estejam em contato com o investigado, além de a medida ser idônea para a investigação do fato ou averiguação do paradeiro do investigado, que, de outro modo, malograda ou dificultada. ${ }^{60}$

Compete à autoridade judicial a ordenação da interceptação. Os requisitos da decisão são os mesmos da interceptação domiciliar (§ 100.f, 4 e $\S 100 . d, 2$ ), acima indicados. Para interceptação ambiental, em caso de perigo de demora, a ordem pode ser expedida pelo

\footnotetext{
56 São exemplos de delitos em cuja persecução se admite a interceptação ambiental: crimes contra a autodeterminação sexual ( 1 100.a, 2.1, alínea “f”); homicídio (§ 100.a, 2.1, alínea “"h”); crimes contra a liberdade pessoal (§ 100.a, 2.1, alínea “i”); lavagem de dinheiro (§ 100.a, 2.1, alínea “m”); genocídio (§ 100.a, 2.10, alínea "a"); crimes de guerra (§ 100.a, 2.10, alínea “c").

${ }^{57}$ Recordemos que, na disciplina das interceptações domiciliares (v., supra, nota n. 40), o legislador não se refere a delitos graves, mas a delitos especialmente graves ( $\S 100 . c, 2.1$ a $\S 100 . c, 2.7)$ (ROXIN, Claus. La prohibición... op. cit., p. 168, 173 e 180). Lembramos, também, que á admissibilidade da interceptação domiciliar é mais restrita, se comparada com a interceptação ambiental.

${ }^{58}$ A adequação da técnica, também empregada na regulamentação das comunicações telefônicas, é reconhecida em doutrina. A este respeito, cf.: BACIGALUPO, Enrique. Derecho Penal... op. cit., p. 239.

${ }^{59}$ É o que dispõe o $§ 100 . f, 4$, o qual estabelece a aplicação do $\S 100 . b, 1$.

${ }^{60}$ A ressalva é prevista no $\S 100 . f$, 2. Além desta, o $\S 100 . f, 3$ preconiza a possibilidade de execução da interceptação ambiental, ainda que inevitavelmente afete terceiros.
} 
Ministério Público, a qual deverá ser ratificada pela autoridade judicial no prazo de três dias (§ 100.f, 4 e $\S 100 . b, 1)$.

O prazo de duração da interceptação é de três meses, prorrogável por períodos iguais, desde que subsistam os seus requisitos (§ 100.f, 4 e $\S 100 . b, 1)$.

Terminada a interceptação, a autoridade judicial deve ser informada sobre os seus resultados (§ 100.f, 4 e $\S 100 . b, 4)$.

O procedimento para execução de interceptação de comunicações entre presentes tanto para interceptação domiciliar, quanto para interceptação ambiental - é previsto nos incisos do $\S 101$. Entre as formalidades previstas, destacam-se as expostas doravante.

Realizada a interceptação, os resultados da atividade desenvolvida são documentados em autos processuais $(\S 101,2)$.

Em seguida, devem ser comunicados os interessados. Sendo a interceptação domiciliar, são avisados o investigado em desfavor de quem a medida foi ordenada, as demais pessoas vigiadas e as pessoas que estavam ou habitavam o domicílio no momento em que a medida foi executada $(\S 101,4)$. Se a interceptação for ambiental, devem ser comunicados não só a pessoa em desfavor de quem tenha sido ordenada a medida, como também as pessoas afetadas de maneira relevante $(\S 101,5)$.

A prevista comunicação deve ocorrer tão logo seja possível, desde que não gere perigo para os fins da investigação, a vida, a integridade física e a liberdade de uma pessoa, nem a valores patrimoniais significativos. Para a comunicação ser postergada, é necessária a lavratura de um auto, com o registro de um dos motivos mencionados $(\S 101,5)$. É exigida, demais disso, autorização judicial se a postergação completar doze meses, em interceptação ambiental, e seis meses, em interceptação domiciliar $(\S 101,6)$. 
Os mencionados interessados, que deverão ser comunicados quanto aos resultados da interceptação, podem requerer a órgão jurisdicional competente a avaliação não só da legalidade da medida, como também do modo de sua execução. A sucessiva decisão judicial pode ser impugnada por meio de recurso $(\S 101,7)$.

As informações obtidas por meio da interceptação hão que ser inutilizadas, se não interessarem à persecução penal ou à avaliação judicial da medida. ${ }^{61}$

\subsubsection{Direito argentino}

No direito argentino, a interceptação de comunicação entre pessoas presentes não é disciplinada pela legislação processual.

A Constituição $\operatorname{argentina~}^{62}$ assegura as ações privadas e a inviolabilidade do domicílio, da correspondência epistolar e dos papéis privados, que somente pode ser restringida por lei, respectivamente, nos artigos $19^{63}$ e $18 .{ }^{64}$ Destas disposições constitucionais, a doutrina extrai o direito à intimidade e à vida privada, que ampara tanto as telecomunicações, quanto as comunicações entre pessoas presentes. ${ }^{65}$

\footnotetext{
${ }^{61} \mathrm{O} \S 101,7$ prevê a lavratura de auto de inutilização dos termos da interceptação.

$62 \mathrm{O}$ texto normativo da Constituição argentina consultado é o disponível em: http://www.senado.gov.ar/web/interes/constitucion/capitulo1.php. Acesso em: 05/01/2011.

${ }^{63}$ Os termos normativos do art. 19 são os seguintes: "las acciones privadas de los hombres que de ningún modo ofendan al orden y a la moral pública, ni perjudiquen a un tercero, están sólo reservadas a Dios, y exentas de la autoridad de los magistrados. Ningún habitante de la Nación será obligado a hacer lo que no manda la ley, ni privado de lo que ella no prohíbe ." Em tradução livre do autor: "as ações privadas dos homens que de nenhum modo ofendam a ordem e a moral pública, nem prejudiquem a um terceiro, estão somente reservada a Deus, e isentas da autoridade dos magistrados. Nenhum habitante da Nação será obrigado a fazer o que não manda a lei, nem privado do que ela não proíbe."

${ }^{64}$ Os termos normativos que integram o art. 18 são os seguintes: "el domicilio es inviolable, como también la correspondencia epistolar y los papeles privados; y una ley determinará en qué casos y con qué justificativos podrá procederse a su allanamiento y ocupación". Em tradução livre do autor: "o domicílio é inviolável, como também a correspondência epistolar e os papeis privados; e uma lei determinará em que casos e por quais razões se poderá proceder ao seu ingresso ou ocupação."

${ }^{65}$ É o que afirma MARCELA DE LANGHE: "la doctrina nacional es unánime al afirmar que, en defecto de norma específica, la protección constitucional que ampara la inviolabilidad de la correspondencia, por aplicación analógica, se extiende a las comunicaciones telefónicas, discos y registros de computadores, casetes, etcétera, gozando todas ellas de las mismas garantías que la epistolar, resultando inadmisible cualquier injerencia arbitraria, salvo que cumpla con los requisitos constitucionales". Em tradução livre do autor: "a doutrina nacional é unânime ao afirmar que, em defeito de norma específica, a proteção constitucional que ampara a inviolabilidade da correspondência, por aplicação analógica, estende-se às comunicações telefônicas, discos e registros de
} 
Em legislação nacional infraconstitucional, são regulamentadas as interceptações de comunicações telefônicas.

Entre os meios de prova previstos no título III do Livro II do "Código Procesal Penal de La Nación", 66 é prevista a "intervenção" de comunicações telefônicas ("intervención de comunicaciones telefónicas"), no art. 236. De acordo este dispositivo, a autoridade judicial poderá ordenar, mediante decisão fundada, a intervenção de comunicações telefônicas ou qualquer outro meio de comunicação do imputado, ${ }^{67}$ para impedi-las ou as conhecer. ${ }^{68}$

A despeito de o Código intitular o instituto "intervenção", a doutrina também se refere ao instituto mediante o emprego do termo "interceptación" 69 ou "escucha". 70

Além disso, embora haja previsão normativa de "intervenção" em qualquer outro meio de comunicação no mencionado art. $236,{ }^{71}$ a doutrina a tem como integrante da

computadores, cassetes, etc., gozando todas elas das mesmas garantias que a epistola, resultando inadmissível qualquer ingerência arbitrária, salvo se cumprir os requisitos constitucionais" (Escuchas telefónicas... op. cit., p. 38). Mais ainda: "es claro que integran o concepto de intimidad todos los actos, características y cosas de la persona que están excluidos del conocimiento generalizado por parte de los demás, entre ellos, y en cuanto aquí interesa, deben ubicarse en dicho ámbito las conductas que tienen dimensión intersubjetiva y que expresan una acción comunicativa, tales como los escritos, pinturas, grabaciones, conversaciones en forma directa entre presente, o a distancia por medios técnicos". Em tradução livre do autor: "é claro que integram o conceito de intimidade todos os atos, características e coisas da pessoa que estão excluídos do conhecimento generalizado por parte dos demais; entre eles, e em quanto aqui interessa, devem se situar em dito âmbito as condutas que têm dimensão intersubjetivas e que expressam uma ação comunicativa, tais como os escritos, pinturas, gravações, conversas em forma direta entre presentes, ou à distância por meios técnicos" (Escuchas telefónicas... op. cit., p. 41-42). No mesmo sentido, cf.: SOSA, María Julia. Intervenciones y escuchas telefónicas: requisitos que deberían tenerse en cuenta en nuestra legislación para ser aplicados por nuestros tribunales en consonancia con la constitución nacional, tratados internacionales y jurisprudencia internacional. Ciencias penales contemporáneas: Revista de derecho penal procesal penal y criminología, Mendonza, Ediciones Juridicas Cuyo, año 3, n. 5-6, 2003, p. 153.

${ }^{66} \mathrm{O}$ texto normativo do "Código Procesal Penal de La Nación” consultado é o disponível em: http://www.infoleg.gov.ar/infolegInternet/anexos/0-4999/383/texact.htm. Acesso em: 05/01/2011.

${ }^{67} \mathrm{O}$ art. 236 também prevê que, sob as mesmas condições, o juiz poderá ordenar, mediante decisão fundada, a obtenção dos registros de comunicações do imputado ou de quem com ele se comunica.

${ }^{68} \mathrm{O}$ dispositivo atribui ao Ministério Público, excepcionalmente, a possibilidade de autorizar a "intervenção", mediante manifestação fundamentada, com imediata comunicação ao juiz, quem deverá convalidá-la em prazo de vinte e quatro horas, sob pena de nulidade do ato e consequente ineficácia da prova.

${ }^{69}$ Cf. ECHEVARRIA, Marcelo Horacio. Interceptación de llamadas telefonicas. Revista de Derecho Penal, Procesal Penal y Criminologia, Mendoza, Ediciones Jurídicas Cuyo, año 3 (2003), n. 5/6, 2004, p. 36.

${ }^{70}$ Cf. LANGHE, Marcela de. Escuchas telefónicas... op. cit., p. 215.

${ }^{71}$ É de se notar que a "Ley de Inteligencia Nacional 25.520", de 2001, também prevê a possibilidade de captação de comunicações privadas de qualquer espécie (art. 18)". Os termos normativos deste diploma normativo foram 
regulamentação da intervenção de comunicação telefônica, considerando que a "interceptación de comunicaciones entre presentes" não é prevista em lei processual. ${ }^{72}$

Em face da ausência de regulamentação da interceptação de comunicação entre pessoas presentes, há corrente doutrinária quanto à possibilidade de aplicação da regulamentação da interceptação de comunicação telefônica. ${ }^{73}$

Todavia, a regulamentação legal da interceptação de comunicação telefônica é deveras criticada pela doutrina, pela amplitude dos seus termos, ${ }^{74}$ o que se estende à proposta de aplicação à interceptação de comunicação entre pessoas presentes.

consultados em: LANGHE, Marcela de. Escuchas telefónicas... op. cit., p. 177-179. Em sentido semelhante, o "Código Procesal Penal de la Ciudad Autónoma de Buenos Aires prevê "la intervención de comunicaciones del/la imputado/a por cualquier meio" (art. 117). Ademais, este dispositivo estabelece que, em nenhum caso, poder-se-á usar este meio de investigação para elidir o direito do investigado de se negar a declarar sem importar presunção em seu desfavor ou suprir as declarações testemunhais proibidas por vínculo de parentesco ou de sigilo profissional. Os termos normativos deste diploma normativo foram consultados em: LANGHE, Marcela de. Escuchas telefónicas... op. cit., p. 298-299.

${ }^{72}$ Assim se manifesta RUBÉN A. CHAIA: "nuestra ley procesal mantiene el silencio al respecto [de la interceptación de comunicaciones entre presentes]; sin embargo, la previsión no escapa a la legislación extranjera, tal el caso de Alemania e Italia". Em tradução livre do autor: "nossa lei processual mantém o silêncio com respeito [à interceptação de comunicações entre presentes]; sem embargo, a previsão não escapara à legislação estrangeira, tal o caso da Alemanha e da Itália" (La prueba en el proceso penal. 1. ed. Buenos Aires: Hammurabi, 2010, p. 638-639).

${ }^{73}$ Cf. CHAIA, Rubén A. La prueba... op. cit., p. 639. Há, também, corrente doutrinária no sentido da possibilidade de observância da disciplina de outros meios de prova, como por exemplo, a prova documental, para as "grabaciones": cf. CARBONE, Carlos Alberto. Grabaciones, escuchas telefônicas y filmaciones como medios de prueba. Santa fé: Rubinzal-Culzoni, 2005, p. 115 e ss.

${ }^{74}$ Neste sentido, MARCELO HORACIO ECHEVARRIA, comentando a exigência legal de decisão motivada, assevera: "al omitir o legislador normar taxativamente los presupuestos necesarios y suficientes para la adopción de la medida de interceptación de comunicaciones, es grande la dosis de subjetivismo con que dicha resolución ha de ser fundada". Em tradução livre do autor: "ao omitir o legislador normatizar taxativamente os pressupostos necessários e suficientes para a adoção da medida de interceptação de comunicações, é grande a dose de subjetivismo com que a dita resolução há de ser fundada" (Interceptación de llamadas... op. cit., p. 36). É o que também afirma MARCELA DE LANGHE: "la reglamentación constitucionalmente exigida para habilitar las injerencias estatales frente a la inmunidad garantizada por el secreto de las telecomunicaciones es una materia pendiente en nuestro país. Como se vio, los códigos procesales y leyes especiales sancionadas al efecto, resultan insuficientes para cumplir con el mandato supranacional y constitucional". Em tradução livre do autor: "a regulamentação constitucionalmente exigida para habilitar as ingerências estatais frente à imunidade garantida pelo segredo das telecomunicações é uma matéria pendente em nosso país. Como se viu, os códigos processuais e leis especiais sancionadas a este respeito resultam insuficientes para cumprir com o mandato supranacional e constitucional" (Escuchas telefónicas... op. cit., p. 215). 


\subsection{Direito chileno}

Em Chile, a interceptação de comunicação entre presentes é disciplinada, de forma conjunta com a interceptação de comunicações telefônicas ("interceptación de comunicaciones telefónicas"), nos artigos 222 a 226 do "Código Procesal Penal". 75

Estabelece o art. 19.5 da Lei Maior chilena ${ }^{76}$ a inviolabilidade do lar e de toda forma de comunicação privada. O lar pode ser invadido e as comunicações e os documentos privados podem ser interceptados, abertos ou registrados somente nos casos e formas determinados por lei.

$\mathrm{O}$ art. 226 do "Código Procesal Penal", sob o título "otros medios técnicos de investigación", dispõe sobre "la grabación de comunicaciones entre personas presentes", 77 regidas por este dispositivo e pelos artigos 222 a 225, que disciplinam a interceptação de comunicação telefônica e de outras formas de telecomunicação.

Estes dispositivos preveem, como requisito, para a interceptação de comunicação entre pessoas presentes, a existência de fundadas suspeitas, baseadas em fatos determinados (“fundadas sospechas, basadas en hechos determinados”), de participação do investigado na preparação, pretérita ou atual, ou na consumação de um fato punível a que seja cominada a “pena de crimen" (art. 222, primeira parte, e art. 226). ${ }^{78}$ Verifica-se que o legislador

75 O texto normativo do "Código Procesal Penal" consultado é o disponível em: http:/www.leychile.cl/Consulta/Exportar?radioExportar=Normas\&exportar_formato=pdf\&nombrearchivo=NOR MA1765950\&exportar_con_notas_bcn=True\&exportar_con_notas_originales=True\&exportar_con_notas_al_pie $=$ True\&hddResultadoExportar $=17 \overline{6} 595.2008-03-14.0 .0 \% 23$. Acesso em: 06/01/2011.

76 O texto normativo do da Constituição chilena consultado é o Disponível em: http://www.leychile.cl/Navegar?idNorma=242302. Acesso em: 06/01/2011.

${ }^{77}$ Em tradução livre do autor: "artigo 226. Outros meios técnicos de investigação. Quando o procedimento tiver por objeto a investigação de um fato punível a que seja cominada 'pena de crimen', o juiz de garantia poderá ordenar, por requerimento do Ministério Público, a fotografia, a filmagem ou outros meios de reprodução de imagens pertinentes ao esclarecimento dos fatos. Também se poderá dispor sobre a gravação de comunicações entre pessoas presentes. As normas previstas nos artigos 222 a 225 regerão as diligências previstas neste artigo".

${ }^{78}$ Nos artigos 21 e ss. do Código Penal chileno, discriminam-se as espécies de pena, gradativamente, da mais para a menos gravosa: "penas de crímenes", "penas de simples delito", "pena de las faltas", "penas comunes a las tres clases anteriores", "penas accesorias de los crímenes y simples delitos". As "penas de crímenes" são as seguintes: "presidio perpetuo calificado, presidio perpetuo, reclusión perpetua, presidio mayor, reclusión mayor, relegación perpetua, confinamiento mayor, extrañamiento mayor, relegación mayor, inhabilitación absoluta perpetua para cargos y oficios públicos, derechos políticos y profesionales titulares, inhabilitación especial 
considerou a gravidade do delito, em face da pena cominada, como critério para autorizar a execução do meio de investigação. ${ }^{79}$

Também constitui requisito da medida ora tratada a imprescindibilidade para a investigação (art. 222, primeira parte).

A legitimidade ativa para requerimento da interceptação é atribuída ao Ministério Público (art. 222, primeira parte).

A interceptação pode ser autorizada em desfavor de investigado ou de pessoas contra quem existam suspeitas fundadas, baseadas em fatos determinados, de que sejam intermediárias em comunicações (art. 222, segunda parte). ${ }^{80}$

Consagra-se, demais disso, expressa proibição de interceptação de comunicações entre o investigado e seu advogado, salvo se houver elementos de que o advogado tenha participado da prática das condutas investigadas, expendidos em ordem judicial motivada (art. 222, terceira parte). ${ }^{81}$

perpetua para algún cargo u oficio público o profesión titular, inhabilitación absoluta temporal para cargos, empleos, oficios o profesiones ejercidos en ámbitos educacionales o que involucren una relación directa y habitual con personas menores de edad, inhabilitación absoluta temporal para cargos y oficios públicos y profesionales titulares, inhabilitación especial temporal para algún cargo u oficio público o profesión titular" (art. 21).

${ }^{79}$ Quanto ao citado requisito, MARIA CECILIA RAMÍREZ G. salienta que não basta a gravidade do delito. Exigem-se fundadas suspeitas de prática de crime, extraídas de fatos determinados: "el delito por el cual se concede la medida debe ser concreto, y la noticia de su comisión tiene que haber llegado al tribunal, no teniendo cabida las medidas preventivas o exploratorias desligadas de la realización de un hecho delictivo y tendente sólo a investigar la realización de hipotéticas conductas criminales". Em tradução livre do autor: "o delito para o qual se concede a medida deve ser concreto, e a notícia de seu cometimento deve ter chegado ao juízo, não tendo cabimento as medidas preventivas ou exploratórias, desligadas da realização de um fato delitivo e tendente somente a investigar a realização de hipotéticas condutas criminais" (Protección de las comunicaciones... op. cit., p. 548).

${ }_{80} \mathrm{O}$ dispositivo também prevê, sob os mesmos requisitos, a possibilidade de interceptação de comunicação daqueles que tenham permitido a utilização de seus meios de comunicação pelos investigados e seus intermediários (art. 222, segunda parte), hipótese que mais se relaciona com a interceptação de telecomunicação.

${ }^{81} \mathrm{O}$ dispositivo resguarda o sigilo profissional, tido como inerente ao ministério do advogado e indispensável para a efetividade da defesa, assegurada no art. 19.3 da Constituição chilena. Foi a conclusão a que chegamos em artigo de nossa autoria publicado em periódico cujos dados são: ARANTES FILHO, Marcio Geraldo Britto. A regulamentação do sigilo das comunicações entre pessoas presentes e do sigilo profissional no direito processual penal chileno. Revista Brasileira de Ciências Criminais, São Paulo, RT, n. 80, set-out. 2009, p. 229 e 237-240. 
A autoridade competente para ordenação da interceptação é a juiz de garantia ("juez de garantía"), que deve decidir de forma circunstanciada (art. 222, primeira e quarta partes, e art. 226). ${ }^{82}$ Os requisitos para expedição da ordem judicial são os seguintes: indicação circunstanciada do nome e qualificação (“dirección”) do afetado pela medida; forma da interceptação; e duração da interceptação, que não poderá exceder a sessenta dias. ${ }^{83}$ Admite-se a prorrogação deste prazo, por períodos de igual duração, desde que examinada a concorrência dos requisitos. ${ }^{84}$

O procedimento previsto nos artigos 223 e 224 Código de Processo Penal chileno se refere a interceptações de comunicações telefônicas ou de outras formas de telecomunicação. Destacamos alguns aspectos deste procedimento, considerada a aplicação à interceptação de comunicação entre pessoas presentes, em razão da remissão do art. 226.

A interceptação, que é realizada de forma sigilosa (art. 222, quinta parte), deve ser registrada mediante gravação por magnetofone ou por outros meios técnicos análogos que assegurem sua fidelidade (art. 223, primeira parte). A gravação será entregue ao Ministério Público, que deve conservá-la em segredo e velar para que não seja conhecida por terceiros (art. 223, primeira parte).

\footnotetext{
${ }^{82}$ MARIA INÊS HORVITZ LENNON e JULIAN LOPEZ MASLE salientam a necessidade de autorização judicial prévia, ligando-a a exigência de legalidade para interceptações de comunicações, garantida constitucionalmente (art. 19.5 da Constituição do Chile) (Derecho Procesal... op. cit., p. 123-124).

${ }^{83}$ A Ley 20.000, de 16 de fevereiro de 2005, que sanciona "el trafico ilicito de estupefacientes y sustancias sicotropicas" altera a disciplina da interceptação entre presentes no que se refere à indicação dos dados pessoais do investigado, em desfavor de quem se decrete a interceptação. Basta consignar as circunstâncias que o individualizem. O seu artigo 24 estabelece: "las medidas de retención e incautación de correspondencia, obtención de copias de comunicaciones o transmisiones, interceptación de comunicaciones telefónicas y uso de otros medios técnicos de investigación, se podrán aplicar respecto de todos los delitos previstos en esta ley y cualquiera sea la pena que merecieren, de conformidad a las disposiciones pertinentes del Código Procesal Penal. Sin perjuicio de lo anterior, no regirá lo dispuesto en el inciso cuarto del artículo 222 de ese Código, en cuanto a indicar circunstanciadamente el nombre y dirección del afectado por la medida, siendo suficiente consignar las circunstancias que lo individualizaren o determinaren. Asimismo, no obstante lo prevenido en el artículo 167 de dicho Código, si las diligencias ordenadas no dieren resultado, el fiscal podrá archivar provisionalmente la investigación hasta que aparezcan mejores y nuevos antecedentes".

${ }^{84} \mathrm{Se}$ as suspeitas consideradas para ordenar a medida se dissiparem ou houver transcorrido o prazo de duração fixado para a mesma, deverá ser interrompida imediatamente (art. 222, última parte).
} 
Estimando ser devida, o Ministério Público pode dispor sobre a transcrição escrita da gravação, a qual há que ser feita por funcionário a oficiar como "ministro de fe" sobre a fidelidade com conteúdo da gravação (art. 223, segunda parte).

Prevê-se, também, a necessidade de notificação do afetado (art. 224), posteriormente a realização da interceptação, ${ }^{85}$ na medida em que o objeto da investigação permitir e não puser em perigo a vida ou a integridade corporal de terceiras pessoas. ${ }^{86}$

Além disso, é previsto incidente de inutilização de comunicações interceptadas: as comunicações irrelevantes à investigação devem ser entregues, oportunamente, às pessoas afetadas, destruindo-se a transcrição ou a cópia da gravação que estejam sob a guarda do Ministério Público (art. 223, quarta parte).

Não se procede à referida inutilização quanto a gravações que contenham informações relevantes para outras investigações de fatos que possam constituir delito cuja pena cominada seja "pena de crimen", as quais possam ser utilizadas, conforme as demais normas que regulamentam as interceptações (art. 223, quinta parte).

A incorporação em juízo oral dos resultados obtidos em interceptação deve se realizar da maneira como determinar o juízo, em oportunidade processual pertinente (art. 223, terceira parte). ${ }^{87}$

\footnotetext{
${ }^{85}$ A propósito da prevista notificação, MARIA CECILIA RAMÍREZ G. propugna pela necessidade de informação ao investigado afetado, para discutir a pertinência da medida: "de esta manera el afectado tendrá la oportunidad de discutir la pertinencia de la medida y defender su derecho sí ha sido indebidamente conculcado (control a posteriori). Para hacer efectivo este control es necesario que la escucha sea grabada en cinta magnetofónica o similar y que se proteja contra cualquier eventual alteración; como asimismo, que se lleve un registro de las intervenciones efectuadas". Em tradução livre do autor: "desta maneira, o afetado terá a oportunidade de discutir a pertinência da medida e defender se seu direito foi indevidamente restringido (controle a posteriori). Para fazer efetivo este controle, é necessário que a escuta seja gravada em fita magnetofônica ou similar e que se proteja contra qualquer eventual alteração; como, da mesma forma, registre-se as intervenções efetuadas" (Protección de las comunicaciones... op.cit., p. 547-548).

${ }^{86} \mathrm{O}$ art. 182 do Código de Processo Penal chileno prevê que, em regra, o investigado e os demais intervenientes poderão examinar os autos registram os atos de investigação, bem como obter cópias de seus termos. Excepcionase, no mesmo dispositivo legal, a possibilidade de reserva de registros e de documentos para garantir a eficácia da investigação, pelo prazo máximo de 40 dias, assegurado o acesso à Jurisdição para sua impugnação.

${ }^{87}$ Este dispositivo também prevê que os encarregados da prática da diligência de interceptação poderão ser considerados testemunhas.
} 
Se a interceptação for ordenada em desacordo com os requisitos ou com o procedimento previsto no Código de Processo Penal (respectivamente, nos artigos 222, e 223 a 224), os seus resultados não poderão ser utilizados (art. 225).

\subsection{Direito espanhol}

Em Espanha, a interceptação de comunicação entre pessoas presentes não é tida por disciplinada pela legislação processual.

A Constituição espanhola assegura, contudo, "o segredo das comunicações e, em especial das postais, telegráficas e telefônicas" ("el secreto de las comunicaciones y, en especial, de las postales, telegráficas y telefónicas, salvo resolución judicial”) (art. 18.3). ${ }^{88}$

A doutrina reconhece a ausência de regulamentação legal da interceptação de comunicação entre pessoas presentes. Lembra JESÚs MARTínEZ RUIZ o impasse dela decorrente: "las medidas de investigación consistentes en captaciones o grabaciones de las comunicaciones audiovisuales directas, ambientales o entre presentes con base indiciaria, habiéndose defendido sobre este particular las más diversas posturas en plano doctrinal". ${ }^{89}$

A "Ley de Enjuiciamiento Criminal", 90 principal lei processual penal espanhola, em seu art. 579, disciplina apenas a interceptação de telecomunicações: comunicação postal,

$88 \mathrm{O}$ texto normativo da Constituição espanhola consultado é o Disponível em: http:/www.congreso.es/consti/constitucion/indice/titulos/articulos.jsp?ini=10\&fin=55\&tipo=2. Acesso em: $15 / 12 / 2010$.

${ }^{89}$ Em tradução livre do autor: "as medidas de investigação consistentes em captações ou gravações de comunicações audio-visuais diretas, ambientais ou entre presentes com base indiciária, tem-se defendido sobre este assunto as mais diversas posturas em plano doutrinário" (Límites jurídicos... op. cit., p. 148). E a ausência de disciplina legal engloba também as interceptações domiciliares: "la absoluta falta de cobertura legal en la que se encuentran en nuestro Ordenamiento jurídico las diligencias de investigación subrepticia consistentes en la colocación en espacios domiciliarios de aparatos o instrumentos de escucha, transmisión, grabación del sonido o de la imagen." Em tradução livre do autor: "a absoluta falta de cobertura legal em que se encontram, em nosso Ordenamento jurídico, as diligências de investigação sub-reptícias consistentes na colocação em espaços domiciliários de aparatos ou instrumentos técnicos de escuta, transmissão, gravação do som e da imagem." (RUIZ, Jesús Martínez. Límites jurídicos ... op. cit., p. 84).

90 O texto normativo da "Ley de Enjuiciamiento Criminal" consultado é o disponível em: http://www.boe.es/aeboe/consultas/enlaces/documentos/leyes_procesales/ley_enjuiciamiento_criminal.pdf. Acesso em: 18/12/2010. 
comunicação telefônica e comunicação telegráfica. ${ }^{91}$ Para tanto, é exigida a ocorrência de indícios sobre a possibilidade de obtenção de prova por meio da interceptação, retratados em decisão judicial motivada. ${ }^{92}$

${ }^{91} \mathrm{O}$ artigo 579 foi alterado pela Ley Orgánica 4/1988, de 25 de maio de 1988. Convém lembrar que a situação normativa do ordenamento jurídico espanhol, anterior à alteração operada pela mencionada Ley Orgánica n. 4/1988, de 25 de maio de 1988, foi avaliada pela Corte Européia de Direitos Humanos no Caso Valenzuela Contreras contra España, no qual foi declarada a a insuficiência da disciplina da interceptação de comunicação telefônica. A Corte afirmou a necessidade de a legislação tratar dos seguintes: a definição de categorias de pessoas suscetíveis de ensejar a medida; a fixação de um limite a duração da execução da medida; o procedimento de transcrição das conversas interceptadas; as precauções a observar para comunicar intactas e completas as gravações realizadas, para fins de controle eventual pelo juiz e pela defesa; as circunstâncias nas quais se pode ou se deve apagar ou destruir os registros da gravação (CORTE EUROPEIA DE DIREITOS HUMANOS. Case of Valenzuela Contreras v. Spain (Merits and Just Satisfaction, n. 27671/95). Disponível em: http://cmiskp.echr.coe.int/tkp197/portal.asp?sessionId=63635425\&skin=hudoc-en\&action=request. Acesso em: 16/12/2010). A respeito desta proposta, verifiquem-se, também, as observações constantes no item n. 3.10.1, nota n. 189. Em sentido semelhante à Corte Européia de Direitos Humanos, como ressalta ALEXANDRE H. CATALÀ BAS, o Tribunal Constitucional espanhol indica os aspectos da interceptação de comunicação telefônica que devem ser versados em lei (La problemática adecuación... op. cit., p. 59-60). Retomamos aqui a questão, embora se trate de interceptação de comunicação telefônica, pois, como bem ressalta JESÚS MARTÍNEZ RUIZ, a situação normativa da interceptação de comunicação telefônica avaliada no julgamento coincide com a atual situação normativa da interceptação de comunicação entre pessoas presentes (Límites jurídicos... op. cit., p. 157).

${ }_{92}$ Os termos normativos do artigo 579, com a redação estabelecida pela Ley Orgánica 4/1988, de 25 de maio de 1988, são os seguintes: "1. Podrá el Juez acordar la detención de la correspondencia privada, postal y telegráfica que el procesado remitiere o recibiere y su apertura y examen, si hubiere indicios de obtener por estos medios el descubrimiento o la comprobación de algún hecho o circunstancia importante de la causa. 2. Asimismo, el Juez podrá acordar, en resolución motivada, la intervención de las comunicaciones telefónicas del procesado, si hubiere indicios de obtener por estos medios el descubrimiento o la comprobación de algún hecho o circunstancia importante de la causa. 3. De igual forma, el Juez podrá acordar, en resolución motivada, por un plazo de hasta tres meses, prorrogable por iguales períodos, la observación de las comunicaciones postales, telegráficas o telefónicas de las personas sobre las que existan indicios de responsabilidad criminal, así como de las comunicaciones de las que se sirvan para la realización de sus fines delictivos. 4. En caso de urgencia, cuando las investigaciones se realicen para la averiguación de delitos relacionados con la actuación de bandas armadas elementos terroristas o rebeldes, la medida prevista en el número 3 de este artículo podrá ordenarla el Ministro del Interior o, en su defecto, el Director de la Seguridad del Estado, comunicándolo inmediatamente por escrito motivado al Juez competente, quien, también de forma motivada, revocará o confirmará tal resolución en un plazo máximo de setenta y dos horas desde que fue ordenada la observación." Em tradução livre do autor: "1. Poderá o juiz decidir a detenção da correspondência privada, postal e telegráfica que o acusado remeter ou receber e sua abertura e exame, se houver indícios de obter por estes meios o descobrimento ou a comprovação de algum fato ou circunstância importante para a causa. 2. Da mesma forma, o juiz poderá autorizar, em decisão motivada, a intervenção em comunicações telefônicas do acusado, se houver indícios de obtenção por estes meios do descobrimento de algum fato ou circunstância importante para a causa. 3. De igual forma, o juiz poderá autorizar, em decisão motivada, por um prazo de até três meses, prorrogáveis por iguais períodos, a observação de comunicações postais, telegráficas ou telefônicas das pessoas sobre as quais existam indícios de responsabilidade criminal, assim como das comunicações das que se sirva para a realização de fins delitivos. 4 . Em caso de urgência, quando as investigações se realizarem para a averiguação de delitos relacionados com a atuação de bandos armados, investigados terroristas ou rebeldes, a medida prevista no item número 3 deste artigo poderá ser ordenada pelo Ministro do Interior ou, em sua ausência, pelo Diretor da Segurança de Estado, comunicando-a imediatamente por escrito motivado ao juiz competente, quem, também de forma motivada, revogará ou confirmará a decisão em um prazo máximo de setenta e duas horas desde que foi ordenada a observação." Sobre a disciplina da interceptação de comunicação telefônica, FRANCISO MUÑOZ CONDE afirma: "realmente no pude admitirse, o por lo menos no sin reservas y sometiendo la medida a estrictos 
Diante da constatação da ausência de disciplina legal das interceptações de comunicações entre pessoas presentes, a maioria da doutrina, com fundamento na exigência de reserva legal para possibilitar a autorização judicial de interferência em comunicações presenciais, reputa "ilegítima" a execução deste meio de prova. ${ }^{93}$

Neste sentido, M. L. NOYA FERREIRO adverte sobre a urgência quanto a elaboração de uma lei que reforme a "Ley de Enjuiciamiento Criminal", que fixe os requisitos e o procedimento de execução da interceptação de comunicações orais. ${ }^{94}$ Tal proposta normativa,

requisitos formales y justificándola con criterios materiales en relación con la gravedad del delito y la urgencia y necesidad de aplicarla". Em tradução livre do autor: "realmente, não se pode admitir, ou pelo menos sem reservas e submetendo a medida a estritos requisitos formais e a justificando com critérios materiais em relação com a gravidade do delito e a urgência e necessidade de aplicá-la" (Valoración de las grabaciones... op. cit., p. 60-61). No mesmo sentido, VICENTE GIMENO SENDRA afirma a insuficiência da disciplina da interceptação de comunicação telefônica, em razão de "lacunas", entre as quais estão os requisitos e o procedimento para intervenção na comunicação telefônica e para a transcrição do seu conteúdo (Aspectos procesales y constitucionales más relevantes en los delitos relativos a drogas tóxicas y estupefacientes. In: SORIANO, José Ramón (Dir.). Delitos contra la salud pública y contrabando. Madrid: Lerko Print, 2000, p. 181). Acrescenta ALEXANDRE H. CATALÀ BAS que a disciplina do art. 579 é claramente insuficiente e incompatível com a Constituição espanhola, pois não preconiza, em sua totalidade, as garantias exigidas para as interceptações telefônicas (La problemática adecuación... op. cit., p. 64 e 70-71).

${ }^{93} \mathrm{Cf}$. Em análise das correntes doutrinárias quanto à admissibilidade de restrição às comunicações entre pessoas presentes, JESÚS MARTÍNEZ RUIZ conclui que a maioria da doutrina a considera "ilegítima" (Límites jurídicos... op. cit., p. 148-149). Em sentido contrário, admitindo a possibilidade de restrição às comunicações entre pessoas presentes, cf.: QUERALT, Joan J. Intervención de las telecomunicaciones en sede de investigación judicial y policial. Revista Canaria de Ciencias Penales, n. 2, dic. 1998, p. 115-116; GUILLÉN LÓPEZ, E., MARTÍN MORALES, R., REQUENA LÓPEZ, T. El régimen consitucional de 'la movida'. Granada: Grupo Editorial Universitario, 2002, p. 57, apud RUIZ, Jesús Martínez. Límites jurídicos ... op. cit., p. 149; RAFOLS LLACH, J. Aurorización judicial para la instalación de aparatos de escucha, transmisión y grabación en lugar cerrado. La prueba en el proceso penal, Cuadernos de Derecho Judicial, Madrid, Edit. CGPJ, 1992, p. 567, apud RUIZ, Jesús Martínez. Límites jurídicos ... op. cit., p. 150; RUIZ, Jesús Martínez. Límites jurídicos ... op. cit., p. 172-185. Quanto a tese apresentada por RAFOLS LLACH, quem sustenta a admissibilidade de interceptação de comunicação presencial, com fundamento em interpretação extensiva do art. 579 - em especial referência aos termos normativos "cualquier otro tipo de comunicación", os quais integram a disciplina da interceptação de comunicação telefônica - , JESÚS MARTÍNEZ RUIZ apresenta a crítica no sentido de que a interpretação de normas que propiciem a restrição a direitos fundamentais deve ser restritiva (Límites jurídicos... op. cit., p. 150151). Além disso, embora o autor admita a possibilidade de interceptação de comunicação entre pessoas presentes, ressalva em sua conclusão a necessidade de regulamentação em lei: "queremos insistir en que tal y como reconoce la mayoría de la doctrina, de lege ferenda, resulta innegable la conveniencia de abogar por la perentoria necesidad de adecuar nuestro Ordenamiento jurídico procesal a las exigencias reseñadas en la jurisprudencia tanto del TEDH como de nuestro TC, a la hora de colmar de contenido el principio de legalidad en relación con la restricción singular de los derechos fundamentales". Em tradução livre do autor: "queremos insistir em que tal e como reconhece a maioria da doutrina, de lege ferenda, resulta inegável a conveniência de advogar pela evidente necessidade de adequar nosso Ordenamento jurídico processual às exigências reconhecidas na jurisprudência do TEDH como de nosso TC, com vistas a preencher o conteúdo de legalidade em relação à restrição singular dos direitos fundamentais" (RUIZ, Jesús Martínez. Límites jurídicos... op. cit., p. 185).

${ }^{94}$ Cf. La intervención de comunicaciones orales em el proceso penal. Valencia: Tirant lo Blanch, 2000, p. 138139, apud RUIZ, Jesús Martínez. Límites jurídicos... op. cit., p. 173. Neste sentido, FRANCISO MUÑOZ 
de lege ferenda, visa a adequar o ordenamento jurídico à exigência de reserva de lei para a restrição de direitos fundamentais.

Entretanto, os protestos da doutrina para a instituição de disciplina para a interceptação de comunicação entre pessoas presentes ainda não foram atendidos pelo legislador. ${ }^{95}$

CONDE assevera que: "podemos establecer como principio que las injerencias estatales en la vida privada a través del empleo de medios audio-visuales sólo debe admitirse en los casos fijados legalmente, bajo control judicial y siempre de acuerdo com el principio de necesidad, intervención mínima y proporcionalidad": Em tradução livre do autor: "podemos estabelecer como princípio que as ingerências estatais na vida privada através do emprego de meios audio-visuais somente se deve admitir nos casos fixados legalmente, sob controle judicial e sempre de acordo com o princípio da necessidade, intervenção mínima e proporcionalidade" (Valoración de las grabaciones... op. cit., p. 68).

95 Apesar de não haver regulamentação da interceptação de comunicação entre pessoas presentes em direito espanhol, como salientado na doutrina citada, as comunicações entre pessoas presentes podem ser restringidas por outro meio, que não se confunde com interceptação, e não supre a mencionada ausência de disciplina legal. Cuida-se do instituto previsto na "Ley Organica" n. 4, de 4 de agosto de 1997 (disponível em: https://www.agpd.es/portalwebAGPD/canaldocumentacion/legislacion/normativa_estatal/common/pdfs/E7-cpLEY.PDF. Acesso em: 18/12/2010), que se traduz em utilização, pelas Forças e Corpos de Segurança, de videocâmeras para gravar imagens e sons em lugares públicos, abertos ou fechados, com vistas a assegurar a convivência entre os membros da sociedade, a erradicação da violência, a utilização pacífica das vias e dos espaços públicos e a prevenção de cometimento de delitos, faltas e infrações relacionadas à segurança pública (art. $1^{\circ}$ ). A referida lei estabelece que é vedada, contudo, a gravação de sons, com exceção a situação de ocorrência de um risco concreto e preciso (art. 3.4). A decisão que conceda autorização para a instalação das video-câmeras deve ser motivada e fixar o âmbito físico em que possa ocorrer a gravação (art. 3.4). Preveem-se, ainda, "principios de utilización de las videocâmaras": princípio da proporcionalidade, em sua dupla versão de idoneidade e de intervenção mínima (art. 6.1) - idoneidade do meio, em uma situação concreta, para a manutenção da segurança pública (art. 6.2), e intervenção mínima avaliada por meio de ponderação, em cada caso, entre a finalidade pretendida e a possível restrição do direito a honra, à imagem e a intimidade das pessoas (art. 6.3); a exigência de um razoável risco para a segurança da sociedade, em se tratando de video-câmeras fixas, e de um perigo concreto, no caso das video-câmeras móveis (art. 6.4); a impossibilidade de utilização de videocâmeras no interior de domicílios e de suas dependências - sem o consentimento do titular ou autorização judicial -, em em lugares públicos - se houver restrição direta e grave à intimidade das pessoas -, e para gravação de conversas de natureza estritamente privada (art. 6.5). Entre os direitos dos interessados, destacamos o seguinte: "o público será informado de maneira clara e permanente sobre a existência de video-câmeras fixas, sem especificação de sua localização, e sobre a autoridade responsável” (art. 9.1). A respeito desta regulamentação, FRANCISCO MUÑOZ CONDE salienta que a gravação obtida somente tem valor de "mera denuncia" (Valoración de las grabaciones... op. cit., p. 67). De outro lado, TERESA ARMENTA DEU, embora afirme que se trata de medida de caráter preventivo para proteção da segurança pública, ressalva a possibilidade de conversão em ato de investigação, se a gravação propiciar a identificação do cometimento de um delito ou de seu autor (Lecciones de Derecho... op. cit., p. 167). Não reputamos que o instituto tratado na legislação citada possa ser considerado interceptação de comunicação entre pessoas presentes, consoante os termos normativos nela previstos, pelos seguintes motivos: a expressa previsão de exclusão da possibilidade de gravação do conteúdo de conversa, ressalvada em hipóteses excepcionais; o caráter preventivo do meio; o conhecimento de que a gravação está sendo realizada, o que afasta a natureza de meio de investigação de prova. 


\subsection{Direito francês}

Em França, a restrição às comunicações entre pessoas presentes, por meio de captação e de registro de seu conteúdo, é regulamentada, sob a denominação "sonorização", nos artigos 706-96 a 706-102 da Seção $6^{\mathrm{a}}$ do Capítulo II do Título XXV do "Code de Procédure Pénale". 96

A Constituição francesa, de $1958,{ }^{97}$ assegura a proteção aos direitos humanos em seu preâmbulo. E o seu art. 34 preconiza a necessidade de delimitação, em lei, de regras para a tutela de garantias fundamentais e o exercício das liberdades públicas. Entre estas garantias fundamentais e liberdades públicas, a liberdade de manifestação do pensamento e a vida privada se destacam como valores reconhecidos pela sociedade francesa. ${ }^{98}$

No plano infraconstitucional, o Código de Processo Penal francês intitula interceptação apenas a restrição às telecomunicações. As interceptações de comunicações emitidas pela via de telecomunicações ("interceptions de correspondances émises par la voie des télécommunications"), são disciplinadas, por primeiro, nos artigos 100 a 100.7 da subseção 3.2 do Capítulo I, do Título III. ${ }^{99}$

96 O texto normativo do "Code de Procédure Pénale" consultado é o disponível em: http:/www.legifrance.gouv.fr/affichCode.do;jsessionid=D958077207F878024D82F012B3E08DC0.tpdjo16v_3?i dSectionTA=LEGISCTA000006182887\&cidTexte=LEGITEXT000006071154\&dateTexte=20110104. Acesso em: 04/01/2011.

$97 \mathrm{O}$ texto normativo do da Constituição francesa consultado é o disponível em: http://www.legifrance.gouv.fr/html/constitution/constitution2.htm\#titre1. Acesso em: 04/01/2011.

98 A propósito, LUIZ FRANCISCO TORQUATO AVOLIO, em comentários sobre a restrição a comunicações telefônicas em França, ressalta a liberdade de comunicação como expressão da liberdade de manifestação do pensamento assegurada no art. 11 da Declaração dos Direitos do Homem e do Cidadão, de 1789, integrante do ordenamento francês. Provas ilícitas... op. cit., p. 119. A vida privada é tutelada no art. $8^{\circ}$ da Convenção Européia sobre Direitos Humanos, que igualmente integra o direito francês. Sobre a extensão da vida privada no direito francês, cf.: CIPRIANI, Simonetta. La protezione penale della riservatezza in diritto comparato italiano e francese. Rivista Italiana di Diritto e Procedura Penale, Milano, Giuffrè, anno XL, fasc. 3, gen-mar. 1997, p. 866-870.

${ }^{99}$ Cuida-se de instituto previsto inserido no Código pela de Processo Penal francês pela Lei n. 91.646, de 1991. Antes da instituição da regulamentação da interceptação das telecomunicações, entendia-se que a restrição às telecomunicações era amparada pelo art. 81 do Código de Processo Penal francês, que preconiza a possibilidade de o juiz "proceder, de conformidade com o estabelecido em lei, a todos os atos instrutórios que repute úteis para apuração da verdade" (ALMEIDA, Carlos Alberto Simões de. Medidas cautelares e de polícia do processo penal em direito comparado. Coimbra: Almedina, 2006, p. 77). A este respeito, GASTON STEFANI, GEORGES LEVASSEUR e BERNARD BOULOC observam que embora a Corte de Cassação admitisse a interceptação de comunicação telefônica com fundamento no art. 81 do Código de Processo Penal francês, a Corte Europeia de 
A “interceptação, registro e transcrição de comunicações emitidas pela via de telecomunicações" pode ser decretada, desde que seja evidenciada a necessidade de utilização do meio e se trate de persecução quanto a delito ao qual seja cominada pena de prisão igual ou superior a dois anos. Para tanto, exige-se autorização judicial (art. 100). ${ }^{100}$

Também no Código de Processo Penal, em regulamentação de procedimento para persecução penal de "criminalidade organizada", é prevista a possibilidade de utilização da mencionada interceptação de telecomunicações no art. 706-95 (Secão $5^{\mathrm{a}}$ do Capítulo II do Título XXV).

Além disso, na referida regulamentação de procedimento para persecução penal de "criminalidade organizada", é disciplinada a medida intitulada "sonorizações"101 e "fixações" de imagens em certos locais ou veículos (“des sonorisations et des fixations d'images de certains lieux ou véhicules") (artigos 706-96 a 706-102 da Seção 6 a do Capítulo II do Título $\mathrm{XXV}){ }^{102}$

Direitos Humanos não o fazia, por entender a disposição insuficiente em face das exigências do art. $8^{\circ}$ da Convenção Europeia sobre Direitos Humanos (Procédure Pénale. 17. ed. Paris: Dalloz, 2000, p. 597). No mesmo sentido, cf. PRADEL, Jean. Manuel de procédure pénale. 10. ed. Paris: Éditions Cujas, 2000, p. 374-377.

${ }^{100}$ No que tange aos requisitos previstos no art. 100, GASTON STEFANI, GEORGES LEVASSEUR e BERNARD BOULOC, exemplificando com a interceptação de comunicação telefônica, salientam a gravidade do delito e a necessidade de utilização deste método de investigação (Procédure Pénale... op. cit., p. 598).

${ }^{101}$ Em língua portuguesa, "sonorização" é designação genérica de processo de gravação sonoro (FERREIRA, Aurélio Buarque de Holanda. Novo Dicionário Aurélio. 3. ed. Curitiba: Editora Positivo, 2004. Versão eletrônica).

${ }^{102}$ Esta disciplina foi recentemente instituída, pela Lei n. 2005-1549, de 2005. Em avaliação do ordenamento jurídico francês antes da alteração ocorrida por esta lei, a Corte Européia de Direitos Humanos, no "Case Vetter v. France", analisando o tema da "sonorização" de uma habitação, concretizada sob o regime da interceptação de comunicação telefônica consagrado no "Code de Procedúre Pénale" francês, teve por violada a vida privada assegurada no art. $8^{\circ}$ da Convenção Européia sobre Direitos Humanos. A Corte assinalou que os artigos $100 \mathrm{e}$ seguintes do Código de Processo Penal Francês - inseridos pela Lei n. 91.646, de 10 de julho de 1991 sobre o segredo das comunicações emitidas por via de telecomunicações - não continham qualquer referência à "sonorização", tanto no texto normativo dos dispositivos, quanto no título que os precede, indicando que a medida é voltada a reger a apenas as interceptações de telecomunicações. Interessante notar, ainda, que a sentença foi proferida pela Corte em 31/08/2005, após o que se procedeu à inserção à regulamentação da "sonorização" no Código de Processo Penal, em dezembro de 2005 (CORTE EUROPEIA DE DIREITOS HUMANOS. Case Vetter v. France (Merits and Just Satisfaction, n. 59842/00). Disponível em: http://cmiskp.echr.coe.int/tkp197/portal.asp?sessionId=64240137\&skin=hudocen\&action=request. Acesso em: 03/01/2011). O julgado é referido por BENJAMIM SILVA RODRIGUES (Das escutas... op. cit., p. 440). Em sentido semelhante ao que foi afirmado pela Corte Europeia de Direitos Humanos, DIMITRI GIANNALOPOULOS e RAPHAÊLLE PARIZOT enfatizaram, também em análise do ordenamento jurídico francês antes da alteração normativa de 2005 , que a regulamentação da interceptação de telecomunicação não 
A medida de "sonorização" e "fixação" de imagens em certos locais ou veículos é definida em lei como "a captação, a fixação, a transmissão e o registro de palavras pronunciadas por uma mais pessoas a título privado ou confidencial, em locais ou veículos privados ou públicos, ou de imagem de uma ou mais pessoas que se encontrem em um local privado" (art. 706-96). ${ }^{103}$

A realização da medida deve ser necessária para obtenção de informações sobre a prática de um dos delitos previstos no art. 706-73 do Código de Processo Penal ${ }^{104}$ (art. 70696).

É exigida autorização judicial, por meio de decisão motivada, na qual deve constar: a permissão para que oficiais e agentes de polícia judiciária insiram um dispositivo técnico no local onde se pretenda captar o som ou a imagem (art. 706-96); os elementos que propiciem a identificação dos veículos ou dos locais privados ou públicos visados; a infração que justifica a utilização das medidas; assim como a sua duração, pelo prazo máximo de quatro meses (art. 706-97 e art. 706-98). ${ }^{105}$

As operações de "sonorização" e de "fixação" de imagem devem ser efetuadas sob controle da autoridade judicial (art. 706-96) e documentadas (art. 706-100 a art. 706-102).

\subsubsection{Direito italiano}

Em Itália, a interceptação de comunicação entre presentes ("intercettazione di comunicazione tra persone presenti") é disciplinada, de forma conjunta com outras espécies

prevê a possibilidade de se operar vigilância eletrônica. Esta regulamentação, segundo o entendimento dos autores, de maneira alguma ("pas du tout"), pode ser aplicada à vigilância eletrônica, em razão da expressão restritiva do legislador, que se referiu, apenas, a telecomunicações (La preuve technologique... op. cit., p. 273).

${ }^{103}$ Tradução livre do autor de: "la captation, la fixation, la transmission et l'enregistrement de paroles prononcées par une ou plusieurs personnes à titre privé ou confidentiel, dans des lieux ou véhicules privés ou publics, ou de l'image d'une ou plusieurs personnes se trouvant dans un lieu privé” (art. 706-96).

104 Entre os delitos especificados no Código de Processo Penal francês estão: "bando organizado", "barbárie", "tráfico de entorpecentes" (art. 706-73).

${ }^{105}$ É prevista a possibilidade de renovação da autorização das medidas, pelo mesmo prazo, desde que presentes os requisitos previstos em lei (art. 706-98). 
de interceptações de conversações e comunicações ("intercettazioni di conversazioni o comunicazioni"), no "Codice di Procedura Penale"106 (arts. 266 a 271).

As comunicações entre pessoas presentes, cuja interceptação a lei processual admite, é assegurada no art. 15 da Constituição italiana: ${ }^{107}$ "a liberdade e o segredo da correspondência e de qualquer outra forma de comunicação são invioláveis." O dispositivo constitucional ainda prevê que: "a sua limitação pode ocorrer somente por ato motivado da autoridade judicial com as garantias estabelecidas pela lei."

A admissibilidade da interceptação de comunicações entre presentes é restrita à persecução penal de determinados delitos (art. 266.1 e art. 266.2), ${ }^{108}$ para a investigação dos quais também é cabível a interceptação de outras espécies de comunicação: telefônica e outras formas de telecomunicação (art. 266.1); comunicações informáticas, telemáticas ou intercorrentes entre mais sistemas (art. 266-bis.1). A técnica empregada pelo legislador italiano para delimitação da admissibilidade da interceptação de comunicação entre presentes

106 O texto normativo do "Codice di Procedura Penale" consultado é o disponível em: http://www.altalex.com/index.php?idnot=2011. Acesso em: 20/07/2010.

${ }_{107} \mathrm{O}$ texto normativo da Constituição italiana consultado é o disponível em: http://www.governo.it/governo/costituzione/costituzionerepubblicaitaliana.pdf. Acesso em 20/07/2010.

${ }_{108}$ Por primeiro, o art. 266.1 da lei processual penal prevê os delitos para os quais são admissíveis as interceptações de comunicações telefônicas e de outras formas de telecomunicações, entre os quais estão: delitos não culposos para os quais é prevista a pena de prisão perpétua ou de reclusão superior, no máximo, a cinco anos; delitos contra a administração pública para os quais é prevista a pena de reclusão não inferior, no máximo, a cinco anos; delitos de injúria, ameaça, usura, abusiva atividade financeira, abuso de informações privilegiadas, manipulação de mercado, moléstia ou distúrbio a pessoas por meio de telefone; delitos previstos no artigo 600-ter (Pornografia minorile), § $3 .^{\circ}$, do Código Penal, também se relativos ao material pornográfico de que trata o artigo 600-quarter ("Detenzione di materiale pornografico") do mesmo código. Em seguida, o art. 266.2 dispões que, nos mesmos casos, é admitida a interceptação de comunicações entre presentes. Todavia, é prevista uma ressalva: se realizadas nos locais previstos no art. 614 do Código Penal (domicílio privado), a interceptação é admitida somente se houver fundado motivo para reconhecer que nestes locais se esteja desenvolvendo a atividade criminosa. Cuida-se de delitos "de particular gravidade ou de especial natureza" (Cf. APRILE, Ercole. La prova..., p. 353). No mesmo sentido: Cf. DELL'ANDRO, Enzo Maria. Intercettazioni ambientali... op. cit., p. 160.

O Código de Processo Penal italiano também prevê, no art. 295.3-bis, a possibilidade de decretação de interceptação entre presentes na hipótese de facilitação de procura de foragido ("ricerche del latitante"), em relação a determinados delitos, como, por exemplo, associação de tipo mafioso (articolo 51.3-bis do Código de Processo Penal, c.c. art. 416-bis do Código Penal). Esta modalidade de interceptação entre presentes, juntamente com interceptações de telecomunicações também previstas na referida norma, são espécies de interceptações para a procura dos foragidos ("intercettazioni per le ricerche dei latitanti”) (Cf. APRILE, Ercole; SPIEZIA, Filippo. Le intercettazioni... op. cit., p. 96-103). A respeito da possibilidade de utilização de meios de investigação de prova para objetivos que extrapolam a sua finalidade imediata, cf., supra, item n. 1.2.1.2, nota n. 61. 
é a seguinte: indicação das espécies delitivas, com a respectiva indicação do dispositivo normativo em que são previstas para algumas das espécies delitivas.

Como requisitos, são exigidos graves indícios de prática delitiva e a indispensabilidade da medida para o prosseguimento investigação (art. 267). Se a interceptação de comunicação entre pessoas presentes for operada em domicílio, exige-se, também, fundado motivo para reconhecer que nele se esteja desenvolvendo a atividade criminosa (art. 266.2). ${ }^{109}$

\footnotetext{
109 A doutrina salienta que a gravidade dos indícios é valorada de forma semelhante a que se faz quanto a aplicação de uma medida cautelar pessoal (Cf. APRILE, Ercole. La prova..., p. 354). Tanto os graves indícios de prática de delito, quanto a indispensabilidade da medida para as investigações devem ser avaliadas com fundamento em elementos concretos. Além disso, extrai-se do fundado motivo para interceptação em domicílio não a necessidade de existência da atividade criminosa, mas a possibilidade, em um juízo ex ante, de que a atividade criminosa esteja se desenvolvendo em domicílio privado (Cf. APRILE, Ercole; SPIEZIA, Filippo. Le intercettazioni... op. cit., p. 7, 10 e 63; MARTINO, Corrada di. Le intercettazioni ambientali ... op. cit., p. 1.1491.158 e p. 1.168; MARTINO, Corrada di; PROCACCIANTI, Teresa. Le intercettazioni... op. cit., p. 60-61). PIERFRANCESCO BRUNO, de outro lado, observa que devem existir fundados motivos para reconhecer que, no momento da captação, esteja se desenvolvendo a atividade criminosa, o que, na prática reduz o campo aplicativo a figuras delitivas cuja conduta seja dilatada no tempo, como no caso de sequestro de uma pessoa. Diante disso, o último autor sugere que se repense a disciplina normativa (Intercettazioni di comunicazioni... op. cit., p. 180.).

Da prevista indispensabilidade para o prosseguimento das investigações, extrai-se a impossibilidade de execução de interceptação como primeiro ato investigativo (Cf. MARINELLI, Claudio. Intercettazioni processuali... op.
} cit, p. 72).

Há legislações especiais que alteram o regime das interceptações previsto no Código de Processo Penal italiano, entre as quais destacamos as doravante comentadas.

O "Decreto legge 13 maggio 1991, n. 152, convertido em lei pela Legge 12 luglio 1991, n. 203", ao definir procedimentos urgentes para persecução de criminalidade organizada, prevê, em seu art. 13, regras especiais: indícios suficientes, ao invés de graves indícios; necessidade para o desenvolvimento das investigações em relação a um delito de criminalidade organizada ou de ameaça por meio de telefone, em vez de indispensabilidade do meio para o prosseguimento da investigação; as operações podem ser efetuadas por agentes de polícia judiciária, e não apenas por oficiais de polícia judiciária; a duração máxima é de quarenta dias - prazo distinto dos quinze dias do regime ordinário -, prorrogável por períodos de vinte dias, se presentes os requisitos da medida. Quanto aos requisitos estabelecidos no regime especial, observe-se, por primeiro, que, tratando-se de um delito de criminalidade organizada, a interceptação de comunicação entre presentes é permitida nos lugares indicados no art. 614 do Código Penal (domicílio privado), mesmo que não haja motivo para reconhecer que neles se esteja desenvolvendo a atividade criminosa. Isto porque o referido art. 13 se refere à derrogação, quanto à persecução das espécies delitivas nele previstas, das disposições do art. 266 da lei processual penal (Cf. APRILE, Ercole; SPIEZIA, Filippo. Le intercettazioni... op. cit., p. 63, 87-89, 96). Ademais, a doutrina critica o regime especial. Para além das observações sobre as dificuldades de definição de organização criminosa, considerada a ausência de definição normativa, CLAUDIA CARMONA tece, também, as seguintes críticas ao regime instituído pelo "Decreto Legge n. 152": os exigidos indícios são menos convincentes, se comparados com os exigidos na legislação ordinária (de graves para suficientes); desloca-se a possibilidade de decretação da medida para o início da investigação (de "absolutamente indispensável para o prosseguimento das investigações", passou-se a exigir "necessárias para o desenvolvimento das investigações"; descumpre-se o princípio de subsidiariedade das interceptações, porque falar em "desenvolvimento" é propiciar a execução de interceptação no início das investigações. A autora ressalta, ainda, que o recuo das garantias foi explicado como necessário para a instituição de instrumentos de investigação do fenômeno mafioso e "camorristico" para a polícia e o Ministério Púbico. Todavia, ela adverte: uma forma de restringir a "omertà" (lei do silêncio) é usar instrumentos fundados na surpresa; mas isto contrasta com o plano das garantias de defesa das liberdades 
Atribui-se legitimidade para requerê-las ao Ministério Público (art. 267.1). ${ }^{110}$

Como garantia de liberdade do defensor prevista no art. 103.5 do Código de Processo Penal, é prevista a proibição de se proceder a interceptação relativa a comunicações dos defensores, dos investigadores privados autorizados e encarregados do feito, dos consulentes técnicos e de seus auxiliares. A proibição se estende para as comunicações entre tais pessoas e as pessoas que os assistem. ${ }^{111}$

Em regra, a interceptação deve ser autorizada judicialmente, em decisão motivada, presentes os requisitos legais (art. 267). Excepcionalmente, evidenciada urgência com fundado

pessoais (Le intercettazioni ambientali... op. cit., p. 355-358). O regime especial institui uma atenuação dos requisitos (TONINI, Paolo. A prova... op. cit., p. 250).

O comentado regime especial também é aplicável em outras hipóteses: persecução de terrorismo internacional e de delitos cometidos com finalidade de terrorismo ou de aversão ao ordenamento constitucional (art. $3^{\circ}$ do “Decreto Legge 18 ottobre 2001, n. 374", c.c artigos 270-ter e 280-bis do Código Penal e artigo 407.2, "a", n. 4 do Código de Processo Penal); persecução de delitos contra a personalidade individual e de delitos relacionados à prostituição (art. $9^{\circ}$ da Legge 11 de agosto de 2003, n. 228).

O já referido "Decreto Legge 18 ottobre 2001, n. 374”, convertido pela "Legge 15 diciembre 2001, n. 438”, em seu art. 50, também disciplinou as intituladas "interceptações preventivas" ("intercettazioni preventive"), alterando o art. 226 das "norme di attuazione, di coordinamento, trasitorie e regolamentari del nuovo codice di procedura penale”. Estas interceptações são admitidas para a aquisição de notícias concernentes à prevenção da prática dos delitos referidos nos artigos 407.2, “a", n. 4 e 51.3-bis do Código de Processo Penal, entre os quais destacamos delitos contra a personalidade internacional do Estado, como o terrorismo internacional, delitos contra a personalidade individual, como o de sujeição a condição de escravo, delitos contra a ordem pública, como a associação de tipo mafioso. Entre as espécies de tais interceptações preventivas, está a interceptação de comunicações entre presentes, inclusive se ocorridas nos locais indicados no art. 614 do Código Penal (domicílio privado), não se exigindo o requisito de fundado motivo para se reconhecer que nos referidos locais se esteja desenvolvendo a comunicação (art. 226.1). A medida, que pode ser requerida pelo Ministro dell'interno - ou, sob sua delegação pelos responsáveis pelos Serviços centrais ou por comandantes de polícia - é autorizada pelo Procurador da República pelo período de quarenta dias, prorrogável por períodos sucessivos de vinte dias, se presentes os seus requisitos (arts. 226.1 e 226.2). Os elementos nela obtidos somente podem ser utilizados para fins investigativos (art. 226.5). Cuida-se de interceptações que não seguem, mas precedem ao cometimento de delito, motivo por que se discute a compatibilidade de tal instituto com a ordem constitucional italiana, considerada a necessidade de constar da autorização (MARTINO, Corrada di. Le intercettazioni ambientali... op. cit., p. 1.168; MARTINO, Corrada di; PROCACCIANTI, Teresa. Le intercettazioni ... op. cit., p. 82).

${ }^{110}$ A propósito da atribuição de legitimidade para requerer a execução do meio pelo Ministério Público, críticas da doutrina são dispensadas ao legislador italiano: "l'accesso ai mezzi di ricerca della prova in un processo di parti non puó essere di esclusiva pertinenza del pubblico ministero; né puó pretendersi che le altre parti, persino quella accusata, facciano riferimento a detto organo per guadagnarsi l'accesso stesso". Em tradução livre do autor: "O acesso aos meios de investigação da prova em um processo de partes não pode ser de atribuição exclusiva do Ministério Público; nem se pode pretender que as outras partes, inclusive a acusada, façam requerimento ao mencionado órgão para obterem o referido acesso" (Cf. TAORMINA, Carlo. Il regime... op. cit., p. 112). No mesmo sentido: Cf. CAPRIOLI, Francesco. Intercettazione e registrazione... op. cit., p. 173 e 177); CARNUCCIO, Paolo. Strategie e tecniche... op. cit., p. 2-3.

${ }^{111}$ A respeito desta proibição de execução de interceptação, cf., supra, item n. 3.6, nota n. 121, e, infra, item n. 124. 
motivo de que do retardo possa derivar grave prejuízo às investigações, o órgão ministerial pode dispor sobre a interceptação, em manifestação motivada (art. 267.2). ${ }^{112} \mathrm{Na}$ hipótese de interceptação disposta pelo Ministério Público, ${ }^{113}$ o juízo deve ser comunicado imediatamente, dentro de 24 horas, para decidir sobre sua convalidação em decisão motivada. ${ }^{114}$

O prazo de duração da interceptação não pode ser superior a quinze dias, o qual pode ser prorrogado em decisão motivada, por períodos de igual duração, desde que estejam presentes os requisitos da medida (art. 267.3).

Entre as formalidades para a execução da interceptação, sobressaem-se minuciosas regras que delineiam o procedimento para sua concretização (art. 268). As operações são realizadas pelo Ministério Público, ou por oficiais de polícia judiciária (art. 267.4).

As comunicações interceptadas são gravadas e são redigidos termos das operações (art. 268.1). É operada a transcrição, ainda que de modo sumário, do conteúdo das comunicações (art. 268.2): "trata-se da denominada degravação informal, utilizável também durante as investigações preliminares a fim de requerer ao juiz as medidas cautelares". ${ }^{115}$

Os referidos termos e gravações são guardados, juntamente com as gravações e as decisões que tenham autorizado, convalidado ou prorrogado a interceptação (art. 268.4). Em seguida, os defensores das partes devem ser imediatamente informados. Eles poderão exercer a faculdade de examinar os autos e escutar as gravações (art. 268.6). ${ }^{116}$

Sucessivamente, o juiz deve desentranhar e destruir as gravações e os respectivos termos de interceptação de comunicação cuja utilização é vedada por lei. Podem ser utilizados apenas os registros de comunicações que não sejam “manifestamente irrelevantes” (art. 268.6).

\footnotetext{
${ }^{112}$ Se o investigado for membro do Parlamento, é exigida autorização da respectiva Câmara para se proceder a interceptações de comunicações (art. 68 da Constituição Italiana e arts. $4^{\circ}$ e $5^{\circ}$ da Legge 20 giugno 2003 n. 140).

${ }^{113}$ Reconhece-se a aplicação do dispositivo também em interceptações de comunicações entre presentes (Cf. APRILE, Ercole; SPIEZIA, Filippo. Le intercettazioni... op. cit., p. 70).

${ }^{114}$ Se a manifestação ministerial não for convalidada, a interceptação não pode prosseguir e os seus resultados não podem ser utilizados (art. 267.2).

${ }^{115}$ Cf. TONINI, Paolo. A prova... op. cit., p. 251.

${ }^{116}$ Cuida-se de norma que visa a operar o "contraditório sobre os resultados da captação" (FILIPPI, Leonardo. Intercettazione di comunicazioni..., p. 4; BARGI, Alfredo. Intercettazioni di comunicazioni... op. cit., p. 802).
} 
Nesta etapa, é assegurada a participação das partes. O desentranhamento e a destruição podem ser requeridos pelas partes ou ordenados ex officio. ${ }^{117}$

Em seguida, o juiz determina a transcrição - agora, integral - das gravações ou a impressão, de forma inteligível, das informações contidas nos fluxos de comunicações informáticas ou telemáticas (art. 268.7). ${ }^{118}$ Para tanto, hão que ser observadas as formas e as garantias previstas para a perícia. ${ }^{119} \mathrm{E}$ eventual interessado pode requerer a destruição de gravação desnecessária para investigação, para tutela de sua intimidade. ${ }^{120}$

Excluídos os registros que eventualmente tenham sido destruídos, os demais termos da interceptação realizada são guardados até a sentença proferida no feito não mais ser sujeita a impugnação (art. 269.2).

Os resultados de interceptações, em regra, podem ser utilizados apenas no procedimento em que sejam executadas, segundo dispõe o art. 270.1, contrario sensu. Mas podem servir para outros procedimentos se forem indispensáveis para averiguação de delitos para os quais é obrigatória a prisão em flagrante (art. 270.1, segunda parte). ${ }^{121}$

A sanção processual aplicável a uma interceptação realizada em descumprimento da sua disciplina é a inutilizzabilità. ${ }^{122}$ Conforme previsto no art. 271.1 , veda-se a utilização de

\footnotetext{
${ }^{117}$ No mesmo sentido, estão os ensinamentos de PAOLO TONINI. Enfatiza o autor que o procedimento "leva o juiz a adquirir todas as gravações porque a lei lhe permite desentranhar e destruir somente os atos indubitavelmente irrelevantes e após ter comunicado as partes" (A prova... op. cit., p. 252).

${ }^{118}$ Os defensores poderão extrair cópia da transcrição ou impressão (art. 268.8).

${ }^{119}$ Com a perícia, pretende-se assegurar a genuinidade dos resultados da interceptação (MARTINO, Corrada di; PROCACCIANTI, Teresa. Le intercettazioni... op. cit., p. 166-167). No mesmo sentido, LEONARDO FILIPPI afirma a necessidade de preservação da integridade dos registros. Segundo o autor, a transcrição não constitui típica atividade de documentação, porque representa operação de transposição, com sinais gráficos, do conteúdo das conversas registradas. Com a perícia, produzida sob o crivo do contraditório, atinge-se a integridade das gravações. Além disso, evitam-se inutilizações indevidas e montagens. (Intercettazione di comunicazioni..., p. 5). 120 "Somente nesse momento, a pessoa interessada pode requerer ao juiz, a fim de tutelar a própria intimidade, a destruição da gravação que a ela se relaciona, deferindo o juiz o pedido se a documentação não for necessária para o procedimento (art. 269, inciso 2, do CPP)" (Cf. TONINI, Paolo. A prova... op. cit., p. 252).

${ }^{121}$ PAOLO TONINI ressalva a possibilidade de utilização, também, como notitia criminis, em outros feitos $(A$ prova... op. cit., p. 252).

${ }_{122} \mathrm{O}$ art. 271.3 prevê que, em qualquer grau do processo, a autoridade judicial pode dispor que a documentação das interceptações previstas nos artigos 271.1 e 271.2, seja destruída, salvo se constituir o corpo de delito.
} 
resultados de interceptação operada sem a observância dos requisitos legais, bem como do procedimento demarcado pelos arts. $267,268.1$ e $268.3 .{ }^{123}$

Tampouco podem ser utilizadas determinadas interceptações de comunicações, as das pessoas indicadas no art. 200.1, se tiverem por objeto fatos conhecidos em razão do exercício de seu ministério, ofício ou profissão, ressalvadas as hipóteses em que tais pessoas depuseram sobre os mencionados fatos, ou os divulgaram de outro modo (art. 271.2). ${ }^{124}$

\subsection{Direito português}

No direito português, a interceptação de comunicação entre presentes é disciplinada, de forma conjunta com a interceptação de comunicações telefônicas, sob o título "das escutas telefónicas", nos artigos 187 a 190 do Código de Processo Penal. ${ }^{125}$

\footnotetext{
${ }^{123} \mathrm{Se}$ as operações forem executadas com violação das rigorosas regras que disciplinam a matéria, perfazem-se vícios procedimentais insanáveis, e se perdem provas descobertas (APRILE, Ercole; SPIEZIA, Filippo. Le intercettazioni... op. cit., p. XVIII).

${ }^{124}$ Com o evidente propósito de resguardo do sigilo profissional, a proibição de utilização é correlacionada à norma que desobriga os profissionais em geral de deporem como testemunha sobre fatos conhecidos no exercício do mister (FILIPPI, Leonardo. Intercettazione di comunicazioni..., p. 7). Conforme disposto nas alíneas do art. 201, a proteção ao sigilo profissional se estende por diferentes profissionais: não apenas os expressamente indicados - por exemplo, o ministro de confissões religiosas, o advogado e o médico - como também os que exerçam outros ofícios ou profissões, aos quais a lei reconheça a faculdade de abstenção de depor. A extensão da proibição probatória relativa a comunicações de defensores é controvertida em doutrina. Lembram ERCOLE APRILE e FILIPPO SPIEZIA a regra prevista no art. 103.5 do Código de Processo Penal (v., supra, neste item, nota n. 111), a qual prevê proibição probatória que veda a execução da interceptação, com vistas à tutela do sigilo profissional e do exercício do direito de defesa. Afirmam, também, que tal proibição não se opera se houver graves indícios em desfavor do advogado quanto à prática de um dos delitos em cuja persecução se admite a interceptação, hipótese em que prevaleceria a sua condição de investigado. Os autores diferenciam esta proibição - de execução da interceptação - das demais hipóteses em que, em abstrato, é possível a execução de interceptação, mas se prevê proibição de utilização (Le intercettazioni... op. cit., p. 80-82). CORRADA DI MARTINO e TERESA PROCACCIANTI identificam a existência de dois regimes: no âmbito do mesmo procedimento em que a interceptação seria disposta e a defesa é exercida, tem-se a proibição de execução (art. 103.5), para tutela da defesa técnica, nela incluída a liberdade de comunicação entre o defensor e o seu assistido; em procedimento diverso daquele em que é exercida a defesa, aplicar-se-ia o art. 271, que admite a interceptação, mas nem todos os resultados poderiam ser utilizados (Le intercettazioni... op. cit., p. 228-229). CLAUDIO MARINELLI apresenta não apenas a crítica da doutrina quanto ao regime estabelecido para a relação profissional entre defensor e cliente, como também a sugestão doutrinária de que a vedação deveria se referir à possibilidade de utilização dos resultados (Cf. MARINELLI, Claudio. Intercettazioni processuali... op. cit, p. 44-45). LEONARDO FILIPPI afirma que a inexequibilidade de interceptação quanto às comunicações estabelecidas entre defensor e cliente se aplica tanto no procedimento em que é disposta a interceptação, quanto em outros procedimentos (Intercettazione di comunicazioni..., p. 3).

${ }_{125} \mathrm{O}$ texto normativo do Código de Processo Penal português consultado é o disponível: http://www.portolegal.com/CPPen.htm. Acesso em: 22/04/2010.
} 
Em âmbito constitucional, as comunicações são asseguradas. $\mathrm{O}$ art. 34.4 da Constituição portuguesa ${ }^{126}$ proíbe toda a ingerência das autoridades públicas na correspondência, nas telecomunicações e nos demais meios de comunicação, ressalvados os casos previstos na lei em matéria de processo criminal.

O art. 190 do Código de Processo Penal, sob o título "extensão", dispõe sobre "a intercepção das comunicações entre presentes", ${ }^{127}$ regidas por este dispositivo e pelos artigos 187 a 189, que disciplinam a interceptação de comunicação telefônica e de outras formas de telecomunicação. ${ }^{128}$

A prevista "intercepção das comunicações entre presentes" é admita na persecução penal de determinados delitos, catalogados em lei, ${ }^{129}$ "se houver razões para crer que a

126 O texto normativo da Constituição portuguesa consultado é o disponível em: http://www.parlamento.pt/Legislacao/Paginas/ConstituicaoRepublicaPortuguesa.aspx. Acesso em: 22/04/2010.

127 "Artigo 190. Extensão. O disposto nos artigos $187 .^{\circ}, 188 .^{\circ}$ e $189 .^{\circ}$ é correspondentemente aplicável às conversações ou comunicações transmitidas por qualquer meio técnico diferente do telefone, designadamente correio electrónico ou outras formas de transmissão de dados por via telemática, bem como à intercepção das comunicações entre presentes." Em língua portuguesa, "intercepção" é sinônimo de "interceptação" (FERREIRA, Aurélio Buarque de Holanda. Novo Dicionário Aurélio. 3. ed. Curitiba: Editora Positivo, 2004. Versão eletrônica.).

${ }^{128}$ A respeito da disciplina conjunta, MANUEL DA COSTA ANDRADE salienta que o legislador "nem sequer terá querido assumir as decisões legislativas indispensáveis à superação das ambiguidades e equívocos subsistentes no quadro de soluções já constantes do Código de Processo Penal. Como sucede, por exemplo, com a norma (artigo $190^{\circ}$ ) que manda aplicar o regime das telecomunicações às 'intercepções das conversações entre presentes'. Um dispositivo que, mais do que solucionar os problemas, se limita a criá-los e, quando muito, a indiciá-los" (Métodos ocultos... op. cit., p. 108-109). Acrescenta BENJAMIM SILVA RODRIGUES: "trata-se de uma equiparação altamente censurável visto que se impunha, numa autônoma valoração, a consagração de um regime diferenciado". O último autor registra, ainda, o seu entendimento quanto a "não admissibilidade da intercepção das comunicações entre presentes nas habitações, devendo a norma, neste ponto, sofrer uma interpretação restritiva, no sentido de que tal intercepção e gravação das comunicações ficam afastadas quando as conversações e comunicações ocorrem nos chamados espaços de intimidade" (Das escutas... op. cit., p. 439-440). ${ }^{129} \mathrm{O}$ art. 187.1 prevê os delitos em cuja persecução se admite a medida: "a) puníveis com pena de prisão superior, no seu máximo, a três anos; b) relativos ao tráfico de estupefacientes; c) relativos a armas, engenhos, matérias explosivas e análogas; d) de contrabando; ou e) de injúria, de ameaça, de coacção, de devassa da vida privada e perturbação da paz e do sossego, quando cometidos através de telefone." Comentando o âmbito de admissibilidade, MANUEL DA COSTA ANDRADE salienta que se trata de "uma enumeração taxativa e fechada", por meio da qual o legislador português positivou um juízo de proporcionalidade" (Sobre as Proibições... op. cit., p. 290). Em sentido semelhante, cf.: ANDRADE, Manuel da Costa. Sobre o regime processual penal das escutas telefônicas. Revista Portuguesa de Ciência Criminal, Lisboa, Aequitas, ano I, fasc. 3, jul-set. 1991, p. 382 e 386; CORREIA, João Conde. Qual o significado... op. cit., p. 63. A doutrina, atenta, ainda, para a necessidade de observância do catálogo previsto em lei, diferencia "conhecimentos da investigação" de "conhecimentos fortuitos". Segundo FRANCISCO AGUILAR, os primeiros são "os fatos, obtidos através de uma escuta telefónica legalmente efectuada, que se reportam ou ao crime cuja investigação legitimou a realização daquela ou a um outro delito (pertencente ou não ao catálogo legal) que esteja baseado na mesma situação histórica da vida (historischen Lebenssachaverhalt) daquele". Já os "conhecimentos fortuitos" são definidos como 
diligência se revelará de grande interesse para a descoberta da verdade ou para a prova" (art. 187.1). ${ }^{130}$

É exigida autorização judicial para a decretação da intercepção de comunicações entre presentes (artigos 187.1 e 187.2). Em regra, é proibida a autorização para a intercepção de conversações ou comunicações entre o arguido e o seu defensor, ressalvada a hipótese em que o juiz tenha fundadas razões para crer que elas constituem "objecto ou elemento de crime" $\left(\right.$ art. 187. 3). ${ }^{131}$

"aqueles factos (ou conhecimentos obtidos através de uma escuta telefónica legalmente efectuada e que não se reportem, nem ao crime cuja investigação determinou a realização daquela, nem a qualquer outro delito (pertencente ou não ao catálogo legal) que esteja baseado na mesma situação histórica da vida daquele. Ou seja, os conhecimentos fortuitos definem-se negativamente face aos conhecimentos da investigação. Daí o seu caráter residual" (Dos conhecimentos fortuitos obtidos através de escutas tefefónicas. Coimbra: Almedina, 2004, p. 1718). Também MANUEL DA COSTA ANDRADE no direito português distingue "conhecimentos fortuitos" de "conhecimentos da investigação". A primeira hipótese se refere à descoberta de fontes de outros crimes na conversa captada, que deve se relacionar a um dos crimes em cuja persecução a lei admita a interceptação ("crime do catálogo"). E a segunda hipótese é por ele observada da seguinte forma: "não são conhecimentos fortuitos tudo aquilo relacionado com os crimes que são directamente objeto da investigação" (Das escutas telefônicas... op. cit. p. 210-211).

${ }^{130}$ Em comentários a esta regra, MANUEL DA COSTA ANDRADE assevera: "é preciso que haja suspeita fundada da prática de crime. Não deve ser lançada escuta para ver se há uma suspeita da prática de crime. Deve haver uma suspeita já fundada em factos determinados como diz a lei”. Além disso, o autor enfatiza a necessidade de observância do princípio da subsidiariedade, com a devida fundamentação, pois não deve ser admitida a intercepção se for possível a utilização de meios menos gravosos (Das escutas telefônicas... op. cit., p. 207-208). Em sentido semelhante, MANUEL MONTEIRO GUEDES VALENTE enfatiza a excepcionalidade do meio de obtenção de prova que restringe as comunicações (Escutas telefónicas... op. cit., p. 58). Demais disso, ANA MARGARIDA SANTOS observa que "o art. $187^{\circ}$ do Código de Processo Penal convoca um princípio de necessidade da utilização de registros de voz que já não releva da licitude da sua obtenção mas sim da avaliação dos meios de investigação disponíveis para a prova do crime que é objecto do processo" (Gravação não consentida de conversa, junção a inquérito, competência do juiz de instrução criminal. Revista do Ministério Público, Lisboa, Editorial Minerva, ano 30, n. 117, jan-mar. 2009, p. 169).

131 "Diferentemente do que sucede com o defensor, a lei processual penal é omissa quanto às escutas telefônicas que contendem com as demais relações de segredo e confiança." Mas a doutrina afirma que "também os portadores de segredo profissional só podem ser objecto de escuta em relação a conversações que "constituam objecto ou elemento de crime"', que esteja previsto entre os crimes do catálogo (ANDRADE, Manuel da Costa. Sobre as Proibições... op. cit., p. 300-301). Com relação a esta proibição probatória, BENJAMIM SILVA RODRIGUES assevera: "os critérios de subjectivização deparam-se, no entanto, com as restrições inerentes às chamadas 'esferas de segredo'. Trata-se de profissões que tomam contacto com aspectos íntimos da vida pessoal e familiar dos cidadãos e em que se estabelece uma relação de confiança entre o profissional e o cliente. Assim, acontecerá relativamente aos advogados, em nome da manutenção do direito de defesa do argüido, bem como ao nível da profissão médica, dos ministros das várias confissões religiosas, etc" (Das escutas... op. cit., p. 286). No mesmo sentido, cf.: ANDRADE, Manuel da Costa. Sobre o regime processual... op. cit., p. 383-384; DINIZ NETO, Eduardo. Meios de obtenção de prova criminal: considerações de direito constitucional aplicado. Ciências Penais: revista da Associação Brasileira de Professores de Ciências Penais, São Paulo, RT, ano 4, n. 6, jan-jun. 2007, p. 170. 
Entre as formalidades previstas para as operações, destacamos a necessidade de lavratura de auto, o qual, junto com as fitas gravadas ou elementos análogos, são levados ao conhecimento do juiz que tiver ordenado ou autorizado as operações, com a indicação das passagens das gravações ou elementos análogos considerados relevantes para a prova (art. 188.1).

Conhecidos os resultados da interceptação, "se o juiz considerar os elementos recolhidos, ou alguns deles, relevantes para a prova, ordena a sua transcrição em auto e fá-lo juntar ao processo; caso contrário, ordena a sua destruição, ficando todos os participantes nas operações ligados ao dever de segredo relativamente àquilo de que tenham tomado conhecimento" (art. 187.3). ${ }^{132}$

Ademais, é assegurada, ao arguido e ao assistente, bem como às pessoas cujas conversações tiverem sido escutadas, a possibilidade de examinar o auto de transcrição e os demais termos da documentação da intercepção, para se inteirarem da conformidade das gravações e obterem, à sua custa, cópias dos elementos naquele referidos (art. 188.5). ${ }^{133}$

\footnotetext{
132 No que tange à previsão de transcrição do conteúdo da comunicação captada, BENJAMIM SILVA RODRIGUES identifica a existência de três teses no direito português (transcrição integral, transcrição parcial e desnecessidade de transcrição: "Para uma determinada corrente, a tese da transcrição integral é a que surgiria como uma técnica de controlo e conhecimento do conteúdo íntegro do resultado da ingerência nas comunicações telfónicas e/ou electrónicas. Configurar-se-ia um princípio da obrigatoriedade de transcrição íntegra, entendendose que as transcrições parciais, por parte dos órgãos policiais, configurariam verdadeiras manipulações ilícitas que, em último termo, lesariam a plenitude das garantias de defesa. Para outros, a opção seria a da tese da transcrição parcial que permitiria a selecção do conteúdo relacionado com o objecto da investigação criminal, seja pelo juiz de instrução criminal ou pelo órgão de polícia criminal, por delegação daquele e a preservação da privacidade das pessoas envolvidas. Com a transcrição parcial pretende-se salvaguardar ao máximo o direito à inviolabilidade do sigilo/segredo/confidencialidade das comunicações do suspeito ou arguido, apenas se acedendo ao que for relevante para a causa. A tese de transcrição parcial podia sustentar-se a partir da aplicação analógica da ideia consagrada no artigo $179^{\circ}$, n. ${ }^{\circ} 3,2 .^{\text {a }}$ parte do $\mathrm{CPP}$, em que o juiz apenas junta a correspondência se a mesma for relevante para a prova. A terceira tese é aquela que advoga a desnecessidade de transcrição, exigindo que as gravações sejam ouvidas, sendo a sua audição válida com meio de prova em si. As gravações seriam tidas como meio de prova, em si, sem qualquer necessidade de transcrição" (Das escutas... op. cit., p. 370371)

${ }^{133}$ A respeito da documentação dos resultados da intercepção de comunicações, BENJAMIM SILVA RODRIGUES afirma que "não é possível atribuir a paternidade de determinada voz a uma dada pessoa sem que ocorra uma perícia científica à voz" (Das escutas... op. cit., p. 612).
} 
Note-se, que o artigo 189 da lei processual penal portuguesa comina a sanção de nulidade à intercepção realizada em contrariedade aos requisitos e condições previstos nos artigos 187 a 188.

Além do regime previsto no Código de Processo Penal, a Lei n. 5, de 11 de janeiro de 2002, ${ }^{134}$ ao estabelecer medidas de combate à criminalidade organizada e económicofinanceira estabelece, em seu art. $6^{\circ}$, instituto intitulado "registo de voz e de imagem, por qualquer meio, sem o consentimento do visado". ${ }^{135}$

Conforme previsto no art. 6.3 da mencionada lei, são aplicáveis a este instituto as já referidas formalidades preconizadas no art. 188 do Código Penal. ${ }^{136}$

Ainda no que tange ao instituto de "registo de voz e imagem", considera-se que é aplicável a regulamentação da intercepção de comunicação telefônica se for necessário o "registo" de voz. ${ }^{137}$

Concluída a apresentação dos ordenamentos estrangeiros selecionados, vejamos, então, como é o regime jurídico da interceptação de comunicação entre pessoas presentes no direito brasileiro. É o objeto do próximo capítulo.

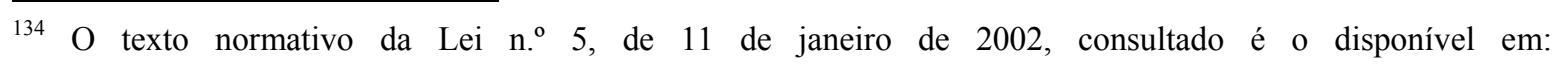
http://www.pgdlisboa.pt/pgdl/leis/lei_mostra_articulado.php?nid=147\&tabela=leis. Acesso em: 02/01/2011.

${ }^{135}$ Os termos normativos do mencionado art. $6^{\circ}$ são os seguintes: "1 - É admissível, quando necessário para a investigação de crimes referidos no artigo $1 .^{\circ}$, o registo de voz e de imagem, por qualquer meio, sem consentimento do visado. 2 - A produção destes registos depende de prévia autorização ou ordem do juiz, consoante os casos. 3 - São aplicáveis aos registos obtidos, com as necessárias adaptações, as formalidades previstas no artigo $188 .^{\circ}$ do Código de Processo Penal." O previsto art. $1^{\circ}$ prevê o catálogo de delitos em cuja persecução penal, desde que tenham sido praticado "de forma organizada", admitem-se os institutos nela previstos, entre os quais estão o "tráfico de estupefacientes", o "terrorismo e organização terrorista", o "tráfico de armas" (artigos 1.1 e 1.2). Em língua portuguesa, "registo" é sinônimo de "registro" (FERREIRA, Aurélio Buarque de Holanda. Novo Dicionário Aurélio. 3. ed. Curitiba: Editora Positivo, 2004. Versão eletrônica.).

${ }^{136}$ Além disso, sustenta-se, em doutrina, a aplicação da norma do art. 187.3, que proíbe a intercepção de conversações e comunicações telefônicas e outras equiparadas (RODRIGUES, Benjamim Silva. Das escutas... op. cit., p. 499).

${ }^{137}$ Assim se manifesta BENJAMIM SILVA RODRIGUES, para quem se deve recorrer "ao meio 'escutas telefónicas' quando apenas for necessário o registo de voz e, pelo contrário, sendo necessário captar a imagem, para associar a determinada voz, urge recorrer ao instituo do registo de voz e imagem, desde que o respectivo tipo legal de crime admita tal meio de obtenção de prova." O autor afirma mais: "tudo aponta para uma relação de subsidiariedade em matéria de registo de voz" (Das escutas... op. cit., p. 498). 


\title{
CAPÍTULO $5^{\circ}$
}

\section{A INTERCEPTAÇÃO DE COMUNICAÇÃO ENTRE PESSOAS PRESENTES NO DIREITO PROCESSUAL PENAL BRASILEIRO}

\begin{abstract}
Sumário: 5.1. A tutela constitucional das comunicações entre pessoas presentes - 5.2. A restrição processual penal às comunicações entre pessoas presentes - 5.3. A interceptação de comunicação entre pessoas presentes na legislação infraconstitucional: 5.3.1. O regime processual penal: 5.3.1.1. O regime previsto na Lei n. 9.034, de 1995; 5.3.1.2. Segue: a proposta de integração com o regime previsto na Lei $\mathrm{n}^{\circ}$ 9.296, de 1996; 5.3.1.3. Segue: a proposta de integração com o sistema processual penal; 5.3.1.4. Repercussão processual de interceptação de comunicação entre pessoas presentes ilícita; 5.3.1.5. Meios de impugnação de interceptação de comunicação entre pessoas presentes ilícita; 5.3.2. O regime penal - 5.4. Projetos de lei sobre a interceptação de comunicação entre pessoas presentes - 5.5. Sugestões de lege ferenda.
\end{abstract}

\subsection{A tutela constitucional das comunicações entre pessoas presentes}

$\mathrm{Na}$ história brasileira, evidencia-se evolução na proteção das diversas formas de comunicações. O Poder Constituinte progrediu desde a previsão da inviolabilidade do sigilo da correspondência, no início do período republicano. Atualmente, sob a égide da Constituição de 1988, além de telecomunicações, comunicações entre pessoas presentes - também conhecidas por comunicações orais ou por comunicações presenciais $^{1}$ - são protegidas.

É na Constituição de 1891 que se identifica a concepção primeira de proteção à comunicação epistolar, ${ }^{2}$ sob a forma de inviolabilidade de sigilo, a qual foi mantida nas ordens constitucionais seguintes.

\footnotetext{
${ }^{1}$ A respeito da nomenclatura, da abrangência e dos antecedentes históricos das comunicações entre pessoas presentes, cf., supra, itens n. 2.1, n. 3.1 e n. 3.2.

${ }^{2}$ Confira-se o texto normativo: "Art. 72. A Constituição assegura a brasileiros e a estrangeiros residentes no País a inviolabilidade dos direitos concernentes à liberdade, à segurança individual e à propriedade, nos termos seguintes: § 18. É inviolável o sigilo da correspondência.”
} 
$\mathrm{Na}$ evolução da tutela das comunicações em âmbito constitucional - da Constituição de 1891 à Constituição de 1988 - merecem destaque a Constituição de 1937, a Constituição de 1967 e a Emenda Constitucional de 1969.

A Constituição de 1937, tanto assegurou a liberdade de manifestação do pensamento de forma oral, ${ }^{3}$ quanto previu a possibilidade de censura "de todas as comunicações orais", em estado de emergência. ${ }^{4}$

Já a Constituição de 1967, e sua Emenda de 1969, preconizaram a tutela das telecomunicações: epistolar, telefônicas e telegráficas. ${ }^{5}$

$\mathrm{Na}$ ordem constitucional brasileira instaurada em 1988, as telecomunicações foram protegidas expressamente: "é inviolável o sigilo da correspondência e das comunicações telegráficas, de dados e das comunicações telefônicas, salvo, no último caso, por ordem judicial, nas hipóteses e na forma que a lei estabelecer para fins de investigação criminal ou instrução processual penal”, conforme disposto no art. $5^{\circ}$, caput e inciso XII da Constituição Federal.

A constatação de que o Poder Constituinte não inseriu, expressamente, a proteção das comunicações entre pessoas presentes no texto normativo não pode significar que esta forma de comunicação seja irrelevante para a comunidade brasileira. Lembre-se de que a comunicação entre pessoas presentes constitui um valor, relevante por demais para o ser

\footnotetext{
${ }^{3}$ Era o que dispunha o seu art. 122, item 15: “Art. 122. A Constituição assegura aos brasileiros e estrangeiros residentes no País o direito à liberdade, à segurança individual e à propriedade, nos termos seguintes: 15) todo cidadão tem o direito de manifestar o seu pensamento, oralmente, ou por escrito, impresso ou por imagens, mediante as condições e nos limites prescritos em lei."

${ }^{4}$ A possibilidade de censura era prevista no seguinte dispositivo: "Art 168. Durante o estado de emergência as medidas que o Presidente da República é autorizado a tomar serão limitadas às seguintes: b) censura da correspondência e de todas as comunicações orais e escritas."

${ }^{5} \mathrm{Na}$ Constituição de 1967, a tutela era prevista no $\S 9^{\circ}$ do art. 150: "a Constituição assegura aos brasileiros e aos estrangeiros residentes no país a inviolabilidade dos direitos concernentes à vida, à liberdade, à segurança e à propriedade, nos termos seguintes: $\S 9^{\circ}$ - São invioláveis a correspondência e o sigilo das comunicações telegráficas e telefônicas.” Na sucessiva Emenda de 1969, era preconizada no art. 153 , § 9: "a Constituição assegura aos brasileiros e aos estrangeiros residentes no País a inviolabilidade dos direitos concernentes à vida, à liberdade, à segurança e à propriedade, nos têrmos seguintes: $\S 9^{\circ}$ É inviolável o sigilo da correspondência e das comunicações telegráficas e telefônicas."
} 
humano, que, como ser social, necessita de comunicação com os seus semelhantes. ${ }^{6}$ É a primeira forma de comunicação do indivíduo, acompanhando-o por toda a sua vida.

Considerada a importância das comunicações entre presentes para a sociedade brasileira, a identificação de sua tutela exige interpretação das normas constitucionais em conformidade com o contexto histórico, social e político em que foram instituídas, especialmente em razão do avanço tecnológico que a matéria envolve. ${ }^{7}$ Em 1988, os meios tecnológicos para restrição de comunicações entre pessoas presentes conhecidos pela humanidade eram poucos, ineficazes e de dimensão perceptível a olho nu.

Hoje, a existência de instrumentos microscópicos e acessíveis, que propiciam a captação da comunicação entre pessoas presentes com alta qualidade, impõe o reconhecimento da tutela das comunicações entre pessoas presentes.

Sendo assim, afirmamos que as comunicações são protegidas entre pessoas presentes na Lei Maior, de forma implícita: é possível extrai-la do texto normativo constitucional, por meio da interpretação de direitos e garantias fundamentais nela previstos. Os fundamentos constitucionais da tutela das comunicações entre pessoas presentes são: a liberdade de manifestação do pensamento, o direito à intimidade e à vida privada, a inviolabilidade do domicílio e o direito a não autoincriminação. ${ }^{8}$

No art. $5^{\circ}$, caput e inciso IV, estabelece-se que é livre a manifestação do pensamento. A liberdade de comunicação entre pessoas presentes é espécie da liberdade de manifestação do pensamento. ${ }^{9}$ A propósito, para a promoção da comunicação social, garante-se a liberdade de manifestação do pensamento, sob qualquer forma. ${ }^{10}$

\footnotetext{
${ }^{6}$ Cf., supra, item n. 2.1.

${ }^{7}$ Cf. BADARÓ, Gustavo Henrique Righi Ivahy. Direito processual penal: tomo I... op. cit., p. 282.

8 No que tange aos fundamentos constitucionais da tutela das comunicações entre pessoas presentes e à correlação de cada um deles com as comunicações entre pessoas presentes, observações mais aprofundadas foram expendidas no Capítulo $2^{\circ}$ desta dissertação, dedicado aos "Fundamentos Constitucionais da Tutela das Comunicações entre Pessoas Presentes": cf., supra, itens n. 2.1 a 2.5.

${ }^{9}$ Cf., supra, item n. 2.2 .

${ }^{10} \mathrm{O}$ art. 220 da Constituição Federal prevê: "a manifestação do pensamento, a criação, a expressão e a informação, sob qualquer forma, processo ou veículo não sofrerão qualquer restrição, observado o disposto nesta Constituição."
} 
A intimidade e a vida privada são asseguradas no art. $5^{\circ}$, caput e inciso $\mathrm{X}^{11} \mathrm{O}$ conteúdo de uma comunicação entre pessoas presentes é protegido sob a forma da inviolabilidade do sigilo das comunicações entre pessoas presentes, o qual é expressão do direito à intimidade e à vida privada. ${ }^{12}$

É de se ressaltar que a tutela da inviolabilidade do sigilo das comunicações entre presentes também é evidenciada na previsão constitucional de restrição ao sigilo das comunicações em situações emergenciais, em Estado de Sítio (arts. 137 a 139) e em Estado de Defesa (art. 136). ${ }^{13}$

Durante o Estado de Sítio, é admitida restrição "ao sigilo das comunicações” (art. 139, caput e inciso III). Diferentemente, para o Estado de Defesa, é preconizada a restrição do sigilo de correspondência e do sigilo de comunicação telegráfica e telefônica (art. 136, $\S 1^{\circ}$, inciso I, alíneas "b" e "c"). A referência genérica a "comunicações" na primeira disposição evidencia que, além da inviolabilidade do sigilo de telecomunicações expressas no texto normativo constitucional, também se protege outras formas de sigilo das comunicações - em especial, o sigilo de comunicação entre pessoas presentes -, que pode ser restringido em situações excepcionais, como, por exemplo, no caso do Estado de Sítio.

\footnotetext{
11 "São invioláveis a intimidade, a vida privada, a honra e a imagem das pessoas, assegurado o direito a indenização pelo dano material ou moral decorrente de sua violação", conforme disposto no art. $5^{\circ}$, caput e inciso $\mathrm{X}$ da Constituição Federal.

${ }^{12}$ Cf., supra, item n. 2.3 .

${ }^{13}$ De acordo com MANOEL GONÇALVES FERREIRA FILHO, trata-se de estados de emergência. O Estado de Sítio "consiste na suspensão temporária e localizada de garantias constitucionais." "O Estado de Sítio suspende as garantias dos direitos fundamentais, e, nunca, segundo se afirma impensadamente, esses direitos. Suspende aquelas limitações postas à ação governamental que acompanham declaração de direitos. Com isso, alarga a esfera de ação legítima do Estado." "Medida excepcional e perigosa, o Estado de Sítio só deve ser declarado em circunstâncias excepcionais e graves, de perigo extremo para a ordem constitucional. Para o constituinte brasileiro, essas circunstâncias se agrupam em duas hipóteses: a comoção grave (art. 137, I) e a guerra externa (art. 137, II)." (Curso de direito constitucional. 27. ed. São Paulo: Saraiva, 2001, p. 332-334). Segundo o autor, "o Estado de emergência e as medidas de emergência que na verdade correspondiam a estado de sítio mitigado, vigentes na Constituição anterior, desapareceram. A Constituição de 5 de outubro criou o estado de defesa para fazer face a ameaças à ordem pública ou à paz social à frente de grave e iminente instabilidade institucional. Calamidades de grandes proporções na natureza, que comprometam a ordem e a paz social, autorizam a decretação do Estado de Defesa" (Curso de direito... op. cit., p. 338-339).
} 
Também a inviolabilidade do domicílio, assegurada no art. $5^{\circ}$, caput e inciso $\mathrm{XI}^{14}$ embasa a comunicação entre pessoas presentes, se ocorrer em um domicílio. ${ }^{15}$ A proteção ao espaço domiciliar, ao mesmo tempo em que garante ao indivíduo o exercício da liberdade de comunicação, possibilita-lhe a exclusão de terceiros, para assegurar o caráter reservado do conteúdo da comunicação.

O direito a não autoincriminação, consagrado no art. $8^{\circ}$, item $2^{\circ}$, alínea "g" da Convenção Americana sobre Direitos Humanos, e no art. $5^{\circ}, \S 2^{\circ}$ da Constituição Federal, é mais um fundamento da tutela das comunicações entre pessoas presentes. ${ }^{16}$ A possibilidade de não se autoincriminar garante a liberdade de comunicação, notavelmente quanto ao poder de não se comunicar, e assegura a inviolabilidade do sigilo das comunicações, em hipóteses em que a comunicação ocorra.

Mas o reconhecimento da tutela das comunicações entre presentes, extraída dos referidos direitos e garantias individuais, não implica uma proteção absoluta. A restrição às comunicações entre pessoas presentes é admissível, desde que sejam observados determinados limites: a reserva de lei, a reserva de jurisdição e a proporcionalidade. ${ }^{17}$

Portanto, na ordem constitucional brasileira, a tutela das comunicações entre pessoas presentes é fundamentada em direitos e garantias fundamentais previstos na Lei Maior: a liberdade de manifestação do pensamento, o direito à intimidade e à vida privada, a inviolabilidade do domicílio e o direito a não autoincriminação.

A tutela das comunicações entre pessoas presentes, com fundamento nestes direitos e garantias processuais, pode ser afirmada sob duas perspectivas: a da liberdade de comunicação entre pessoas presentes (poder de se comunicar ou de não se comunicar); e a da

\footnotetext{
${ }^{14}$ A garantia da inviolabilidade do domicílio é prevista no art. $5^{\mathrm{o}}$, caput e inciso XI da Constituição: "a casa é asilo inviolável do indivíduo, ninguém nela podendo penetrar sem consentimento do morador, salvo em caso de flagrante delito ou desastre, ou para prestar socorro, ou, durante o dia, por determinação judicial.”

${ }^{15}$ Cf., supra, itens n. 2.4 e n. 3.10.

${ }^{16}$ Cf., supra, item n. 2.5 .

17 Sobre os limites para a restrição dos direitos e garantias individuais que fundamentam a tutela das comunicações entre pessoas presentes, cf. supra, item n. 2.6, e, infra, item n. 5.2.
} 
inviolabilidade do sigilo de comunicação entre pessoas presentes ${ }^{18}$ É esta a interpretação dos dispositivos da Constituição que nos parece se amoldar à dignidade da pessoa humana (art. $1^{\circ}$, caput e inciso III da Constituição Federal).

\subsection{A restrição processual penal às comunicações entre pessoas presentes}

A proteção constitucional atribuída às comunicações presenciais não é absoluta. A Constituição expressamente prevê a possibilidade de restrição à inviolabilidade do domicílio, por autorização judicial e durante o dia (art. $5^{\circ}$, caput e inciso XI). Mas, estando ou não os interlocutores em domicílio, é admissível a restrição das comunicações entre presentes, desde que sejam observados limites também preconizados na Constituição Federal: a reserva de lei, a reserva de jurisdição e a proporcionalidade. ${ }^{19}$

Note-se que ligada à reserva de lei, a garantia da inadmissibilidade das provas obtidas por meios ilícitos (art. $5^{\circ}$, caput e inciso LVI da Constituição Federal), também limita a restrição das comunicações entre pessoas presentes em atividade probatória tendente à descoberta de fontes de prova. ${ }^{20}$

Interessa-nos a restrição às comunicações entre pessoas presentes justificadas pela necessidade de repressão a prática de condutas tidas pelo legislador nacional como delitivas (art. 144, caput $\S 1^{\circ}$, incisos I e II, e $\S 4^{\circ}$ da Constituição Federal).

\footnotetext{
${ }^{18}$ São as conclusões a que chegamos no exame sobre os direitos e garantias que embasam as comunicações entre pessoas presentes: a liberdade de comunicação entre pessoas presentes é espécie da liberdade de manifestação do pensamento; a inviolabilidade do sigilo de comunicação entre pessoas presentes é expressão do direito à intimidade e à vida privada. Ademais, a inviolabilidade do domićlio e o direito a não autoincriminação asseguram as comunicações entre pessoas presentes, nas duas perspectivas a que nos referimos (cf., supra, itens n. 2.1 a n. 2.5).

${ }^{19}$ De forma mais aprofundada, os limites à restrição de comunicação entre pessoas presentes foi examinados no item n. 2.6, supra.

${ }^{20}$ Sobre a garantia da inadmissibilidade de provas obtidas por meios ilícitos, cf., supra, item n. 1.6 .
} 
As técnicas de captação de comunicações entre presentes são variadas. ${ }^{21} \mathrm{O}$ conteúdo de uma comunicação entre pessoas presentes só pode ser conhecido enquanto perdurar a ação comunicativa, pois é caracterizada por instantaneidade. ${ }^{22}$ Disto decorre a necessidade de a restrição se operar no fluxo da comunicação, para captação e sucessiva gravação do seu conteúdo, e. g., em interceptação. Por isso, falamos em restrição da comunicação.

No plano infraconstitucional, entre as formas de restrição das comunicações entre pessoas presentes, o legislador disciplinou apenas a interceptação de comunicações entre pessoas presentes.

A legislação processual penal brasileira "permite" a interceptação de comunicações entre pessoas presentes, como espécie de "procedimentos de investigação e formação de prova", em persecução penal de "ações praticadas por quadrilha ou bando ou organizações ou associações criminosas de qualquer tipo" (artigos $1^{\circ}$ e $2^{\circ}$, caput, inciso IV da Lei n. 9.034, de $1995)$.

Entretanto, não se disciplina o instituto por completo. A deficiência dos requisitos e a ausência de delimitação de um procedimento probatório para sua execução dificultam a exigida "circunstanciada autorização judicial” (artigo 2º inciso IV e da Lei n. 9.034, de 1995).

\footnotetext{
${ }^{21}$ Quanto às formas de restrição de comunicação entre pessoas presentes, cf., supra, itens n. 3.7, 3.7.1 e 3.7.2.

${ }^{22}$ Tal raciocínio também é desenvolvido por TERCIO SAMPAIO FERRAZ JUNIOR, em considerações sobre as comunicações telefônicas (Sigilo de dados... op. cit., p. 26-27). Em sentido semelhante, afirmando a instantaneidade como elemento da comunicação telefônica, a justificar a restrição no curso da comunicação, cf.: PRADO, Geraldo. Limite às interceptações telefônicas e a jurisprudência do Superior Tribunal de Justiça. Rio de Janeiro: Lumen Iuris, 2005, p. 71-74; BADARÓ, Gustavo Henrique Righi Ivahy. Direito processual penal: tomo I... op. cit., p. 283; BADARÓ, Gustavo Henrique Righi Ivahy. Interceptações de comunicações telefônicas... op. cit., p. 490.
} 


\subsection{A interceptação de comunicação entre pessoas presentes na legislação infraconstitucional}

A compreensão da interceptação de comunicação entre pessoas presentes é facilitada se bipartidos, no campo penal, os planos do direito material e do direito processual, nos quais consideramos necessária a proteção das comunicações entre pessoas presentes.

A importância do plano processual penal decorre da necessidade de compreensão do regime do instituto, da repercussão processual de uma interceptação ilícita - na qual estão inseridos os reflexos da restrição ilegal às comunicações entre pessoas presentes no fenômeno probatório, considerada a inadmissibilidade de provas obtidas por meios ilícitos - e dos meios de impugnação por interessados no decorrer da persecução penal.

E temos por relevante a referência ao plano do direito material, embora não seja o objeto principal do presente estudo, porque a comunicação entre pessoas presentes se liga a bens jurídicos relevantes, de modo a justificar a proteção por normas incriminadoras. Para além da sanção processual aplicada à prova obtida em interceptação de comunicação entre pessoas presentes ilícita, interessa à sociedade a punição dos responsáveis pela ilicitude, tendo ou não sido realizada no curso de uma persecução penal.

Iniciemos pelo plano processual, para que, conhecido o atual regime processual penal da interceptação de comunicação entre pessoas presentes, possamos avaliar o regime penal.

\subsubsection{O regime processual penal}

O exame do regime processual penal da interceptação de comunicações entre pessoas presentes abrange a avaliação de três temas: o regime jurídico ${ }^{23}$ do instituto, a repercussão processual de interceptação ilícita e os meios de impugnação de interceptação ilícita.

\footnotetext{
${ }^{23}$ Com a locução "regime jurídico" queremos expressar o conjunto de normas extraídas do ordenamento jurídico que, de forma não autônoma, são aplicáveis à interceptação de comunicação entre pessoas presentes no Brasil. A
} 


\subsubsection{O regime previsto na Lei n. 9.034, de 1995}

A Lei n. 9.034, de 3 de maio de 1995, "regula meios de prova e procedimentos investigatórios que versem sobre ilícitos decorrentes de ações praticadas por quadrilha ou bando ou organizações ou associações criminosas de qualquer tipo" $\left(\operatorname{art.} 1^{\circ}\right)$.

No curso de persecução penal pertinente às referidas espécies delitivas, conforme disposto em seu art. $2^{\circ}$, "são permitidos" a utilização de meios de investigação de prova que a lei intitula "procedimentos de investigação e formação de prova".

Entre os denominados "procedimentos de investigação e formação de prova", está a interceptação ambiental, a qual foi inserida pela Lei n. 10.217, de 11 de abril de 2001, com os seguintes termos normativos: "a captação e a interceptação ambiental de sinais eletromagnéticos, óticos ou acústicos, e o seu registro e análise, mediante circunstanciada autorização judicial.” (art. $2^{\circ}$, inciso IV da Lei n. 9.034, de 1995). ${ }^{24}$

Os termos normativos da mencionada lei impõem acurada reflexão.

Por primeiro, note-se que, ao se referir à "captação e a interceptação ambiental de sinais eletromagnéticos, óticos ou acústicos, e o seu registro" (grifos nossos), o legislador foi redundante, porque a captação e o registro do sinal acústico já são elementos integrantes do conceito de interceptação. ${ }^{25}$

\footnotetext{
locução "disciplina jurídica” (cf., supra, item n. 3.10) é empregada com o significado de um conjunto de normas jurídicas, autônomo e organizado, que regulamenta os diversos aspectos do instituto em análise.

${ }^{24}$ Em 2002, o legislador pretendeu alargar a "admissibilidade" do instituto. A então instituída Lei no 10.409, que dispunha "sobre a prevenção, o tratamento, a fiscalização, o controle e a repressão à produção, ao uso e ao tráfico ilícitos de produtos, substâncias ou drogas ilícitas que causem dependência física ou psíquica”, previa, em seu artigo 33 - por remissão às disposições da Lei $n^{\circ} 9.034$ - a possibilidade de interceptação ambiental. Todavia, o art. 33 se referia à persecução penal dos crimes definidos na lei, os quais seriam previstos em seu Capítulo II, vetado pelo Poder Executivo. Esta lei foi revogada pela Lei $\mathrm{n}^{\circ} 11.343$, de 2006, que "prescreve medidas para prevenção do uso indevido, atenção e reinserção social de usuários e dependentes de drogas; estabelece normas para repressão à produção não autorizada e ao tráfico ilícito de drogas; define crimes e dá outras providências", não prevê semelhante disposição. O seu art. 53, ao tratar de "procedimentos investigatórios", não se refere, expressamente ou por remissão, à Lei $n^{\circ} 9.034$, à interceptação ambiental.

${ }^{25}$ Quanto ao conceito de interceptação de comunicação entre pessoas presentes, cf., supra, item n. 3.2.
} 
Além disso, dos termos normativos da apontada lei, notamos que se tratou apenas de uma das espécies ${ }^{26}$ da interceptação de comunicações entre pessoas presentes: a interceptação ambiental. Não é preconizada na lei a outra espécie, a interceptação domiciliar, que sequer é referida na lei.

Apesar de a interceptação ambiental ser admitida na lei, ambas as espécies de interceptação entre pessoas presentes são atípicas.

Como já pudemos observar, a tipicidade probatória de um determinado meio de prova é integrada pela admissibilidade (nominação e requisitos) e pelo procedimento probatório, também denominado rito probatório ou método probatório. ${ }^{27} \mathrm{Em}$ se tratando de meios de investigação de prova, ambos (admissibilidade e procedimento) devem ser disciplinados em lei, para observância da reserva de lei exigida para a restrição a direitos e garantias fundamentais. $^{28}$ Ausente a delimitação legal da admissibilidade ou do procedimento probatório, caracteriza-se atipicidade do meio de investigação de prova.

Assim, a afirmada atipicidade da interceptação de comunicação entre pessoas presentes, tem fundamentos diversos para as suas modalidades: a atipicidade da interceptação ambiental decorre da ausência de delimitação de procedimento probatório aplicável; a atipicidade da interceptação domiciliar decorre da ausência de delimitação tanto de admissibilidade, quanto de procedimento probatório aplicável.

A atipicidade da interceptação de comunicação entre pessoas presentes, em suas duas modalidades (interceptação ambiental e interceptação domiciliar) já redundaria, por si só, em

\footnotetext{
${ }^{26}$ Sobre as espécies da interceptação de comunicações entre pessoas presentes, cf., supra, item n. 3.7.

${ }^{27}$ Cf., supra, item n. 1.2.3.2.

${ }^{28}$ Como pudemos observar no exame dos seus aspectos gerais, os meios de investigação de prova, por operarem restrições a direitos fundamentais, devem ser disciplinados em lei, por meio da definição de admissibilidade e procedimento, que devem ser interpretados restritivamente. Reiteramos aqui que a vedação do emprego de analogia decorre não só da exigência de reserva de lei para os meios de investigação de prova, como também do elemento "surpresa" que os caracterizam. Como são executados sem o conhecimento de investigados, o contraditório - que seria indispensável para a definição de procedimento probatório por analogia entre os interessados, antes da execução do meio -, perfaz-se de forma diferida (Cf., supra, item n. 1.4.1).
} 
inadmissibilidade de sua execução no ordenamento jurídico brasileiro, por impossibilidade de observância das mencionadas exigências para a restrição de direitos fundamentais.

Todavia, os identificados problemas do regime jurídico da lei não se esgotam na atipicidade da interceptação de comunicação entre presentes.

Há, também, graves deficiências na pretendida admissibilidade da interceptação ambiental, decorrentes da incompletude dos aspectos que devem constar em lei.

Embora seja delimitada na lei, a admissibilidade da interceptação ambiental é deficiente, porque a aludida previsão legal carece de exatidão, especificidade, clareza e precisão, atributos necessários para se ter por caracterizada a exigida reserva de lei. ${ }^{29}$ Além da ausência de definição legal de "organização ou associação criminosa", 30 admitir a interceptação em persecução penal de "ações praticadas por quadrilha ou bando" significa uma ampliação excessiva das hipóteses de cabimento do instituto, considerada a variedade de crimes que possam ser praticados por quadrilha ou bando. ${ }^{31}$

Diferente do previsto na lei, a técnica legislativa recomendável para a delimitação da admissibilidade da interceptação de comunicação entre pessoas presentes, em observância à exigida reserva de lei, é a expressa previsão legal das espécies de delitos em cuja persecução

\footnotetext{
${ }^{29}$ Lei que regulamente restrição a direitos fundamentais, como pudemos observar na restrição às comunicações entre pessoas presentes (v., supra, item n. 2.6), deve ser escrita, estrita, anterior, específica, precisa e clara.

${ }^{30}$ A este respeito, convém esclarecer que o Decreto $\mathrm{n}^{\circ} 5.015$, de 12 de março de 2004, que promulgou a "Convenção das Nações Unidas contra o Crime Organizado Transnacional", também conhecida por "Convenção de Palermo", não definiu a conduta típica de organização ou associação criminosa. O art. $2^{\circ}$, alínea "a" da Convenção, para fins de uniformidade da terminologia nela empregada, define "Grupo criminoso organizado" como "grupo estruturado de três ou mais pessoas, existente há algum tempo e atuando concertadamente com o propósito de cometer uma ou mais infrações graves ou enunciadas na presente Convenção, com a intenção de obter, direta ou indiretamente, um benefício econômico ou outro benefício material”. Todavia, não se trata de tipificação penal da conduta de associação criminosa em âmbito nacional, pois, conforme estabelecido no art. $5^{\circ}$ da Convenção, os Estados signatários deverão definir, em seus ordenamentos jurídicos, as "atividades ilícitas do grupo criminoso organizado". Neste sentido, cf.: MALAN, Diogo Rudge. Gravações Ambientais... op. cit., p. 348. Semelhante entendimento é sustentado por MARIA ELIZABETH QUEIJO, quem afirma a necessidade de definição legal de "associação criminosa" ao analisar outro meio de investigação de prova, a ação controlada, que é prevista no art. $2^{\circ}$, caput e inciso II da Lei $\mathrm{n}^{\circ}$ 9.034, de 1995 (O direito de não produzir... op. cit., p. 368-369).

${ }^{31} \mathrm{O}$ art. 288 do Código Penal tipifica a conduta de "quadrilha ou bando" com os seguintes termos normativos: "associarem-se mais de três pessoas, em quadrilha ou bando, para o fim de cometer crimes: Pena - reclusão, de um a três anos. Parágrafo único: A pena aplica-se em dobro, se a quadrilha ou bando é armado.”
} 
se admita a medida, com a respectiva indicação do dispositivo normativo em que são previstas. $^{32}$

Ademais, reputamos não observada a proporcionalidade no plano legislativo, na definição da admissibilidade da interceptação ambiental. ${ }^{33}$ A restrição aos direitos e garantias que fundamentam a tutela das comunicações entre pessoas presentes somente é possível se justificada por um valor concorrente, também constitucionalmente tutelado. Consideramos que a segurança pública e a repressão a prática de delitos a justifica em face da excepcional gravidade do delito, considerada a relevância do bem jurídico tutelado. ${ }^{34}$ Parece-nos que, da forma como prevista na lei, a extensão de admissibilidade propiciada pela previsão de quadrilha contraria a exigida justificação constitucional.

Ainda no âmbito da admissibilidade da interceptação ambiental, deveria o legislador ter previsto, com requisito, a existência de elementos de materialidade e autoria pertinentes ao delito investigado e de perigo quanto a desparecimento ou a dissimulação de fontes de prova, porque a interceptação de comunicação entre pessoas presentes é medida de natureza cautelar $^{35}$ e meio de investigação de prova repressivo. ${ }^{36}$

Entretanto, referiu-se apenas a "meios de prova e procedimentos investigatórios que versem sobre ilícitos decorrentes de ações praticadas por quadrilha ou bando ou organizações ou associações criminosas de qualquer tipo". Destes termos normativos, extrai-se que deve haver delito previamente cometido e instauração de respectiva persecução penal. Porém, seria

\footnotetext{
32 Note-se, a propósito, a técnica utilizada pelo legislador alemão para delimitação da admissibilidade da interceptação de comunicação entre presentes: previsão das espécies delitivas, com a respectiva indicação do dispositivo normativo em que são previstas (cf., infra, item n. 4.2.2.2.1).

${ }^{33}$ No que tange à exigência de proporcionalidade no plano legislativo, confiram-se as observações expendidas no item n. 2.6, supra.

${ }^{34}$ Quanto aos critérios que justificam a determinação dos delitos, cf., supra, item n. 3.10.1. ANTONIO MAGALHÃES GOMES FILHO afirma como critérios para a interceptação de comunicação telefônica a excepcional gravidade e a forma particular de execução do delito (Direito à prova... op. cit., p. 125). Ressaltamos, contudo, que, embora haja semelhança entre os critérios para delimitação dos delitos em cuja persecução se admita interceptação de comunicação telefônica e interceptação de comunicação entre pessoas presentes, a admissibilidade da segunda, como já observamos, deve ser mais restrita, porque a restrição a direitos e garantias fundamentais é mais intensa (v., supra, itens n. 3.9, n. 3.10.1 e n. 3.10.2, e, infra, item n. 5.5).

${ }^{35}$ Cf., supra, itens n. 1.3 e n. 3.4 .

${ }^{36}$ Cf., supra, itens n. 1.4 .3 e n. 3.4
} 
preciso exigir, expressamente, a existência de elementos de materialidade e autoria delitiva como requisito da medida. ${ }^{37}$

Acrescentem-se às deficiências da pretendida admissibilidade legal da interceptação ambiental a ausência de delimitação legal do procedimento probatório que a torna atípica, e implica, sob outra perspectiva, a inobservância de reserva de lei.

Aliás, as especificidades da medida impõem a definição legal de um procedimento autônomo, considerada a exigência de definição do modo de realização da medida, o qual repercute nas fases de autorização, de execução e de documentação dos atos praticados na interceptação. ${ }^{38}$ Por esse motivo, tal procedimento não pode ser equiparado ao procedimento de interceptação das demais espécies de comunicação. O legislador silenciou a respeito do assunto.

De outro lado, no regime preconizado na lei, é correta a exigência legal de autorização judicial, circunstanciada, porque a restrição a direitos fundamentais que a concretização da medida implica é matéria reservada à jurisdição. ${ }^{39}$ No entanto, a prevista autorização judicial deveria vir, necessariamente, acompanhada da exigência legal de motivação, fundada em elementos concretos, quanto à necessidade de execução da medida. ${ }^{40}$

Por todos os motivos expostos, o regime instituído na Lei $\mathrm{n}^{\circ}$ 9.034, de 1995, não propicia a restrição, que implicaria a observância das exigências de reserva de lei - nela incluída a tipicidade probatória -, de reserva de jurisdição e de proporcionalidade. ${ }^{41} \mathrm{O}$

\footnotetext{
${ }^{37}$ Em sentido semelhante, SÉRGIO MARCOS DE MORAES PITOMBO afirma a necessidade de elementos razoáveis da prática de delito para decreto de interceptação de comunicação telefônica (Sigilo nas comunicações: aspecto processual penal. Boletim IBCCRIM, São Paulo, n. 49, dez. 1996, p. 8).

${ }^{38}$ A propósito da autonomia do procedimento probatório, outras observações foram expendidas nos itens n. 3.10.2, supra, e itens n. 5.3.1.2 e n. 5.5, infra.

${ }^{39}$ Sobre a exigência de reserva de jurisdição, cf., supra, item n. 2.6.

${ }^{40}$ Quanto à avaliação da proporcionalidade em concreto, por meio da avaliação sucessiva da adequação, da necessidade e da proporcionalidade em sentido estrito, cf., supra, item n. 2.6.

${ }^{41}$ A exigência de reserva de lei, em conjunto com a reserva de jurisdição e com a proporcionalidade, constituem limitações às restrições de comunicações entre pessoas presentes (v., supra, item n. 2.6).
} 
regime previsto na lei conduz à violação dos direitos e garantias individuais que fundamentam a tutela das comunicações entre pessoas presentes, assegurados constitucionalmente. ${ }^{42}$

Sendo assim, consideramos que a interceptação de comunicação entre pessoas presentes (interceptação ambiental ou interceptação domiciliar) - no âmbito de admissibilidade desta lei ou na persecução penal de outros delitos nela não previstos - deve ser indeferida, de plano, por autoridade judicial à qual seja requerida a interceptação de comunicações entre pessoas presentes.

Efetivada a interceptação de comunicação entre pessoas presentes, com ou sem autorização judicial, configura-se violação aos direitos e garantias constitucionais que tutelam as comunicações entre pessoas presentes. Por conseguinte, a interceptação é ilícita, inadmissível (art. $5^{\circ}$, caput e inciso LVI da Constituição Federal). ${ }^{43}$

\subsubsection{Segue: a proposta de integração com o regime previsto na}

\section{Lei $\mathrm{n}^{0}$ 9.296, de 1996}

O regime jurídico previsto na Lei n. 9.034, de 1995, como analisado no item anterior, não propicia a observância das exigências para a restrição das comunicações entre pessoas presentes, inviabilizando a realização da interceptação de comunicação entre pessoas presentes.

Entretanto, na doutrina brasileira, há entendimento firmado no sentido de que a interceptação entre pessoas presentes possa ser efetivada por meio da observância do procedimento previsto para a interceptação de telecomunicações, ${ }^{44}$ previsto na Lei ${ }^{\circ} 9.296$, de $1996 .^{45}$

\footnotetext{
${ }^{42}$ Com relação à diferença entre restrição e violação de direitos fundamentais, cf., supra, item n. 2.6, nota n. 124.

${ }^{43}$ No que se refere à repercussão processual da interceptação ilícita e aos meios de impugnação preconizados no ordenamento jurídico brasileiro, cf., infra, itens n. 5.3.1.4e n. 5.3.1.5.

${ }^{44}$ Cf.: SILVA, Eduardo Araujo da. Crime organizado... op. cit., p. 105; DEZEM, Guilherme Madeira. Da prova penal... op. cit., p. 299-308. Em sentido contrário: MALAN, Diogo Rudge. Gravações Ambientais... op. cit., p. 350 e p. 355.

${ }^{45}$ A Lei n. 9.296, de 1996, regulamenta a interceptação de telecomunicações. O seu art. $1^{\circ}$ estabelece que a interceptação de comunicações telefônicas, de qualquer natureza, para prova em investigação criminal e em
} 
Consideramos que este procedimento não pode ser aplicado à interceptação de comunicações entre pessoas presentes, em razão de sua natureza jurídica desta medida e de sua incompatibilidade com o procedimento.

A interceptação de comunicação entre pessoas presentes é meio de investigação de prova. ${ }^{46}$ Conforme afirmamos anteriormente, em razão da restrição a direitos fundamentais, a admissibilidade e o procedimento dos meios de investigação de prova devem estar regulamentados em lei. Para a aplicação de procedimento probatório, por analogia, a meios de prova atípicos, é necessária a observância do contraditório antes de sua realização. Isto se inviabiliza em meios de investigação de prova, porque confronta com a surpresa que os caracteriza: o contraditório não se opera antes da execução do meio; mas, sim, de forma diferida (postergada). ${ }^{47}$

E a impossibilidade de aplicação do procedimento probatório que ora afirmamos se estende às duas espécies de interceptação de comunicação entre pessoas presentes. ${ }^{48}$

A interceptação domiciliar sequer é referida pela Lei n. 9.034, de modo que a proposta de aplicação do procedimento previsto na Lei n. 9.296, de 1996, inviabiliza-se. O âmbito de admissibilidade da medida não é legalmente previsto, o que fulmina a exigência de reserva de lei, antes mesmo de se cogitar do procedimento probatório aplicável à espécie.

No que se refere à interceptação ambiental, apesar de ser versada no art. $2^{\circ}$, inciso IV da Lei n. 9.034, há graves falhas na admissibilidade instituída pela lei, que também conduzem à inobservância da exigida reserva de lei. ${ }^{49}$ Ainda que se instituísse uma admissibilidade

instrução processual penal, observará o disposto nesta Lei e dependerá de ordem do juiz competente da ação principal, sob segredo de justiça. Conforme previsto no parágrafo único deste artigo, o disposto na lei aplica-se à interceptação do fluxo de comunicações em sistemas de informática e telemática.

${ }^{46}$ Cf., supra, itens n. 1.1 a n. 1.6, e n. 3.4.

${ }^{47}$ Cf., supra, item n. 1.4.1.

${ }^{48}$ Quanto às espécies de interceptação de comunicação entre pessoas presentes, cf., supra, item n. 3.7.

${ }^{49}$ Cf., supra, item n. 5.3.1.1. 
adequada à reserva de lei, o procedimento previsto n. Lei n. 9.296 - ao qual a Lei n. 9.034 não se remete - não é compatível com a interceptação ambiental. ${ }^{50}$

Cumpre-nos, neste ponto, antes de salientarmos os motivos que sustentam a mencionada incompatibilidade, apresentar o procedimento previsto na Lei n. 9.296, de 1996, preconizado nos seus arts. $2^{\circ}$ a $9^{\circ}$.

No parágrafo único do art. $2^{\circ}$, são previstas formalidades para requerimento $\mathrm{e}$ autorização da interceptação, nos quais deve ser descrita com clareza a situação objeto da investigação, inclusive com a indicação e qualificação dos investigados, salvo impossibilidade manifesta, devidamente justificada.

Além disso, segundo o art. $4^{\circ}$, o requerimento de interceptação, em regra, é escrito e deve conter a demonstração de que a sua realização é necessária à apuração de infração penal ${ }^{51}$ com indicação dos meios a serem empregados - , e de que a prova não pode ser descoberta por outros meios (art. $2^{\circ}$, inciso II). De forma excepcional, o requerimento pode ser formulado verbalmente, desde que seja posteriormente registrado em termos $\left(\operatorname{art} .4^{\circ}, \S 1^{\circ}\right) .{ }^{52}$

\footnotetext{
50 A interceptação ambiental foi inserida na Lei $n^{\circ} 9.034$ em 2001, quando já havia sido disciplinada a interceptação de comunicações telefônicas. Mas o legislador sequer estabeleceu, por remissão - com o que discordaríamos -, a possibilidade de aplicação do procedimento probatório previsto na Lei $n^{\circ}$ 9.296, o que infringe a necessária reserva de lei exigida para a matéria em questão.

${ }^{51} \mathrm{~A}$ admissibilidade das modalidades de interceptação é prevista no art. $2^{\circ}$ : não será admitida a interceptação de comunicações telefônicas quando ocorrer qualquer das seguintes hipóteses: I - não houver indícios razoáveis da autoria ou participação em infração penal; II - a prova puder ser feita por outros meios disponíveis; III - o fato investigado constituir infração penal punida, no máximo, com pena de detenção. A técnica empregada pelo legislador, para delimitação da admissibilidade do instituto é criticável, pela formulação negativa e pela amplitude. A este respeito, cf., supra, item n. 3.10. O art. $3^{\circ}$, e seus incisos I e II, preveem a autoridade competente para autorização da medida, e atribui legitimidade ao Ministério Público e à autoridade policial. A propósito de legitimados ativos para requerimento de interceptação e de autoridade competente para decretá-la, cf., supra, item n. 3.5 .

52 "A previsão do pedido verbal, reduzido a termo, embora restrito a casos excepcionais, desperta alguma preocupação, uma vez que o exame do juiz a respeito da presença dos requisitos de admissibilidade da medida - a que o mesmo art. $3^{\circ}$ alude expressamente - deverá basear-se exclusivamente nas afirmações da autoridade requerente. A urgência pode justificar a previsão legislativa, nesses casos excepcionais. Mas teria sido oportuna a previsão de convalidação da ordem pelo juiz, à luz da ratificação escrita do pedido verbal, com a inutilização do resultado da interceptação na hipótese de falta de convalidação." (GRINOVER, Ada Pellegrini. O regime brasileiro... op. cit., p. 9; GRINOVER, Ada Pellegrini. A marcha... op. cit., p. 109).
} 
A autoridade judicial, no prazo máximo de vinte e quatro horas, deve decidir, de forma fundamentada, sobre o pedido $\left(\operatorname{art} .4^{\circ}, \S 2^{\circ}\right) .{ }^{53}$ Em decisão, deve haver a indicação da forma de execução da interceptação e da duração da medida, que não pode exceder o prazo de quinze dias, renovável por igual período, ${ }^{54}$ se comprovada a indispensabilidade do meio de prova (art. $\left.5^{\circ}\right)$.

Autorizada a interceptação, a autoridade policial deve conduzir a execução da interceptação, ${ }^{55}$ dando ciência ao Ministério Público, que pode acompanhá-la (art. $\left.6^{\circ}\right) .{ }^{56}$ "No caso de a diligência possibilitar a gravação da comunicação interceptada, ${ }^{57}$ será determinada a sua transcrição" $\left(\operatorname{art.} 6^{\circ}, \S 1^{\circ}\right) . .^{58}$

\footnotetext{
${ }^{53}$ É necessária a apresentação de elementos concretos que demonstrem a ocorrência das hipóteses de cabimento da medida (BADARÓ, Gustavo Henrique Righi Ivahy. Direito processual penal: tomo I... op. cit., p. 292).

${ }^{54}$ A doutrina brasileira tem se insurgido contra indefinidas prorrogações de interceptação de comunicação telefônica. ADA PELLEGRINI GRINOVER salienta que "a lei não esclarece se, após a primeira prorrogação, outra será possível. O Projeto Miro Teixeira era expresso, prevendo tantas prorrogações quantas necessárias, desde que continuassem presentes os pressupostos de admissibilidade da ordem de interceptação." (O regime brasileiro... op. cit., p. 10; A marcha... op. cit., p. 110). Sobre a questão, GERALDO PRADO, distingue a suspensão e a restrição a direitos fundamentais. Segundo o autor, ambas são provisórias; mas, enquanto a restrição atinge o direito parcialmente, sem atingir o seu núcleo fundamental, a suspensão paralisa ou impede, durante algum tempo, o direito como um todo. Com base nestas premissas, o autor lembra que, em situação excepcional de Estado de Defesa, é possível a restrição ao direito de sigilo das comunicações telefônicas (art. 136 , § $1^{\circ}$, inciso II, alínea "c" da Constituição Federal), por prazo "não superior a trinta dias, podendo ser prorrogado uma vez, por igual período" (art. 136, $\S 2^{\circ}$ ). Em sequência, conclui o autor que admitir "sucessivas prorrogações de interceptações telefônicas, no lugar de definir o prazo máximo de trinta dias (quinze dias, prorrogável uma vez por mais quinze), como única interpretação do artigo $5^{\circ}$ da Lei n. 9.296, de 1996, conforme a Constituição, equipara a restrição (provisória) do direito à inviolabilidade das comunicações telefônicas, tratando mais gravemente situação jurídica que por expressa previsão constitucional não é equiparável em gravidade àquelas que estão sujeitas ao estado de defesa (art. 136 da Constituição da República). Fere-se o princípio da razoabilidade e se afasta da interpretação sistemática da Constituição, concedendo primazia à função de segurança pública em detrimento do papel assinalado ao juiz pela Carta de 1988, tal seja, o de garantidor do direitos fundamentais" (Limite às interceptações... op. cit., p. 45-46).

${ }^{55} \mathrm{O}$ art. $7^{\circ}$ prevê que, para os procedimentos de interceptação, a autoridade policial poderá requisitar serviços e técnicos especializados às concessionárias de serviço público.

${ }^{56}$ O Ministério Público deve ter papel mais ativo do que a mera cientificação da ocorrência e do resultado da interceptação. Consideradas as suas funções institucionais, deve se manifestar sobre o pedido, se formulado pela autoridade policial, e acompanhar a execução da interceptação (GRINOVER, Ada Pellegrini; FERNANDES, Antonio Scarance; GOMES FILHO, Antonio Magalhães. As nulidades... op. cit., p. 178).

${ }^{57}$ A respeito desta norma, ADA PELLEGRINI GRINOVER, ANTONIO MAGALHÃES GOMES FILHO e ANTONIO SCARANCE FERNANDES observam: "embora a lei dê a entender que a interceptação possa não ser acompanhada da gravação (art. $6^{\circ}, \S 1^{\circ}$ ), recomenda-se ao juiz que determine, para posterior transcrição das conversas interceptadas. Somente assim poderá haver melhor aferição da veracidade da prova, sua idoneidade técnica e autenticidade da voz, para oportuna valoração do juiz." (As nulidades... op. cit., p. 170). Em semelhante sentido, cf. GRINOVER, Ada Pellegrini. O regime brasileiro... op. cit., p. 10; GRINOVER, Ada Pellegrini. $A$ marcha... op. cit., p. 110. Ainda a respeito do tema, GUSTAVO HENRIQUE RIGHI IVAHY BADARÓ assevera que "não há justificativa para a ressalva. Todas as interceptações devem ser gravadas, sob pena de se impossibilitar o exercício do contraditório e da ampla defesa em relação ao seu conteúdo". "A não-gravação da
} 
Terminada a interceptação, a autoridade policial deve providenciar a respectiva documentação, encaminhando o respectivo resultado ao juiz, acompanhado de auto circunstanciado, com o resumo das operações realizadas $\left(\operatorname{art.} 6^{\circ}, \S 2^{\circ}\right) . .^{59}$

Recebida a documentação da interceptação, o juiz determina a instauração de dois incidentes: o incidente de apensamento e o incidente de inutilização.

A interceptação é realizada em autos apartados. Concluídos os atos que a integram e documentado o seu resultado, deve haver o apensamento aos autos do inquérito policial ou do processo criminal, preservando-se o sigilo das diligências, gravações e transcrições respectivas $\left(\operatorname{art.} 8^{\circ}\right)^{60}$

conversa interceptada viola a ampla defesa, por impossibilitar o exercício do direito à prova" (Direito processual penal: tomo I... op. cit., p. 293).

${ }^{58}$ A necessidade de documentação por meio de transcrição do conteúdo das conversas interceptadas é ressaltada em doutrina. GUSTAVO HENRIQUE RIGHI IVAHY BADARÓ enfatiza que se trata de condição de validade da prova. E mais: "é a transcrição da conversa registrada, que se consubstanciará em um laudo de degravação, que permitirá o exercício do contraditório, com a possibilidade de impugnar a prova obtida e produzir contraprova. Não basta que os registros das gravações sejam 'colocados à disposição da defesa' (p.ex: facultando-lhes a consulta aos CDs das gravações, pois muitas vezes há sobreposições de vozes, ruídos, chiados, o que impede a compreensão perfeita do diálogo" (Direito processual penal: tomo I... op. cit., p. 295-296). Interessante notar a proposta do Instituto Brasileiro de Direito Processual para o projeto de novo Código de Processo Penal a respeito do tema: "Art. 249. Recebida a integralidade do material original obtido nas operações técnicas, e não havendo necessidade de diligências complementares, o juiz competente dele dará ciência às partes. $\S 1^{\circ} \mathrm{A}$ partir desse momento, e em prazo adequado e suficiente fixado pelo juiz, poderão as partes examinar o auto circunstanciado e obter cópia integral das gravações, indicando, em 48 (quarenta e oito) horas, os trechos cuja transcrição pretendem. $\S 2^{\circ} \mathrm{O}$ juiz determinará a transcrição dos trechos indicados pelas partes, bem como de outros que entenda pertinentes e relevantes." A proposta normativa assegura a transcrição das conversas interceptadas às partes e ao juízo (INSTITUTO BRASILEIRO DE DIREITO PROCESSUAL. Propostas de emendas... op. cit., p. 25).

${ }^{59}$ Mesmo em caso de resultado negativo da diligência, ocasião em que não tenham sido descobertas provas, é necessária a documentação da interceptação (BADARÓ, Gustavo Henrique Righi Ivahy. Direito processual penal: tomo I... op. cit., p. 295).

${ }_{60}$ É salientada em doutrina a necessidade de observância do contraditório no incidente de apensamento. Quanto ao Ministério Público, sendo o titular da ação penal, deve se manifestar previamente à diligência e pode acompanhar a sua realização. No que se refere à defesa, cuida-se de contraditório diferido, que lhe propicia analisar a prova em diversos aspectos, tais como: a licitude da prova; a idoneidade técnica das operações; a autenticidade de voz e dos registros do conteúdo da comunicação; a fidelidade das gravações (BADARÓ, Gustavo Henrique Righi Ivahy. Direito processual penal: tomo I... op. cit., p. 296-297). No mesmo sentido, enfatizando a indispensabilidade de observância do contraditório, cf.: GRINOVER, Ada Pellegrini; FERNANDES, Antonio Scarance; GOMES FILHO, Antonio Magalhães. As nulidades... op. cit., p. 178; .ZILLI, Marcos Alexandre Coelho. A iniciativa instrutória... op. cit., p. 205; GRECO FILHO, Vicente. Interceptação telefônica... op. cit., p . 57-58; MACHADO, André Augusto Mendes; KEHDI, André Pires de Andrade. Sigilo das comunicações... op. cit., p. 256. O segredo das operações técnicas de interceptação se encerra com a sua conclusão. Concluída a interceptação, não pode haver sigilo entre as partes (GRINOVER, Ada Pellegrini. O 
Segundo o parágrafo único do art. $8^{\circ}$, o apensamento deve ocorrer "imediatamente antes" do relatório do inquérito policial (art. 10, $\S 1^{\circ}$ do Código de Processo Penal), no caso de diligência no curso da investigação criminal, ou na remessa dos autos processuais ao juiz para o "despacho" previsto no art. 407, ${ }^{61}$ do art. $502^{62}$ e do art. 538, ${ }^{63}$ todos do Código de Processo Penal. $^{64}$

$\mathrm{O}$ art. $9^{\circ}$ trata do incidente de inutilização: "a gravação que não interessar à prova será inutilizada por decisão judicial, durante o inquérito, a instrução processual ou após esta, em virtude de requerimento do Ministério Público ou da parte interessada. ${ }^{" 65}$ Conforme disposto

regime brasileiro... op. cit., p. 12; GRINOVER, Ada Pellegrini. A marcha... op. cit., p. 113-114; GRINOVER, Ada Pellegrini; FERNANDES, Antonio Scarance; GOMES FILHO, Antonio Magalhães. As nulidades... op. cit., p. 180)

${ }^{61} \mathrm{O}$ antigo art. 407 do Código de Processo Penal cuidava de momento procedimental do procedimento do júri posterior à apresentação de alegações pelas partes, ocasião em que os autos eram remetidos à conclusão do juiz, para elaboração de decisão pertinente ao juízo de admissibilidade da acusação (pronúncia, impronúncia, absolvição sumária e desclassificação). Na atual sistemática do Código - consideradas as alterações normativas operadas pela Lei n. 11.719, de 2008 -, no procedimento do júri, momento semelhante é retratado no art. 411 , $9^{\circ}$ do Código de Processo Penal.

${ }^{62} \mathrm{O}$ art. 502 do Código de Processo Penal, atualmente revogado, versava sobre momento procedimental do procedimento ordinário posterior à apresentação de alegações finais pelas partes, ocasião em que os autos eram remetidos à conclusão do juiz, para elaboração de sentença. Na atual sistemática do Código - consideradas as alterações normativas operadas pela Lei n. 11.719, de 2008 -, no procedimento ordinário, a sentença, em regra, é proferida em audiência (art. 400). De forma excepcional, em face da complexidade do feito ou do número de acusados, o juízo pode conceder às partes prazo para apresentação de defesa escrita, após o que profere sentença (art. 403, § $3^{\circ}$ do Código de Processo Penal).

${ }^{63} \mathrm{O}$ antigo art. 538 do Código de Processo Penal tratava de momento procedimental integrante do procedimento sumário posterior ao prazo de três dias posterior ao interrogatório, para apresentação de defesa prévia. Na atual sistemática do Código - consideradas as alterações normativas operadas pela Lei n. 11.719, de 2008 -, no procedimento sumário, após a apresentação de resposta preliminar à acusação, os autos são remetidos à autoridade judicial para formulação de juízo sobre a absolvição sumária (art. 397) e juízo de admissibilidade da acusação (art. 399).

${ }^{64} \mathrm{O}$ momento para instalação do incidente de apensamento é inadequado, pois não propicia o pleno exercício das faculdades por interessados. ADA PELLEGRINI GRINOVER, ANTONIO MAGALHÃES GOMES FILHO e ANTONIO SCARANCE FERNANDES, afirmando a necessidade de observância do contraditório, ressaltam a inadequação dos momentos previstos no art. $8^{\circ}$. Além disso, esclarecem que a protelação do apensamento - para oportunidade anterior ao relatório, no inquérito, e para as diligências finais, em ação penal - impede a manifestação produtiva do investigado ou acusado quanto à prova (As nulidades... op. cit., p. 178-179). Tão logo se conclua a documentação do resultado interceptação, os interessados - investigados, Ministério Público e defesa, na fase de investigação, e Ministério Público, acusado e defesa, partes em ação penal -, devem ser intimados para se manifestar sobre os respectivos termos. Neste sentido, cf.: GRINOVER, Ada Pellegrini. O regime brasileiro... op. cit., p. 10-11; GRINOVER, Ada Pellegrini.A marcha... op. cit., p. 112-113; BADARÓ, Gustavo Henrique Righi Ivahy. Direito processual penal: tomo I... op. cit., p. 296-297; MOURA, Maria Thereza Rocha de Assis. Interceptação telefônica... op. cit., p. 411; GRECO FILHO, Vicente. Interceptação telefônica... op. cit., p. 57-58.

${ }^{65}$ Se a inutilização antecedesse ao apensamento, na presença das partes, seria resguardada a privacidade de terceiros (GRINOVER, Ada Pellegrini; FERNANDES, Antonio Scarance; GOMES FILHO, Antonio Magalhães. 
em seu parágrafo único, “o incidente de inutilização será assistido pelo Ministério Público, sendo facultada a presença do acusado ou de seu representante legal.",66

O regime do procedimento probatório previsto na Lei n. 9.296 apresenta defeitos, seja pelas dúvidas que suscita, seja pelas regras que não se coadunam com os direitos e garantias processuais assegurados pela Lei Maior, exigindo do intérprete uma construção tendente a harmonizá-lo com a ordem constitucional. ${ }^{67}$

Os mencionados defeitos, extraídos dos termos normativos acima transcritos, são identificados nas fases de autorização, de execução e de documentação da interceptação, entre os quais destacamos: a prevista possibilidade de formulação de pedido verbalmente; a prevista possibilidade de interceptação sem gravação e sem transcrição; a inadequação do momento previsto para o incidente de apensamento; a ausência de previsão de concessão de oportunidade de participação aos sujeitos ativos e passivos no incidente de apensamento; a

As nulidades... op. cit., p. 179; GRINOVER, Ada Pellegrini. O regime brasileiro... op. cit., p. 12; GRINOVER, Ada Pellegrini. A marcha... op. cit., p. 113; FERNANDES, Antonio Scarance. A lei de interceptação... op. cit., p. 59).

${ }^{66}$ Neste incidente, os interessados podem requerer a inutilização de trechos do conteúdo da comunicação interceptada, constante de registros e de transcrições. Embora a lei "faculte" a presença do acusado ou de seus representantes legais, o incidente de inutilização deve ser realizado em contraditório dos interessados, investigado ou acusado e Ministério Público. Também o terceiro pode requerer a inutilização, desde que evidenciado o seu interesse. Neste sentido, cf.: GRINOVER, Ada Pellegrini. O regime brasileiro... op. cit., p. 12; GRINOVER, Ada Pellegrini. A marcha... op. cit., p. 113; GRINOVER, Ada Pellegrini; FERNANDES, Antonio Scarance; GOMES FILHO, Antonio Magalhães. As nulidades... op. cit., p. 179; FERNANDES, Antonio Scarance. A lei de interceptação... op. cit., p. 64; BADARÓ, Gustavo Henrique Righi Ivahy. Direito processual penal: tomo I... op. cit., p. 296-297. MARIA THEREZA ROCHA DE ASSIS MOURA ressalta a participação da defesa no incidente de inutilização: "a participação da defesa no incidente de inutilização da prova deve ser sempre assegurado, ainda que instaurado no curso das investigações" (Interceptação telefônica... op. cit., p. 412). Quanto ao terceiro, ANTONIO SCARANCE FERNANDES observa: "o terceiro, cuja conversa foi interceptada em virtude de ter mantido comunicação com o investigado, deve ter sua intimidade respeitada. Pode participar do incidente de inutilização da prova." (Processo penal... op. cit., p. 102). Mas o autor ressalva que somente pode ser extraído da gravação aquilo que não interessar à prova (FERNANDES, Antonio Scarance. A lei de interceptação... op. cit., p. 60). Ainda em comentários aos incidentes, de apensamento e de inutilização, a doutrina reputa cabível interposição de apelação (art. 593, inciso II do Código de Processo Penal) a decisões nele proferidas (GRINOVER, Ada Pellegrini. O regime brasileiro... op. cit., p. 12; GRINOVER, Ada Pellegrini. A marcha... op. cit., p. 113; FERNANDES, Antonio Scarance. A lei de interceptação... op. cit., p. 64; MOURA, Maria Thereza Rocha de Assis. Interceptação telefônica... op. cit., p. 412; GRECO FILHO, Vicente. Interceptação telefônica... op. cit., p. 56).

${ }^{67}$ Neste sentido, ADA PELLEGRINI GRINOVER afirma que a lei "suscita diversos problemas de interpretação, sendo em muitos casos lacunosa" (GRINOVER, Ada Pellegrini. O regime brasileiro... op. cit., p. 16; GRINOVER, Ada Pellegrini. A marcha... op. cit., p. 118). Ainda sofre a questão dos defeitos da lei, cf.: GRINOVER, Ada Pellegrini; FERNANDES, Antonio Scarance; GOMES FILHO, Antonio Magalhães. As nulidades... op. cit., p. 170 e $177-179$. 
deficiência da previsão de concessão de oportunidade de participação aos sujeitos ativos e passivos no incidente de inutilização. ${ }^{68}$

Além dos defeitos apontados, como vimos anteriormente, ${ }^{69}$ a autonomia da interceptação de comunicação entre pessoas presentes, consideradas as suas especificidades, opera-se tanto no plano da admissibilidade, quanto no plano do procedimento probatório.

Em procedimento probatório de interceptação de comunicação entre pessoas presentes, deve-se prever a necessidade de indicação do modo de sua realização, com a exigência legal de indicação: do local (domiciliar ou não) onde se pretenda captar o conteúdo de uma comunicação presencial; do meio técnico a ser empregado; da forma de utilização do meio técnico; e da forma de inserção do meio técnico no referido local.

É por todas essas razões, pertinentes aos defeitos do "procedimento" previsto na Lei n. 9.296/96 e à autonomia do procedimento da interceptação de comunicação entre pessoas presentes, que discordamos da proposta de integração ao regime da Lei n. 9.296/96.

\subsubsection{Segue: a proposta de integração com o sistema processual penal}

Como visto no item anterior, a proposta da doutrina brasileira de integração com o regime previsto na Lei n. 9.296, de 1996, é formulada com vistas voltadas à aplicação do procedimento probatório nela previsto para a interceptação de comunicação entre pessoas presentes.

Segundo o nosso entendimento, o mencionado procedimento probatório não é aplicável à interceptação de comunicação entre pessoas presentes. $^{70}$ Sendo assim, diante da falha

\footnotetext{
${ }^{68}$ As observações da doutrina brasileira sobre o procedimento probatório previsto na Lei n. 9.296, de 1996, foram registradas nas notas de rodapé do presente item.

${ }^{69} \mathrm{Cf}$., supra, item n. 3.10.

${ }^{70}$ Cf., supra, item n. 5.3.1.2.
} 
regulamentação da admissibilidade e da ausência de procedimento probatório, tal medida não pode ser executada no direito brasileiro.

Mas há outras questões que, apesar de não regulamentadas pela Lei n. 9.296, surgem do regime por ela instituído. Referimo-nos às questões da autenticidade de voz e de registros do conteúdo da comunicação, do encontro fortuito e da utilização do resultado da interceptação em outras investigações ou processos, as quais consideramos pertinentes, também, à interceptação de comunicação entre pessoas presentes. ${ }^{71}$

A doutrina brasileira, considerando as normas integrantes do sistema processual brasileiro, propõe soluções a estas questões, que passamos a apresentar, para avaliação de sua relevância na formulação de sugestões, de lege ferend $a,{ }^{72}$ para a delimitação de uma disciplina jurídica para a interceptação de comunicação entre pessoas presentes no direito processual penal brasileiro.

O exame de autenticidade, de voz e de registros do conteúdo da comunicação interceptada, liga-se ao tema da eficácia probatória da interceptação. ${ }^{73}$ Uma vez que se reconhece eficácia probatória ao seu resultado no decorrer da persecução penal, os interessados podem contestar a mencionada autenticidade, ao se depararem com a documentação da interceptação.

A estas questões, a doutrina propõe a utilização dos meios de prova previstos no ordenamento brasileiro.

\footnotetext{
${ }^{71}$ Recorde-se de que os sujeitos ativos, os sujeitos passivos e a admissibilidade são questões regulamentadas pela lei, e foram anteriormente examinadas de forma conjunta com os aspectos dogmáticos da interceptação de comunicação entre pessoas presentes (cf., supra, itens n. 3.5, n. 3.6 e n. 3.10).

${ }^{72}$ Cf., supra, itens n. 3.10, e, infra, n. 5.5.

${ }^{73}$ Quanto à eficácia probatória dos meios de investigação de prova, cf., supra, item n. 1.5.
} 
Assim, para comprovação da autenticidade de voz, sugere-se, por exemplo, o testemunho de quem tenha presenciado a comunicação ${ }^{74}$ e a perícia de voz. ${ }^{75}$ Além destes, pode-se cogitar do reconhecimento de voz.

Em razão da possibilidade de o investigado ou o acusado se negar a fornecer material para o exame pericial, considerado o direito a não autoincriminação, é lembrada, ainda, a consideração de indícios, "coerentes e concordes", para se atestar a autenticidade da voz. ${ }^{76} \mathrm{O}$ local onde ocorreu a comunicação, como, por exemplo, o domicílio do investigado ou do acusado, pode ser uma informação relevante na avaliação da autenticidade da voz em interceptação de comunicação presencial disciplinada em lei.

A solução de utilização dos meios de prova também é apresentada para a comprovação da autenticidade de registros do conteúdo da comunicação, dos quais se tenham extraído as transcrições. Nesta hipótese, enfatiza-se a utilização da prova pericial. ${ }^{77}$ Para tanto, devem ser mantidos os suportes nos quais tenha sido gravado o conteúdo da comunicação interceptada, para possibilitar a perícia.

Parece-nos que já defluem do sistema processual os meios de prova para atestar a autenticidade de voz e do registro do conteúdo da comunicação em lei. Mas, considerando que a interceptação se perfaz por meio de uma operação técnica, consideramos adequada a

\footnotetext{
${ }^{74}$ Cf. GRINOVER, Ada Pellegrini. Interceptações telefônicas... op. cit., p. 425. Acerca do assunto, GUSTAVO HENRIQUE RIGHI IVAHY BADARÓ afirma, quanto à interceptação de comunicação telefônica, a possibilidade de comprovação por testemunhas "(que tenham presenciado a conversa telefônica)" (Direito processual penal: tomo I... op. cit., p. 298). Atente-se para o fato de que o testemunho se refere à participação de interlocutores em uma comunicação ocorrida. Não se trata de testemunho sobre o conteúdo da comunicação.

75 “Em razão dos avanços dos meios tecnológicos, têm surgido diversas modalidades de perícias não previstas ou disciplinadas pelo CPP. Um exemplo é a perícia de voz, para comprovação da autoria do diálogo objeto de interceptação telefônica, nos casos em que o interlocutor nega ter participado da conversa" (GOMES FILHO, Antonio Magalhães; BADARÓ, Gustavo Henrique Righi Ivahy. Prova e sucedâneos... op. cit., p. 181). No mesmo sentido, cf. GRINOVER, Ada Pellegrini. Interceptações telefônicas... op. cit., p. 425.

${ }^{76}$ Cf. BADARÓ, Gustavo Henrique Righi Ivahy. Direito processual penal: tomo I... op. cit., p. 299.

${ }^{77}$ Neste sentido, BADARÓ, Gustavo Henrique Righi Ivahy. Direito processual penal: tomo I... op. cit., p. 300; CAZERTA, Therezinha Astolphi. Meios eletrônicos no processo penal. Revista do Tribunal Regional Federal da $3^{\text {a }}$ Região, São Paulo, v. 76, p. 101-123, mar-abr. 2006, p. 112. ADA PELLEGRINI GRINOVER, ANTONIO MAGALHÃES GOMES FILHO e ANTONIO SCARANCE FERNANDES sustentam a aplicação do art. 383, parágrafo único do Código de Processo Civil, segundo o qual a reprodução mecânica (como a fotográfica, fonográfica ou de outra espécie), se impugnada a sua autenticidade, impõe ao juiz a realização de exame pericial (As nulidades... op. cit., p. 178). Em sentido semelhante, cf.: GRINOVER, Ada Pellegrini. O regime brasileiro... op. cit., p. 11; GRINOVER, Ada Pellegrini.A marcha... op. cit., p. 112.
} 
proposta de remissão normativa à prova pericial para solução, no que couber, da autenticidade de gravação ou de voz. ${ }^{78}$

Outra questão não regulamentada pela Lei n. 9.296, de 1996, versa sobre a possibilidade de utilização de prova obtida por interceptação em outro processo criminal. Tratando-se de meio de investigação de prova, como é o caso da interceptação, consideramos que a questão da utilização pode versar sobre a fonte de prova e acerca dos elementos de informação que a acompanharam em sua descoberta.

A este respeito, a doutrina, salientando que a Constituição previu a interceptação em matéria criminal, entende possível a utilização em feito da mesma natureza. ${ }^{79}$

Em nosso entender, por se tratar de matéria relacionada à restrição de direitos e garantias fundamentais - para a qual se exige reserva de lei, precisa e clara $^{80}$ - deve constar da disciplina legal da interceptação o tratamento da utilização da prova em outro feito. ${ }^{81}$

A terceira questão versa sobre o encontro fortuito, também denominado descoberta fortuita. Cuida-se de situação em que, em execução de interceptação, descubram-se fontes de

\footnotetext{
${ }^{78}$ Note-se a proposta do Instituto Brasileiro de Direito Processual para o projeto de novo Código de Processo Penal a respeito do tema: "Art. 249. $\S 3^{\circ}$. As dúvidas a respeito da autenticidade da gravação ou da voz serão decididas pelo juiz, aplicando-se, no que couber, o disposto no art. 221 do Código de Processo Penal." O referido artigo 218, integrante da disciplina da prova documental, tem os seguintes termos normativos: "art. 221. A letra e a firma dos documentos particulares serão submetidas a exame pericial, quando contestada sua autenticidade. Parágrafo único. A mesma providência será determinada quando impugnada a autenticidade de qualquer tipo de reprodução mecânica, como a fotográfica, cinematográfica, fonográfica ou de outra espécie.” (INSTITUTO BRASILEIRO DE DIREITO PROCESSUAL. Propostas de emendas... op. cit., p. 26).

${ }^{79}$ ANTONIO SCARANCE FERNANDES assim se manifesta, ressalvando a necessidade de que o acusado seja o mesmo, e se observe o princípio do contraditório e da ampla defesa (Processo penal... op. cit., p. 101). Além desta possibilidade identificada em doutrina, também se poderia pensar na possibilidade de utilização em outra investigação criminal, da fonte e dos elementos de informação. No Projeto Miro Teixeira, quanto à interceptação de comunicação telefônica, a regra prevista era a da inadmissibilidade da prova em outro processo relativo a crime diverso, ressalvado os instaurados em razão de suposta prática de crime que admitia a interceptação (art. $\left.8^{\circ}\right)$.

${ }^{80}$ Cf., supra, item n. 2.6.

${ }^{81}$ A proposta do Instituto Brasileiro de Direito Processual para o projeto de novo Código de Processo Penal a respeito do tema em interceptação de comunicação telefônica é a seguinte: "art. 251. Os resultados das operações técnicas não poderão ser utilizados para a instrução de processos ou investigações relativos a crimes diversos daqueles para os quais a autorização foi dada, salvo quando se tratar de crime conexo ou de outro crime constante do artigo 242, hipótese em que se observará o disposto nesta seção, no que couber." O art. 242 especifica os delitos em cuja persecução se admite a quebra do sigilo das comunicações telefônicas (INSTITUTO BRASILEIRO DE DIREITO PROCESSUAL. Propostas de emendas... op. cit., p. 26).
} 
prova pertinentes a delito distinto daquele que fundamentou a autorização da medida. Também pode ocorrer se for descoberta a participação de outras pessoas - distintas do investigado em desfavor de quem se decretou interceptação - no cometimento do delito. ${ }^{82}$

A doutrina, em geral, tendo por pressuposto a licitude da interceptação, considera válida a descoberta fortuita de delitos nela operada, embora o faça sob fundamentos distintos, entre as quais destacamos: a existência de relação de conexão ou de continência com o crime que justificou a medida; ${ }^{83}$ a gravidade do delito, aproveitando o "resultado da interceptação em processo ou investigação diversos daquele para o qual a ordem foi dada, desde que atinente a crime de igual ou maior gravidade"; 84 "o da existência de nexo entre o crime descoberto e o investigado". 85

Quanto à descoberta fortuita da participação de outras pessoas não mencionadas na autorização judicial, afirma-se que é admissível, porque o art. $2^{\circ}$ da Lei n. 9.296 admite a autorização mesmo diante da impossibilidade de indicação ou qualificação dos investigados. ${ }^{86}$

No que se refere à última questão, também por se tratar de matéria relacionada à restrição de direitos e garantias fundamentais, reputamos que o encontro fortuito deva ser tratado em lei, de forma precisa e clara $^{87}$

Destarte, o tratamento legal da autenticidade de gravação e de voz, da utilização da prova em outros feitos e do encontro fortuito, na esteira dos entendimentos propostos pela

\footnotetext{
${ }^{82}$ Neste sentido, GUSTAVO HENRIQUE RIGHI IVAHY BADARÓ observa que pode haver "descoberta fortuita de crimes e descoberta fortuita de autores ou partícipes" (Direito processual penal: tomo I... op. cit., p. 288-289). LUIZ FLÁVIO GOMES lembra que o encontro fortuito pressupõe a licitude da interceptação (Interceptação telefônica e "encontro fortuito" de outros fatos. Boletim IBCCRIM, São Paulo, n. 51, fev. 1997, p. 6).

${ }^{83}$ Cf. BADARÓ, Gustavo Henrique Righi Ivahy. Direito processual penal: tomo I... op. cit., p. 289.

${ }^{84}$ ADA PELLEGRINI GRINOVER, ANTONIO MAGALHÃES GOMES FILHO e ANTONIO SCARANCE FERNANDES fundamentam esta solução com esteio na proporcionalidade (As nulidades... op. cit., p. 175).

${ }^{85}$ Cf. FERNANDES, Antonio Scarance. Processo penal... op. cit., p. 98.

${ }^{86}$ Cf. GRINOVER, Ada Pellegrini; FERNANDES, Antonio Scarance; GOMES FILHO, Antonio Magalhães. As nulidades... op. cit., p. 175-176.

${ }^{87}$ A proposta do Instituto Brasileiro de Direito Processual para o projeto de novo Código de Processo Penal a respeito do tema: "Art. 252. Na hipótese de a quebra do sigilo das comunicações telefônicas de qualquer natureza revelar, fortuitamente, indícios de crime que não se inclua nas hipóteses do artigo 241, o juiz deverá remeter ao Ministério Público, que poderá requisitar a instauração de inquérito policial." (INSTITUTO BRASILEIRO DE DIREITO PROCESSUAL. Propostas de emendas... op. cit., p. 26).
} 
doutrina, visa ao resguardo dos direito e garantias fundamentais restringidos em interceptação de comunicação.

\subsubsection{Repercussão processual de interceptação de comunicação entre pessoas presentes ilícita}

A exigência de legalidade dos atos praticados na execução de uma interceptação de comunicações entre pessoas presentes é garantia inerente ao devido processo legal. Esta exigência tem dúplice fundamento: por um lado, a restrição das comunicações entre pessoas presentes com vistas à descoberta de fontes de prova é matéria reservada à lei ${ }^{88}$ de outro, somente a prova legal, colhida mediante a observância da disciplina dos meios de prova, é apta para fundamentar a avaliação de questões surgidas na persecução penal e, por consequência, para construção da verdade processual. ${ }^{89}$

O descumprimento da disciplina normativa torna ilegal a interceptação de comunicação entre pessoas presentes, e, considerada a indevida restrição de bens jurídicos, implica a formação de prova ilícita: a interceptação de comunicação entre pessoas presentes ilícita. ${ }^{90}$ Mas se recorde de que ilícita não é a interceptação em si - como meio de investigação de prova, instituto abstrato -; mas, sim, atos concretamente praticados em interceptação efetivada, que tornam, a fortiori, ineficazes a descoberta de fontes de provas (ilicitude na colheita). A ilicitude se estende para as fontes de prova descobertas no curso da interceptação.

Eventuais "provas" obtidas em interceptação ilícita são inadmissíveis (art. 50, caput e inciso LVI da Constituição Federal), i. e., não existem no mundo jurídico, são destituídas de eficácia jurídica. ${ }^{91}$

\footnotetext{
${ }^{88}$ Cf., supra, itens n. 2.6 e 5.1 .

${ }^{89}$ Cf., supra, itens. n. 1.2.2.1 e 1.6.

${ }^{90}$ Doravante, referir-nos-emos apenas à interceptação ilícita, para expressar a interceptação de comunicações entre pessoas presentes ilícita.

${ }^{91}$ Quanto ao gênero "prova ilícita”, cf. GRINOVER, Ada Pellegrini; FERNANDES, Antonio Scarance; GOMES FILHO, Antonio Magalhães. As nulidades... op.cit., p. 136; BADARÓ, Gustavo Henrique Righi Ivahy. Direito Processual Penal: tomo I... op. cit., p. 206-207.
} 
Em razão da ineficácia de interceptação ilícita, fontes de prova descobertas e informações que delas poderiam ser extraídas no decorrer da persecução penal não poderão ser utilizadas. Por isso, a documentação da interceptação ilícita deve ser desentranhada de autos de investigação ou de ação penal.

Antes de se desentranhar uma prova, os interesses envolvidos na declaração de sua ilicitude devem ser apreciados. Pode haver interesses superiores que justifiquem, em caráter excepcional, e por aplicação da proporcionalidade, a admissibilidade da prova ilícita. Nesta hipótese, a prova não será desentranhada, podendo ser regularmente utilizada pelo juízo. Tratando-se, por exemplo, de prova da inocência do acusado, o interesse de proteção de sua liberdade jurídica prepondera sobre a legalidade da prova. ${ }^{92}$

Entretanto, em regra, aplica-se a sanção processual de inadmissibilidade, que, a rigor, impede que a prova viciada ingresse nos autos. Se vier a ser juntada em autos, impõe-se que seja excluída, por meio do desentranhamento de autos (art. 157, caput do Código de Processo Penal). ${ }^{93}$

Considerado o interesse público da proteção dos direitos fundamentais violados na obtenção de prova por meios ilícitos, o reconhecimento da inadmissibilidade da prova e o desentranhamento dos autos pode ser operado pelo juiz ex officio. Ademais, deve ser assegurada aos interessados a faculdade de requerê-los.

Desentranhada a documentação de interceptação ilícita, instaura-se um incidente de inutilização. Segundo previsto no $\S 3^{\circ}$ do art. $157, \S 3^{\circ}$, "preclusa a decisão de desentranhamento da prova declarada inadmissível, esta será inutilizada por decisão judicial, falcutado às partes acompanhar o incidente."94

\footnotetext{
${ }^{92}$ Foi a conclusão a que chegamos em análise sobre a garantia da inadmissibilidade de provas obtidas por meios ilícitos, feita anteriormente (item n. 1.6, supra). No que tange à proporcionalidade, verifiquem-se, também, as observações anotadas no item n. 2.6, supra.

${ }^{93}$ Antes da expressa previsão da lei processual penal, já reconhecia a doutrina a aplicação às provas obtidas por meio ilícito, por interpretação extensiva, o disposto no art. 145, inciso IV do Código de Processo Penal, que determina o desentranhamento de documento considerado falso.

${ }_{94}$ Critica-se a previsão da providência de inutilização da documentação da prova ilícita, pela possibilidade de utilização em outro processo de forma válida. "Pense-se, como exemplo, da situação em que os autores da
} 
É prevista a faculdade de as partes acompanharem o incidente. Mas a presença das partes não poder ser vista como mera faculdade. É imprescindível a presença da acusação, do acusado e do defensor. Em relação à defesa, esta providência é necessária para a garantia tanto da autodefesa, quanto da defesa técnica. ${ }^{95}$ Entendemos que também deve ser assegurada a participação de terceiros interessados, que tenham sido interlocutores da comunicação interceptada.

O desentranhamento de interceptação ilícita (inadmissível) dos autos de investigação ou de ação penal e o incidente de inutilização decorrem, portanto, de sua inexistência, que se traduz em absoluta ineficácia probatória.

Na regulamentação do desentranhamento e do incidente de inutilização, não se previu o momento da persecução penal em que devem ser operados. A referência a "partes", no $\S 3^{\circ}$ do art. 157, poderia conduzir a equivocada conclusão de que podem ocorrer apenas em fase processual.

Porém, seja em fase pré-processual, seja em fase processual, é possível o desentranhamento e a sucessiva inutilização da prova ilícita.

Em fase pré-processual, o juiz fiscalizador da investigação pode reconhecer a ilicitude da interceptação, ordenar o seu desentranhamento e inutilizá-la, ex officio ou por requerimento dos interessados.

Ao formar a opinio delicti, se o ente acusador verificar que a interceptação é fundamental para a formalização posterior da acusação - a qual, sem ela, não seria ofertada -,

violação de direito, da qual resultou a prova ilícita, venham a ser processados pelo crime correspondente (tortura, violação de domicílio, interceptação telefônica ilegal etc). Nesse caso, se destruída a prova, como manda a lei, ficará prejudicada a demonstração do próprio fato praticado para obtê-la. Não se pode descartar, ainda, a hipótese de usar uma prova ilícita pro reo em outro processo, como o da revisão criminal. Mais razoável era a proposta do Projeto de Lei n. 4.206/2001, que previa o arquivamento sigiloso em cartório." (GRINOVER, Ada Pellegrini; FERNANDES, Antonio Scarance; GOMES FILHO, Antonio Magalhães. As nulidades... op.cit., p. 136). Sem embargo da pertinência da crítica, de lege lata, é preconizado o incidente de inutilização, o qual devemos considerar nesta exposição sobre a repercussão processual de interceptação ilícita.

${ }^{95}$ Cf. GOMES FILHO, Antonio Magalhães. Provas: Lei 11.690... op. cit., p. 271. 
deve requerer o arquivamento dos autos da investigação. $\mathrm{O}$ ente acusador deve requerer a declaração da ilicitude da interceptação, o seu desentranhamento, além de pedir o arquivamento, com a justificativa de que a persecução penal não pode prosseguir com base em outros elementos. $^{96}$

Se a formalização de uma acusação for fundada em interceptação ilícita, cumpre, então, fazer referência aos momentos procedimentais em que é possível a ordenação de desentranhamento e a inutilização destas provas, tendo como parâmetro o rito ordinário (artigos 394 a 405) e o rito sumário (artigos 394 a 397, e 531 a 538). ${ }^{97}$

Oferecida a acusação, deve ser submetida à apreciação de um juiz, para uma análise liminar, ocasião em que emite um primeiro juízo de admissibilidade da acusação. ${ }^{98}$ Se a

\footnotetext{
${ }^{96}$ No mesmo sentido, manifesta-se ANTONIO SCARANCE FERNANDES, ao tratar da prova ilícita obtida na fase de inquérito policial (A lei de interceptação... op. cit., p. 66). Também o faz ao avaliar a repercussão processual da prova obtida mediante quebra do sigilo financeiro ilícita (O sigilo... op. cit., p. 163).

${ }^{97}$ A análise dos momentos procedimentais do rito sumário e do rito ordinário é feita considerada a previsão na Lei $\mathrm{n}^{0}$ 9.034, de 1995, de que a interceptação de comunicação entre pessoas presentes "é permitida" em persecução penal de associação criminosa e de quadrilha ou bando. A pena cominada à quadrilha ou bando é de reclusão, de 1 a 3 anos (art. 288, caput do Código Penal), e de reclusão, de 2 a 6 anos, se a quadrilha ou bando é armado (art. 288, parágrafo único do Código Penal). Em se admitindo imputação exclusiva de quadrilha ou bando, o procedimento será sumário ou ordinário (art. 394, caput e $\S 1^{\circ}$, incisos I e II, do Código de Processo Penal), conforme se trate, respectivamente, da forma simples ou qualificada do delito. Contudo, considerados os elementos normativos do tipo penal em questão ("associarem-se mais de três pessoas, em quadrilha ou bando, para o fim de cometer crimes"), em geral, a imputação deve versar sobre a quadrilha ou bando e acerca do(s) delito(s) cometido(s) por seus integrantes, o que justifica o exame do procedimento ordinário, como procedimento padrão. Quanto à associação criminosa, conforme anteriormente observado, não vislumbramos tipificação penal no ordenamento brasileiro: cf., supra, item n. 5.3.1.1, nota n. 30. A referência que ora se faz ao âmbito de "admissibilidade" da lei serve para reiterar a lembrança de que, mesmo nela prevista, eventual interceptação de comunicações entre pessoas presentes ordenada é ilícita. Todavia, não desconhecemos a possível ocorrência de interceptação de comunicações entre pessoas presentes fora do âmbito de "admissibilidade" da lei. Neste caso, o raciocínio quanto à ilicitude da interceptação e de sua repercussão processual - nela considerados os momentos procedimentais - seria semelhante. Registramos que a prova ilícita apresenta peculiaridades em se tratando de procedimento de feito da competência do Tribunal do Júri, no qual tenham ingressado irregularmente. Se a decisão de pronúncia se pautar em prova ilícita, deve ser reformada no julgamento de recurso a ela interposta ou anulada em julgamento de habeas corpus, ordenando-se o desentranhamento em ambos os casos. Havendo preclusão de pronúncia, o julgamento dos jurados será nulo, considerando que a ausência de motivação obsta o conhecimento das provas valoradas. De outro lado, se as provas ilícitas não forem consideradas em pronúncia, cabe ao Presidente do Tribunal do Júri ordenar o desentranhamento dos autos, para que delas os jurados não tomem conhecimento. O Conselho de Sentença deve ser dissolvido se houver referência a elas em plenário (GRINOVER, Ada Pellegrini; FERNANDES, Antonio Scarance; GOMES FILHO, Antonio Magalhães. As nulidades... op.cit., p. 136-137). Outras considerações sobre o habeas corpus, independentemente do procedimento aplicável ao feito, constam no item n. 5.3.1.5.

${ }^{98}$ Em doutrina, quanto à regulamentação da fase de formação do juízo de admissibilidade da acusação, que prevê a possibilidade de "recebimento da denúncia" por duas vezes (art. 396 e art. 399), há três correntes doutrinárias quanto ao momento em que se deva por ter recebido a denúncia: na primeira oportunidade (art. 396)
} 
acusação for fundada exclusivamente em elementos de informação extraídos de prova obtida em interceptação ilícita, impõe-se sua rejeição liminar, por faltar justa causa para o exercício da ação penal (art. 395, caput e inciso III). ${ }^{99}$ Igual solução se teria se a acusação, ainda que parcialmente fundada em elementos de interceptação ilícita, com o seu desentranhamento, não mais se vislumbrasse justa causa para ação penal. Além disso, as provas ilícitas devem ser desentranhadas e inutilizadas.

Não sendo rejeitada a peça acusatória, depois de oferecida a resposta de acusado (art. 396 e art. 396-A), o juiz deve avaliar, atento aos argumentos expendidos pela defesa, se a acusação merece prosperar. Em um novo juízo de admissibilidade da acusação, embora a lei processual penal não se refira à rejeição nesta oportunidade, a autoridade judicial pode rejeitála, ${ }^{100}$ por falta de justa causa, se, de acordo com o observado anteriormente, forem excluídos os elementos de interceptação ilícita em que se fundava a ação.

(MENDONÇA, Andrey Borges de. Nova reforma do Código de processo penal: comentada artigo por artigo. São Paulo: Método, 2008., p. 267-268); na segunda oportunidade (art. 399) (BADARÓ, Gustavo Henrique Righi Ivahy. Direito processual penal: tomo II. 2. ed. Rio de Janeiro: Elsevier, 2009, p.8-9; TOURINHO FILHO, Fernando da Costa. Manual de processo... op. cit., p. 679-680); e tanto na primeira (art. 396), quanto na segunda oportunidade (art. 399), em juízos progressivos de admissibilidade (FERNANDES, Antonio Scarance; LOPES, Mariângela. O recebimento da denúncia no novo procedimento. Boletim do IBCCRIM, n. 190, p. 2-3, set. 2008). Preferimos o segundo entendimento, considerada a sistemática da legislação, que prevê resposta do acusado, para propiciar que a denúncia não seja recebida. Independentemente da corrente seguida, reputamos que não há preclusão quanto à matéria de ilicitude de provas nestes momentos.

99 A respeito do tema da justa causa para a ação penal, MARIA THEREZA ROCHA DE ASSIS MOURA assevera: "a análise da justa causa, vale dizer, da justa razão ou da razão suficiente para a instauração da ação penal, não se faz apenas de maneira abstrata (vale dizer, em tese), mas também, e principalmente, calcada na conjugação dos elementos acima mencionados (isto é, em hipótese) que demonstrem a existência de fundamento de fato e de Direito, a partir do caso concreto". Sobre o fundamento de fato, a autora observa: "a existência do fundamento de fato pressupõe a existência de acusação que guarde ressonância para com a prova, relacionada com a existência material de um fato, no caso concreto, típico e ilícito, indícios suficientes de autoria e, porque não dizer, um mínimo de culpabilidade." Mais ainda: “a justa causa para o recebimento da acusação não sobressai apenas de seus elementos formais, mas, mormente, da sua fidelidade à prova que demonstre a legitimidade da imputação. Segue-se que a necessidade de existência de justa causa funciona como mecanismo para impedir, em hipótese, a ocorrência de imputação infundada, temerária, leviana, caluniosa e profundamente imoral.” (Justa causa para ação penal - Doutrina e jurisprudência. São Paulo: RT, 2001, p. 223, 243 e 247). Considerado o conceito apresentado, concluímos que, em sendo fundada uma denúncia em elementos de informação extraídos de prova obtida em interceptação ilícita - lembre-se: prova inexistente -, falta o fundamento de fato exigido para a caracterização da justa causa. Em jurisprudência, quanto a ligação entre justa causa e a legalidade da prova que respalde a acusação, cf.: BRASIL. Supremo Tribunal Federal. Habeas Corpus $n$. 90094/ES, 2 $2^{\mathrm{a}}$ Turma, Min. Rel. Eros Grau, j. em 08/06/2010, DJ 06/08/2010, v.u.. Disponível em: http://www.stf.jus.br/portal/jurisprudencia/listarJurisprudencia.asp?s1=prova+e+il\%EDcita+e+justa $+\mathrm{e}+$ causa\&pa gina $=1 \&$ base=baseAcordaos. Acesso em: 20/12/2010.

100 "Mesmo aqueles que entendem que, logo após o oferecimento da denúncia, já haverá o seu recebimento, antes mesmo da resposta, deverão admitir que tal ato não terá efeitos preclusivos para o juiz, que poderá revê-lo, diante 
Ainda que não seja alegada a ilicitude de interceptação em resposta à acusação, não preclui a possibilidade de alegação e de reconhecimento do vício processual, porque atinge o interesse público do correto exercício da função jurisdicional, que tem por primado a legalidade probatória. ${ }^{101}$

Com efeito, a matéria pode ser debatida em alegações finais (artigos 403 e 534).

O momento em que a sentença é proferida é mais uma oportunidade para o juízo declarar a ilicitude de provas e declarar o seu desentranhamento e inutilização, ex officio ou em exame das preliminares suscitadas pelas partes.

Mesmo em oportunidades distintas dos mencionados momentos procedimentais, por iniciativa própria ou em atendimento a requerimento de interessados, é possível o desentranhamento e a inutilização da interceptação ilícita e das provas nela descobertas. $\mathrm{O}$ interesse público inerente à questão prescinde de momento específico para sua avaliação.

\subsubsection{Meios de impugnação de interceptação de comunicação entre pessoas presentes ilícita}

Evidenciada a repercussão de uma interceptação de comunicações entre pessoas presentes ilícita $^{102}$ no desenrolar da persecução penal, diante de não reconhecimento da ilicitude da prova por juízo oficiante em fase pré-processual ou em fase processual, os interessados podem se insurgir com a utilização de meios de impugnação.

Avaliemos, entre os meios de impugnação preconizados pelo sistema processual, quais deles propiciam a manifestação de insurgência por interessados e a sucessiva obtenção de um provimento jurisdicional, no qual seja declarada ilícita a interceptação e ordenado o seu

da resposta oferecida pelo acusado, e rejeitar a denúncia em razão de vícios processuais." (BADARÓ, Gustavo Henrique Righi Ivahy. Direito processual penal: tomo II... op.cit., p. 10).

${ }^{101}$ A respeito da legalidade probatória, cf., supra, itens n. 1.2.3.1, n. 1.6 e n. 2.6.

${ }^{102} \mathrm{Em}$ seguida, mencionaremos apenas interceptação ilícita, para expressar a interceptação de comunicações entre pessoas presentes ilícita. A ilicitude da interceptação se estende para as fontes de prova nela descobertas. 
desentranhamento dos autos da investigação ou da ação penal, seguida de inutilização da respectiva documentação.

Antes disso, duas observações preliminares são necessárias.

Por primeiro, considere-se a previsão de um meio de impugnação como um dos aspectos que devem estar previstos em lei, para consecução da exigida reserva de lei para restrição às comunicações entre pessoas presentes. ${ }^{103}$

A segunda observação se refere à ligação dos meios de impugnação com os já mencionados momentos procedimentais. ${ }^{104}$ A eventual ausência de manifestação de interessados ou de ofício pelo juízo não convalidam a interceptação ilícita. A questão acerca da ilicitude da interceptação não preclui, e inexiste saneamento na sentença ou em qualquer outro momento procedimental previsto no art. 571 do Código de Processo Penal.

Os interessados podem impugnar a ilicitude da interceptação por meio de interposição de recursos ou de promoção de ações impugnativas.

Exercendo direito a recurso, ${ }^{105}$ as partes podem sustentar, em razões recursais, questões atinentes a regularidade formal, entre as quais se insere a questão da inadmissibilidade da interceptação ilícita.

Lembre-se, inicialmente, de que não é previsto recurso contra a já referida decisão em que se ordena o desentranhamento da interceptação ilícita (art. 157, caput e $\S 3^{\circ}$ ). É possível sustentar a aplicação, por analogia, do art. 581, inciso XVIII do Código de Processo Penal, que

\footnotetext{
${ }^{103}$ A respeito da extensão da reserva de lei, cf., supra, itens n. 2.6 e 3.10.1.

${ }^{104}$ Cf., supra, item n. 5.3.1.4.

${ }^{105}$ A possibilidade de interposição de recurso para impugnação de decisão que avalie a ilicitude de interceptação pressupõe prévia promoção de ação. ADA PELLEGRINI GRIVONER, ANTONIO MAGALHÃES GOMES FILHO e ANTONIO SCARANCE FERNANDES definem recurso como "meio voluntário de impugnação de decisões utilizado antes da preclusão e na mesma relação jurídica processual, apto a propiciar a reforma, a invalidação, o esclarecimento ou a integração da decisão." (Recursos no processo penal: teoria geral dos recursos, recursos em espécie, ações de impugnação, reclamação aos tribunais. 6. ed. São Paulo: RT, 2009, p. 27). E complementam: "a doutrina prefere hoje conceituar o poder de recorrer como aspecto, elemento, ou modalidade do próprio direito de ação e de defesa." (Recursos no processo penal... op. cit., p. 28).
} 
prevê o cabimento de recurso em sentido estrito para impugnação de decisão sobre o incidente de falsidade; ou do art. 593, inciso II, também do Código de Processo Penal, que preconiza a apelação contra decisão com força de definitiva. ${ }^{106}$

Mas, mesmo não interpostos os referidos recursos, consideramos que a interpretação que melhor resguarda a liberdade do acusado é a de que a questão sobre a licitude da interceptação possa ser versada tanto nos já mencionados momentos procedimentais, ${ }^{107}$ quanto por meio da interposição de outros recursos ou de propositura de ações impugnativas. ${ }^{108}$

Assim, o recurso em sentido estrito cabível contra decisão que rejeite a acusação (art. 581, caput e inciso I do Código de Processo Penal) pode propiciar a avaliação da licitude da interceptação. Como já observamos no exame dos momentos procedimentais, a acusação pode estar fundamentada em elementos extraídos de uma interceptação ilícita, sem os quais não se configuraria a justa causa para a ação penal. Nesta hipótese, rejeitada a acusação, pode ser analisada a questão sobre a ilicitude da prova nesta modalidade recursal, com a possível manutenção ou reforma da decisão.

Também a apelação interposta à sentença serve como meio de impugnação de interceptação ilícita. Estando a sentença amparada em fontes de prova descobertas em interceptação ilícita (inadmissíveis), não haverá vício de motivação, mas erro de julgamento, o qual poderá significar a reforma da sentença em julgamento de apelação. ${ }^{109}$

Em julgamento deste recurso, o tribunal deve desconsiderar provas ilicitamente obtidas em interceptação - que tenham sido irregularmente admitidas e consideradas em sentença - e

\footnotetext{
${ }^{106}$ No mesmo sentido, cf. GOMES FILHO, Antonio Magalhães. Provas: Lei 11.690... op. cit., p. 271.

${ }^{107}$ Cf., supra, item n. 5.3.1.4.

${ }^{108}$ ANTONIO MAGALHÃES GOMES FILHO sustenta que a preclusão de decisão sobre a inadmissibilidade da interceptação ilícita e das fontes de prova nela descobertas se perfaz somente com o trânsito em julgado da sentença final, condenatória ou absolutória (Provas: Lei $11.690 \ldots$ op. cit., p. 271). Entendimento mais restritivo é sustentado por VICENTE GRECO FILHO, para quem as decisões em que se reconheça a necessidade de desentranhamento são interlocutórias e irrecorríveis, sendo que "não precluem e poderão ser objeto de reexame como preliminar do recurso contra a sentença final, de modo que somente nesta oportunidade é que poderá ocorrer a preclusão" (Manual de processo penal. 8. ed. São Paulo: Saraiva, 2010, 191).

${ }^{109}$ Cf. GOMES FILHO, Antonio Magalhães. Direito à prova... op. cit., p. 168.
} 
ordenar o seu desentranhamento. E o recurso deve ser julgado sem as considerar, porque não existem juridicamente. $^{110}$

Em análise sobre a possibilidade de reforma de sentença baseada em prova ilícita, Antonio Magalhães GOMES Filho salienta que dois princípios devem ser considerados: o que veda a reformatio in pejus em recurso exclusivo da defesa (art. 617 CPP); e a garantia do duplo grau de jurisdição, prevista no art. $8^{\circ}$, item $2^{\circ}$, alínea "h" da Convenção Americana sobre Direitos Humanos. ${ }^{111}$

Em observância ao primeiro princípio, se a prova ilícita utilizada em sentença for favorável à defesa, somente em sede de recurso da acusação, é possível reformar a sentença. ${ }^{112}$

Ao contrário, sendo a prova ilícita utilizada para condenar ou agravar a situação do acusado, distinguem-se os efeitos do reconhecimento da inadmissibilidade de provas: "se, com a supressão, for possível a absolvição, ou a redução da pena agravada, essa deve ser a solução, com a reforma da sentença. Mas, se mesmo sem a prova inadmissível, houver base para manter-se a condenação ou o agravamento da pena, a invalidação deve ser decretada, para que outra sentença possa ser proferida, somente com base nas provas admissíveis, assegurando-se o duplo grau de jurisdição em favor da defesa". ${ }^{113}$

A questão sobre a inadmissibilidade de interceptação ilícita e de fontes de prova nela descobertas pode ser aventada, ainda, em embargos infringentes e de nulidade (art. 609, parágrafo único do Código de Processo Penal), em recurso especial (art. 105, caput e inciso

\footnotetext{
${ }^{110}$ Cf. GRINOVER, Ada Pellegrini; FERNANDES, Antonio Scarance; GOMES FILHO, Antonio Magalhães. As nulidades... op.cit., p. 136. A respeito de julgamento de recurso interposto a decisão fundada em provas ilícitas, ANTONIO SCARANCE FERNANDES, em exame sobre direito estrangeiro, conclui que duas soluções foram apresentadas: a) anulação da sentença e novo julgamento; b) manutenção da sentença ou reforma da sentença, julgando o recurso como se a prova não existisse. Se, sem a consideração da prova ilícita, o seu conteúdo não se sustentar nas demais provas produzidas, a decisão deve ser reformada. Com relação ao Brasil, ele afirma: "se a sentença levar em conta uma prova ilícita, deve ser vista no recurso a sua influência no resultado do processo. O tribunal julgará o recurso como se a prova ilícita inexistisse, reformando a sentença quando, sem a prova ilícita, outra teria sido a decisão". O autor ressalva, ainda, que, em se tratando de julgamento proferido por júri, a decisão deve ser anulada e a prova ilícita excluída, para não influir no novo julgamento (Prova e sucedâneos... op. cit., p. 229 e 236).

${ }^{111}$ Cf. GOMES FILHO, Antonio Magalhães. Direito à prova... op. cit., p. 168.

${ }^{112}$ Cf. Ibidem, p. 168.

${ }^{113}$ Cf. Ibidem, p. 168.
} 
III da Constituição Federal) e em recurso extraordinário (art. 102, caput e inciso III da Constituição Federal), desde que configurados os seus pressupostos de admissibilidade.

Além da impugnação da interceptação ilícita em recurso, a lei processual também preconiza a possibilidade de utilização de outros meios de impugnação para reconhecimento da ilicitude da interceptação e a ordenação de seu desentranhamento e sucessiva inutilização: as ações autônomas, como o habeas corpus, o mandado de segurança e a revisão criminal. Algumas destas ações de impugnação ${ }^{114}$ podem ser promovidas já na fase pré-processual.

Se a ilicitude de interceptação repercutir, ainda que em potencial, em coação ou ameaça de coação à liberdade de locomoção de investigado ou de acusado, ${ }^{115}$ justifica a impetração de habeas corpus (art. $5^{\circ}$, caput e inciso LXVIII da Constituição Federal).

A ação de habeas corpus pode ser promovida tanto na fase investigativa, ${ }^{116}$ quanto na fase processual ${ }^{117}$ - mesmo que operado o trânsito em julgado de sentença, enquanto não

${ }^{114} \mathrm{O}$ traço característico que distinguem os recursos, dos quais já tratamos, das ações de impugnação é o seguinte: "pelo recurso, não se instaura uma nova relação processual (um novo processo), operando-se por ele um mero prosseguimento da relação processual já existente. Ao contrário, o meio autônomo de impugnação configura sempre o exercício de uma nova ação, dando vida a uma diversa relação jurídica processual." (GRINOVER, Ada Pellegrini; GOMES FILHO, Antonio Magalhães; FERNANDES, Antonio Scarance. Recursos no processo penal... op. cit., p. 27).

115 "A amplitude de proteção conferida ao indivíduo pelo habeas corpus decorre, fundamentalmente, da possibilidade de sua concessão em caráter preventivo, permitindo que o Judiciário se antecipe na apreciação da legalidade de uma prisão, antes mesmo que esta se concretize. Daí a distinção que se faz entre habeas corpus liberatório e preventivo: no primeiro, o que se pretende é a restituição da liberdade de alguém que se encontra efetivamente preso, ao passo que na segunda hipótese se pede a tutela antecipadamente, para evitar que a ameaça de prisão se efetive" (GRINOVER, Ada Pellegrini; GOMES FILHO, Antonio Magalhães; FERNANDES, Antonio Scarance. Recursos no processo penal... op. cit., p. 271). Já observamos que mesmo nas hipóteses de "admissibilidade" da interceptação de comunicação entre pessoas presentes, prevista na Lei n 9.034, de 1995 (quadrilha ou da "associação criminosa"), eventual interceptação autorizada é ilícita, por descumprimento das exigências para restrição das comunicações entre pessoas presentes (cf., supra, itens n. 2.6 e n. 5.3.1.1), o que, considerando a cominação de pena privativa de liberdade à primeira espécie delitiva, possibilita a impugnação por habeas corpus, se houver coação ilegal ou ameaça de coação ilegal à liberdade de locomoção.

${ }^{116}$ Em se verificando que a interceptação é fundamental para a formalização posterior da acusação - que, sem ela, não seria ofertada - o interessado pode requerer concessão de habeas corpus com o fim de obter a declaração da ilicitude da interceptação e o trancamento de inquérito policial, por falta de justa causa para a continuidade da investigação. Em semelhante sentido, manifesta-se ANTONIO SCARANCE FERNANDES, ao tratar da prova ilícita obtida na fase de inquérito policial (A lei de interceptação... op. cit., p. 66), e ao examinar a repercussão processual da prova obtida mediante quebra do sigilo financeiro ilícita (O sigilo e a prova... op. cit., p. 163).

${ }^{117}$ Havendo acusação fundada em interceptação ilícita, é possível a impetração de habeas corpus em favor do acusado, para se obter a declaração a inadmissibilidade da prova ilícita. Como consequência, há que ser ordenado o trancamento da ação penal por falta de justa causa, se não houver outros elementos nos quais se funde a ação penal. 
cumprida a pena - desde que a ilicitude das provas possa ser demonstrada de plano. Sendo o habeas copus o meio de impugnação de sentença, o tribunal deve anular a sentença, indicar as provas ilícitas e ordenar o seu desentranhamento. ${ }^{118}$

Entretanto, não se vislumbrando constrangimento ou ameaça de constrangimento à liberdade de locomoção, por meio de propositura de mandado de segurança (art. $5^{\circ}$, caput $\mathrm{e}$ inciso LXIX da Constituição Federal), ${ }^{119}$ a ilicitude de interceptação pode ser atacada, tanto na fase pré-processual, quanto na fase processual. ${ }^{120}$

Outra ação que possibilita a impugnação de ilicitude de interceptação é a revisão criminal. Embora seja menos recorrente, considerada a repercussão processual da interceptação ilícita para o desenrolar do processo, é possível que seja reconhecida em revisão criminal (art. 626, caput do Código de Processo Penal), desde que decisão condenatória tenha transitado em julgado. A decisão poderá ser desconstituída pela via da revisão criminal, com possível alteração de seu conteúdo, como resultado de juízo rescisório. ${ }^{121}$

Todos estes meios de impugnação, recursos e ações impugnativas, servem, portanto, para assegurar a legalidade de meios de investigação de prova, que, como vimos, são instrumentos voltados à descoberta de fontes de prova que interessem à persecução penal. Integram, pois, o regime processual penal da interceptação de comunicação entre pessoas presentes.

\footnotetext{
${ }^{118}$ Cf. GRINOVER, Ada Pellegrini; FERNANDES, Antonio Scarance; GOMES FILHO, Antonio Magalhães. As nulidades... op.cit., p. 136.

${ }^{119}$ Em relação à discussão de ilicitude na execução de meio de investigação de prova, MARIA THEREZA ROCHA DE ASSIS MOURA , tratando de quebra de sigilo bancário, observa que "é necessário verificar se há ou não constrangimento ou ameaça de constrangimento à liberdade de locomoção, para se concluir, no caso concreto, de habeas corpus ou mandado de segurança" (Meios de impugnação à quebra indevida de sigilo bancário. In: SALOMÃO, Heloisa Estellita (Coord.). Direito penal empresarial. São Paulo: Dialética, 2001, p. 179).

${ }^{120}$ Ao cogitarmos a possibilidade de impetração de mandado de segurança, imaginamos uma interceptação de comunicação entre pessoas presentes ilícita em persecução penal de delitos para os quais não seja cominada pena privativa de liberdade, ou, versando sobre delitos previstos na Lei $\mathrm{n}^{\circ} 9.605$, de 1998, a pessoa jurídica seja a suposta autora da infração. Também o terceiro que tenha sido interlocutor da interceptação ilícita pode impetrar mandado de segurança, para proteção de seu direito líquido e certo à intimidade, para evitar divulgação de segredo, por exemplo, garantindo a não inclusão de trechos da gravação, por não estarem relacionados à prova. Em semelhante sentido, sustentando a possibilidade de impetração de mandado de segurança por terceiro em interceptação de comunicação telefônica, cf.: FERNANDES, Antonio Scarance. Processo penal... op. cit., p. 102. ${ }^{121}$ Cf. GRINOVER, Ada Pellegrini; FERNANDES, Antonio Scarance; GOMES FILHO, Antonio Magalhães. As nulidades... op. cit., p. 136.
} 


\subsubsection{O regime penal}

Visto o regime processual penal da interceptação de comunicação entre pessoas presentes, temos por relevante a avaliação da repercussão penal de uma conduta de captação ilícita do conteúdo desta espécie de comunicação. Isto porque, além da sanção processual aplicada à prova obtida em interceptação ilícita, interessa à sociedade a punição dos responsáveis pela prática da conduta ilícita.

No Brasil, hodiernamente, a tímida tutela penal da intimidade, no campo das conversações, cinge-se às telecomunicações, ${ }^{122}$ comunicações telefônicas e comunicações em sistemas de informática e telemática. Segundo previsto no art. 10 da Lei $\mathrm{n}^{\circ}$ 9.296, de 1996, "constitui crime realizar interceptação de comunicações telefônicas, de informática ou telemática, ou quebrar segredo da Justiça, sem autorização judicial ou com objetivos não autorizados em lei."

No direito brasileiro, não é incriminada a conduta de interceptação de comunicação entre pessoas presentes. Tampouco se tipificam as condutas de divulgação ou de utilização do conteúdo de comunicação entre pessoas presentes, captado lícita ou ilicitamente. Apesar de inexistente a incriminação dessas condutas, não significa que a comunicação presencial esteja desamparada penalmente.

Lembre-se de que a interceptação de comunicação entre pessoas presentes tem como espécie a interceptação domiciliar, na hipótese em que a comunicação ocorra em espaço tido por domicílio. ${ }^{123}$ A conduta de entrada ou de permanência em domicílio alheio ou em suas dependências para efetivação da interceptação de comunicação entre pessoas presentes pode caracterizar o delito previsto no art. 150 do Código Penal (violação de domicílio). ${ }^{124}$

\footnotetext{
${ }^{122}$ No que se refere às interceptações de telecomunicações, cf., também, supra, itens n. 3.8.1e n. 5.3.1.2.

${ }^{123}$ Quanto às espécies de comunicação entre pessoas presentes, cf., supra, itens n. 3.7, n. 3.7.1 e n. 3.7.2.

124 Os termos normativos do delito de violação de domicílio são os seguintes: "art. 150. Entrar ou permanecer, clandestina ou astuciosamente, ou contra a vontade expressa ou tácita de quem de direito, em casa alheia ou em suas dependências: pena - detenção, de um a três meses, ou multa. $\S 1^{\circ}$. Se o crime é cometido durante a noite, ou em lugar ermo, ou com o emprego de violência ou de arma, ou por duas ou mais pessoas: pena - detenção, de seis
} 
A conduta de interceptação ambiental, também modalidade da interceptação de comunicação entre pessoas presentes, se ocorrida em local que não seja domicílio, ${ }^{125}$ não é tutelada pela legislação penal.

Além disso, a conduta de divulgação do conteúdo de conversa entre pessoas presentes gravada por um dos interlocutores, ${ }^{126}$ não havendo justa causa, pode configurar o delito previsto no art. 154 do Código Penal, que tipifica a conduta de divulgação de segredo, sem justa causa, de se que tenha ciência em razão de função, ministério, ofício ou profissão, e cuja revelação possa produzir dano a outrem. ${ }^{127}$

De lege lata, é esse o regime penal de proteção das comunicações entre pessoas presentes. $^{128}$

meses a dois anos, além da pena correspondente à violência. $\S 2^{\circ}$. Aumenta-se a pena de um terço, se o fato é cometido por funcionário público, fora dos casos legais, ou com inobservância das formalidades estabelecidas em lei, ou com abuso do poder. $\S 3^{\circ}$. Não constitui crime a entrada ou permanência em casa alheia ou em suas dependências: I - durante o dia, com observância das formalidades legais, para efetuar prisão ou outra diligência; II - a qualquer hora do dia ou da noite, quando algum crime está sendo ali praticado ou na iminência de o ser. $\S$ $4^{\circ}$. A expressão "casa" compreende: I - qualquer compartimento habitado; II - aposento ocupado de habitação coletiva; III - compartimento não aberto ao público, onde alguém exerce profissão ou atividade. $\S 5^{\circ}$. Não se compreendem na expressão "casa": I - hospedaria, estalagem ou qualquer outra habitação coletiva, enquanto aberta, salvo a restrição do n..$^{\circ}$ II do parágrafo anterior; II - taverna, casa de jogo e outras do mesmo gênero."

${ }^{125}$ No que tange à interceptação ambiental, como espécie da interceptação de comunicação entre pessoas presentes, cf., supra, itens n. 3.7 e n. 3.7.2.

${ }^{126}$ Outras observações sobre a gravação de conversa entre pessoas presentes por um dos interlocutores constam no item n. 3.8.2, supra.

${ }^{127}$ Em outro sentido, ADA PELLEGRINI GRINOVER observa: "se a gravação em si não constitui - como não constitui - ilícito penal, sua divulgação - quando clandestina - pode configurar o crime de divulgação de segredo (art. 153 do Código Penal), tipificado como 'divulgar alguém, sem justa causa, conteúdo de documento particular ou de correspondência confidencial, de que é destinatário out detentor, e cuja divulgação possa produzir dano a outrem' (grifei)." (Do regime das interceptações telefônicas no projeto de novo CPP - Proposta de Emendas do IBDP. Boletim IBCCRIM, São Paulo, ano 18, ago. 2010, p. 2). No mesmo sentido, ANTONIO SCARANCE FERNANDES, em atenção ao disposto no art. 153 do Código Penal, afirma que é ilícita a conduta do destinatário ou do detentor de correspondência confidencial ou documento particular que, sem justa causa, divulga o seu conteúdo. O autor adverte que "a aferição da justa causa envolve a aplicação do princípio da proporcionalidade e só se justifica a utilização do conteúdo secreto como prova quando, em determinado caso, há necessidade de se dar proteção a bem de maior valor do que o preservado pelo sigilo do segredo, desde que também esteja amparado constitucionalmente" (Processo penal... op. cit., p. 92).

${ }^{128}$ Como visto anteriormente, a inviolabilidade do sigilo das comunicações presenciais são expressão do direito à intimidade e à vida privada (cf., supra, item n. 2.3). No Brasil, há tempos se afirma a necessidade de um aprimoramento da tutela penal da intimidade. Vejam-se, a propósito do tema, as ponderações de PAULO JOSÉ DA COSTA JUNIOR: "a tutela penal da intimidade só se fez, no direito brasileiro, de forma mediata e insuficiente, por meio de normas que protegem a honra e o segredo. A insuficiência do jus conditum brasileiro não impede, contudo, que se admita a relevância da intimidade. Que se reconheça a existência do bem. Que se 
Uma observação da mais alta relevância é necessária: a ausência de tipificação penal da interceptação de comunicação entre pessoas presentes realizada não exclui a possibilidade de considerá-la ilícita sob a perspectiva processual penal, pois são ilícitas as provas obtidas por meio da violação aos direitos e garantias individuais que fundamentam a tutela das comunicações entre pessoas presentes. ${ }^{129}$

Volvendo aos fundamentos constitucionais da tutela das comunicações entre pessoas presentes (a liberdade de manifestação do pensamento, o direito à intimidade e à vida privada, a inviolabilidade do domicílio e o direito a não autoincriminação) ${ }^{130}$ e ao caráter insidioso de sua restrição, ${ }^{131}$ identificamos que constituem um valor relevante, merecedor de amparo penal.

Entendemos, por isso, que, além da disciplina processual penal específica para a interceptação de comunicações entre pessoas presentes, é preciso instituir uma disciplina penal, igualmente específica.

A nosso ver, devem ser incriminadas não só a conduta de interceptação de comunicação entre pessoas presentes que divergirem das hipóteses e do procedimento previstos em lei, como também a conduta de divulgação e de utilização do conteúdo da comunicação entre pessoas presentes, captado lícita ou ilicitamente. ${ }^{132}$ Desta forma, protege-se

enfatize a dignidade social interior. Sobretudo após a Constituição de 1988, em seu art. $5^{\circ}, \mathrm{X}$, ter declarado invioláveis a intimidade e a vida privada. Mas a verdadeira tutela da intimidade não é ainda admissível, por carência normativa. $\mathrm{O}$ direito à intimidade deriva do espírito do sistema, do complexo da valoração normativa do nosso direito, da consciência social, das idéias e tendências dominantes. Pode-se indubitavelmente afirmar que o nosso direito é propenso a conferir tutela ao bem jurídico da intimidade. E que, se não se configura ainda, diante do direito positivo brasileiro, um direito à intimidade, concretiza-se ao menos um direito à conservação e ao respeito da vida privada." (O direito de estar só... op. cit., p. 114-115).

${ }^{129}$ Os direitos e garantias individuais que fundamentam a tutela das comunicações entre pessoas presentes foram expostos nos itens n. 2.2 a 2.5, e 5.1, supra. No que se refere à prova ilícita e à garantia da inadmissibilidade de provas obtidas por meios ilícitos, cf., supra, itens n. 1.2.3.1e n. 1.6.

${ }^{130}$ Os fundamentos constitucionais das comunicações entre pessoas presentes estão expostos no Capítulo $2^{\circ}$ (itens n. 2.2 a 2.5 , supra).

${ }^{131} \mathrm{O}$ caráter insidioso da restrição às comunicações entre pessoas presentes é examinado, com especial ênfase à restrição operada por interceptação de comunicação entre pessoas presentes, no Capítulo $3^{\circ}$ (item n. 3.9).

${ }^{132}$ Neste sentido, cf.: GRINOVER, Ada Pellegrini. Novo anteprojeto... op. cit., p. 21. 
tanto o segredo, quanto a reserva do conteúdo da comunicação, que igualmente interessam aos interlocutores de uma conversa em âmbito privado. ${ }^{133}$

Com efeito, a criminalização de tais condutas contribuirá para evitar indevidas intromissões nas diferentes esferas privadas, por meio de captação abusiva e desmedida de comunicações entre pessoas presentes, porque estimula a observância dos direitos e garantias que fundamentam a tutela das comunicações entre pessoas presentes. Intimidar-se-ão tanto os particulares, quanto as autoridades públicas, porquanto o sujeito ativo dos indigitados delitos haverá que ser comum.

\subsection{Projetos de lei sobre a interceptação de comunicação entre pessoas presentes}

Os problemas constatados no atual regime da interceptação de comunicações entre pessoas presentes no direito processual penal brasileiro não se encerram no plano do direito positivado. Há projetos de lei em trâmite no Congresso Nacional sobre o tema, ${ }^{134}$ também com deficiências, às quais se soma a vagarosa dedicação do Poder Legislativo no exame da matéria, postergando a feitura de uma legislação que observe as exigências para a restrição das comunicações entre pessoas presentes. ${ }^{135}$

O Projeto de Lei n. 3.514, de 1989, também conhecido por Projeto Miro Teixeira, que cuidava com mais zelo de meios de investigação de prova restritivos da inviolabilidade do sigilo das comunicações, referia-se à licitude de gravação de conversa entre presentes feita por um dos interlocutores, destinada à prova de um direito ameaçado ou violado (art. 12). Não preconizava a interceptação de comunicações entre pessoas presentes.

\footnotetext{
${ }^{133}$ Os interesses no segredo e na reserva integram o direito à intimidade e à vida privada, consoante exposto em considerações específicas no item n. 2.3 do Capítulo $2^{\circ}$.

${ }^{134}$ As informações pertinentes aos Projetos de Lei mencionados no presente item foram extraídas do site da Câmara dos Deputados (disponível em: http://www.camara.gov.br/sileg; acesso em: 29/12/2010) e do Senado (disponível em: http://www.senado.gov.br/atividade/materia/getPDF.asp?t=85509\&tp=1; acesso em: $10 / 01 / 2011)$.

${ }^{135}$ Quanto às exigências para a restrição das comunicações entre pessoas presentes, cf., supra, item n. 2.6 e item n. 3.10.
} 
O mesmo se pode dizer quanto ao Projeto de Lei n. 1.258, de 1995, no qual se reproduziram disposições do projeto mencionado no excerto anterior (art. 12).

Em 2007, apresentou-se o Projeto de Lei n. 1.443. Pretende-se regular, em conjunto com a interceptação de comunicações telefônicas, a então intitulada "captação de imagem e som ambiental por todos os meios, para prova em investigação criminal e em instrução processual penal" (art. $1^{\circ}$ ). Note-se que esta proposta legislativa sequer se refere à interceptação domiciliar.

No ano seguinte, foi apresentado o Projeto de Lei n. 3.272, de 2008, no qual se propõe disciplina para a interceptação de comunicação telefônica. Em seu art. 20, prevê-se: "as gravações ambientais de qualquer natureza, quando realizadas pela autoridade policial, sujeitam-se às disposições desta Lei, no que couber." Nele também não se dispõe sobre a interceptação domiciliar.

Disposição normativa semelhante consta, também, do Projeto de Lei n. 4.047, de 2008, outra proposta de disciplina para a interceptação de comunicação telefônica. Conforme disposto em seu art. 23: "a captação e a interceptação ambiental de sinais eletromagnéticos, óticos ou acústicos, e o seu registro e análise sujeitam-se às disposições desta Lei, no que couber." Uma vez mais, a interceptação domiciliar não é referida.

Em 2009, três projetos de lei apresentados se referem ao tema.

O Projeto de Lei n. 5.285, de 2009, é uma proposta normativa semelhante à do Projeto de Lei n. 1.443, de 2007, versando, em conjunto com a interceptação de comunicação telefônica, de "captação de imagem e som ambiental por todos os meios, para prova em investigação criminal e em instrução processual penal" (art. $1^{\circ}$ ).

No Projeto de Lei n. 5.286, do mesmo ano, que também visa à regulamentação de interceptação de comunicação telefônica é previsto, em seu art. $2^{\circ}$ : "submetem-se ao mesmo 
regime jurídico, o registro, a análise e a utilização da informação contida nas comunicações objeto de quebra de sigilo por ordem judicial, o fluxo de comunicações em sistemas de tecnologia da informação e telemática e a captação de imagem e som ambiental por todos os meios."

Ainda no ano de 2009, iniciou-se a tramitação de projeto de novo Código de Processo Penal (Projeto de Lei do Senado n. 156, de 2009), no qual se disciplina espécies de meios de investigação de prova. Entre as propostas formuladas na tramitação do aludido projeto está a de inserção, na disciplina da interceptação de comunicação telefônica, de dispositivo com os seguintes termos normativos: "as gravações ambientais de qualquer natureza, quando realizadas pela autoridade policial, sujeitam-se às disposições desta seção, no que couber."136

Note-se que as propostas normativas apresentadas sobre o tema da interceptação de comunicação entre pessoas presentes versam sobre a instituição de disciplina jurídica, de forma conjunta com a interceptação de comunicação telefônica.

De acordo com o que afirmamos, ao tratarmos das propostas sobre a autonomia da disciplina jurídica da interceptação de comunicação entre pessoas presentes, o tratamento de forma semelhante ao da interceptação de telecomunicação é proposto com vistas voltadas à técnica processual empregada em tais institutos: a interceptação. ${ }^{137}$

No entanto, deve-se atentar para o objeto do primeiro instituto: a comunicação presencial, cuja interceptação implica a restrição, de forma mais intensa e insidiosa de direitos e garantias fundamentais. E, com fulcro em seu objeto (as comunicações presenciais), deve-se regulamentar a interceptação de comunicação entre pessoas presentes de forma autônoma, sob a perspectiva tanto da admissibilidade, quanto do procedimento probatório. ${ }^{138}$

É por tais razões que, da promulgação da Constituição Federal, em 15 de outubro de 1998, ao dias atuais, evidencia-se um verdadeiro retrocesso em termos de tutela da

\footnotetext{
${ }^{136}$ Cf. INSTITUTO BRASILEIRO DE DIREITO PROCESSUAL. Propostas de emendas... op. cit., p. 26.

${ }^{137}$ Cf., supra, item n. 3.10.

${ }^{138}$ Cf., supra, item n. 3.10.
} 
comunicação entre pessoas presentes: o Poder Constituinte consagrou os direitos e garantias que a fundamentam, mas não foi acompanhado pelo Poder Legislativo, em sua missão de tutelá-la em legislação infraconstitucional. Para tanto seria necessária a elaboração de disciplina de institutos que atenda às exigências para a restrição legítima das comunicações entre pessoas presentes, o que, definitivamente, não ocorreu.

\subsection{Sugestões de lege ferenda}

A interceptação de comunicação entre pessoas presentes, como procuramos evidenciar nas observações precedentes, não pode ser ignorada.

A falta de uma disciplina legal deste meio de prova que atenda às exigências para a restrição das comunicações entre pessoas presentes, de um lado, pode ocasionar intromissões indevidas em liberdades alheias, nelas incluída a intimidade; por outro, a sociedade brasileira e os órgãos públicos que a integram deixam de contar com a possibilidade de utilização de instrumento eficaz para a persecução penal.

É indispensável, portanto, que este meio de prova seja minuciosamente regulamentado, por meio de uma disciplina legal específica, clara e precisa, a fim de que possa ser admitido, observados os seus requisitos e limites normativos. Assim, ao mesmo tempo em que se protege o indivíduo contra ingerências indevidas em suas liberdades, possibilita-se ao Poder Público a utilização de um instrumento para a descoberta de fontes de prova na persecução de crimes de elevada gravidade.

E chegado ao fim desta análise crítica, tomamos a liberdade, com a devida licença, de usarmos os resultados do presente trabalho para a formulação de sugestões de iure condendo, com a apresentação de bases que temos por relevantes para a disciplina legal da interceptação de comunicação entre pessoas presentes Parece-nos necessário ser estabelecido em lei: 
a) as espécies de delitos em cuja persecução penal se admita a interceptação ambiental, restringindo-a a crimes graves, considerada a relevância do bem jurídico tutelado;

b) as espécies de delitos em cuja persecução penal se admita, durante o dia, a interceptação domiciliar, restringindo-a também a crimes graves, considerada a relevância do bem jurídico tutelado, de forma mais restrita do que a especificação de delitos para os quais se admita a interceptação ambiental;

c) o requisito de existência de elementos robustos e concretos de materialidade e autoria da prática de um dos delitos para os quais se admita a interceptação de comunicação entre pessoas presentes, a interceptação domiciliar ou a interceptação ambiental;

d) o requisito de necessidade de utilização da interceptação de comunicação entre pessoas presentes, de modo que somente se autorize a utilização se houver elementos da insuficiência de outros instrumentos para a elucidação dos fatos;

e) a exigência de autorização judicial motivada, com prazo de duração razoável, admitindo-se prorrogação, desde que comprovada a sua necessidade;

f) os sujeitos ativos da interceptação de comunicação entre pessoas presentes, com atribuição de legitimidade ativa ao Ministério Público, ao ofendido, ao acusado, representado por seu defensor, e a autoridade policial, e a atribuição da execução da operação técnica aos órgãos da polícia repressiva;

g) os sujeitos passivos da interceptação de comunicação entre pessoas presentes, vedando-se a interceptação de comunicação entre investigados ou acusados e profissionais, e entre investigados ou acusados e familiares, ressalvada a possibilidade de interceptação destas comunicações se houver elementos de que os profissionais e os familiares tenham participado da prática do delito investigado; 
h) os requisitos formais do requerimento de interceptação de comunicação entre pessoas presentes, exigindo-se: a apresentação da qualificação do investigado ou do acusado, ou de elementos que possibilitem a sua identificação; a qualificação do fato investigado; a indicação de elementos concretos de materialidade e de autoria delitivas e da necessidade de utilização da interceptação; a indicação da espécie de interceptação; a indicação do local onde se pretenda interceptar a comunicação e dos elementos que liguem o acusado ou o investigado ao local; a indicação do meio técnico a ser empregado; o modo de inserção do meio técnico no local; o modo de utilização do meio técnico; o período em que se pretenda operar a interceptação;

i) os requisitos formais da autorização judicial de interceptação de comunicação entre pessoas presentes, exigindo-se: a apresentação da qualificação do investigado ou do acusado, ou de elementos que possibilitem a sua identificação; a qualificação do fato investigado; a indicação de elementos concretos de materialidade e de autoria delitivas e da necessidade de utilização da interceptação; a indicação da espécie de interceptação; a indicação do local onde se pretenda interceptar a comunicação; a indicação do meio técnico a ser empregado; o modo de inserção do meio técnico no local e dos elementos que liguem o acusado ou o investigado ao local; o modo de utilização do meio técnico; o período em que se pretenda operar a interceptação; o prazo de sua duração;

j) a indispensabilidade de lavratura de auto circunstanciado das diligências efetuadas, de manutenção de registros, até o trânsito em julgado de sentença, e de transcrição do conteúdo da comunicação entre pessoas presentes;

k) a obrigatoriedade de ciência, quando concluída a interceptação, ao investigado ou ao acusado, aos seus defensores, e a terceiros que tenham sido interlocutores da comunicação, assegurando-lhes o acesso aos resultados e a reprodução da documentação da interceptação, bem como o requerimento de destruição de trechos da comunicação que não interessem para a persecução penal; 
l) a impossibilidade de utilização dos resultados de interceptação de comunicação entre pessoas presentes em investigações ou processos diferentes daqueles para os quais foi autorizada, ressalvando-se a hipótese de conexão, continência ou de outro delito para o qual seja admitida a interceptação;

m) a impossibilidade de utilização de prova obtida em interceptação de comunicação entre pessoas presentes sem a observância das prescrições legais, considerada a sua inadmissibilidade;

n) o resguardo sob sigilo da tramitação da interceptação de comunicação entre pessoas presentes, de investigações ou de processos que contiverem provas ou elementos informativos nela obtidos e da manutenção dos respectivos registros.

Uma última observação: a vida em sociedade exige o constante progresso e aprimoramento das instituições jurídicas, sempre com vistas voltadas a amoldá-las à dignidade da pessoa humana. Ficam estas sugestões no horizonte da história do direito processual penal brasileiro, como proposta para reflexão e instituição de uma disciplina jurídica autônoma para a interceptação de comunicações entre pessoas presentes. 


\section{CONCLUSÃO}

A interceptação de comunicação entre pessoas presentes, tema atual e polêmico, é permeada por muitas questões, relacionadas a sua complexa natureza jurídica, aos fundamentos constitucionais da tutela das comunicações presenciais e aos aspectos que devem integrar a sua disciplina jurídica.

O encerramento da pesquisa efetuada sobre o tema deve vir acompanhada da exposição sistemática das conclusões a que chegamos na feitura do trabalho. Algumas delas foram antecipadas no desenvolvimento dos capítulos; outras, nas sugestões de lege ferenda formuladas como proposta de disciplina jurídica para o direito brasileiro. Por dever de síntese, passamos a registrá-las:

a) os meios de investigação de prova, institutos previstos no direito processual penal brasileiro, são instrumentos jurídicos destinados a descoberta de fontes de prova para a persecução penal. Trata-se de medidas cautelares que propiciam restrição legítima a direitos e garantias fundamentais, desde que os meios de investigação de prova sejam típicos, extraordinários e repressivos;

b) a eficácia probatória dos meios de investigação de prova, em regra, refere-se à descoberta de fontes de prova; de forma excepcional, a eficácia probatória se estende por eventuais elementos de informação que sejam conhecidos em conjunto com a descoberta de fontes de prova;

c) é cominada às provas obtidas por meios ilícitos e às provas dela derivadas, em regra, a sanção processual de inadmissibilidade, que implica sua inexistência jurídica; de forma excepcional, admitem-se provas ilícitas e provas dela derivadas, desde que preponderem valores constitucionais superiores à exigência de legalidade probatória; 
d) as comunicações entre pessoas presentes são tuteladas pela Constituição da República Federativa do Brasil, de forma implícita. Os direitos e garantias individuais que fundamentam a tutela das comunicações entre pessoas presentes são: a liberdade de manifestação do pensamento, que tem como espécie a liberdade de comunicação entre pessoas presentes; o direito à intimidade e à vida privada, do qual decorre a inviolabilidade do sigilo das comunicações entre pessoas presentes; a inviolabilidade do domicílio; e o direito a não autoincriminação;

e) embora assegurada constitucionalmente, é admissível a restrição às comunicações entre pessoas presentes, observadas as seguintes exigências: a reserva de lei, a reserva de jurisdição e a proporcionalidade. Uma das formas de restrição à comunicação entre pessoas presentes é a sua interceptação;

f) a interceptação de comunicação entre pessoas presentes é instrumento processual que consiste em atividade de captação e de registro de comunicação entre pessoas presentes de caráter reservado, por um terceiro, com o emprego de meios técnicos, utilizados em operação oculta e simultânea à comunicação, sem o conhecimento dos interlocutores ou com o conhecimento de um ou de alguns deles;

g) para restringir, de maneira legítima, as comunicações entre pessoas presentes, a interceptação deve ser meio de investigação de prova típico, extraordinário e repressivo;

h) a interceptação de comunicação entre pessoas presentes é gênero, do qual decorrem duas espécies: a interceptação domiciliar e a interceptação ambiental. O local em que é executada a interceptação de comunicação entre pessoas presentes diferencia as suas espécies: em domicílio, a interceptação é domiciliar; em espaço físico que não seja caracterizado domicílio, a interceptação é ambiental; 
i) o objeto da interceptação de comunicação entre pessoas presentes, a comunicação presencial, implica intensificação do seu caráter insidioso e, por consequência, maior grau de restrição a direitos e garantias fundamentais;

j) as especificidades da interceptação de comunicação entre pessoas presentes justificam a instituição de uma disciplina distinta da disciplina da interceptação de telecomunicações. A autonomia da disciplina da interceptação de comunicação entre pessoas presentes se opera sob dois planos: a admissibilidade, mais restrita, se comparada com a da interceptação de telecomunicações; e o procedimento probatório, que propicie a delimitação e a realização do modo da interceptação, bem como a sua avaliação pelos seus sujeitos;

k) em disciplina de interceptação de comunicação entre pessoas presentes, a admissibilidade da interceptação domiciliar deve ser mais restrita do que a da interceptação ambiental;

l) devem ser dispostos em disciplina de comunicação entre pessoas presentes os seguintes aspectos: requisitos; sujeitos ativos; sujeitos passivos; autoridade competente para autorização; requisitos do requerimento; requisitos da autorização; prazo de duração; procedimento probatório, integrado pelas fases de autorização, de execução e de documentação; utilização dos resultados da interceptação em outros processos ou investigações; proibição de utilização dos resultados de interceptação que contrarie as normas da disciplina; o resguardo sob sigilo da tramitação da interceptação, dos feitos que a ela se refiram e da manutenção dos respectivos registros;

m) no direito processual penal brasileiro, a interceptação de comunicação entre pessoas presentes, cujo regime é previsto na Lei n. 9.034, de 1995, é um meio de investigação de prova atípico;

n) os fundamentos da atipicidade das espécies de interceptação de comunicação entre pessoas presentes são diferentes: a interceptação ambiental é atípica por ausência de 
procedimento probatório; a interceptação domiciliar é atípica por ausência de admissibilidade e de procedimento probatório;

o) na admissibilidade da interceptação ambiental preconizada na Lei n. 9.034, há graves deficiências decorrentes da incompletude dos aspectos que devem constar em lei e da inobservância da proporcionalidade no plano normativo, as quais devem ser somadas à ausência de procedimento probatório que a torna atípica;

p) o regime instituído na Lei $\mathrm{n}^{\circ}$ 9.034, de 1995 não possibilita a observância das exigências para a restrição de comunicações entre presentes por meio de interceptação: a reserva de lei, a reserva de jurisdição e a proporcionalidade. Interceptação de comunicação entre pessoas presentes que seja operada, sob o regime previsto na Lei n ${ }^{\circ} 9.034$, de 1995, ou fora deste regime, é ilícita;

q) não é possível a aplicação, por analogia, à interceptação de comunicação entre pessoas presentes do procedimento probatório previsto, para a interceptação de telecomunicações, na Lei n. 9.296, de 1996. Além de a interceptação de comunicação entre pessoas presentes integrar os meios de investigação de prova, para os quais não se admite a aplicação de procedimento probatório por analogia, há evidentes incompatibilidades entre o procedimento previsto na Lei n. 9.296 e o instituto da interceptação de comunicação entre pessoas presentes;

r) a ilicitude de interceptação de comunicação entre pessoas presentes pode ser contestada em momentos procedimentais de ritos processuais, em recursos e em ações impugnativas;

s) a comunicação entre pessoas presentes, como valor relevante para a sociedade brasileira, consagrado constitucionalmente, deve ser penalmente amparada, por meio da incriminação da conduta de interceptação de comunicação entre pessoas presentes que divergirem das hipóteses e do procedimento previstos em lei, como também da conduta de 
divulgação e de utilização do conteúdo da comunicação entre pessoas presentes, captado lícita ou ilicitamente;

Eis as conclusões a que chegamos sobre a interceptação de comunicação entre pessoas presentes no direito processual penal brasileiro. São considerações que reputamos voltadas ao aprimoramento da disciplina jurídica deste instituto, para o efetivo resguardo dos direitos e garantias individuais que fundamentam a tutela das comunicações presenciais e, por conseguinte, para proteção à dignidade da pessoa humana. 


\title{
BIBLIOGRAFIA
}

\begin{abstract}
A
AGUILAR, Francisco. Dos conhecimentos fortuitos obtidos através de escutas tefefónicas. Coimbra: Almedina, 2004.
\end{abstract}

ALEXY, Robert. Teoria dos Direitos Fundamentais. Tradução de Virgílio Afonso da Silva. São Paulo: Malheiros, 2008.

ALMA, Marco Maria. Intercettazioni telefoniche e ambientali: questioni giurisprudenciali. Brescia: Consiglio Superiore della Magistratura, 2007.

ALMEIDA, Carlos Alberto Simões de. Medidas cautelares e de polícia do processo penal em direito comparado. Coimbra: Almedina, 2006.

AMBOS, Kai; BELING, Ernest; GUERRERO, Julián Óscar. Las prohibiciones probatorias. Bogotá: Editorial Temis, 2009.

AMODIO, Ennio. Libero convincimento e tassatività dei mezzi di prova: un approccio comparativo. Rivista Italiana di Diritto e Procedura Penale, Milano, Giuffrè, anno XLII, p. 39, gen-mar. 1999.

ANDRADE, Manuel da Costa. Métodos ocultos de investigação (Plädoyer para uma teoria geral). In: COLÓQUIO EM HOMENAGEM AO INSTITUTO BRASILEIRO DE CIÊNCIAS CRIMINAIS, 2007, Coimbra. Justiça Penal Portuguesa e brasileira: tendências e reforma. 1. ed. São Paulo: IBCCRIM, 2008. p. 99-118. 
. Das Escutas telefônicas. In: SILVA, Marco Antonio da (Coord.). Direito penal especial, processo penal e direitos fundamentais: visão luso-brasileira. São Paulo: Quartier Latin do Brasil, 2006, p. 205-213.

. Sobre as Proibições de Prova em Processo Penal. Coimbra: Coimbra Ed., 1992.

. Sobre o regime processual penal das escutas telefônicas. Revista Portuguesa de Ciência Criminal, Lisboa, Aequitas, ano I, fasc. 3, p. 369-408, jul-set. 1991.

APRILE, Ercole; SPIEZIA, Filippo. Le intercettazioni telefoniche ed ambientali: innovazioni tecnologiche e nuove questioni giuridiche. Milano: Giuffrè, 2004. (Teoria e Pratica del Diritto, sez. III, n. 133. Diritto e Procedura Penale).

La prova penale (artt. 187-271 cod. proc. pen.). Milano: Giuffrè, 2002. (Pratica giuridica: dottrina e giurisprudenza nella casistica. Senconda serie diretta de O. Fanelli, n. 12).

ARANTES FILHO, Marcio Geraldo Britto. A regulamentação do sigilo das comunicações entre pessoas presentes e do sigilo profissional no direito processual penal chileno. Revista Brasileira de Ciências Criminais, São Paulo, RT, n. 80, p. 208-245, set-out. 2009.

ARISTÓTELES. A Política. Tradução de Nestor Silveira Chaves. São Paulo: Editora Escala, [2010]. (Coleção Grandes Obras do Pensamento Universal, n. 16).

ÁVILA, Cynthia; BORINSKY, Mariano; FERNÁNDEZ, Eduardo; LAGO, Daniel. Primeira parte: los sistemas nacionales europeos: el sistema procesal penal español. In: HENDLER, Edmundo S. (Dir.). Sistemas procesales penales comparados. 1. ed. Buenos Aires: Ad-Hoc S.R.L, 1999.

ÁVILA, Humberto. Teoria dos princípios: da definição à aplicação dos princípios jurídicos. 7. ed. São Paulo: Malheiros, 2007. 
AVOLIO, Luiz Francisco Torquato. Provas ilícitas - interceptações telefônicas, ambientais e gravações clandestinas. 3. ed. São Paulo: RT, 2003.

BACIGALUPO, Enrique. Derecho Penal y El Estado de Derecho. 1. ed. Santiago: Editorial Juridica de Chile, 2005.

BADARÓ, Gustavo Henrique Righi Ivahy. Interceptações de comunicações telefônicas e telemáticas: limites ante o avanço da tecnologia. In: LIMA, José Corrêa de; CASARA, Rubens R. R. (Coords.). Temas para uma perspectiva crítica do Direito: homenagem ao Professor Geraldo Prado. Rio de Janeiro: Lumen Juris, 2010. p. 483-499.

. Correlação entre acusação e sentença. 2. ed. São Paulo: RT, 2009.

. Direito processual penal: tomo II. 2. ed. Rio de Janeiro: Elsevier, 2009.

; LOPES JR., Aury. Direito ao processo penal no prazo razoável. 2. ed. Rio de Janeiro: Lumen Juris, 2009.

. Direito processual penal: tomo I. 1. ed. Rio de Janeiro: Elsevier, 2008.

; GOMES FILHO, Antonio Magalhães. Prova e sucedâneos de prova no processo penal brasileiro. Revista Brasileira de Ciências Criminais, São Paulo, RT, n. 65, p. 175-208, mar-abr. 2007.

. Provas atípicas e provas anômalas: inadmissibilidade da substituição da prova testemunhal pela juntada de declarações escritas de quem poderia ser testemunha. In: YARSHELL, Flávio Luiz; MORAES, Maurício Zanoide de (Orgs.). Estudos em Homenagem à Professora Ada Pellegrini Grinover. 1. ed. São Paulo: DPJ, 2005. p. 341-352. 
Ônus da prova no processo penal. 1. ed. São Paulo: RT, 2003.

BADARÓ, Gustavo Henrique Righi Ivahy. Vícios de Motivação da sentença penal: ausência de motivação, motivação contraditória, motivação implícita e motivação per relationem. Revista Brasileira de Ciências Criminais, São Paulo, Ano 9, n. 38, p. 122-141, abr-jun. de 2002.

BALDUCCI, Paola. Le garanzie nelle intercettazioni tra costituzione e legge ordinaria. Milano: Giuffrè, 2002. (Studi di diritto processuale penale, raccolti da Giovanni Conso, n. 95).

BARGI, Alfredo. Intercettazioni di comunicazioni o conversazioni. In: Digesto delle Discipline Penalistiche: aggiornamento. 4. ed. Torino: UTET, 2005. Tomo I: A-M, p. 788-804.

BARROS, Romeu Pires de Campos. Processo penal cautelar. Rio de Janeiro: Forense, 1982.

BAS, Alexandre H. Català. La problemática adecuación de la legislación española sobre escuchas telefónicas a las exigencias del Convenio europeo de derechos humanos y sus consecuencias. Revista del Poder Judicial, Madrid, ano II, n. 66, p. 14-71, 2002.

BASTOS, Celso Ribeiro; MARTINS, Ives Gandra. Comentários à Constituição do Brasil: promulgada em 5 de outubro de 1988. São Paulo: Saraiva, 1988. v. 2.

BEDAQUE, José Roberto dos Santos. Tutela cautelar e tutela antecipada: tutelas sumárias e de urgência (tentativa de sistematização). 5. ed. São Paulo: Malheiros, 2009.

BELING, Ernest; AMBOS, Kai; GUERRERO, Julián Óscar. Las prohibiciones probatorias. Bogotá: Editorial Temis, 2009. 
BELLOQUE, Juliana Garcia. O recrudescimento da repressão ao crime e as garantias da prova oral. 2007. Tese (Doutorado) - Faculdade de Direito, Universidade de São Paulo (USP), São Paulo, 2007.

. Sigilo Bancário: análise crítica da LC 105/2001. São Paulo: RT, 2003.

. Nova disciplina jurídica da quebra do sigilo das comunicações telefônicas. Boletim IBCCRIM, São Paulo, Ano 11, n. 127, p. 12, jun. 2003.

BORINSKY, Mariano; ÁVILA, Cynthia; FERNÁNDEZ, Eduardo; LAGO, Daniel. Primeira parte: los sistemas nacionales europeos: el sistema procesal penal español. In: HENDLER, Edmundo S. (Dir.). Sistemas procesales penales comparados. 1. ed. Buenos Aires: Ad-Hoc S.R.L, 1999.

BOSCO, Dario; ZAPPALÀ, Angelo; MARCHETTI, Daniela. Intercettazioni telefoniche e ambientali: metodi, limiti e sviluppi nella trascrizione e verbalizzazione. Torino: Centro Scientifico Editore, 2007.

BOULOC, Bernard; STEFANI, Gaston; LEVASSEUR, Georges. Procédure Pénale. 17. ed. Paris: Dalloz, 2000.

BRANDEIS, Louis D; WARREN, Samuel D. The right to privacy. Harvard Law Review, V. IV, n. 5, dec.1890. Disponível em: http://faculty.uml.edu/sgallagher/Brandeisprivacy.htm. Acesso em: 07/09/2010.

BRASIL. Senado. Projeto de Lei do Senado n. 156, de 2009. Disponível em: http:/www.senado.gov.br/atividade/materia/getPDF.asp?t=85509\&tp=1. Acesso em: $10 / 01 / 2011$. 
BRASIL. Senado. Comissão de Juristas responsável pela elaboração de anteprojeto de reforma do Código de Processo Penal. Anteprojeto. Brasília: Senado Federal, 2009. Disponível em: http://legis.senado.gov.br/mate-pdf/58503.pdf. Acesso em: 04/10/2009.

BRUNO, Pierfrancesco. Intercettazioni di comunicazioni o conversazioni. In: Digesto delle Discipline Penalistiche. 4. ed. Torino: UTET, [2001]. v. VII, p. 175-207.

\section{C}

CALAMANDREI, Piero. Introduzione allo studio sistematico dei provedimenti cautelari. In: CAPPELLETTI, Mauro (Org.). Opere Giuridiche. Napoli: Moriano, 1983. v. IX, p. 157-254.

- Introdução ao Estudo Sistemático dos Procedimentos Cautelares. Tradução de Carla Roberta Andreasi Bassi. Campinas: Servanda, 2000.

CALMON FILHO, Petrônio. A investigação criminal na reforma do Código de Processo Penal: agilidade e transparência. Revista Brasileira de Ciências Criminais, São Paulo, ano 9, n. 34, p. 63-106, abr-jun. 2001.

CANTONE, Raffaele. La prova documentale. Milano: Giuffrè, 2004.

CAPRARO, Laura. Intercettazioni in autoventtura, eccezionali ragioni di urgenza e motivazione per relationem. Rivista Italiana di Diritto e Procedura Penale, Milano, Giuffrè, anno XLV, p. 1441-1461, 2002.

CAPRIOLI, Francesco. Intercettazione e registrazione di colloqui tra persone presenti nel passaggio dal vecchio al nuovo codice di procedura penale. Rivista Italiana di Diritto $e$ Procedura Penale, Milano, Giuffrè, anno XXXIV, p. 143-177, 1991.

CARBONE, Carlos Alberto. Grabaciones, Escuchas telefônicas y filmaciones como medios de prueba. Santa fé: Rubinzal-Culzoni, 2005. 
CARMONA, Claudia. Le intercettazioni ambientali in relazione alla normativa del 1991 sui reati di criminalità organizzata. Rivista Italiana di Diritto e Procedura Penale, Milano, Giuffrè, anno XLII, fasc. 1, p. 344-358, gen/mar. 1999.

CARNUCCIO, Paolo. Strategie e tecniche difensive in tema di intercettazioni. Torino: Giappichelli, 2007.

CATENA, Víctor Moreno; SENDRA, Vicente Gimeno; DOMÍNGUEZ, Valentín Cortés. Lecciones de Derecho Procesal Penal. 2. ed. Madrid: Colex, 2007.

CAVERO, José Martínez de Pisón. La configuración constitucional del derecho a la intimidad. Derechos y Libertades: Revista del Instituto Bartolome de Las Casas, Madrid, año II, n. 3, p. 313-340, may-dic. 1994.

CAZERTA, Therezinha Astolphi. Meios eletrônicos no processo penal. Revista do Tribunal Regional Federal da $3^{a}$ Região, São Paulo, v. 76, p. 101-123, mar-abr. 2006.

CERNICCHIARO, Luiz Vicente. Lei 9296/96: interceptação telefônica. Boletim IBCCRIM, São Paulo, n. 47, p. 3, out. 1996.

CERVETTI, Fernanda. Captazione indebita di dialoghi tra imputati detenuti. Rivista Italiana di Diritto e Procedura Penale, Milano, Giuffrè, Anno XIX, fasc. 3, p. 1.102-1.111, lug-set. 1976.

CHAIA, Rubén A. La prueba en el proceso penal. 1. ed. Buenos Aires: Hammurabi, 2010.

CHIAVARIO, Mario. O processo penal na Itália. In: DELMAS-MARTY, Mireille (Org.). Processo Penal e direitos do homem: rumo à consciência européia. Trad. Fernando de Freitas Franco. Barueri: Manole, 2004. p. 43-57. 
CHOUKR, Fauzi Hassan. Garantias constitucionais na investigação criminal. 2. ed. Rio de Janeiro: Lumen Juris, 2001.

CINTRA, Antonio Carlos de Araújo; GRINOVER, Ada Pellegrini; DINAMARCO, Cândido Rangel. Teoria Geral do Processo. 21. ed. São Paulo: Malheiros, 2005.

CIPRIANI, Simonetta. La protezione penale della riservatezza in diritto comparato italiano e francese. Rivista Italiana di Diritto e Procedura Penale, Milano, Giuffrè, anno XL, fasc. 3, p. 866-934, gen-mar. 1997.

COMOGLIO, Luigi Paolo. Prove ed accertamento dei fatti nel nuovo c.p.p. Rivista Italiana di Diritto e Procedura Penale, Milão, Giuffrè, anno XXXIII, fasc. 1, p. 113-147, gen-mar. 1990.

COMPARATO, Fábio Konder. Comissões Parlamentares de Inquérito: limites. Revista Trimestral de Direito Público, ano 2, n. 5, São Paulo, p. 66-74, 1994.

CONDE, Francisco Munoz; LANGHE, Marcela de. Presentación. In: ROXIN, Claus. La prohibición de autoincriminación y las escuchas domiciliarias. 1. ed. Buenos Aires: Hammurabi, 2008.

. Valoración de las grabaciones audiovisuales en el proceso penal. $2^{\mathrm{a}}$ ed. Buenos Aires: Hammurabi, 2007.

CORDERO, Franco. Procedura Penale. 3. ed. Milano: Giuffrè, 1995.

CORREIA, João Conde. Qual o significado de abusiva intromissão na vida privada, no domicílio, na correspondência e nas telecomunicações (art. 32, n. 8, 2. parte, da C.R.P.)? Revista do Ministério Público, Lisboa, ano 20, n. 79, p. 45-67, jul-set. 1999. 
CORTESI, Maria Francesca; FILIPPI, Leonardo. Intercettazione preventiva di comunicazioni. In: Enciclopedia Giuridica - Istitvto Enciclopedia Italiana fondata da Giovanni Treccani. Roma: Istituto Poligrafico e Zecca dello Stato, 2003. vol. XVII, p. 1-11.

COSTA, Paula Bajer Fernandes Martins da. Igualdade no direito processual penal brasileiro. São Paulo: RT, 2001.

- Inquérito policial e a investigação dos fatos que antecede a ação penal no ordenamento jurídico instaurado pela Constituição de 1988. Revista Brasileira de Ciências Criminais, São Paulo, ano 5, n. 19, p. 171-178, jul-set. 1997.

COSTA JUNIOR, Paulo José da. O direito de estar só: tutela penal da intimidade. 4. ed. São Paulo: RT, 2007.

CRETElla JR, José. Comentários à Constituição de 1988. Rio de Janeiro: Forense Universal, 1997. v. 1. (art. $1^{\circ}$ a $5^{\circ}$, incisos I a LXVII).

\section{D}

DELGADO, Lucrecio Rebollo. Vida privada y protección de datos en la Unión Europea. Dykinson, S. L: Madrid, 2008.

DELL'ANDRO, Enzo Maria. Intercettazioni ambientali e Costituizione. In: IANNONE, Leonardo (Org.). Percorsi di Procedura Penale: dal garantismo inquisitório a un accusatorio non garantito. Milano: Giuffrè, 1996.

DELMANTO, Roberto; DELMANTO JUNIOR, Roberto. A permissão constitucional e a nova lei de interceptação telefônica. Boletim IBCCRIM, São Paulo, n.47, p. 1-2, out. 1996.

DELMANTO JUNIOR, Roberto; DELMANTO, Roberto. A permissão constitucional e a nova lei de interceptação telefônica. Boletim IBCCRIM, São Paulo, n.47, p. 1-2, out. 1996. 
DEU, Teresa Armenta. Lecciones de Derecho Procesal Penal. 3. ed. Madrid: Marcial Pons, 2007.

DEZEM, Guilherme Madeira. Da prova penal: tipo processual, provas típicas e atípicas: (Atualizado de acordo com as Leis 11.689/08, 11.690/08 e 11.719/08). Campinas: Millenium, 2008.

D'ISA, R. L'aplicazione del cumulo giuridico ai sensi dell'articolo 81 C.P. quando le pene previste per i reati della fattispecie complessa siano eterogenee. Rivista Italiana di Diritto e Procedura Penale, Milão, Giuffrè, anno XXXV, p. 1.405-1.424, out-dic. 1992.

DINAMARCO, Cândido Rangel. A instrumentalidade do processo. 13. ed. São Paulo: Malheiros, 2008.

DINAMARCO, Cândido Rangel; CINTRA, Antonio Carlos de Araújo; GRINOVER, Ada Pellegrini. Teoria Geral do Processo. 21. ed. São Paulo: Malheiros, 2005.

DINAMARCO, Cândido Rangel. Instituições de direito processual civil. 2. ed. São Paulo: Malheiros, 2002. v. III.

DINAMARCO, Cândido Rangel. Fundamentos do processo civil moderno. 5. ed. São Paulo: Malheiros, 2002. t. I.

DINIZ NETO, Eduardo. Meios de obtenção de prova criminal: considerações de direito constitucional aplicado. Ciências Penais: revista da Associação Brasileira de Professores de Ciências Penais, São Paulo, RT, ano 4, n. 6, p. 151-173, jan-jun. 2007.

DOMÍNGUEZ, Valentín Cortés; SENDRA, Vicente Gimeno; CATENA, Víctor Moreno. Lecciones de Derecho Procesal Penal. 2. ed. Madrid: Colex, 2007. 
DONEDA, Danilo. Da privacidade à proteção dos dados pessoais. Rio de Janeiro: Renovar, 2006.

ECHEVARRIA, Marcelo Horacio. Interceptación de llamadas telefonicas. Revista de Derecho Penal, Procesal Penal y Criminologia, Mendoza, Ediciones Jurídicas Cuyo, año 3 (2003), n. 5/6, p. 31-51, 2004.

\section{F}

FEITOZA, Denilson. Direito processual penal: teoria, crítica e práxis. 6. ed. Niterói: Impetus, 2009.

FELICIONI, Paola. Le ispezioni e le perquisizioni. Milano: Giuffrè, 2004.

FERNANDES, Antonio Scarance. Processo penal constitucional. 6. ed. São Paulo: RT, 2010.

; GRINOVER, Ada Pellegrini; GOMES FILHO, Antonio Magalhães. As nulidades no processo penal. 11. ed. São Paulo: RT, 2009.

; GRINOVER, Ada Pellegrini, GOMES FILHO, Antonio Magalhães. Recursos no processo penal: teoria geral dos recursos, recursos em espécie, ações de impugnação, reclamação aos tribunais. 6. ed. São Paulo: RT, 2009.

O equilíbrio na repressão ao crime organizado. In: FERNANDES, Antonio Scarance; ALMEIDA, José Raul Gavião de; MORAES, Maurício Zanoide (Coords.). Crime organizado: aspectos processuais. São Paulo: RT, 2009. 
. Reflexões sobre as noções de eficiência e de garantismo no processo penal. In: FERNANDES, Antonio Scarance; ALMEIDA, José Raul Gavião de; MORAES, Maurício Zanoide de. Sigilo no processo penal. São Paulo: RT, 2008. p. 9-28.

; LOPES, Mariângela. O recebimento da denúncia no novo procedimento. Boletim do IBCCRIM, n. 190, p. 2-3, set. 2008.

- Prova e sucedâneos de prova no processo penal. Revista Brasileira de Ciências Criminais, São Paulo, RT, n. 66, p. 195-236, mai-jun. 2007. . O sigilo e a prova criminal. Revista da Associação de Professores de Ciências Penais, RT, São Paulo, ano 3, n. 4, p. 153-164, jan-jun. 2006.

. O equilíbrio na investigação criminal. In: YARSHELL, Flávio Luiz; MORAES, Maurício Zanoide de (Orgs.). Estudos em Homenagem à Professora Ada Pellegrini Grinover. 1. ed. São Paulo: DPJ, 2005, p. 319-330.

. A reação defensiva à imputação. São Paulo: RT, 2002.

A lei de interceptação telefônica. In: PENTEADO, Jaques de Camargo (Coord.). Justiça penal - 4: críticas e sugestões: provas ilícitas e reforma pontual. São Paulo: RT, 1997, p. 48-70.

- Interceptações telefônicas: aspectos processuais da nova lei. Boletim IBCCRIM. São Paulo: n. 45, p. 15-16, ago. 1996.

; GOMES FILHO, Antonio Magalhães. Os resultados da interceptação telefônica como prova penal. Revista de Processo, São Paulo, RT, ano 11, n. 44, p. 85-99, out/dez. 1986. 
FERNÁNDEZ, Eduardo; ÁVILA, Cynthia; BORINSKY, Mariano; LAGO, Daniel. Primeira parte: los sistemas nacionales europeos: el sistema procesal penal español. In: HENDLER, Edmundo S. (Dir.). Sistemas procesales penales comparados. 1. ed. Buenos Aires: Ad-Hoc S.R.L, 1999.

FERNÁNDEZ, Ricardo Rodríguez. La intervención telefónica como restricción al derecho fundamental a la intimidad. Revista Penal, Barcelona, n. 5, p. 65-73, 2000.

FERRAZ JUNIOR, Tercio Sampaio. Sigilo de dados: o direito à privacidade e os limites à função fiscalizadora do Estado. In: PIZOLIO, Rinaldo; GAVALDÃO JUNIOR, Jayr Viégas. Sigilo Fiscal e Bancário. São Paulo: Quartier Latin, 2005. p. 15-40.

FERREIRA FILHO, Manoel Gonçalves. Curso de direito constitucional. 27. ed. São Paulo: Saraiva, 2001.

. Direitos humanos fundamentais. 4. ed. São Paulo: Saraiva, 2000.

. Comentários à Constituição brasileira de 1988. São Paulo: Saraiva, 1990. v. 1.

FERREIRA, Pinto. Comentários à Constituição brasileira. São Paulo: Saraiva, 1989. v. 1 (arts. $1^{\mathrm{o}}$ a 21$)$.

FILIPPI, Leonardo; CORTESI, Maria Francesca. Intercettazione preventiva di comunicazioni. In: Enciclopedia Giuridica - Istitvto Enciclopedia Italiana fondata da Giovanni Treccani. Roma: Istituto Poligrafico e Zecca dello Stato, 2003. vol. XVII, p. 1-11.

Intercettazione di comunicazioni. In: Enciclopedia Giuridica - Istitvto Enciclopedia Italiana fondata da Giovanni Treccani. Roma: Istituto Poligrafico e Zecca dello Stato, 2001. vol. XVII, p. 1-8. 
GASPAR, António Henriques. Os novos desafios do processo penal no século XXI e os direitos fundamentais (um difícil equilíbrio). Revista Portuguesa de Ciência Criminal, Coimbra, ano 15, n. 2, p. 257-274, abr-jun. 2005.

GIANNALOPOULOS, Dimitri; PARIZOT, Raphaêlle. La preuve technologique des interceptions et surveillances. In: GIUDICELLI-DELAGE, Geneviève (Dir.). Les transformations de l'administration de la preuve pénale. Paris: Société de Législation Comparé, 2006. p. 245-289.

GOMBAU, José Francisco Valls; SOLER, José Maria Rifá. Derecho procesal penal. Madrid: Iurgium, 2000.

GOMES FILHO, Antonio Magalhães; GRINOVER, Ada Pellegrini, FERNANDES, Antonio Scarance. As nulidades no processo penal. 11. ed. São Paulo: RT, 2009.

; GRINOVER, Ada Pellegrini, FERNANDES, Antonio Scarance. Recursos no processo penal: teoria geral dos recursos, recursos em espécie, ações de impugnação, reclamação aos tribunais. 6. ed. São Paulo: RT, 2009.

. O livre convencimento do juiz no projeto de Código de Processo Penal: primeiras anotações. Boletim IBCCRIM, São Paulo, ano 17, n. 200, p. 08-09, julho 2009.

. Provas: Lei 11.690, de 09.06.2008. In: MOURA, Maria Thereza de Assis (Coord.). As reformas no processo penal: as novas Leis de 2008 e os Projetos de Reforma. São Paulo: RT, 2008. p. 246-297.

; BADARÓ, Gustavo Henrique Righi Ivahy. Prova e sucedâneos de prova no processo penal brasileiro. Revista Brasileira de Ciências Criminais, São Paulo, RT, n. 65, p. 175-208, mar-abr. 2007. 
. Notas sobre a terminologia da prova (reflexos no processo penal brasileiro).

In: YARSHELL, Flávio Luiz, MORAES, Maurício Zanoide de (Orgs.). Estudos em Homenagem à Professora Ada Pellegrini Grinover. 1. ed. São Paulo: DPJ, 2005. p. 303-318.

. A motivação das decisões penais. 1. ed. São Paulo: RT, 2001.

. Direito à prova no processo penal. São Paulo: RT, 1997.

. A violação do princípio da proporcionalidade pela Lei 9.296/96. Boletim IBCCRIM, São Paulo, n. 45, p. 14, ago. 1996.

. Presunção de inocência e prisão cautelar. 1. ed. São Paulo: Saraiva, 1991.

; FERNANDES, Antonio Scarance. Os resultados da interceptação telefônica como prova penal. Revista de Processo, São Paulo, RT, ano 11, n. 44, p. 85-99, out-dez. 1986.

GOMES, Luiz Flávio. Interceptação telefônica "de ofício": inconstitucionalidade. Revista IOB de Direito Penal e Processo Penal, IOB, ano VIII, n. 45, p. 13-20, ago-set. 2007. . Interceptação telefônica e "encontro fortuito" de outros fatos. Boletim IBCCRIM, São Paulo, n. 51, p. 6, fev. 1997.

GÖSSEL, Karl Heinz. El derecho procesal penal en el estado de derecho. Dirigido por Edgarde Alberto Donna. 1. ed. Santa Fe: Runbinzal-Culzoni, 2007.

GRAU, Eros Roberto. Ensaio e discurso sobre a interpretação/aplicação do direito. 4.ed. São Paulo: Malheiros, 2006.

GRECO FILHO, Vicente. Manual de processo penal. 8. ed. São Paulo: Saraiva, 2010. 
. Interceptação telefônica: considerações sobre a Lei n. 9.296, de 24 de julho de 1996. 2. ed. São Paulo: Saraiva, 2005.

GREVI, Vittorio. Un caso di registrazione di colloqui fra persone presenti. L'Indice Penale, Padova, Cedam, Anno X, n. 3, p. 493-496, set-dic. 1976.

GRINOVER, Ada Pellegrini. Do regime das interceptações telefônicas no projeto de novo CPP - Proposta de Emendas do IBDP. Boletim IBCCRIM, São Paulo, ano 18, p. 2-3, ago. 2010.

; FERNANDES, Antonio Scarance; GOMES FILHO, Antonio Magalhães. As nulidades no processo penal. 11. ed. São Paulo: RT, 2009.

; GOMES FIHO, Antonio Magalhães; FERNANDES, Antonio Scarance. Recursos no processo penal: teoria geral dos recursos, recursos em espécie, ações de impugnação, reclamação aos tribunais. 6. ed. São Paulo: RT, 2009.

As garantias constitucionais do novo processo penal na América Latina. In: MARTINS, Ives Gandra da Silva; JOBIM, Eduardo (Coords.). O Processo na Constituição. São Paulo: Quartier Latin, 2008. p. 120-133.

; CINTRA, Antonio Carlos de Araújo; DINAMARCO, Cândido Rangel. Teoria Geral do Processo. 21. ed. São Paulo: Malheiros, 2005.

. O processo: estudos e pareceres. São Paulo: Perfil, 2005.

- O interrogatório como meio de defesa. Revista do Instituto Brasileiro de Ciências Criminais, São Paulo, n. 53, p. 185-200, mar-abr. 2005.

- Novo anteprojeto de lei disciplina a quebra de sigilo das comunicações telefônicas. Revista Literária de Direito, São Paulo, ano 9, n. 47, p. 19-21, jun-jul. 2003. 
A defesa penal e sua relação com a atividade probatória. Revista Brasileira de Ciências Criminais, São Paulo, RT, ano 10, n. 40, p. 91-104, out-dez. 2002.

. A marcha do processo. Rio de Janeiro: Forense Universitária, 2000.

. O regime brasileiro das interceptações telefônicas. Revista Forense, Rio de Janeiro, v. 338, ano 93, p. 3-16, abr-jun. 1997.

. Que juiz inquisidor é esse?. Boletim IBCCRIM, São Paulo, n.v 30, p. 01, jun. 1995.

Prova emprestada. Revista Brasileira de Ciências Criminais, São Paulo, RT, ano 1, n. 4, p.60-69, out-dez. 1993.

Interceptações telefônicas e gravações clandestinas no processo penal. Revista Universitaria de Derecho Procesal, Madrid, n. 4, p. 419-445, 1990.

. Liberdades públicas e processo penal: as interceptações telefônicas. 2. ed. São Paulo: RT, 1982.

. Interrogatório do réu e direito ao silêncio. Ciência Penal, São Paulo, v. 3, n. 1, p. 15-31, 1976.

GRUPO DE PROTECCIÓN DE LAS PERSONAS POR LO QUE RESPECTA AL TRATAMIENTO DE DATOS PERSONALES. Recomendación 2/99 sobre la protección de 1 aintimidad en el contexto de al interceptación de las telecomunicaciones, de 3 de mayo de 1999.

Disponível

em: http://www.agpd.es/portalwebAGPD/canaldocumentacion/docu_grupo_trabajo/wp29/1999/co $\mathrm{mmon} / \mathrm{pdfs} /$ Recomendaci-oo-n-2-99-sobre-la-protecci-oo-n-de-la-intimidad-en-el-contextode-la-interceptaci-oo-n-de-las.pdf. Acesso em: 14/10/2010. 
GUERRERO, Julián Óscar; AMBOS, Kai; BELING, Ernest. Las prohibiciones probatorias. Bogotá: Editorial Temis, 2009.

HAIRABEDIÁN, Maximiliano. La grabación como prueba en el proceso penal. Pensamiento penal y criminológico: revista de derecho penal integrado, Córdoba, Editorial Mediterrânea, ano 3, n. 4, p. 119-150, 2002.

I

INSTITUTO BRASILEIRO DE DIREITO PROCESSUAL. Propostas de emendas ao projeto de lei de código de processo penal. Substitutivo CCJ do Senado. Disponível em: http://novo.direitoprocessual.org.br/content/blocos/96/1. Acesso em: 06/01/2011.

$\mathbf{K}$

KARAM, Maria Lucia. Meios invasivos de busca de provas: incompatibilidade com a democracia. Boletim IBCCRIM, São Paulo, ano 17, n. 200, p. 17-18, jul. 2009.

KEHDI, André Pires de Andrade; MACHADO, André Augusto Mendes. Sigilo das comunicações e de dados. In: FERNANDES, Antonio Scarance; ALMEIDA, José Raul Gavião de; MORAES, Maurício Zanoide de (Coord.) Sigilo no processo penal: eficiência e garantismo. São paulo: Editora Revista dos Tribunais, 2008. p. 239-266.

\section{$\mathbf{L}$}

LAGO, Daniel; ÁVILA, Cynthia; BORINSKY, Mariano; FERNÁNDEZ, Eduardo. Primeira parte: los sistemas nacionales europeos: el sistema procesal penal español. In: HENDLER, Edmundo S. (Dir.). Sistemas procesales penales comparados. 1. ed. Buenos Aires: Ad-Hoc S.R.L, 1999. 
LANGHE, Marcela de; CONDE, Francisco Munoz. Presentación. In: ROXIN, Claus. La prohibición de autoincriminación y las escuchas domiciliarias. 1. ed. Buenos Aires: Hammurabi, 2008.

. Escuchas telefónicas. 1. ed. Buenos Aires: Hammurabi, 2009.

LARONGA, Antonio. Le prove atipiche nel processo penale. Padova: Cedam, 2002.

LEVASSEUR, Georges; STEFANI, Gaston; BOULOC, Bernard. Procédure Pénale. 17. ed. Paris: Dalloz, 2000.

LENNON, Maria Ines Horvitz; MASLE, Julian Lopez. Derecho procesal penal chileno. Tomo II. 1. ed. Santiago: Editorial Juridica de Chile, 2004.

LIMA, Marcellus Polastri. A tutela cautelar no processo penal. Rio de Janeiro: Lumen Juris, 2005.

LOPES JR., Aury; BADARÓ, Gustavo Henrique Righi Ivahy. Direito ao processo penal no prazo razoável. 2. ed. Rio de Janeiro: Lumen Juris, 2009.

. A (in)existência de poder geral de cautela no processo penal. Boletim IBCCRIM, São Paulo, ano 17, n. 203, p. 08-09, out. 2009.

. Direito ao processo penal no prazo razoável. Revista Brasileira de Ciências Criminais, São Paulo, n. 65, p. 209-250, mar-abr. 2007.

. Sistemas de investigação preliminar no processo penal. 1. ed. Rio de Janeiro: Lumen Juris, 2001. 
A crise do inquérito policial: breve análise dos sistemas de investigação preliminar no processo penal. Revista Ibero-Americana de Ciências Penais, Porto Alegre, ano 1, n. 0, p. 57-86, mai-ago. 2000.

LOPES, Mariângela; FERNANDES, Antonio Scarance. O recebimento da denúncia no novo procedimento. Boletim do IBCCRIM, n. 190, p. 2-3, set. 2008.

. O agente infiltrado como meio de investigação. Dissertação de Mestrado - Faculdade de Direito, Universidade de São Paulo (USP), São Paulo, 2006.

\section{M}

MACHADO, André Augusto Mendes; KEHDI, André Pires de Andrade. Sigilo das comunicações e de dados. In: FERNANDES, Antonio Scarance; ALMEIDA, José Raul Gavião de; MORAES, Maurício Zanoide de (Coord.) Sigilo no processo penal: eficiência e garantismo. São paulo: Editora Revista dos Tribunais, 2008. p. 239-266.

MALAN, Diogo Rudge. Gravações Ambientais Domiciliares no Processo Penal. In: LIMA, José Corrêa de; CASARA, Rubens R. R. (Coords.). Temas para uma perspectiva crítica do Direito: homenagem ao Professor Geraldo Prado. Rio de Janeiro: Lumen Juris, 2010. p. 345356.

. Direito ao confronto no processo penal. Rio de Janeiro: Lumen Iuris, 2009.

MARCHETTI, Daniela; BOSCO, Dario; ZAPPALÀ, Angelo. Intercettazioni telefoniche e ambientali: metodi, limiti e sviluppi nella trascrizione e verbalizzazione. Torino: Centro Scientifico Editore, 2007.

MARINELLI, Claudio. Intercettazioni processuali e nuovi mezzi di ricerca della prova. Torino: Giappichelli, 2007. (Procedura Penale: studi, n. 24. Collana diretta da M. Bargis, G. Giostra, V. Grevi, G. Illuminati, R.E. Kostoris, R. Orlandi, E. Zappalà). 
MARQUES, José Frederico. Elementos de direito processual penal. Atualização de Eduardo Reale Ferrari e Guilherme Madeira Dezem. Campinas: Millennium, 2009. v. 2.

MARTÍNEZ, Sara Aragoneses. Capítulo primero: procesos ordinarios: sección primera: el proceso por delitos graves: $§ 12$. El sumario. In: SANTOS, Andrés de La Oliva; MARTÍNEZ, Sara Aragoneses; SEGOVIA, Rafael Hinojosa; ESPARZA, Julio Muerza; GARCÍA, José Antonio Tomé. Derecho procesal penal. 8. ed. Ramón Areces, Madrid, 2007.

MARTINO, Corrada di. Le intercettazioni ambientali. L'Indice Penale, Verona, Cedam, anno VI, nº 3, p. 1.147-1.171, set-dic. 2003.

; PROCACCIANTI, Teresa. Le intercettazioni telefoniche. Padova: Cedam, 2001.

MARTINS, Ives Gandra; BASTOS, Celso Ribeiro. Comentários à Constituição do Brasil: promulgada em 5 de outubro de 1988. São Paulo: Saraiva, 1988. v. 2.

MARTINS, Leonardo. Proporcionalidade como critério do controle de constitucionalidade (problemas de sua recepção pelo direito e jurisdição constitucional brasileiros). Revista da AJURIS (Associação dos Juízes do Rio Grande do Sul), ano XXXIII, n. 101, p. 193-233, mar. 2006.

MASLE, Julian Lopez; LENNON, Maria Ines Horvitz. Derecho procesal chileno. Tomo II. 1. ed. Santiago: Editorial Juridica de Chile, 2004.

MENDONÇA, Andrey Borges de. Nova reforma do Código de processo penal: comentada artigo por artigo. São Paulo: Método, 2008.

MERCONE, Mario. Manuale di Procedura Penale. 4. ed. Napoli: Esselibri - Simone, 1997. 
MIRANDA, Pontes de. Comentários à Constituição de 1967, com a Emenda n. 1, de 1969. 2. ed. São Paulo: RT, 1971. t. V.

MONTESANO, Luigi. Le prove disponibili d'ufficio e l'imparzialità del giudice civile. Rivista Trimestrale di Diritto e Procedura Civile, Milano, Giuffrè, anno XXXII, p. 189-206, 1978.

MORAES, Maurício Zanoide de. Presunção de Inocência no processo penal brasileiro: análise da estrutura normativa para a elaboração legislativa e para a decisão judicial. Rio de Janeiro: Lumen Juris, 2010.

. Perplexidade de Jano: quando o passado é mais presente do que o futuro (nova regulamentação do interrogatório e sua aplicabilidade na fase pré-processual). Estudos em Homenagem à Professora Ada Pellegrini Grinover. 1. ed. São Paulo: DPJ, 2005, p. 365-381.

. Interrogatório: uma leitura constitucional. In: MORAES, Maurício Zanoide de et al. Escritos em homenagem a Alberto Silva Franco. São Paulo: RT, 2003, p. 334-343.

; MOURA, Maria Thereza Rocha de Assis. Direito ao silêncio no interrogatório. Revista Brasileira de Ciências Criminais, São Paulo, v. 2, n. 6, p. 133-147, abr-jun. 1994.

MOURA, Maria Thereza Rocha de Assis. Meios de impugnação à quebra indevida de sigilo bancário. In: SALOMÃO, Heloisa Estellita (Coord.). Direito penal empresarial. São Paulo: Dialética, 2001.

. Justa causa para ação penal - Doutrina e jurisprudência. São Paulo: RT, 2001.

. Interceptação telefônica: breves reflexões. Revista Brasileira de Ciências Criminais, São Paulo, RT, ano 6, n. 21, p. 411-412, jan-mar. 1998. 
; MORAES, Maurício Zanoide de. Direito ao silêncio no interrogatório. Revista Brasileira de Ciências Criminais. São Paulo: v. 2, n. 6, p. 133-147, abr-jun. 1994.

\section{$\mathbf{O}$}

OXFORD PRO BONO PUBLICO. Legal opinion in interception communication. Oxford: 2006. Disponível em: http://www2.law.ox.ac.uk/opbp/OPBP\%20Intercept\%20Evidence\%20Report.pdf. Acesso em: $03 / 01 / 2011$.

\section{$\mathbf{P}$}

PARIZOT, Raphaêlle; GIANNALOPOULOS, Dimitri. La preuve technologique des interceptions et surveillances. In: GIUDICELLI-DELAGE, Geneviève (Dir.). Les transformations de l'administration de la preuve pénale. Paris: Société de Législation Comparé, 2006. p. 245-289.

PERCHINUNNO, Vincenzo. I mezzi di recerca della prova. In: PISANI, Mario; MOLARI, Alfredo; PERCHINUNNO, Vincenzo; CORSO, Piermaria. Manuale di Procedura Penale. Bologna: Monduzzi Ed, 1994. cap. XVII. p. 251-257.

PIOVESAN, Flávia. Introdução ao sistema interamericano de proteção dos direitos humanos: a Convenção Americana de Direitos Humanos. In: GOMES, Luiz Flávio; PIOVESAN, Flávia (Coords.). O sistema interamericano de proteção dos direitos humanos e o direito brasileiro. São Paulo: RT, 2000. Cap. I, p. 17-52.

A incorporação, a hierarquia, e o impacto dos tratados internacionais de proteção dos direitos humanos no direito brasileiro. In: GOMES, Luiz Flávio; PIOVESAN, Flávia (Coords.). O sistema interamericano de proteção dos direitos humanos e o direito brasileiro. São Paulo: RT, 2000. Cap. V, p. 153-179. 
PISANI, Mario. La tutela giuridica della vita privata. L'indice penale, Padova, Cedam, anno I, n. 3, p. 431-440, set-dic. 1967.

PITOMBO, Cleunice A. Valentim Bastos. Da busca e apreensão no processo penal. 2. ed. São Paulo: RT, 2005. (Coleção estudos de processo penal Joaquim Canuto Mendes de Almeida, v. 2).

. Considerações sobre a tutela da intimidade e vida privada no processo penal. Revista Brasileira de Ciências Criminais, São Paulo, ano 7, n. 26, p. 59-79, abr-jun. 1999.

PITOMBO, Sérgio Marcos de Moraes. Sigilo nas comunicações: aspecto processual penal. Boletim IBCCRIM, São Paulo, n. 49, p. 07-08, dez. 1996.

O juiz penal e a pesquisa da verdade material. In: PORTO, Hermínio Alberto Marques; SILVA, Marco Antonio Marques da. Processo penal e Constituição Federal. São Paulo: Acadêmica, 1993.

. Inquérito policial: novas tendências. Belém: Cejup, 1987.

PRADEL, Jean. Manuel de procédure pénale. 10. ed. Paris: Éditions Cujas, 2000.

PRADO, Geraldo. Limite às interceptações telefônicas e a jurisprudência do Superior Tribunal de Justiça. Rio de Janeiro: Lumen Iuris, 2005.

PROCACCIANTI, Teresa; MARTINO, Corrada di. Le intercettazioni telefoniche. Padova: Cedam, 2001.

\section{Q}

QUEIJO, Maria Elizabeth. O direito de não produzir prova contra si mesmo (o princípio nemo tenetur se detegere e suas decorrências no processo penal). São Paulo: Saraiva, 2003. 
QUERALT, Joan J. Intervención de las telecomunicaciones en sede de investigación judicial y policial. Revista Canaria de Ciencias Penales, n. 2, p. 107-125, dic. 1998.

RAMÍREZ G., Maria Cecilia. Protección de las comunicaciones telefónicas en Chile. In: MARTÍN, Adán Nieto (coord.). Homenaje ao Dr. Marino Barbero Santos - in memoriam. V. II. Cuenca: Ediciones de la Universidad de Castilla-La Mancha, 2001. p. 531-550.

RICCI, Gian Franco. Atipicità della prova, processo ordinário e rito camerale. Rivista Trimestrale di Diritto e Procedura Civile, Milano, Giuffrè, anno LVI, n. 2, p. 409-452, giugno 2002.

RICCI, Gian Franco. Le prove atipiche. Milano: Giuffrè, 1999.

RODRIGUES, Benjamim Silva. Das escutas telefónicas: I: a monitorização dos fluxos informacionais e comunicacionais. 2. ed. Coimbra: Coimbra Ed., 2008.

ROXIN, Claus. La prohibición de autoincriminación y las escuchas domiciliarias. Presentación de Francisco Muñoz Conde y Marcela De Langhe. 1. ed. Buenos Aires: Hammurabi, 2008.

. Derecho procesal penal. 25. ed. Tradução de Gabriela Córdoba y Daniel Pastor. Buenos Aires: Editores Del Puerto, 2003.

RUIZ, Jesús Martínez. Límites jurídicos de las grabaciones de la imagen y el sonido. Barcelona: Bosch, 2004. 
SAAD GIMENES, Marta Cristina Cury. As medidas assecuratórias do Código de Processo Penal como forma de tutela cautelar destinada à reparação do dano causado pelo delito. 2007. Tese (Doutorado) - Faculdade de Direito, Universidade de São Paulo (USP), São Paulo, 2007.

. O Direito de defesa no inquérito policial. São Paulo: RT, 2004.

SANGUINETI, Luigi Maria. Lezioni di Procedura Penale. Milano: Giuffrè, 1996.

SANTOS, Ana Margarida. Gravação não consentida de conversa, junção a inquérito, competência do juiz de instrução criminal. Revista do Ministério Público, Lisboa, Editorial Minerva, ano 30, n. 117, p. 159-180, jan-mar. 2009.

SCHLÜCHTER, Ellen. Derecho Procesal Penal. Colaboración de Jörg Knupger y Mathias Terbach. Traduccion de Iñaki Esparza Leibar y Andrea Planchadell Gargallo. 2. Ed. Valencia: Tirant lo Blanc, 1999.

SCHWARTZ, Paul M.; SOLOVE, Daniel J. Privacy, information and technolgy. 2. ed. New York: Aspen Publishers, 2009.

SENDRA, Vicente Gimeno. Derecho Procesal Penal. 2. ed. Madrid: Colex, 2007.

SENDRA, Vicente Gimeno; CATENA, Víctor Moreno; DOMÍNGUEZ, Valentín Cortés. Lecciones de Derecho Procesal Penal. 2. ed. Madrid: Colex, 2007.

Aspectos procesales y constitucionales más relevantes en los delitos relativos a drogas tóxicas y estupefacientes. In: SORIANO, José Ramón (Dir.). Delitos contra la salud pública y contrabando. Madrid: Lerko Print, 2000. 
SERRANO, Nicolas Gonzalez-Cuellar. Proporcionalidad y derechos fundamentales en el processo penal. 2. ed. Madrid: Colex, 1990.

SEVA, Antonio Pablo Rives. La intervención de las comunicaciones en la jurisprudencia penal. Elcano (Navarra): Aranzadi, 2000.

SILVA, José Afonso da. Comentário Contextual à Constituição. 3. ed. São Paulo: Malheiros, 2006.

SILVA, Luís Virgílio Afonso da. O proporcional e o razoável. Revista dos Tribunais, São Paulo, ano 91, volume 798, p. 23-50, abr. 2002.

SILVA, Eduardo Araujo da. Crime organizado: procedimento probatório. São Paulo: Atlas, 2003.

SIMONS, Christian Sthefan. A prova ilícita no directo processual penal norte-americano e alemão e as influências no processo penal brasileiro. 2007. Dissertação (mestrado) Faculdade de Direito, Universidade de São Paulo (USP), 2007.

SIRACUSANO, Delfino. Le prove: le prove, il procedimento probatório e il processo. In: SIRACUSANO, Delfino; GALATI, Antonini; TRANCHINA, Giovanni; ZAPPALÀ, Enzo. Diritto Processuale Penale. Milano: Giuffrè, 2006. v. 1. cap. 1. p. 329-368.

. Le prove: i mezzi di ricerca della prova. In: SIRACUSANO, Delfino; GALATI, Antonini; TRANCHINA, Giovanni; ZAPPALÀ, Enzo. Diritto Processuale Penale. Milano: Giuffrè, 2006. v. 1. cap. 3. p. 399-411.

- Prefazione. In: SIRACUSANO, Delfino; GALATI, Antonini; TRANCHINA, Giovanni; ZAPPALÀ, Enzo. Diritto Processuale Penale. 2. ed. Milano: Giuffrè, 2006. v. 1.p. V. 
. Prova - III) Nel nuovo Codice di Procedura Penale. In: Enciclopedia Giuridica - Istitvto Enciclopedia Italiana fondata da Giovanni Treccani. Roma: Istituto Poligrafico e Zecca dello Stato, 2003. vol. XXV, p. 1-16.

SOLER, José Maria Rifá; GOMBAU, José Francisco Valls. Derecho procesal penal. Madrid: Iurgium, 2000.

SOLOVE, Daniel J.; SCHWARTZ, Paul M.. Privacy, information and technolgy. 2. ed. New York: Aspen Publishers, 2009.

SOSA, María Julia. Intervenciones y escuchas telefónicas : requisitos que deberían tenerse en cuenta en nuestra legislación para ser aplicados por nuestros tribunales en consonancia con la constitución nacional, tratados internacionales y jurisprudencia internacional. Ciencias penales contemporáneas: Revista de derecho penal procesal penal y criminología, Mendonza, Ediciones Juridicas Cuyo, año 3, n. 5-6, p. 143-174, 2003.

SPIEZIA, Filippo; APRILE, Ercole. Le intercettazioni telefoniche ed ambientali: innovazioni tecnologiche e nuove questioni giuridiche. Milano: Giuffrè, 2004. (Teoria e Pratica del Diritto, sez. III, n. 133. Diritto e Procedura Penale).

STEFANI, Gaston; LEVASSEUR, Georges; BOULOC, Bernard. Procédure Pénale. 17. ed. Paris: Dalloz, 2000.

STRECK, Lenio Luiz. As interceptações telefônicas e os direitos fundamentais: Constituição, Cidadania, Violência: a Lei 9.296/96 e seus reflexos penais e processuais. Porto Alegre: Livraria do Advogado, 2001.

TAORMINA, Carlo. Il regime della prova nel processo penale. Torino: G. Giappichelli, 2007. 
TARUFFO, Michele. La prova dei fatti giuridici: nozioni generali. Milano: Giuffrè, 1992.

. Modelli di prova e di procedimento probatorio. Rivista di Diritto Processuale, Padova, v. 45, n. 2, p. 420-48, apr-giug. 1990.

TOMKINS, Adam; TURPIN, Colin. British Government and the Constitution. 6. ed. Cambridge: Cambridge University Press, 2007, p. 475. Disponível em: $\mathrm{http}$ ://books.google.com.br/books?id=QYuF6jmoem8C\&pg=PA475\&dq=interception+rules\& $\mathrm{hl}=$ pt-BR\&ei=6QqaTMGLCIT48AaHpJFJ\&sa=X\&oi=book_result\&ct=bookthumbnail\&resnum $=10 \& v e d=0 \mathrm{CF} 0 \mathrm{Q} 6 \mathrm{wEwCTgK} \# \mathrm{v}=$ onepage $\& \mathrm{q}=$ interception $\% 20 \mathrm{rules} \& \mathrm{f}=\mathrm{fa}$ lse. Acesso em: 02/01/2011.

TONINI, Paolo. A prova no processo penal italiano. Tradução de Alexandra Martins e Daniela Mróz. São Paulo: RT, 2002.

TOURINHO FILHO, Fernando da Costa. Manual de processo penal. 11. ed. São Paulo: Saraiva, 2009.

TUCCI, Rogério Lauria. Direitos e garantias individuais no processo penal brasileiro. 2. ed. São Paulo: RT, 2004.

- Teoria do direito processual penal: jurisdição, ação e processo penal (estudo sistemático). São Paulo: RT, 2002.

TURPIN, Colin; TOMKINS, Adam. British Government and the Constitution. 6. ed. Cambridge: Cambridge University Press, 2007, p. 475. Disponível em: http://books.google.com.br/books?id=QYuF6jmoem8C\&pg=PA475\&dq=interception+rules\& $\mathrm{hl}=$ pt-BR\&ei=6QqaTMGLCIT48AaHpJFJ\&sa=X\&oi=book_result\&ct=bookthumbnail\&resnum $=10 \& v e d=0 \mathrm{CF} 0 \mathrm{Q} 6 \mathrm{wEwCTgK} \# \mathrm{v}=$ onepage $\& \mathrm{q}=$ interception $\% 20 \mathrm{rules} \& \mathrm{f}=\mathrm{fa}$ 1se. Acesso em: 02/01/2011 
UBERTIS, Giulio. Prova - II) Teoria generale del processo penale. In: Enciclopedia Giuridica - Istitvto Enciclopedia Italiana fondata da Giovanni Treccani. Roma: Istituto Poligrafico e Zecca dello Stato, [2004]. vol. XXV, p. 1-12.

VALENTE, Manuel Monteiro Guedes. Escutas telefónicas: da excepcionalidade à vulgaridade. 2. ed. Coimbra: Almedina, 2008.

VALENTE, Rubens. Internet dissemina novos métodos de grampo ilegal. Folha de São Paulo, São Paulo, 22 de dezembro de 2008. Disponível em: http://www1.folha.uol.com.br/fsp/brasil/fc2212200804.htm. Acesso em: 22/12/2008.

\section{W}

WARREN, Samuel D.; BRANDEIS, Louis D. The right to privacy. Harvard Law Review, V. IV, n. 5, dec. 1890. Disponível em: http://faculty.uml.edu/sgallagher/Brandeisprivacy.htm. Acesso em: 07/09/2010.

WEIS, Carlos. Os Direitos Humanos Contemporâneos. 1. Ed. São Paulo: Malheiros, 2006.

WONG, Thomas. Regulation of Interception of Communications in Selected Jurisdictions. 2005. Disponível em: http://www.legco.gov.hk/yr04-05/english/sec/library/0405rp02e.pdf. Acesso em: 03/01/2011. 
YARSHELL, Flávio Luiz. Antecipação de prova sem o requisito da urgência e direito autônomo à prova. São Paulo: Malheiros, 2009.

\section{$\mathbf{Z}$}

ZAPPALÀ, Angelo; BOSCO, Dario; MARCHETTI, Daniela. Intercettazioni telefoniche e ambientali: metodi, limiti e sviluppi nella trascrizione e verbalizzazione. Torino: Centro Scientifico Editore, 2007.

Le garanzie giurisdizionali in tema di libertà personale e di ricerca della prova. In: CONVEGNO PRESSO L'UNIVERSITÀ DI CATANIA, set-ott. 1993, Noto Marina. Libertà personale e ricerca della prova nell'attuale asseto delle indagini preliminari. Milano: Giuffrè, 1995. p. 53-77.

ZILLI, Marcos Alexandre Coelho. Resquícios inquisitórios na Lei 9.034/1998. Revista Brasileira de Ciências Criminais, São Paulo, n. 46, p. 174-195, jan-fev. 2004.

. A iniciativa instrutória do juiz no processo penal. São Paulo: RT, 2003.

\section{FONTES JURISPRUDENCIAIS}

BRASIL. Supremo Tribunal Federal. Habeas Corpus n. 90094/ES, 2a Turma, Min. Rel. Eros Grau, j. em 08/06/2010, DJ de 06/08/2010, v.u.. Disponível em: http://www.stf.jus.br/portal/jurisprudencia/listarJurisprudencia.asp?s1=prova+e+il\%ED cita + e+justa + e + causa \& pagina $=1 \&$ base=baseAcordaos. Acesso em: 20/12/2010. 
. Supremo Tribunal Federal. Recurso Extraordinário n. 349.703/RS, Trib. Pleno, Min. Rel. Carlos Britto, j. em 03/12/2008, DJ de 05/06/2009, m.v.. Disponível em: http://www.stf.jus.br/portal/jurisprudencia/listarJurisprudencia.asp?s1=349703\&pagina=2\&ba se=baseAcordaos. Acesso em: 28/10/2010.

. Supremo Tribunal Federal. Informativo n. 584 (Voto vencido do Min. Celso de Mello no Inq 2424/RJ). Disponível em: http://www.stf.jus.br//arquivo/informativo/documento/informativo584.htm. Acesso em: 20/12/2010.

CORTE EUROPEIA DE DIREITOS HUMANOS. Case of Malone v. The United Kingdom (Judgmentes [Merits], n. 8691/79). Disponível em: $\mathrm{http}: / / \mathrm{cmiskp}$. echr.coe.int/tkp197/view.asp?action=html\&documentId=695410\&portal=hbkm \&source=externalbydocnumber\&table=F69A27FD8FB86142BF01C1166DEA398649. Acesso em: 26/09/2010.

. Case of Funke v. France (Merits and Just Satisfaction, n. 10828/84). Disponível em: http://cmiskp.echr.coe.int/tkp197/portal.asp?sessionId=60604352\&skin=hudocen\&action=request. Acesso em: 14/10/2010.

. Case of Lambert v. France (Judgment [Merits and Just Satisfaction], n. 23618/94) . Disponível em: http://cmiskp.echr.coe.int/tkp197/view.asp?item=1\&portal=hbkm\&action=html\&highlight=La mbert\&sessionid=59715152\&skin=hudoc-en. Acesso em: 26/09/2010.

Case of Valenzuela Contreras v. Spain (Merits and Just Satisfaction, n. 27671/95). Disponível em: http://cmiskp.echr.coe.int/tkp197/portal.asp?sessionId=63635425\&skin=hudocen\&action=request. Acesso em: 16/12/2010. 
Case P.G. and J.H. v. The United Kingdom (Merits and Just Satisfaction, n. 44787/98). Disponível em: http://cmiskp.echr.coe.int/tkp197/portal.asp?sessionId=64240137\&skin=hudocen\&action=request. Acesso em: 03/01/2011.

. Case Vetter v. France (Merits and Just

Satisfaction, n. 59842/00). Disponível em:

http://cmiskp.echr.coe.int/tkp197/portal.asp?sessionId=64240137\&skin=hudocen\&action=request. Acesso em: 03/01/2011.

U. S. SUPREME COURT. Katz v. United States, 389 U.S. 347 (1967). Disponível em: http://caselaw.lp.findlaw.com/scripts/getcase.pl?court=US\&vol=389\&invol=347. Acesso em: 05/01/2011.

\section{FONTES METODOLÓGICAS}

UNIVERSIDADE DE SÃO PAULO. Sistema Integrado de Bibliotecas da USP. Diretrizes para apresentação de dissertações e teses da USP: documento eletrônico e impresso Parte I (ABNT)/Sistema Integrado de Bibliotecas da USP ; Vânia Martins Bueno de Oliveira Funaro, coordenadora [et al.]. 2. ed. rev. ampl. São Paulo : Sistema Integrado de Bibliotecas da USP, 2009. Disponível em: http://www.teses.usp.br/info/diretrizesfinal.pdf. Acesso em: 21/12/2010.

- Resolução FD/PÓS n. 01/2002. Disponível em: http://www.direito.usp.br/. Acesso em: 21/12/2010. 


\section{DICIONÁRIOS}

ACADEMIA BRASILEIRA DE LETRAS. Vocabulário Ortográfico da Língua Portuguesa. $5^{a}$ Ed. São Paulo: Editora Global: 2009.

ASENSIO, Margarita Ostojska; MARSÁ, Victor; PALÉS, Marisol. Dicionario de bolsillo español-portugués portugués español. Madrid: Espasa Calpe, 2001.

BURTIN-VINHOLES, S. Dicionário Francês-Português PortuguêS-Francês. 19. ed. Rio de Janeiro: Globo, 1958.

CARDIM, Ismael (co-editor); HOUAISS, Antônio (editor). Dicionário Inglês-Português. 15. ed. Rio de Janeiro: Record, 2005.

CINTRA, Geraldo de Ulhôa; CRETELLA JÚNIOR, José. Dicionário Latino-Português. 7. ed. São Paulo: Companhia Editora Nacional, 1956.

CRETELLA JÚNIOR, José; CINTRA, Geraldo de Ulhôa. Dicionário Latino-Português. 7. ed. São Paulo: Companhia Editora Nacional, 1956.

FERREIRA, Aurélio Buarque de Holanda. Novo dicionário aurélio. 3. ed. Curitiba: Editora Positivo, 2004. Versão eletrônica.

HOUAISS, Antônio (editor); CARDIM, Ismael (co-editor) et al. Dicionário Inglês-Português. 15. ed. Rio de Janeiro: Record, 2005.

LUFT, Celso Pedro. Dicionário Prático de Regência Nominal. 4. ed. São Paulo: Editora Ática, 2005.

. Dicionário Prático de Regência Verbal. 8. ed. São Paulo: Editora Ática, 2003. 
MARSÁ, Victor; PALÉS, Marisol; ASENSIO, Margarita Ostojska. Dicionario de bolsillo español-portugués portugués español. Madrid: Espasa Calpe, 2001.

MEA, Giuseppe. Dicionário de italiano-português. 2. ed. Porto: Porto Editora, 2000.

PALÉS, Marisol; MARSÁ, Victor; ASENSIO, Margarita Ostojska. Dicionario de bolsillo español-portugués portugués español. Madrid: Espasa Calpe, 2001. 